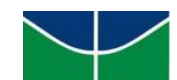

Universidade de Brasília

Instituto de Relações Internacionais

Programa de Pós-Graduação em Relações Internacionais

Doutorado em Relações Internacionais
\end{abstract}

\title{
Desenvolvimento e mudança climática: estímulos à inovação em energia de baixo carbono em países de industrialização tardia (1997-2014)
}

\author{
RAFAEL RAMALHO DUBEUX
}

Orientador:

Professor Dr. EDUARDo VIOLA

Brasília/DF - 2015 
Universidade de Brasília

Instituto de Relações Internacionais

Programa de Pós-Graduação em Relações Internacionais

Doutorado em Relações Internacionais

\title{
Desenvolvimento e mudança climática: estímulos à inovação em energia de baixo carbono em países de industrialização tardia (1997-2014)
}

\author{
RAFAEL RAMALHO DUBEUX
}

Tese de Doutorado submetida ao Instituto de Relações Internacionais da Universidade de Brasília como parte dos requisitos necessários para a obtenção do Grau de Doutor em Relações Internacionais, área de concentração em Política Internacional e Comparada.

Data da Defesa da Tese:

14 de maio de 2015

$14 \mathrm{~h}$

Banca Examinadora:

Prof. Dr. Eduardo Viola (UnB), orientador

Prof. Dr. Eiiti Sato (UnB), examinador interno

Profa. Dra. Danielly Silva Ramos Becard (UnB), examinadora interna

Prof. Dr. Fábio Albergaria de Queiroz (UCB/DF), examinador externo

Prof. Dr. Ricardo Abramovay (USP), examinador externo

Brasília/DF - 2015 
Com amor, para Heloisa e para nosso bebê em gestação, que já irradia tanta alegria. 
"O futuro deve ser uma fronteira aberta à invenção do homem." Celso Furtado

"A Idade da Pedra não acabou por falta de pedras, e a Idade do Petróleo se acabará bem antes de esgotar o petróleo." Ahmed Zaki Yamani, Ministro de Petróleo da Arábia Saudita

"Se todos os insetos desaparecessem da Terra, dentro de 50 anos toda a vida na Terra acabaria. Se todos os seres humanos desapareceram da Terra, dentro de 50 anos todas as formas de vida iriam florescer."

Jonas Salk 


\section{AGRADECIMENTOS}

Esta tese não seria viável sem a colaboração e o apoio de muitas pessoas e instituições, a quem devo enorme reconhecimento.

Em primeiro lugar, quero agradecer profundamente ao professor Eduardo Viola. Orientador sempre presente e com observações precisas, devo a ele o próprio tema da pesquisa e o ânimo necessário para levá-la a cabo. Mente inquieta e brilhante, suas análises e provocações exerceram papel central em minhas reflexões sobre o tema da tese. Mesmo com pontos de vista diferentes em nossos francos e respeitosos debates sobre o cenário político brasileiro, minha admiração por seu trabalho, que já era enorme ao tempo do mestrado, só cresceu nesse período. Um sincero muito obrigado!

Aos funcionários da UnB, meu agradecimento na superação dos inúmeros obstáculos procedimentais da universidade. Obrigado, Odalva, Anderson e Vanessa.

Aos amigos do curso, minha gratidão pelas conversas gostosas, pela companhia, pela troca de ideias e especialmente pelo compartilhamento das angústias próprias do doutorado. Obrigado a todos, especialmente Paulinha Moreira, Silvana Schimanski, Larissa Basso e Matías Franchini.

Aos amigos do grupo de pesquisa RedeClim, foi um grande aprendizado e um prazer participar das reuniões periódicas da equipe, ouvir os relatos das pesquisas de cada um e trocar ideias sobre mudança climática e relações internacionais.

Aos professores e amigos da Universidade da Califórnia, Berkeley, minha gratidão por esse período fantástico no doutorado sanduíche. Essa instituição é uma das provas mais evidentes de que universidades públicas podem ter excelência. Aos professores Dan Farber, Steve Weissman, Daniel Kammen e Steven Vogel meu muito obrigado pelas aulas e pelas conversas sobre a tese. Agradeço especialmente aos maravilhosos amigos que propiciaram uma vivência menos solitária em uma terra tão distante: Max Duarte, Maria Rojec, Marine Boudot, Elsa Lemaître-xavier, JB e Céline Bégué, Taylor Henshaw e Vanessa Lanfranchi. Thanks a lot! Aliás, desse período também não posso deixar de agradecer aos vários amigos brasileiros que foram nos visitar na Califórnia e permitir que matássemos um pouquinho a saudade da terra das palmeiras, onde canta o sabiá. Obrigado, meus queridos! 
Também quero fazer um agradecimento especial ao governo federal, que permitiu o meu afastamento para o doutorado sanduíche. Sem esse apoio institucional, o doutorado sanduíche não se teria realizado e sabe-se lá se teria sido possível concluir a pesquisa e a elaboração da tese. Nesse campo profissional, os agradecimentos vão mesmo para os amigos do trabalho que - sem reclamar (muito) - toleraram me ouvir tantas vezes divagando sobre inovação, energia, câmbio e mudança climática. Muito grato pela paciência! E ainda mais agradecido pela convivência sempre fraterna em um ambiente por natureza tão estressante. Agradeço especialmente a Ivo Corrêa, Felipe de Paula, Regis Dudena, Dario Durigan, Felipe Daud, César Carrijo, Miguel Ragone, Daienne Machado e Maria Paula Amorim, além de Marcos Toscano, Danilo Gennari, Danilo Limoeiro e Gabriel Elias. Agradeço em especial ao amigo Ivo pela confiança - espero que a redação final da tese não tenha atrapalhado muito minha dedicação ao trabalho.

Aos amigos candangos devo um agradecimento especial. Acho que o que mais marcou essa temporada no exterior foi a falta que a presença dos amigos faz. Aos camaradas do Instituto Alvorada, aos migrantes pernambucanos e a todos os que ganharam o zombeteiro título de cidadão pernambucano por equiparação, fica o registro de meu imenso carinho por vocês. Um obrigado especial pelas sempre inacabáveis discussões sobre os rumos do Brasil aos camaradas Victor Cravo, Marcos Toscano, João Paulo Resende, Carlos Vitor Bezerra, Antônio Cruz, Bernardo Carvalho, Walmar Andrade, Luiz Gonzaga Castro, Celina Pereira, Clarice Calixto, Ricardo Horta, Vânia Vieira, Emilio Chernavsky e Pedro Pontual. Sigamos na luta!

Não sei nem como deixar o registro de gratidão à família. Pai, mãe, Rô e Ceci, Ju e Pam, e Maria, amo vocês. Valeu por tudo! Que falta que a distância nos impõe! Pai e mãe, não sei como poderia ter sido mais estimulado por vocês do que fui. Maum, você é minha guru e fonte de inspiração!

Ao amor da minha vida, companheira de todas as viagens, parceira de todas as experiências, com quem divido tudo e em cujo abraço busco abrigo: para minha felicidade, estamos irremediavelmente vinculados agora que portas no ventre nosso bebê. Contigo, sinto-me sempre disposto a novas aventuras - quaisquer que sejam. Sem tua companhia, apoio e troca de ideias, não estaria entregando esta tese. Ela é tua também. 


\section{RESUMO}

Exibindo uma matriz energética relativamente limpa e favorecido pela disponibilidade de recursos hídricos, terras aráveis abundantes para biomassa e vastas reservas de petróleo, o Brasil não está encorajando na mesma intensidade que outros países inovações tecnológicas em energias de baixo carbono. O sistema de aprendizado tecnológico passivo em torno do qual se estruturou a industrialização tardia do país constitui um obstáculo para as atividades de inovação local, situação que é agravada pela perda de competitividade industrial decorrente da persistente sobreapreciação cambial. China, Taiwan e Coreia, por outro lado, premidos pela necessidade de limitar suas emissões de carbono na geração de energia e de reduzir a vulnerabilidade à importação de fontes energéticas, estão adotando políticas públicas para fomentar inovações em energia limpa. Esses países asiáticos são favorecidos pelo sistema de aprendizado tecnológico ativo que escorou a industrialização tardia, além de beneficiarem-se de moedas depreciadas que favorecem a manufatura local. As políticas energéticas e tecnológicas dessas quatro nações refletem esses diferentes contextos. No caso brasileiro, a geração de energia segue dependente de importação de tecnologias estrangeiras e mantém a aposta em fontes tradicionais de energia, o que resultou em uma indústria energética de baixo carbono tecnologicamente dependente, ainda que a matriz energética seja comparativamente pouco poluente. China, Taiwan e Coreia adotaram intensos estímulos à inovação no setor e estão construindo gradualmente uma indústria energética tecnologicamente autônoma, ainda que mantenham níveis de emissão de carbono bastante elevados em suas matrizes de energia.

Palavras-chave: DESENVOLVIMENTO. MUDANÇA CLIMÁTICA. INOVAÇÃO TECNOLÓGICA. ENERGIA DE BAIXO CARBONO. POLÍTICAS PÚBLICAS. BRASIL. CHINA. COREIA DO SUL. TAIWAN. 


\begin{abstract}
Flaunting a clean energy mix and favored by hydropower availability, abundant land for biomass and vast oil reserves, Brazil is not intensely encouraging clean and innovative energy technologies. The passive learning system forged during the country's late industrialization hampers the efforts towards innovation, and the situation is worsened by an overvalued currency that affects its manufacturing activities. China, Taiwan and South Korea, on the other hand, endangered by the need to limit carbon emissions in the energy sector and to reduce the vulnerability to its enormous energy imports, are adopting bold policies to foster clean technologies. These Asian countries are favored by the active learning system that underpinned their industrialization and the depreciated currency that favors local manufacturing. The energy and technology policies of those four countries reflect these different contexts. Brazilian energy policies rely on imported technologies and bet on traditional sources of energy, resulting in a technologically dependent low carbon energy industry, though exhibiting comparatively clean energy mix. China, Taiwan and Korea adopted pro-innovation energy policies and are building a gradually autonomist energy industry, despite the current very high level of carbon emissions in their energy sectors.
\end{abstract}

Palavras-chave: DEVELOPMENT. CLIMATE CHANGE. TECHNOLOGY INNOVATION. LOW CARBON ENERGY. PUBLIC POLICIES. BRAZIL. CHINA. SOUTH KOREA. TAIWAN. 


\section{ÍNDICE DE FIGURAS}

\begin{tabular}{|c|c|c|}
\hline NÚMERO & TÍTULO & PÁGINA \\
\hline 1 & $\begin{array}{l}\text { Exemplos de impactos associados com mudança da temperatura } \\
\text { global média }\end{array}$ & 58 \\
\hline 2 & Medidas adotadas pela Califórnia para mitigar o desafio climático & 77 \\
\hline 3 & Reservas listadas em comparação com o limite de emissões & 167 \\
\hline 4 & Quota de energia renovável nos EUA & 182 \\
\hline 5 & $\begin{array}{l}\text { Metas de energia renovável na União Europeia, em participação da } \\
\text { matriz elétrica, } 2010\end{array}$ & 183 \\
\hline 6 & Disponibilidade das novas renováveis no planeta & 184 \\
\hline 7 & $\begin{array}{l}\text { Principais fatores a influenciar a indústria de energia de baixo } \\
\text { carbono }\end{array}$ & 317 \\
\hline
\end{tabular}




\section{ÍNDICE DE TABELAS}

\begin{tabular}{|c|c|c|}
\hline NÚMERO & TÍTULO & PÁGINA \\
\hline 1 & $\begin{array}{l}\text { Classificação das variáveis e dos processos em que atuam } \\
\text { instituições e políticas }\end{array}$ & 38 \\
\hline 2 & Diferença de potencial dos principais gases de efeito estufa & 55 \\
\hline 3 & $\begin{array}{l}\text { Exemplos de possíveis impactos climáticos devido a mudanças nos } \\
\text { eventos climáticos extremos }\end{array}$ & 59 \\
\hline 4 & Exemplos selecionados de adaptação, por setor & 62 \\
\hline 5 & Exemplos selecionados de tecnologias chave de mitigação por setor & 64 \\
\hline 6 & Metas voluntárias no âmbito do Acordo de Copenhague & 75 \\
\hline 7 & $\begin{array}{l}\text { Principais indicadores de alguns dos atores mais relevantes nas } \\
\text { negociações climáticas }\end{array}$ & 82 \\
\hline 8 & $\begin{array}{l}\text { Posições dos países classificados como superpotências, grandes } \\
\text { potências ou potências médias }\end{array}$ & 89 \\
\hline 9 & Ideb nos ensinos fundamental e médio & 129 \\
\hline 10 & $\begin{array}{l}\text { Ranking de universidades elaborado pela Universidade de } \\
\text { Shanghai Jiao Tong, } 2013\end{array}$ & 131 \\
\hline 11 & $\begin{array}{l}\text { Origem do capital das dez maiores empresas do Brasil em vendas } \\
\text { em 2012, por setor }\end{array}$ & 134 \\
\hline 12 & $\begin{array}{l}\text { Importação de bens de capital em proporção da renda nacional } \\
\text { bruta, 1965-1987 }\end{array}$ & 135 \\
\hline 13 & $\begin{array}{l}\text { Ranking de publicações em períodos científicos indexados, 1993- } \\
2013\end{array}$ & 139 \\
\hline 14 & Nota média dos estudantes na edição do PISA de 2012 & 145 \\
\hline 15 & $\begin{array}{l}\text { Fabricantes de unidades geradoras das principais hidrelétricas no } \\
\text { Brasil }\end{array}$ & 213 \\
\hline 16 & Patentes concedidas pelo INPI, 1990-2010 & 214 \\
\hline 17 & Principais fabricantes de aerogeradores no Brasil, 2012 & 226 \\
\hline 18 & $\begin{array}{l}\text { Cinco maiores usinas hidrelétricas da China e fabricantes das } \\
\text { unidades geradoras }\end{array}$ & 246 \\
\hline 19 & Dez maiores fabricantes mundiais de turbinas eólicas & 253 \\
\hline 20 & Dez maiores fabricantes mundiais, tecnologias selecionadas & 260 \\
\hline 21 & Reatores nucleares em operação na China, 2014 & 263 \\
\hline 22 & Reatores nucleares em operação na Coreia do Sul, 2014 & 266 \\
\hline 23 & Relação entre renda per capita nominal e em PPP, 2013 & 279 \\
\hline 24 & $\begin{array}{l}\text { Participação percentual da indústria no valor adicionado a preços } \\
\text { básicos, 2000-2013 }\end{array}$ & 287 \\
\hline 25 & Reservas internacionais, agosto de 2013 & 289 \\
\hline 26 & $\begin{array}{l}\text { Patentes concedidas pelo UPSTO por residência do beneficiário, } \\
2002-2013\end{array}$ & 297 \\
\hline 27 & $\begin{array}{l}\text { Evolução das patentes de tecnologias limpas concedidas pelo } \\
\text { USPTO, por residência do beneficiário, 2002-2013 }\end{array}$ & 298 \\
\hline
\end{tabular}




\section{ÍNDICE DE GRÁFICOS}

\begin{tabular}{|c|c|c|}
\hline NÚMERO & TÍTULO & PÁGINA \\
\hline 1 & $\begin{array}{l}\text { Conhecimento como fator nas diferenças de renda entre o Brasil e a } \\
\text { Coreia, 1960-2000 }\end{array}$ & 14 \\
\hline 2 & Distribuição do valor por iPhone e por iPad, em 2010 & 17 \\
\hline 3 & Variação da temperatura terrestre, em terra e oceano, $1850-2012$ & 52 \\
\hline 4 & $\begin{array}{l}\text { Mudança do nível dos oceanos e cobertura de gelo no verão ártico, } \\
\text { 1990-2012 }\end{array}$ & 53 \\
\hline 5 & $\begin{array}{l}\text { Mudanças nos gases estufa a partir de concentrações no gelo e } \\
\text { dados recentes }\end{array}$ & 56 \\
\hline 6 & $\begin{array}{l}\text { Emissão global de gases estufa de origem antropogênica, por } \\
\text { setores, } 2010\end{array}$ & 63 \\
\hline 7 & $\begin{array}{l}\text { Concentração de } \mathrm{CO}_{2} \text {-eq e aumento da temperatura para diferentes } \\
\text { cenários }\end{array}$ & 67 \\
\hline 8 & Consumo de eletricidade per capita & 76 \\
\hline 9 & Taxa de desmatamento anual no Brasil, em $\mathrm{km}^{2}$ & 92 \\
\hline 10 & Perfil das emissões de gases estufa no Brasil & 94 \\
\hline 11 & $\begin{array}{l}\text { Emissões brasileiras de gases de efeito estufa, em } \mathrm{CO}_{2} \mathrm{eq}, 1990- \\
2010\end{array}$ & 94 \\
\hline 12 & Expansão da capacidade instalada do Sistema Elétrico Brasileiro & 96 \\
\hline 13 & $\begin{array}{l}\text { Maiores importadores líquidos de petróleo, em milhões de barris } \\
\text { por dia, } 2013\end{array}$ & 101 \\
\hline 14 & Matriz energética de Coreia do Sul e Taiwan, 2013 & 102 \\
\hline 15 & Fontes primárias de energia na China, 2011 & 104 \\
\hline 16 & Consumo e importação de petróleo na China, 1990-2013 & 105 \\
\hline 17 & $\begin{array}{l}\text { Geração de energia média na Califórnia por fonte e demanda } \\
\text { líquida de energia }\end{array}$ & 112 \\
\hline 18 & Geração solar e eólica na Califórnia, em 19 de fevereiro de 2013 & 113 \\
\hline 19 & $\begin{array}{l}\text { Geração solar fotovoltaica em unidade geradora da Califórnia, em } \\
19 \text { de fevereiro de } 2013\end{array}$ & 113 \\
\hline 20 & Nota dos estudantes no teste do PISA & 126 \\
\hline 21 & Aquisição de tecnologias estrangeiras - Coreia do Sul & 135 \\
\hline 22 & Aquisição de tecnologias estrangeiras - Brasil & 135 \\
\hline 23 & Investimento estrangeiro direto, entradas líquidas, em \% do PIB & 136 \\
\hline 24 & Gastos com P\&D, em \% do PIB & 137 \\
\hline 25 & Pesquisadores em P\&D, por milhão de habitantes & 138 \\
\hline 26 & $\begin{array}{l}\text { Patentes registradas por nacionais de países selecionados, 2000- } \\
2013\end{array}$ & 140 \\
\hline 27 & Limites das emissões para evitar aumento superior a $2^{\circ} \mathrm{C}$ & 165 \\
\hline 28 & Créditos certificados para projetos do MDL em cada país sede & 191 \\
\hline 29 & Licenciamento de veículos flex-fuel no Brasil & 218 \\
\hline 30 & $\begin{array}{l}\text { Histórico de vendas de combustíveis no Brasil, em bilhões de } \\
\text { litros/GNV em bilhões de } \mathrm{m}^{3}\end{array}$ & 219 \\
\hline 31 & Importações e exportações de etanol no Brasil & 221 \\
\hline 32 & $\begin{array}{l}\text { Geração eólica no mundo, acumulado e capacidade adicionada em } \\
2013\end{array}$ & 250 \\
\hline 33 & Produção global da indústria fotovoltaica, 2000-2013 & 258 \\
\hline 34 & $\begin{array}{l}\text { Distribuição global de capacidade instalada de energia solar } \\
\text { fotovoltaica, } 2013\end{array}$ & 259 \\
\hline
\end{tabular}




\begin{tabular}{|c|l|c|}
\hline 35 & Crescimento e abundância de recursos naturais, 1970-1989 & 271 \\
\hline 36 & Taxa de câmbio efetiva real e esperada real & 277 \\
\hline 37 & Índice Big Mac para Brasil, Coreia, China e Taiwan, 1999-2012 & 278 \\
\hline 38 & $\begin{array}{l}\text { Taxa de poupança doméstica e uso de poupança externa, em \% do } \\
\text { PIB, 1947-2007 }\end{array}$ & 280 \\
\hline 39 & $\begin{array}{l}\text { Taxa de investimento, poupança interna e poupança externa, em \% } \\
\text { do PIB, 1990-2011 }\end{array}$ & 282 \\
\hline 40 & Preço do minério de ferro, 1992-2007 & 284 \\
\hline 41 & Evolução das alíquotas nominais de importação, 1983-2012 & 286 \\
\hline 42 & $\begin{array}{l}\text { Evolução das patentes de tecnologias limpas concedidas pelo } \\
\text { UPSTO, por residência do beneficiário, 2002-2013 }\end{array}$ & 298 \\
\hline 43 & Investimentos em P\&D por proporção do PIB & 299 \\
\hline 44 & Pesquisadores em P\&D por milhão de pessoas & 299 \\
\hline 45 & $\begin{array}{l}\text { Patenteamento de institutos públicos de pesquisa; Percentual de } \\
\text { patentes requeridas no âmbito do PCT, 2004-2009 }\end{array}$ & 300 \\
\hline 46 & Fontes primárias de energia, 2012 & 301 \\
\hline 47 & Expectativa para o mercado de equipamentos no Brasil em 2023 & 313 \\
\hline 48 & Inovação, manufatura e geração de energia de baixo carbono, 2012 & 322 \\
\hline
\end{tabular}




\section{LISTA DAS PRINCIPAIS SIGLAS E ABREVIAÇÕES}

ANEEL: Agência Nacional de Energia Elétrica

AR4: Fourth Assessment Report (Quarto Relatório de Avaliação) - relatório de 2007 do IPCC que sintetiza a pesquisa científica sobre mudança do clima à época

AR5: Fifth Assessment Report (Quinto Relatório de Avaliação) - relatório de 2014 do IPCC que sintetiza a pesquisa científica sobre mudança do clima à época

BAU: business as usual (maneira habitual de fazer negócios): expressão utilizada para cenários climáticos em que não há mudança relevante na forma operar das empresas

COP: Conferência das Partes

CQNUMC: Convenção Quadro das Nações Unidas sobre Mudança do Clima

EIA/EUA: US Energy Information Administration (Agência de Informação sobre Energia dos Estados Unidos)

EMBRAPII: Associação Brasileira de Pesquisa e Inovação Industrial

EPE: Empresa de Pesquisa Energética

FINEP: Financiadora de Estudos e Projetos

FIT: feed-in tariffs (tarifas de alimentação): tarifas diferenciadas do sistema elétrico que podem ser utilizadas para custear fontes energéticas mais caras, como as renováveis

IED: investimento estrangeiro direto

INEP: Instituto Nacional de Estudos Educacionais Anísio Teixeira

INPI: Instituto Nacional de Propriedade Industrial

IOE: industrialização orientada para a exportação

IPCC: Intergovernmental Panel on Climate Change (Painel Intergovernamental sobre Mudança do Clima)

ISI: industrialização por substituição de importação

LNG: liquefied natural gas (gás natural liquefeito)

LULUCF: land use, land use change and forestry (gestão do uso da terra, mudanças no uso da terra e silvicultura)

MCTI: Ministério da Ciência, Tecnologia e Inovação

MDL: Mecanismo de Desenvolvimento Limpo

MEC: Ministério da Educação

OCDE: Organização para a Cooperação e Desenvolvimento Econômico

OMC: Organização Mundial do Comércio

P\&D: pesquisa e desenvolvimento

PCH: Pequena Central Hidrelétrica

PDE: Plano Decenal de Expansão de Energia

PISA: Programme for International Student Assessment (Programa de Avaliação Internacional de Estudantes)

PTF: Produtividade Total dos Fatores

REC: Renewable Energy Certificate (Certificado de Energia Renovável)

RPS: Renewable Portfolio Standard (Quota de Energia Renovável)

USPTO: United States Patents and Trademark Office (Escritório de Propriedade Industrial dos Estados Unidos)

TRIPS: Agreement on Trade-Related Aspects of Intellectual Property Rights (Acordo sobre Aspectos dos Direitos de Propriedade Intelectual Relacionados ao Comércio) 


\section{SUMÁRIO}

CAPÍTULO 1

DESENVOLVIMENTO ECONÔMICO E O REGIME INTERNACIONAL DE PATENTES

1.1. Progresso tecnológico e desenvolvimento econômico .........................................10

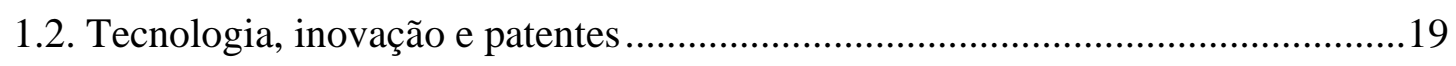

1.3. Evolução dos tratados internacionais sobre propriedade intelectual .....................24

1.4. Instrumentos estatais de fomento à pesquisa e à tecnologia................................34

CAPÍTULO 2

REGIME INTERNACIONAL EM FORMAÇÃO PARA A MUDANÇA CLIMÁTICA

2.1. O nascimento do regime climático internacional: a Convenção da ONU sobre Mudanças Climáticas e o Protocolo de Quioto ...........................................................4

2.2. As evidências científicas do fenômeno e de suas possíveis soluções....................50

2.3. Últimos acontecimentos na formação do regime climático e perspectivas das

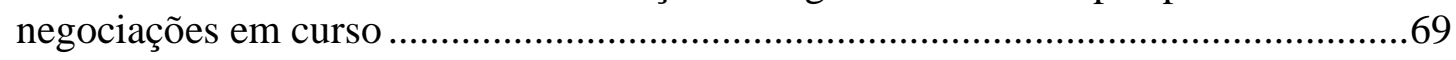

2.4. Posição dos países selecionados no debate (Brasil, Coreia, Taiwan, China) .......81

CAPÍTULO 3 90

GERAÇÃO DE ENERGIA E EMISSÃO DE GASES ESTUFA: LIMITES E POTENCIAIS

3.1. A abundância de fontes de energia no Brasil e a situação de relativo conforto para conter as emissões.

3.2. A carência de fontes energéticas limpas na Coreia, Taiwan e China e a centralidade do setor de energia em suas emissões de gases estufa . .98

3.3. É real o receio de restrições decorrentes do regime de mudança climática?......107

3.4. Os desafios associados às novas renováveis

CAPÍTULO 4

APRENDIZADO TECNOLÓGICO EM PAÍSES DE INDUSTRIALIZAÇÃO TARDIA

4.1. Diferenças entre aprendizado tecnológico passivo e ativo

4.2. Brasil e o aprendizado passivo 126

4.3. Coreia, Taiwan e China e o aprendizado ativo.

4.4. A industrialização e a incorporação de tecnologia como um projeto nacional ..156

4.5. Energia de baixo carbono e o nascimento da uma nova indústria. 163 
COMO FOMENTAR NOVAS TECNOLOGIAS? POLÍTICAS PÚBLICAS NO SETOR DE ENERGIA EM PAÍSES DE INDUSTRIALIZAÇÃO TARDIA

5.1. Por que a mudança climática não se resolve pelo mercado? ..............................169

5.2. Panorama das políticas públicas para energia de baixo carbono.........................177

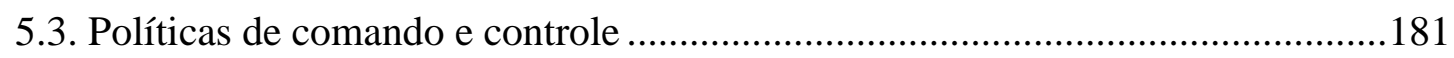

5.4. Privatização do bem comum: definição de teto e comércio de licenças para

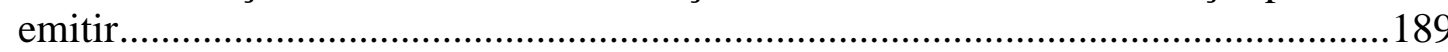

5.5. Incentivos e desincentivos econômicos ...........................................................193

5.6. Medidas preponderantemente de política industrial e tecnológica......................200

5.7. Custos e benefícios das medidas: quem se favorece e quem arca com o ônus ..205

CAPÍTULO 6

AS NOVAS TECNOLOGIAS DE ENERGIA LIMPA NOS PAÍSES EXAMINADOS

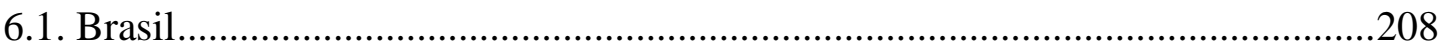

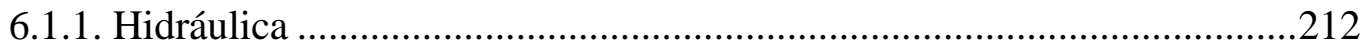

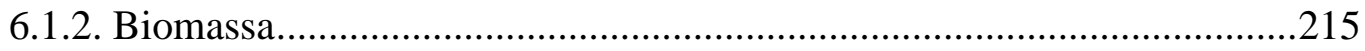

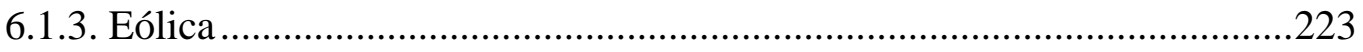

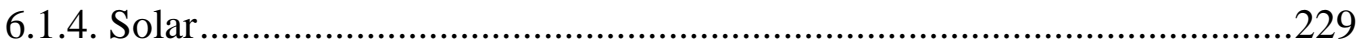

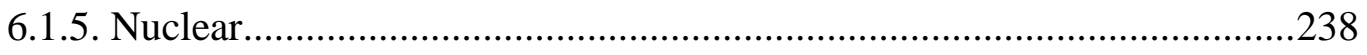

6.2. O contraste com os casos de China, Coreia e Taiwan ......................................243

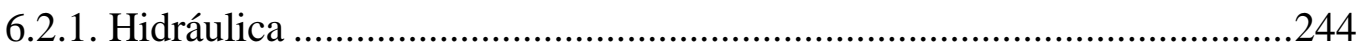

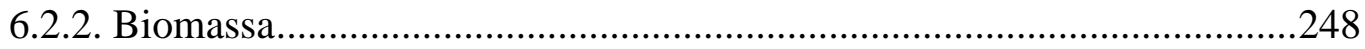

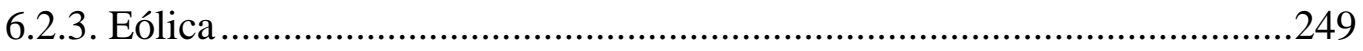

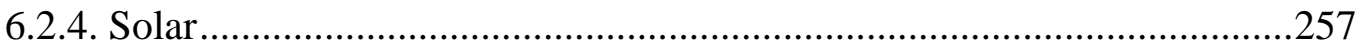

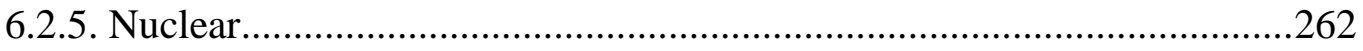

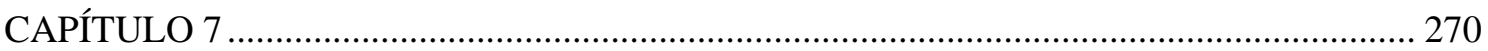

DOENÇA HOLANDESA E SEUS EFEITOS NAS MANUFATURAS DE ENERGIA NO BRASIL E NA BUSCA DE LIDERANÇA TECNOLÓGICA

7.1. Paradoxo da plenitude: como funciona a maldição dos recursos naturais .........270

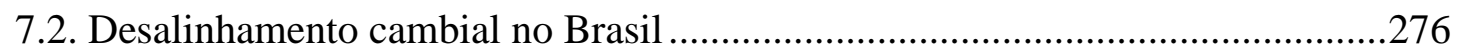

7.3. Desalinhamento cambial e limitação da poupança doméstica............................280

7.4. Desindustrialização precoce no Brasil..............................................................283

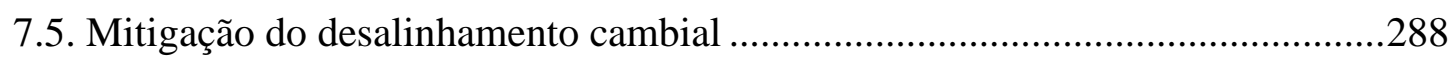

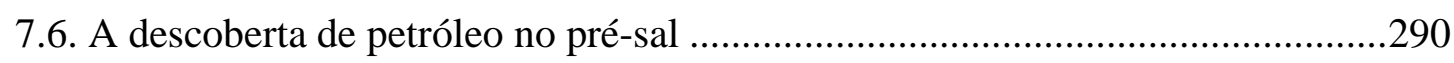


MODERNIZAÇÃO INDUSTRIAL DEPENDENTE E AUTONOMISTA NO SETOR DE ENERGIA

8.1. Síntese dos principais indicadores de energia renovável nos países selecionados

8.2. Crença dos agentes: percepção dos dirigentes nacionais sobre a relevância do tema e a oportunidade existente.

8.3. A modernização dependente: os riscos de reprodução do aprendizado passivo na nova indústria de energia de baixo carbono

8.4. Indicador sintético para mensurar situação do setor de energia de baixo carbono 


\section{INTRODUÇÃO}

Esta tese de doutorado tem por objetivo comparar como Brasil, Coreia do Sul, China e Taiwan estão se preparando, no campo das tecnologias de geração de energia com baixa emissão de carbono, para enfrentar os obstáculos postos pelo novo cenário internacional marcado por mudanças climáticas.

Embora ainda não esteja claro que tipo de regime internacional sucederá ao Protocolo de Quioto, de 1997, pode-se afirmar já ser bastante evidente que todos os países, incluindo aqueles em desenvolvimento, estão sendo induzidos a reduzir suas emissões de gases de efeito estufa. Esse processo de indução tende a se tornar mais vinculante nos próximos anos. Até o momento, em vez de um acordo internacional juridicamente vinculante para diminuir as emissões globais de gases estufa, prevalecem os esforços domésticos isolados de algumas nações, o que sugere a formação de um regime por meio do chamado modelo bottom-up.

Nesse contexto, o setor de energia é crucial, uma vez que ele responde por uma parcela significativa das emissões de gases estufa de origem antropogênica. Por essa razão, a geração de energia com baixa emissão de carbono é apontada como uma das mais importantes medidas para a mitigação das mudanças climáticas. As tecnologias para a produção em larga escala de energias de baixo carbono é, portanto, decisiva para o fortalecimento das economias nacionais nesse contexto de restrições crescentes ao uso de fontes poluentes. As empresas e as nações que obtiverem as melhores tecnologias tendem a usufruir as vantagens de liderar a corrida tecnológica nesse campo.

Cerca de metade da energia gerada no Brasil se origina de fontes limpas, e não de combustíveis fósseis - o carvão, por exemplo, que é fundamental em vários países, no Brasil contribui com menos de $2 \%$ do total. A produção hidráulica responde por aproximadamente $85 \%$ do total da capacidade instalada de eletricidade no país, mas essa tecnologia já está razoavelmente consolidada e enfrenta obstáculos naturais e políticos para seguir acrescentando capacidade de geração. Ainda que exista alguma geração nacional de energia solar, eólica e nuclear, elas fornecem uma contribuição relativamente acanhada para o conjunto da matriz energética brasileira. Existe ainda uma participação relevante da biomassa, conquanto essa contribuição seja ainda primordialmente baseada em tecnologias de primeira geração.

O Brasil conseguiu promover um processo de industrialização tardia a partir de meados do século XX. Muito embora o país tenha logrado formar um setor industrial amplo e 
diversificado, as tecnologias utilizadas foram incorporadas principalmente mediante investimentos estrangeiros diretos e, secundariamente, mediante importação de maquinarias e equipamentos, ou mesmo pelo licenciamento de tecnologias estrangeiras. Diferentemente de países como a Coreia do Sul, que absorveram tecnologias estrangeiras e criaram inovações a partir delas, uma parcela significativa do setor industrial brasileiro ainda é fortemente dependente da importação de tecnologias, inclusive o setor de energia.

Até a aprovação do Acordo TRIPS sobre propriedade intelectual, os países em desenvolvimento podiam fazer uso desimpedido da imitação de produtos estrangeiros e da engenharia reversa ${ }^{1}$. Essas práticas foram significativamente limitadas por esse acordo internacional, que obrigou essas nações a adotar novas estratégias para a absorção e o desenvolvimento de novas tecnologias, como a aproximação entre universidades e indústrias.

Esta pesquisa tem por objetivo comparar a produção de tecnologias para geração de energia de baixo carbono no Brasil e em outros países de industrialização tardia. O período central de análise vai de 1997, quando foi assinado o Protocolo de Quioto, até 2014. Foi ao longo dessa época que a inevitabilidade das mudanças climáticas se tornou mais clara e as novas regras internacionais sobre patentes foram implantadas no nível doméstico.

A pesquisa se originou com a hipótese de que, favorecido por condições naturais (amplo potencial hidrelétrico disponível, terras aráveis para biomassa e vastas reservas de petróleo recém descobertas), o governo brasileiro não encorajou - na mesma intensidade que outros - o desenvolvimento de inovações tecnológicas em fontes energéticas de baixo carbono. Ao contrário, a hipótese é que o Brasil mantém a estratégia de expandir sua geração de energia com praticamente as mesmas fontes e tecnologias utilizadas ao longo do século XX.

Inversamente, os demais países examinados estariam promovendo investimentos mais intensos em energias limpas, uma vez que anteveem restrições que tendem a ser postas pelo regime internacional de mudança climática e constatam a carência interna de fontes primárias com baixa emissão de carbono.

Busca-se, para tanto, reunir, sistematizar e analisar informações a respeito dos investimentos no campo de inovações em energias descarbonizantes promovidos por outros países de industrialização tardia - um tema que deve ser determinante para a economia do século XXI, marcada por crescentes incertezas associadas ao aquecimento global.

\footnotetext{
${ }^{1}$ Engenharia reversa consiste num método de desvendar o processo de fabricação de um bem por meio de experimentos com o produto final, desmontando-o e remontando-o, a fim de compreender seu funcionamento e poder reproduzi-lo.
} 
Como aponta LIJPHART (1971), a pesquisa comparada nas ciências sociais é um dos métodos científicos à disposição do pesquisador, ao lado do método experimental, estatístico e dos estudos de caso. O método permite realçar as similitudes e as distinções entre os países a serem comparados, dadas as dificuldades em realização de pesquisas experimentais em ciências sociais e dada a insuficiência de dados para a utilização ampla de métodos estatísticos.

Nesse sentido, a pesquisa permite descobrir relações empíricas entre as variáveis examinadas dos países comparados. No caso em questão, temos como variável dependente a produção de inovação tecnológica em cada país na área de energia de baixo carbono. $\mathrm{O}$ indicador é principalmente medido por meio de patentes, embora indiretamente esteja relacionado com a manufatura local de equipamentos para o setor. Como variáveis independentes, podem ser apontadas as políticas públicas que favorecem as energias de baixo carbono - como tributos sobre o carbono e quotas para fontes renováveis - e também a disponibilidade de recursos naturais.

Além do Brasil, esta pesquisa comparada focaliza especialmente a Coreia do Sul, a China e Taiwan. A escolha dessas três últimas nações se deve ao fato de serem também caracterizadas como economias de industrialização tardia e por terem lançado mão de iniciativas consideradas arrojadas no campo das tecnologias limpas. As políticas públicas adotadas por esses países servem, por conseguinte, como um interessante parâmetro de comparação com as medidas concebidas e executadas no Brasil.

Para realizar essa comparação, o que se pretende examinar são alguns indicadores de tecnologia para geração de energia de baixo carbono, tais como a participação dos investimentos estrangeiros no setor de energia, a manufatura de equipamentos para o uso no setor energético, os sistemas governamentais de incentivos para fontes limpas e ainda o papel das pesquisas acadêmicas e suas conexões com o setor industrial.

Como fontes de energia com baixa emissão de carbono, a pesquisa baseou-se nas fontes hidráulica, biomassa, eólica, solar e nuclear. Os combustíveis fósseis (particularmente carvão, petróleo e gás natural) foram descartados por não constituírem fontes de baixa emissão de carbono. A despeito do desenvolvimento de tecnologia para captura e estocagem de carbono na queima dessas fontes fósseis, a tecnologia ainda está em estágio experimental e seu custo está bem distante de torná-la comercialmente viável no futuro próximo. No que tange a outras fontes de baixo carbono, como energia geotérmica, elas não estão no centro dinâmico das pesquisas e das inovações em curso e dificilmente sua utilização poderia ser base para países com maior dimensão populacional. 
As fontes da pesquisa são principalmente secundárias, oriundas de relatórios sobre geração de energia e sobre atividades manufatureiras organizados principalmente por órgãos governamentais dos países examinados, por organizações internacionais e ainda por associações de produtores (tais como as associações de fabricantes de produtos eólicos e solar).

Afora essas fontes, foram realizadas entrevistas com empresários e com gerentes de empresas do setor no Brasil. A pesquisa também se valeu da aplicação de survey com autoridades do governo brasileiro, buscando aferir percepções sobre o fenômeno da mudança climática e da inovação tecnológica na área de energia de baixo carbono. Malograram, entretanto, as tentativas de realizar entrevistas e survey com empresários e representantes governamentais sulcoreanos, chineses e taiwaneses, embora alguns acadêmicos desses países tenham participado de entrevistas.

Por se tratar de tema extremamente atual, nem sempre as fontes para certas informações mais recentes estavam já consolidadas em relatórios oficiais ou em artigos acadêmicos. Por isso, em casos pontuais, recorremos também a reportagens jornalísticas que traziam informações úteis à compreensão de certos acontecimentos.

No Capítulo 1, fazemos uma análise a respeito do papel da tecnologia para o desenvolvimento econômico de longo prazo. A revisão de literatura sobre o tema realça a importância do surgimento de novas tecnologias para garantir crescimento econômico e elevação da renda e do bem-estar da população. Também examinamos a evolução do regime internacional de patentes e os reflexos da mudança do regime sobre as estratégias de desenvolvimento econômico dos países de industrialização tardia.

Em seguida, no Capítulo 2, examinamos o cenário de mudanças climáticas, abordando as evidências científicas disponíveis e o tortuoso processo de formação de um regime internacional a respeito do tema. Realçamos a gradual criação de um regime de mudança climática que, já no presente, induz o crescimento rumo a tecnologias de baixo carbono, embora ainda com estímulos limitados.

No Capítulo 3, fazemos um balanço da situação dos quatro países examinados em termos de geração de energia e de emissão de gases estufa. Ele confirma o relativa conforto brasileiro por dispor de uma matriz energética comparativamente mais limpa e o espaço para reduzir as emissões por meio do desmatamento e da agricultura. No caso dos asiáticos, fica evidenciada a alta intensidade de carbono, a dependência de importação e os riscos que um regime de restrição ao carbono imporia às economias de cada um deles.

Passamos, então, já no Capítulo 4, à comparação entre as diferentes trajetórias para a formação do setor industrial de cada país. Enquanto que no Brasil prevaleceu um 
ambiente de aprendizado tecnológico passivo, caracterizado pela mão-de-obra relativamente pouco qualificada, investimentos em subsidiárias integrais de empresas estrangeiras e baixo engajamento em atividades de pesquisa, os países asiáticos em questão adotaram rumo diverso. Ainda que em níveis distintos em cada país, lá prevaleceu o aprendizado tecnológico ativo, marcado pela qualificação crescente da mão-de-obra, prevalência de empresas nacionais absorvendo tecnologia estrangeira e crescente envolvimento em pesquisa.

Em cima desse parque industrial diferenciado, examinamos no Capítulo 5 as políticas públicas adotadas nas últimas duas décadas com foco em enfrentar o problema da mudança climática e em fomentar tecnologias de baixo carbono. Além das diferentes opções de políticas públicas disponíveis, procuramos as opções feitas por cada país e as vantagens e desvantagens de cada escolha.

No Capítulo 6, procuramos detalhar como as nações examinadas se encontram em relação às cinco principais fontes de baixo carbono: hidráulica, biomassa, eólica, solar e nuclear. Fazemos uma análise com foco especial na capacidade de manufatura das empresas sediadas nesses países, de modo a avaliar o grau de aprendizado tecnológico e a capacidade de disputar globalmente a liderança em inovação nessas áreas.

Já no Capítulo 7 examinamos a relação da indústria de baixo carbono com a questão do paradoxo da plenitude, ou da maldição dos recursos naturais. Além de examinar a literatura na área, argumentamos que a abundância de recursos naturais no Brasil contribuiu para a existência de uma indústria pouco competitiva em razão da tendência recorrente à apreciação cambial. Além disso, no caso particular dos recursos energéticos, o Brasil também direcionou seus recursos para fontes tradicionais de energia, em particular para o petróleo do pré-sal, reduzindo o esforço então em curso de fortalecimento da indústria local de biomassa.

Por fim, no Capítulo 8, procuramos sintetizar os principais elementos da pesquisa. Confirmamos que os quatro países conseguiram, também na área de energia de baixo carbono, erigir um setor industrial avançado. Entretanto, nesse setor o Brasil vem confirmando o padrão de aprendizado tecnológico passivo, baseando-se principalmente na importação de tecnologias estrangeiras - à exceção do setor de biomassa. Já os três asiáticos examinados mantêm o padrão de aprendizado ativo: suas empresas ingressaram tardiamente no setor, mas várias delas já estão entre as maiores fabricantes mundiais e com atividades de inovação e de patenteamento significativa.

Em arremate, confirmamos em parte a hipótese de que o Brasil adotou um modelo de industrialização passiva no campo do baixo carbono. Embora a afirmação seja válida para a maior parte das fontes, despontam algumas áreas com maior intensidade 
tecnológica desenvolvida no Brasil, como o setor de biomassa e mesmo algumas poucas empresas no campo eólico e hidráulico.

Quanto a China, Coreia e Taiwan, a despeito do progresso de algumas de suas empresas em energias de baixo carbono, o avanço não é uniforme e o uso de fontes com baixa emissão ainda não se concretizou em larga escala no nível doméstico. Embora estejam hoje mais bem situados para um eventual regime internacional limitador de emissões, os países não têm adotado as novas fontes internamente, continuam vulneráveis à importação de combustíveis fósseis e mantêm o padrão de elevada emissão de carbono. 


\section{CAPÍTULO 1 \\ DESENVOLVIMENTO ECONÔMICO E \\ O REGIME INTERNACIONAL DE PATENTES}

\subsection{Progresso tecnológico e desenvolvimento econômico}

Busca-se, neste capítulo, analisar a relação entre desenvolvimento econômico, inovação tecnológica e propriedade industrial. Para tanto, faz-se uso da análise por mim realizada em "Inovação no Brasil e na Coreia do Sul: os efeitos do novo regime internacional de patentes sobre as estratégias de desenvolvimento econômico" (DUBEUX, 2010).

O desenvolvimento da pesquisa científica e da inovação é um dos pilares para assegurar o desenvolvimento econômico dos países. É crescente a preocupação com a qualidade do crescimento econômico das nações diante do intenso processo de inovação por que passam as diversas cadeias produtivas. Os avanços tecnológicos, quase sempre decorrentes de avanços científicos, têm proporcionado um ritmo veloz e intenso de mudanças, provocando um processo de inovação extremamente dinâmico e, em alguns casos, aprofundando a defasagem tecnológica existente e criando outras.

O tema, entretanto, não é novo. Os fatores que levam ao crescimento econômico são objeto de estudo da economia desde seus primórdios. Tanto Adam SMITH (1723-1790), quanto Karl MARX (1818-1883) versaram sobre o crescimento econômico e sobre fatores que impulsionavam os avanços na produtividade da economia, notadamente o capital e o trabalho.

Foi a partir dos trabalhos de Joseph SCHUMPETER (1883-1950), na primeira metade do século XX, que a tecnologia passou a ser considerada fator essencial para a trajetória do crescimento. Em sua obra "Capitalismo, Socialismo e Democracia", publicada originalmente em 1942, o autor redigiu um curto Capítulo VII, que até hoje serve de ponto de partida para as teorias evolucionárias do crescimento (SCHUMPETER, 1975). Nas seis páginas desse capítulo, intitulado "O Processo de Destruição Criativa”, o autor critica a visão de que o crescimento econômico é um processo estacionário e equilibrado, defendendo que, na verdade, ocorre um processo evolutivo e repleto de desequilíbrios.

Segundo SCHUMPETER, o capitalismo é por natureza um método de mudança econômica e nunca poderá ser estacionário. $\mathrm{O}$ autor enfatiza que as mudanças não decorrem 
meramente das sucessões de fatos naturais e sociais (guerras, revoluções, catástrofes, etc.), isto é, esses fatos condicionam as mudanças industriais, mas não são os fatores centrais. Tampouco o caráter evolutivo se deve aos aumentos quase automáticos da população, do capital ou do sistema monetário. O impulso fundamental que determina e mantém a máquina econômica em movimento provém dos novos produtos, dos novos métodos de produção e de transporte, dos novos mercados e das novas formas de organização industrial que os empreendedores criam.

Assim, o autor conclui haver um processo permanente de destruição criativa, pelo qual as estruturas econômicas são modificadas por dentro, incessantemente destruindo as velhas e criando novas. Para SCHUMPETER, constituem uma história de revoluções as mudanças verificadas, por exemplo, nos aparatos produtivos de uma fazenda, do início do sistema racionalizado de rotação de colheitas e de arado até os modernos mecanismos da agricultura mecanizada e das autoestradas. O mesmo se constata na estrutura produtiva da indústria do ferro e do aço, no setor energético baseado no carvão ou nos cursos d'água, assim como nos transportes, passando das carruagens aos aviões. A abertura de novos mercados (nacionais ou estrangeiros), a estrutura organizacional (dos ofícios às fábricas), tudo isso indica o mesmo processo de mutação industrial.

Daí por que, para o citado autor, a análise de uma indústria isoladamente, pode clarificar detalhes de seus mecanismos, mas é inconclusiva para além dela. Afinal, o processo de destruição criativa por vezes faz desaparecer setores inteiros de uma economia em razão do desenvolvimento de outro mais moderno. Um exemplo notório é o telégrafo, instrumento hoje inteiramente obsoleto e substituído por diversos outros métodos de comunicação em tudo superiores: mais rápidos, mais seguros e mais econômicos.

SCHUMPETER destaca ainda que, embora a revolução seja incessante, há momentos mais intensos e outros de relativa calmaria. Conquanto o processo esteja sempre em curso - no sentido de que sempre há revolução ou absorção de seus resultados -, podem ser constatados ciclos econômicos.

Com base nessa análise, o autor também critica a análise tradicionalmente feita a respeito da concorrência, em geral baseada apenas no critério de preços. Mesmo considerando parâmetros mais amplos para a competição, como qualidade e métodos de venda, o autor ainda os julga rígidos e não correspondentes à realidade da disputa: o que realmente conta é a competição de novos produtos, novas tecnologias, novas fontes de suprimento, novos tipos de organização (organização de larga escala, por exemplo). Essas inovações é que provocam alterações substantivas nos preços e na qualidade e repercutem na sobrevivência das empresas, ao passo que a competição tradicionalmente discutida é meramente marginal na taxa de lucro 
das empresas. O autor compara a competição tradicional a um arrombamento de porta, ao passo que a corrida da inovação seria equivalente a um bombardeio. É esta que, no longo prazo, traz repercussões relevantes.

Outro autor que merece destaque no estudo do crescimento econômico é o norteamericano Robert SOLOW. Em artigos publicados na década de 1950, ele propôs uma nova teoria do crescimento, indicando que o progresso tecnológico produz mais efeitos do que o aumento do capital ou da força de trabalho ${ }^{2}$.

SOLOW defendeu que o investimento em máquinas não pode ser uma fonte de crescimento no longo prazo. Argumentou ainda que, com o transcorrer dos anos, a única fonte de crescimento possível é a mudança tecnológica. Ainda segundo o economista, em artigo publicado em 1957, a mudança tecnológica respondeu por sete oitavos do crescimento dos Estados Unidos por operário, durante a primeira metade do século XX.

Para compreender o raciocínio de SOLOW, convém fazer uma breve explicação da teoria tradicional do crescimento, baseada no modelo de crescimento de HARROD$\mathrm{DOMAR}^{3}$, em que o investimento é o elemento chave.

Segundo essa visão, para produzir crescimento econômico, é preciso investir em mais máquinas. Quanto mais máquinas, maior a produção. Ocorre que o aspecto relevante do crescimento econômico é o aumento da produção por trabalhador, já que isso é que permitiria elevar o nível de bem-estar da população, e não propriamente o crescimento da produção absoluta. Para permitir que todos possam desfrutar de bons padrões de vida, é necessário que a produção aumente por trabalhador, e não de modo agregado.

Como a produção se baseia essencialmente em maquinaria e em trabalhadores, o aumento do número de máquinas implicaria fazer cada trabalhador operar mais de uma máquina (ou mais de uma etapa em cada máquina). Ocorre que há um limite para o aumento da capacidade individual de trabalho, sob pena de se estabelecer a alucinada situação do personagem do clássico filme "Tempos Modernos", de Charles Chaplin. À medida que se aproxima o limite exigível de cada trabalhador, o aumento das máquinas gera rendimentos decrescentes por pessoa. O rendimento de cada máquina adicional será cada vez menor. Daí os elementos de sua teoria de rendimentos decrescentes para trabalho e máquina separadamente, e os retornos constantes de escala para o aumento conjugado de capital e de trabalho.

\footnotetext{
2 Os dois artigos mais importantes de Solow sobre o tema foram "A contribution to the Theory of Economic Growth" (1956) e "Technical Change and the Aggregate Production Funcition" (1957).

${ }^{3} \mathrm{O}$ modelo conhecido por Harrod-Domar, desenvolvido separadamente por Sir Roy Harrod e Evsey Domar, baseia-se na ideia de que a produção depende de capital e de trabalho, de modo que o aumento do investimento gera acumulação de capital e, portanto, é o principal fator do crescimento econômico.
} 
Apesar dessa análise, o fato observável é que as economias vinham crescendo há décadas, sem que o ritmo decaísse. Em outras palavras, não se verificava aparentemente o rendimento decrescente de escala esperado. SOLOW concluiu, então, que o fator decisivo para a continuidade do crescimento era a mudança tecnológica, que permitira novos arranjos de forma que a produção rendesse mais por cada trabalhador envolvido no processo. $\mathrm{O}$ salto tecnológico contrabalançaria os rendimentos decrescentes de cada trabalhador por máquina, já que a mudança tecnológica economizaria o ingrediente do qual se dispõe de suprimento fixo, a mão-de-obra.

Para aplicar o modelo à economia de um país, seria necessário analisar o incremento de capital e de trabalho ao longo do tempo. A soma dos dois, contudo, não explica boa parte de todo o crescimento verificado. Essa diferença é o que se passou a denominar "resíduo de Solow", atribuído ao avanço da produtividade decorrente da inovação tecnológica. Daí por que SOLOW, como assessor econômico de alguns governos norte-americanos na década de 1960, propunha o aumento do investimento em pesquisas científicas para acelerar o crescimento no longo prazo.

Cabe examinar, portanto, de que modo ocorreria esse avanço tecnológico, isto é, por que uma economia pode apresentar melhor desempenho do que outra que dispõe de insumos de capital e de trabalho semelhantes (BANCO MUNDIAL, 2008). A Produtividade Total dos Fatores (PTF) seria o conceito que abrangeria essas mudanças de produtividade, incluindo melhorias no nível educacional, na capacitação e na tecnologia.

Exemplo interessante dessa diferença na PTF de duas economias pode ser verificado nos casos do Brasil e da Coreia do Sul, duas das nações examinadas nesta pesquisa. Para tanto, é preciso ter em mente que a industrialização tardia desses dois países - entre as décadas de 1930 e 1980 no caso brasileiro e entre 1960 e 1990 no exemplo sulcoreano - foi em larga medida baseada na cópia de tecnologias estrangeiras, especialmente por meio da engenharia reversa. $\mathrm{O}$ rápido ritmo de crescimento dos dois países indica uma trajetória de crescimento do PIB muito semelhante a partir dos anos 1960 e até 1980. A partir dessa data, houve um evidente descolamento na trajetória de cada um: enquanto a economia sul-coreana prosseguiu num compasso veloz de crescimento, a economia brasileira praticamente estagnou.

Nesse período após 1980, os parques industriais de ambos os países estavam se consolidando e iniciava-se uma guinada tecnológica. O Brasil acabou envolto em problemas macroeconômicos graves, relacionados à crise da dívida externa e à hiperinflação. Esse cenário macroeconômico dificultou enormemente o processo de adaptação das empresas às mudanças 
tecnológicas então em curso, do que resultou a quase estagnação da renda per capita nacional por duas décadas.

A Coreia do Sul, por seu turno, conseguiu transitar de uma economia que copiava produtos e processos, para uma economia que produzia sua própria tecnologia. Dessa transição, resultaram imensos ganhos de produtividade, que se revelaram no aumento substancial da renda per capita no país. No início da década de 1980, a renda sul-coreana era inferior à brasileira (US\$ 4.114, contra US\$ 5.198, considerada a paridade do poder de compra de dólares de 1990); em 2000, a renda dos sulcoreanos já era mais do que o dobro da nacional (US\$ 13.985, contra US\$ 5.556 ${ }^{4}$ ).

\section{GRÁFICO 1}

Conhecimento como fator nas diferenças de renda entre o Brasil e a Coreia, 1960-2000

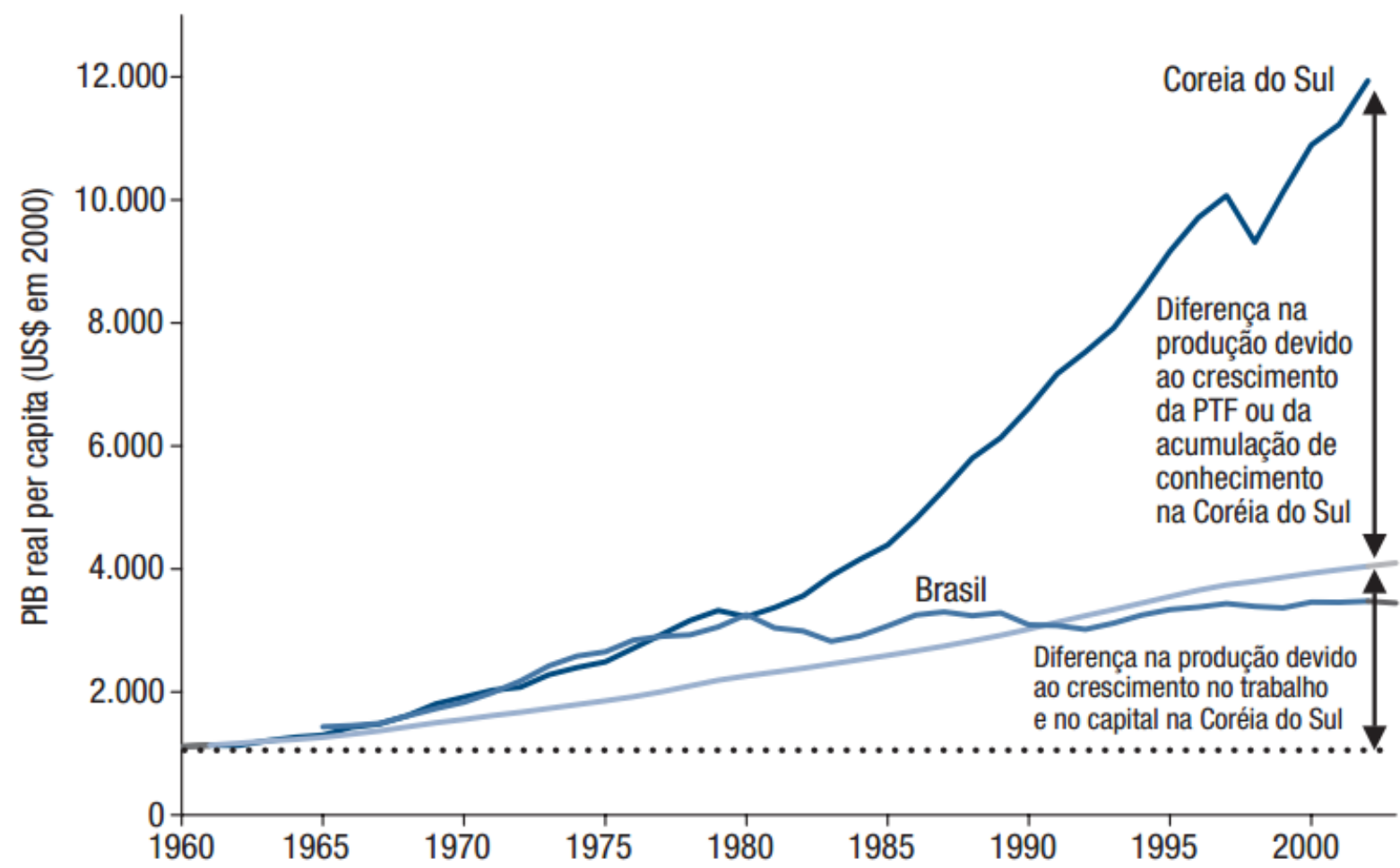

Fonte: Banco Mundial, 2008.

O Gráfico 1 demonstra como o aumento da produtividade da economia sulcoreana suplantou a brasileira a partir dos anos 1980. Mas o gráfico revela, especialmente, o quanto do aumento da economia decorreu da tecnologia, medida como aumento da renda decorrente do aumento da produtividade total dos fatores. Trata-se de dados elaborados pelo

\footnotetext{
${ }^{4}$ Esses valores foram extraídos do levantamento histórico realizado por Angus MADDISON, denominado "Historical Statistics for the World Economy", abrangendo do ano 1 D.C. até 2003, utilizando o denominado Geary-Khamis dollar de 1990, isto é, uma unidade monetária em paridade do poder de compra de 1990.
} 
programa Conhecimento para o Desenvolvimento, do Banco Mundial (Knowledge for Development, K4D, World Bank).

Para a elaboração do Gráfico 1, utiliza-se o método-padrão de contabilidade do crescimento econômico de SOLOW, representando uma estimativa da contribuição relativa de fatores tangíveis - como a acumulação de capital físico e um número maior de anos de escolaridade da força de trabalho - e de fatores ligados ao uso do conhecimento - como a qualidade da educação, o fortalecimento das instituições, a facilidade de disseminar informações técnicas e os recursos organizacionais e administrativos. Nesse modelo, o progresso técnico aumenta o produto potencial de um determinado conjunto de insumos. Avaliações empíricas são aplicadas em seguida para mensurar em que intensidade o crescimento pode ser atribuído ao aumento dos insumos (mais trabalho e mais capital), ou ao uso mais produtivo dos insumos, que correspondente à produtividade total dos fatores (BANCO MUNDIAL, 2008).

De todo modo, é preciso ressalvar que o modelo de SOLOW foi criado para explicar o aumento da renda na economia norte-americana, não sendo necessariamente adequado à análise dos países em desenvolvimento. Afinal, nas economias atrasadas, a mera atualização do parque industrial por máquinas mais modernas já permite ganhos de produtividade substanciais, o que não necessariamente exigirá inovações, mas mera atualização do maquinário para se alinhar aos mais avançados. Trata-se, efetivamente, de um processo de catching up, ou emparelhamento, distinto da estratégia das economias desenvolvidas, que já estão no estado da arte da tecnologia e buscam avançar ainda mais.

Merece destaque, também, mais recentemente, a obra de Richard NELSON a respeito do tema do crescimento econômico. Entre suas várias contribuições, destaca-se, por se relacionar ao tema desta tese, o livro "As fontes do crescimento econômico" (2006), no qual aborda o apoio governamental à pesquisa e desenvolvimento (P\&D).

De fato, como aponta o autor, a partir da Segunda Guerra Mundial, os programas públicos de apoio à $\mathrm{P} \& \mathrm{D}$ têm constituído parte importante da economia nos países desenvolvidos. Uma variedade de órgãos estatais tem dado suporte às atividades de pesquisa por diferentes razões e de diferentes maneiras. O autor, embora reconhecendo o risco de simplificação, classifica essas atividades de apoio em três grupos:

a) aquelas cujo principal propósito é avançar o conhecimento em determinados campos científicos, pelos quais a agência patrocinadora vislumbra a possibilidade de ampliar seus próprios interesses operacionais no longo prazo; 
b) aquelas em que a agência governamental pode ter uma responsabilidade operacional junto com a necessidade de novos e melhores equipamentos; e

c) aquelas que visam a satisfazer as necessidades de curto prazo de um ramo específico ou de um grupo de clientes. Essas três categorias são meros tipos ideais, eis que, na prática, a maior parte das agências públicas atua conjugando umas e outras modalidades.

Nos Estados Unidos, entre as instituições que o autor arrola como financiadoras de pesquisa estão as universidades, a National Science Foundation, os National Institutes of Health, o Departamento de Defesa, a Comissão de Energia Atômica e o Departamento de Energia. NELSON ressalta ainda que todos esses financiamentos são na verdade de pequena escala quando comparados à $\mathrm{P} \& \mathrm{D}$ vinculada às compras governamentais, lideradas pelo Departamento de Defesa.

NELSON ressalta também que, conquanto não tenha sido planejada com esse propósito, a grande aproximação entre o Departamento de Defesa e o setor produtivo foi o fator-chave da supremacia tecnológica e comercial dos Estados Unidos durante os anos 1960 e 1970, especialmente pela criação das tecnologias de uso dual (militar e civil).

Merece observação ainda o tipo de integração existente nas pesquisas financiadas pelo Estado em conjunto com o setor privado. NELSON assinala que elas só passaram a ocorrer em larga escala a partir da Segunda Guerra Mundial. O papel do governo se expandiu largamente desde que SCHUMPETER expôs suas ideias, já que em vários países os governos assumiram a responsabilidade pelo financiamento das pesquisas universitárias e por boa parte do ensino superior de ciências e engenharia. Houve, de certa forma, uma socialização dos riscos relacionados às pesquisas, ou ao menos certa coordenação dos esforços nacionais considerados estratégicos.

NELSON compara, então, o relacionamento de empresas com o setor público nos Estados Unidos e no Japão. Aponta que, no país asiático, há um importante papel do MITI (Ministry of International Trade and Industry), ao traçar diretrizes gerais, coordenação de ações e até mesmo interação entre concorrentes em pesquisas pré-competitivas. Segundo NELSON, a cooperação em pesquisas pré-competitivas (mais genéricas, com resultados de difícil apropriação imediata no mercado) também ocorre nos Estados Unidos, ainda que por mecanismos distintos. Ele aponta que empresas norte-americanas têm sido levadas a se envolver em trabalhos similares, associadas com as universidades.

Esse tipo de mecanismo de cooperação - pelo qual técnicos se reúnem, partilham conhecimentos e ideias sobre os rumos que a tecnologia está tomando e procuram traçar ações coordenadas - também é fortemente verificado na Coreia do Sul. Exemplo 
evidente desse tipo de mecanismo se verificou no caso do desenvolvimento das recentes tecnologias de comunicação (CDMA, WiBro, etc.), com o apoio do ETRI (Electronics and Telecommunications Research Institute).

A título exemplificativo da importância da inovação tecnológica para o aumento da renda nacional, é válido mencionar o estudo de KRAEMER, LINDEN \& DEDRICK (2011) a respeito dos ganhos obtidos ao longo da cadeia de fornecedores do iPhone e do iPad, da empresa Apple. Ambos os produtos são majoritariamente fabricados na China, pela companhia taiwanesa Foxconn. Entretanto, as tecnologias existentes nesses equipamentos foram desenvolvidas em vários países, notadamente nos EUA.

Daí porque, contrariamente à avaliação comum de que os chineses são os grandes beneficiados pela fabricação dos aparelhos, o estudo mostra que os benefícios estão concentrados nos países que desenvolveram as tecnologias, e não no país fabricante. Conforme se observa do Gráfico 2, de cada dólar pago na compra de um produto, apenas $2 \%$ vão para os trabalhadores chineses. Os acionistas da Apple, majoritariamente residentes nos EUA, ficam com 59\% do total no caso do iPhone e $45 \%$ no caso do iPad (incluindo os ganhos com distribuição e varejo). À luz desses dados, faz todo o sentido a expressão "Designed in California - Assembled in China”, inscrita em cada uma das máquinas. Coreanos, japoneses, taiwaneses e europeus também abocanham parcela relevante de cada produto dadas as inovações por eles desenvolvidos e incorporadas em partes do aparelho.

\section{GRÁFICO 2}

Distribuição do valor por iPhone e por iPad, em 2010
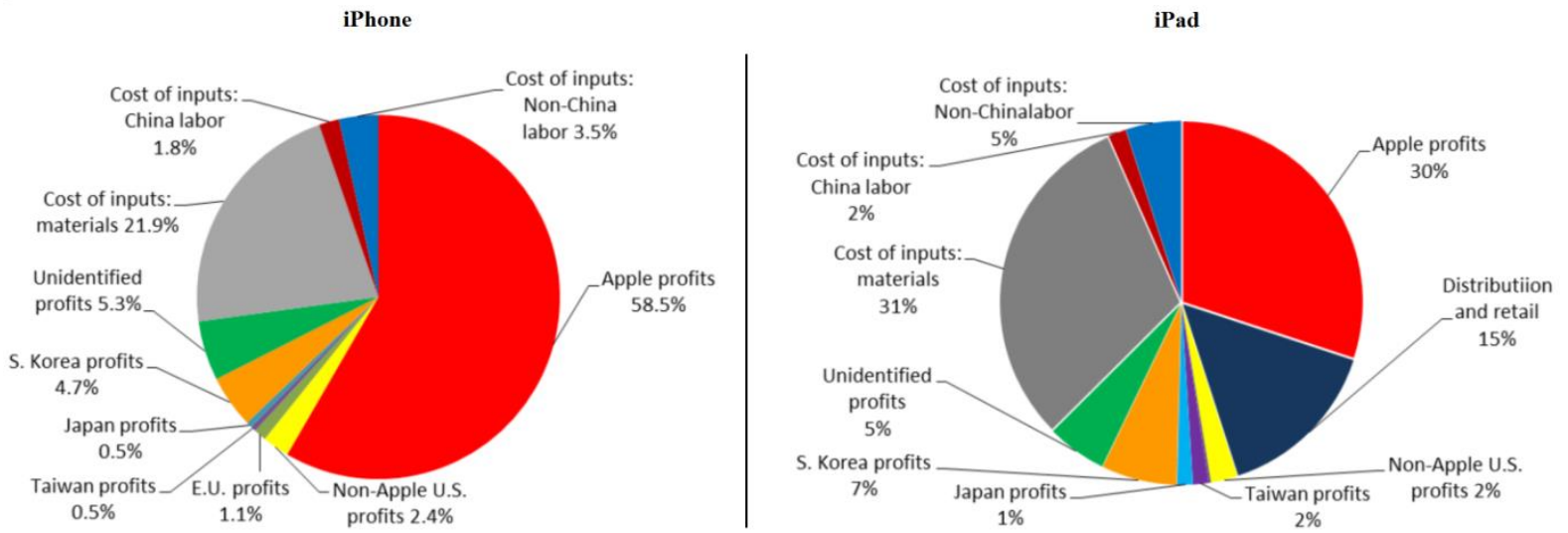

Fonte: KRAEMER, LINDEN \& DEDRICK (2011)

Naturalmente, a distribuição de ganhos nos casos do iPhone e do iPad não podem ser necessariamente estendidos a outros produtos menos intensivos em tecnologias, 
dadas as peculiaridades do setor de TI e a estrutura de mercado em que a Apple está inserida. Mas os casos do iPhone do iPad retratam, de maneira quase caricatural, a vantagem de dispor de uma economia intensiva em tecnologia, e não apenas baseada em montagem industrial.

Vê-se, portanto, que a inovação tecnológica é elemento-chave para assegurar o crescimento econômico de longo prazo. O que se pretende examinar nesta tese são quais os mecanismos capazes de produzir melhores resultados para o país. Nessa análise, dois assuntos centrais devem ser chamados ao debate: a) o papel do Estado no fomento à ciência e tecnologia; e b) o papel da legislação de patentes para países com baixo, médio e alto grau de desenvolvimento econômico.

No caso do Brasil, a Constituição de 1988 disciplina no Título VII a atividade econômica, fixando que cabe ao Estado o papel de agente normativo e regulador e impondo à lei a tarefa de planejar o desenvolvimento nacional equilibrado. A atuação estatal há de compreender o exercício das funções de incentivo e planejamento e também as de fiscalização, podendo manifestar-se como intervenção por absorção, por direção ou por indução (GRAU, 2003). Na análise do sistema de inovação nacional, seria possível afirmar que o Estado atua mediante direção (mecanismos compulsórios) e especialmente por meio da indução, isto é, mediante a criação de estímulos não-cogentes a determinadas atividades.

Considerando a existência de uma economia de mercado no país, a inovação pode ser abordada de três maneiras: a) a socialização dos riscos e custos incorridos para a criação; b) a apropriação privada dos resultados por meio de uma exclusividade artificial (patentes ou direitos autorais); c) pela cumulação dos dois instrumentos anteriores (BARBOSA, 2006).

A criação de mecanismos legais de garantia da propriedade intelectual se presta a estimular o inventor a produzir novos produtos ou processos que permitam usufruir de uma utilidade, conferindo-se-lhe um direito exclusivo, embora temporário, de uso e de exploração da invenção. A criatividade é, assim, estimulada porque garante ao inventor auferir vantagens pecuniárias (PIMENTEL, 1999).

Há autores, porém, que apontam a perniciosidade dos direitos de propriedade intelectual para países com baixo grau de inovação tecnológica. Alegam que os países que hoje apresentam alto grau de desenvolvimento não respeitavam os direitos patentários dos demais até atingirem certa maturidade tecnológica, a partir de quando passaram a reconhecer e a defender os direitos para os inventores (CHANG, 2004). Além disso, continua o argumento, uma legislação patentária muito rigorosa, sem flexibilidade (como o licenciamento 
compulsório), poderia provocar efeitos sociais contrários ao interesse público (MITTELBACH, 2001).

É preciso ressalvar, entretanto, que até poucas décadas atrás não existia pressão substancial dos países desenvolvidos sobre os demais em relação à proteção da propriedade intelectual, já que ainda não estava estruturada a denominada "sociedade do conhecimento". Noutras palavras, no âmbito do estudo das relações internacionais, não existia de forma mais nitidamente caracterizado um regime internacional para a questão da propriedade intelectual. O dramático avanço da importância do conhecimento e da inovação tecnológica como fatores cruciais de progresso e de crescimento das economias trouxe a questão da propriedade intelectual para o cerne das discussões sobre comércio e desenvolvimento.

Conquanto o progresso tecnológico já venha sendo reconhecido há algumas décadas como um importante fator de desenvolvimento econômico, a escala tecnológica, a velocidade das mudanças e sua profundidade estão agora remodelando cada aspecto social, econômico e político (GILPIN, 2001). Desse modo, as taxas de crescimento econômico tornaram-se ainda mais dependentes do que no passado das estratégias das empresas privadas e das políticas públicas nacionais de inovação.

A nova teoria do crescimento baseia-se na assunção de que as mudanças tecnológicas são, geralmente, incrementais num contexto de paradigmas tecnológicos estabilizados. Essa teoria também sugere que, por vezes, podem ocorrer drásticas modificações nas posições relativas de economias nacionais em razão de mudanças tecnológicas mais profundas ("technological leapfrogging") (GILPIN, 2001).

Ao examinar os caminhos trilhados por Brasil, Coreia do Sul, Taiwan e China em resposta à mudança do regime internacional da propriedade intelectual ocorrida a partir dos anos 1980, verificaremos como o progresso tecnológico de alguns deles repercutiu sobre a renda e o bem-estar de seus cidadãos, ao passo que o avanço sutil da produção no Brasil acarretou uma quase estagnação da renda per capita nacional.

\subsection{Tecnologia, inovação e patentes}

Ao se estudar tecnologia e inovação, é possível utilizar diversas abordagens e indicadores. Conquanto vários deles sejam válidos, empregaremos neste trabalho 
fundamentalmente o registro de patentes de invenção. Antes de explicar como funcionam as patentes e por que as utilizaremos como principal indicador de inovação tecnológica, cabe esclarecer os diferentes conceitos com que se trabalha nesse campo.

Tecnologia consiste num aprimoramento técnico para se atingir certa finalidade. Pode-se dizer que, em tempos remotos, a utilização do fogo ou de pedras como instrumentos de defesa e de caça constituiu uma tecnologia, ainda que rudimentar. Trata-se de um mecanismo que permite alcançar determinado objetivo por uma via mais fácil, mais segura ou mesmo mais conveniente.

Já inovação consiste na capacidade de utilizar um novo produto ou processo que não era antes utilizado, ou ao menos não para essa nova finalidade. Trata-se de conceito relacionado à existência anterior de determinado produto. Não necessariamente está relacionado a tecnologia, já que um produto inovador pode não ter base tecnológica.

Como aponta o documento inicial do Observatório de Inovação e Competitividade, do Instituto de Estudos Avançados da Universidade de São Paulo, mais da metade do desempenho da economia dos Estados Unidos e dos países europeus estão associados diretamente à inovação. Inovação, nessa análise, está ligada a processos dinâmicos capazes de transformar uma ideia em um novo serviço ou um produto, em um novo modelo de negócios, ou uma forma de superar um gargalo de gestão. Nessa categorização, está afastada a concepção de que inovação estaria necessariamente ligada unicamente às atividades de alta tecnologia (USP/IEA, 2008).

As patentes, por sua vez, possuem um conceito definido em lei: trata-se de invenção que atenda a três requisitos: novidade, atividade inventiva e aplicação industrial ${ }^{5}$ (art. 8 da Lei no 9.279, de 14 de maio de 1996).

Para que se avalie se a invenção dispõe da característica da novidade, segundo FEDERMAN (2006), a lei impõe o que se denomina de busca de anterioridade, isto é, uma pesquisa para verificar o estado da técnica. Apenas serão concedidas patentes às invenções que não estejam abrangidas pelo estado da técnica. Ainda que a invenção não esteja patenteada no país ou no estrangeiro, se já se tratar de um invento exposto ao público antes do depósito da patente no país, não poderá ser concedido o privilégio. Aquele que, em viagem ao exterior, descobre uma invenção lá disseminada, não terá direito de patenteá-la no país, eis que o estado

\footnotetext{
${ }^{5}$ A legislação brasileira sobre patentes espelha o principal tratado sobre propriedade intelectual (Acordo TRIPS, examinado mais adiante). Esse tratado exige requisitos equivalentes para o patenteamento de uma invenção: "provided that they are new, involve an inventive step and are capable of industrial application" (art. 27 do Acordo). Os demais temas da lei de patentes brasileira abordados no Capítulo também são similares ao tratamento dado pela norma internacional.
} 
da técnica também leva em conta o que é acessível ao público em outros países. De fato, é nesse sentido que dispõe a atual Lei de Patentes brasileira, no art. 11, §§ 1ํㅡ e 2o:

$\S 1$ 1O estado da técnica é constituído por tudo aquilo tornado acessível ao público antes da data de depósito do pedido de patente, por descrição escrita ou oral, por uso ou qualquer outro meio, no Brasil ou no exterior, ressalvado o disposto nos arts. 12, $16 \mathrm{e}$ 17.

$\S 2$ - Para fins de aferição da novidade, o conteúdo completo de pedido depositado no Brasil, e ainda não publicado, será considerado estado da técnica a partir da data de depósito, ou da prioridade reivindicada, desde que venha a ser publicado, mesmo que subseqüentemente.

Além da novidade, será necessário demonstrar a atividade inventiva, característica que será reconhecida se, para um técnico no assunto, a pretensa invenção não decorrer de maneira evidente ou óbvia do estado da técnica (Lei de Patentes: "Art. 13. A invenção é dotada de atividade inventiva sempre que, para um técnico no assunto, não decorra de maneira evidente ou óbvia do estado da técnica"). Cabe, neste ponto, trazer outra vez o exemplo de FEDERMAN: se meio quilo de sal for colocado em uma jarra com um litro de água, o resultado será água salgada. Se nessa jarra forem acrescidos 50 gramas de sal, é evidente que a água ficará mais salgada. Não se pode falar, em relação ao estado da técnica, de nenhuma atividade inventiva nesse acréscimo de 50 gramas de sal. Porém, se hipoteticamente o resultado desse pequeno acréscimo de sal for uma água 'doce', aí sim seria pertinente falar de atividade inventiva, uma vez que, mediante procedimentos conhecidos, teria sido obtido um resultado diferente e inesperado.

Para que se conceda uma patente, é preciso ainda verificar se a invenção apresenta alguma aplicação industrial. Assim, por exemplo, produtos meramente decorativos não são patenteáveis (podem até gozar de outra proteção legal, como o direito autoral, mas não da patente de invenção). Daí por que o art. 10 da Lei de Patentes brasileira veda o patenteamento de teorias científicas, métodos matemáticos, obras literárias e estéticas, regras de jogo, etc.

Por fim, embora não seja um requisito intrínseco à natureza da patente, FEDERMAN alerta que, além dessas três condições intrínsecas para o patenteamento, é preciso acrescentar outra, de ordem formal, relacionada ao pedido de patente: a suficiência descritiva. Trata-se, na verdade, de condição formal para que o pedido de patente seja deferido. Essa é 
uma exigência extremamente relevante, pois é justamente o que legitima o pedido de patente, eis que permite que tanto o examinador de patentes, quanto a sociedade consigam entender e eventualmente reproduzir a invenção. A divulgação da tecnologia é a moeda de troca pela garantia de exclusividade de exploração da invenção.

De fato, como esclarece Denis Borges BARBOSA (2003), como contrapartida pelo acesso do público ao conhecimento dos pontos essenciais do invento, a lei dá ao titular da patente um direito limitado no tempo. O pressuposto é que seria socialmente mais produtiva, em tais condições, a troca da exclusividade de fato (a do segredo da tecnologia) pela exclusividade temporária de direito de exploração. Assim, para concluir a conceituação de patente e sua relação com inovação e tecnologia, transcrevemos a afirmação de BARBOSA: "patente, na formulação clássica, é um direito, conferido pelo Estado, que dá ao seu titular a exclusividade da exploração de uma tecnologia.”

Registre-se ainda que, afora a patente de invenção, sobre a qual discorremos brevemente acima, a legislação prevê também a patente de modelo de utilidade. Segundo a Lei de Patentes (art. 9ํ), "é patenteável como modelo de utilidade o objeto de uso prático, ou parte deste, suscetível de aplicação industrial, que apresente nova forma ou disposição, envolvendo ato inventivo, que resulte em melhoria funcional no seu uso ou em sua fabricação". Como, porém, os modelos de utilidade estão relacionados em regra a mudanças meramente incrementais nos produtos, não os abordaremos nesta pesquisa.

Vale ainda indicar que, para fins de obtenção de apoio por meio dos instrumentos previstos na Lei no 10.973, de 2 de dezembro de 2004 - Lei de Inovação, é preciso utilizar o conceito de "criação", assim definido pelo art. 2º, inciso II, da lei:

II - criação: invenção, modelo de utilidade, desenho industrial, programa de computador, topografia de circuito integrado, nova cultivar ou cultivar essencialmente derivada e qualquer outro desenvolvimento tecnológico que acarrete ou possa acarretar o surgimento de novo produto, processo ou aperfeiçoamento incremental, obtida por um ou mais criadores.

Esse conceito engloba não apenas as patentes (que seriam parte das “invenções”), mas também inovações não-patenteáveis que contenham características tecnológicas.

No que tange ao estágio da evolução dos países rumo à economia do conhecimento, é preciso reconhecer a dificuldade em aferir a intensidade das inovações ou das 
tecnologias. Os melhores indicadores desses conceitos em âmbito nacional somente podem ser obtidos por meio de pesquisas de campo com grande amostragem nacional, de difícil execução no curso de uma tese de doutorado não focada exclusivamente nisso.

Daí por que a utilização de dados consolidados de patentes se revela o melhor instrumento para avaliar a capacidade tecnológica de um país, ainda que esse indicador apresente insuficiências. De fato, o patenteamento em um país não é uma medida inteiramente acurada do grau de inovação presente em sua economia, eis que alguns fatores distorcem uma aferição precisa. Influenciam nesse processo, distorcendo para maior ou menor, a cultura empresarial local, o ramo de atividade econômica, a utilização intensa do segredo industrial em lugar da patente, a estrutura dos órgãos de registro de patentes, o grau de integração das empresas locais com a economia mundial, etc.

Apesar das impropriedades, o registro de patentes, em larga medida, é o principal indicador da produção tecnológica de um país. Como indica o relatório da Fundação de Amparo à Pesquisa do Estado de São Paulo - FAPESP a respeito da produção científica e tecnológica do Estado de São Paulo, "estatísticas de patentes contribuem para a avaliação da dimensão tecnológica de sistemas de inovação" (FAPESP, 2005).

Dessa forma, entende-se que a quantidade de inovação tecnológica produzida nos países analisados, numericamente expressa em patentes, desempenha o papel de variável dependente. Essa dinâmica pode ser aferida com relativa segurança pela variação ao longo dos anos do número de patentes registradas no Escritório de Patentes dos Estados Unidos (USPTO - United States Patent and Trademark Office) relacionadas a energia de baixo carbono. Por outro lado, deve-se considerar os incentivos existentes no país à inovação tecnológica como variáveis independentes. Seriam eles principalmente os benefícios fiscais, as subvenções a setores econômicos, as compras públicas e os investimentos públicos em institutos de ciência e tecnologia.

A legislação patentária de cada país, por sua vez, deve ser considerada historicamente uma variável em larga medida independente (mecanismos de defesa do direito do inventor, tipos de invenções passíveis de patenteamento, grau de proteção das invenções estrangeiras, etc.), uma vez que é tanto fruto de tradições no quadro jurídico interno, quanto de estímulos externos. Entretanto, a partir da mudança do regime internacional na década de 1980 e, especialmente, a partir da adoção do Acordo TRIPS, em 1994, seu papel passa a ser fortemente condicionado por fatores externos, convertendo-se em verdadeira variável de controle, já que houve uniformização das principais regras legais concernentes à propriedade 
industrial - abrangência de praticamente todos os campos tecnológicos e fixação de prazo mínimo para a proteção da patente, conforme se verá adiante.

De fato, a aceitação das regras do Acordo TRIPS permitiu estabelecer uma variável de controle importantíssima, podendo-se aferir seus reflexos na legislação nacional e a influência das outras medidas governamentais sobre a inovação tecnológica de cada país. $\mathrm{Na}$ prática, o Acordo TRIPS deu significativo passo para o estabelecimento de um verdadeiro regime internacional na área da propriedade intelectual ao tornar semelhantes as regras sobre direitos de patente em países diversos. De todo modo, será analisado o período de adoção das regras fixadas pelo Acordo TRIPS e em que medida a pouca flexibilidade permitida pelo acordo foi utilizada por cada um dos países examinados.

\subsection{Evolução dos tratados internacionais sobre propriedade intelectual}

O regime internacional é caracterizado pelo conjunto, implícito ou explícito, de princípios, normas, regras e processos decisórios em torno dos quais convergem as expectativas dos atores em determinado assunto, conforme clássica definição de Stephen KRASNER (1982).

Como aponta KRASNER, ao longo dos anos 1950 e 1960, o estudo das relações internacionais estava centrado nas questões militares, classificadas como high politics (alta política). A partir da década de 1970, porém, diversos fatores contribuíram para a análise de outros aspectos das relações internacionais: a redução da tensão entre os Estados Unidos e a União Soviética, o fim da Guerra do Vietnã, o crescente papel do comércio internacional, os reclamos dos países subdesenvolvidos por uma nova ordem internacional, a formação do cartel dos países produtores de petróleo (OPEP) e o aumento subsequente do preço do produto e também a crise econômica que se abateu sobre as principais economias (a estagflação dos anos 1970). Essa nova situação exigia novas explicações, uma vez que a tradicional análise dos realistas a respeito do jogo de soma zero já não auxiliava tanto a compreensão do mundo, como as previsões futuras.

Foi nesse contexto que os estudos centrados em outros aspectos das relações internacionais (low politics, ou baixa política) passaram a ser valorizados. Economia, diplomacia, meio-ambiente, vários novos temas entraram na agenda. Para a compreensão desse 
fenômeno, o estudo dos regimes internacionais também ingressou na pauta. Daí que esta pesquisa examina como se moldaram as estratégias de desenvolvimento econômico de algumas nações sob as restrições do regime internacional de propriedade industrial e sob o regime em formação de mudança climática, como se verá ao longo dos próximos capítulos.

Tal qual esclarece KRASNER, regimes internacionais não são o mesmo que acordos internacionais. Acordos são, frequentemente, meros arranjos temporários, ao passo que regimes tendem a facilitar acordos e se caracterizam pelo longo prazo. Nesse ponto, cabe examinar o que pode ser caracterizado como mudança de regime. Retomando o conceito de regime apresentado por KRASNER, as mudanças de regimes se caracterizam pelas mudanças de princípios e de normas, e não de regras e de processos decisórios. A modificação desses dois últimos representa alteração dentro do regime, e não mudança do regime.

Para melhor compreender esse argumento, é preciso ter em mente os conceitos envolvidos. Princípios significam crenças sobre fato, causalidades e integridade. Normas são padrões de comportamento definidos em termos de direitos e obrigações. Regras são específicas prescrições ou proscrições de ação. Processos decisórios são as práticas prevalecentes para tomar e para executar decisões coletivas.

No tema de propriedade intelectual, pode-se dizer que houve, nas décadas recentes, uma mudança nos princípios e nas normas que regem o assunto. Como se exporá adiante, de um regime caracterizado quase que apenas pelo princípio do tratamento nacional ${ }^{6}$, passou-se a um regime baseado no respeito rigoroso da propriedade intelectual para o desenvolvimento de todos os países, estabelecendo-se padrões de comportamento rígidos por meio da fixação de direitos e obrigações claros, regras para implantar o novo sistema e novas formas de arbitrar os litígios.

Não se pretende aqui examinar a polêmica teórica a respeito da caracterização dos regimes como variáveis intervenientes ou autônomas. Num modo ou noutro, o importante para esta pesquisa é avaliar a razão do desenvolvimento do regime de propriedade intelectual. KRASNER indica que as causas mais comuns para a formação de regimes seriam o interesse egoístico dos atores, o poder político, normas e princípios, hábitos e costumes e conhecimento.

\footnotetext{
${ }^{6}$ Segundo esse princípio, os nacionais de cada um dos países membros da Convenção deveriam gozar, em todos os outros países membros, da mesma proteção, vantagens e direitos concedidos pela legislação do país a seus nacionais, sem que nenhuma condição de domicílio ou de estabelecimento seja exigida. Assim, vedava-se que os nacionais do país fossem privilegiados em relação aos estrangeiros, mas não se impunha a observância de normas uniformes de patentes, já que o país poderia simplesmente não reconhecer o direito de patentear em determinados ramos econômicos, quer para os nacionais, quer para os estrangeiros.
} 
No caso do novo regime internacional de propriedade intelectual, forjado a partir dos anos 1980 e consolidado no Acordo TRIPS, pode-se dizer que o regime se formou em razão do poder político. O poder político influencia a formação de regimes a serviço do bem comum ou para fortalecer a posição de alguns atores. No caso do Acordo TRIPS, pela forma como ocorreram as negociações para a fixação dessas novas diretrizes, detalhadas mais à frente, pode-se dizer que o novo regime veio à tona para fortalecer a posição dos países que estavam na ponta tecnológica, notadamente os Estados Unidos e as nações europeias. A distribuição assimétrica do poder levou os países desenvolvidos a pressionar as nações em desenvolvimento no sentido de acatar regras rígidas de proteção às patentes, melhorando a posição das nações mais prósperas na arena internacional.

Independentemente do juízo acerca da conveniência da adoção de regras rigorosas de patentes para os países em desenvolvimento, o fato é que um novo regime de propriedade intelectual se estabeleceu nas últimas décadas do século XX. Em lugar de examinar os efeitos positivos ou negativos do novo regime para os países em desenvolvimento $^{7}$, optou-se por estudar como os países adaptaram suas estratégias de progresso tecnológico diante do novo cenário internacional.

Como já se apontou, foi observada substancial alteração no regime da propriedade intelectual a partir de meados da década de 1980, culminando com a aprovação, em 1994, do Acordo Internacional TRIPS (Agreement on Trade-Related Aspects of Intellectual Property Rights). Até então, o regime internacional se baseava fundamentalmente na regra de que, caso garantida a propriedade intelectual aos nacionais do país, seria obrigatório assegurála aos dos demais países integrantes da Convenção de Paris, de 1883 (princípio do tratamento nacional). Faremos a seguir um breve histórico do regime internacional na área, examinando especialmente os principais tratados existentes.

Como resume Breno HERMANN (2004), a concessão de monopólios de exploração das invenções a seus criadores se baseia na ideia de que o inventor deve ser recompensado pela invenção útil à sociedade. Apesar de alguns autores criticarem a proteção das patentes, apontando o risco de restrição à competição e de custos maiores ao consumidor final, há alguns fortes argumentos em favor de sua instituição:

a) o sistema de patentes seria o principal estímulo à criação de novas tecnologias, já que supriria a falta de estímulos ao investimento em pesquisa;

\footnotetext{
${ }^{7}$ Há vários artigos e estudos a respeito dos efeitos do Acordo TRIPS para os países em desenvolvimento, dos quais destacamos os textos elaborados pela UNCTAD (Conferência das Nações Unidas sobre Comércio e Desenvolvimento) e pelo ICTSD (International Centre for Trade and Sustainable Development).
} 
b) o sistema de patentes constituiria uma garantia de proteção a investidores nos países que reconhecem tais direitos imateriais, já que o desenvolvedor do produto não teria como competir com uma empresa que, sem gastos em pesquisa, simplesmente copiasse o novo produto e o comercializasse a preços inferiores; e

c) o sistema de patentes facilitaria a transferência de tecnologia, uma vez que condiciona o privilégio à divulgação dos resultados das pesquisas e cria condições para a negociação de licenças.

Boa parte da literatura, porém, reconhece que não existe um nível ótimo de proteção à propriedade intelectual para todos os países e para todos os setores econômicos. A depender da área e do grau de desenvolvimento, a proteção ou a imitação pode provocar resultados mais positivos.

Embora a literatura faça referência a direitos de propriedade intelectual em séculos anteriores - mesmo o Brasil já previa a patente em Alvará de 28 de abril de 1809, editado por Dom João VI, tornando o país um dos quatro primeiros países no mundo a ter legislação sobre o tema (BARBOSA, 2003) -, os dois primeiros instrumentos de abrangência internacional sobre esse assunto datam do fim do século XIX: para a propriedade industrial foi elaborada a Convenção de Paris, em 1883; para os direitos autorais ${ }^{8}$ foi produzida a Convenção de Berna, em 1886. Trataremos neste trabalho apenas da primeira delas, especialmente a parte relacionada às patentes de invenção.

A Convenção de Paris, de 1883, permitia aos Estados-Membros excluir determinados setores do direito de proteção. A regra de ouro fixada pela norma era que, uma vez garantida a proteção a um nacional do país, o mesmo tipo de proteção deveria ser assegurado aos cidadãos dos países integrantes do acordo internacional (princípio do tratamento nacional).

Para BARBOSA (2003), o objetivo da Convenção não era uniformizar as leis nacionais - como ocorre com o Acordo TRIPS -, tampouco condicionar o tratamento nacional à reciprocidade. Pelo contrário, o tratado confere ampla liberdade legislativa para cada país, exigindo apenas paridade: o tratamento que for dado ao nacional também deve beneficiar o estrangeiro.

\footnotetext{
${ }^{8}$ É válido esclarecer que a expressão "propriedade intelectual" é o gênero do qual são espécies a propriedade industrial e os direitos do autor. A propriedade industrial, por sua vez, é composta pelas patentes de invenção, modelos de utilidade, marcas, desenhos industriais, indicações geográficas e cultivares. Já os direitos autorais se relacionam às obras literárias e artísticas, programas de computador e domínios de internet.
} 
A Convenção também prevê outras regras, entre as quais a prioridade unionista (prazo de um ano para requerer em outro país o pedido já formulado no país do inventor) e a territorialidade da patente (o privilégio somente se aplica nos limites do Estado em que está registrado o invento). Dentro do espírito de cooperação recíproca, a União de Paris não previa um aparelho repressor para os países que descumprissem as regras, ainda que fosse possível remeter o caso à Corte Internacional de Justiça. A Convenção possui uma estrutura relativamente flexível, autoriza a adesão com ressalvas, é aberta à saída e à entrada de novos membros - o Japão, por exemplo, integrou a União, retirou-se e, em seguida, retornou à Convenção.

Vale observar que, quando de sua formação, apenas dez países assinaram a Convenção de Paris, entre os quais o Brasil. Na época, a Inglaterra liderava a produção econômica mundial, despontando como o principal produtor de manufaturas e principal detentor de tecnologias industriais. Estados Unidos e Alemanha iniciavam sua arrancada industrial e já começavam a desenvolver suas próprias tecnologias, além de copiar as estrangeiras. Os Estados Unidos viraram membros da Convenção ainda nos fins da década de 1880, ao passo que a Alemanha só se juntou à União em 1903, segundo dados da Organização Mundial da Propriedade Intelectual.

A história tem sido pródiga em exemplos de nações que, em estágios iniciais de desenvolvimento tecnológico, recusam-se a estabelecer regimes rígidos de proteção de patentes. Ha-Joon CHANG (2004) aponta diversos casos em que isso ocorreu. Os Estados Unidos, por exemplo, recusaram-se a integrar a Convenção de Berna, sob o argumento de que precisavam assegurar seu desenvolvimento por meio do acesso facilitado aos trabalhos adiantados de outras nações. Japão e Suíça só passaram a dispor de legislação mais rigorosa sobre a matéria em 1976 e 1978, respectivamente (KIM, 2005).

Como aponta Ana Maria Mülser PARADA (2005), o início do século XX testemunhou uma disputa que praticamente se repetiria no final do século, ainda que com outros atores. Em 1904, depois de negociações infrutíferas sobre patentes no setor químico, a Alemanha ameaçou sancionar comercialmente a Suíça, caso o país não estabelecesse patentes para processos químicos no prazo de três anos. A Suíça acabou por modificar sua legislação em 1907, pondo fim ao contencioso entre essas nações.

Por décadas, o regime internacional da propriedade intelectual permaneceu sem alterações substanciais. Foram assinados os Acordos de Bruxelas (1900), de Washington (1911), Haia (1925), Londres (1934), Lisboa (1958) e Estocolmo (1967), mas seus resultados eram de modificações apenas acessórias no texto original da Convenção de Paris. Também em 
1967, em Estocolomo, foi criada a Organização Mundial da Propriedade Intelectual (OMPI), que passou a ser responsável pelos tratados sobre a matéria até então editados, substituindo o antigo Bureaux Internationaux Réunis pour la Protection de la Propriété Intellectuelle BIRPI, instituição incumbida das Convenções de Paris e de Berna.

A partir da década de 1960, os países em desenvolvimento passaram a pleitear modificações no Acordo Internacional, a fim de fomentar o crescimento econômico das nações industrialmente atrasadas e assegurar a repartição adequada dos recursos provenientes das novas tecnologias. O debate se estendeu até o início da década de 1980, quando uma mudança repentina na posição negociadora norte-americana alterou completamente o quadro internacional.

De fato, a partir do governo de Ronald Reagan (1981-1989), os Estados Unidos passaram a recusar qualquer flexibilização nas normas então vigentes e, pelo contrário, passaram a cobrar duras regras de respeito à propriedade intelectual. Puseram fim às negociações então em curso na esfera da OMPI, na qual os países em desenvolvimento dispunham de mais força, e impuseram o tema na agenda do GATT (General Agreement on Tariffs and Trade) - organismo que antecedeu a OMC (Organização Mundial do Comércio) por ocasião dos debates de liberalização comercial da Rodada Uruguai.

Não bastasse a inclusão do assunto no âmbito do GATT, os Estados Unidos passaram a aplicar unilateralmente sanções comerciais aos países que não atendessem a seus interesses, por meio da chamada Seção 301 da Lei de Comércio estadunidense. Essa legislação permite que os Estados Unidos imponham "sanções contra países que mantenham leis, políticas ou práticas que violem ou não reconheçam direitos ou benefícios norte-americanos em acordos comerciais ou que sejam considerados injustificáveis, desarrazoados ou discriminatórios e afetem ou restrinjam o comércio norte-americano".

Como desconsiderar, afinal, as ameaças de retaliação da principal economia do planeta, cujo PIB, isoladamente, representava cerca de $25 \%$ da economia mundial? Apesar de a legislação norte-americana produzir, em princípio, efeitos apenas domesticamente, o fato é que suas ameaças e efetivas sanções passaram a compor o quadro do regime internacional de propriedade intelectual.

\footnotetext{
9 "Section 301 of the Trade Act of 1974, as amended (19 U.S.C. $§ 2411$ ), is the principal statutory authority under which the United States may impose trade sanctions against foreign countries that maintain acts, policies and practices that violate, or deny U.S. rights or benefits under, trade agreements, or are unjustifiable, unreasonable or discriminatory and burden or restrict U.S. commerce.” (Resumo da Seção 301 da Lei de Comércio dos Estados Unidos, elaborado pelo Departamento de Comércio dos Estados Unidos. Disponível em http://www.osec.doc.gov/ogc/occic/301.html, em 12 de setembro de 2008.)
} 
As cobranças por respeito a normas não-convencionadas de propriedade intelectual alteraram o regime internacional. Utilizando a conceituação de KRASNER, não foram apenas regras acessórias que foram modificadas, mas os próprios princípios em que se assentava o anterior regime começaram a ser esfacelados. Não bastava assegurar o tratamento nacional, passou a ser necessário garantir patentes em todos os ramos econômicos e segundo padrões rigorosos de aplicação.

A partir de então, ainda que sem tratado internacional que impusesse tais obrigações, vários países foram gradativamente sendo compelidos a seguir a legislação estadunidense. Como aponta GRUNDMAN, citado por BARBOSA (2003), "nos últimos vinte e cinco anos, os Estados Unidos tiveram três grandes itens de exportação: a música rock, os jeans e as leis norte-americanas".

Com efeito, a partir do governo Reagan, os Estados Unidos desfecharam uma ofensiva unilateral, impondo sanções de várias naturezas aos países que não se conformassem com parâmetros por eles tidos como aceitáveis. Essa mudança de postura é atribuída, em parte, à posição unilateralista que o governo republicano adotou em diversas áreas, mas é atribuída também à perda substancial da liderança tecnológica dos Estados Unidos em diversos setores. Isso ocorreu em larga medida devido à utilização eficiente do regime internacional anterior pelo Japão e por outros países do leste asiático, inclusive Coreia do Sul e Taiwan. Esses países empregaram intensamente a imitação e o uso adaptativo, para, em seguida, desenvolverem tecnologias próprias (BARBOSA, 2003).

Em depoimento transcrito no livro Guerra de Patentes (TACHINARDI, 1993), o então embaixador brasileiro Paulo Nogueira Batista, que chefiou a delegação brasileira entre 1983 e 1987 na Rodada Uruguai, relata de maneira incisiva a mudança de postura dos Estados Unidos na gestão de Ronald Reagan. Diz ele que os Estados Unidos não estavam preparados para aceitar o declínio relativo de sua influência em questões econômicas internacionais e, por isso, a gestão de William Brock (Secretário de Comércio dos EUA entre 1981 e 1985) inaugurou o estilo "Rambo" de relacionamento comercial internacional.

Ainda segundo o embaixador brasileiro, a palavra de ordem em Washington a seus diplomatas era uma espécie de diplomacia do big stick, mas as ameaças eram formuladas em voz alta - em vez de sussurradas, como sugeria com mais sutileza Teddy Roosevelt, no início do século. Os EUA pretendiam continuar a fixar por decisão unilateral os padrões a serem observados pelo resto do mundo. Dizia ele que, embora inspiradores do GATT, os EUA nunca se sentiram, como de resto em relação ao FMI, na obrigação de respeitar as normas 
fixadas quando sua aplicação não lhes fosse conveniente (Depoimento de Paulo Nogueira Batista, em TACHINARDI, 1993).

O fato é que, ao longo dos anos 1960 e 1970, os países vinham discutindo mudanças na Convenção de Paris, a fim de aumentar os mecanismos que facilitassem a difusão tecnológica nos países em desenvolvimento. Momento crucial desses debates - e ponto de inflexão evidente - ocorreu em 1981, em conferência diplomática em Genebra. O debate se centrava na modificação do regime que impunha o tratamento nacional ao estrangeiro para um regime que estabelecesse uma "desigualdade igualitária" em favor dos países em desenvolvimento.

Como relata BARBOSA (op. cit.), no curso dessa conferência internacional, os países em desenvolvimento estavam favoráveis à modificação do tratado, os europeus eram moderadamente favoráveis, e os Estados Unidos, isolados, queriam pôr fim à convenção. O debate inicial seria se a mudança da Convenção de Paris exigiria voto da maioria ou unanimidade. Por 113 votos a 1, optou-se pela maioria. O único voto contrário foi o dos EUA.

Ainda segundo BARBOSA, quando se encerrou essa votação, o representante do governo estadunidense se levantou e protestou: afirmou que estava presenciando uma bela discussão sobre transferência de tecnologia e equidade econômica, mas o relevante é o interesse das empresas que ele representava. Disse ainda que não estavam discutindo cooperação entre pessoas, mas interesses empresariais. Por essa razão, a conferência não poderia continuar.

De fato, a conferência não continuou - pela decisão de um país, contra os outros 113. A partir desse evento, o que ganhou força foram as negociações sobre propriedade intelectual na nova rodada de negociações comerciais no âmbito do GATT, afastando as discussões que vinham sendo amadurecidas na esfera da OMPI (BARBOSA, 2003).

Essa nova postura da principal economia do planeta impôs, de fato, um novo regime internacional, caracterizado pela necessidade de fixar parâmetros mínimos de respeito às patentes, ainda que eles não estivessem expressamente ajustados em um tratado. $\mathrm{O}$ fato é que os princípios que sustentavam o antigo regime de propriedade intelectual foram substituídos por novos.

Na China, a Lei de Patentes foi editada em 1984, justamente na década em que se forjou a abertura econômica do país. O país não era até então membro da Convenção da União de Paris, o que só veio a ocorrer em 1985. Já acompanhando as discussões do rascunho para o futuro Acordo TRIPS, a legislação chinesa foi modificada em fins de 1992, aproximando-a em vários aspectos às exigências que passariam a ser feitas pelo Acordo TRIPS. Entre elas, vale mencionar a extensão do prazo de duração da patente de quinze para vinte anos, 
a inclusão de substâncias farmacêuticas entre as patenteáveis e restrições ao licenciamento compulsório (CHENGSI, 1998).

Apesar disso, apenas em 2001 a China se tornou membro da Organização Mundial do Comércio e enfrenta críticas internacionais veementes a respeito da débil aplicação de suas normas de propriedade intelectual (EVANS, 2003). Pouco antes da adesão, em 2000, foi promovida uma nova emenda em sua Lei de Patentes para torná-la mais consentânea com as exigências do Acordo TRIPS (OMC, 2001).

No caso da Coreia do Sul, houve substancial modificação em sua legislação já nos anos 1980. Em síntese, pode-se apontar que, de 31 de dezembro de 1986, uma nova legislação (Lei no 3.891) foi editada sob pressão norte-americana, provocando grande impacto em todos os ramos industriais do país, causando prejuízos especialmente às indústrias farmacêutica e química. Apesar de, em parte, a lei não ter sido aplicada com todo o rigor, o número de ações judiciais para sancionar aqueles que a descumpriam quintuplicou entre os anos de 1989 e 1993, passando de 2.254 a 10.423 processos, o que sugere a ampliação de seu enforcement (KIM, 2005). Fato é que a Coreia do Sul adiou ao máximo a aplicação rigorosa da nova legislação, assim como a assunção de obrigações no campo internacional, fazendo abrangente uso do período de transição facultado pelo Acordo Trips.

A peculiar situação internacional de Taiwan, não reconhecida como nação soberana pela China e sem representação nas Nações Unidas, deixa o país em relativo limbo jurídico no campo externo. Em 2002, contudo, o país logrou aderir à OMC - e por conseguinte ao Acordo TRIPS - sob a qualificação de "Taipei Chinês - Território Aduaneiro Separado de Taiwan, Penghu, Kinmen and Matsu" (OMC, 2014). Vale notar que Taiwan não era - e continua sem ser - parte dos outros acordos de propriedade intelectual, notadamente da Convenção da União de Paris e da Convenção de Berna, de modo que nem mesmo o princípio do tratamento nacional era assegurado no país.

Em paralelo aos esforços para ajustar sua legislação de modo a viabilizar a adesão à OMC, Taiwan também foi alvo de intensa pressão estadunidense para enrijecer sua legislação patentária. Em 1994, aprovou uma modificação substancial em sua lei de patentes, em que ampliou os setores econômicos passíveis de patenteamento, alongou o período de duração das patentes para vinte anos e fixou mecanismos de aplicação da lei. Em 1997 e em 2001, novas alterações foram promovidas, mas só entraram em vigor em 2002, como condições para o ingresso na OMC.

No período inicial das novas regras, o enforcement da legislação era considerado frágil pelos EUA, que apenas em 2009 retiraram Taiwan da lista de países "sob 
observação" por descuidar da legislação intelectual, sob a ótica estadunidense. Aliás, a China continental continua na lista de países "sob observação prioritária", ao passo que o Brasil segue entre os países "sob observação". O único dos quatro examinados que não consta mais da lista é a Coreia do Sul, mas continua recebendo menções críticas sobre o tema nos relatórios anuais do Departamento de Comércio dos EUA (USTR, 2012).

O Brasil, legitimado por ser um dos integrantes da primeira Convenção internacional sobre a matéria, a de Paris, também tentou resistir às novas regras e adiar sua incorporação ao Direito brasileiro. Amargou, porém, fortes ameaças de retaliação norteamericana, especialmente por conta da proteção ao mercado de informática e por conta da indústria de fármacos, como relata Maria Helena TACHINARDI, em "A Guerra das Patentes" (1993). Só em 1996 o Brasil adotou uma nova legislação de patentes, mais adaptada às pretensões estadunidenses.

Antes disso, no desenrolar da Rodada Uruguai e em paralelo às ameaças norteamericanas de utilização das sanções da Seção 301 de sua Lei de Comércio, as negociações conduziram à aprovação do texto do Acordo TRIPS, juntamente com a conclusão da rodada comercial e a criação da OMC. O novo Acordo sobre patentes impunha uma série de regras rigorosas, estabelecendo padrões mínimos de respeito à propriedade (por exemplo, prazo mínimo de vinte anos para a patente de invenção) e mecanismos de enforcement para garantir o cumprimento da lei.

Vê-se, portanto, que o Acordo TRIPS representou a coroação da mudança do regime internacional sobre o assunto, iniciada na primeira metade da década de 1980. As regras anteriores, em resumo, dispunham meramente que o que se estabelecesse para o nacional do país teria que ser aplicado ao nacional dos demais membros do acordo. Já o TRIPS impôs o reconhecimento da propriedade intelectual de modo amplo e rígido: alargou-se a abrangência da proteção à propriedade intelectual, fixaram-se prazos de proteção e estabeleceram-se procedimentos para conferir eficácia às normas.

Como já se apontou, o tema desta pesquisa nasce desse cenário. A partir dessa mudança de regime, as nações em desenvolvimento se viram forçadas a desconsiderar a possibilidade de simplesmente copiar produtos e processos e passaram a buscar mecanismos alternativos para estimular o progresso tecnológico, tais como modificações no tipo de educação ofertado, no crédito subsidiado e no papel dos institutos públicos de pesquisa.

Cabe observar que, após a conclusão da Rodada Uruguai, restringiu-se enormemente a liberdade dos países em desenvolvimento para formular suas políticas comerciais, limitando-se o uso de cotas, tarifas e outras barreiras não-tarifárias. Em particular, 
o Acordo TRIPS alterou drasticamente o caráter difuso do regime internacional de propriedade intelectual, tornando mais difícil a imitação de produtos e de processos já existentes estratégias largamente utilizadas nas fases iniciais da industrialização de outros países, como Estados Unidos e, em larga medida, dos países de industrialização tardia (CIMOLI; DOSI; NELSON \& STIGLITZ, 2006).

\subsection{Instrumentos estatais de fomento à pesquisa e à tecnologia}

A industrialização tardia exigiu estratégias econômicas distintas daquelas adotadas por países cuja tecnologia já se encontrava no estado-da-arte. O estudo da industrialização brasileira, sul-coreana, taiwanesa e chinesa indica bem alguns dos mecanismos utilizados. Examinaremos aqui apenas a razão por trás dessas medidas e quais os instrumentos utilizados e as condicionantes para sua escolha.

A história e a literatura econômicas fornecem inúmeras formas de buscar o processo de emparelhamento com os líderes (catching up). Entre os inúmeros mecanismos utilizados, podemos destacar as variadas políticas que favorecem a indústria nascente, especialmente naqueles setores que têm potencial de longo prazo: créditos subsidiados para determinados ramos, proteção à produção nacional por meio de tarifas aduaneiras, quotas de importação, isenção tributária para importação de máquinas, equipamentos e insumos essenciais, apoio à exportação de produtos, tributação da exportação de itens com baixo grau de tecnologia e redução progressiva dos encargos para a alta tecnologia, benefícios tributários para a industrialização, etc.

Todas essas medidas, com variações e combinações distintas de modalidade e de intensidade, foram utilizadas pelos países em sua largada de industrialização. A Inglaterra, os Estados Unidos, a Alemanha, a França, o Japão, nenhum deles deixou de fazer uso dessas políticas defendidas pelo norte-americano Alexander HAMILTON (1791) e pelo alemão Friederich LIST (1841), arquitetos teóricos da industrialização de seus países. As opções de política industrial dos países latino-americanos e dos países do leste asiático (os tigres asiáticos) não foram por outro caminho: em alguns casos, como a Coreia, houve apenas um aprimoramento das medidas, visando a torná-las mais eficazes (CANUTO, 1994; e CHANG, 2004). 
Em "Instituições e políticas moldando o desenvolvimento industrial: uma nota introdutória”, CIMOLI, DOSI, NELSON e STIGLITZ (2006) apontam o estreitamento das opções de política industrial nos últimos anos do século XX. Pressões internacionais de variadas espécies restringiram o rol de políticas que as nações em desenvolvimento podiam escolher no processo de emparelhamento.

Como apontam os citados autores - com base nos quais este tópico foi redigido -, é preciso considerar a fragilidade da tese de que as políticas públicas só se fazem necessárias, do ponto de vista teórico, quando existirem falhas de mercado (concorrência imperfeita, informação assimétrica, externalidades, etc.). Apesar da polêmica que envolve o tema, a ideia das falhas de mercado pode conduzir a erro, pois presume que as condições sob as quais se desenvolve a economia comum estariam, em regra, apartadas dessas falhas. Para os autores, porém, não é bem isso o que ocorre, como explica o excerto a seguir:

"Ao contrário: o problema está em que dificilmente uma situação empírica qualquer apresentará alguma semelhança significativa com tal "padrão de medida" - por exemplo, em termos de plenitude do mercado, de perfeição da concorrência, dos conhecimentos possuídos pelos agentes econômicos, da imutabilidade das tecnologias e preferências, da "racionalidade" da tomada de decisões, etc. (a lista é mesmo muito longa!). Num sentido mais profundo, quando julgado segundo esses padrões gerais, o mundo inteiro pode ser encarado como uma enorme falha de mercado!"

(CIMOLI, DOSI, NELSON, STIGLITZ, 2006).

Nessa linha, cabe avaliar não tanto se a situação do segmento econômico examinado é realmente ótima, mas sim se os problemas com o arranjo institucional são suficientemente graves para demandar políticas ativas - ou ainda se as políticas podem ocasionar falhas de governo ainda mais severas do que as falhas de mercado, resultando em alocação ineficiente de recursos.

No caso do processo de emparelhamento, as instituições e as políticas voltadas para o aprendizado tecnológico cumprem papel essencial, devendo buscar a criação de sistemas nacionais de produção e de inovação. Tanto a geração de conhecimentos científicos e tecnológicos, quanto a imitação e a adaptação tecnológica exigem uma ampla variedade de atores complementares, incluindo empresas e também instituições públicas de pesquisa e treinamento, comunidades de intercâmbio, sociedades técnicas, entre outros.

Apesar disso, as inovações perseguidas pelas economias em processo de emparelhamento diferem das buscadas por grande parcela das pesquisas realizadas em 
economias maduras. Enquanto as novas tecnologias e novas práticas incorporadas pelas economias em desenvolvimento são novas apenas em seu contexto, elas estão de modo geral já estabelecidas nos países situados na fronteira tecnológica.

O fato é que as políticas estatais ativas em favor do emparelhamento geraram grande insatisfação nas empresas e nos governos dos países líderes, especialmente quando a indústria apoiada não se restringia a suprir o mercado interno do país em desenvolvimento, mas passava a ocupar o mercado mundial. Como apontam os citados autores, logo após a Segunda Guerra Mundial, os argumentos em favor do livre comércio estavam majoritariamente voltados à eliminação da proteção e de subsídios nos países ricos, havendo certa simpatia à tese de conferir alguma proteção a novas indústrias nos países retardatários. Entretanto, os tratados internacionais mais recentes têm sido cada vez mais dirigidos contra a proteção face às importações crescentes oriundas dos países retardatários e contra os subsídios de países que estão buscando o emparelhamento.

Em relação à propriedade intelectual, durante o século XIX e início do século XX, como já expusemos, os regimes legais de propriedade intelectual não restringiam seriamente a capacidade de copiar tecnologias de outros países. Tal como no caso da proteção e dos subsídios, os problemas começaram a surgir quando empresas em processo de emparelhamento começaram a se aventurar e a obter sucesso no mercado mundial, em alguns casos até mesmo exportando para os mercados internos das empresas detentoras das patentes. A crescente frequência dessas situações foi claramente um importante fator que desencadeou a negociação para o Acordo TRIPS. E o tratado não prejudicou apenas as empresas que exportavam para os mercados desenvolvidos, mas também aquelas que se mantinham operando prioritariamente no mercado de seu país de origem.

A mudança do contexto internacional a partir dos anos 1990 levou a uma reconfiguração das políticas estatais ativas. A abertura do mercado, a inicial mortandade de muitas empresas nacionais em face da concorrência externa, o novo cenário jurídico internacional relativo a concorrência internacional e mesmo as mudanças dos padrões tecnológicos impuseram uma readequação das políticas.

As medidas adequadas para hoje dificilmente seriam as mesmas utilizadas no fim do século XIX como estratégia de emparelhamento da Alemanha e dos Estados Unidos; ou mesmo as da segunda metade do século XX, pelos países asiáticos. Os paradigmas da eletromecânica aos quais Alemanha e Estados Unidos se dedicaram no final de século XIX são bastante diferentes dos modelos da tecnologia da informação a que se dedicaram Coreia e Taiwan para se aproximar da fronteira tecnológica. 
Daí por que CIMOLI, DOSI, NELSON e STIGLITZ propõem novas medidas, como modificações nas modalidades de ensino ofertadas, apoio às firmas nacionais, redesenho do papel dos centros de pesquisa e de treinamento públicos, etc.

A essas mudanças nos padrões dos paradigmas tecnológicos, deve-se somar a já mencionada modificação no quadro do regime de comércio internacional e do regime internacional da propriedade intelectual. Como apontam os mencionados autores, esses novos regimes (OMC, TRIPS e outros) provocaram a redução do grau de liberdade de que desfrutam os países em desenvolvimento para a fixação de suas políticas industrial e comercial, já que os países que se emparelharam em outras ondas de industrialização puderam fazer uso de um cardápio de medidas hoje bastante circunscritas (quotas, tarifas, barreiras tarifárias e nãotarifárias, imitação e reinvenção de produtos e de processos estrangeiros).

Avulta a importância, nesse cenário, de uma política especificamente voltada ao desenvolvimento tecnológico. O grau de liberdade existente para os países formularem suas políticas ainda permite a adoção de medidas relevantes. Sua utilização, porém, variará conforme o setor e a tecnologia, e também segundo a distância de cada país em relação à fronteira tecnológica.

As medidas que CIMOLI ET AL. destacam como ainda possíveis, em alguma sorte, encontram-se transcritas na Tabela 1, que sintetiza as principais providências sugeridas pelos autores para o processo de aprendizado tecnológico, indicando seus propósitos específicos e as instituições incumbidas de sua execução.

A Tabela 1 demonstra que, apesar das restrições pela mudança do regime internacional de comércio e de propriedade intelectual, ainda existem várias medidas ao alcance dos formuladores das políticas públicas de emparelhamento. Mesmo no campo da propriedade intelectual, Carlos CORREA (2003) aborda as variações possíveis mesmo com o Acordo TRIPS, especialmente na área de saúde pública. Segundo esse autor, o Acordo TRIPS restringiu, mas não extinguiu inteiramente a autonomia dos países de conceberem diferentes regras dentro da moldura do tratado internacional. Merece destaque a "Declaração de Doha sobre o Acordo TRIPS e a Saúde Pública"10, adotada em novembro de 2001, quando se indicou que, em eventual conflito entre direitos de propriedade intelectual e saúde pública, esta última deveria prevalecer, dando margem a nova jurisprudência na interpretação do tratado.

\footnotetext{
${ }^{10}$ Essa declaração foi aprovada pela Conferência Ministerial da Organização Mundial do Comércio, em encontro realizado em novembro de 2001 (4⿳亠丷厂二 Conferência Ministerial da OMC). Foi nessa conferência que foi lançada a Agenda de Desenvolvimento de Doha, com o início de nova rodada comercial, até hoje não concluída.
} 
TABELA 1

Classificação das variáveis e dos processos em que atuam instituições e políticas (fatores gerais e fatores relativas ao aprendizado tecnológico)

\begin{tabular}{|c|c|c|}
\hline $\begin{array}{c}\text { Áreas de intervenção } \\
\text { de políticas }\end{array}$ & Medidas de políticas & Instituições relacionadas \\
\hline $\begin{array}{l}\text { (I) Oportunidades de inovação } \\
\text { científica e tecnológica }\end{array}$ & $\begin{array}{l}\text { Políticas científicas, cursos de } \\
\text { pós-graduação, projetos } \\
\text { tecnológicos de fronteira }\end{array}$ & $\begin{array}{l}\text { Universidades de pesquisa, } \\
\text { centros públicos de pesquisa, } \\
\text { instituições médicas, agências } \\
\text { espaciais e militares, etc. }\end{array}$ \\
\hline $\begin{array}{l}\text { (II) Aprendizado e aptidões } \\
\text { tecnológicas socialmente } \\
\text { distribuídos }\end{array}$ & $\begin{array}{l}\text { Políticas educacionais e de } \\
\text { treinamento em sentido amplo }\end{array}$ & $\begin{array}{l}\text { Da educação primária às escolas } \\
\text { politécnicas, aos land-grant } \\
\text { colleges dos EUA }\end{array}$ \\
\hline $\begin{array}{l}\text { (III) Medidas de apoio } \\
\text { direcionadas à indústria, afetando } \\
\text { por exemplo os tipos de firmas, } \\
\text { etc. - primordialmente a estrutura, } \\
\text { a propriedade e as formas de } \\
\text { governança das firmas mercantis } \\
\text { (locais versus estrangeiras, } \\
\text { empresas de propriedade familiar } \\
\text { versus companhias de capital } \\
\text { aberto, etc.) }\end{array}$ & $\begin{array}{l}\text { Da formação de empresas de } \\
\text { propriedade do Estado à } \\
\text { privatização das mesmas, das } \\
\text { políticas para "campeões } \\
\text { nacionais" a políticas que afetam } \\
\text { os investimentos de empresas } \\
\text { multinacionais, passando por toda } \\
\text { a legislação relativa à governança } \\
\text { empresarial }\end{array}$ & $\begin{array}{l}\text { Holdings de propriedade estatal, } \\
\text { bancos mercantis públicos, } \\
\text { capitalistas de risco do setor } \\
\text { público, empresas de utilidade } \\
\text { pública }\end{array}$ \\
\hline $\begin{array}{l}\text { (IV) As capacidades dos agentes } \\
\text { econômicos (em primeiro lugar as } \\
\text { de firmas mercantis) em termos } \\
\text { de conhecimentos tecnológicos } \\
\text { incorporados a eles, a eficiência e } \\
\text { velocidade com que buscam o } \\
\text { acesso a novos avanços } \\
\text { tecnológicos e organizacionais, } \\
\text { etc. }\end{array}$ & $\begin{array}{l}\text { Cf. especialmente os pontos (ii), } \\
\text { (iii) e também as políticas de } \\
\text { P\&D e políticas que afetam a } \\
\text { adoção de novos equipamentos, } \\
\text { etc. }\end{array}$ & $\begin{array}{l}\text { Agências reguladoras vinculadas, } \\
\text { agências que controlam os } \\
\text { subsídios à pesquisa e à produção, } \\
\text { entidades controladoras do } \\
\text { comércio, agências que concedem } \\
\text { e controlam os Direitos de } \\
\text { Propriedade Intelectual. }\end{array}$ \\
\hline $\begin{array}{l}\text { (V) Os sinais e os incentivos } \\
\text { econômicos percebidos pelos } \\
\text { agentes com fins lucrativos } \\
\text { (incluindo preços e taxas de } \\
\text { lucratividade reais e esperados, } \\
\text { condições para a apropriabilidade } \\
\text { de inovações, barreiras ao } \\
\text { ingresso, etc.). }\end{array}$ & $\begin{array}{l}\text { Regulações de preços, tarifas e } \\
\text { quotas no comércio internacional, } \\
\text { regimes de Direitos de } \\
\text { Propriedade Intelectual, etc. }\end{array}$ & $\begin{array}{l}\text { Autoridades antitruste, } \\
\text { instituições que controlam os } \\
\text { processos de falência, etc. }\end{array}$ \\
\hline $\begin{array}{l}\text { (VI) Mecanismos de seleção } \\
\text { (superpostas às acima } \\
\text { mencionadas) }\end{array}$ & $\begin{array}{l}\text { Políticas e legislação antitruste e } \\
\text { que regulam a concorrência, o } \\
\text { ingresso no mercado e as } \\
\text { falências; alocação de } \\
\text { financiamentos; mercados para } \\
\text { propriedade empresarial, etc. }\end{array}$ & \\
\hline $\begin{array}{l}\text { (VII) Padrões de distribuição de } \\
\text { informações e de interação entre } \\
\text { os diferentes tipos de agentes } \\
\text { (como clientes, fornecedores, } \\
\text { bancos, acionistas, } \\
\text { administradores, trabalhadores, } \\
\text { etc.) }\end{array}$ & $\begin{array}{l}\text { Governança dos mercados de } \\
\text { trabalho, dos mercados de } \\
\text { produtos, relações entre os bancos } \\
\text { e o setor produtivo, etc. passando } \\
\text { por todos os arranjos } \\
\text { coletivamente compartilhados } \\
\text { para o controle e a mobilidade do } \\
\text { compartilhamento de informações } \\
\text { no interior das firmas, formas de } \\
\text { cooperação e concorrência entre } \\
\text { firmas rivais, etc. (como, por } \\
\text { exemplo, as históricas diferenças } \\
\text { entre firmas japonesas e anglo- } \\
\text { saxônicas) }\end{array}$ & \\
\hline
\end{tabular}


Segundo CORREA, a confirmação de que o Acordo TRIPS deixou espaço para flexibilidade no âmbito nacional, especialmente em relação ao uso da licença compulsória e das importações paralelas, tem implicações políticas e legais importantes. Isso indica, politicamente, que a pressão exercida pelos países desenvolvidos para impedir o uso de flexibilidades contrariaria o espírito e o propósito do Acordo TRIPS, especialmente em áreas em que há problemas graves, como a saúde pública.

Em termos legais, essa Declaração significa que eventuais litígios advindos da aplicação do Acordo terão que levar em conta interpretações do texto normativo mais consentâneas com as necessidades dos países-membros. Esse precedente pode vir a assumir alguma relevância em futuras discussões sobre inovações na área de energia de baixo carbono, dada urgência crescente de difundir as tecnologias para reduzir as emissões de gases estufa.

Esta pesquisa se restringirá à análise de uma das políticas adotadas no âmbito de energias de baixo carbono, dada a conexão com o tema da mudança climática, tratado mais à frente. Nesse contexto, serão examinadas, entre outras, as políticas de fomento às energias de baixo carbono, as políticas aduaneiras e também o papel das instituições públicas de pesquisa e sua interação com empresas privadas.

Ao analisar políticas de emparelhamento tecnológico, Roberto MAZZOLENI e Richard NELSON (2006) apontam que “o papel de universidades e laboratórios públicos é muito importante no processo pelo qual países com tecnologia e economia atrasadas em relação à fronteira podem emparelhar-se em tecnologia e prática industrial". Nesse debate, MAZZOLENI e NELSON apresentaram como tese central que o novo ambiente legal (exemplos: OMC e TRIPS), o fato de as empresas e as finanças operarem num contexto mais global e também a existência de maior conexão entre as comunidades científicas e técnicas tornam, hoje, o desenvolvimento de capacidades domésticas em pesquisa e treinamento avançado mais importantes para o emparelhamento do que antes foram. E sua importância tende a crescer.

Para tanto, esses autores apresentam episódios de sucesso em três países: o Japão, no final do século XIX e início do século XX, a Coreia e Taiwan na segunda metade do século XX, e o Brasil nesse mesmo período. Sobre este, destacam a indústria aeronáutica por meio da Embraer (fruto do Centro Técnico Aeroespacial - CTA e do Instituto Tecnológico da Aeronáutica - ITA, sendo ambas instituições públicas) e o desenvolvimento da agricultura nacional por meio da Empresa Brasileira de Pesquisa Agropecuária - Embrapa.

Os temas examinados neste Capítulo constituem a estrutura sobre a qual a pesquisa se erige, isto é, são os conhecimentos necessários para a compreensão do fenômeno 
do progresso tecnológico. Examinamos a relação da tecnologia com o desenvolvimento econômico, os conceitos de patentes e inovação, o histórico dos tratados internacionais sobre propriedade intelectual e as relações entre cultura empresarial e instrumentos estatais de fomento à tecnologia.

O que se pretende nesta pesquisa é utilizar essa base conceitual abordada neste Capítulo no contexto das mudanças climáticas, tratadas no Capítulo 2. À luz da formação iminente de um regime internacional sobre mudanças climáticas, ainda que frágil e desprovido de um tratado formal vinculante, pretende-se examinar como os países selecionados estão reagindo ao novo cenário e que tipos investimentos vêm fazendo. 


\section{CAPÍTULO 2 \\ REGIME INTERNACIONAL EM FORMAÇÃO \\ PARA A MUDANÇA CLIMÁTICA}

\subsection{O nascimento do regime climático internacional: a Convenção da ONU sobre Mudanças Climáticas e o Protocolo de Quioto}

Neste segundo capítulo, serão abordados o regime internacional vigente a respeito das mudanças climáticas, as evidências científicas que dão sustentação às discussões em curso, as perspectivas para o regime climático nos próximos anos e a posição nesse debate dos países selecionados. Nos capítulos seguintes, faremos o vínculo entre o desenvolvimento econômico baseado em inovação tecnológica e as restrições que estão sendo gradualmente estabelecidas às emissões de gases de efeito estufa.

Os dois principais marcos do regime internacional de mudança climática são a Convenção Quadro das Nações Unidas sobre Mudanças Climáticas - CQNUMC, de 1992, e o Protocolo de Quito, de 1997. A formação desse regime se originou do moderno movimento ambientalista, na virada dos anos 1960 para os anos 1970, mas as primeiras pesquisas sobre os efeitos da ação antrópica sobre o clima remontam aos princípios do século XIX.

De fato, em publicações de 1824 a 1827, o físico francês Jean Baptiste Joseph FOURIER (1768-1830) realizou pesquisas sobre a temperatura atmosférica e sugeriu pela primeira vez a existência do denominado efeito estufa. Para Fourier, apenas a radiação direta recebida do sol não seria suficiente para manter a temperatura em níveis tão elevados, dado o tamanho do planeta e sua distância para a estrela. Baseado nos experimentos então disponíveis, principalmente o forno solar do físico Horace DE SAUSSURE ${ }^{11}$, ele passou a sugerir que a composição da atmosfera formaria uma barreira que ajudaria a reter parte do calor recebido do sol, resultando daí num aquecimento adicional (WEART, 2008).

\footnotetext{
${ }^{11}$ O físico suíço Horace-Bénédict DE SAUSSURE (1740-1799) é considerado o fundador do alpinismo e tido como o inventor do forno solar. Para construí-lo, ele montou uma caixa que isolava o ar e era encoberta por três camadas de vidro para reter a radiação solar e evitar que o ar aquecido se dissipasse. Esse experimento se mostrou exitoso, atingindo temperaturas acima de $100^{\circ}$ Celsius, tanto em altitudes baixas, como em áreas elevadas dos Alpes, o que sugeria que a temperatura externa do ar não interferia no efeito do aquecimento verificado dentro do forno (BUTTI, 2004).
} 
No início dos anos 1860, o físico britânico John TYNDALL (1820-1893) explicou suas pesquisas a respeito da absorção de radiação infravermelha por determinados gases e sua compreensão a respeito do efeito estufa na Terra. A tecnologia utilizada nessas pesquisas permitiu demonstrar, empiricamente, pela primeira vez, que não só o vapor d'água absorvia a radiação infravermelha, mas também o dióxido de carbono, o ozônio, o metano, o nitrogênio e outros compostos. Em sua avaliação, não houvesse o efeito de retenção do calor por esses elementos, a temperatura na Terra seria bem mais baixa, especialmente durante a noite (TYNDALL, 1961; FLEMING, 1998).

Ainda mais próximo às pesquisas atuais, o sueco Svante August ARRHENIUS (1859-1927), vencedor do prêmio Nobel de Química em 1903, procurou demonstrar, lastreado em medições à época disponíveis, que a concentração de dióxido de carbono na atmosfera estava relacionada com a temperatura do planeta. Embora visse o fenômeno como positivo por abrandar a temperatura terrestre, ele foi o primeiro grande cientista a apontar, na virada do século XIX para o XX, que o clima poderia ser alterado a partir da elevação da concentração de carbono decorrente das atividades industriais (ARRHENIUS, 1908; VIOLA, FRANCHINI e RIBEIRO, 2013).

No período após a Segunda Guerra Mundial, merecem destaque as pesquisas realizadas pelos estadunidenses Roger REVELLE (1909-1991) e Charles David KEELING (1928-2005), que promoveram medições sobre concentrações atmosféricas de dióxido de carbono no Observatório de Mauna Loa, no Havaí, e também na Antártida. No fim dos anos 1950, as pesquisas de REVELLE, em coautoria com o austríaco Hans SUESS (1909-1993), sugeriram que era insuficiente a capacidade dos oceanos de absorver o excesso de dióxido de carbono produzido por atividades antropogênicas. Para eles, haveria uma camada na superfície dos oceanos, de modo que, para que o carbono fosse por eles absorvido, seria necessário dividir a molécula em um componente do ácido de carbono. Essa necessária reação química restringiria o ritmo de ingresso do dióxido de carbono na superfície oceânica.

Desse modo, os autores apresentaram medições indicativas de que a emissão de gases a partir de atividades humanas poderia provocar um efeito estufa mais acentuado do que o naturalmente existente, o que, no longo prazo, poderia provocar um aquecimento global acima da variação natural da temperatura do planeta. O artigo de REVELLE e SUESS apontava que o crescimento da quantidade de $\mathrm{CO}_{2}$ na atmosfera decorria da queima de combustíveis fósseis a partir da Revolução Industrial. Embora, apontavam os autores à época, o aumento na concentração de dióxido de carbono na atmosfera ainda seja pequeno, ele poderia tornar-se significativo nas próximas décadas se continuar a crescer exponencialmente o uso de 
combustíveis fósseis na atividade industrial, vaticinavam os autores (REVELLE e SUESS, 1957).

Como apontam VIOLA, FRANCHINI e RIBEIRO (2013), a partir dos anos 1960 várias outras instituições e programas internacionais passaram a conferir atenção ao tema, como o Global Atmosphere Watch e o Global Atmospheric Research Programme, ambos instituídos no âmbito da Organização Meteorológica Mundial nos anos finais dessa década.

Em 1968, foi criado o Clube de Roma, uma associação civil liderada por um industrial italiano (Aurelio Peccei) e um cientista escocês (Alexander King). Essa organização conseguiu chamar a atenção mundial com a publicação, em 1972, do relatório intitulado "Os Limites do Crescimento", elaborado pelos pesquisadores do Massachussets Institute of Technology (MIT) Donella MEADOWS, Denis MEADOWS, Jorgen RANDERS e William BEHRENS III. O documento, que também passou a ser apelidado de "Relatório Meadows", foi a publicação sobre questões ambientais com maior vendagem na história e alertou sobre os riscos decorrentes do crescimento continuado da população e da economia em face de recursos naturais limitados.

O livro se baseava em vários modelos, que consideravam variáveis como o crescimento populacional, a industrialização, o suprimento de alimentos, o uso de recursos naturais e a poluição. $\mathrm{O}$ crescimento econômico exponencial e o aumento apenas linear que a tecnologia permitiria para o suprimento de recursos naturais provocariam o colapso desse paradigma de desenvolvimento (MEADOWS ET AL., 1972).

Todas essas pesquisas e publicações resultaram na convocação da Conferência das Nações Unidas sobre Meio Ambiente Humano, denominada também de Conferência de Estocolmo, de 1972.

Como indicam VIOLA ET AL. (2013), a partir desse período as discussões climáticas passam de uma fase predominantemente científica para uma etapa de maior politização.

A Conferência de Estocolmo pode ser apontada como o principal marco para o ambientalismo moderno. A partir daí os movimentos ambientalistas ganham espaço nos debates públicos nacionais e internacionais. Partidos verdes surgem em vários países, fazendo uso principalmente da bandeira ecológica ${ }^{12}$, tais como na Austrália (1972), Nova Zelândia

\footnotetext{
${ }^{12}$ Além da bandeira ecológica, os partidos verdes tradicionalmente se localizam na centro-esquerda do espectro político-ideológico, adotando um discurso que enfatiza quatro temas: sabedoria ecológica, não-violência, a democracia participativa e justiça social. Esses quatro temas foram definidos como os pilares da política do partido verde alemão, que logrou uma particular influência global nesse campo.
} 
(1972), Reino Unido (chamado inicialmente de People, depois de Ecology Party em 1975 e finalmente Partido Verde em 1985), Alemanha (1980) e França (1984). A imprensa nãoespecializada e parcela relevante da opinião pública inserem o tema em suas agendas de discussão.

Além dos partidos políticos, a sociedade civil também foi afetada por essa mobilização. Inúmeras organizações não-governamentais (ONG's) de atuação internacional foram criadas nesse período - entre as quais o Greenpeace, fundado com o propósito original de lutar contra o extermínio das baleias e depois expandido seu escopo de ação (ALVES, 2001).

$\mathrm{O}$ contexto internacional em que se deu a conferência estava marcado por preocupações estratégico-militares, dada a disputa geopolítica sistêmica entre os Estados Unidos e a União Soviética. Ainda com predomínio de governos autoritários, os países socialistas e as nações em desenvolvimento viam com desconfiança essa nova agenda, tida como mais um conjunto de entraves para o desenvolvimento econômico (ALVES, 2001).

Em termos concretos, a Conferência de 1972 resultou na aprovação de uma declaração de 26 princípios relacionados ao meio ambiente e ao desenvolvimento, um plano de ações e uma resolução. Mas a principal consequência da Conferência de Estocolmo foi lançar luzes para os efeitos das ações humanas sobre o meio ambiente e, desse modo, fortalecer os incipientes movimentos ambientalistas.

A publicidade conferida à questão ensejou a proliferação de negociações internacionais relacionadas ao tema e o aumento das mobilizações nos países desenvolvidos relacionadas à temática ambiental. Até o início dos anos 1970 as reuniões internacionais sobre clima tinham marcado viés científico, voltadas que eram à padronização dos critérios de mensuração das variações climáticas. A partir desse período, os encontros ganham caráter político mais marcante e passam a ocorrer sob os auspícios das Nações Unidas (VIOLA ET AL., 2013).

Em fins de 1972, como resultado das discussões da Conferência de Estocolmo, foi criado o Programa das Nações Unidas para o Meio Ambiente - PNUMA. A instituição, que não chega a ter status de agência internacional, fica sediada em Nairóbi, no Quênia, e tem por objetivo auxiliar os países a implantar boas políticas e ações na área ambiental.

Em 1979, ocorreu a primeira Conferência Climática Mundial, em Genebra, Suíça, patrocinada pela Organização Meteorológica Mundial. Foi a primeira grande mobilização internacional voltada propriamente à mudança climática - e não ao meio ambiente - e resultou na instituição de dois programas associados ao tema: o Programa Climático Mundial e o Programa de Pesquisa Climática Mundial. 
No início dos anos 1980, o então secretário-geral da ONU, Javier Perez de Cuellar, decidiu designar uma comissão para promover um estudo a respeito da mudança climática. Para coordenar esse trabalho, ele convidou a ex-primeira ministra da Noruega, Gro Brundtland. Esses esforços resultaram na publicação em 1987 do documento intitulado "Our common future: From one Earth to one World" ("Nosso futuro comum: de uma Terra para um só mundo", em português), também nominado de Relatório Brundtland (WORLD COMISSION ON ENVIRONMENT AND DEVELOPMENT, 1987).

Ao longo dessas duas décadas, os movimentos ecológicos lograram a formação de alguns acordos internacionais sobre temas tópicos, tais como o de poluição marítima (Convenção de Londres, de 1972), o de extinção de espécies (Convenção de Washington, 1973), e o de habitat de aves aquáticas (Convenção de Ramsar, 1975, e emendas de Paris, 1982, e de Regina, 1987). O mais importante desses tratados é a Convenção de Viena para a Proteção da Camada de Ozônio, de 1985, juntamente com seu Protocolo de Montreal, de 1987. Esse é o maior exemplo de um acordo abrangente que conseguiu ampla adesão e efetividade internacional.

Todas essas ações, juntamente com as novas pesquisas acadêmicas, resultaram na criação de um movimento conjunto do PNUMA e da OMM para a criação de um organismo que consolidasse os dados científicos dispersos a respeito da mudança climática. Essa nova instituição não teria propriamente estrutura para realizar pesquisas, mas sim para reunir os pesquisadores da área e consolidar o estado da arte da pesquisa científica nesse campo. Surgiu, então, em 1988, o Painel Intergovernamental sobre Mudança do Clima, que passou a ser mais conhecido pela sigla em inglês: IPCC.

O IPCC passou a publicar periodicamente relatórios que consolidavam as pesquisas promovidas em todo o planeta sobre mudança climática, permitindo a adoção de políticas públicas tecnicamente embasadas. Nesses documentos, o IPCC apontava o que já havia de comprovação científica e o que ainda estava no campo da incerteza e mereceria maiores estudos. O primeiro relatório de avaliação da instituição (First Assessment Report) foi publicado em 1990 e, logo em seguida, foi acompanhado de um relatório suplementar, lançado em 1992.

As informações compiladas pelo IPCC serviram de base para a Conferência das Nações Unidas para o Meio Ambiente e o Desenvolvimento, realizada no Rio de Janeiro em 1992. Esse evento, também designado por Eco-92, Rio-92 ou Cúpula da Terra (Earth Summit), culminou com a aprovação do mais importante tratado sobre o tema, a Convenção Quadro das Nações Unidas sobre Mudança do Clima - CQNUMC. 
Além da CQNUMC, a Rio-92 também resultou na aprovação e na abertura para assinaturas da Convenção sobre Diversidade Biológica, além da aprovação dos documentos denominados de Agenda 21 (conjunto de iniciativas para serem tomadas em vários níveis de organizações, de governos locais à ONU, em várias áreas em que a conduta humana afeta o meio ambiente), Declaração de Princípios sobre Florestas (coletânea de regras não-vinculantes juridicamente a respeito do manejo, conservação e desenvolvimento sustentável de todos os tipos de florestas) e Declaração do Rio sobre Meio Ambiente e Desenvolvimento (conjunto de 27 princípios que orientariam o desenvolvimento sustentável em todo o mundo).

Para esta pesquisa, centraremos as atenções na CQNUMC, que é o eixo atual do regime internacional sobre mudança climática. A Convenção passou a receber adesões dos países a partir de 1992 e entrou em vigor em março de 1994. Em 2011, já eram 194 os Estados que se tornaram membros da Convenção.

O acordo divide os países em três categorias:

a) os países do Anexo I, caracterizados por serem países industrializados ou economias em transição (países que migravam de uma economia planejada centralmente para uma economia de mercado, cujos exemplos mais evidentes são os ex-integrantes da União Soviética);

b) os países do Anexo II, um subgrupo do anexo I, composto por economias desenvolvidas e aptas a arcar com parcela dos custos dos países em desenvolvimento (fundamentalmente os membros à época da OCDE) ${ }^{13}$; e

c) os assim chamados "países não-Anexo I", que são as nações em desenvolvimento.

Pela convenção, os países do Anexo I assumem o compromisso de adotar políticas nacionais e medidas para mitigar a mudança climática mediante a limitação da emissão de gases de efeito estufa de origem antropogênica e a proteção e fortalecimento dos sumidouros e reservatórios de gases estufa. A Convenção assevera que as políticas e as medidas devem demonstrar a liderança dos países desenvolvidos na modificação das tendências de longo prazo das emissões antropogênicas e reconhece que contribuiria para essa modificação de tendência o retorno ao final da década [de 1990, no caso] aos níveis anteriores de emissões antrópicas. $\mathrm{O}$ acordo não estabelece, entretanto, quais os exatos limites e as metas objetivas a que cada país está compelido (art. $4^{\circ}$, item 2, da CQNUMC).

\footnotetext{
${ }^{13}$ A Turquia integrava o Anexo II, mas foi retirada desse grupo - e voltou a compor apenas o Anexo I, embora sem fixação de meta de redução - em razão de emenda ao tratado adotada na COP 7, em 2001, sob o argumento de que o país se caracterizava mais adequadamente como uma economia em transição.
} 
As nações que compõem o Anexo II devem ainda, além das obrigações como integrantes do Anexo I, não só auxiliar os países em desenvolvimento a atender aos objetivos da convenção, inclusive promovendo, facilitando e financiando a transferência de tecnologia, como também ajudá-los a custear as medidas de adaptação para aqueles particularmente vulneráveis aos efeitos adversos da mudança climática (art. 4º itens 3 a 5, da CQNUMC).

Os países "não-Anexo I" não precisam necessariamente reduzir suas emissões, salvo se os países do Anexo I os financiarem e forneceram a tecnologia adequada. Trata-se de aplicação do princípio das "responsabilidades comuns, porém diferenciadas", visando a permitir que os países em desenvolvimento não tenham seu crescimento afetado pelas restrições ambientais. Todavia, a todos os países, inclusive os "não-Anexo I", cabem alguns deveres gerais, como a elaboração de um inventário de emissões, a prestação de informações, a cooperação internacional e a adoção de programas públicos que auxiliem no enfrentamento da mudança climática (art. $4^{\circ}$, item 1, da CQNUMC).

A partir do ano seguinte à entrada em vigor do tratado, em 1994, vêm sendo realizadas anualmente as Conferências dos Estados Partes, denominadas de COP pela sigla em inglês, para avaliar a implantação do acordo e o enfrentamento da mudança climática.

A COP 3 (Terceira Conferência dos Estados Partes da CQNUMC) foi realizada em 1997, na cidade de Quioto, a antiga capital japonesa. Na ocasião, os países integrantes da convenção alcançaram um acordo para fixar metas de redução das emissões para os componentes do Anexo I da CQNUMC. Esses países assumiram o compromisso de reduzir entre 2008 e 2012 os níveis de emissão de gases estufa em até $8 \%$ (na média 5,2\% ${ }^{14}$ ) em relação a certo patamar de emissão, usualmente o ano-base de $1990^{15}$.

O período de 2008-2012 foi considerado o primeiro período de compromisso e, em seguida, um novo acordo teria que definir as novas metas de redução das emissões.

\footnotetext{
${ }^{14}$ Em rigor, nem todos os países estão obrigados a "reduzir" suas emissões - a redução é resultado da média. O acordo estabelece metas em relação ao ano-base, mas alguns países apenas se comprometeram a manter suas emissões (casos de Nova Zelândia, Rússia e Ucrânia), ou mesmo a limitar seu incremento (casos da Noruega, em 1\%, da Austrália, em 8\%, e da Islândia, em 10\%) (UNFCCC, 2008).

15 A escolha do ano de 1990 como ano-base para a comparação das emissões foi objeto de controvérsia. Rejeitouse a opção por calcular as emissões históricas do país, com base no argumento de que são frágeis os dados sobre emissões anteriores a esse ano. Além disso, 1990 foi um ano em que Reino Unido, Alemanha e Rússia tiveram emissões particularmente elevadas em razão de fatores conjunturais, o que favoreceu esses países ao calcular o quanto precisariam reduzir de emissões. O Reino Unido trocou o carvão pelo gás natural nesse período, graças às enormes reservas desse combustível no Mar do Norte. A Alemanha se favoreceu por ser o ano seguinte à integração da Alemanha Oriental, que enfrentou um colapso industrial nos anos seguintes (1990 foi o pico das emissões). E as economias em transição, incluindo a Rússia, também tomaram como base o ano de maior emissão de suas economias, algumas delas retomando até 1986 (LIVERMAN, 2009).
} 
É preciso registrar que o Protocolo de Quioto permite que o volume acordado para as emissões de cada país seja majorado ou suavizado por meio das chamadas atividades LULUCF ou pela participação nos mecanismos flexíveis de Quioto. Na prática, essas duas opções flexibilizam as metas do Protocolo, já que permitem ao integrante do Anexo I modificar o patamar do compromisso assumido, desde que essa nação gere, cancele, adquira ou transfira permissões de emissão, o que aumentará ou reduzirá seu nível de compromisso, conforme o caso.

LULUCF é a sigla em inglês para a gestão do uso da terra, as mudanças no uso da terra e a silvicultura (land use, land use change and forestry). Diferentemente da CQNUMC, o Protocolo de Quioto restringiu o cômputo das atividades LULUCF para a finalidade de modificar a meta de emissões líquidas do país apenas às ações diretamente induzidas pelo homem de florestamento, reflorestamento e de desflorestamento desde 1990 (art. $3^{\circ}$, item 3). São os chamados sumidouros de carbono. Além dessas ações, que devem ser obrigatoriamente calculadas para redefinir a meta de redução do país, há ainda atividades que podem ser opcionalmente consideradas nesse primeiro período de compromisso, que abrangem o manejo florestal, o uso de terras agrícolas, a gestão de pastagens e a revegetação (art. $3^{\circ}$, item 4 , e UNFCCC, 2008).

Já os mecanismos flexíveis são divididos em três tipos: o comércio de emissões, a implementação conjunta e o mecanismo de desenvolvimento limpo. Eles aumentam a flexibilidade das metas, uma vez que permitem o alcance das metas de limitação das emissões por meio de opções mais baratas promovidas fora do território do país.

O comércio de emissões (emissions trading) permite que parte dos limites de emissão de um país do Anexo I seja transacionado com os limites de outro integrante do Anexo I. Desse modo, as emissões agregadas desses países não se alteram, mas elas podem ser redistribuídas de modo que os que não alcançaram sua meta possam "comprar" o que outro logrou em excesso (art. 17). Os países podem também estabelecer regimes domésticos ou regionais de comércio de emissões, como o fez a União Europeia.

Por sua vez, a chamada implementação conjunta (joint implementation) é um mecanismo baseado em projetos, por meio do qual um integrante do Anexo I pode investir em um projeto que reduz emissões ou eleva o sequestro de carbono em outro país do Anexo I, recebendo os créditos pela redução das emissões ou pela remoção de carbono obtida pelo projeto $\left(\operatorname{art.} 6^{\circ}\right)$.

Por fim, o terceiro mecanismo flexível de Quioto é o mecanismo de desenvolvimento limpo - MDL (clean development mechanism), que também é baseado em 
projetos. O MDL confere créditos gerados a partir de projetos que mitiguem a mudança do clima realizados em países não integrantes do Anexo I. Os projetos precisam apresentar benefícios reais, mensuráveis e de longo prazo e as reduções de emissões devem ser adicionais às que ocorreriam na ausência da atividade certificada. Por um lado, esse instrumento ajudaria os países em desenvolvimento (não-Anexo I) a atingir o desenvolvimento sustentável, já que receberiam aporte financeiro e técnico para a realização do projeto. Por outro, ele auxiliaria os integrantes do Anexo I a cumprirem seus objetivos quantificados de limitação das emissões (art. 12 do protocolo).

Há ainda regras para garantir sanções aos que descumprirem o acordo. Se um Estado Parte não atingir o objetivo fixado para o período de avaliação, ele precisará compensar essa diferença no segundo período de compromisso, acrescida de 30\%, além de suspender sua elegibilidade para transferir créditos nos mecanismos flexíveis (art. $3^{\circ}$, item 14, do protocolo, e também UNFCCC, 2008). Além disso, o país ficará suspenso de tomar parte no comércio de emissões. A despeito dessas regras, o Direito Internacional enfrenta a notória dificuldade de aplicar penalidades aos que não observam suas normas. Por depender da permanência voluntária do país no tratado, nada impede que o Estado simplesmente abandone o Protocolo ou mesmo a CQNUMC.

Protocolos são acordos complementares a um tratado. No caso, o Protocolo de Quioto é um complemento à CQNUMC. Ele foi crucial para definir metas objetivas, mensuráveis e orientar as políticas públicas das nações nos anos seguintes à sua aprovação.

Ocorre, porém, que o acordo demorou a entrar em vigor devido a várias cláusulas que ficaram em aberto em 1997 e somente foram concluídas em 2001. Quando o fez, não dispunha da abrangência necessária a tornar-se efetivo. $\mathrm{O}$ então maior emissor global de gases estufa, os Estados Unidos, retirou-se do protocolo em 2001, durante o governo Bush, sem chegar sequer a ratificá-lo. A China, que à época não era o principal emissor, mas em meados da década de 2000 assumiu esse posto, não está obrigada a reduzir suas emissões por não integrar o Anexo I.

De fato, o protocolo somente entrou em vigor em fevereiro de 2005, mas sem a participação dos dois maiores emissores. Apesar da tibieza, o Protocolo de Quioto foi um instrumento crucial para orientar as negociações climáticas internacionais que lhe sucederam. A fixação de metas por países e a criação de mecanismos flexíveis foram elementos importantes das negociações travadas nas Conferências das Partes seguintes.

De todo modo, um regime internacional não significa necessariamente um tratado internacional. Entendemos aqui por regime um conjunto de princípios, regras e acordos 
de procedimento em torno dos quais convergem as expectativas dos atores (KRASNER, 1982). Nesse sentido, ainda que não haja um acordo juridicamente vinculante, estamos vivenciando a formação de um regime que impõe limites às emissões de carbono pelos países. O regime não é só o acordo, ou a codificação formal.

No caso do regime climático, há um movimento bottom-up, que está criando um regime: os países nos quais a opinião pública possui viés mais ambientalista enfrentam um obstáculo para o crescimento das emissões. Acompanha-se, hoje, a formação de um regime não formalizado em acordo multilateral, mas caracterizado por iniciativas de diversas nações, pressionadas por suas respectivas sociedades civis, que em conjunto vão compondo uma coleção mais ou menos alinhada para reduzir a curva das emissões ou mesmo reduzir o total de gases estufa lançados na atmosfera.

Considerando, portanto, um sentido mais amplo para o vocábulo "regime", o que se vê no campo da mudança climática é um vetor tecnológico e cultural em desenvolvimento favorável à proteção de um bem coletivo global. Para além da CQNUMC e do Protocolo de Quito, esse regime se baseia na necessidade de uma consciência pública favorável a estabilizar o clima e em um vetor tecnológico que favoreça o investimento em tecnologias não intensivas em carbono (VIOLA ET AT., 2013).

\subsection{As evidências científicas do fenômeno e de suas possíveis soluções}

Para discutir os possíveis rumos das negociações climáticas, convém examinar a base científica sobre a qual se assenta a discussão. Essas informações estão disponíveis na vasta literatura já erigida a respeito do aquecimento global e, especialmente, de forma consolidada, nos relatórios periodicamente divulgados pelo IPCC.

Como indicamos no tópico 2.1., o IPCC foi criado com o propósito de examinar e sistematizar os conhecimentos científicos já alcançados sobre mudanças climáticas, e não propriamente com o objetivo de desenvolver pesquisas novas. Essa instituição, portanto, avalia e consolida as pesquisas já publicadas em periódicos científicos ligados ao tema.

Os documentos mais recentes com uma visão abrangente do tema são o $4^{\circ}$ e o $5^{\circ}$ Relatórios de Avaliação do IPCC - chamados de AR4 e AR5 em razão da sigla em inglês (4th Assessment Report e 5th Assessment Report), divulgados em 2007 e em 2014, 
respectivamente. Portanto, tomaremos esses documentos como base neste tópico, acompanhado, aqui e acolá, de referências a outras publicações realizadas.

Há quem diga, como o físico estadunidense Joseph ROMM (2010), que o relatório em verdade majoritariamente subestima a mudança climática. Para ele, desde 2007, cresceram as evidências científicas de mudança climática perigosa, duradoura e potencialmente irreversível (ROMM, 2010).

Como já se apontou no tópico 2.1., o Primeiro Relatório do IPCC foi publicado em 1990, acompanhado de um Relatório Suplementar de 1992 - foram esses os documentos que embasaram as discussões e as decisões da Rio-92. O segundo relatório de avaliação foi lançado em 1995 e auxiliou nas discussões do Protocolo de Quioto, de 1997. O Terceiro Relatório foi divulgado em 2001; o Quarto, em 2007; e o Quinto, em 2014.

Além dos sumários para os formuladores de políticas públicas (Summary for Policymakers), o chamado Relatório de Avaliação contempla, em verdade, quatro documentos:

1) A síntese do relatório;

2) A base física científica da mudança do clima, elaborada pelo Grupo de Trabalho I;

3) Impactos, adaptação e vulnerabilidades, formulado pelo Grupo de Trabalho II; e

4) Mitigação da mudança climática, concebido pelo Grupo de Trabalho III.

Esses documentos apontam, em síntese, que o aquecimento do sistema climático global é inequívoco, o que agora é evidente a partir de observações da temperatura média do ar e dos oceanos, do derretimento generalizado de neve e de gelo e ainda do aumento do nível médio global do mar. Três dados ajudam a compreender o fenômeno:

1) A temperatura média da superfície do planeta vem aumentando consistentemente desde 1850 .

2) O nível do mar vem se elevando também de maneira consistente no mesmo período mencionado acima.

3) A cobertura de neve e de gelo no hemisfério norte, incluindo do Ártico, vem se reduzindo consistentemente.

O Gráfico 3, oriundo do AR5 do IPCC, ilustra a primeira das afirmativas. O Gráfico 4, também oriundo do AR5 do IPCC, sintetiza as informações referentes à elevação dos oceanos e à redução da cobertura de gelo no verão ártico: 
GRÁFICO 3

Variação da temperatura terrestre, em terra e oceano (1850-2012)

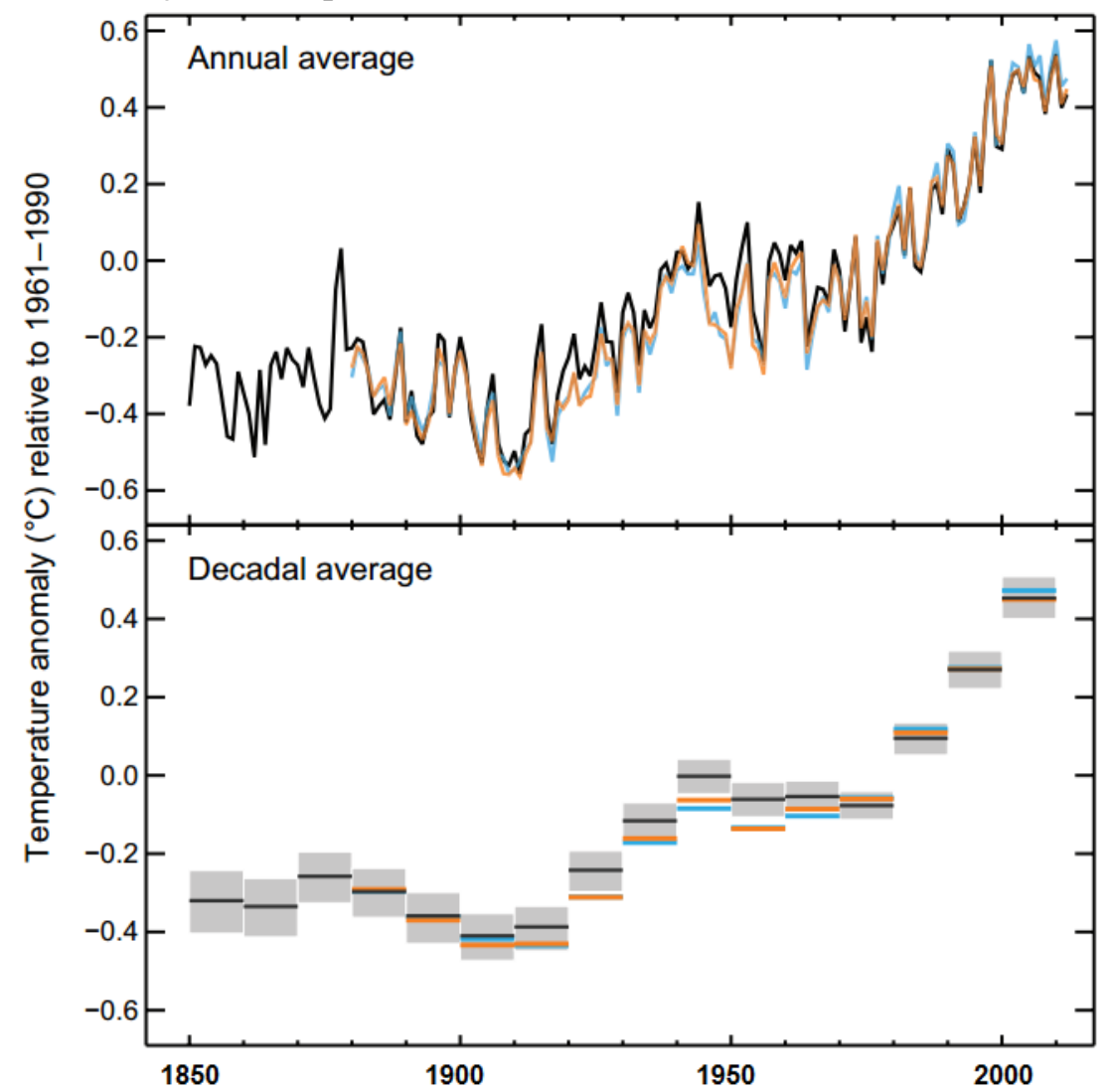

Fonte: IPCC, AR5

OBS.: O quadro superior do primeiro gráfico mostra a variação da temperatura média anual na superfície do planeta. O quadro inferior revela a média da temperatura por década. As diferenças positivas ou negativas foram definidas a partir do período 1961-1990. As áreas sombreadas mostram intervalos de incerteza estimados.

Para dar concretude aos dados, pode-se mencionar o caso da Amazônia. Caso mantida a trajetória de aumento da temperatura média, deve haver gradual substituição da floresta tropical úmida por uma savana, que seria menos rica em biodiversidade que a do cerrado do Centro-Oeste. Uma das consequências disso é a mudança no regime de chuvas no restante do continente, afetando os chamados "rios voadores": o vapor d'água proveniente da floresta amazônica é impulsionado pelos ventos ao longo da cordilheira dos Andes e precipitase em chuvas no Mato Grosso, Mato Grosso do Sul, Goiás, Minas Gerais, São Paulo e Sul do Brasil. Sem as chuvas, fica em risco uma das regiões agropecuárias mais produtivas do planeta, trazendo à tona a questão da segurança alimentar (RICUPERO, 2012).

É valido ainda fazer referência ao modelo chamado Had3CM, formulado por um dos mais respeitados institutos britânicos sobre o clima, o Hadley Center for Climate Prediction and Research. Segundo o modelo, citado pelo pesquisador do INPA Philip FEARNSIDE (2010), a permanecerem as projeções de aumento das emissões no cenário usual, 
a conjunção das altas temperaturas com menos chuva criaria um efeito similar a um El Niño permanente e acarretaria a morte da floresta amazônica antes de 2080. Ainda que esse seja o mais catastrófico dos cenários, ele foi apontado como o mais provável pelo climatologista brasileiro do INPE José Antonio Marengo, citado por FEARNSIDE (2010) e por RICUPERO (2012).

\section{GRÁFICO 4}

Mudança do nível dos oceanos e cobertura de gelo no verão ártico (1990-2012)

Global average sea level change
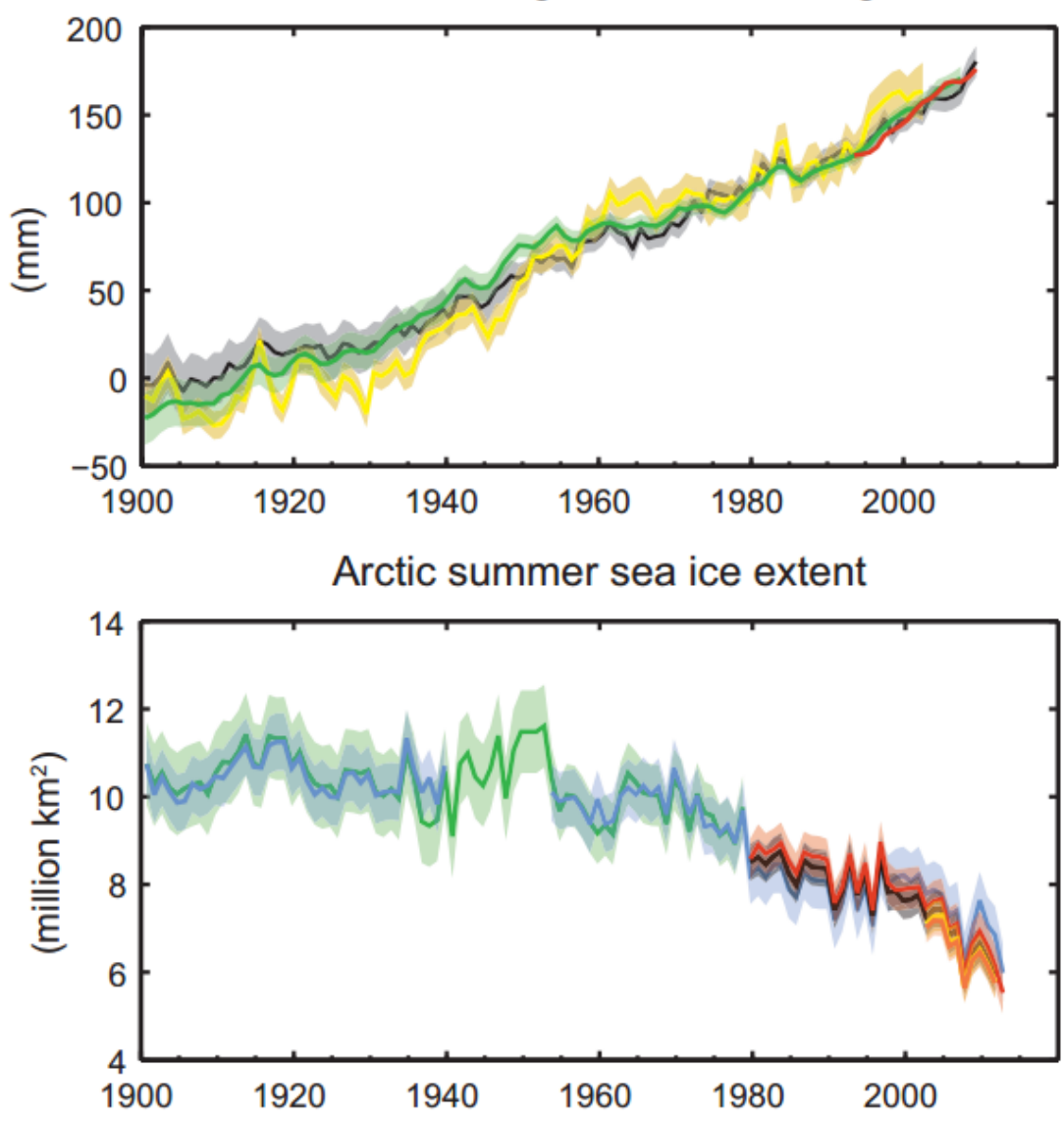

Fonte: AR5

Por volta de 2100, a temperatura média da Amazônia pode se elevar em até $8,3^{\circ} \mathrm{C}$, ainda segundo esse modelo do Hadley Center. Como lembra RICUPERO (2012), é uma diferença de temperatura média do planeta de apenas $5^{\circ} \mathrm{C}$ que nos separa da última Era Glacial.

Em síntese, pode-se dizer que, ainda que não se consiga indicar com precisão qual a proximidade da quebra do equilíbrio dos ecossistemas amazônicos, o princípio da precaução nos aconselha a levar em consideração que esse ponto de ruptura pode não estar distante no futuro (NOBRE, SAMPAIO e SALAZAR, 2007). 
Os relatórios do IPCC apontam ainda que as observações disponíveis de todos os continentes e da maioria dos oceanos mostram que muitos ecossistemas estão sendo afetados por mudanças climáticas regionais, particularmente a elevação das temperaturas. Essas mudanças abrangem tanto o regime hidrológico, como a variação na abundância de algas, plânctons e peixes. Esses possíveis efeitos da elevação de temperatura incluem impactos na agricultura e no manuseio de floresta (incêndios, pestes, etc.), mortalidade decorrente de calor e mudanças em vetores de doenças infecciosas.

Uma vez verificadas essas novas circunstâncias, o relatório parte para a análise das possíveis causas. Verificou-se que a emissão de gases de efeito estufa devido a atividades humanas cresceu a partir do início da Revolução Industrial, e o acréscimo apenas entre 1970 e 2004 chegou a 70\%. O mais importante dos gases estufa decorrente de atividade antropogênica é o dióxido de carbono $\left(\mathrm{CO}_{2}\right)$, cujas emissões cresceram 80\% entre 1970 e 2004.

O relatório afirma, então, que é extremamente provável (extremely likely) que essas modificações verificadas no clima desde meados do século XX estejam ligadas predominantemente à ação antrópica, que vem gerando gases que ampliam o efeito estufa naturalmente existente no planeta.

São seis os gases considerados pelo Protocolo de Quioto como causadores do efeito estufa: dióxido de carbono $\left(\mathrm{CO}_{2}\right)$, metano $\left(\mathrm{CH}_{4}\right)$, óxido nitroso $\left(\mathrm{N}_{2} \mathrm{O}\right)$, compostos de hidrofluorocarbonetos (HFCs), compostos de perfluorocarbonetos (PFCs) e hexafluoreto de enxofre $\left(\mathrm{SF}_{6}\right)$. Embora também contribuam para o efeito estufa, não são cobertos pelo Protocolo de Quioto os compostos de clorofluorocarbonetos (CFCs), que já estão regulados pelo Protocolo de Montreal, de $1987^{16}$.

Para calcular o potencial desses gases no efeito estufa, foi necessário construir uma escala única. Para isso, utiliza-se o efeito que o dióxido de carbono produz e compara-se esse a uma massa equivalente dos demais gases. Ou seja, uma unidade de $\mathrm{CO}_{2}$ corresponde à linha base para a medição do potencial de aquecimento global dos demais. Disso resulta a unidade de $\mathrm{CO}_{2}$-eq (ou equivalência em dióxido de carbono).

Ocorre, contudo, que os gases permanecem na atmosfera por períodos distintos, o que significa que seu potencial pode ser intenso no início e declinante nos anos seguintes, ou o contrário. Por essa razão, a comparação com uma unidade de $\mathrm{CO}_{2}$ é realizada levando em

\footnotetext{
${ }^{16} \mathrm{O}$ vapor d'água também é capaz de absorver radiação infravermelha e, desse modo, também produz o efeito estufa. Entretanto, sua concentração na atmosfera depende fundamentalmente da temperatura do ar, mediante evaporação, condensação e congelamento, o que praticamente afasta a possibilidade de controlar sua concentração. Por isso não foi calculado seu potencial de aquecimento global. Vale ainda registrar que o ozônio também contribui para o efeito estufa.
} 
conta o período de permanência do gás na atmosfera, e o cotejo usualmente é feito para períodos de 20 anos, 100 anos (a referência mais usual) e 500 anos. O metano, por exemplo, permanece na atmosfera por aproximadamente 12 anos, de modo que seu potencial de aquecimento global é alto para o período de vinte anos (equivale a 72 unidades de $\mathrm{CO}_{2}$ ) e menor para um período de 100 anos (equivale a 25 unidades de dióxido de carbono). A Tabela 2 sintetiza, de maneira simplificada, a diferença de potencial dos principais gases:

TABELA 2

\begin{tabular}{|l|c|c|c|c|}
\hline \multicolumn{1}{|c|}{ Principais gases estufa } & \multirow{2}{*}{$\begin{array}{c}\text { Permanência na } \\
\text { atmosfera, } \\
\text { em anos }\end{array}$} & \multicolumn{3}{c|}{$\begin{array}{c}\text { Potencial ao longo do } \\
\text { tempo* }\end{array}$} \\
\cline { 3 - 5 } & & $\begin{array}{c}\mathbf{2 0} \\
\text { anos }\end{array}$ & $\begin{array}{c}\mathbf{1 0 0} \\
\text { anos }\end{array}$ & $\begin{array}{c}\mathbf{5 0 0} \\
\text { anos }\end{array}$ \\
\hline Metano $\left(\mathrm{CH}_{4}\right)$ & 12 & 72 & 25 & 7,6 \\
\hline Óxido nitroso $\left(\mathrm{N}_{2} \mathrm{O}\right)$ & 114 & 289 & 298 & 153 \\
\hline HFC-23 $\left(\mathrm{CHF}_{3}\right)$ & 270 & 12.000 & 14.800 & 12.200 \\
\hline PFC-14 $\left(\mathrm{CF}_{4}\right)$ & 50.000 & 5.210 & 7.390 & 11.200 \\
\hline Hexafluoreto de enxofre $\left(\mathrm{SF}_{6}\right)$ & 3200 & 16.300 & 22.800 & 32.600 \\
\hline
\end{tabular}

* Dióxido de carbono tem potencial de aquecimento global igual a 1, já que ele é a unidade tomada para a linha de base para a comparação com os demais.

Fonte: Elaboração própria a partir do AR4, do IPCC

Verificada essa diferença no potencial de aquecimento global dos gases, é importante também examinar o Gráfico 5, que expõe o significativo incremento de alguns desses principais gases estufa durante a era industrial, notadamente nas últimas décadas. $\mathrm{O}$ gráfico expõe as concentrações de $\mathrm{CO}_{2}, \mathrm{CH}_{4}$ e $\mathrm{N}_{2} \mathrm{O}$ ao longo dos últimos 10.000 anos (quadros maiores) e desde 1750 (quadros menores). As medidas expostas foram retiradas de núcleos de camadas de gelo (foram utilizadas cores diferentes para os diferentes estudos) e, para os anos mais recentes, de amostras da atmosfera (linhas vermelhas). A força radiativa relativa a 1750 está demonstrada no eixo da direita dos quadros maiores.

Conforme o relatório do IPCC, as concentrações de $\mathrm{CO}_{2}$ na atmosfera se devem primariamente ao uso de combustíveis fósseis. As mudanças no uso da terra exercem uma contribuição significativa, mas inferior. Em relação ao $\mathrm{CH}_{4}$, o IPCC entende que é muito provável que sua elevação seja predominante atribuível à agricultura e ao uso de combustíveis fósseis. No que tange ao $\mathrm{N}_{2} \mathrm{O}$, o aumento da concentração desses gases na atmosfera se deve principalmente à agricultura. 


\section{GRÁFICO 5}

Mudanças nos gases estufa a partir de concentrações no gelo e dados recentes
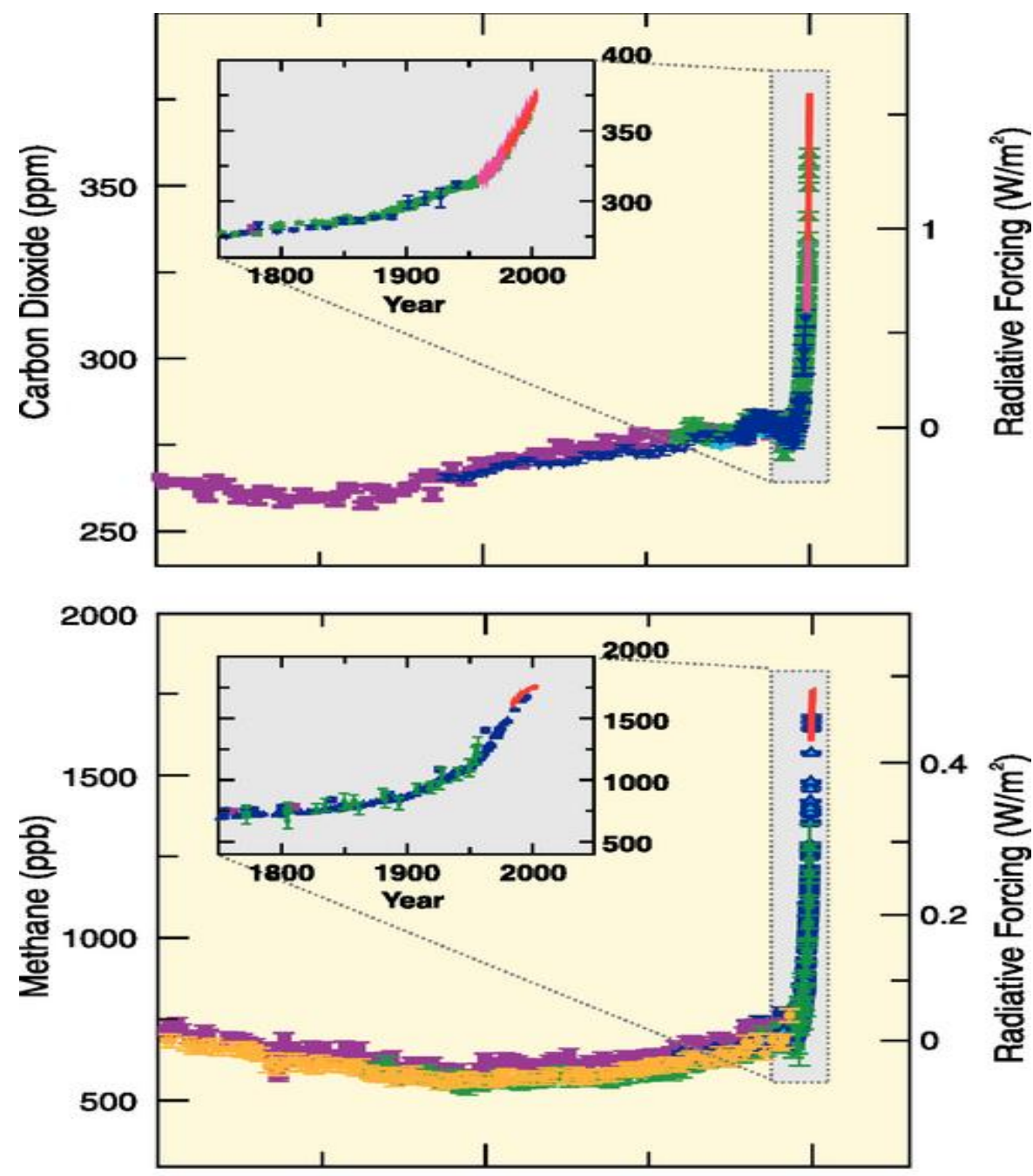

Fonte: AR4

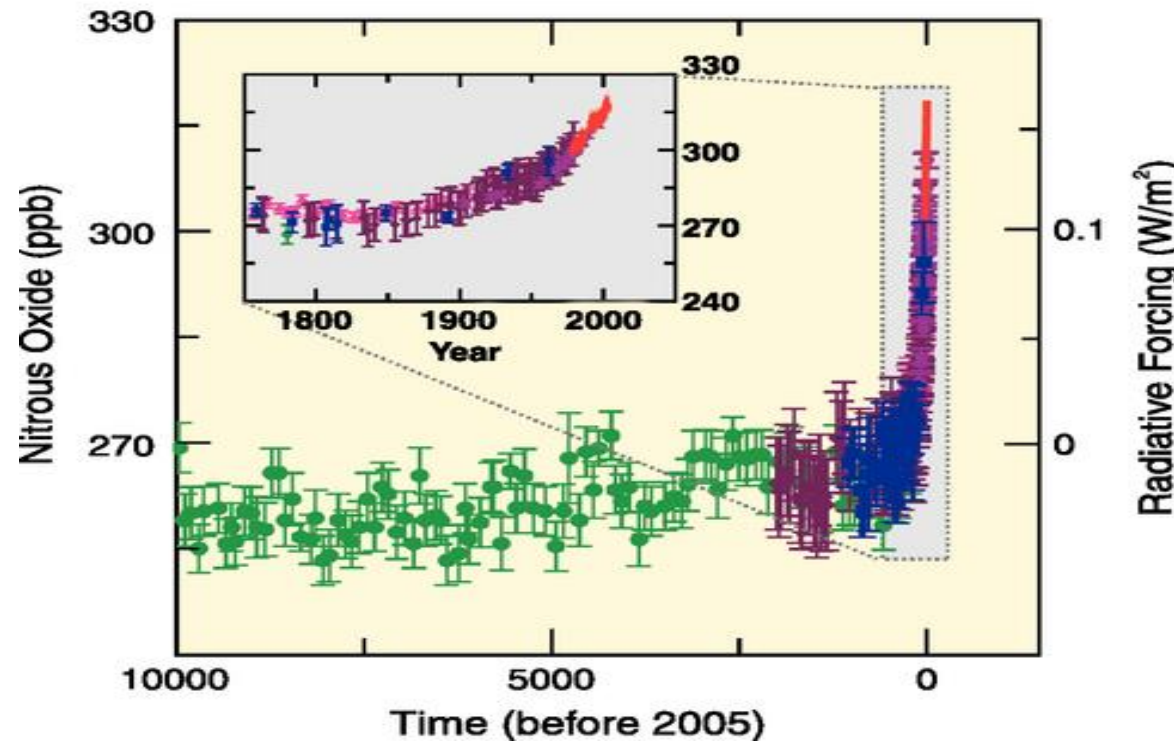


Para tornar ainda mais contundente o argumento do aquecimento provocado por atividades humanas, o relatório aponta que, a seguir os modelos climáticos de instituições diferentes, o mundo teria enfrentado um resfriamento nos últimos cinquenta anos em razão tanto das forças solares, quanto das atividades vulcânicas. Em outras palavras, apenas considerando as atividades humanas é que o aumento observado da temperatura poderia ser justificado.

Como indica RICUPERO (2012), existe praticamente consenso científico de que o teto das emissões tem de ser atingido dentro de mais ou menos 10 anos, já que, do contrário, poderão desencadear-se processos de retroalimentação que podem acelerar o aquecimento a um ponto irreversível.

A partir dessas informações e avaliações, o relatório estima o comportamento climático nos próximos anos, traçando vários cenários possíveis. O relatório demonstra que há grande concordância e bastantes provas de que, a se manterem as políticas de mitigação e as práticas de desenvolvimento vigentes quando de sua elaboração, mantendo-se a predominância dos combustíveis fósseis, a emissão de gases estufa continuará a crescer nas próximas décadas. É o que se vem chamando de cenário BAU (business as usual).

É muito provável que a manutenção ou a elevação dos atuais níveis de emissão de gases estufa muito provavelmente provocaria um aquecimento adicional e induziria muitas mudanças no sistema climático global, ainda maiores do que as verificadas no século XX.

Ainda que as concentrações de gases estufa fossem mantidas constantes no nível do ano 2000 , uma elevação de $0,1^{\circ} \mathrm{C}$ por década seria esperada. A depender, contudo, do aumento dos níveis das emissões, as projeções de aumento da temperatura variam bastante. As projeções trabalham com incertezas e, especialmente a partir de elevações maiores de temperatura, a margem de erro superior é maior, porque há processos de retroalimentação do aquecimento para os quais não há modelos ainda inteiramente consistentes.

Por exemplo, o descongelamento no Ártico pode provocar a liberação do metano hoje estocado na região - o que pode agravar fortemente o aquecimento e provocar ainda maior degelo. Além disso, o aquecimento reduz a reabsorção do $\mathrm{CO}_{2}$ atmosférico nos oceanos e em terra, aumentando a fração das emissões antrópicas que permanecem na atmosfera.

A Figura 1 procura consolidar os diferentes impactos relacionados às possíveis variações de temperatura que o planeta pode vivenciar. As mudanças projetadas indicam variações no acesso à água, impactos nos diferentes ecossistemas, mudanças na produtividade 
da terra para produção de alimentos, regiões costeiras afetadas por alagamentos e tempestades e, por fim, consequências para a saúde da população.

FIGURA 1

Exemplos de impactos associados com mudança da temperatura global média

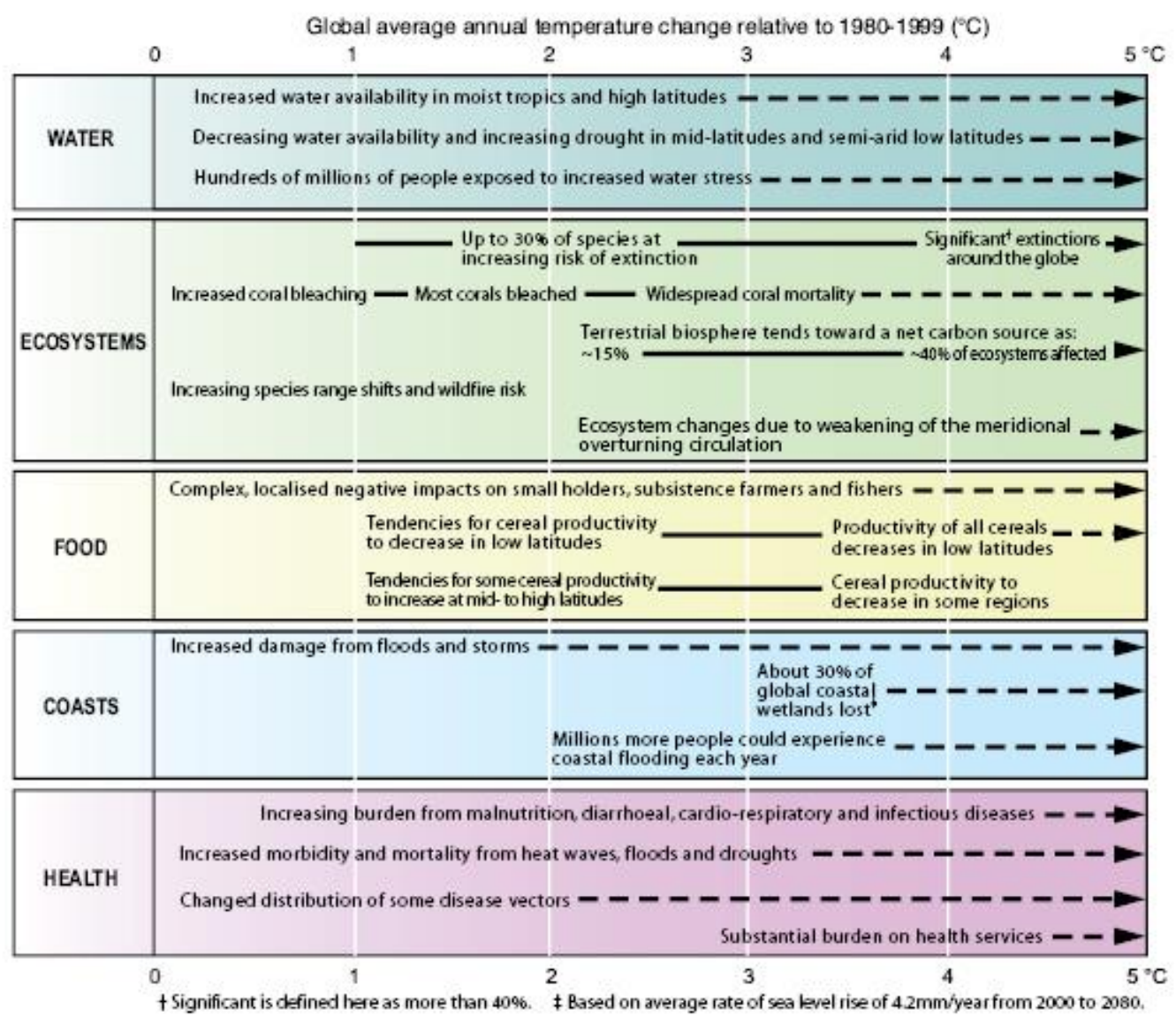

Warming by 2090-2099 relative to $1980-1999$ for non-mitigation scenarios

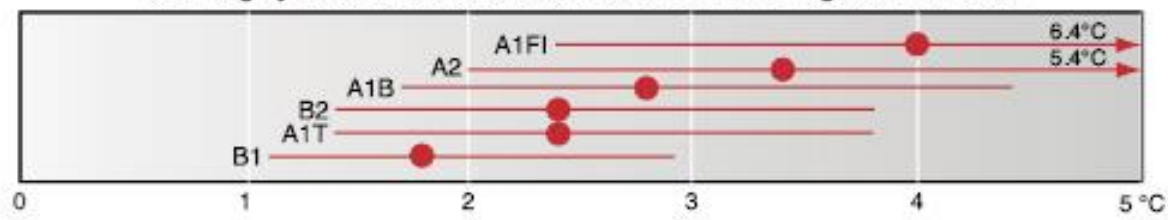

Painel superior: exemplos ilustrativos de impactos globais projetados para as mudanças climáticas associados com diferentes níveis de elevação da temperatura média ao longo do século XXI.

As linhas pretas contínuas remetem aos impactos.

As setas com linhas pontilhadas indicam impactos continuando com o aumento da temperatura.

As indicações gráficas estão postas de modo que a parte mais à esquerda do texto indica o nível aproximado de aquecimento associado com o início do impacto listado.

As indicações quantitativas para escassez de água e inundações representam o impacto adicional da mudança climática em relação às condições projetadas através do intervalo dos cenários SRES.

A adaptação às mudanças climáticas não está incluída nessas estimativas. O intervalo de confiança para as indicações é elevado.

Painel inferior: Pontos e barras indicam a melhor estimativa e o intervalo provável de aquecimento avaliado pelos seis cenários SRES para 2090-2099 em relação a 1980-1999.

Fonte: AR4 
Também merece registro a alteração na frequência e na intensidade de climas extremos, com efeitos evidentes sobre a humanidade. Entre eles, pode-se mencionar o aumento no número de dias e noites quentes e em sua intensidade, aumentos de precipitações intensas, além de probabilidade maior de secas e de ciclones tropicais. A alteração na frequência e na intensidade de eventos climáticos extremos, juntamente com a elevação do nível do mar, deve provocar principalmente efeitos adversos nos sistemas humanos e naturais, como prevê IPCC na Tabela 3.

A camada de gelo na Groelândia deve continuar a contribuir para a elevação do nível do mar, mesmo depois de 2100, segundo projeções indicadas pelo IPCC. Algumas projeções apontam que o derretimento completo da camada de gelo que reveste a Groelândia poderia resultar num aumento de $7 \mathrm{~m}$ do nível do mar, caso as temperaturas elevadas sejam mantidas por séculos em comparação com os níveis pré-industriais. Na Antártida, entretanto, os modelos sugerem que deve haver pouca perda da camada de gelo, já que, mesmo havendo elevação, as temperaturas devem permanecer bastante baixas.

Há aí também efeitos de retroalimentação do processo de aquecimento: o derretimento da cobertura de gelo ou de neve faz com que os raios solares, em lugar de atingirem a cobertura de coloração branca e, por consequência, serem refletidos, atinjam o solo ou a água mais escura, de modo que a radiação é absorvida em maior quantidade - o que provocaria maior derretimento. É o que se chama de alteração do albedo, ou coeficiente de reflexão.

TABELA 3

Exemplos de possíveis impactos climáticos devido a mudanças nos eventos climáticos extremos

\begin{tabular}{|c|c|c|c|c|c|}
\hline \multirow{2}{*}{$\begin{array}{l}\text { Fenômeno e } \\
\text { direção da } \\
\text { tendência }\end{array}$} & \multirow{2}{*}{$\begin{array}{l}\text { Probabilidade } \\
\text { de tendências } \\
\text { futuras } \\
\text { baseadas nas } \\
\text { projeções para } \\
\text { o século XXI } \\
\text { dos cenários } \\
\text { do SRES }\end{array}$} & \multicolumn{4}{|c|}{ Exemplos dos principais impactos projetados por setor } \\
\hline & & $\begin{array}{l}\text { Agricultura, } \\
\text { florestas e } \\
\text { ecossistemas }\end{array}$ & $\begin{array}{l}\text { Recursos } \\
\text { hídricos }\end{array}$ & $\begin{array}{c}\text { Saúde } \\
\text { humana }\end{array}$ & $\begin{array}{c}\text { Indústria, } \\
\text { assentamentos } \\
\text { humanos e } \\
\text { sociedade }\end{array}$ \\
\hline $\begin{array}{l}\text { Na maior } \\
\text { parte das } \\
\text { áreas } \\
\text { terrestres, } \\
\text { dias mais } \\
\text { quentes; } \\
\text { menos dias e } \\
\text { noites frios; } \\
\text { dias e noites } \\
\text { quentes mais } \\
\text { frequentes }\end{array}$ & $\begin{array}{l}\text { Virtualmente } \\
\text { certo }\end{array}$ & $\begin{array}{l}\text { Aumento da } \\
\text { produtividade em } \\
\text { ambientes mais } \\
\text { frios; queda da } \\
\text { produtividade em } \\
\text { lugares mais } \\
\text { quentes; aumento } \\
\text { de surtos de } \\
\text { insetos }\end{array}$ & $\begin{array}{l}\text { Efeitos sobre } \\
\text { os recursos } \\
\text { hídricos } \\
\text { relacionados ao } \\
\text { degelo; efeitos } \\
\text { sobre algumas } \\
\text { fontes de água }\end{array}$ & $\begin{array}{l}\text { Redução da } \\
\text { mortalidade } \\
\text { humana em } \\
\text { razão da } \\
\text { diminuição da } \\
\text { exposição ao } \\
\text { frio }\end{array}$ & $\begin{array}{l}\text { Redução da } \\
\text { demanda para } \\
\text { aquecimento; } \\
\text { aumento da } \\
\text { demanda por ar } \\
\text { condicionado; } \\
\text { Perda da } \\
\text { qualidade do ar } \\
\text { nas cidades; } \\
\text { redução das } \\
\text { interrupções de } \\
\text { transporte } \\
\text { decorrentes de }\end{array}$ \\
\hline
\end{tabular}




\begin{tabular}{|c|c|c|c|c|c|}
\hline & & & & & $\begin{array}{l}\text { neve e gelo; } \\
\text { impactos sobre o } \\
\text { turismo de } \\
\text { inverno }\end{array}$ \\
\hline $\begin{array}{l}\text { Períodos } \\
\text { quentes / } \\
\text { ondas de } \\
\text { calor. A } \\
\text { frequência } \\
\text { aumenta na } \\
\text { maioria das } \\
\text { áreas } \\
\text { terrestres }\end{array}$ & Muito provável & $\begin{array}{l}\text { Diminuição da } \\
\text { produtividade em } \\
\text { regiões mais } \\
\text { quentes devido ao } \\
\text { stress térmico; } \\
\text { perigo crescente } \\
\text { de incêndios }\end{array}$ & $\begin{array}{l}\text { Aumento da } \\
\text { demanda por } \\
\text { água; } \\
\text { problemas na } \\
\text { qualidade da } \\
\text { água (exemplo: } \\
\text { floração de } \\
\text { algas - algal } \\
\text { blooms) }\end{array}$ & $\begin{array}{l}\text { Aumento do } \\
\text { risco de mortes } \\
\text { relacionadas } \\
\text { ao calor, } \\
\text { especialmente } \\
\text { para idosos, } \\
\text { doentes } \\
\text { crônicos, } \\
\text { muito jovens e } \\
\text { socialmente } \\
\text { isolados. }\end{array}$ & $\begin{array}{l}\text { Redução na } \\
\text { qualidade de vida } \\
\text { para pessoas em } \\
\text { áreas quentes } \\
\text { sem habitações } \\
\text { adequadas; } \\
\text { impactos para os } \\
\text { mais velhos, } \\
\text { muito jovens e } \\
\text { pobres }\end{array}$ \\
\hline $\begin{array}{l}\text { Eventos de } \\
\text { precipitação } \\
\text { intensa. } \\
\text { Frequência } \\
\text { aumenta na } \\
\text { maioria das } \\
\text { áreas. }\end{array}$ & Muito provável & $\begin{array}{l}\text { Prejuízo para as } \\
\text { safras, erosão do } \\
\text { solo, } \\
\text { incapacidade para } \\
\text { cultivar a terra } \\
\text { devido ao } \\
\text { encharcamento } \\
\text { dos solos }\end{array}$ & $\begin{array}{l}\text { Efeitos } \\
\text { adversos na } \\
\text { qualidade da } \\
\text { água de } \\
\text { superfície e } \\
\text { subterrâneas; } \\
\text { contaminação } \\
\text { do } \\
\text { abastecimento } \\
\text { de água; } \\
\text { escassez de } \\
\text { água pode ser } \\
\text { aliviada }\end{array}$ & $\begin{array}{l}\text { Aumento do } \\
\text { risco de } \\
\text { mortes, } \\
\text { ferimentos e } \\
\text { doenças } \\
\text { respiratórios, } \\
\text { infecciosas e } \\
\text { de pele }\end{array}$ & $\begin{array}{l}\text { Destruição de } \\
\text { assentamentos, } \\
\text { comércio, } \\
\text { transportes e } \\
\text { sociedades } \\
\text { devido a } \\
\text { inundações; } \\
\text { pressões sobre } \\
\text { infraestrutura } \\
\text { urbana e rural; } \\
\text { perda de } \\
\text { propriedades }\end{array}$ \\
\hline $\begin{array}{l}\text { Aumento das } \\
\text { atividades de } \\
\text { ciclones } \\
\text { tropicais } \\
\text { intensos }\end{array}$ & Provável & $\begin{array}{l}\text { Prejuízos para as } \\
\text { safras; } \\
\text { desenraizamento } \\
\text { de árvores; danos } \\
\text { aos recifes de } \\
\text { coral }\end{array}$ & $\begin{array}{l}\text { Quedas de } \\
\text { energia podem } \\
\text { causar } \\
\text { interrupção do } \\
\text { abastecimento } \\
\text { público de } \\
\text { água }\end{array}$ & $\begin{array}{l}\text { Aumento do } \\
\text { risco de } \\
\text { mortes, lesões, } \\
\text { doenças de } \\
\text { origem } \\
\text { alimentar e de } \\
\text { água } \\
\text { imprópria, } \\
\text { distúrbios pós- } \\
\text { traumáticos de } \\
\text { stress }\end{array}$ & $\begin{array}{l}\text { Perturbações por } \\
\text { enchentes e } \\
\text { ventos fortes; } \\
\text { seguradoras } \\
\text { privadas podem } \\
\text { retirar a } \\
\text { cobertura de } \\
\text { riscos em zonas } \\
\text { vulneráveis; } \\
\text { potencial para } \\
\text { migrações } \\
\text { populacionais; } \\
\text { perdas de } \\
\text { propriedades }\end{array}$ \\
\hline
\end{tabular}

Fonte: AR4 (tradução livre)

O derretimento do gelo polar deve provocar impactos variados, como o provável aumento do risco de extinção de espécies e mudanças significativas na circulação das correntes marítimas (chamada de circulação termoalina). Só a mudança na intensidade e na velocidade das correntes marítimas pode afetar a temperatura e a biodiversidade em inúmeras regiões do planeta, a produtividade da pesca, a capacidade de reabsorção do $\mathrm{CO}_{2}$ pelos oceanos, a concentração de oxigênio nos oceanos e mesmo a vegetação terrestre - o que pode, também, produzir efeitos de retroalimentação para o aquecimento. 
Além dos dados atinentes à elevação da temperatura média da atmosfera e da análise das prováveis causas do fenômeno, o relatório aponta as opções de adaptação e de mitigação da mudança climática. O vocábulo "adaptação" tem sido usado para as respostas ao aquecimento global com o propósito de reduzir a vulnerabilidade de sistemas biológicos aos efeitos da mudança climática. Os modelos indicam que, mesmo se forem estabilizadas as emissões no curto prazo, alguns efeitos da mudança climática perdurarão por alguns anos e tornarão inafastável a necessidade de se adaptar.

A outra resposta ao aquecimento global é a chamada "mitigação", expressão associada à redução das emissões de gases estufa ou ao aumento da remoção desses gases da atmosfera, notadamente por meio dos chamados sumidouros de carbono. Quanto maior a efetividade das ações de mitigação, menor o esforço necessário para a adaptação. Aliás, como apontam os relatórios, se os esforços de mitigação forem absolutamente ineficazes, é possível que a magnitude da adaptação necessária a certos sistemas seja virtualmente inalcançável.

Na avaliação do IPCC, uma grande variedade de opções de adaptação está disponível, mas para diminuir a vulnerabilidade seria necessário intensificar sua implantação. Ainda não são inteiramente compreendidos os limites, os custos e os obstáculos para a difusão dos mecanismos existentes.

O relatório aponta ainda que a vulnerabilidade à mudança climática pode ser agravada por outros fatores, como a pobreza, o acesso desigual aos recursos, a insegurança alimentar, as tendências na globalização econômica e mesmo os conflitos e as doenças.

O relatório elenca inúmeros exemplos de iniciativas de adaptação planejadas, divididas por setor, algumas das quais vêm sendo implantadas e apresentam custos modestos, particularmente se considerada a relação custo-benefício, conforme se verifica na Tabela 4. Entre as ações de adaptação, o relatório aponta a política pública correspondente a cada setor.

Embora algumas iniciativas de adaptação na área de energia sejam também examinadas nesta tese, o foco do trabalho está voltado para as iniciativas de mitigação da área de energia, como se verá adiante.

O IPCC observa que a capacidade de adaptação está intimamente conectada com o nível de desenvolvimento econômico e social. Além disso, os modelos climáticos indicam que, além de disporem de menor capacidade adaptativa, os países em desenvolvimento devem ser mais fortemente afetados pelas mudanças climáticas. Os países desenvolvidos dispõem de mais recursos, mais pessoas qualificadas, instituições mais sólidas e maior tecnologia para enfrentar os desafios da adaptação (COLE, 2007). Entretanto, mesmo dentro dessas sociedades, essas capacidades não estão igualmente distribuídas, já que há grupos 
sociais bem mais vulneráveis do que outros - os setores atingidos pelo Furacão Katrina, em Nova Orleans, em 2005, são um bom exemplo dessa distribuição desigual de capacidade adaptativa, mesmo no seio de um dos países mais ricos do mundo.

TABELA 4

Exemplos selecionados de adaptação, por setor

\begin{tabular}{|c|c|c|c|}
\hline Setor & $\begin{array}{c}\text { Opção de adaptação / } \\
\text { estratégia }\end{array}$ & $\begin{array}{l}\text { Políticas públicas } \\
\text { subjacentes }\end{array}$ & $\begin{array}{c}\text { Limitações principais e } \\
\text { oportunidades para } \\
\text { implementação } \\
\text { (Fonte normal = limitações } \\
\text { Itálico = oportunidades) }\end{array}$ \\
\hline Agricultura & $\begin{array}{l}\text { Ajuste de épocas de plantio e } \\
\text { variedades de culturas; } \\
\text { relocalização de culturas; } \\
\text { gestão melhorada da terra, por } \\
\text { exemplo, controle de erosão e } \\
\text { proteção do solo através do } \\
\text { plantio de árvores }\end{array}$ & $\begin{array}{l}\text { Políticas de P\&D; } \\
\text { reforma institucional; } \\
\text { posse da terra e reforma } \\
\text { agrária; treinamento, } \\
\text { capacitação; seguro } \\
\text { agrícola, incentivos } \\
\text { financeiros, por } \\
\text { exemplo, subsídios e } \\
\text { créditos fiscais }\end{array}$ & $\begin{array}{l}\text { Limitações tecnológicas e } \\
\text { financeiras; acesso a novas } \\
\text { variedades; mercados; } \\
\text { período de crescimento } \\
\text { das culturas mais longo } \\
\text { em latitudes mais altas; } \\
\text { receitas de "novos" } \\
\text { produtos }\end{array}$ \\
\hline $\begin{array}{l}\text { Infraestrutura / } \\
\text { assentamentos } \\
\text { (incluindo zonas } \\
\text { costeiras) }\end{array}$ & $\begin{array}{l}\text { Reassentamentos; barreiras } \\
\text { contra tempestades e marés; } \\
\text { reforço das dunas; aquisição de } \\
\text { terras e criação de zonas } \\
\text { úmidas como pântanos como } \\
\text { tampão contra a elevação do } \\
\text { nível do mar e inundações; } \\
\text { proteção das barreiras naturais } \\
\text { existentes }\end{array}$ & $\begin{array}{l}\text { Normas e regulamentos } \\
\text { que considerem as } \\
\text { alterações climáticas } \\
\text { em desenhos ou } \\
\text { modelos; políticas de } \\
\text { uso da terra; códigos de } \\
\text { construção; seguro }\end{array}$ & $\begin{array}{l}\text { Barreiras financeiras e } \\
\text { tecnológicas; } \\
\text { disponibilidade de espaço } \\
\text { para reassentamentos; } \\
\text { políticas integradas e de } \\
\text { gestão; sinergias com } \\
\text { objetivos de } \\
\text { desenvolvimento } \\
\text { sustentável }\end{array}$ \\
\hline Transportes & $\begin{array}{l}\text { Realinhamento ou realocação; } \\
\text { padrões de design e } \\
\text { planejamento de estradas, } \\
\text { ferrovias e outras } \\
\text { infraestruturas para lidar com o } \\
\text { aquecimento e a drenagem }\end{array}$ & $\begin{array}{l}\text { Integração da mudança } \\
\text { climática com a política } \\
\text { nacional de transportes; } \\
\text { investimento em P\&D } \\
\text { para situações } \\
\text { especiais, como as } \\
\text { áreas de permafrost }\end{array}$ & $\begin{array}{l}\text { Barreiras financeiras e } \\
\text { tecnológicas; } \\
\text { disponibilidade de rotas } \\
\text { menos vulneráveis; } \\
\text { tecnologias melhoradas e } \\
\text { integração com os setores- } \\
\text { chave (por exemplo, } \\
\text { energia) }\end{array}$ \\
\hline Energia & $\begin{array}{l}\text { Fortalecimento de } \\
\text { infraestrutura aérea de } \\
\text { transmissão e de distribuição; } \\
\text { cabeamento subterrâneo para } \\
\text { distribuição; eficiência } \\
\text { energética; uso de fontes } \\
\text { renováveis; redução da } \\
\text { dependência de fontes únicas } \\
\text { de energia }\end{array}$ & $\begin{array}{l}\text { Incorporação das } \\
\text { mudanças climáticas } \\
\text { nos desenhos das } \\
\text { políticas nacionais de } \\
\text { energia; regulamentos e } \\
\text { incentivos fiscais e } \\
\text { financeiros para } \\
\text { incentivar a utilização } \\
\text { de fontes alternativas; }\end{array}$ & $\begin{array}{l}\text { Acesso a alternativas } \\
\text { viáveis; barreiras } \\
\text { financeiras e tecnológicas; } \\
\text { aceitação das novas } \\
\text { tecnologias; estímulo a } \\
\text { novas tecnologias; uso de } \\
\text { recursos locais }\end{array}$ \\
\hline
\end{tabular}

Fonte: AR4

É nas ações relacionadas à mitigação que esta tese está focada, particularmente nas ações na área de energia. A geração energética responde por parcela significativa do total de emissão de gases estufa de origem antrópica, conforme expõe o Gráfico 6. Eletricidade e aquecimento representam cerca de $25 \%$, outras energias correspondem a mais $9,6 \%$, além de o 
setor de transporte, diretamente associado ao uso de energia, contribuir com outros $14 \%$. Somados esses três subgrupos, diretamente relacionados à geração primária de energia, chegase praticamente à metade do total de emissões antrópicas.

\section{GRÁFICO 6}

Emissão global de gases estufa de origem antropogênica, por setores, em 2010

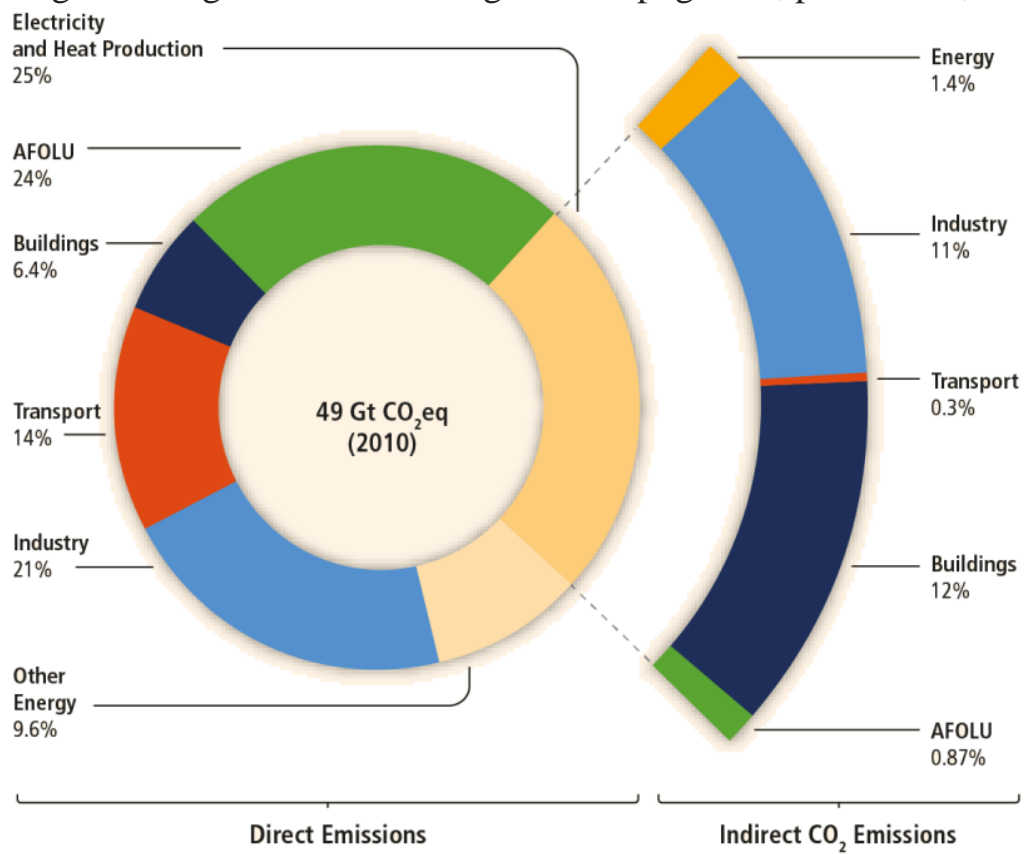

OBS.: AFOLU é a sigla para "Agriculture, Forestry and Other Land Use".

Fonte: AR5

O relatório do IPCC expõe que as pesquisas realizadas, quer com a perspectiva de decomposição (top-down), quer com a de síntese (bottom-up), indicam um elevado nível de concordância e bastante evidência de que há um potencial econômico substancial para a mitigação das emissões globais de gases estufa nas próximas décadas. Esse potencial poderia compensar o crescimento projetado das emissões globais ou mesmo reduzi-las para os níveis atuais.

$\mathrm{Na}$ avaliação do relatório do IPCC, nenhuma das tecnologias, isoladamente, teria capacidade de fornecer todo o potencial de mitigação de cada setor. A conjugação de várias tecnologias é, portanto, central para que os resultados sejam efetivos. Parece claro também que o potencial de mitigação apenas por meio da ação do mercado não comportaria todo o potencial de mitigação existente no caso de serem adotadas políticas adequadas e removidas as barreiras à sua difusão. A Tabela 5 aponta os principais exemplos de políticaschave em cada setor, indicando suas barreiras e suas potencialidades: 
TABELA 5

Exemplos selecionados de tecnologias chave de mitigação por setor

\begin{tabular}{|c|c|c|c|}
\hline Setor & $\begin{array}{l}\text { Tecnologias-chave de mitigação } \\
\text { e práticas já disponíveis } \\
\text { comercialmente } \\
\text { Tecnologias-chave de mitigação e } \\
\text { práticas projetadas para serem } \\
\text { comercializadas antes de 2030, } \\
\text { em itálico }\end{array}$ & $\begin{array}{l}\text { Políticas, medidas e } \\
\text { instrumentos apontados } \\
\text { como efetivos } \\
\text { ambientalmente }\end{array}$ & $\begin{array}{l}\text { Principais limitações ou } \\
\text { oportunidades } \\
\text { (fonte normal= } \\
\text { limitações; } \\
\text { fonte em itálico= } \\
\text { oportunidades) }\end{array}$ \\
\hline \multirow[t]{2}{*}{$\begin{array}{l}\text { Fornecimento } \\
\text { de energia }\end{array}$} & \multirow{2}{*}{$\begin{array}{l}\text { Melhoria da eficiência na geração } \\
\text { e distribuição de energia; troca de } \\
\text { combustível do carvão para o gás; } \\
\text { energia nuclear; aquecimento e } \\
\text { energia renováveis (hidrelétrica, } \\
\text { solar, eólica, geotérmica e } \\
\text { bioenergia); produção combinada } \\
\text { de calor e energia; primeiras } \\
\text { aplicações de captura e } \\
\text { armazenamento de dióxido de } \\
\text { carbono (CCS) (por exemplo, } \\
\text { armazenamento de } \mathrm{CO}_{2} \text { oriundo } \\
\text { do gás natural); } \\
\text { CCS para instalações de geração } \\
\text { de eletricidade a partir de } \\
\text { biomassa, gás e carvão; energia } \\
\text { nuclear avançada; energia } \\
\text { renovável avançada, incluindo a } \\
\text { energia das marés e das ondas, } \\
\text { concentração de energia solar e } \\
\text { energia solar fotovoltaica }\end{array}$} & $\begin{array}{l}\text { Redução dos subsídios } \\
\text { aos combustíveis fósseis; } \\
\text { tributação ou encargos } \\
\text { sobre combustíveis } \\
\text { fósseis }\end{array}$ & $\begin{array}{l}\text { Resistência por } \\
\text { interesses instalados } \\
\text { pode torná-los difíceis de } \\
\text { implementar }\end{array}$ \\
\hline & & $\begin{array}{l}\text { Tarifas especiais para } \\
\text { tecnologias de energias } \\
\text { renováveis; exigências de } \\
\text { energia renovável; } \\
\text { subsídios aos produtores }\end{array}$ & $\begin{array}{l}\text { Podem ser adequados } \\
\text { para criar mercados } \\
\text { para tecnologias de } \\
\text { baixa emissão }\end{array}$ \\
\hline \multirow[t]{3}{*}{ Transportes } & \multirow{3}{*}{$\begin{array}{l}\text { Mais veículos com eficiência em } \\
\text { combustíveis; veículos híbridos; } \\
\text { veículos a diesel mais limpos; } \\
\text { biocombustíveis; alterações do } \\
\text { modal de transporte rodoviário } \\
\text { para o ferroviário e para sistemas } \\
\text { de transportes públicos; } \\
\text { transportes não motorizados } \\
\text { (bicicleta, caminhada); } \\
\text { planejamento do uso da terra e dos } \\
\text { transportes; } \\
\text { biocombustíveis de segunda } \\
\text { geração; aeronaves de maior } \\
\text { eficiência energética; veículos } \\
\text { elétricos e híbridos avançados, } \\
\text { com baterias mais potentes e } \\
\text { confiáveis }\end{array}$} & $\begin{array}{l}\text { Economia de combustível } \\
\text { obrigatória; mistura de } \\
\text { biocombustível e padrões } \\
\text { de } \mathrm{CO}_{2} \text { para o transporte } \\
\text { rodoviário }\end{array}$ & $\begin{array}{l}\text { A cobertura parcial da } \\
\text { frota de veículos pode } \\
\text { limitar a eficácia }\end{array}$ \\
\hline & & $\begin{array}{l}\text { Impostos sobre compra, } \\
\text { registro e uso de veículos } \\
\text { a motor; precificação de } \\
\text { uso de estrada e } \\
\text { estacionamento }\end{array}$ & $\begin{array}{l}\text { A eficácia da tende a se } \\
\text { reduzir para rendimentos } \\
\text { mais elevados }\end{array}$ \\
\hline & & $\begin{array}{l}\text { Influenciar as } \\
\text { necessidades de } \\
\text { mobilidade mediante } \\
\text { ordenamento territorial e } \\
\text { planejamento de } \\
\text { infraestrutura; } \\
\text { investimento em meios } \\
\text { de transporte públicos } \\
\text { atrativos e formas de } \\
\text { transporte não } \\
\text { motorizadas }\end{array}$ & $\begin{array}{l}\text { Particularmente } \\
\text { apropriado para países } \\
\text { que estão construindo } \\
\text { seus sistemas de } \\
\text { transporte }\end{array}$ \\
\hline \multirow[t]{2}{*}{ Indústria } & \multirow{2}{*}{$\begin{array}{l}\text { Uso final mais eficiente de } \\
\text { equipamento elétrico; recuperação } \\
\text { de calor e de energia; reciclagem } \\
\text { de materiais e substituição; } \\
\text { controle de emissões de outros } \\
\text { gases além do } \mathrm{CO}_{2} ; \text { uma grande } \\
\text { variedade de tecnologias de } \\
\text { processo específicas; eficiência } \\
\text { energética avançada; } C C S\end{array}$} & $\begin{array}{l}\text { Fornecimento de } \\
\text { informação de referência; } \\
\text { padrões de desempenho; } \\
\text { subsídios; créditos } \\
\text { tributários }\end{array}$ & $\begin{array}{l}\text { Pode ser adequado para } \\
\text { estimular a absorção de } \\
\text { tecnologia. É importante } \\
\text { a estabilidade da política } \\
\text { nacional em face da } \\
\text { competitividade } \\
\text { internacional }\end{array}$ \\
\hline & & $\begin{array}{l}\text { Licenças } \\
\text { comercializáveis }\end{array}$ & $\begin{array}{l}\text { Mecanismos de alocação } \\
\text { previsíveis e sinais de }\end{array}$ \\
\hline
\end{tabular}




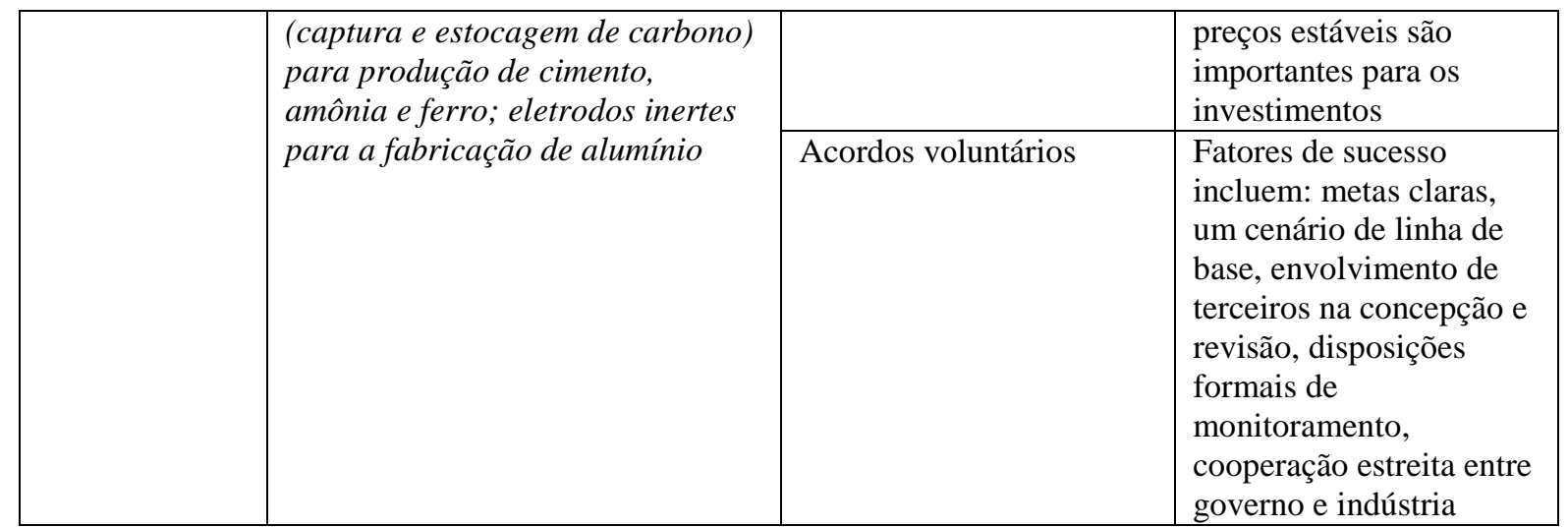

Fonte: AR4 (tradução livre)

O relatório do IPCC aponta que as decisões de investimento em infraestrutura entre 2005 e 2030 terão impacto de longo prazo sobre as emissões de gases estufa, graças à longevidade das plantas de energia e ao estoque das demais infraestruturas. Para reduzir as emissões de estufa em 2030 seria necessária uma profunda mudança no padrão dos investimentos, conquanto, nas contas consolidadas pelo relatório, isso exija investimentos adicionais líquidos tão-somente de $5 \%$ a $10 \%$.

Nesse contexto, existe uma ampla variedade de instrumentos à disposição dos governos para criar incentivos para as ações de mitigação - ou para desestimular a continuidade dos investimentos em tecnologias intensivas em carbono. Quais os mais eficazes desses instrumentos e como têm sido aplicados nos países é o que se buscará demonstrar nos capítulos seguintes deste trabalho. Na avaliação do IPCC, a aplicabilidade das ferramentas depende fundamentalmente das circunstâncias do país e do contexto setorial.

O relatório aponta as principais políticas a serem adotadas na área, conforme experiências já examinadas:

- Integração da política climática com políticas de desenvolvimento mais amplas, o que torna mais fácil a superação das barreiras - no pacote anticíclico lançado pela Coreia do Sul em 2009, 81\% dos recursos foram focados em investimentos de baixo carbono e, na China, foram cerca de 38\% dos recursos para temas "verdes" (ROBINS, CLOVER E SINGH, 2009)

- Regulações e padronizações costumam garantir alguma confiança para os níveis de emissão de gases estufa, embora eles não estimulem inovações e avanços tecnológicos

- Tributos e encargos podem ajudar a estabelecer um preço para o carbono, mas não garantem um nível específico de emissões. A literatura identifica que a tributação é um 
mecanismo eficiente para internalizar os custos das emissões de gases estufa (precifica as externalidades negativas do carbono)

- O comércio de emissões (tradable permits) também ajuda na formação do preço para o carbono, mas a alocação das autorizações tem consequências distributivas e é difícil estimar o custo total de exigir essas permissões.

- Incentivos financeiros, como subsídios e créditos tributários, têm sido utilizados para fomentar o desenvolvimento e a difusão de novas tecnologias. Ainda que o custo econômico dessa alternativa seja maior do que o das anteriores, esses instrumentos têm se revelado críticos para superar certos obstáculos.

- Acordos voluntários entre indústria e governos têm se mostrado politicamente atrativos, ampliado a conscientização em torno do tema e cumprido um papel na evolução das políticas climáticas nacionais. Entretanto, a maioria dos acordos não se mostraram relevantes para a redução das emissões em relação às projetadas, embora em alguns poucos países tenha havido aceleração na escolha das melhores tecnologias e reduções mensuráveis de emissões.

- Campanhas de conscientização e abertura de informações sobre o assunto podem ter efeitos positivos por estimular a escolha do consumidor e mudança de comportamentos, mas seu impacto ainda não foi mensurado.

- As atividades de pesquisa, desenvolvimento e demonstração podem estimular avanços tecnológicos, reduzir custos da mudança e viabilizar progressos rumo à estabilização das emissões.

Em relação aos custos da transição para uma economia de baixo carbono, o IPCC também aponta que há bastantes evidências de que as ações de mitigação induzidas por políticas públicas adequadas podem resultar em benefícios que compensam uma parcela substancial de seus custos, tais como melhoria da saúde pública em razão da redução da poluição do ar.

O IPCC observa ainda que decisões sobre política macroeconômica e sobre políticas não ligadas ao clima podem afetar significativamente as emissões de gases estufa, a capacidade de adaptação e a vulnerabilidade do país às mudanças climáticas. Não podem, portanto, ser tratados de modo inteiramente apartado. Na mesma toada, tornar o desenvolvimento mais sustentável pode robustecer a capacidade de adaptação e de mitigação, mas existem barreiras para a implementação desse modelo de desenvolvimento. 
O IPCC entende que há alto nível de confiança no fato de que nem a adaptação, tampouco a mitigação poderiam, isoladamente, evitar os impactos estimados do aquecimento global e da mudança climática. Entende-se, entretanto, que uma pode complementar a outra e, desse modo, reduzir de maneira substancial os riscos associados a essas mudanças.

A adaptação é necessária mesmo em cenários de menor aquecimento, já que eventual - e improvável - estabilização das emissões de gases estufa deve ser insuficiente para conter certo nível de elevação das temperaturas. Por outro lado, se não houver esforços de mitigação, os efeitos no longo prazo podem tornar a adaptação insuficiente. Há clareza, por isso, de que quanto antes se iniciarem os esforços de mitigação, menores as necessidades de adaptação e menores os custos para adaptar toda a infraestrutura a uma economia de baixo carbono.

\section{GRÁFICO 7}

Concentração de $\mathrm{CO}_{2}$-eq e aumento da temperatura para diferentes cenários

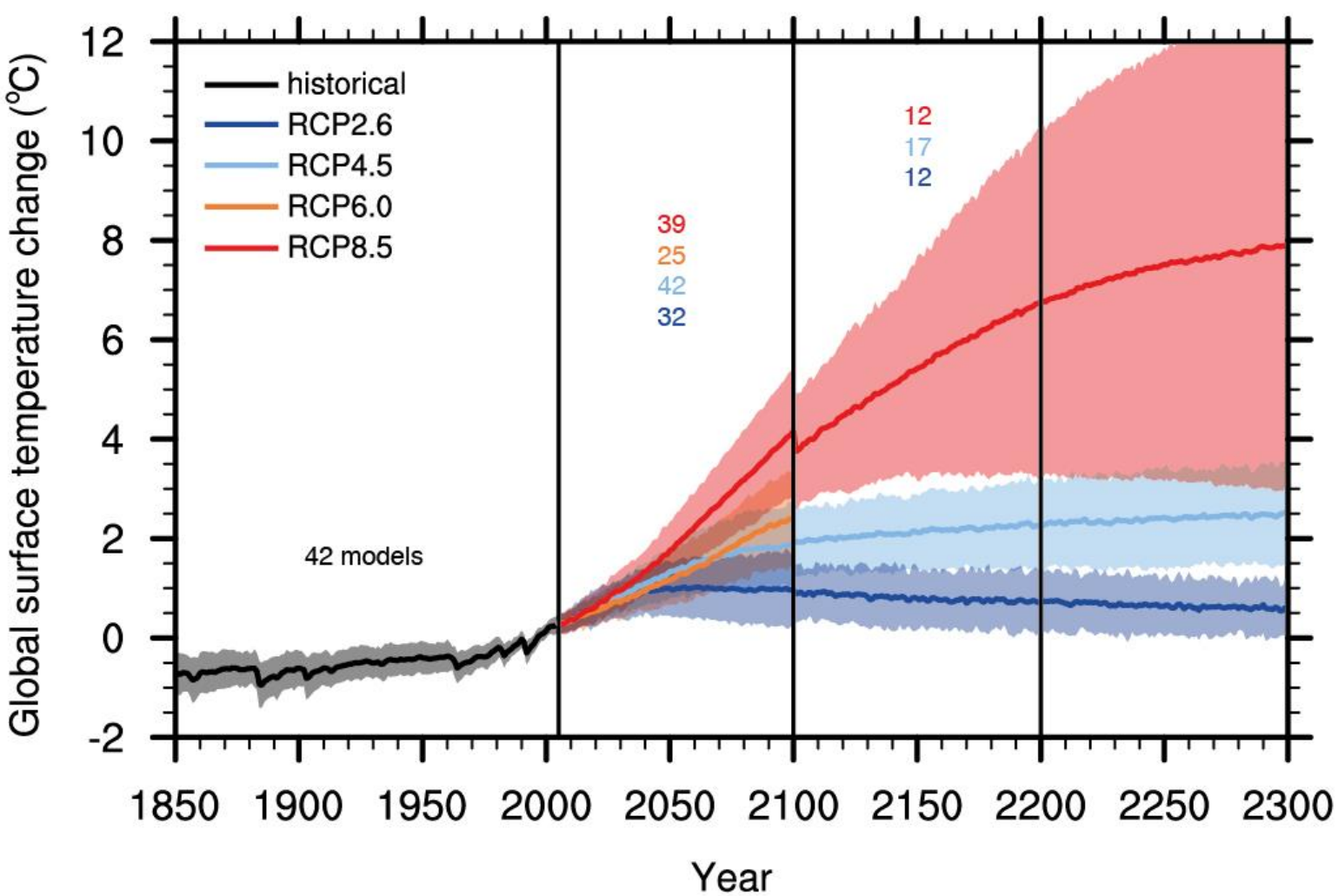

OBS.: RCP é a sigla para as diferentes "representative concentration pathways". No caso do RCP 2.6, assume-se que elas estabilizariam entre 2010-2020 e se reduziriam substancialmente depois disso. Para o cenário do RCP 4.5, o pico de emissões seria em torno de 2040, com redução posterior. No RCP 6, o pico seria em torno de 2080, com subsequente declínio. No RCP 8.5, as emissões seguiriam em alto ao longo do século XXI.

Fonte: AR5 
Para conseguir estabilizar as concentrações de gases estufa na atmosfera, é necessária ação de curto prazo para permitir que as emissões cheguem a um pico e, a partir de então, comecem a declinar. Para que seja menor o nível de estabilização dos gases estufa, mais baixo e mais cedo precisaria ser alcançado esse ápice de emissões.

Existe um amplo reconhecimento na literatura científica de que é altamente improvável que apenas um tipo de tecnologia possa resolver o problema da mudança do clima. É necessário, pois, considerar um portfólio de tecnologias (MIGUEZ, OLIVEIRA e MENDES, 2010). Na avaliação do IPCC, houve amplo acordo e muitas provas de que os níveis de estabilização de gases estufa avaliados podem ser atingidos pelo desenvolvimento de um portfólio de tecnologias que já estão disponíveis atualmente, ou cuja comercialização é esperada já nas próximas décadas.

Nesse contexto, as tecnologias associadas às energias limpas desempenham um papel crucial, mesmo que haja um nível razoável de incerteza nessas estimativas. Ainda consoante o $5^{\circ}$ Relatório do IPCC, todos os cenários projetados de estabilização do carbono na atmosfera indicam que mais de metade da redução viria do fornecimento e uso de energia e de processos industriais. Medidas de eficiência energética cumpririam um papel crucial em muitos dos cenários avaliados, para a maioria das regiões do planeta. Para um nível mais baixo de estabilização dos gases estufa, as estimativas sugerem a necessidade de ampliar o uso de fontes de energia de baixo carbono, como a energia renovável, a energia nuclear e o sequestro de carbono (carbon capture and storage - CCS). Para a concretização desses cenários, calcula o IPCC, a melhoria da intensidade de carbono por unidade de energia e por unidade do PIB precisaria se intensificar em velocidade bem superior à verificada nos últimos anos.

Com o propósito de alcançar níveis de estabilização mais reduzidos, o custo seria minimizado se forem implantadas tecnologias de baixo carbono no âmbito global, assim como se forem desenvolvidas tecnologias mediante parcerias entre o setor público e o privado para $\mathrm{P} \& \mathrm{D}$. A contribuição que cada tecnologia fornece à mitigação varia conforme o tempo e a região do planeta e depende ainda do nível de desenvolvimento, do tipo de tecnologia disponível e de seus custos relativos e do nível de estabilização planejado.

Para que o nível de estabilização se situe na faixa mais baixa da estimativa (entre 490 e 540ppm de $\mathrm{CO}_{2}$-eq), seria necessário ampliar investimentos no curto prazo, além de intensificar substancialmente a difusão rápida e a comercialização das tecnologias de ponta de baixo carbono. Na avaliação do IPCC, sem volume significativo de investimentos e transferência de tecnologia eficaz, pode ser difícil alcançar a pretendida redução das emissões numa escala relevante. Para tanto, seria necessário adotar as políticas públicas adequadas, 
superando os obstáculos existentes e fornecendo os incentivos pertinentes para seu desenvolvimento, aquisição, emprego e difusão.

Há também certo nível de incerteza quanto aos custos macroeconômicos para as medidas necessárias à estabilização da concentração de carbono na atmosfera. O custo estimado para a mitigação não é tão elevado quanto o risco de não adotar medida alguma.

Em resumo, como apontam NOBRE ET AL. (2007), a elevação da temperatura média da atmosfera é ponto pacífico. As evidências de influência antrópica são muito fortes (extremamente provável, com 95\% de confiança, segundo o AR5 do IPCC). Se as tendências de elevação das emissões forem mantidas, algumas regiões do globo podem vivenciar aumentos de temperatura de até $6^{\circ} \mathrm{C}$ até o fim do século XXI, embora o cenário mais provável seja a elevação entre $2^{\circ} \mathrm{C}$ e $4,5^{\circ} \mathrm{C}$. A estimativa mais provável é de $3^{\circ} \mathrm{C}$ e é muito improvável que ela seja inferior a $1,5^{\circ} \mathrm{C}$.

\section{3. Últimos acontecimentos na formação do regime climático e perspectivas das negociações em curso}

Mesmo depois de assinado, o Protocolo de Quioto não entrou em vigor com facilidade. Segundo os termos acordados, para que o instrumento produzisse seus efeitos legais seria necessária a ratificação de 55 Estados-Partes e a participação desses países deveria representar ao menos $55 \%$ do total de emissões de gases estufa dentre os integrantes do Anexo I, com base nas emissões de 1990 (art. 25 do Protocolo). Como os Estados Unidos - à época o maior emissor global - deixaram de ratificar o acordo, como já se apontou anteriormente, tornou-se mais difícil formar uma coalizão suficientemente ampla para conferir eficácia ao protocolo.

Os países membros da União Europeia ratificaram o acordo em 2002 e, somados a outros países que também internalizaram o texto, a exigência de 55 nações foi alcançada em 2002. Entretanto, o requisito de 55\% das emissões dentre os países do Anexo I só foi atingindo quando a Rússia aprovou o texto em novembro de 2004, tornando-o juridicamente vinculante para os que o ratificaram a partir de fevereiro de 2005 (prazo de três meses após o alcance dos requisitos). 
O único signatário do acordo original de 1997 que não o ratificou foram os Estados Unidos. O Canadá chegou a assiná-lo e a ratificá-lo, mas abandonou o protocolo em dezembro de 2011, logo em seguida à COP 17, em Durban. Japão, Rússia e Nova Zelândia anunciaram entre 2011 e 2012 que não assumiriam novos compromissos no âmbito do protocolo, inclusive na extensão do período então em discussão.

Os esforços para forjar um sucessor juridicamente vinculante para o Protocolo de Quito não lograram êxito até o momento. Sucessivas conferências e encontros de cúpula não resultaram em acordo global. Para fins de registro da evolução histórica das negociações, mencionam-se a seguir os principais encontros e delineamentos preliminares já estabelecidos.

Em junho de 2007, no encontro do G8, foi divulgado um comunicado (não vinculante juridicamente) em que os países integrantes desse fórum assumem o objetivo de reduzir pela metade as emissões de $\mathrm{CO}_{2}$ até 2050. O anúncio, entretanto, remete às negociações no âmbito da CQNUMC, para abranger também os países em desenvolvimento.

As conferências anuais da CQNUMC e de Quioto seguiram ocorrendo, mas sem progressos substantivos. Merece destaque a mobilização mundial em torno da COP 15 (15th Conference of the Parties) e da MOP 5 (5th Meeting of the Parties to the Kyoto Protocol), ocorridas ambas no final de 2009 em Copenhague, na Dinamarca. Esse período foi marcado por diversos fatos que galvanizaram a opinião pública em vários países e resultaram em elevada expectativa de um acordo amplo, que acabou por não se concretizar.

De fato, no período imediatamente anterior a essa Conferência uma série de acontecimentos mobilizou a imprensa não-especializada e repercutiu entre os principais negociadores. VIOLA (2008) chama a atenção para a mudança de percepção na opinião pública mundial a partir de 2005, que fortaleceu o cenário favorável à formação de um novo regime sobre o aquecimento global. São arrolados os seguintes fatores que contribuíram para o reconhecimento da necessidade de envidar esforços para lidar com o assunto:

a) a partir de 2005, houve a intensificação de fenômenos climáticos de grande impacto, como furacões (EUA e países caribenhos), incêndios (EUA e Austrália), mortes por ondas de calor (Europa), tufões e tormentas (Japão, China, Índia, Filipinas e Indonésia), secas severas (Austrália, Índia, partes da África e Amazônia brasileira), e inundações catastróficas (Índia e África);

b) a divulgação em 2006 pelo governo britânico do relatório de Nicholas Stern sobre o custo econômico da mudança climática (The Stern Review on the Economics of Climate Change), apontando a mudança climática como a 
maior falha de mercado já verificada e apresentando prescrições de políticas públicas para superá-la, como tributos sobre o carbono (STERN, 2006);

c) o lançamento em 2006 do filme "Uma Verdade Inconveniente", do expresidente estadunidense $\mathrm{Al}$ Gore, que chama a atenção para a gravidade do aquecimento global e sugere ações imediatas para enfrentá-lo;

d) a publicação em 2007 do Quarto Relatório do IPCC, que praticamente afastou as incertezas sobre a origem antropogênica do aquecimento global e destacou que ele é mais acelerado do que se avaliava previamente;

e) a concessão em 2007 do Prêmio Nobel da Paz a Al Gore e ao IPCC, pelas atividades listadas acima, lançando os holofotes da imprensa para a temática;

f) a reunião realizada em abril de 2007 do Conselho de Segurança da ONU para, pela primeira vez, debater o tema nesse foro das Nações Unidas, considerando as mudanças climáticas uma ameaça à segurança e à estabilidade política;

g) por fim, a eleição do presidente estadunidense Barack Obama também conferiu sinais de mudança na posição internacional da maior economia do mundo.

Esses fatores ajudaram a aumentar a percepção popular e da imprensa nãoespecializada quanto à importância do tema. Entretanto, uma série de acontecimentos prejudicou o objetivo de celebrar um grande acordo em Copenhague. Merecem destaque a grave crise econômica que se abateu sobre Estados Unidos e Europa a partir de setembro de 2008, a intensa polarização da política estadunidense entre republicanos e democratas e a correspondente incapacidade para formar compromissos, a ofensiva republicana contra a ciência do clima, além de denúncias sobre supostas impropriedades na elaboração do relatório do IPCC (o chamado "Climategate”) (VIOLA, 2011, e VIOLA ET AL., 2013).

De fato, depois de intensas negociações, os delegados presentes à conferência apenas "tomaram nota" do chamado "Acordo de Copenhague", que, em verdade, não constitui um tratado juridicamente vinculante. Trata-se de uma declaração negociada principalmente entre os Estados Unidos e o BASIC (Brasil, África do Sul, Índia e China), cuja principal cláusula reconhece o argumento científico para que o aumento da temperatura global não exceda $2^{\circ} \mathrm{C}$, a fim de evitar interferência antropogênica de efeitos desastrosos sobre o sistema climático. Nem mesmo a linha de base para os $2^{\circ} \mathrm{C}$ de elevação foi definida. 
Não alcançado um acordo amplo em Copenhague e tendo em vista a permanência da crise econômica, a agenda climática internacional perdeu a centralidade nas discussões internacionais. As conferências seguintes, ocorridas em Cancun (2010) e em Durban (2011), também não resultaram em avanços significativos.

Na primeira delas, além da proposta de criar um Fundo do Clima Verde de US\$ 100 bi até 2020 (sem especificar as fontes), a mais importante definição foi o reconhecimento da necessidade de manter o aumento da temperatura até $2^{\circ} \mathrm{C}$ acima do nível pré-industrial, ratificando o que o Acordo de Copenhague estabelecera sem efeitos vinculantes. Contudo, como não se fixaram as metas para cada país, os efeitos são mais retóricos e simbólicos do que legais.

Na segunda, em Durban, acordou-se a chamada "Plataforma de Durban", consistente em produzir um tratado legalmente vinculante sobre aquecimento global a ser concluído até 2015 e para se tornar efetivo até 2020 (MACHADO, 2012). O resultado foi anunciado como um avanço por incluir nessa "plataforma" tanto os países desenvolvidos EUA incluso, apesar de ter rejeitado Quioto -, quanto os países em desenvolvimento, incluindo Brasil, China e Índia.

O acordo também estabelece um segundo período de compromisso para o Protocolo de Quioto nesse ínterim, iniciado a partir de 2013, embora ele dependa de ajustes técnicos para quantificação exata das metas pendentes de aprovação na COP 18, em Doha. Como já se apontou, esse protocolo não abrange os dois maiores emissores de gases estufa, EUA e China. No que concerne ao Fundo do Clima Verde, foram adotadas algumas regras para a distribuição dos US\$ 100 bi, mas a fonte dos recursos, que era o tema central, continuou indefinida.

Em 2012, em Doha, Qatar, foi formalizada a instituição do segundo período de compromisso para o Protocolo de Quioto até 2020, mas vários países ficaram de fora das metas (tais como Canadá, Japão, Rússia), além dos que já não haviam se submetido ao texto original do protocolo (EUA e países em desenvolvimento). Também não se avançou na regulamentação do Fundo do Clima Verde. Igualmente, careceu de progressos relevantes o encontro de 2013, ocorrido em Varsóvia, na Polônia.

Em 2012, foi realizado no Brasil o encontro denominado de Rio+20, o quarto evento de uma família de grandes conferências promovidas pelas Nações Unidas com o propósito de discutir os rumos do planeta. São as cúpulas da Terra-Earth Summits. A primeira delas foi a de Estocolmo, em 1972; a segunda foi a Rio-92, realizada no Rio de Janeiro, em 
1992; e a terceira foi promovida em Johanesburgo, na África do Sul, em 2002 - e por isso também chamada de Rio+10.

A referência aos vinte anos (+20) deve ser interpretada com um duplo enfoque: o primeiro, voltado para trás, sinaliza que o evento ocorre vinte anos após a realização da Rio92; o segundo, voltado para a frente, sugere que a conferência buscou definir como estará a humanidade daqui a vinte anos, isto é, em 2032 (MACHADO, 2012).

Apesar da mobilização de inúmeros chefes de Estado, o resultado da conferência também não trouxe implicações concretas para a formação de um regime internacional acerca da matéria.

Tanto a Rio+20, quanto as frustrações sucessivas nas conferências realizadas sob a CQNUMC sugerem que o modelo top-down de negociação não vem logrando sucesso em concertar os numerosos e intrincados interesses em jogo. O modelo top-down nesse temavale esclarecer - é aquele por meio do qual se determina, à luz da ciência, o valor agregado de reduções necessário para o conjunto dos países e se negocia o esforço individual de cada nação para alcançá-lo, de maneira juridicamente obrigatória (MACHADO, 2012).

Nesse contexto avulta a importância crescente dos compromissos voluntários assumidos por alguns países, que, aos poucos, vêm formando um regime internacional no modelo bottom-up, e não mediante um amplo acordo apoiado por todas as nações. Esse movimento é resultado fundamentalmente das pressões do público doméstico de alguns desses países (casos de Europa, Brasil, algumas unidades federativas dos EUA) ou de decisões estratégicas dos governos, que anteveem uma janela de oportunidade para novas tecnologias e novos negócios (casos da Coreia e da China).

Por meio do modelo bottom-up, cada país é livre para determinar o montante de seu esforço de redução, sem necessariamente obrigar-se juridicamente no âmbito internacional, ou seguir regras comuns de contabilização das emissões. Ele se concretiza pela promessa e pela verificação (pledge and review), quando cada nação declara o que fará e submete o resultado da implementação a um processo de revisão internacional. Não há garantia, nesse caso, de que a soma dos esforços espontâneos seja suficiente para alcançar a redução das emissões necessárias ao conjunto do planeta (MACHADO, 2012).

Como aponta FRIEDMAN (2009), a situação climática é claramente insustentável no longo prazo. A adoção de um sistema de energia limpa não é mais uma opção, mas um imperativo. Dessa necessidade crítica surge uma oportunidade. As companhias e os países que conseguirem as fontes de energia mais abundantes, baratas, confiáveis e limpas terão a resposta para as principais questões globais. Os países que alcançarem, mediante atividades 
de $\mathrm{P} \& \mathrm{D}$, tecnologias para produzir energia abundante, barata, confiável e limpa estarão à frente da nova indústria. Em outras palavras, energia limpa é poder (FRIEDMAN, 2009).

Essa visão estratégica da importância da energia limpa vem dando sustentação para as decisões políticas de alguns governos, que desse modo passam ao largo dos impasses diplomáticos para o acordo top-down e reforçam o surgimento do regime bottom-up.

É fato que o segundo período de compromisso dá alguma sobrevida ao modelo, além de prorrogar o funcionamento dos mecanismos flexíveis. Sua eficácia, todavia, permanece em questão em razão da ausência de compromissos assumidos, pelo menos, por Estados Unidos, China e Índia, os três grandes emissores de gases estufa.

Mesmo que menos eficaz do que o modelo top-down, parece que ganha força o modelo bottom-up. Boa parte das promessas de redução divulgadas pelos países se originou nos preparativos para a Conferência de Copenhague, em 2009, mas alguns dos compromissos foram assumidos posteriormente. Segundo informações disponíveis na página da CQNUMC, países que hoje representam mais de $80 \%$ das emissões globais apoiaram o Acordo de Copenhague, ainda que não seja vinculante, e enviaram ao secretariado da CQNUMC suas propostas de redução de emissões para o ano de 2020 (UNFCCC, 2012).

Alguns países apresentaram propostas de redução tomando como base as emissões de $\mathrm{CO}_{2}$-eq de 1990. É o caso da União Europeia, que se comprometeu com redução de 20 a $30 \%$ e do Japão, que estabeleceu em 25\% sua meta - desde que outros países desenvolvidos também assumam metas comparáveis e os países em desenvolvimento contribuam adequadamente para o esforço global. A Austrália assumiu o compromisso de reduzir entre $5 \%$ (incondicionalmente) e $25 \%$ (condicionado a um acordo global) tomando como base o ano 2000. Canadá e Estados Unidos prometeram reduzir em 17\%, tomando o ano de 2005 como referência.

Alguns países fixaram suas metas tomando como base o cenário BAU (business as usual), tais como o Brasil (redução entre 36,1 e 38,9\%), o México (30\%) a África do Sul (34\%), a Coreia do Sul (30\%) e Israel (20\%). Houve ainda aqueles países que assumiram metas de redução a partir da intensidade de carbono por unidade do PIB em 2005, como a China (40 a $45 \%$ ) e a Índia (20 a 25\%).

Sintetizando as propostas dessas nações, a Tabela 8 procura sistematizar as metas lançadas e, para torná-las comparáveis, procura converter as metas de diferentes anos base para o ano base de 1990. Vale ressalvar que, ainda assim, elas não são inteiramente comparáveis porque nem todos incluem as atividades LULUCF nas metas apresentadas e 
porque as estimativas feitas a partir de intensidade do PIB variam imensamente em razão das variações na projeção do PIB.

TABELA 6

Metas voluntárias no âmbito do Acordo de Copenhague

\begin{tabular}{|l|c|c|}
\hline & $\begin{array}{c}\text { Meta proposta / Base de } \\
\text { referência }\end{array}$ & $\begin{array}{c}\text { Estimativa da meta em } \\
\text { relação às emissões de 1990 }\end{array}$ \\
\hline União Europeia & $-20 \%$ a $-30 \% / 1990$ & $-20 \%$ a $-30 \%$ \\
\hline Japão & $-25 \% / 1990$ & $-25 \%$ \\
\hline Austrália & $-5 \%$ ou $-25 \% / 2000$ & $-3,89 \%$ a $-24,1 \%$ \\
\hline Canadá & $-17 \% / 2005$ & $+0,25 \%$ \\
\hline Estados Unidos & $-17 \% / 2005$ & $-3,67 \%$ \\
\hline Israel & $-20 \% /$ BAU & $+91,6 \%$ \\
\hline África do Sul & $-34 \%$ / BAU & $+48,2 \%$ \\
\hline México & $-30 \% /$ BAU & $+19,8 \%$ \\
\hline BRASIL & $-36,1$ a $-38,9 \% /$ BAU & $+6,4 \%$ a $+1,7 \%$ \\
\hline COREIA DO SUL & $-30 \% /$ BAU & $+63,9 \%$ \\
\hline CHINA & -40 a $-45 \% /$ Intensidade do PIB & $-15 \%$ a $+204 \%$ \\
\hline Índia & $-20 \mathrm{a}-25 \% /$ Intensidade do PIB & $+87 \mathrm{a}+277 \%$ \\
\hline
\end{tabular}

Fonte: UNFCCC (2012) e USCAN CLIMATE WORK (2015).

OBS.: A uniformização das metas para o ano-base de 1990 resulta em estimativas extremamente variadas no caso das metas que se baseiam na intensidade do PIB (casos de China e Índia).

Além desses compromissos voluntários assumidos por essas nações, foram adotadas várias iniciativas no âmbito regional, estadual e municipal. Nos Estados Unidos, o segundo maior emissor de gases estufa e um dos países que, juntamente com a China, tem desempenhado um papel-chave para obstaculizar um amplo acordo sobre o tema, há várias iniciativas na esfera subnacional a respeito do assunto.

Mais da metade dos cinquenta Estados estadunidense tem planos de ações para enfrentar a mudança climática e nove deles têm metas de redução de emissões. Elas abrangem incentivos fiscais, quotas de energia renovável, net metering para energias de baixo carbono, promoção da eficiência energética, entre outras (DSIRE, 2014). Vale destacar que, dentre esses nove, estão alguns dos principais centros econômicos e populacionais dos Estados Unidos, como a Califórnia (maior Estado, em população e PIB) e Nova York (terceiro maior, em população e PIB). Além dos dois, integram o grupo dos que têm meta Nova Jersey, Maine, Massachusetts, Connecticut, Novo México, Washington e Oregon.

Há, em verdade, uma grande divisão na sociedade americana entre os estados governados por democratas, que adotam políticas para mitigar mudanças climáticas, e os Estados republicanos, que encamparam, no geral, uma postura negacionista em relação ao problema (embora, mesmo em Estados republicanos, haja progressos significativos, como o avanço da energia eólica no Texas). O desfecho dessas duas diretrizes pode ser claramente 
sintetizado no Gráfico 8, que sintetiza os esforços pela redução do consumo de energia desde os anos 1970:

\section{GRÁFICO 8}

Per Capita Electricity Consumption

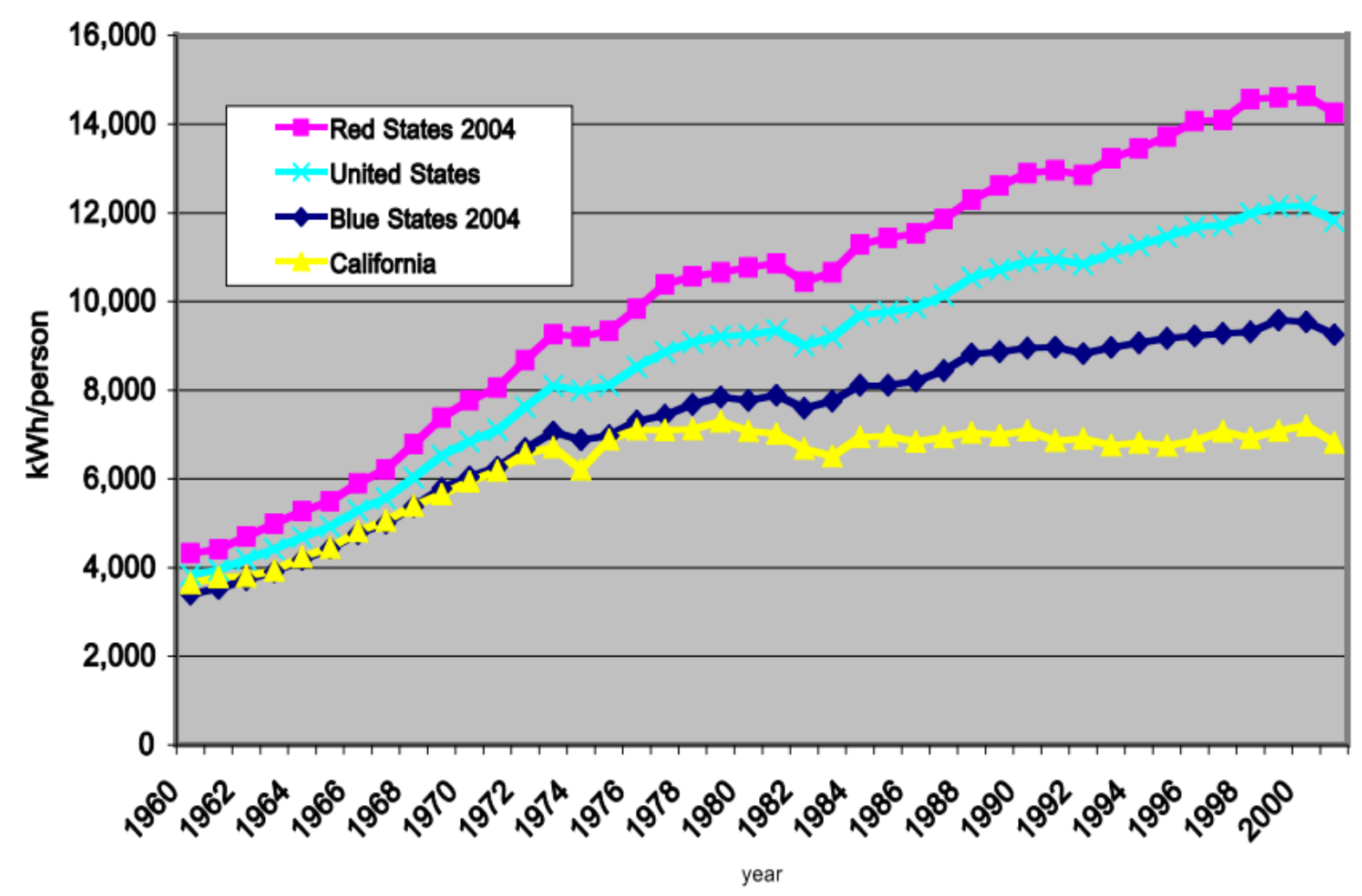

Fonte: KAMMEN, 2013.

No caso da Califórnia, o mais populoso (38 milhões de habitantes) e a maior economia dos Estados Unidos (PIB estadual equivalente a US\$ 1,9 trilhão, o $9^{\circ}$ ou $10^{\circ}$ do mundo, se fosse um país), os esforços de descarbonização são consideráveis e têm ajudado a consolidar uma indústria de ponta voltada a tecnologias de baixo carbono.

As medidas adotadas pela Califórnia estão sintetizadas na Figura 2, da qual se destacam o rigoroso regime de cap-and-trade já em operação desde o início de 2013, metas de instalação de paineis solares e quota para energia renovável. As medidas contaram com o apoio de parte das empresas locais, especialmente o poderoso grupo de empresas de tecnologia da informação, interessadas no mercado de softwares que surgirá para o gerenciamento do novo sistema.

Há ainda ações interestaduais, como a iniciativa regional para os gases estufa, que instituiu um sistema cap-and-trade para vários estados do nordeste, incluindo Delaware, 
Vermont e New Hampshire, além de Nova York e outros (Regional Greenhouse Gas Initiative - RGGI). Há ainda iniciativa da associação dos governadores e várias ações no campo municipal. San Francisco, por exemplo, divulgou recentemente ter reduzido suas emissões abaixo dos níveis verificados em 1990, mesmo com a elevação da população e do PIB nesse período (Global Compact Cities Programme, 2012).

FIGURA 2

Medidas adotadas pela Califórnia para mitigar o desafio climático

\section{California has some of the most aggressive policies to address these challenges}

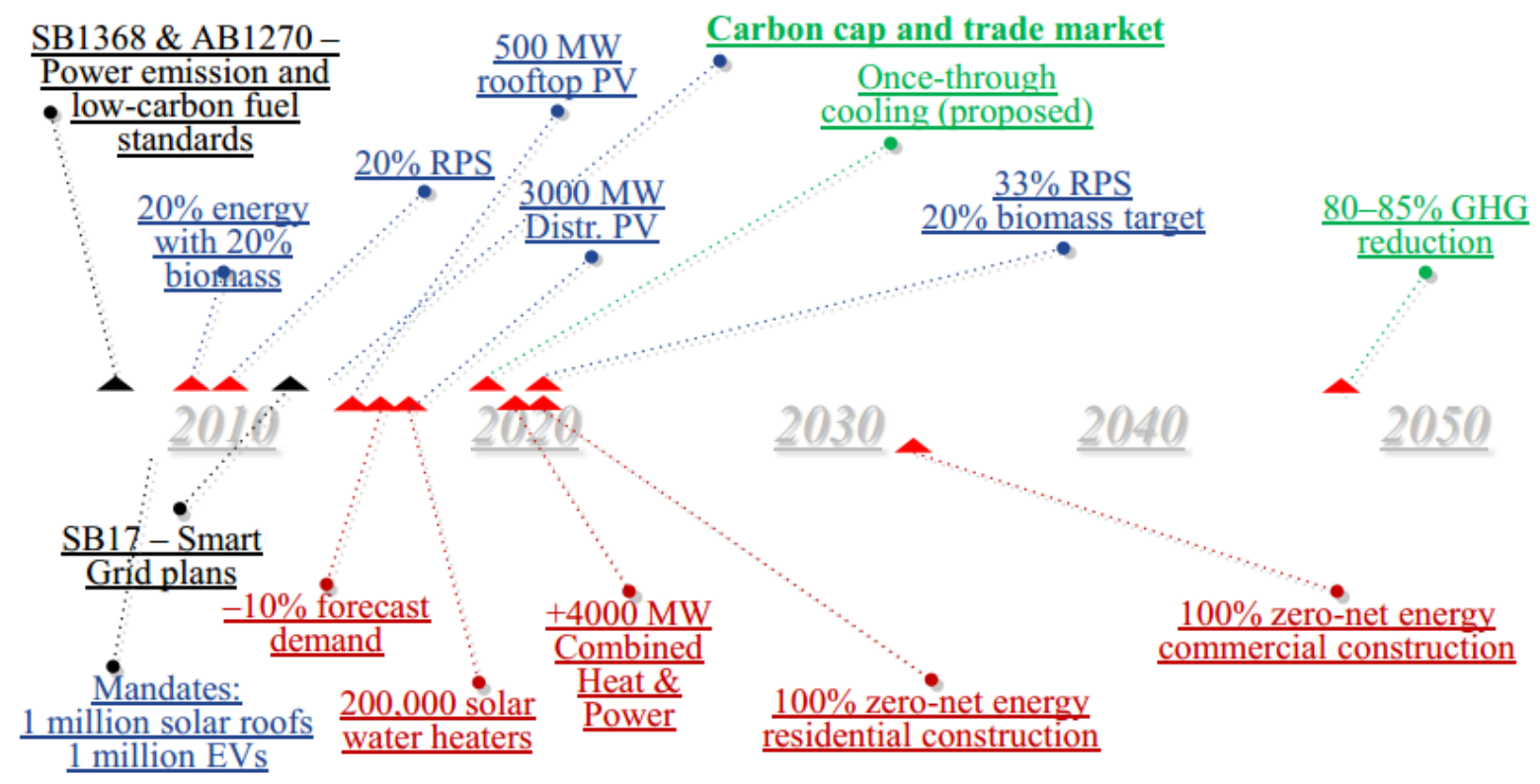

\section{0,000 miles of pipeline; 20 million smart meters; $\$ 10 \mathrm{~B} \mathrm{CapEx} /$ year}

Fonte: KAMMEN, 2013.

Em 2014, o governo de Barack Obama anunciou, em face do impasse congressual em aprovar medidas legislativas mais consistentes relacionadas ao aquecimento global, a adoção gradual de medidas executivas, à margem do Congresso. Para tanto, determinou, por meio da agência ambiental estadunidense, a incorporação de padrões de emissões mais rigorosos para novas e antigas usinas térmicas, além de fomentar os Estados a fixarem políticas e metas específicas de redução dos gases estufa. O objetivo da iniciativa é abater as emissões em $30 \%$ até 2030, tomando o ano de 2005 como referência.

A China, como se verá detalhadamente adiante, também vem adotando gradativamente medidas consistentes para a descarbonização, entre as quais quotas ousadas 
para fontes de baixo carbono, fomento à eficiência energética e até mesmo políticas regionais de cap-and-trade.

A União Europeia constitui o terceiro ator central nas discussões. O mecanismo europeu de comércio de emissões é o mais abrangente em vigor atualmente, tendo sido adotado em 2005 (European Union Emissions Trading Scheme). Afora isso, há ações domésticas de vários de seus membros para estimular energias de baixo carbono e eficiência energética.

À parte das ações adotadas no âmbito nacional ou supranacional, há típicas iniciativas de paradiplomacia em curso. Durante a Rio+20, por exemplo, houve um encontro paralelo dos prefeitos de grandes metrópoles. Nesse evento chamado de C40 (Large Cities Climate Leadership Group), os prefeitos assumiram o compromisso de reduzir as emissões de carbono em suas cidades em mais de um bilhão de toneladas de carbono até 2030 - as cidades filiadas à entidade emitiram, segundo estimativas delas próprias então divulgadas, cerca de 1,7 bilhão de toneladas de $\mathrm{CO}_{2}$-eq em 2010. Formado por cidades como Nova York, Londres, Paris, Rio de Janeiro, São Paulo, Beijing, Mumbai e Tóquio, esse conjunto de metrópoles representa parcela significativa da população mundial e das emissões de gases estufa.

Todos esses fatores contribuem para a formação gradativa de um regime internacional de mudança climática que fomenta a consolidação de uma economia de baixo carbono. Ao contrário das repetitivas e até o momento pouco frutíferas negociações multilaterais sobre o tema, as iniciativas unilaterais ou regionais, num formato bottom-up, estão dando à luz regras e deveres que se impõem aos países e podem tornar custosos os usos de tecnologias de elevado impacto para o efeito estufa.

A corroborar esses fatos estiveram algumas ações do G20 no estímulo à economia verde quando das ações anticíclicas para combater a crise financeira deflagrada a partir de 2008. Autores como Thomas FRIEDMAN, Paul KRUGMAN e Nicholas STERN têm argumentado que a resposta à crise financeira poderia também ser utilizada para enfrentar os problemas climáticos. Apontam que os custos estimados para enfrentar o aquecimento global são gerenciáveis, mas a inação nesse campo poderia acarretar prejuízos incalculáveis. A crise abriria oportunidade para iniciativas ambientais que ajudem a solucionar problemas como o déficit fiscal (tributação sobre o carbono, com redução proporcional sobre o trabalho), elevado desemprego (programa de investimentos em infraestrutura verde) e a competitividade em tecnologias de ponta (pacote fiscal em favor de eficiência energética e de recursos naturais) (KRUGMAN, 2010; STERN, RIBERA e TUBIANA, 2012).

Como apontam ROBINS, CLOVER e SINGH (2009), cerca de 15\% dos recursos destinados pelos países do G20 ao enfrentamento da crise foram conferidos a ações 
ligadas à economia de baixo carbono. Nesse conjunto, merecem destaque a Coreia do Sul, que destinou cerca de $80 \%$ de seu pacote anticíclico para medidas "verdes", e a China, que conferiu aproximadamente $35 \%$ de suas ações anticíclicas para ações relacionadas aos setores menos poluentes da economia.

Além das ações individualmente tomadas por esses países, o conjunto do G20 inclinou-se a apoiar medidas de restabelecimento do crescimento a partir da economia "verde", como apontam VIOLA ET AL. (2013). Por iniciativa do México, desde a reunião dos ministros da Fazenda de fevereiro de 2012, o grupo formado pelas maiores economias do mundo, desenvolvidas e em desenvolvimento, vem reconhecendo a oportunidade de restaurar o crescimento econômico mediante estímulos que, ao mesmo tempo, ajudem no enfrentamento de diversos problemas ambientais, como as mudanças climáticas e também a degradação dos solos, a poluição e a escassez de água.

A expectativa em relação a essas medidas é que elas estimulem aumentos de produtividade, mediante maior eficiência no uso de recursos naturais e energéticos, abram novos mercados para produtos e serviços “verdes", ajudem a lidar com os desequilíbrios fiscais (tributação de carbono e fim de subsídios a combustíveis fósseis) e contribuam para evitar impactos negativos que podem se originar do agravamento de questões ambientais.

Vale notar o peso político internacional do G20. As nações que integram o G20 respondem por $80 \%$ do PIB mundial, $80 \%$ do comércio internacional e dois terços da população global. Desde a deflagração da crise financeira global em 2008, o G20 assumiu o papel informal de coordenação das ações econômicas mundiais, embora tenha havido um arrefecimento da articulação recentemente. Por um lado esse agrupamento conferiu mais representatividade em relação ao G7, que não era composto por países em desenvolvimento, e por outro o foro se mostrou - ao menos inicialmente - mais eficaz do que a Assembleia Geral das Nações Unidas, usualmente paralisada pelos impasses políticos decorrentes de sua ampla representatividade.

A despeito desses movimentos, permanece distante a formação de um amplo regime global juridicamente vinculante. Como já apontara VIOLA (1999), as dificuldades de avanço no âmbito da CQNUMC se devem aos seguintes fatores: a) baixa disposição da sociedade norte-americana em diminuir suas emissões; b) fraca capacidade de liderança do Japão, única grande economia desenvolvida com energia como vetor de redução das emissões de gases estufa; c) mínima disposição de reorientar as políticas públicas para atenuar as emissões nos países emergentes; d) crescente complexidade do problema e de busca de soluções no interior da comunidade científica; e) dificuldade para firmar o acordo em Quioto 
devido à complexidade simultaneamente internacional e transnacional das clivagens e coalizões.

De fato, o Protocolo de Quioto não conseguiu enfrentar a questão do aquecimento global de modo satisfatório - o que se percebe pela não-ratificação do acordo pelos Estados Unidos, então maior emissor de carbono, e pela ausência de metas para a China, hoje líder em emissão.

Ainda segundo VIOLA, nos anos 1990 outras convenções internacionais trouxeram impactos para os debates internacionais hoje em curso. Em primeiro lugar, ampliouse consideravelmente a consciência pública internacional sobre a questão ambiental e foi inaugurado o conceito de "common concern of humankind". Além disso, os Estados Unidos mantiveram uma postura cautelosa em todos os debates que não envolviam proteção clara da propriedade intelectual - apesar de esse fator se manifestar mais intensamente na Convenção sobre Biodiversidade, também se reflete nos debates atuais sobre mudanças climáticas.

Apesar de dispor de uma matriz energética limpa e de estar na vanguarda na tecnologia do etanol, o Brasil tem evitado aliança com outros países em posições semelhantes, optando por se aliar à China e à Índia, cujos interesses nesse tema divergem dos brasileiros VIOLA (2008). Nesse contexto, as negociações globais hoje caminhariam para três possíveis cenários:

a) o cenário hobbesiano, consistente na estagnação da capacidade de cooperação internacional da humanidade, resultando em aumentos das emissões com efeitos graves para o meio ambiente;

b) o cenário de Quioto aprofundado, que se caracterizaria por um segundo período de compromisso entre os países, com metas de redução para os desenvolvidos e com metas de redução da curva de crescimento das emissões dos emergentes; e

c) o cenário de Grande Acordo, marcado por metas de forte redução das emissões de carbono entre os grandes emissores (EUA, Canadá, União Europeia, Rússia, China, Índia, Austrália, Coreia do Sul, Indonésia, África do Sul e México).

Para VIOLA, a adoção do Grande Acordo seria uma convergência dos interesses do Brasil com os da humanidade. O Brasil teria papel crucial no engajamento e persuasão de China e Índia. Nesse cenário, o país seria favorecido na transição para a economia de baixo carbono, já que dispõe fartamente de hidroeletricidade e de biocombustíveis em sua matriz energética, apresenta grande potencial de exploração de energia eólica e solar, além de poder tornar-se grande exportador de etanol. Esse cenário permitiria que o Brasil aproveitasse 
todas as possibilidades de uma economia de baixo carbono por conta das reservas incomparáveis de água doce, biodiversidade e terras agricultáveis.

Conquanto ainda seja nebuloso o tipo de regime internacional que sucederá ao Protocolo de Quioto, é cada vez mais evidente que praticamente todos os países, incluindo os emergentes, estão sendo induzidos a reduzir suas emissões de gases estufa. Esse processo de indução tende a se tornar ainda mais intenso nos próximos anos.

Até o momento, em vez de um acordo juridicamente vinculante para reduzir as emissões globais, esforços domésticos isolados de algumas nações têm prevalecido, o que indica um modelo bottom-up de construção do regime. Nesse contexto, o setor de energia é crucial, já que ele contabiliza uma porção significativa das emissões de gases estufa de origem antropogênica. O campo das tecnologias limpas é, portanto, decisivo para o fortalecimento das economias das nações nesse cenário de restrições crescentes ao uso de fontes poluentes.

\subsection{Posição dos países selecionados no debate: Brasil, Coreia, Taiwan, China}

As negociações para a formação de um regime global sobre mudanças climáticas têm sido marcadas por sucessivos impasses, como se apontou no tópico anterior. Há fortes pressões da parte de alguns países em favor de um acordo rigoroso legalmente vinculante, que fixe metas nacionais para a redução das emissões, mas, de outro lado, algumas nações adotam posturas bastante conservadoras e não aceitam submeter suas estruturas econômicas já consolidadas a mudanças substanciais.

Graças ao aumento da percepção da opinião pública mundial e ao cálculo estratégico de algumas nações, pode-se verificar uma mudança da política externa de alguns dos atores centrais nesse imbróglio. Para examinar previamente a posição dos países selecionados nesta pesquisa, convém examinar o quadro mais amplo das negociações e a postura de outros atores chave nesse processo decisório.

Nessa análise, trabalharemos com as categorias utilizadas por VIOLA ET AL. (2013), que sugere a superação da dicotomia entre países desenvolvidos e países em desenvolvimento, utilizada nas discussões internacionais, e propõe uma nova classificação, explicada adiante. Preliminarmente transcrevemos na Tabela 7 os dados de alguns dos principais atores: 
TABELA 7

Principais indicadores de alguns dos atores mais relevantes nas negociações climáticas

\begin{tabular}{|c|c|c|c|c|c|c|}
\hline & $\begin{array}{c}\text { População } \\
\text { 2011, em } \\
\text { milhões } \\
\text { (em \% do } \\
\text { total) }\end{array}$ & $\begin{array}{l}\text { PIB 2011, } \\
\text { em bilhões } \\
\text { de US\$ } \\
\text { (em \% do } \\
\text { total) }\end{array}$ & $\begin{array}{c}\text { Emissões } \\
\text { de } \mathrm{CO}_{2} \text { em } \\
2011, \text { em } \\
\text { bilhões de } \\
\text { ton (em \% } \\
\text { do total) }\end{array}$ & $\begin{array}{c}\text { PIB per } \\
\text { capita em } \\
\text { PPP em } \\
2011 \\
\text { (mil US\$ } \\
\text { de 2013) }\end{array}$ & $\begin{array}{l}\text { Emissões } \\
\text { de } \mathrm{CO}_{2} \text {, em } \\
\text { toneladas } \\
\text { per capita }\end{array}$ & $\begin{array}{c}\text { Emissões } \\
\text { de } \mathrm{CO}_{2} \text {, em } \\
\text { bilhões de } \\
\text { ton, por } \\
\text { US\$ } 1.000 \\
\text { do PIB }\end{array}$ \\
\hline CHINA & $1.345(19,2)$ & $7,3(10,2)$ & $9,55(28,1)$ & 8,3 & 7,1 & 1.308 \\
\hline Índia & $1.198(17,1)$ & $1,9(2,7)$ & $1,84(5,4)$ & 3,8 & 1,5 & 968 \\
\hline UE & $501(7,1)$ & $17,6(24,6)$ & $3,79(11,1)$ & 34,6 & 7,6 & 215 \\
\hline EUA & $315(4,5)$ & $15,5(21,7)$ & $5,39(16)$ & $\begin{array}{l}51,4 \\
\end{array}$ & 17,1 & 348 \\
\hline BRASIL & $194(2,8)$ & $2,5(3,5)$ & $0,45(1,3)$ & 11,9 & 2,3 & 180 \\
\hline Rússia & $141(2,0)$ & $1,9(2,7)$ & $1,78(5,2)$ & 17,1 & 12,6 & 937 \\
\hline Japão & $127(1,8)$ & $5,9(8,3)$ & $1,24(3,6)$ & 35,6 & 9,8 & 210 \\
\hline COREIA & $48(0,7)$ & $1,2(1,7)$ & $0,63(1,9)$ & 31,9 & 13,1 & 525 \\
\hline TAIWAN & $23(0,3)$ & $0,5(0,7)$ & $0,28(0,8)$ & 38,5 & 12,2 & 560 \\
\hline
\end{tabular}

Fontes: População: The Economist, 2012. PIB: Banco Mundial, 2014. PIB per capita: CIA World Factbook, 2014. Emissão de $\mathrm{CO}_{2}$ a partir de combustíveis fósseis e produção de cimento: Netherlands Environmental Assessment Agency, 2013. Cálculos feitos pelo autor.

Utilizando a classificação adotada por VIOLA ET AL. (2013), existem, nesse foro negociador internacional, três superpotências, cinco grandes potências e pouco mais de vinte potências médias.

Na primeira categoria estão os Estados Unidos, a China e a União Europeia (considerada aqui em conjunto, dado que a posição da entidade, nesse tema, transparece um nível razoável de coesão). Esses entes compartilham três características: a) pelo menos 15\% das emissões globais de gases estufa ou do PIB global; b) forte capital tecnológico e humano para a "descarbonização" da economia; c) poder de veto sobre qualquer acordo global efetivo. Juntos eles somam cerca de metade do PIB e das emissões globais (VIOLA, 2011).

Os Estados Unidos e a China - os dois maiores emissores - têm atribuído um ao outro a responsabilidade pela paralisia das negociações climáticas. Enquanto que os EUA argumentam que os países em desenvolvimento também devem assumir responsabilidades pela redução das emissões, notadamente os chineses por serem os maiores emissores de gases estufa, a China exige que os países desenvolvidos, notadamente os EUA, assumam responsabilidade diferenciada nessa questão, à luz da responsabilidade histórica pelas emissões e da diferença no nível de renda entre as nações. Como realça VIOLA (2012), um se esconde atrás do outro para justificar os limites de suas posições e não assumir compromissos.

Os Estados Unidos eram até recentemente os maiores emissores de gases estufa do planeta, já que contam com uma matriz energética baseada em combustíveis fósseis - o 
petróleo representa 37\%, o gás natural 22\% e o carvão 22\% (EIA, 2011a). Desde aproximadamente 2006 (YALE, 2012), a China assumiu a liderança global nas emissões graças à matriz energética baseada fortemente no carvão -, mas os EUA continuam liderando as emissões históricas consideradas a partir de 1850. As emissões totais americanas correspondem a cerca de $15 \%$ do total global, o que representa um valor elevado per capita (17 toneladas), mas apenas 348 toneladas de carbono a cada dólar de PIB, o que o caracteriza como relativamente eficiente em termos de emissões por riqueza produzida.

No caso dos EUA, a posição conservadora nesse tema se consolidou a partir do primeiro mandato do presidente George W. Bush, em 2001, quando ele anunciou que o país não adotaria acordos internacionais sobre o clima que prejudicassem sua economia. Na ocasião, o presidente Bush anunciou que o país não ratificaria o Protocolo de Quioto, o que esvaziou parcialmente o acordo, como se indicou no tópico anterior.

É curioso notar que foi George Herbert Walker Bush, pai de George W. Bush, quem participou da Rio-92 e assinou a CQNUMC como representante dos EUA. No governo seguinte, sob a administração do democrata Bill Clinton, foi negociado o Protocolo de Quioto, em 1997. Já se argumentava que, mesmo se a gestão seguinte fosse de um presidente democrata, dificilmente o Congresso dos EUA aprovaria o protocolo. Vale consignar que, ainda em julho de 1997, o Senado dos EUA aprovara a Resolução Byrd-Hagel, por 95 votos a zero, estabelecendo que o Senado não aceitaria a assinatura de um protocolo à CQNUMC sem metas vinculantes para os países em desenvolvimento e que pudesse prejudicar a economia dos EUA. Mas foi sob a gestão republicana de George W. Bush que ficou explícita a recusa do país em assumir compromissos relevantes na área ambiental.

A posse de Barack Obama como presidente dos EUA em 2009 reacendeu as expectativas de que os Estados Unidos voltariam a ter uma postura mais favorável ao multilateralismo e à proteção do meio ambiente. Entretanto, não se confirmou o esforço internacional do presidente nessa matéria, o que se atribui fundamentalmente ao recrudescimento da crise financeira durante seu mandato, à prioridade conferida inicialmente ao tema da reforma do sistema de saúde, à radicalização do partido republicano no tema (que assumiu uma postura negacionista, especialmente a partir da formação do grupo denominado de Tea Party) e à perda da maioria democrata na Câmara dos Representantes nas eleições de meio de mandato, em 2010.

Em 2014, Obama anunciou importantes medidas domésticas para a redução dos gases estufa, fazendo uso do poder regulamentar conferido pela Lei do Ar Limpo (Clean Air $A c t$ ) à agência ambiental federal. Os detalhes das medidas ainda estão sendo negociados com 
os Estados, mas deve haver metas de redução e restrição ao uso de tecnologias como as térmicas a carvão sem captura e estocagem de carbono.

No campo externo, a postura internacional dos EUA vinha se caracterizando como bastante conservadora, porquanto o Legislativo conservador desempenha um papel relevante, que praticamente anula as sinalizações da administração Obama para alguma mudança nesse campo. O único avanço relevante foi o anúncio, em fins de 2014, de um acordo bilateral com a China, por meio do qual os EUA se comprometem a reduzir suas emissões em $28 \%$ até 2025 em relação às emissões de 2005; e a China se compromete a chegar ao pico das emissões até 2030 e a elevar as fontes não-fósseis a $20 \%$ de sua matriz energética no mesmo ano. Muito embora as metas anunciadas não sejam propriamente desafiadoras, elas representaram uma quebra no discurso de acusação recíproca entre EUA e China, que são os dois maiores emissores de gases estufa.

A China, por sua vez, líder mundial em emissões absolutas desde aproximadamente 2006, é responsável por $29 \%$ das emissões globais, o que representa 7 toneladas per capita e 1.308 tonelada de carbono por dólar do PIB. Trata-se de um volume elevado de emissões totais, o que é em parte justificável pela imensa população de 1,3 bi (19\% do total), mas já significa um volume per capita acima da média mundial (e não baixo, como por vezes se anuncia) e de alta intensidade de carbono.

A China adotou até 2006 uma posição na política externa bastante conservadora no campo das mudanças climáticas. A partir de então, houve uma guinada na postura do país, atribuída tanto à percepção de sua vulnerabilidade aos efeitos do aquecimento global, quanto a um cálculo estratégico de oportunidade econômica. Em 2008, o país lançou seu Plano Nacional de Mudanças Climáticas e deu ênfase ao setor no pacote de estímulo anticíclico quando da crise de 2008.

Em novembro de 2009, o governo chinês anunciou o objetivo voluntário de reduzir até 2020 suas emissões de $\mathrm{CO}_{2}$ em 40 a $45 \%$ por unidade do PIB comparado aos níveis de 2005 (UNFCCC, 2011a). Não se trata de diminuição absoluta, tampouco de queda em relação ao cenário BAU, mas de tornar a economia menos intensiva em carbono.

Com esse propósito, o $12^{\circ}$ Plano Quinquenal da China (2011-2015) estabeleceu que até 2015 as emissões de $\mathrm{CO}_{2}$ por unidade do PIB devem ser cortadas em 17\% comparadas ao nível de 2010, além de definir a meta de 11,4\% para fontes primárias de energia de origem não-fóssil (UNFCCC, 2011a). Esse plano chinês foi considerado como a maior contribuição para a redução de gases estufa entre todos os países, segundo Nicholas STERN, autor do 
famoso relatório que leva seu próprio nome (THE ECONOMIST, 2012). Em artigo sobre o tema, STERN assim abordou o Plano Quinquenal chinês:

\begin{abstract}
"Seria a estratégia de crescimento verdadeira: crescimento com alto carbono não tem futuro. O baixo carbono é o modelo para o século XXI. Nós não podemos nos permitir a continuidade da teoria e da prática superadas do século XX. É por isso que o $12^{\circ} \mathrm{Plano}$ Quinquenal, com razão, adota esse novo modelo.” (STERN, 2010, em tradução livre ${ }^{17}$ )
\end{abstract}

VIOLA aponta existir uma clivagem entre forças globalistas e nacionalistas no seio do Estado chinês. A despeito da prevalência destas nos últimos anos, é crescente o papel das primeiras. Ao mesmo tempo em que o país utiliza largamente uma das piores fontes de energia para sua economia (carvão), é a China também a maior investidora em fontes alternativas. O país respondeu, em 2011, pela maior quantidade de energia produzida a partir dos ventos e de paineis solares fotovoltaicos fabricados (GWEC, 2012, e EARTH POLICY INSTITUTE, 2011), além de ter lançado vultosos investimentos nucleares - são 27 reatores nucleares em construção (EIA, 2011b).

A União Europeia é a única das superpotências que tem pressionado pela formação de um regime internacional efetivo para promover uma rápida transição para uma economia de baixo carbono. Todavia, como as outras duas superpotências dispõem, de fato, de poder de veto, um acordo eficaz não é alcançado.

As emissões da UE representam cerca de $11 \%$ do total, que representam 8 toneladas per capita e 215 toneladas de carbono por cada dólar de PIB. Conquanto formada por países bastante heterogêneos quanto às emissões per capita e à intensidade de carbono na economia, seus principais líderes vinham mobilizando esforços para a formação de um regime rigoroso para amainar o aquecimento global. O agravamento da crise econômica, porém, retirou o tema do centro da agenda europeia.

Os movimentos internacionais dessas três superpotências é o que tem definido a ausência de definição de um regime internacional que combata eficazmente as mudanças climáticas. A UE pressiona pelo regime, mas perdeu seu protagonismo por ser o centro da crise econômica. Os Estados Unidos e a China, como se apontou, vinham utilizando a reticência do outro para não assumir compromissos relevantes, embora o acordo bilateral de 2014 possa

\footnotetext{
${ }^{17}$ No original: "It would be the real growth strategy: high-carbon growth has no future. Low-carbon growth is the model for the 21 st century. We cannot afford to continue with the outmoded theory and practice of the 20th century. That is why the 12th five-year plan, quite rightly, embraces this new model." (STERN, 2010)
} 
prenunciar uma mudança. E os demais atores internacionais não têm influência suficiente para alcançar o acordo, dado o poder de veto tácito das três superpotências.

No campo das grandes potências estão incluídos o Brasil, a Índia, a Rússia, o Japão e a Coreia do Sul. Ainda na classificação de VIOLA, além de Taiwan, estão categorizados como potências médias Canadá, México, Venezuela, Colômbia, Argentina, Noruega, Suíça, Israel, Ucrânia, Turquia, Egito, Nigéria, África do Sul, Emirados Árabes Unidos, Arábia Saudita, Irã, Paquistão, Bangladesh, Tailândia, Malásia, Cingapura, Vietnã, Indonésia, Austrália e Filipinas.

Além das três superpotências, que por óbvio são atores chave nas negociações internacionais, abordaremos neste tópico apenas aquelas nações que são objeto da pesquisa, ou seja, Brasil, Coreia do Sul e Taiwan.

O Brasil é responsável por cerca de 1\% das emissões globais, o que corresponde a 2 toneladas per capita e 180 toneladas por dólar de PIB. Trata-se de um patamar per capita considerado baixo. A intensidade de carbono na economia também é de razoável eficiência, abaixo de 200. O perfil de emissões no país vem se alterando substancialmente graças à queda consistente nas taxas de desmatamento (passaram de 27,7 mil km² em 2004 para cerca de 6,4 mil km² em 2011) e, por outro lado, ao aumento paulatino das emissões oriundas da produção energética, transportes, indústria, agropecuária e refino de petróleo.

Como esclarece VIOLA, há cinco complexos energéticos atuantes no Brasil: um de alto carbono (petróleo e gás, que vem crescendo acentuadamente em razão das descobertas do pré-sal) e quatro de baixo carbono (hidrelétrico, etanol, nucelar e eólico). Desses quatro, apenas o eólico vem crescendo em ritmo comparável ao petróleo, mas a base da qual partiu é muito reduzida e, por isso, seu poder de influenciar as políticas públicas ainda é bastante limitado.

Vale notar que foi aprovada em fins de 2009, à época da Conferência de Copenhague, a Lei n- 12.187, de 29 de dezembro de 2009, que estabeleceu a Política Nacional sobre Mudança do Clima e representou um passo bastante avançado para o país. Por lei, o Brasil assumiu o compromisso voluntário, quantificável e verificável, de reduzir suas emissões de gases estufa entre 36,1 e 38,9\% em relação às emissões projetadas até 2020. Trata-se do país de renda média com a meta mais arrojada na área até o momento. Esse esforço de redução em relação ao cenário BAU corresponderia, aproximadamente, a um aumento de $+6,4 \%$ ou de $+1,7 \%$ em relação às emissões totais de 1990 (USCAN, 2012).

Vale notar ainda que os esforços brasileiros não se restringem ao âmbito federal. Dos 27 Estados, 17 estão implantando política de mudança climática e 12 já adotaram 
legislação específica sobre o tema. Na conferência Durban, o Brasil defendeu a aprovação de um instrumento juridicamente vinculante que abrangesse todos os países, baseados nas recomendações científicas, para o período imediatamente posterior a 2020. Isso significa a assunção de responsabilidades e de metas também pelos países em desenvolvimento, porém apenas após 2020 (UNFCCC, 2011b).

A Coreia do Sul emite cerca de $2 \%$ do total global, o que representa 13 toneladas per capita e 525 por US\$1,00 do PIB. O patamar de emissões por cabeça é considerado elevado, embora haja intensidade de carbono apenas intermediária na economia.

O país é o integrante da OCDE (Organização para a Cooperação e Desenvolvimento Econômico, entidade que congrega as economias mais ricas do mundo) que apresentou a maior elevação de suas emissões de gases estufa entre 1990 e 2005 (YALE, 2012). Embora integre a OCDE, a Coreia não foi inserida no Anexo 1 de Quioto, razão pela qual não está juridicamente vinculada às reduções lá acordadas. Apesar disso, o país tem se destacado por anunciar uma transição acelerada para uma economia de baixo carbono, investindo intensamente em tecnologias limpas. No pacote anticíclico lançado em janeiro de 2009, propôs que $81 \%$ dos recursos fossem destinados a investimentos ligados à mudança climática (ROBINS, CLOVER e SINGH, 2009).

A Coreia vem defendendo nos foros internacionais um segundo período de compromisso para o Protocolo de Quioto, evitando um período de vácuo legal. Além disso, o país tem advogado um regime climático no qual todos os países respondam pelos esforços para o enfrentamento do aquecimento global, o que incluiria os emergentes. Por não integrar o Anexo I do Protocolo de Quioto, o país passaria a assumir obrigações no caso da aprovação de um regime dessa natureza. Trata-se, portanto, de uma posição reformista nesse campo.

Em 2008, a Coreia adotou o lema "Low Carbon, Green Growth" (Baixo Carbono, Crescimento Verde) e anunciou sua meta voluntária de mitigação do efeito estufa, comprometendo-se a reduzir em 30\% suas emissões em 2020 em relação ao cenário BAU (UNFCCC, 2011c). Em 2010, foi aprovada a Lei Geral sobre Baixo Carbono e Crescimento Verde. O objetivo vem sendo buscado por políticas do estilo command-and-control (grandes empresas passaram a ter um objetivo mandatório de redução de emissões), um sistema capand-trade que deve ser colocado em operação em 2015 (já aprovado por lei em fevereiro de 2012, correspondendo ao terceiro país a fazê-lo) e um novo portfólio de padrões para energias renováveis (YALE, 2012).

Taiwan é responsável pela emissão de apenas $0,8 \%$ do total mundial, o que equivale a uma emissão per capita de 12 toneladas de gases estufa e, em proporção de US\$ 
1,00 do PIB, corresponde a 560. Trata-se de um volume elevado per capita, com eficiência mediana por unidade do PIB. O país tem se caracterizado pelos vultosos investimentos em energia solar fotovoltaica e em ciência e tecnologia de modo geral. Cerca de 2,8\% do PIB são direcionados para atividades de P\&D.

Taipei tem adotado uma posição reformista no campo das mudanças climáticas. Entretanto, Taiwan vivencia a peculiar situação de não ser considerada uma nação soberana pelas Nações Unidas - e pela maior parte de seus membros. Desde que a República Popular da China assumiu seu posto na ONU, em 1971, Taiwan não toma parte formalmente das negociações e nem mesmo é convidada para as negociações do clima. Desse modo, o país não pode aderir formalmente à CQNUMC e ao Protocolo de Quioto - o que o deixa de fora também dos mecanismos flexíveis, que permitiriam receber recursos mediante, por exemplo, o mecanismo de desenvolvimento limpo. A situação se torna ainda mais especial pelo fato de Taiwan ser uma ilha (em verdade, um conjunto delas), que pode ser bastante afetada pela elevação do nível do mar.

Desse modo, ainda que o país pretenda lançar a imagem de membro responsável na comunidade das nações e tenha adotado ações iniciais para mitigar suas emissões, o país não participa formalmente das negociações climáticas internacionais. Desde pelo menos 2008, o governo de Taiwan estabeleceu como prioridades políticas a redução do carbono em sua economia. Uma das metas na política externa do país, a partir de 2009, é integrar formalmente os foros internacionais, especialmente a CQNUMC. Nesse mesmo ano, o país foi aceito como observador na Assembleia da Organização Mundial da Saúde. Mas até o momento sua participação na CQNUMC vem sendo obstada - como, de resto, em outras organizações internacionais das quais a República Popular da China é parte. Em que pese o apoio manifestado pelo governo dos EUA e pelo Parlamento Europeu, entre outros países, a China se mantém fortemente contrária à ampliação do espaço internacional de Taiwan.

Com o propósito de consolidar as posições dos países classificados como superpotências, grandes potências ou potências médias, elaborou-se a Tabela 8. A planilha tomou como base a tabela elaborada por VIOLA ET AL. (2013), que, entretanto, inclui também uma análise do regime político desses países, não abarcado aqui.

Os países examinados, como se verifica, são alguns dos que têm adotado em alguma medida políticas progressistas sobre mudança climática. O que se examinará nesta tese é que ações concretas vêm sendo implantadas em cada um no campo da energia, que é um dos setores cruciais para a mitigação do aquecimento global. 
TABELA 8

\begin{tabular}{|c|c|c|c|}
\hline $\begin{array}{c}\text { Influência / } \\
\text { Resposabilidade } \\
\text { climática }\end{array}$ & Conservadora & $\begin{array}{c}\text { Conservadora } \\
\text { moderada }\end{array}$ & Reformista \\
\hline Superpotência & & $\begin{array}{l}\text { CHINA } \\
\text { EUA }\end{array}$ & UE \\
\hline Grande potência & $\begin{array}{l}\text { Índia } \\
\text { Rússia }\end{array}$ & BRASIL & $\begin{array}{c}\text { Japão } \\
\text { COREIA DO SUL }\end{array}$ \\
\hline Média potência & $\begin{array}{l}\text { Arábia Saudita, Irã, } \\
\text { Vietnã, Emirados } \\
\text { Árabes Unidos, Egito, } \\
\text { Paquistão, Nigéria, } \\
\text { Venezuela, Tailândia, } \\
\text { Argentina, Indonésia, } \\
\text { Ucrânia, Canadá }\end{array}$ & $\begin{array}{l}\text { TAIWAN, África do } \\
\text { Sul, Israel, } \\
\text { Bangladesh, Malásia, } \\
\text { Turquia, México, } \\
\text { Filipinas, Colômbia, } \\
\text { Austrália }\end{array}$ & $\begin{array}{c}\text { Cingapura } \\
\text { Noruega } \\
\text { Suíça }\end{array}$ \\
\hline
\end{tabular}

Fonte: Elaboração própria a partir de Tabela de VIOLA ET AL., 2013.

Também se buscou demonstrar neste capítulo que avultam as evidências científicas a respeito da mudança climática e da necessidade de adotar tanto ações de adaptação, quanto de mitigação. Entre estas, estão abrangidas as tecnologias ligadas ao setor energético com baixa emissão de carbono. Mesmo que a formação de um acordo global legalmente vinculante ainda pareça distante, vai-se formando gradativamente um regime informal que tende a, no longo prazo, reduzir os espaços de mercado para tecnologias intensivas em carbono. Daí a importância de largar na frente para a produção dessas novas tecnologias de energia limpa, eis que o setor de energia representa uma parcela considerável das emissões antrópicas.

É no desenvolvimento de tecnologias para energia com baixo carbono que os temas tratados no capítulo 1 e capítulo 2 se mesclam. Afinal, a tecnologia desenvolvida pelos países que largaram na frente da economia de baixo carbono haverá de ser, de algum modo, difundida para os demais. Como essa transferência se dará, quem a custeará e quem dela se beneficiará são questões de grande importância. 


\section{CAPÍTULO 3 \\ GERAÇÃO DE ENERGIA E EMISSÃO DE GASES ESTUFA: \\ LIMITES E POTENCIAIS}

\subsection{A abundância de fontes de energia no Brasil e a situação de relativo conforto para conter as emissões}

A geração de energia está fortemente correlacionada com o nível de renda do país, ainda que existam certas variações decorrentes do padrão de consumo. À medida que a economia nacional cresce, ela demanda mais energia, tanto para a produção de bens e serviços, quanto para o consumo crescente da população. Portanto, para países com nível de renda apenas intermediário, como o Brasil, não apenas a manutenção do patamar de energia gerado é relevante, mas a própria expansão da oferta energética é de importância indiscutível para assegurar crescimento econômico de longo prazo.

Não à toa a origem das fontes energéticas tem sido historicamente um tema de importância geopolítica singular. A busca por combustíveis fósseis, aliás, já deu ensejo a várias conflagrações armadas e crises econômicas. Não se trata de assunto de importância secundária para nenhum país.

Para adicionar complexidade ao assunto, dada a crescente preocupação internacional com a mudança climática, caminha-se para um regime - formalizado ou não em tratado - de restrição das emissões de carbono oriundas da geração de energia. Como indicado no Capítulo 2, o setor de energia representa uma fatia relevante das emissões de gases estufa, vários países desenvolvidos já assumiram metas de redução desses gases por meio do Protocolo de Quito (ainda que muitos não as tenham observado) e é crescente a pressão para que os países periféricos assumam compromissos de redução das emissões, mesmo que mais tênues do que os fixados para os países ricos. De fato, muitos países em desenvolvimento já adotaram metas voluntárias, incluindo o Brasil, para reduzir as emissões em relação ao aumento projetado.

Ocorre que se vive hoje, no caso brasileiro, uma situação de conforto relativo no que tange à disponibilidade de fontes energéticas tradicionais acessíveis no território nacional. Deixando à margem outros impactos ambientais de cada uma das opções energéticas, o fato é que o Brasil ainda dispõe de amplo potencial hidrelétrico inexplorado, principalmente 
na região amazônica, tornou-se grande produtor de energia a partir de biomassa, especialmente etanol e biodiesel, e localizou reservas imensas de petróleo e de gás na faixa oceânica adjacente à sua costa.

Além das fontes tradicionais de energia, o território brasileiro também foi agraciado com ventos propícios à geração eólica de energia, mesmo com as tecnologias atualmente existentes, assim como com nível de radiação solar razoavelmente intenso para eventual utilização da energia solar em larga escala.

Quanto às emissões de carbono no Brasil, a maior parte delas estava relacionada, no início do século XXI, ao desmatamento, e não à geração de energia - descolando-se do padrão observado nos países industrializados e nos países de renda média. Isso se devia principalmente ao fato de que o Brasil se destacava mundialmente ao gerar eletricidade principalmente a partir de fontes hidráulicas (reduzindo a participação da energia nas emissões totais) e também ao nível de desmatamento em níveis preocupantemente elevados para a preservação da floresta amazônica (o que elevava desproporcionalmente as emissões decorrentes de mudanças no uso da terra).

Esse perfil peculiar de emissões permitiria que o Brasil reduzisse suas emissões baseando-se não tanto na restrição de oferta energética tradicional, mas sim na redução dos níveis de desmatamento - um objetivo menos difícil de ser alcançado. Se à queda do desmatamento for acrescida a diminuição das emissões oriundas do setor agrícola oriundas do uso de fertilizantes nitrogenados, o país gozaria, então, de espaço suficiente para ampliar suas emissões decorrentes da geração de energia sem esbarrar em metas voluntárias de emissão ou em compromissos internacionais eventualmente acordados.

De fato, já é esse o caminho que o país vem percorrendo. A taxa de desmatamento foi consistentemente reduzida na última década, passando de $28 \mathrm{mil} \mathrm{km}^{2}$ anuais em 2004 para a faixa de 5 mil km² em 2012 e 2013, conforme demonstra o Gráfico 9. Essa mudança acarretou uma redução substancial do total de emissões brasileiras no período, já que elas se concentravam em larga medida no desmatamento.

A redução das emissões decorreu de uma série de medidas tomadas ao longo da década de 2000, especialmente sob a gestão da Ministra do Meio Ambiente Marina Silva, no governo do Presidente Lula. Algumas ações se basearam em leis aprovadas ainda na administração anterior, mas cuja efetividade ainda não havia sido posta à prova na integralidade, tais como a Lei de Crimes Ambientais (Lei no 9.605/1998) e a Lei do Sistema Nacional de Unidades de Conservação (Lei no 9.985/2000). A estratégia de redução do 
desflorestamento se baseou no Plano de Prevenção e Controle do Desmatamento na Amazônia Legal - PPCDAm, lançado em 2004 e sucessivamente atualizado.

\section{GRÁFICO 9}

Taxa de desmatamento anual no Brasil $\left(\mathrm{em} \mathrm{km}^{2}\right)$

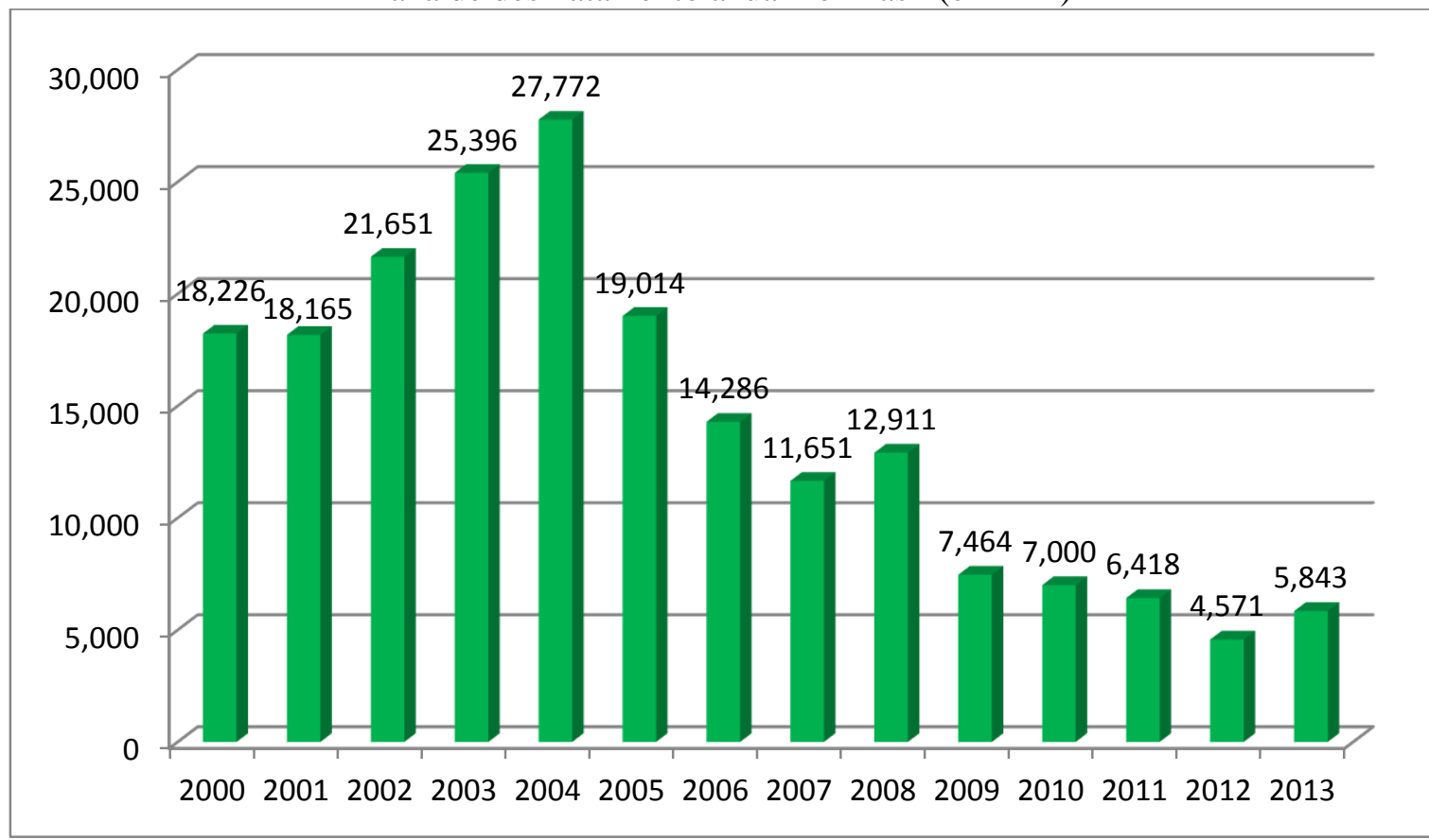

Fonte: INPE, Prodes, 2014.

Esse plano de redução do desmatamento envolve mais de duzentas ações estruturadas em torno de eixos, como o fundiário e territorial (homologação de novas terras indígenas e criação de inúmeras unidades de conservação); monitoramento e controle (mapeamento das áreas por satélite, casado com atuação policial e fiscalizatória nos locais sensíveis); promoção de práticas de gerenciamento sustentável da floresta; e ainda embargos a fornecedores e restrição de crédito para áreas de maior intensidade de desmatamento (Decreto no 6.321/2007). Esse conjunto de ações é apontado como responsável pela queda acentuada do desmatamento, que oscila em torno de $5.000 \mathrm{~km}^{2}$ nos últimos anos (ALLEN, 2013).

A agricultura, por sua vez, que também tem uma participação expressiva nas emissões de carbono do país, foi objeto de um plano governamental para reduzir suas emissões. Além das emissões associadas à energia necessária às atividades agrícolas, a maior parcela das emissões oriundas do setor provém da mudança do uso do solo, das atividades pecuárias e especialmente do uso intensivo de fertilizantes, especialmente os nitrogenados. A retirada de florestas para a agricultura está associada à queima ou à decomposição do carbono anteriormente integrante da vegetação. A criação de animais, notadamente dos bovinos, está 
associada à emissão de metano decorrente do processo digestivo. Por fim, a adubação por meio de fertilizantes nitrogenados modifica o ciclo natural desse composto e permite que ele emita óxido nitroso $\left(\mathrm{N}_{2} \mathrm{O}\right)$, um dos gases que acarretam o efeito estufa.

O governo federal lançou o Plano de Agricultura de Baixo Carbono - Plano ABC - com o propósito de reduzir as emissões do setor. A medida atende não só ao propósito de reduzir as emissões de carbono do país, como também a evitar eventuais medidas protecionistas de outros países sob pretextos ambientais.

O projeto consiste fundamentalmente no apoio aos produtores rurais por meio de financiamento a taxas subsidiadas e de assistência técnica para adoção de práticas mais eficientes para a recuperação de pastos degradados, integração lavoura-pecuária-floresta, plantio de florestas comerciais, fixação biológica de nitrogênio, tratamento de resíduos animais e plantio direto na palha. Segundo relatório da Fundação Getúlio Vargas (ASSAD, 2013), a agropecuária brasileira pode passar, em uma década, de uma forte emissora de gases estufa para uma atividade eficiente em sua mitigação. Mas o texto alerta para as dificuldades na implementação do plano, que tem alcançado índice de participação ainda abaixo do esperado.

Como resultado dessas duas ações (desmatamento e agricultura), as últimas informações a respeito das emissões de carbono no Brasil indicam uma queda acentuada da participação do desmatamento, conjugada com a elevação correspondente das demais fontes de gases estufa. Como houve algum avanço nas políticas de redução das emissões no caso da agricultura, a participação do setor não se elevou de maneira tão acentuada, a despeito do crescimento da produção econômica verificado. Em termos absolutos, houve elevação de apenas 5,2\% de 2005 a 2010, em que pese o forte crescimento da produção agropecuária brasileira (MCTI, 2013). Ainda assim, passou de $20 \%$ para $35 \%$ do total em termos relativos.

Energia, processos industriais e resíduos sólidos praticamente dobraram sua participação nas emissões totais, embora a elevação em termos absolutos não tenha sido tão significativa. Os Gráficos 11 e 12 sintetizam essas informações.

O total de emissões de gases estufa no Brasil caiu acentuadamente, de pouco mais de 2 bilhões de toneladas de $\mathrm{CO}_{2}$ eq em 2005, para 1,25 tonelada em 2010, puxado pela redução substancial do desmatamento (que, no gráfico, está incluído na categoria "uso da terra e florestas"). Esse decréscimo aproximou o perfil das emissões brasileiras do padrão internacional, em que o setor energético tem peso acentuado. De fato, o setor de energia ampliou sua participação em termos relativos: de 2005 a 2010, passou de $16 \%$ para $32 \%$ do total, embora a elevação se deva mais à queda da contribuição do desmatamento do que ao 
aumento absoluto das emissões do setor de energia, que, no mesmo período, passaram de 329 para $399 \mathrm{GgCO}_{2}$ eq (incremento de $21 \%$ ).

\section{GRÁFICO 10}

Perfil das emissões de gases estufa no Brasil

\section{Emissões de 2,03 bilhões de toneladas de $\mathrm{CO}_{2} \mathrm{eq}$ em 2005}

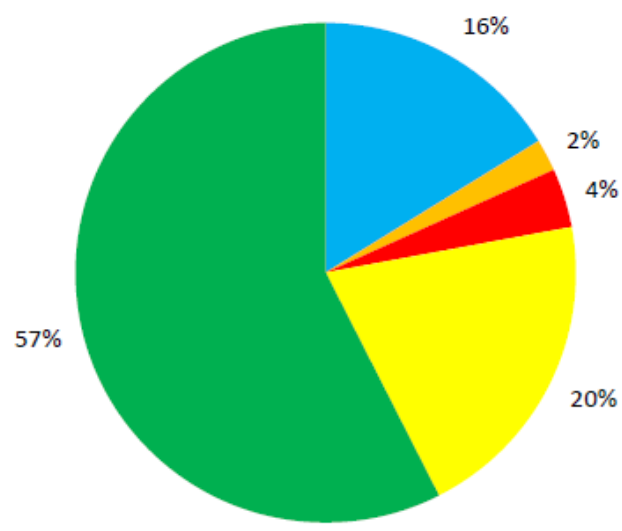

Emissões de 1,25 bilhão de toneladas de $\mathrm{CO}_{2}$ eq em 2010

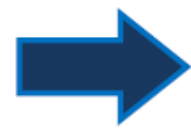

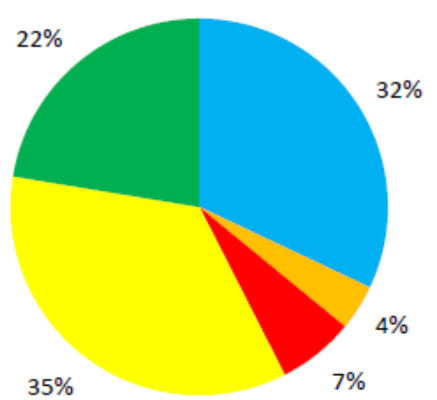

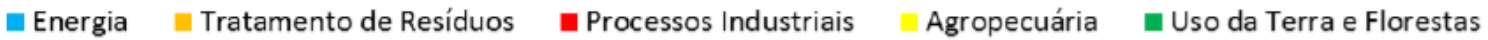

GRÁFICO 11

Emissões brasileiras de gases de efeito estufa (1990-2010), em $\mathrm{CO}_{2}$ eq

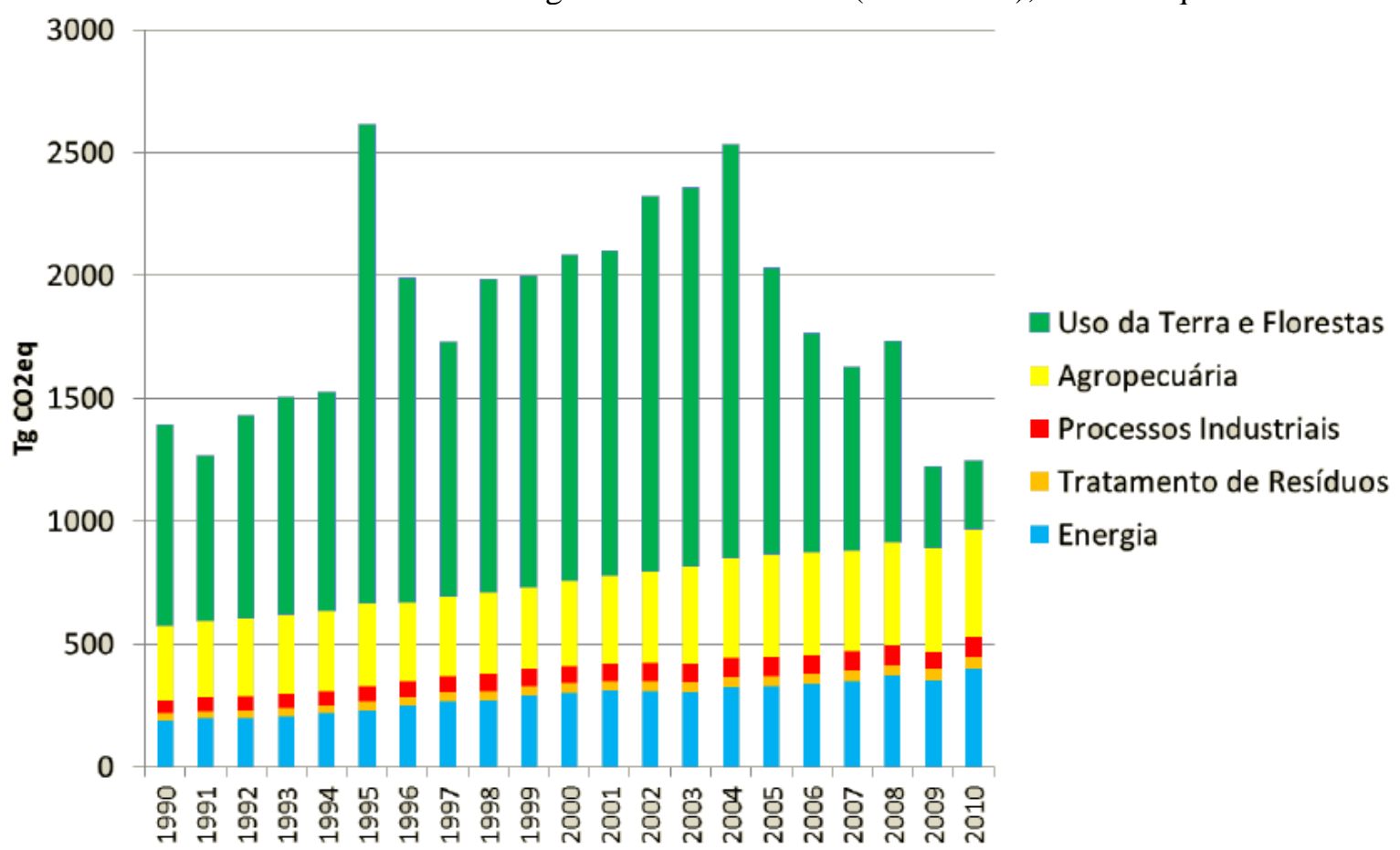

$\mathrm{Tg}=$ milhões de toneladas

Fonte: MCTI, a partir da atualização de dados do $2^{\circ}$ Inventário Nacional de Gases Estufa, 2013. 
Por essa razão, o planejamento para a geração de energia no Brasil, diante da relativa tranquilidade em termos de emissão proporcionadas pelo uso intensivo de fontes hidráulicas, pela redução do desmatamento e pelas mudanças em curso na agricultura, segue o modelo de expansão em larga medida baseado em fontes usuais de energia do país.

O Plano Decenal de Expansão de Energia 2022, elaborado pelo Ministério de Minas e Energia e pela Empresa de Pesquisa Energética (BRASIL, 2013), prevê, para a matriz elétrica, que a expansão da oferta seguirá baseada em usinas hidráulicas, juntamente com algum incremento das fontes térmicas e de outras renováveis, incluindo eólica, biomassa e solar.

Em dezembro de 2012, o Brasil dispunha de cerca de 118 GW de capacidade instalada no sistema elétrico - sem incluir os sistemas isolados remanescentes, que dispõem de mais $3 \mathrm{GW}$. Desse total, cerca de 78,3 GW são de geração hidráulica, além de 6,2 GW de eletricidade oriunda de Itaipu correspondente à parte não-consumida pelo Paraguai. Isso representa aproximadamente $71 \%$ da matriz total em fonte hidráulica, sem incluir as PCHs (Pequenas Centrais Hidrelétricas, com capacidade de até $30 \mathrm{MW}$ cada).

As usinas térmicas de combustíveis fósseis respondem por aproximadamente 16,5 GW, ou 14\% da capacidade instalada do sistema. As duas usinas nucleares em operação representam $2 \%$ do total. O restante (13\%) está distribuído em “outras renováveis”, abrangendo biomassa, PCHs, eólicas e uma fatia minúscula de solar.

A energia eólica passou por um crescimento acentuado nos últimos anos, dada a queda dos preços para empreendimentos eólicos nos leilões realizados pela ANEEL. A geração de energia solar tem baixíssima participação no sistema e deve continuar a figurar como secundária nas estatísticas, uma vez que o custo da energia daí originada ainda é bem mais elevado do que o das demais. No geral, é possível dizer que se trata de matriz elétrica de emissão de carbono relativamente baixa, notadamente quando comparada com a de outros países, como se observará adiante.

O PDE 2022 estabelece cenários para a expansão do sistema elétrico, utilizando como base estimativas de crescimento econômico, tipos de indústria, mudanças demográficas, etc. A partir da necessidade de carga estimada para 2022, fixam-se as necessidades de expansão da oferta e são considerados os leilões já realizados para entrega de energia nos próximos cinco anos, além dos estudos em curso para novas expansões. O Gráfico 12 sintetiza a expansão estimada para o sistema elétrico em 2022.

Como se pode verificar, a previsão é que o sistema prossiga com ampla preponderância da fonte hidráulica, que deve se expandir do patamar atual em torno de $80 \mathrm{GW}$ 
para cerca de 120 GW. Há também previsão de expansão suave da capacidade térmica, nuclear e especialmente das outras renováveis, grupo no qual se destacam a eólica e a biomassa. Seguirão preponderantes as fontes tradicionalmente utilizadas no Brasil, para as quais o país já dispõe de tecnologia e de manufatura razoavelmente consolidadas.

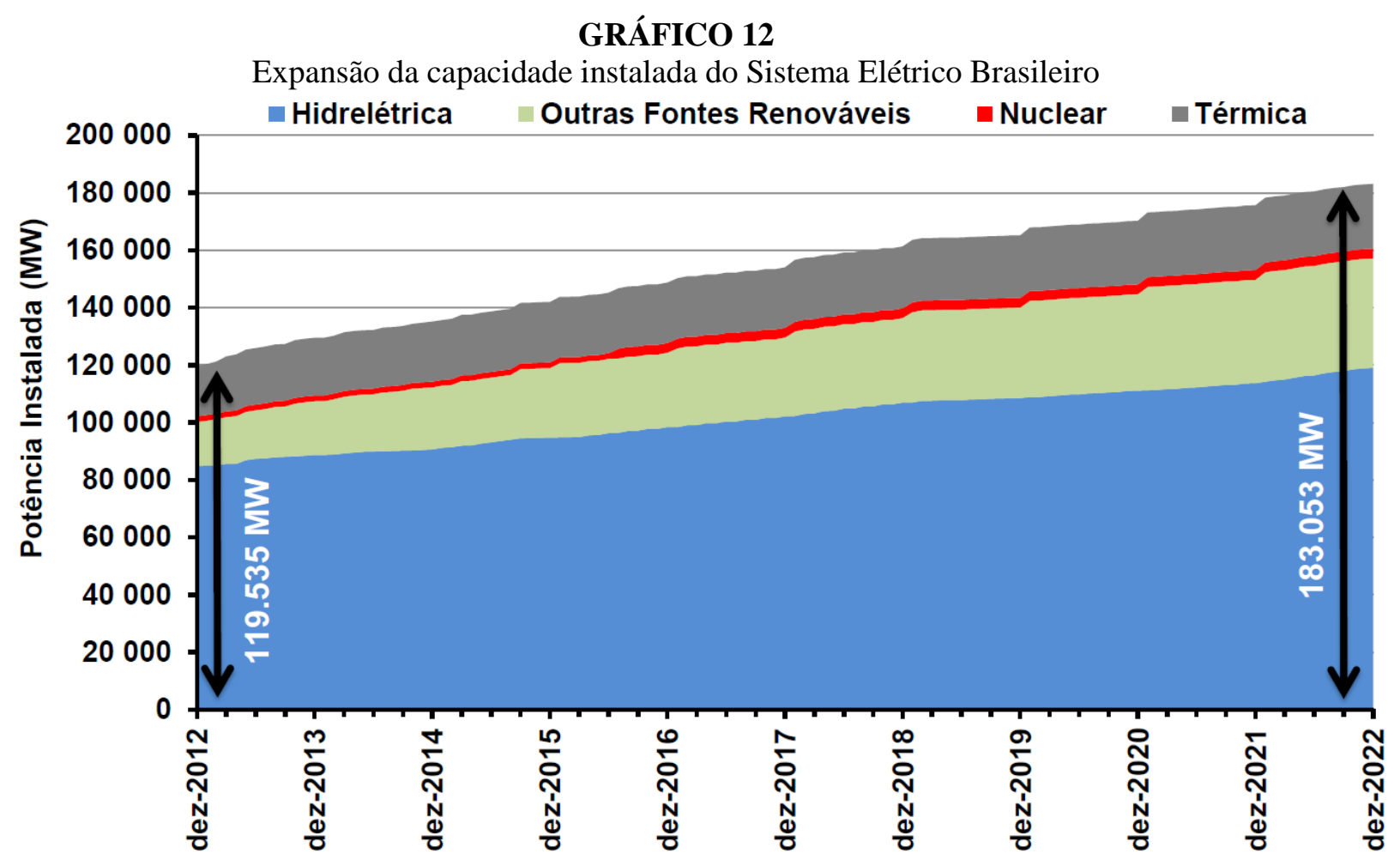

Fonte: Brasil, MME/EPE, 2013.

A pequena elevação esperada para as fontes térmicas, baseadas em gás, carvão ou óleo, não chega a desfigurar a característica comparativamente limpa da matriz elétrica brasileira. As emissões oriundas dessa expansão térmica - especialmente se o carvão não exercer papel dominante - não devem afetar substancialmente as emissões per capita brasileiras de gases estufa. No total elas devem perder participação, caindo de $14 \%$ para $12 \%$ do total.

Vale notar que parcela representativa dos incrementos de capacidade já está contratada. Os leilões A-3 e A-5 já definiram boa parte dos novos empreendimentos a entrar em operação até 2018. Dentre as novas renováveis, a eólica é a que se destaca, com capacidade adicional já contratada até 2018 de 11,3 GW, seguida de 1,8 GW de biomassa, além de 1,1 GW em PCH. A participação dessas fontes deve saltar para $21 \%$ do total em 2022. As usinas nucleares, com a entrada em operação de Angra 3 prevista para o final da década, deve manter a participação dessa fonte na casa de $2 \%$. Mas é a fonte hidráulica que tem destaque nos leilões já realizados para suprimento até 2018, com capacidade de 19,5 GW já contratada, incluindo 
as usinas de Belo Monte e Jirau. A despeito disso, até o fim do ciclo de 2022, a expectativa é a que a participação das grandes usinas hidrelétricas se reduza a $65 \%$, saindo dos atuais $71 \%$.

É preciso registrar que essa expansão planejada não está isenta de riscos. Os três principais são os seguintes:

a) a expansão da capacidade hidráulica, cerne do sistema, está baseada principalmente em empreendimentos na Amazônia, região em que, a depender do desenho do empreendimento, pode haver impactos ambientais relevantes, inclusive em termos de emissões de gases estufa decorrentes de alagamentos de áreas cobertas por vegetação;

b) por se localizarem na região Norte, os empreendimentos de geração precisam estar acompanhados de sistemas de transmissão cada vez mais extensos, uma vez que o Sudeste concentra a maior parte da carga, o que traz riscos e custos adicionais; e

c) a manutenção da hidroeletricidade como principal fonte sujeita o sistema a riscos hidrológicos, particularmente por serem utilizados reservatórios cada vez menores e também pela própria dinâmica da mudança climática impactando padrões pluviométricos.

O próprio PDE 2022 aborda algumas dessas questões. O documento ressalta a complementariedade entre as hidrelétricas, de um lado, e as usinas eólicas e de biomassa de outro. Os períodos de chuva contrastam com os períodos de maior intensidade de vento e mesmo com a entressafra da cana-de-açúcar. Isso permitiria que o Brasil utilize a fonte hidráulica como back up para as fontes eólicas - e não o gás natural e outros combustíveis fósseis, como ocorre em outros países. Entretanto, o aumento da capacidade de armazenamento hidráulico de energia previsto até 2022 é de apenas $2 \%$ da capacidade de estocagem existente em dezembro de 2012.

No setor de transporte, as fontes utilizadas pelo Brasil são fundamentalmente o petróleo e o etanol. O primeiro tem papel preponderante - é justamente da queima de petróleo para transporte que se origina a parcela mais significativa das emissões brasileiras do setor energético. De fato, o segmento de transporte responde por $47 \%$ do total de emissões do setor energético, ou $204 \mathrm{MtCO}_{2}$ eq do total de $437 \mathrm{MtCO}_{2}$ eq lançados na atmosfera pelo uso de energia no Brasil em 2012, sempre de acordo com o PDE.

Dentro do setor de transporte, destaque-se a utilização do óleo diesel para o transporte de cargas e de passageiros no modal rodoviário como o principal responsável pelas emissões, seguida pela gasolina para veículo individuais, com participação relevante. Como se verá mais detalhadamente adiante, o Brasil tem dois programas relevantes para utilização de biocombustíveis: a) o biodiesel, que já é obrigatoriamente misturado ao diesel vendido no 
Brasil; e b) o programa de etanol, que tanto pode ser objeto de venda isolada, na modalidade hidratada, como em mistura obrigatória à gasolina, na modalidade anidro.

Apesar da relevância desses programas de biocombustíveis e da expectativa de que venham a ocupar parcela crescente da fonte primária de energia para o setor de transporte, ainda assim o PDE 2022 estima que haverá aumento das emissões absolutas do segmento. No entanto, em termos relativos, espera-se que o setor de transporte reduza suas emissões em relação ao total das emissões do setor energético, baixando dos atuais $47 \%$ para cerca de $44 \%$ em 2022. Essa diferença de 3\% deve ser absorvida pelo aumento da utilização de fontes fósseis na matriz elétrica e também pela maior emissão decorrente da própria atividade de produção e de refino de petróleo e gás natural, em razão da exploração do pré-sal.

Entretanto, é preciso levar essas estimativas com bastante cautela devido ao elevado nível de incertezas nesse campo, especialmente devido dois fatores: a) a drástica queda do preço internacional do petróleo em 2014, que, se mantida, pode até pôr em questão a viabilidade de parcelas do pré-sal; e b) a difícil situação financeira e gerencial da Petrobras, explicitadas pelas operações de combate à corrupção e aprofundadas pela perda do grau de investimento da empresa por uma das agências de classificação de risco.

Em síntese, o Brasil dispõe de relativa facilidade para expandir seu parque de geração de energia, uma vez que encontra no próprio território as principais fontes de energia necessárias e boa parte delas acarreta baixa emissão de gases estufa. Mesmo eventual acréscimo nas emissões decorrentes do setor energético pode ser contrabalançado pela queda do desmatamento e pelas mudanças no uso de fertilizantes agrícolas nitrogenados e de outras práticas agrícolas intensivas em gases estufa.

\subsection{A carência de fontes energéticas limpas na Coreia, Taiwan e China e a centralidade do setor de energia em suas emissões de gases estufa}

Diferentemente do Brasil, os países asiáticos considerados nesta tese enfrentam situação bastante diferente no que tange à expansão de sua capacidade de geração de energia e às opções para redução das emissões de carbono. Coreia do Sul e Taiwan dispõem de baixíssimos recursos energéticos em seus respectivos territórios, dependendo fortemente da importação de combustíveis fósseis. A China, por sua vez, está provida de vastas opções para 
ampliar a geração de energia, mas elas estão concentradas principalmente em combustíveis fósseis, que provocam elevadas emissões de carbono.

Nos três países, cerca de três quartos das emissões de gases estufa se originaram do setor energético, incluindo eletricidade e transportes. No caso de Taiwan, o setor de energia representa cerca de $75 \%$ das emissões de gases estufa; na China chega a 77\%; e na Coreia alcança 85\% do total (UNFCCC, 2013). Esses números revelam uma diferença profunda em relação à realidade brasileira do início do século XXI. Qualquer estratégia eficaz, portanto, para reduzir as emissões agregadas dos países implica alterações relevantes na área de energia.

A matriz energética dessas nações é fortemente dependente do uso de combustíveis fósseis. O carvão representa parcela relevante da geração de eletricidade nos três países, alcançando na China dois terços da matriz. Afora o carvão, o uso de gás natural tem papel relevante no setor de eletricidade, e os derivados do petróleo representam a quase totalidade das fontes utilizadas para o setor de transporte, uma vez que em nenhum deles há participação relevante de combustíveis alternativos para transporte, como o etanol, ou eletrificação em massa do setor.

Conforme detalhado nos subtópicos seguintes, os países asiáticos em questão utilizam combustíveis fósseis em larga escala, dependem de importações para assegurar o suprimento de energia e têm no setor energético a única opção para reduzir de modo significativo suas emissões de gases estufa. De fato, os demais setores (florestas, agricultura, processos industriais, resíduos) respondem por parcela relativamente pequena das emissões totais desses países, de modo que, embora haja esforços para elevar sua eficiência, ganhos relevantes só podem advir do setor energético.

Esse cenário contrasta com a realidade brasileira examinada no tópico anterior, em que o setor energético tem uma contribuição baixa em razão do uso intensivo de hidroeletricidade e de etanol, há fontes energéticas abundantes no próprio território do país, o setor de energia é apenas um dos que contribuem para os gases estufa e há espaço bastante para reduzir as emissões dos outros setores.

\subsubsection{Coreia e Taiwan e a completa dependência da importação de combustíveis fósseis}

Os territórios da Coreia do Sul e de Taiwan são formados, respectivamente, por uma península e uma ilha, ambas de extensão territorial reduzida, além de várias pequenas ilhotas margeando o território principal. O território sulcoreano é equivalente ao do Estado de Pernambuco, e o de Taiwan é pouco maior do que Alagoas. 
Nenhum dos dois países dispõe de vastos recursos naturais. As exportações das duas nações nos estágios iniciais da industrialização (anos 1960) eram minúsculas, porque simplesmente não havia o que exportar de matéria-prima e, à época, a produção industrial era praticamente nula. No caso da Coreia do Sul, por exemplo, os principais produtos de exportação nos anos 1960 incluíam molusco, algodão bruto e pequenas quantidades de minérios de ferro e de tungstênio, em valores muito reduzidos (KIM, 2011). Manufaturar foi um imperativo econômico de sobrevivência.

À medida que a indústria local foi se desenvolvendo, a geração de energia precisava acompanhar o passo. A mesma necessidade de fontes energéticas se verificou com a expansão da frota de veículos. À falta de fontes primárias de energia disponíveis, os países se tornaram grandes importadores de combustíveis fósseis, incluindo petróleo, gás e carvão.

Pela localização geográfica, também não dispõem de gasodutos ou oleodutos que forneçam suprimento seguro. Taiwan é uma ilha. A Coreia do Sul, ainda que geograficamente classificada como parte de uma península, é na prática um país ilhado, já que sua única conexão terrestre com o continente asiático se dá por meio da Coreia do Norte, nação com a qual vive sob constante tensão militar. Tanto Taiwan, quanto Coreia dependem, portanto, inteiramente da importação de fontes energéticas por via marítima.

Conforme informações da EIA/EUA sobre produção nacional e importação de combustíveis (Gráfico 13), Coreia do Sul e Taiwan figuram na lista dos onze maiores importadores de petróleo do mundo, mesmo não figurando entre as onze maiores economias (a sul-coreana é a $14^{\mathrm{a}}$; a taiwanesa, a $27^{\mathrm{a}}$ ). Esse indicador é um forte retrato da grande carência desses dois países em termos de energia e da vulnerabilidade a que ficam sujeitos em caso de perturbação ou interrupção dos fluxos internacionais de comércio de combustíveis fósseis.

A situação não é muito diferente para outros combustíveis fósseis, já que a ausência de fontes energéticas se estende para todas as fontes fósseis. A Coreia do Sul é o segundo maior importador de gás natural liquefeito (LNG, em inglês) e o terceiro maior importador de carvão do mundo. Taiwan ocupa o sexto lugar em LNG e o quinto em carvão (EIA/EUA, 2013d e EIA/EUA, 2013e).

São, portanto, países fortemente dependentes da importação por via marítima de combustíveis fósseis. Não só para o setor de transporte, mas também para a própria geração de eletricidade. Essa dependência tende a provocar um sentimento de forte insegurança energética, uma vez que a importação não visa a complementar a produção local, mas sim a compor praticamente toda a matriz energética. De fato, Coreia e Taiwan importam mais de $97 \%$ de 
todas as fontes primárias de energia que utilizam, incluindo petróleo, gás natural, carvão e urânio (EIA/EUA, 2013d e EIA/EUA, 2013e).

\section{GRÁFICO 13}

Maiores importadores líquidos de petróleo, em milhões de barris por dia, 2013

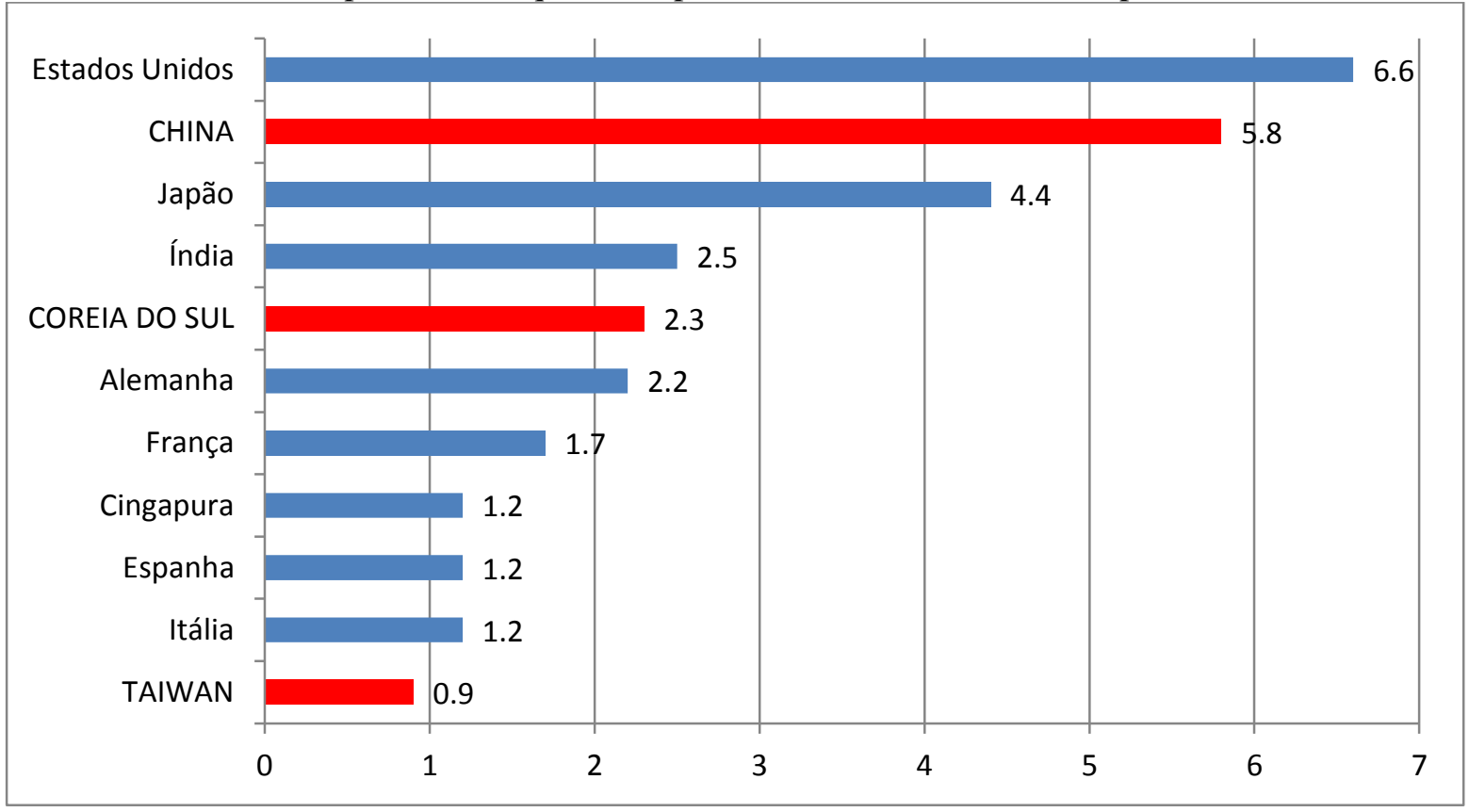

Fonte: US Energy Information Administration, EIA/EUA (2015).

Tanto Coreia do Sul, quanto Taiwan desenvolveram um programa nuclear com o duplo propósito de acessar essa sensível tecnologia e de diversificar as fontes de energia. Mesmo no caso da nuclear, entretanto, os países precisam importar o urânio, já que nenhum dos dois dispõe de reservas do mineral.

No caso da Coreia do Sul, especialmente, houve um esforço particular para tornar-se um líder na produção de energia nuclear, que representa cerca de 30\% da geração de eletricidade. Atualmente o país é o sexto maior produtor de energia nuclear do mundo, com 20 reatores em funcionamento e 14 programados até 2024, visando a atingir metade de toda a eletricidade gerada (EIA/EUA, 2013d). Em Taiwan, a energia nuclear representa cerca de 10\% da capacidade instalada, com três usinas nucleares em operação e uma quarta em construção. Ainda que a participação nuclear se eleve nos dois países, persiste uma significativa vulnerabilidade para o suprimento das fontes térmicas tradicionais de energia (EIA/EUA, 2013e).

O esforço sulcoreano para se tornar líder tecnológico em energia nuclear, todavia, sofreu um grande abalo em 2012/2013, quando emergiu um grande escândalo de corrupção envolvendo a indústria local. Foram reveladas relações espúrias entre reguladores, 
fornecedores e geradores, fragilizando a segurança do sistema e dando ensejo ao uso de certificações de segurança falsas. Os fatos fragilizaram a imagem de confiabilidade e de segurança que o setor vinha tentando construir, inclusive para tornar-se exportador da tecnologia (THE NEW YORK TIMES, 2013).

O resumo da matriz energética desses países pode ser visualizado no Gráfico 14. A participação de fontes de baixo carbono praticamente se limita à energia nuclear, já que as fontes hídrica, eólica e solar têm participação muito pouco significativas. Essas informações realçam a alta dependência da importação de fontes fósseis, o que os torna vulneráveis duplamente: a) pelo risco de interrupções no fornecimento dessas fontes energéticas; e b) pela dependência de fontes intensivas em carbono num cenário internacional de crescente restrição às emissões.

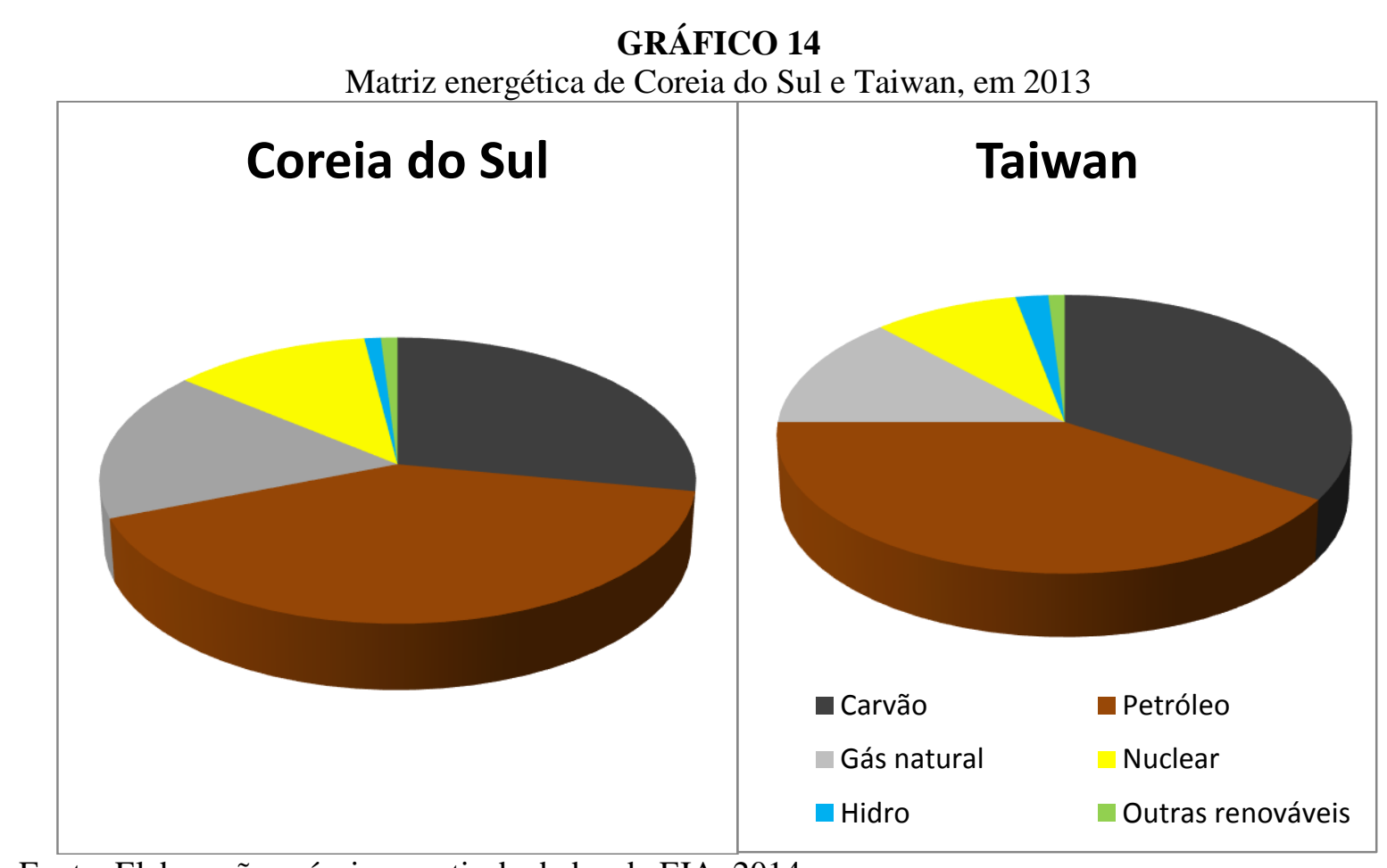

Fonte: Elaboração própria a partir de dados da EIA, 2014.

Afora a dependência da importação de combustíveis fósseis, há outro fator que pressiona a situação energética desses países: a elevada intensidade de carbono per capita e também por unidade do PIB. Se considerada a emissão de gases estufa oriunda do setor energético e dividi-la por dólar gerado no PIB, os dois países figuram na lista de grandes poluidores por riqueza produzida, conforme Tabela 7, no Capítulo 2. O mesmo indicador negativo se apresenta quando feito o cálculo por habitante. 
Quando dividido esse valor pelo PIB, Taiwan fica com índice 560 e Coreia 525, bem superior ao Japão (índice 210) e União Europeia (índice 215). O Brasil apresenta índice de 180. Esse valor sinaliza o nível de eficiência de uma economia ao gerar riqueza, apontando o quanto de riqueza se pode gerar com menor emissão marginal. Coreia e Taiwan, portanto, são pouco eficientes em termos de emissão, já que precisam emitir um volume muito elevado para gerar a mesma quantidade de riqueza.

Se, em lugar do PIB, dividirmos as emissões de gases estufa por habitante, o indicador chega a 12,2 em Taiwan e 13,1 na Coreia. Esse número é superior ao do vizinho Japão, com índice 9,8 e à União Europeia, com 7,6. O Brasil, como visto, tem indicador de apenas 2,3, contrastando com o elevado nível de emissão por habitante dos países asiáticos.

Utilizando estimativas do relatório THE WORLD FACTBOOK, da CIA, referentes ao ano de 2010, a Coreia do Sul emitiu por consumo de energia o equivalente a 569 milhões de toneladas métricas ( $7^{\circ}$ maior do mundo) e Taiwan emitiu 251 milhões de toneladas métricas (25음 mundo) (CIA, 2013).

O resultado desses fatores é que Coreia e Taiwan vivem uma situação de insegurança energética e virtual impossibilidade de manter o ritmo tradicional de crescente importação de fósseis em razão das mudanças climáticas.

Esse cenário contrasta com a situação brasileira, já que o Brasil é forte emissor per capita, não emite em grande quantidade por unidade do PIB, as emissões de gases estufa nacionais não estão concentradas no setor energético, e o país não depende substantivamente da importação de fontes primárias de energia. O cenário também se diferencia, embora em menor escala, da situação energética chinesa, conforme exposto adiante.

3.2.2. Alta intensidade de carbono na energia da China e necessidade geopolítica de reduzir importações

A China dispõe de amplas reservas energéticas, diferentemente de Taiwan e da Coreia. O país tem desenvolvido recentemente a hidroelétrica em larga escala, mas a abundância de fontes primárias de energia se concentra mesmo no carvão.

Entretanto, afora as pressões internacionais crescentes para reduzir as emissões por conta do aquecimento global (a China tornou-se o maior emissor de gases estufa por volta de 2006), o uso intensivo do carvão tem provocado severos problemas ambientais também no âmbito local (poluição de rios e lençóis freáticos, ar atmosférico em grandes cidades com concentrações gigantescas de partículas finas denominadas PM 2.5, etc.) e gerado instabilidade 
política no próprio país. A China precisa, portanto, reduzir a dependência do carvão, tanto para evitar a pressão ambiental externa, quanto a elevada insatisfação doméstica com a poluição.

A geração de energia a partir de carvão na China se elevou bastante na última década, acompanhando, de certo modo, o crescimento da economia. Mas mesmo os abundantes recursos locais não estão atendendo inteiramente à demanda doméstica. O país, que era um exportador de carvão, passou a importador líquido a partir de 2009. O volume de importações de carvão, entretanto, não é tão substancial em termos proporcionais e a opção por importar se deve mais a razões logísticas do que à insuficiência do produto no território do país.

Como a maior parte da demanda chinesa está no leste do país, próximo ao litoral, é mais fácil e barato importar carvão de países próximos (especialmente Indonésia e Austrália) do que trazê-lo das principais regiões produtoras da China, localizadas em boa parte no Noroeste do país. Some-se ainda que há estrangulamentos logísticos para trazer quantidades ainda maiores de carvão às regiões consumidoras e preocupações com o impacto ambiental local e com a segurança das operações de transporte (EIA/EUA, 2013c).

No entanto, a despeito de importar carvão, ainda há vastas reservas do produto no território chinês, as importações representam uma parcela reduzida do carvão consumido e a oferta é suprida por mercados próximos e considerados de baixa turbulência política (Austrália e Indonésia). As limitações para seguir expandindo a geração à base de carvão são, nesse caso, fundamentalmente ambientais.

\section{GRÁFICO 15}

Fontes primárias de energia na China, 2011

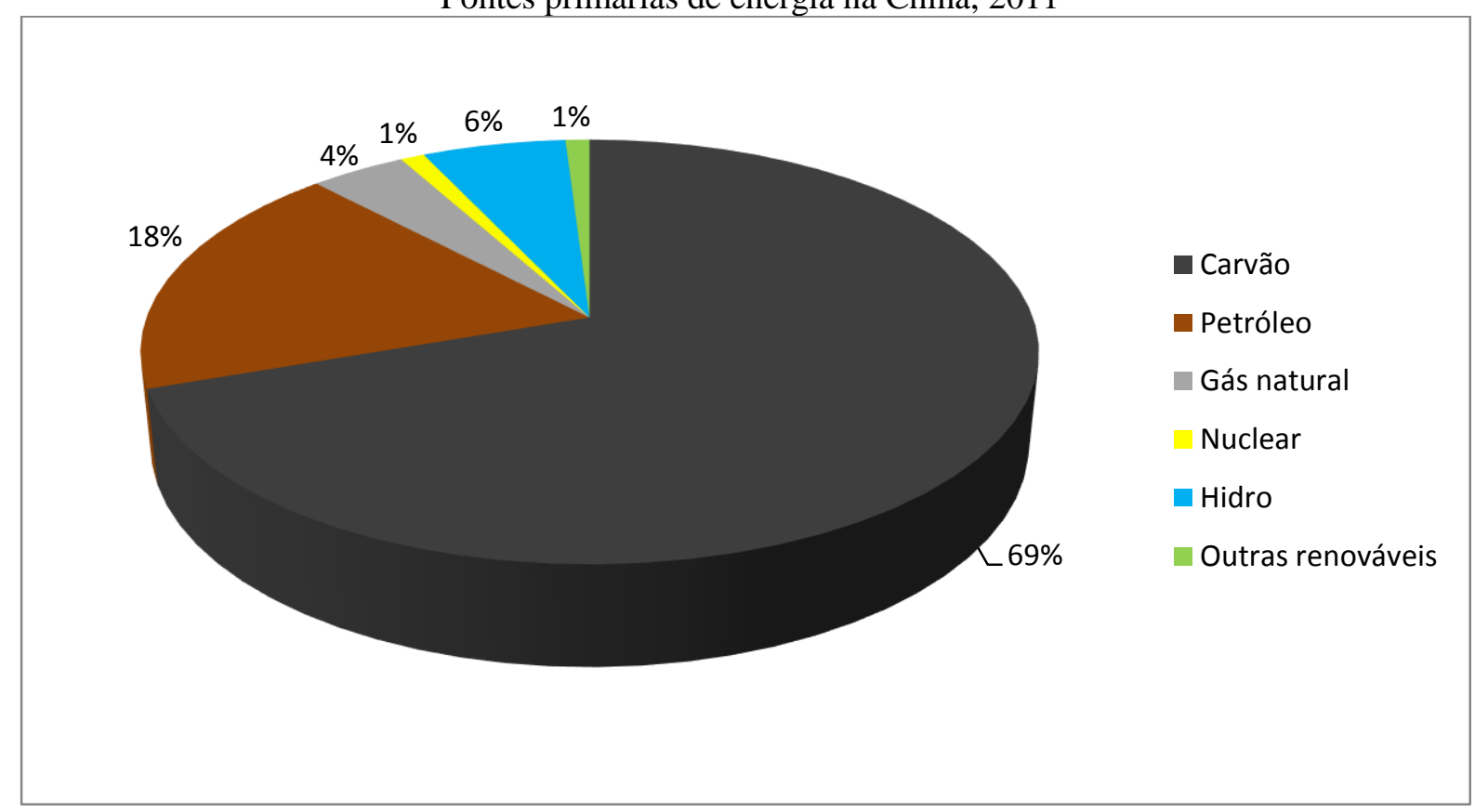

Fonte: EIA/EUA, 2013c. 
A situação muda quando se trata de combustíveis para transporte. Nesse caso, além do problema ambiental, há também uma questão geopolítica. A China dispõe de uma produção relevante de petróleo, mas o incremento acelerado do consumo doméstico tornou o país o segundo maior importador mundial, como indicado no Gráfico 16, e com demanda crescente.

No caso do óleo, a China não produz o suficiente para seu consumo crescente. Dados da EIA/EUA mostram a elevação paulatina da diferença entre produção e consumo, resultando em importação crescente (Gráfico 16). Em 2011, pela primeira vez, mais da metade do óleo consumido na China proveio do exterior. A EIA/EUA projeta que, em 2035, 75\% da demanda por óleo na China terá que ser suprida por meio de importações, dada a elevação esperada da demanda e a limitação para ampliar a oferta doméstica (EIA, 2013c).

\section{GRÁFICO 16}

Consumo e importação de petróleo na China, 1990-2013

(milhares de barris por dia)

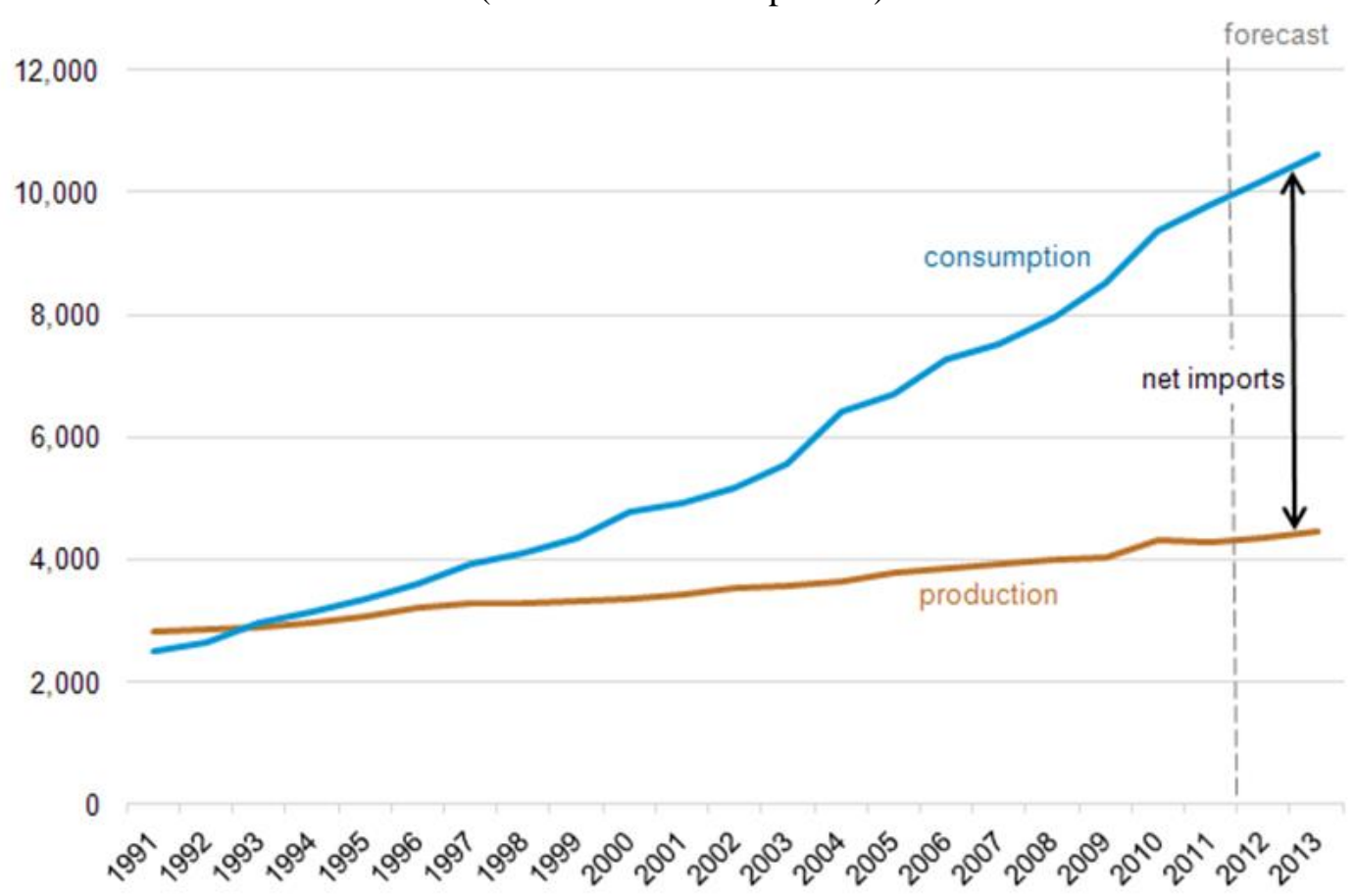

Fonte: EIA/EUA, 2013c.

Esse cenário de dependência de importação de petróleo tem provocado particular preocupação na China, porque contrasta com a crescente segurança energética dos Estados Unidos. No momento em que a China ascendeu à segunda maior economia do planeta e mantém um ritmo de crescimento que pode transformar seu PIB no maior do mundo em uma 
ou duas décadas ${ }^{18}$, a comparação com a situação dos Estados Unidos se torna inevitável. Em contraste com a crescente dependência chinesa, os EUA podem estar em vias de se tornar autossuficientes em hidrocarbonetos. Esse movimento estadunidense rumo a uma maior autonomia energética se deve principalmente ao aumento acelerado da produção doméstica de combustíveis fósseis, especialmente do gás do xisto obtido a partir de novas técnicas de exploração, como a fratura hidráulica e a perfuração horizontal.

Tudo isso tem forçado o regime chinês a rever a matriz energética e conferir maior relevância à geração a partir de outras fontes. No caso da eletricidade, o país embarcou em um programa para ampliar velozmente a produção de energia nuclear e, para tanto, está construindo mais de duas dezenas de reatores nucleares de última geração simultaneamente. Além disso, como se verá em mais detalhes nos próximos capítulos, o país vem estimulando fortemente o desenvolvimento de tecnologias para geração solar, eólica e, em menor escala, biomassa.

No caso da biomassa, embora haja algum esforço para desenvolver em pequena escala tecnologias para geração de energia a partir dessa fonte, essas práticas não foram disseminadas em razão do receio de provocar insegurança alimentar. Dada a imensa população chinesa, eventual competição por terra entre biocombustíveis e alimentos poderia trazer impactos locais relevantes.

Vale notar que a preocupação com a mudança climática não se deve apenas a eventuais pressões externas, mas também à percepção dos principais atores políticos do governo de que a China é um dos países de porte mais vulneráveis às mudanças climáticas. Essa percepção se ampliou na segunda metade da década de 2000, quando o país lançou seu plano nacional de mudança climática (VIOLA, 2011b). Impactos significativos sobre o clima local tenderiam a provocar maior instabilidade política, o que reforça a necessidade de mitigar o aquecimento global e diminuir a completa dependência de energia intensiva em carbono.

Vale ainda observar que a China, diferentemente do Brasil, não dispõe de outros meios para reduzir as emissões a não ser modificando sua matriz energética, que concentra a maior parte das emissões locais. Para enfrentar a questão, portanto, a China não pode se limitar a tratar da questão do desmatamento ou da agricultura. Alterar a produção energética é decisivo.

Em suma, há um quadro de insegurança energética relevante (contrastando com a situação dos EUA) e de impossibilidade de exaurir o carvão local por conta do risco de

\footnotetext{
18 O PIB chinês superou o PIB dos EUA em 2014 ou 2015 quando calculado em paridade do poder de compra. Mas, em se calculando pelo valor de mercado, o PIB dos EUA ainda fica à frente, com cerca de US\$ 17 trilhões em 2013, contra cerca de US\$ 9 trilhões do país asiático no mesmo ano (dados do FMI).
} 
agravar o quadro de mudança climática e mesmo da instabilidade doméstica provocada pela poluição.

\section{3. É real o receio de restrições decorrentes do regime de mudança climática?}

\subsubsection{Direito Internacional e os limites para a aplicação de sanções}

O lançamento de gases de efeito estufa no planeta Terra traz relevantes repercussões para a governança desse espaço público global, que é a atmosfera. Um dos desafios centrais para o enfrentamento da mudança climática é que, diferentemente de formas tradicionais de poluição, cujos impactos se restringem ao nível local, os gases estufa afetam o clima global qualquer que tenha sido o local em que foi produzido.

Noções tradicionais de responsabilidade civil, com base na qual se organizou inicialmente o Direito Ambiental (DOREMUS, 2008), são de difícil aplicação no caso da mudança climática. Afinal, como imputar a responsabilidade de uma usina térmica a carvão na China pela mudança climática que se está verificando no sertão nordestino do Brasil? Qual o direito aplicável ao caso? Como estabelecer o nexo de causalidade entre a queima do hidrocarboneto e a mudança especificamente observada em certo local?

A utilização, portanto, do Direito Civil tradicional não atende às necessidades de mitigar o problema e impor sanções aos que exercem atividades poluentes - de resto, toda a humanidade incorre em algum grau na conduta. Normas de Direito Internacional - ou assemelhadas - se impõem para regular o problema. Daí a elaboração da Convenção Quadro das Nações Unidas sobre a Mudança do Clima e os sucessivos esforços para estabelecer protocolos vinculantes e abrangentes.

Surge, então, a questão da sanção no Direito Internacional. O fato de não haver uma entidade detentora de monopólio do uso legítimo da força legítima no campo internacional provoca dificuldades de várias ordens para assegurar a eficácia de suas eventuais prescrições. Some-se ainda que, no caso das mudanças climáticas, nem mesmo existe um acordo vinculante com direitos e obrigações detalhadamente estabelecidos. Como já se viu no Capítulo 2, há uma Convenção que estabelece as normas gerais para o regime de mudança climática, mas não foram estabelecidos em minúcia os deveres a cargo de cada país. 
Pode-se arguir, ceticamente, que qualquer nação está autorizada a deixar de seguir a Convenção Quadro das Nações Unidas sobre Mudança do Clima. Mesmo os países signatários do Protocolo de Quioto e integrantes de seu Anexo 1 puderam desvencilhar-se de suas obrigações ao deixar de ratificá-lo ou mesmo denunciá-lo. Uma leitura dessa natureza poderia concluir - equivocadamente, a nosso sentir - que não são eficazes as normas do Direito Internacional, em geral, e do regime internacional de mudança do clima, em particular. Nessa linha, não faria sentido que os países levassem em conta a necessidade de redução das emissões para suas estratégias de desenvolvimento de longo prazo.

Ocorre que, muito embora as sanções do Direito Internacional sejam, no mais das vezes, mais limitadas do que as punições do Direito Interno, há casos em que os regimes internacionais assumem um grau vinculante esmagador. É o caso, por exemplo, do regime internacional de armas nucleares (Tratado de Não-Proliferação de Armas Nucleares), um acordo vinculante forte, aplicado inclusive com o uso ou a ameaça de uso da força - mesmo que aplicada com alto grau de discricionariedade. Ou ainda o regime internacional de comércio (sintetizado no sistema da Organização Mundial do Comércio), de caráter bastante vinculante, ainda que sua efetividade não seja assegurada por meio do uso da violência legítima, mas do risco de perdas econômicas substanciais aplicáveis pelo chamado "soft law", ou quase-direito.

As sanções existentes no Direito Internacional variam enormemente conforme a relevância do bem jurídico atribuída pelos atores centrais. Mas é razoavelmente consensual que o contencioso internacional é ainda hoje um contencioso de compensação, e não um contencioso punitivo (REZEK, 2000). Nem sempre as compensações são pecuniárias, mas a lista de possibilidade engloba de um desagravo público e um pedido formal de desculpas, passando pela restauração do statu quo ante ou ainda pela indenização em dinheiro.

O sistema da OMC criou novas possibilidades de compensação comercial, abrangendo o licenciamento compulsório de patentes, a elevação de alíquotas aduaneiras de certos produtos e outras medidas de cunho comercial. Mesmo que nem sempre aplicadas concretamente, como o demonstra o caso do algodão entre o Brasil e os Estados Unidos, a possibilidade de, com respaldo da ordem jurídica internacional, retaliar o país infrator e punir segmentos de sua economia têm possibilitado a busca por soluções negociadas para superar as irregularidades verificadas. Mesmo que o mecanismo não caracterize uma sanção à moda tradicional do Direito Interno, essas medidas têm apresentado relevante efeito dissuasório.

No campo das mudanças climáticas, as sanções previstas no âmbito do Protocolo de Quioto são bastante limitadas, consistentes fundamentalmente na majoração da meta de redução do país para o período subsequente. Como o Protocolo se insere numa 
convenção relativamente fraca, a punição não é suficiente para determinar os rumos das ações domésticas dos países signatários - inclusive porque não são relevantes as sanções em caso de denúncia do tratado internacional.

Ocorre que, como indicamos no Capítulo 2, cresce a percepção de segmentos importantes da sociedade civil de vários atores centrais a respeito dos riscos da mudança climática. À medida que se robustecem as evidências científicas da ação antrópica no aquecimento global, avoluma-se a pressão para que governos - nacionais e subnacionais - e entidades privadas adotem medidas para o enfrentamento do problema.

Como já se apontou, mesmo que improvável a aprovação no curto prazo de um acordo climático abrangente e de caráter forte, estão sendo adotadas medidas no campo subnacional e no campo privado que tendem a criar um regime internacional de não consolidado num tratado, mas com natureza vinculante forte. Esboçam-se medidas em várias áreas, já apontadas no Capítulo 2, em nível municipal, estadual ou mesmo nacional. Não se trata propriamente de um regime internacional típico, inscrito num tratado vinculante, mas sim de um regime internacional caracterizado pela existência de normas difusas mas crescentemente mandatórias.

Afinal, no caso particular das mudanças climáticas, afora os esforços estatais, há iniciativas muito importantes em outros níveis que também criam normas de caráter quase obrigatório para outros atores. É o caso das iniciativas do setor privado, criando cadeias produtivas de baixo carbono que afetam um número crescente de pessoas e de empresas.

\subsubsection{Articulações do setor privado para reduzir emissões}

Um tanto à margem das ações dos governos para limitar a emissão de gases estufa na economia, várias iniciativas do setor privado estão sendo lançadas e implantadas em larga escala. Muito embora parte das iniciativas possa ser claramente caracterizada como ações de marketing empresarial, e não de efetiva sustentabilidade, há uma parcela significativa e crescente de ações relevantes e com efeitos concretos sobre o mercado no curto e médio prazos.

De fato, várias das grandes multinacionais adotaram práticas anunciadas como "verdes" ou "sustentáveis". Ainda que nesse grupo se incluam as que adotaram programas efetivos e alguns de cunho mais propagandístico, o fato é que nesse grupo estão inseridas multinacionais do porte da Coca-Cola, Nestlé, Procter\&Gamble, Unilever, Walmart, McDonald's, Nike, IBM, Google, Siemens ou General Electric (ABRAMOVAY, 2013). Ainda que nem todas as ações resultem em efeitos concretos relevantes para a melhoria do meio- 
ambiente, o compromisso público de empresas desse porte dificilmente passaria despercebido - e não seria denunciado por concorrentes e grupos de defesa do consumidor - se não houvesse algum grau de concretização das medidas.

Vale a pena observar o poder de influência enorme que essas empresas têm no mercado no mundial. Para ficar num exemplo, se grandes redes varejistas deixam de comprar produtos de áreas desmatadas ilegalmente, ou se recusam a adquirir itens sem um nível de eficiência energética por elas determinado, o impacto da medida sobre os fornecedores é dramático - eventualmente até mais rigoroso do que o de boa parte das ações tomadas pelo poder público nos últimos anos, premidos que ficam os governos pelos receios de impacto econômico adverso de cada restrição imposta. Ora, se as empresas já restringem a compra de produtos originados de áreas onde pode ter ocorrido desmatamento, por que não poderiam restringir a compra de produtos para cuja produção foi utilizada uma fonte energética muito poluente?

Há uma tendência crescente a que práticas dessa natureza sejam adotadas por grandes conglomerados econômicos, fixando limitações e vedações sem escrutínio público claro e de duvidosa legalidade sob a ótica do livre comércio internacional. De fato, crescentemente a OMC tem se debruçado sobre o tema para avaliar a legitimidade, sob a ótica internacional, de medidas de restrição dessa natureza, eis que podem embutir um elemento de protecionismo de mercado travestido de ações privadas.

Sem dúvida, à vista do avanço paulatino - porém crescente - dessas restrições implantadas no âmbito privado, reforça-se a ideia de que está em curso a formação de um regime internacional que tende a limitar as emissões de carbono pelos países. Nesse contexto, reforça-se a necessidade de adaptar as economias a um cenário assim restritivo, especialmente nos casos de países que fazem uso de matriz energética muito poluente, mesmo que as restrições por vezes se originem de instituições privadas, e não estatais.

Tal como mencionado anteriormente, esse cenário permite contrastar a situação brasileira com a dos países asiáticos selecionados. Eventual restrição ao uso de energia fóssil dificilmente afetaria o Brasil de maneira significativa, dada a matriz energética comparativamente mais limpa do país. Já a China, a Coreia e Taiwan podem a vir a sofrer restrições ao comércio - ainda que consideradas ilegítimas num momento inicial - em razão do uso intensivo de fontes energéticas altamente poluidoras, particularmente carvão e petróleo.

Essa diferença de cenários robustece o sentimento de urgência desses países asiáticos em promover uma transição para uma matriz menos dependente de fontes emissoras. O Brasil, por seu turno, passa ao largo dessas preocupações, ao menos no que tange às fontes 
de energia - a preocupação, conquanto bastante reduzida, persiste apenas no que tange ao desmatamento e à exportação de produtos de origem agrícola, como o etanol.

Em resumo, a matriz energética limpa, a disponibilidade de recursos naturais renováveis e a elevada participação do desmatamento nas emissões de gases estufa no Brasil permitem que a economia continue a crescer e a usar mais energia sem emissões adicionais de carbono, desde que mantida a política - relativamente mais simples - de redução das taxas de desmatamento e promovido uso mais racional dos fertilizantes nitrogenados na agricultura. Nos demais países, a redução das emissões no setor de energia é medida que se impõe para evitar uma tragédia ambiental e fugir de prováveis restrições internacionais ao uso intensivo de carbono.

\subsection{Os desafios associados às novas renováveis}

A expansão das denominadas "novas renováveis", notadamente eólica e solar, não traz consigo apenas o desafio de baratear o custo da geração de energia. A geração a partir de eólica e solar traz grandes desafios para o gerenciamento do sistema elétrico e também para o próprio impacto ambiental.

No que tange ao gerenciamento do sistema elétrico, o maior desafio posto pelas novas renováveis está relacionado à intermitência da geração. Como o sistema elétrico exige que a demanda de energia esteja casada com o fornecimento em tempo real, tão importante quanto a capacidade de geração total de certa fonte é a capacidade de geração em tempo real. Noutra palavras, se aumentar a demanda por energia em certo horário do dia, é preciso que o fornecimento se amplie de imediato.

No entanto, não é possível estocar vento ou radiação solar para uso no horário de maior demanda, diferentemente do que ocorre com as fontes fósseis ou mesmo com a geração hidráulica (estocável em barragens). As fontes tradicionais são “despacháveis”, isto é, podem ser produzidas no momento em que o sistema exigir, diferentemente das novas renováveis que são intermitentes.

Para ilustrar essa dificuldade, é válido trazer à tona o gráfico do consumo médio de energia na Califórnia ao longo das 24h de um dia, exposto no Gráfico 17. 


\section{GRÁFICO 17}

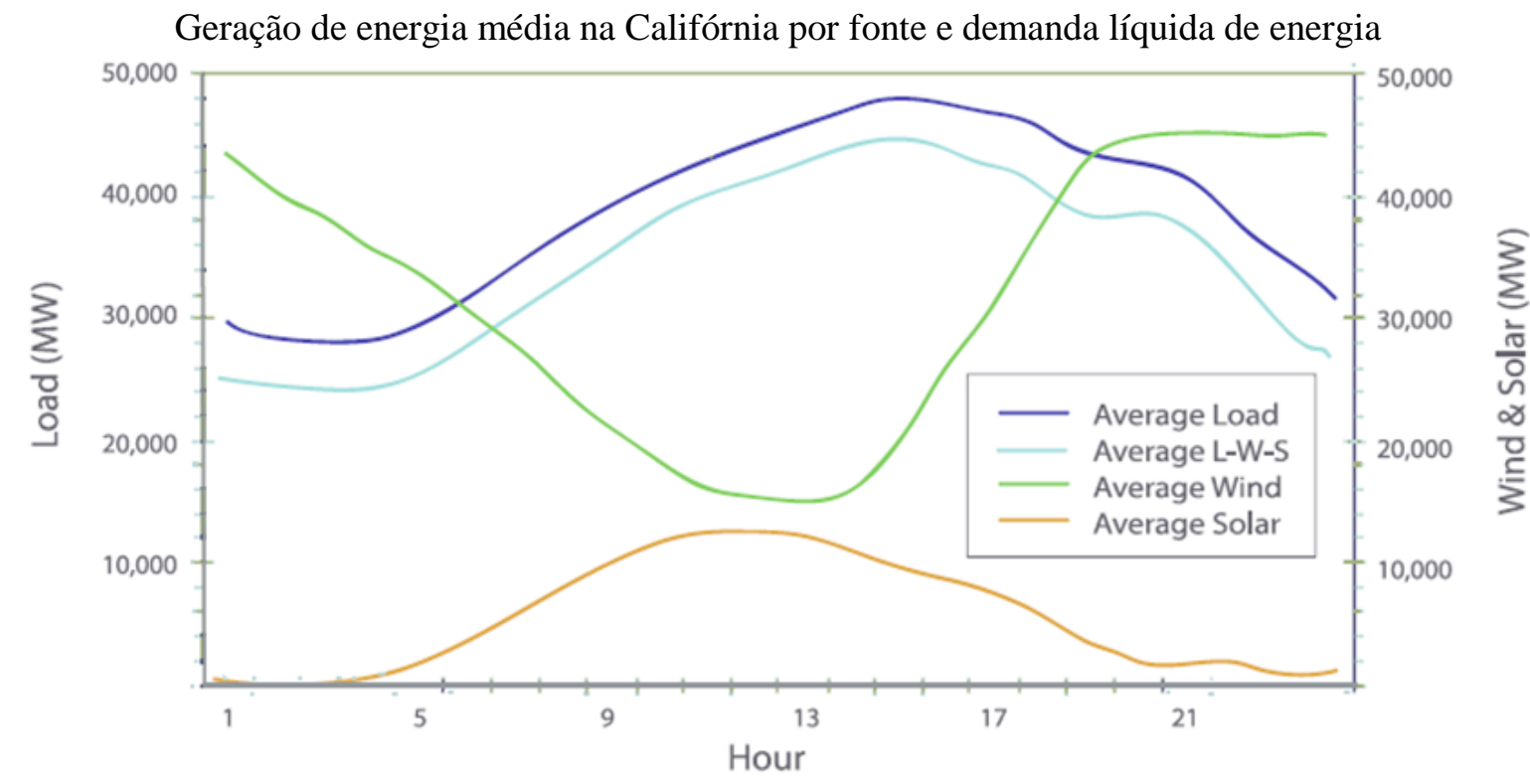

A linha roxa desse gráfico, com variações de país a país, representa razoavelmente a demanda por energia em várias sociedades: é usualmente mais baixa durante a madrugada, eleva-se durante o dia até atingir o pico em fins da tarde ou início da noite e depois se reduz novamente. Claro que há variações conforme haja maior ou menor presença de indústrias na região, conforme a estação do ano (uso de ar condicionado ou aquecedores), conforme se trate de feriados ou dias úteis, etc.

Para que o sistema funcione adequadamente, é preciso que o fornecimento de energia acompanhe essa demanda em tempo real, em geral com uma pequena margem acima, para eventuais quedas imprevistas de alguma usina geradora ou aumento inesperado da demanda. Utilizando novamente informações da Califórnia, é preciso observar a oferta média de energia eólica e solar ao longo de um dia está ilustrada nas linhas verde (média eólica) e laranja (média solar).

À primeira vista, o Gráfico 17 sugere que, somadas, a eólica e a solar acompanham de maneira próxima a demanda de energia indicada na linha roxa. Entretanto, em primeiro lugar, há na verdade um período de desencaixe entre a demanda e a oferta, que é o fim da tarde e o início da noite. Nesse momento, o sol já está se pondo (e com a ele a geração de eletricidade) e os ventos ainda não se elevaram. É justamente esse o período da demanda de pico. Seria necessário ter uma grande capacidade instalada, que ficaria em larga medida ociosa durante o dia, e seria acionada apenas no horário de pico. Essa estrutura torna muito caro o funcionamento do sistema. 
Para tornar a situação ainda mais complexa, é preciso levar em conta que o Gráfico 17 aponta a média anual da radiação solar e da intensidade dos ventos, mas a média, como se sabe, esconde uma variação enorme em cada dia. Utilizando-se, por exemplo, os dados referentes à geração solar e eólica em um dia escolhido a esmo na Califórnia em um local específico (Gráfico 18 e Gráfico 19), vê-se que a geração individualizada de cada aparelho é bem mais distante da média anual indicada no Gráfico 17.

\section{GRÁFICO 18}

Geração solar e eólica na Califórnia em 19 de fevereiro de 2013

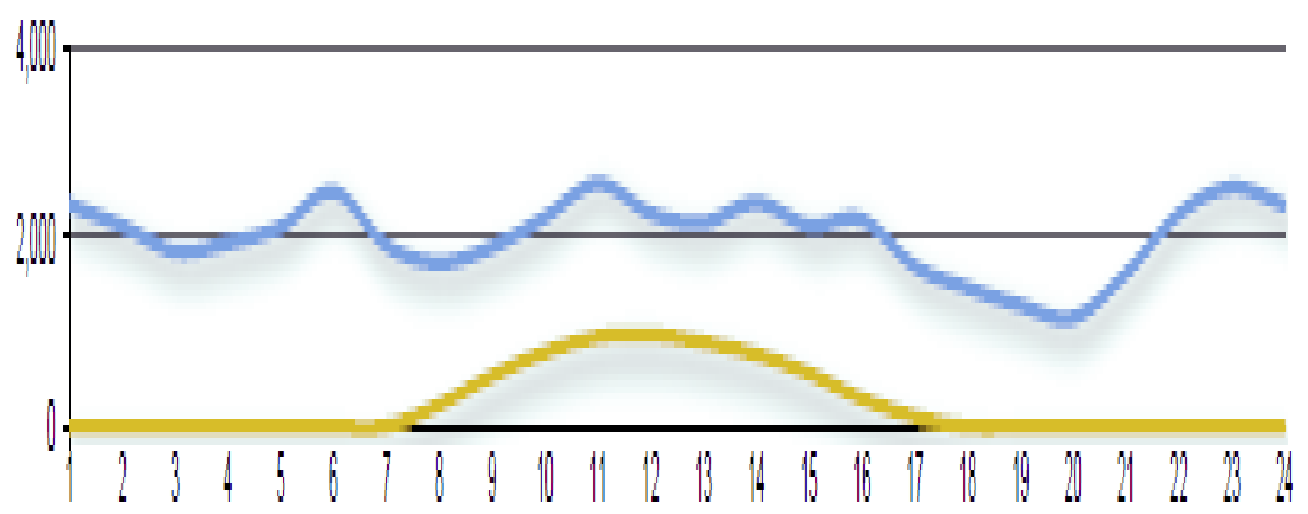

GRÁFICO 19

Geração solar fotovoltaica em unidade geradora da Califórnia 19 de fevereiro de 2013

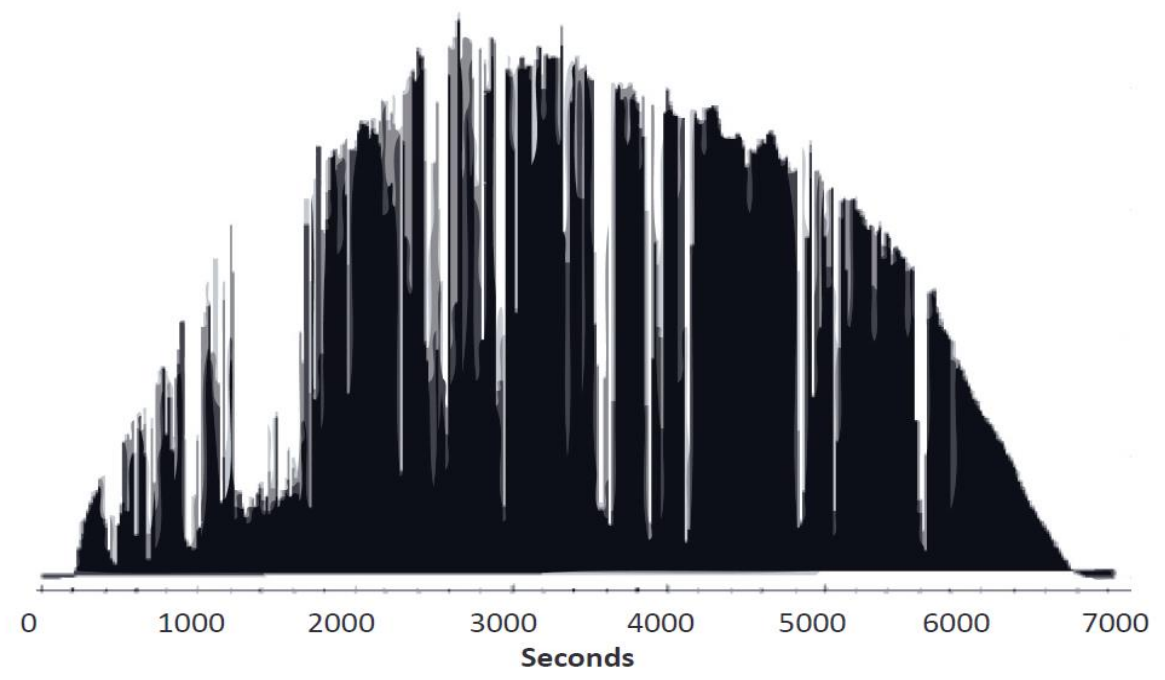

Conquanto a geração solar trace no gráfico um "v" invertido, na prática as interferências são enormes e provocam enorme variação da geração ao longo do dia. No caso dos ventos, a média aponta uma geração elevada à noite, mas a variação em cada dia é extremamente significativa, provocando grande dificuldade de previsão da oferta de energia. 
Nesse contexto, o aprimoramento dos instrumentos e dos métodos de previsão de tempo torna-se essencial para que o sistema possa ser manejado adequadamente. Sem uma previsão mais acurada, gerenciar o sistema passa a ser tarefa extremamente difícil, com altíssimo nível de instabilidade da oferta, o que põe em risco a confiabilidade de toda a rede elétrica.

Por outro lado, aponta-se que a expansão da geração eólica e solar em vários lugares mitigaria o problema da imprevisibilidade por meio da diversificação geográfica e de fontes. No caso da geográfica, eventual redução dos ventos e maior cobertura de nuvem em um local seria quase fatalmente compensada com ventos mais fortes e radiação solar mais intensa em outra região. Além disso, a diversificação das fontes permitiria que as demais usinas compensassem eventuais baixas momentâneas nas novas renováveis. Mas há ainda uma enorme incerteza quanto à redução dos riscos que a mera diversificação provocaria.

Há, portanto, grande necessidade de dispor de usinas que sirvam como "back $u p$ ", isto é, que possam entrar em funcionamento imediatamente em caso de a oferta de energia solar ou eólica não atender à previsão. As usinas nucleares e de carvão não são usualmente adequadas para esse papel, eis que seu funcionamento eficiente e seguro demanda que elas atuem praticamente a todo vapor, utilizando ao máximo da capacidade instalada em todo o tempo. As usinas de térmicas (especialmente gás natural) e as hidrelétricas são mais adequadas para esse tipo de funcionamento, eis que, em geral, podem elevar abruptamente a geração de energia em relativamente pouco tempo.

No caso do Brasil, o uso de hidroeletricidade em larga escala é um fator positivo, que tende a tornar menos preocupante essa transição. Em outros países, isso provoca um desafio enorme e encarece a inclusão dessas fontes da rede elétrica, já que, na prática, elas demandam a construção concomitante de usinas para back up.

Vale notar que esses problemas são particularmente relevantes para as usinas eólicas e solar fotovoltaica, não afetando tanto as usinas solares que concentram calor, porque estas podem armazenar a energia térmica por período prolongado e "despachar" energia nos momentos em que houver necessidade.

Para construir ou operar usinas apenas no período de pico da demanda, o custo dessa geração é desproporcionalmente elevado, já que se construirá toda a estrutura das usinas, mas elas operarão apenas em momentos específicos e limitados. O amortecimento desse investimento se dilui e encarece bastante o preço da energia para esses momentos de pico.

Essa situação provocada pela intermitência tem chamado atenção para a necessidade de desenvolver maneiras eficientes de estocar a energia delas oriunda. Do 
contrário, à medida que a penetração das novas renováveis na matriz se eleva, aumentam-se os riscos de gerenciamento do sistema. Conquanto a armazenagem também traga custos adicionais, ela permitiria maior segurança ao sistema e menor dependência de combustíveis fósseis para exercer o papel de back up.

Há inúmeras formas de armazenamento de energia, destacando-se, entre as de possível uso em grande escala, o bombeamento de água para a parte superior das represas (energia potencial), as baterias e as células de combustíveis (energia química) e as rodas voadoras ou flywheel (energia cinética). Essas e outras tecnologias de armazenamento ainda têm custos elevados, que seriam acrescidos aos próprios custos de geração das fontes renováveis, tornando ainda mais cara a transição para uma matriz de baixo carbono (CPUC, 2012).

O relevante é observar que o uso crescente de eólica ou solar demandará um uso progressivo desses métodos de estocagem de energia. Isso, por sua vez, impõe também repensar o modelo elétrico, já que o desenho atual não esclarece quem arcaria com os custos de construir essas estruturas de grande escala. No caso da Califórnia, em que a participação das renováveis vem crescendo nos últimos anos, está em análise a proposta que estipula o dever das concessionárias de energia de dispor de capacidade de armazenamento proporcional à energia que elas fornecem. Nesse caso, o custo seria arcado pelos consumidores, rateando-se o ônus por todas as fontes de geração de energia, e não apenas sobre as novas renováveis.

Em paralelo a esse processo, o setor de transportes também passa por um processo de eletrificação. Já existem hoje cerca de 90 modelos de carros híbridos ou elétricos à disposição no mercado, entre os quais o Nissan Leaf, o Toyota Prius, o Chevrolet Volt e mesmo carros luxuosos, como o Tesla Roadster. Há uma aposta crescente de que o setor de transporte passará a ser, ao menos em parte, baseado em eletricidade.

Uma ideia que tem ganhado adeptos, a despeito da complexidade, é utilizar as baterias desses carros como back up do sistema. Segundo esse modelo, quando esses carros já estivessem abastecidos, mas ainda conectados à rede, a concessionária de energia poderia eventualmente utilizar a energia lá armazenada para fazer frente à demanda de energia, pagando ao proprietário do veículo pelo uso da bateria. Se de fato a eletrificação atingir uma parcela significativa dos veículos, a utilização das baterias dos automóveis evitaria a construção desnecessária de usinas de back up com combustíveis fósseis ou mesmo a construção de grandes estruturas de armazenamento de energia em larga escala. É o que se chama de colheita da energia da bateria de veículos elétricos (ELKIND, 2014). 
Ocorre que, para que um sistema dessa natureza funcione, é preciso rever boa parte do desenho do modelo elétrico e de várias das estruturas que o mantêm. Os medidores de energia das casas, por exemplo, teriam que ser necessariamente substituídos pelos medidores bidirecionais, isto é, os que mediriam o fluxo de eletricidade não apenas da distribuidora para as residências, mas também da residência para o sistema elétrico. Os medidores bidirecionais, aliás, são parte essencial para o funcionamento da geração distribuída, como aquela originada a partir da instalação de paineis solares em residências e indústrias, que confeririam créditos para os usuários conforme a geração elétrica de suas residências fosse utilizada para abastecer o sistema.

Outra política possível é a utilização de respostas à demanda (demand response), medida pela qual seria possível exercer certas restrições à demanda por energia, especialmente em certos horários. Seria possível, por exemplo, suspender linhas de produção industrial em certos horários e até mesmo permitir à concessionária que controle, com a anuência do usuário, certos aparelhos elétricos em uso. Por exemplo, no caso de pico de demanda, a concessionária poderia elevar a temperatura do termostato do ar condicionado de $20^{\circ} \mathrm{C}$ para $22{ }^{\circ} \mathrm{C}$, reduzindo temporariamente a demanda por energia sem grande prejuízo ao conforto do usuário.

No entanto, para viabilizar medidas dessa natureza seria necessária a implantação de uma verdadeira rede inteligente (smart grid). Há certa controvérsia sobre o exato conceito de rede inteligente, mas linhas gerais se aponta para a integração de sistemas eletrônicos com a rede elétrica, o que permitiria monitorar o funcionamento do sistema com mais precisão e nele intervir quando necessário. Novamente, trata-se de mudança em larga escala no sistema elétrico, já que demandaria a troca de vários aparelhos existentes, mudança na estrutura das tarifas do setor, admissão de créditos aos consumidores, etc.

Some-se ainda uma discussão que se abriria a respeito da privacidade dos usuários e de seus dados, já que as redes inteligentes hoje existentes permitem acessar com detalhes, para cada usuário, os horários de utilização de seus aparelhos, inclusive diferenciando quais aparelhos estão em uso e até mesmo, para ficar num exemplo, a que canais de televisão o usuário assiste.

Além das dificuldades de emparelhar a demanda e a oferta, há outros desafios técnicos associados à integração crescente dessas fontes à rede, entre os quais as dificuldades para que o abastecimento do sistema se dê na mesma frequência. Devido à variação intensa na capacidade de geração das novas renováveis, prover o sistema com eletricidade sob a mesma frequência do restante do sistema se torna crescentemente difícil. 
Ademais, o modelo tradicional de energia elétrica está assentado na geração de eletricidade em larga escala em locais distantes dos centros urbanos, seguida de transmissão e distribuição para os consumidores. Esse modelo se torna mais complexo à medida que a geração distribuída (mini ou microgeração em unidades consumidoras) passa a ter papel crescente no sistema. A estrutura do sistema foi desenhada para fluir em um sentido e, de repente, vê-se desafiada a, eventualmente, correr também no sistema inverso, pondo em risco aparelhos mais antigos da estrutura de distribuição e de transmissão.

Somem-se ainda os riscos de choques elétricos pelos trabalhadores das empresas elétricas que fazem a manutenção do sistema, já que, em casos de queda de energia a partir da geração concentrada, existe o perigo de que a geração distribuída não seja interrompida, mantendo os fios elétricos da distribuição ainda carregados de eletricidade.

Por fim, é preciso fazer alusão à eventual retomada em larga escala da corrente contínua, em substituição à corrente alternada, hoje predominante. Essa "guerra das correntes" teve enorme importância no início da expansão das redes elétricas, em fins do século XIX, sintetizada na disputa entre as tecnologias defendidas de um lado por Thomas Edison, da GE (corrente contínua), e de outro lado Nicolas Tesla, da Westinghouse (corrente alternada). Afinal vencida a batalha em favor da corrente alternada, praticamente todo o sistema elétrico mundial foi desenvolvido com base nesse modelo de transmissão de eletricidade, principalmente pelas menores perdas em transmissões de longa distância.

Ocorre que, mais recentemente, o uso crescente de aparelhos eletrônicos que funcionam sob corrente contínua tem reduzido a necessidade da corrente alternada, ao que se soma o fato de que a geração solar fotovoltaica é originalmente contínua. Embora seja possível converter um tipo de corrente em outra, por meio de um conversor, esse processo não é inteiramente eficiente e provoca perdas, além de encarecer a geração por exigir um equipamento adicional. Some-se ainda que a geração distribuída torna desnecessária a transmissão de energia em longas distâncias, fazendo ruir a principal vantagem da corrente alternada. No entanto, praticamente todo o sistema elétrico atual foi edificado sob a corrente alternada, erguendo uma barreira enorme à mudança do sistema.

Em síntese, todo o manuseio do sistema elétrico está em jogo, eis que o crescente papel trazido pelas novas renováveis está provocando uma ampla revisão do modelo elétrico. Esse modelo, desenhado em fins do século XIX e início do século XX, já não mais dá conta da complexidade das demandas sociais por eletricidade em face das limitações ambientais decorrentes da mudança climática. 
A Europa, em especial a Alemanha, largou na frente nos esforços bastante ousados para ampliar a participação das novas renováveis em sua matriz energética. Muito embora os europeus tenham até o momento conseguido preservar a confiabilidade do sistema, problemas crescentes para seu manuseio têm sido observados. A imprevisibilidade própria da geração com as novas renováveis têm trazido flutuações inesperadas no sistema, dificultando seu manuseio e provocando riscos de instabilidade e perda de confiabilidade.

$\mathrm{Na}$ Europa, em alguns momentos, a geração crescente de energia por meio de fontes renováveis tem provocado preços negativos para o fornecimento de energia por outras fontes, como a nuclear e o carvão, que demandam uso a pleno vapor por quase todo o tempo. Assim, em momento de baixa demanda por energia e excesso de fornecimento pelas novas renováveis, que têm prioridade no sistema, prejuízos volumosos têm se acumulado para os geradores de energia de base, que se veem obrigados a pagar (e não a receber) pela energia que fornecem nos horários de excesso de oferta (THE ECONOMIST, 2013).

No caso da Califórnia, que também adotou políticas para ampliar a participação das novas renováveis, o sistema também logrou preservar a confiabilidade do sistema, mas os medidores bidirecionais e o smart grid foram implantado na maior parte do Estado, parcela relevante da energia é importada de Estados vizinhos e, ainda assim, o custo da eletricidade no Estado é o mais alto dos 48 Estados contínuos do país: US\$ 0,1598 por kWh, contra a média nacional de US\$ 0,1071 por kWh, segundo dados de julho de 2013 (EIA, 2013).

Não bastasse a rediscussão de todo o modelo elétrico, as novas renováveis também têm trazido preocupações relacionadas ao seu impacto ambiental. Muito embora ainda sejam em geral menos emissoras de gases estufa, há diversas questões ambientais provocadas por sua penetração crescente na matriz elétrica.

No caso da energia eólica, são três os principais impactos:

1) Mortalidade de pássaros e morcegos;

2) Barulho provocado pelas unidades geradoras; e

3) Impacto estético em áreas naturais.

A depender da tecnologia utilizada, o impacto sobre pássaros e morcegos pode ser maior ou menor. De todo maneira, é inegável que várias aves têm sido afetadas pela instalação de parques eólicos. Segundo estimativas, anualmente são cerca de 33 mil aves que morrem ao esbarrarem com as pás das unidades geradoras eólicas, além de 4,3 morcegos por turbina. No caso dos morcegos, percebeu-se que a mortalidade se deve não tanto ao choque direto, mas ao grande impacto que as pás provocam na pressão do ar em volta das torres, acarretando a destruição dos pequenos pulmões desses mamíferos (MENSING, 2012). 
No caso do barulho provocado pela passagem das pás junto às torres, além de distúrbios e estresse para os animais silvestres que vivem na região, há também impacto para os seres humanos. Muito embora o barulho seja considerado baixo em termos de decibéis, esse fator tem mobilizado comunidades a resistir à instalação de torres próximas às suas residências por queixa quanto à perturbação de seu sossego.

Por fim, há ainda o impacto estético que as torres provocam, ao modificar a beleza natural das regiões em que instaladas. Nesse caso, a resistência das comunidades diretamente afetadas tem provocado dificuldades crescentes para o licenciamento.

Esses três problemas são particularmente relevantes no caso das eólicas, porque, não raro, os locais com melhor intensidade de vento são justamente áreas de migração de pássaros, parques nacionais, regiões à beira mar de utilização turística. Para tornar a situação mais difícil, frequentemente a construção de linhas de transmissão é também um desafio justamente por se localizarem nesses locais, eis que demandariam passar em áreas ambientalmente protegidas e por se localizarem muitas vezes distantes dos centros consumidores.

Por fim, a geração eólica necessita de grandes áreas para produzir uma quantidade de energia relativamente pequena, quando comparada às fontes tradicionais. Por exemplo, numa conta aproximada, para dispor da capacidade de $1 \mathrm{GW}$, equivalente a uma usina nuclear de médio porte, seriam necessárias 500 torres de 2MW, das mais utilizadas atualmente, cada uma com cerca de $120 \mathrm{~m}$ de altura, equivalente a um edifício de 40 andares. Mesmo nesse caso, a geração nuclear produziria mais energia porque o fator de capacidade ${ }^{19}$, no caso dos Estados Unidos, gira em torno de $90 \%$, ao passo que as eólicas têm um fator de capacidade da ordem de $40 \%$. Desse modo, mesmo utilizando uma área extraordinariamente maior, a geração seria substancialmente menor.

Esses fatores têm provocado frequentes disputas entre grupos defensores do meio ambiente: de um lado os que querem a expansão das fontes renováveis e de outro os que defendem a preservação do local por onde passaria a transmissão ou onde se instalaria a geração.

Situação semelhante se verifica com a energia solar fotovoltaica. Problemas de transmissão são frequentes para unidades concentradas, dada a distância para os centros

\footnotetext{
${ }^{19} \mathrm{O}$ fator de capacidade de uma usina de energia é a razão entre produção efetiva de energia durante um período de tempo em comparação com a produção potencial se fosse possível que ela operasse a plena capacidade continuamente durante o mesmo período. Para calcular esse índice, divide-se o total de energia produzida ao longo de um período (em geral um ano) pelo total que poderia ser gerado se ela funcionasse ininterruptamente durante o mesmo tempo.
} 
consumidores e o custo adicional que isso impõe. Também há impactos sobre a fauna e flora das regiões em que são instaladas as plantas, geralmente regiões desérticas ou semidesérticas, que, contrariando a percepção de muitos leigos, contêm bastante biodiversidade. Similarmente à eólica, os paineis solares também geram pouca energia por área ocupada e têm fator de capacidade ainda mais baixo do que a energia oriunda dos ventos.

Apesar de a fonte da energia em si (a radiação solar) ser gratuita e sem impacto ambiental relevante, a produção do material utilizado nos paineis provoca depende da mineração de vários produtos, da utilização de inúmeros reagentes químicos na manufatura, da emissão de gases com grande potencial de efeito estufa e da relativamente pouca durabilidade do produto.

De fato, o painel solar hoje mais utilizado é baseado em silício, que precisa ser extraído pelo processo de mineração que é agressivo ao meio ambiente. Eventual utilização em larga escala de paineis solares exigiria ampliar substancialmente a mineração do silício e de outros produtos necessários à confecção. Durante a manufatura, é preciso utilizar vários produtos químicos para converter os lingotes de silício em celulares solares, além de produzir resíduos extremamente tóxicos, entre os quais tetracloreto de silício, arsênio, chumbo, hidróxido de sódio. Dependendo da tecnologia empregada, alguns desses processos industriais acarretam emissão de gases hexafluoretano $\left(\mathrm{C}_{2} \mathrm{~F}_{6}\right)$, trifluoreto de nitrogênio $\left(\mathrm{NF}_{3}\right)$ e hexafluoreto de enxofre $\left(\mathrm{SF}_{6}\right)$, cujo potencial de efeito estufa é considerado entre 10 mil e 25 mil vezes superior ao do dióxido de carbono (ZEHNER, 2012).

Os paineis solares daí resultantes têm sido vendidos com promessa de funcionamento de 25 anos. Para não entrar no questionamento a respeito da veracidade desse prazo, ainda assim seria necessário encontrar uma maneira de lidar com imensas quantidades de paineis que perderiam uso em relativamente pouco tempo. As usinas tradicionais de energia, incluindo as hidrelétricas e termelétricas, frequentemente operam por períodos bem maiores de tempo, embora a variação seja grande a depender da tecnologia. É preciso, portanto, encontrar uma maneira de tratar os paineis solares, repletos de materiais tóxicos, de modo a torná-los realmente renováveis do ponto de visto do ciclo de vida completo.

Ainda assim, dada a gravidade do problema das mudanças climáticas, a energia eólica e a solar ainda são as principais apostas para a geração de energia no longo prazo, juntamente com a fonte hídrica, a biomassa e a geotérmica. Quando observado todo o ciclo de vida, são elas as que dispõem de menor potencial de emissão de gases estufa, notadamente quando comparadas com as fontes fósseis. 
Ocorre que as fontes hídricas, a biomassa e a geotérmica, só podem ser utilizadas nos locais em que esses recursos estão presentes (rios ou mar, terras aráveis e regiões vulcânicas), o que frequentemente não corresponde à demanda total por energia de cada país, e já passaram pelo momento mais promissor da curva de aprendizado por se tratar de tecnologias maduras.

A nuclear também é uma opção de baixa emissão de carbono, mas enfrenta os problemas relacionados à segurança da operação e aos dejetos nucleares, além do risco de emprego da tecnologia para fins militares. A eólica e a solar estão em alguma medida presentes em todas as regiões e trazem menos preocupações quanto à segurança das operações, mas há enormes diferenças em sua intensidade e regularidade entre os países. Nos últimos anos, têm sido elas as principais responsáveis pelo crescimento da oferta de energia de baixo carbono e vivenciam uma curva de aprendizado tecnológico promissora, com aumento paulatino da eficiência e queda dos custos.

Em síntese, todas as fontes trazem consigo riscos e desvantagens - incluindo as principais promessas de energia de baixo carbono, como a solar e a eólica. Mas existem mecanismos para mitigar esses riscos e avanços tecnológicos possíveis que reduzam as desvantagens que as tecnologias atuais ainda carregam. A transição para o baixo carbono quase fatalmente precisaria ser realizada de modo gradual - ainda que mais rápida do que o ritmo atual -, de modo a viabilizar a superação dos desafios que os estágios atuais das novas fontes ainda acarretam. 


\section{CAPÍTULO 4 \\ APRENDIZADO TECNOLÓGICO EM PAÍSES DE INDUSTRIALIZAÇÃO TARDIA}

"The important thing for Government is not to do things which
individuals are doing already, and to do them a little better or a
little worse; but to do those things which at present are not done
at all."
Keynes, 1926

\subsection{Diferenças entre aprendizado tecnológico passivo e ativo}

Cada país que passou pelo processo de industrialização vivenciou uma experiência singular e inimitável, eis que moldada pela história, pela estrutura econômica anterior, pela posição geográfica e por vários outros fatores. Não obstante, é possível traçar alguns elementos comuns a certos países, diferenciar práticas de outros e avaliar políticas públicas que se revelaram mais ou menos eficazes para certos objetivos.

A comparação entre países mais relevante para a finalidade deste trabalho envolve os países de industrialização tardia. Nessa categoria se incluem as nações que passaram por um processo de industrialização acelerado no século XX, notadamente parte da América Latina (Brasil, Argentina e México, a partir dos anos 1930), parte do leste asiático (Coreia do Sul, Taiwan, Hong Kong e Cingapura, a partir de 1960) e China (a partir de 1980).

O que caracteriza o processo de industrialização tardia é que o estado da técnica das primeiras indústrias dessas nações estava originalmente muito defasado em relação aos países líderes - alguns europeus, os Estados Unidos e o Japão. É verdade que a industrialização nos Estados Unidos ou na Alemanha também pode ser considerada tardia em relação à manufatura inglesa. Mas nesses países o processo transcorreu ainda no século XIX, com distância tecnológica bem menor e noutro contexto internacional.

Por essa razão, restringiremos a análise aos países de industrialização tardia da segunda metade do século XX. Desse grupo, além do Brasil, do grupo latino americano, examinaremos a situação de China, Coreia do Sul e Taiwan, todos do grupo asiático, para explicitar com mais clareza a comparação entre dois modelos de aprendizado tecnológico. A comparação do Brasil com outros latino-americanos não se revela muito útil nesta pesquisa, 
eis que os demais países da região revelam traços de aprendizado semelhantes aos brasileiros, e não as marcas mais nítidas do percurso diferenciado que os asiáticos trilharam.

Como indicado por VIOTTI (1997), os países retardatários no processo de industrialização não criaram, ao menos inicialmente, um sistema nacional de inovação tecnológica. O passo inicial nas primeiras décadas é de aprendizado tecnológico, via de regra mediante a imitação das tecnologias já utilizadas nos países desenvolvidos. Esse traço, aliás, também se encontrou no processo de industrialização do século XIX de alguns dos países que hoje são líderes tecnológicos, incluindo os Estados Unidos e a Alemanha (CHANG, 2004).

Nesse sentido, as nações retardatárias forjam, em verdade, um sistema de aprendizado tecnológico, e não propriamente de inovação. A maior parte das indústrias inicialmente instaladas faz uso de tecnologias concebidas e aprimoradas no exterior. Essa realidade é comum a todos os países de industrialização tardia da segunda metade do século XX.

O que diferencia a experiência brasileira do processo de industrialização sulcoreano, chinês e taiwanês é o modo como se estruturou esse aprendizado: ao passo que no Brasil se formou um sistema de aprendizado preponderantemente passivo, pode-se afirmar que nos países asiáticos mencionados o sistema de aprendizado pode ser qualificado de ativo.

A diferença entre esses modelos pode ser caracterizada da seguinte maneira. No sistema passivo, o aprendizado tecnológico é limitado à reprodução da mesma técnica de manufatura desenhada no exterior. Os produtos manufaturados são os mesmos, os insumos são equivalentes e os processos industriais são repetidos de maneira muito próxima à original. A diferença entre o processo de manufatura de um país desenvolvido e aquela realizada em um país cujo sistema é passivo é que os processos e produtos são apenas adaptados às realidades locais. No caso do Brasil, cunhou-se o termo "tropicalização" para indicar o processo de adaptação dos produtos europeus e americanos ao clima e às peculiaridades do território e da população brasileira.

Já no sistema de aprendizado ativo, conquanto a dependência tecnológica seja também marcante, outros fatores impulsionaram que as técnicas estrangeiras fossem verdadeiramente incorporadas e avanços adicionais fossem feitos aos produtos. Não se trata, ainda, de promover inovações radicais nos produtos e processos industriais, mas em apropriarse das tecnologias estrangeiras, dispor da habilidade de trabalhar com essas técnicas de outras maneiras e eventualmente fazer ajustes que aprimorem essas tecnologias.

Vale aqui insistir que não se trata, ainda, no momento inicial da industrialização, de um sistema de inovação. O sistema de aprendizado ativo é ainda fortemente dependente das 
tecnologias desenvolvidas no exterior. Seu nível de inovação é relativamente baixo quando comparado com os dos países desenvolvidos. As inovações radicais nos produtos e nos processos industriais continuam a originar-se, em sua maioria, dos países centrais.

Mas o relevante é que o sistema de aprendizado ativo viabiliza o passo seguinte, que é a criação de um sistema nacional de inovação. Pode-se argumentar que há um continuum entre um sistema de aprendizado passivo, um sistema de aprendizado ativo e, em seguida, um sistema de inovação. Mas é um equívoco pensar-se que as etapas se sucedem naturalmente. Bem ao contrário, como se buscará demonstrar mais à frente nesta pesquisa, a mudança do sistema passivo para os estágios subsequentes é muito mais difícil do que se poderia imaginar no momento inicial. Em verdade, trata-se de uma ruptura entre esses diferentes sistemas.

Para esclarecer ainda mais as diferenças entre o aprendizado ativo e o passivo, é válido observar os exemplos indicados por VIOTTI (2001), que aponta como formas de absorção tecnológica passiva as seguintes práticas:

- projetos de investimento por meio de investimentos estrangeiros diretos ou contratos estilo turnkey ${ }^{20}$;

- licenciamento tecnológico;

- aquisição de pacotes de equipamentos associados a assistência técnica pelo fornecedor dos bens de capital.

Diferentemente, ainda seguindo os exemplos do mesmo autor, seriam práticas comuns de absorção tecnológica nos sistemas de aprendizado ativo:

- projetos de investimento agressivamente sob o controle de empresa local;

- aquisição de tecnologias e equipamentos progressivamente sob o controle de empresa local;

- imitação e cópia; e

- engenharia reversa.

Para explicar as diferenças nas práticas predominantes nas economias de países de industrialização tardia, VIOTTI lança mão de quatro grupos de indicadores na comparação que realiza entre Brasil e Coreia do Sul:

a) padrões nacionais de educação e treinamento dos trabalhadores;

b) padrões nacionais de aquisição tecnológica;

\footnotetext{
${ }^{20}$ Acordos turnkey são referidos aqui como os pacotes contratados sem transferência de tecnologia do fornecedor para o comprador, uma vez que o produto é entregue pronto para o uso, sem necessidade de absorção tecnológica. A expressão vem da ideia de que o comprador precisaria apenas "girar a chave" para ligar o equipamento.
} 
c) padrões nacionais de comprometimento de recursos para o aprendizado tecnológico; e

d) indicadores dos resultados do esforço nacional de aprendizado tecnológico.

Nos tópicos seguintes deste Capítulo, examinaremos indicadores dos países examinados relacionados a essas quatro categorias.

Antes disso, cabe apontar que, para além desses quatro fatores, agregamos ainda que o desenho da competição entre as empresas nacionais e estrangeiras resultantes dos diferentes modelos de abertura de mercado, a baixa integração entre o setor empresarial e os centros públicos de pesquisa e ainda as condições macroeconômicas também contribuíram para essas diferentes trajetórias.

Enquanto que o modelo brasileiro se baseou principalmente na industrialização por substituição de importações (ISI), a Coreia do Sul fez uso, além da substituição de importações, da industrialização orientada para a exportação (IOE). Para garantir espaços em mercados internacionais mais competitivos, as empresas sulcoreanas mantinham conexão direta com o estado da arte da tecnologia e se viam forçadas a investir na diferenciação de produtos e no aprimoramento da qualidade dos bens (DUBEUX, 2010).

No que tange à integração entre universidades e empresas, há um contraste nítido entre a frágil relação desses entes no Brasil e a intensa conexão dos mesmos grupos nos países asiáticos. As universidades e os centros de pesquisa públicos brasileiros mantiveram relação de bastante afastamento do setor empresarial brasileiro e vice-versa - com raras exceções, tais como o ITA e a Embraer e mais recentemente as escolas de engenharia da UFRJ, UFSC e USP, aliás, bem sucedidas. As diferenças das dinâmicas dessas instituições, os diferentes contextos em que foram criadas e as regras pouco amistosas para o estreitamento de laços ajudam a explicar esse distanciamento. Essa experiência contrasta com a verificada nos países asiáticos, em que os centros públicos de pesquisa foram não raro criados com o propósito de realizar pesquisas voltadas para os processos industriais que se desenvolviam em sua volta.

Quanto às condições macroeconômicas, é difícil ignorar a grave crise pela qual passaram os países latino-americanos ao longo dos anos 1980 e 1990. China à parte, a trajetória de aumento da renda do Brasil, da Coreia do Sul e de Taiwan mantém certo paralelismo nos anos 1960 e 1970, mas a partir daí, enquanto que as economias asiáticas seguem crescendo, a economia brasileira praticamente estagna. A crise da dívida, a hiperinflação, os choques econômicos provocados por sucessivos planos de estabilização, tudo isso se somou às diferenças já existentes entre o tipo de aprendizado tecnológico para dificultar a ruptura do modelo de aprendizado passivo no Brasil. 


\subsection{Brasil e o aprendizado passivo}

Para caracterizar o aprendizado passivo verificado no processo de industrialização tardia do Brasil, examinaremos indicadores das quatro categorias indicadas por VIOTTI, além dos três outros fatores complementares que reforçaram o processo de aprendizado passivo predominante no setor industrial brasileiro.

4.2.1. Padrão nacional de educação e de treinamento de trabalhadores

No que tange ao padrão nacional de educação e de treinamento de trabalhadores, ainda que notória a deficiência do sistema educacional brasileiro, é necessário explicitá-la em números que permitam cotejá-la com a situação dos demais países.

Há várias maneiras de examinar o sistema educacional dos países. Muitos se utilizam dos indicadores de alfabetização e de escolaridade, mas serão utilizados aqui os dados a respeito do desempenho qualitativo dos estudantes em testes padronizados. A preferência por esse indicador se deve ao fato de que ele permite aferir a qualificação média da mão-de-obra em vias de ingressar no mercado de trabalho.

\section{GRÁFICO 20}

Nota dos estudantes no teste do PISA

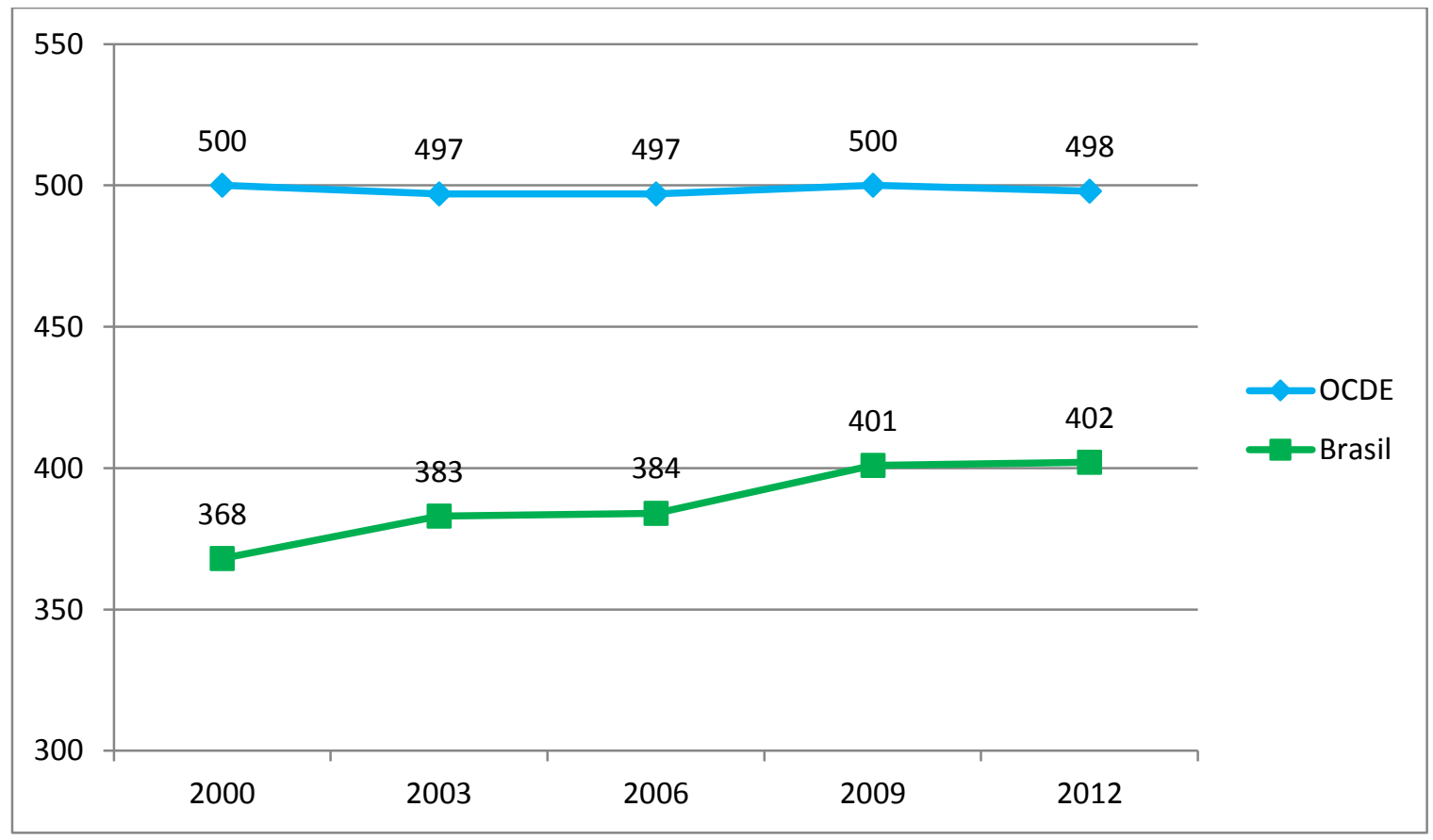

Fonte: INEP, 2013. 
O mais relevante teste para aferir esse desempenho dos estudantes é o PISA (Programme for International Student Assessment), organizado pela OCDE. Por meio desse programa são avaliados estudantes de 15 anos que constituam amostras representativas de mais de sessenta países (vários dos quais não-integrantes da OCDE, como o Brasil), incluindo as redes públicas e privadas, com exames em Português, Matemática e Ciências. O teste é aplicado trienalmente, tendo sido aplicado até o momento nos anos de 2000, 2003, 2006, 2009 e 2012 (embora nem todos os países tenham participado de todas as edições). Para números educacionais anteriores a esse período, resta recorrer a indicadores quantitativos de educação, como anos de escolaridade e alfabetização. O Gráfico 20 expõe a nota dos estudantes brasileiros no PISA, comparada com a média dos estudantes integrantes da OCDE.

Os resultados apontam um desempenho muito baixo dos estudantes brasileiros. Da lista de 65 países e territórios que participaram do exame, o Brasil figurou em $55^{\circ}$ colocado. A presença de estudantes com esses níveis excepcionais de desempenho é ainda mais importante para a inovação tecnológica do que a média do sistema educacional. Por isso, ainda mais preocupante do que a nota média do Brasil é que o percentual de estudantes brasileiros com desempenho muito elevado em matemática (notas superiores a 607, na escala do PISA) foi de apenas $0,8 \%$ na avaliação de 2012, enquanto que, na média da OCDE, o percentual de estudantes nesse nível mais elevado foi de 12,6\%. Na Coreia do Sul esse índice ficou em 30,9\%, em Taiwan ele chegou a 37,2\%, e em Xangai chegou a impressionantes 55,4\% (OECD, 2013).

Considerando a participação dos estudantes com alto desempenho, o tamanho da população e assumindo por aproximação que os estudantes compõem parcela equivalente da população em todos esses países (o dado não é preciso demograficamente, mas permite uma aproximação), pode-se dizer que, mesmo em termos absolutos, há mais do que o dobro de estudantes de 15 anos com desempenho excelente em Xangai, em Taiwan (cada uma delas com apenas 23 milhões de habitantes) e na Coreia do Sul (com 50 milhões) do que em todo o Brasil (com 200 milhões). É certo que o restante da China não oferece qualidade educacional equivalente à de Xangai, mas ainda assim o número é contundente e existem outras localidades do país com sistemas educacionais em rápida ascensão, como Beijing e Shenzhen.

Em leitura e em ciências, a diferença é menos acentuada do que em matemática, mas ainda assim revela diferenças significativas entre os países. Enquanto que os estudantes brasileiros com alto desempenho ficam em torno de $1 \%$ do total, os alunos taiwaneses, coreanos e chineses nos níveis mais altos oscilam entre $10 \%$ e $30 \%$ do total. 
Apenas para fins de referência, vale a pena observar o desempenho do sistema educacional dos Estados Unidos, líder mundial de inovação. Embora a média dos estudantes estadunidenses seja apenas equivalente à média dos países da OCDE, a desigualdade do sistema revela, nos números desagregados, uma parcela em torno de robustos $9 \%$ dos estudantes com desempenho excepcional em leitura, em matemática e em ciências, em um país com mais de 300 milhões de habitantes e com população extremamente diversificada.

Por outro lado, apesar de a média brasileira ser muito mais baixa do que a média dos países desenvolvidos, o Gráfico 20 indica ao menos que o país vem melhorando seu desempenho. Na última década, o Brasil foi o país que mais evoluiu no ranking do Pisa, resultado de mudanças empreendidas no sistema educacional e da elevação do orçamento do setor. A despeito da melhoria, os resultados ainda são extremamente baixos e retratam um nível de qualificação média da mão-de-obra bastante deficiente.

Além disso, autores como KLEIN relativizam a melhora da nota de vários países, incluindo o Brasil, ao atribuir a maior parte da elevação da nota média à melhoria do fluxo escolar, e não tanto ao aumento do desempenho dos estudantes. Em outras palavras, mais estudantes de quinze anos estavam em séries avançadas, mas, se comparados os estudantes de quinze anos das mesmas séries, o avanço desse subgrupo foi menos significativo - em rigor, foi significativo apenas em matemática (KLEIN, 2011). A despeito da observação de KLEIN, não se pode negar que a melhora do fluxo escolar sem a redução das notas médias dos estudantes é um avanço relevante.

Outro indicador importante para aferir a qualificação dos estudantes brasileiros é o Ideb (Índice de Desenvolvimento da Educação Básica), criado no âmbito do Ministério da Educação. Esse indicador se baseia em análises bienais de fluxo escolar e de notas dos estudantes em exames padronizados. O MEC estabeleceu submetas para cada município e o objetivo geral de alcançar em 2021 a média nacional de 6,0, que seria um desempenho equivalente ao dos países da OCDE (próximo à nota 500 na escala do PISA). No caso do Ideb, os indicadores retratam um padrão similar ao verificado no exame do PISA/OCDE: desempenho muito baixo das notas, mas paulatina evolução.

O IDEB foi criado pelo INEP em 2007, que consolida duas importantes informações na área educacional: a) o desempenho dos estudantes em língua portuguesa e em matemática; e b) fluxo escolar. Foram utilizados dados de provas nacionais desde 2005 e foram estabelecidas metas bienais até 2022, quando se espera que as notas dos estudantes brasileiros alcancem o nível verificado nos países desenvolvidos (seria uma nota no IDEB igual a 6,0). 
TABELA 9

Ideb nos anos INICIAIS do Ensino Fundamental

\begin{tabular}{|c|c|c|c|c|c|c|c|c|c|c|}
\hline & \multicolumn{5}{|c|}{ IDEB Observado } & \multicolumn{5}{|c|}{ Metas } \\
\hline & 2005 & 2007 & 2009 & 2011 & 2013 & 2007 & 2009 & 2011 & 2013 & 2021 \\
\hline Total & 3.8 & 4.2 & 4.6 & 5.0 & 5.2 & 3.9 & 4.2 & 4.6 & 4.9 & 6.0 \\
\hline \multicolumn{11}{|c|}{ Dependência Administrativa } \\
\hline Estadual & 3.9 & 4.3 & 4.9 & 5.1 & 5.4 & 4.0 & 4.3 & 4.7 & 5.0 & 6.1 \\
\hline Municipal & 3.4 & 4.0 & 4.4 & 4.7 & 4.9 & 3.5 & 3.8 & 4.2 & 4.5 & 5.7 \\
\hline Privada & 5.9 & 6.0 & 6.4 & 6.5 & 6.7 & 6.0 & 6.3 & 6.6 & 6.8 & 7.5 \\
\hline Pública & 3.6 & 4.0 & 4.4 & 4.7 & 4.9 & 3.6 & 4.0 & 4.4 & 4.7 & 5.8 \\
\hline
\end{tabular}

Ideb nos anos FINAIS do Ensino Fundamental

\begin{tabular}{|c|c|c|c|c|c|c|c|c|c|c|}
\hline & \multicolumn{5}{|c|}{ IDEB Observado } & \multicolumn{5}{|c|}{ Metas } \\
\hline & 2005 & 2007 & 2009 & 2011 & 2013 & 2007 & 2009 & 2011 & 2013 & 2021 \\
\hline Total & 3.5 & 3.8 & 4.0 & 4.1 & 4.2 & 3.5 & 3.7 & 3.9 & 4.4 & 5.5 \\
\hline \multicolumn{11}{|c|}{ Dependência Administrativa } \\
\hline Estadual & 3.3 & 3.6 & 3.8 & 3.9 & 4.0 & 3.3 & 3.5 & 3.8 & 4.2 & 5.3 \\
\hline Municipal & 3.1 & 3.4 & 3.6 & 3.8 & 3.8 & 3.1 & 3.3 & 3.5 & 3.9 & 5.1 \\
\hline Privada & 5.8 & 5.8 & 5.9 & 6.0 & 5.9 & 5.8 & 6.0 & 6.2 & 6.5 & 7.3 \\
\hline Pública & 3.2 & 3.5 & 3.7 & 3.9 & 4.0 & 3.3 & 3.4 & 3.7 & 4.1 & 5.2 \\
\hline
\end{tabular}

Ideb no Ensino Médio

\begin{tabular}{|c|c|c|c|c|c|c|c|c|c|c|}
\hline & \multicolumn{1}{|c|}{ IDEB Observado } & \multicolumn{7}{c|}{ Metas } \\
\cline { 2 - 11 } & $\mathbf{2 0 0 5}$ & $\mathbf{2 0 0 7}$ & $\mathbf{2 0 0 9}$ & $\mathbf{2 0 1 1}$ & $\mathbf{2 0 1 3}$ & $\mathbf{2 0 0 7}$ & $\mathbf{2 0 0 9}$ & $\mathbf{2 0 1 1}$ & $\mathbf{2 0 1 3}$ & $\mathbf{2 0 2 1}$ \\
\hline Total & $\mathbf{3 . 4}$ & $\mathbf{3 . 5}$ & $\mathbf{3 . 6}$ & $\mathbf{3 . 7}$ & $\mathbf{3 . 7}$ & $\mathbf{3 . 4}$ & $\mathbf{3 . 5}$ & $\mathbf{3 . 7}$ & $\mathbf{3 . 9}$ & $\mathbf{5 . 2}$ \\
\hline \multicolumn{10}{|c|}{ Dependência Administrativa } \\
\hline Estadual & $\mathbf{3 . 0}$ & $\mathbf{3 . 2}$ & $\mathbf{3 . 4}$ & $\mathbf{3 . 4}$ & $\mathbf{3 . 4}$ & $\mathbf{3 . 1}$ & $\mathbf{3 . 2}$ & $\mathbf{3 . 3}$ & $\mathbf{3 . 6}$ & $\mathbf{4 . 9}$ \\
\hline Privada & $\mathbf{5 . 6}$ & $\mathbf{5 . 6}$ & $\mathbf{5 . 6}$ & $\mathbf{5 . 7}$ & $\mathbf{5 . 4}$ & $\mathbf{5 . 6}$ & $\mathbf{5 . 7}$ & $\mathbf{5 . 8}$ & $\mathbf{6 . 0}$ & $\mathbf{7 . 0}$ \\
\hline Pública & $\mathbf{3 . 1}$ & $\mathbf{3 . 2}$ & $\mathbf{3 . 4}$ & $\mathbf{3 . 4}$ & $\mathbf{3 . 4}$ & $\mathbf{3 . 1}$ & $\mathbf{3 . 2}$ & $\mathbf{3 . 4}$ & $\mathbf{3 . 6}$ & $\mathbf{4 . 9}$ \\
\hline
\end{tabular}

Fonte: INEP

Um elemento importante do indicador é que, ao reunir fluxo escolar e rendimento do estudante, o indicador evita que, em busca de resultados falsamente positivos, escolas retenham indevidamente estudantes com pior desempenho, ou aprovem estudantes a qualquer custo. Em qualquer das situações, a nota seria prejudicada (quer porque o fluxo caiu, no primeiro caso, quer porque as notas dos que foram aprovados se reduziria).

Tanto no caso do PISA, da OCDE, quanto do IDEB, do INEP, a média divulgada esconde desigualdades enormes na qualidade do ensino. Caso segregadas as informações, constata-se a existência de realidades bem díspares: o sistema público federal, por exemplo, tem desempenho equivalente ao dos países mais bem classificados no PISA, alcançando uma média de 528 pontos, equivalente à do Canadá (527) e à do Japão (529). A rede privada 
brasileira atinge a marca de 502 pontos, próxima à média da OCDE e superior à da Noruega (500) e à da Dinamarca (499). Por outro lado, o sistema público não-federal alcança apenas 387 pontos, equivalente ao da Indonésia (385) ou ao do Azerbaijão (389).

Os dados educacionais nos permitem concluir, portanto, que, muito embora a qualidade média da educação seja muito deficiente, há um grupo seleto de escolas com nível de preparação bastante elevado. Por um lado se pode dizer que a média dos trabalhadores tenderá a ser menos produtiva em razão da baixa qualificação, mas por outro é possível afirmar que o grupo bem preparado não é estatisticamente desprezível em razão da grande população brasileira e poderia liderar um processo de inovação tecnológica em empresas e em universidades.

Nesse ponto, é válido também observar o desempenho do ensino superior brasileiro. Também nesse critério, os indicadores educacionais não são favoráveis ao país. Além de ter uma proporção de estudantes universitários relativamente baixa na faixa etária dos 18 aos 24 anos, as instituições de ensino superior brasileiras não se destacam entre as melhores do mundo.

Nessa análise, faremos uso do ranking acadêmico de instituições de ensino superior elaborado pela Universidade de Shanghai Jiao Tong, que confere particular importância às pesquisas. Nessa listagem das melhores 500 universidades do mundo, figuram apenas seis universidades brasileiras (contra 28 da China, 11 da Coreia e nove de Taiwan, como se examinará mais à frente). Nenhuma das brasileiras se enquadram entre as 100 melhores da lista.

Tendo em vista que o ranking confere peso maior para as atividades de pesquisa, o indicador é mais um a demonstrar a relevância da qualificação da mão-de-obra e de sua conexão com atividades de inovação nos países asiáticos. Embora o número de instituições brasileiras não seja desprezível - pelo contrário, o país é o que tem maior número de universidades listadas entre as nações da América Latina -, ainda assim ele mostra que, proporcionalmente, é baixo o número de instituições universitárias de elite no Brasil. Já a comparação per capita mostra disparadamente na frente a Coreia do Sul e Taiwan, com China e Brasil bem mais atrás.

A despeito de incluir a educação entre os critérios para distinguir um sistema de aprendizado passivo ou ativo, convém afastar a tese de que a educação de qualidade por si só acarretaria o desenvolvimento econômico dos países. O histórico de várias nações - inclusive da Coreia, de Taiwan e da China, como se verá adiante - revela que o inverso tende a ser mais verdadeiro, ou ao menos que se trata de um processo de retroalimentação, por meio do qual o 
crescimento econômico passa a exigir mão-de-obra mais qualificada, que por sua vez engendra novas tecnologias e crescimento econômico adicional. Há vários exemplos de progresso econômico dissociados de avanços educacionais, assim como há países cujos indicadores educacionais melhoraram, mas não conseguiram traduzir esse progresso em prosperidade econômica. É mais provável o crescimento fomentar a escolaridade, do que a escolaridade estimular o crescimento (PRITCHETT, 1997; EASTERLY, 2004).

\section{TABELA 10}

Universidades de países selecionados, extraídas do ranking acadêmico elaborado pela

Universidade de Shanghai Jiao Tong, 2013

\begin{tabular}{|c|c|c|c|}
\hline Instituição / China & $\begin{array}{l}\text { Posição no } \\
\text { ranking }\end{array}$ & Instituição / Brasil & Ranking \\
\hline Fudan University & $151-200$ & University of Sao Paulo & $101-150$ \\
\hline Peking University & $151-200$ & Federal University of Minas Gerais & $301-400$ \\
\hline Shanghai Jiao Tong University & $151-200$ & Federal University of Rio de Janeiro & $301-400$ \\
\hline Tsinghua University & $151-200$ & Sao Paulo State University & $301-400$ \\
\hline Zhejiang University & $151-200$ & State University of Campinas & $301-400$ \\
\hline Nanjing University & $201-300$ & $\begin{array}{l}\text { Federal University of Rio Grande do } \\
\text { Sul }\end{array}$ & $401-500$ \\
\hline Sun Yat-sen University & $201-300$ & Instituição / Coreia & Ranking \\
\hline $\begin{array}{l}\text { University of Science and } \\
\text { Technology of China }\end{array}$ & $201-300$ & Seoul National University & $101-150$ \\
\hline Beijing Normal University & $301-400$ & $\begin{array}{l}\text { Korea Advanced Institute of Science } \\
\text { and Technology }\end{array}$ & $201-300$ \\
\hline China Agricultural University & $301-400$ & Sungkyunkwan University & $201-300$ \\
\hline Harbin Institute of Technology & $301-400$ & Yonsei University & $201-300$ \\
\hline $\begin{array}{l}\text { Huazhong University of Science and } \\
\text { Technology }\end{array}$ & $301-400$ & Hanyang University & $301-400$ \\
\hline Jilin University & $301-400$ & Korea University & $301-400$ \\
\hline Shandong University & $301-400$ & $\begin{array}{l}\text { Pohang University of Science and } \\
\text { Technology }\end{array}$ & $301-400$ \\
\hline Sichuan University & $301-400$ & Catholic University of Korea & $401-500$ \\
\hline Xian Jiao Tong University & $301-400$ & Kyung Hee University & $401-500$ \\
\hline Beihang University & $401-500$ & Kyungpook National University & $401-500$ \\
\hline Central South University & $401-500$ & Pusan National University & $401-500$ \\
\hline Dalian University of Technology & $401-500$ & Instituição / Taiwan & Ranking \\
\hline Lanzhou University & $401-500$ & National Taiwan University & $101-150$ \\
\hline Nankai University & $401-500$ & National Tsing Hua University & $201-300$ \\
\hline Peking Union Medical College & $401-500$ & Chang Gung University & $301-400$ \\
\hline $\begin{array}{l}\text { South China University of } \\
\text { Technology }\end{array}$ & $401-500$ & National Cheng Kung University & $301-400$ \\
\hline Southeast University & $401-500$ & National Chiao Tung University & $301-400$ \\
\hline Tianjin University & $401-500$ & China Medical University & $401-500$ \\
\hline Tongji University & $401-500$ & National Central University & $401-500$ \\
\hline Wuhan University & $401-500$ & National Sun Yat-Sen University & $401-500$ \\
\hline Xiamen University & $401-500$ & National Yang Ming University & $401-500$ \\
\hline
\end{tabular}

Fonte: SHANGAI JIAO TONG RANKING, 2014. 
Não se quer, com isso, rechaçar a importância da educação. Pelo contrário: a educação tem o valor intrínseco de permitir que as pessoas busquem exercer plenamente suas potencialidades, ainda que não ela não trouxesse benefícios para a economia. Mas o fato é que, embora o progresso educacional não resulte automaticamente em crescimento econômico, a educação de qualidade cria condições para que os trabalhadores se adaptem mais facilmente a novas tecnologias e aumenta o número dos que têm condições de criar novos processos e novos produtos. Como o progresso tecnológico tem um caráter evolucionário, a ampliação do número dos que estão concebendo novas tecnologias tende a ampliar a quantidade de novos produtos e processos e, por conseguinte, elevar as chances de sucesso de alguma ou de algumas dessas invenções.

Em síntese, pode-se apontar que a qualificação média do trabalhador brasileiro, mesmo depois da evolução das últimas décadas, continua substancialmente atrás da média dos países desenvolvidos e mesmo dos países asiáticos examinados nesta pesquisa. Além da deficiência do sistema educacional, o foco brasileiro na formação em ciências humanas contrasta com a formação lógico-matemática e de ciências duras dos sistemas educacionais dos três países asiáticos em questão.

\subsubsection{Padrão de aquisição tecnológica}

"JOÃO: Telegrama do Alabama Pro senhor Max Overseas Ai, meu Deus do céu Me sinto tão feliz

TERESINHA: Chegou a confirmação Da United coisa e tal Que nos passa a concessão Para o náilon tropical

MAX: Sei que o náilon tem valor Mas começa a me enjoar Tive ideia bem melhor Nós vamos ramificar

TERESINHA: Já ramifiquei, ha ha Fiz acordo com a Shell Coca-Cola, RCA E vai ser sopa no mel

CORO: Que beleza 
Que riqueza

Tá chovendo

Da matriz

Ai, meu Deus do céu

Me sinto tão feliz"

Excerto da canção Ópera, da peça Ópera do Malandro, de Chico Buarque

Um segundo elemento para distinguir os modelos de aprendizado tecnológico reside na maneira como a tecnologia estrangeira foi incorporada à produção manufatureira nacional. No caso brasileiro, os investimentos estrangeiros diretos, com pacotes turnkey, exerceram um papel decisivo. Parcela significativa da chamada "indústria nacional" no Brasil é, em rigor, composta por filiais integrais de empresas sediadas no exterior que, no contexto da expansão de sua produção para outros países no período pós-Segunda Guerra Mundial, estabeleceram fábricas em países periféricos, como o Brasil.

Nesse contexto, a tecnologia para a produção desses bens já vinha pronta das matrizes. O desenvolvimento tecnológico no Brasil se limitava, quando havia, à "tropicalização" dos produtos, isto é, sua adaptação ao clima e aos padrões de consumo locais. Novos produtos e novas tecnologias não eram desenvolvidos pela filial brasileira, mas tãosomente pela matriz. Esta, por sua vez, a partir da avaliação quanto à conveniência de importálos prontos, ou de expandir o parque industrial para montá-los no Brasil, tomava a decisão quanto ao local em que a fabricação seria realizada. Até mesmo os padrões de consumo dos países centrais iam se reproduzindo para parcelas da população dos países periféricos que ingressavam no sistema. Certo é que o "sentido da tecnologia" se dava dos países centrais para os países periféricos, a partir de centros decisórios distantes do território brasileiro (FURTADO, 2000; BORJA, 2008).

Houve, é certo, importação de tecnologia por meio do licenciamento de tecnologias estrangeiras e também via importação de máquinas e equipamentos. Mas o papel dessas vias de incorporação tecnológica foi bem mais secundário quando comparado com o que ocorreu nos países do leste asiático, como se examinará à frente.

Para se ter uma ideia da presença maciça de empresas estrangeiras que apenas manufaturam no Brasil, sem se preocupar necessariamente com investimentos em pesquisa no país, basta olhar a origem do capital das dez maiores empresas que operam no território nacional em alguns setores selecionados de manufatura. Como se observa da Tabela 11, as empresas de capital estrangeiro têm papel muito destacado na manufatura brasileira. A maior parte dessas empresas pode ser caracterizada como subsidiária integral das empresas 
estrangeiras, isto é, existe uma empresa criada nos termos da legislação brasileira cujo capital é inteiramente detido pela matriz da multinacional. Como se verá à frente, essa situação contrasta com a situação da Coreia e de Taiwan - em que a presença de empresas de capital local é mais acentuada - e também com a da China, onde até existe participação relevante de empresas estrangeiras, mas preponderantemente consorciadas com capital local.

TABELA 11

Origem do capital das dez maiores empresas do Brasil em vendas em 2012, por setor

\begin{tabular}{|l|c|c|c|c|c|}
\hline & Automobilístico & $\begin{array}{c}\text { Bens de } \\
\text { capital }\end{array}$ & Eletroeletrônico & $\begin{array}{c}\text { Química e } \\
\text { Petroquímica }\end{array}$ & $\begin{array}{c}\text { Tecnologia e } \\
\text { Computação }\end{array}$ \\
\hline $\begin{array}{l}\text { Empresas } \\
\text { brasileiras }\end{array}$ & 0 & 4 & 0 & 3 & 3 \\
\hline $\begin{array}{l}\text { Empresas } \\
\text { estrangeiras }\end{array}$ & 10 & 6 & 10 & 7 & 7 \\
\hline
\end{tabular}

Fonte: EXAME/ABRIL, Maiores Empresas do Brasil em Vendas em 2012, 2013.

Essa situação está também caracterizada no setor de bens ligados ao setor de energia. Muito embora o Brasil disponha de empresas de grande porte na construção de barragens de hidrelétricas, a fabricação da parte tecnologicamente mais sensível - a turbina ainda é feita principalmente por empresas estrangeiras com subsidiárias no Brasil, como se verá no Capítulo seguinte. Modelo semelhante vem ocorrendo em outras tecnologias de geração de eletricidade, o que também se examinará no próximo Capítulo.

A importação de bens de capital também compunha uma rubrica com certo peso na busca de tecnologias estrangeiras, ainda que secundária em relação aos investimentos diretos. Já os contratos de licenciamento de tecnologia e de know-how exerceram papel acessório em todas as economias examinadas. Para melhor dimensionar o papel dessas três diferentes modalidades de incorporação de tecnologias estrangeiras à indústria nacional, convém examinar os Gráficos 21 e 22, além da Tabela 12, elaborados por VIOTTI (1997), que sintetizam a situação de Brasil e Coreia do Sul (Taiwan e China serão mais bem examinados noutro momento).

Como se verifica nesses indicadores, o papel do investimento estrangeiro direto foi praticamente nulo na Coreia do Sul, porquanto havia rígidas restrições ao ingresso de capital. No Brasil, diferentemente, o IED exerceu papel de destaque. Até mesmo a importação de bens de capital, que cumpriu papel importante nos dois países em questão, foi utilizada no Brasil em larga medida pelas subsidiárias das empresas estrangeiras. 
GRÁFICO 21

Aquisição de tecnologias estrangeiras

Coréia do Sul

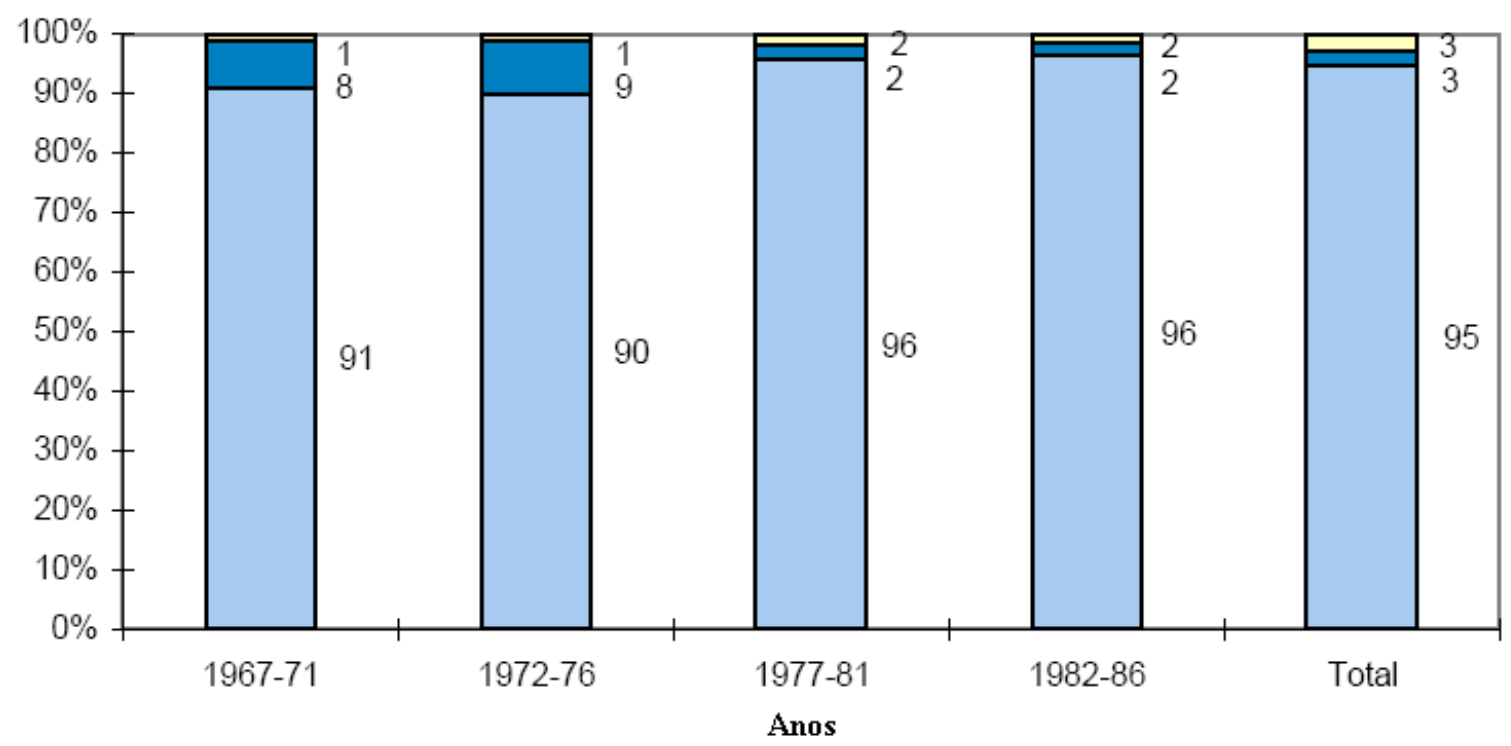

$\square$ Compra direta de tecnologia

\section{GRÁFICO 22}

\section{Aquisição de Tecnologias Estrangeiras}

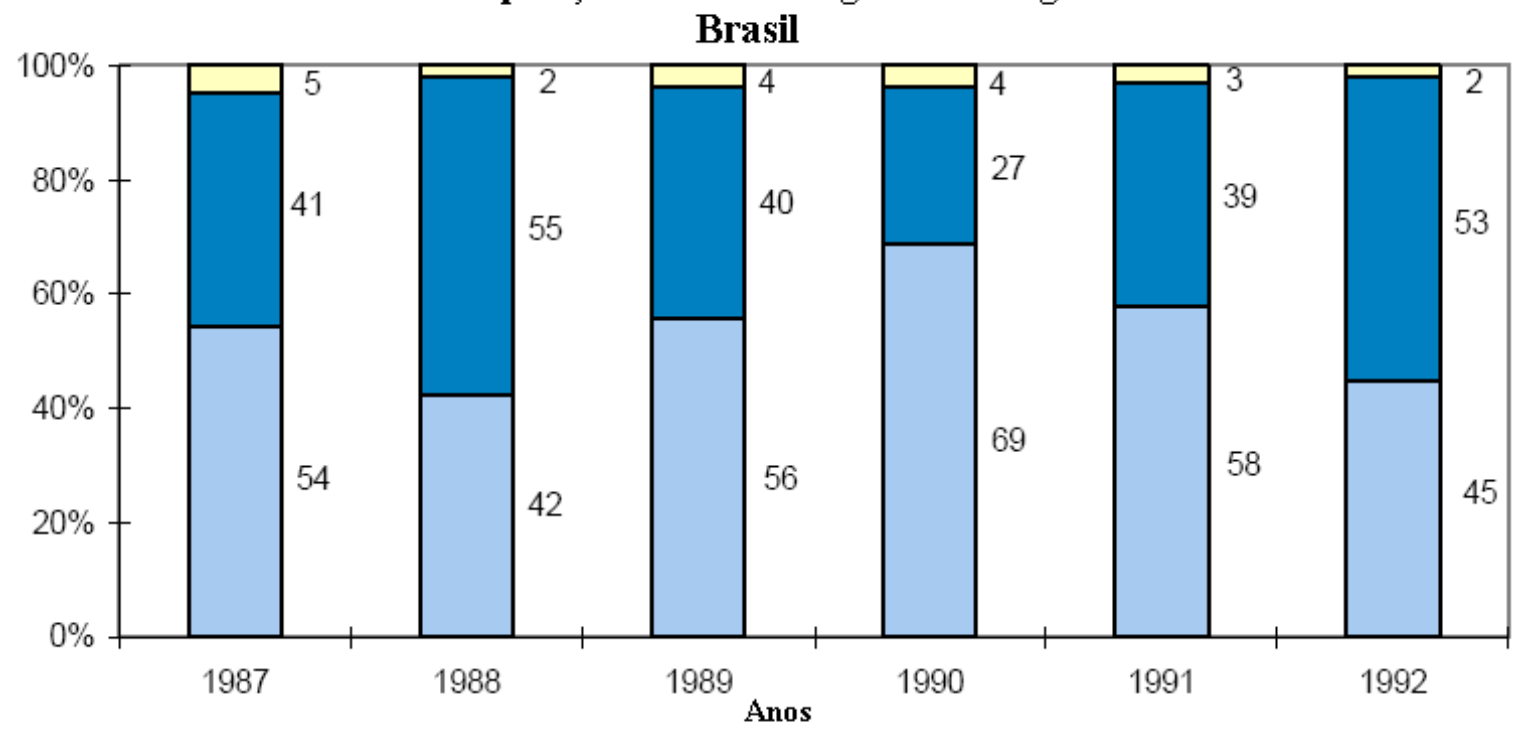

$\square$ Importação de Bens de Capital

$\square$ Investimento Estrangeiro Direto

$\square$ Compra direta de tecnologia

TABELA 12

Importação de bens de capital em proporção da renda nacional bruta, 1965-1987

\begin{tabular}{|l|c|c|c|c|c|c|c|}
\hline & $\mathbf{1 9 6 5}$ & $\mathbf{1 9 7 0}$ & $\mathbf{1 9 7 5}$ & $\mathbf{1 9 8 0}$ & $\mathbf{1 9 8 5}$ & $\mathbf{1 9 8 6}$ & $\mathbf{1 9 8 7}$ \\
\hline Coréia do Sul & 0.991 & 0.902 & 1.272 & 1.119 & 1.114 & 1.034 & 1.066 \\
\hline Brasil & 0.251 & 0.327 & 0.409 & 0.455 & 0.376 & 0.299 & 0.259 \\
\hline
\end{tabular}

Fonte: Dalhman and Frischtak (1993), apud VIOTTI.

Nota: Em alguns anos, os índices são superiores a 1, porque muitos dos bens de capital importados são reexportados como partes de novos produtos. 
Ainda sobre o tema, vale a pena examinar a evolução do investimento estrangeiro direito em relação ao PIB nas últimas décadas, sintetizada no Gráfico 23.

\section{GRÁFICO 23}

Investimento estrangeiro direto, entradas líquidas (em \% do PIB)

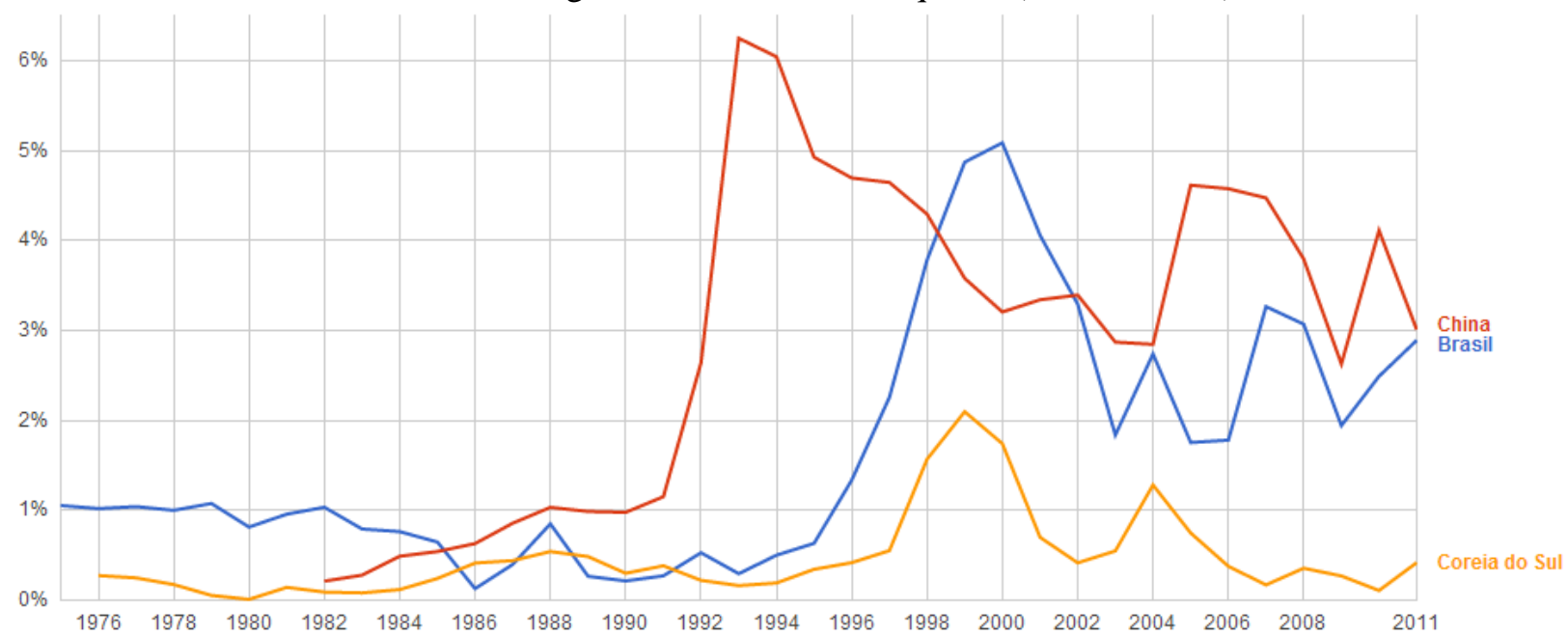

Fonte: Banco Mundial, extraído via Google Public Data, 2014.

Nos anos 1970, a utilização de poupança externa por meio do ingresso de investimento estrangeiro direto cumpriu papel importante no Brasil. Na Coreia, o valor era muito reduzido e, na China, nem mesmo estatísticas existiam à época dadas as enormes restrições então existentes. Nos anos 1980, houve uma queda do IED no Brasil em razão da grave instabilidade macroeconômica do período, marcado pela crise da dívida e pelo descontrole inflacionário. Nos anos 1990 e nos anos 2000, o IED volta a se elevar no Brasil e passa a financiar boa parte do déficit em transações correntes nacionais.

Em contraste, na Coreia o IED exerceu papel reduzido em quase todo o período em razão das restrições domésticas ao ingresso de capital estrangeiro no setor de manufatura. A única exceção foi um breve período logo em seguida à crise asiática de 1997, quando se elevou temporariamente o ingresso de capital estrangeiro na Coreia. Na China, a abertura de Deng Xiaoping provocou uma elevação gradual do IED a partir dos anos 1980, chegando até mesmo a superar os patamares brasileiros. Todavia, como se examinará à frente, o IED na China foi condicionado, em boa parte dos casos, à formação de joint ventures com empresas locais.

Somado à deficiente formação de mão-de-obra e aos fatores que serão examinados nos tópicos seguintes, a manutenção das tecnologias sob o controle de empresas estrangeiras dificultou o processo de emparelhamento tecnológico no Brasil. A capacidade de 
absorver as tecnologias externas e sobre elas produzir aprimoramentos incrementais e inovações radicais se viu limitada.

Em síntese, vê-se que no Brasil os investimentos estrangeiros diretos exerceram - e ainda exercem - papel bastante significativo na incorporação de tecnologias estrangeiras. Como eram as próprias multinacionais que gerenciavam as atividades manufatureiras, $\mathrm{o}$ controle sobre as tecnologias foi incorporado à economia brasileira em menor intensidade do que o que ocorreu nos países asiáticos.

\subsubsection{Comprometimento de recursos para aprendizado tecnológico}

O terceiro elemento diferenciador entre os modelos nacionais de aprendizado diz respeito ao comprometimento de recursos para o aprendizado tecnológico. Esse indicador revela o quanto o país tem se empenhado e reservado recursos para tarefas ligadas à pesquisa e à inovação tecnológica. Utilizaremos aqui os investimentos em $\mathrm{P} \& \mathrm{D}$ em proporção do PIB e também o número de pesquisadores dedicados às atividades de $\mathrm{P} \& \mathrm{D}$.

Os dados de P\&D estão sintetizados no Gráfico 24. Eles apontam evolução nos investimentos de todos esses países, mas um ritmo de incremento muito lento no caso brasileiro. Ao longo da última década os gastos em P\&D no Brasil se mantiveram em torno de $1 \%$ do PIB, com suaves oscilações. Esse cenário contrasta com os dos países asiáticos examinados, que viram seu comprometimento de recursos para a área crescer de maneira aguçada.

\section{GRÁFICO 24}

Gastos com P\&D (em \% do PIB)

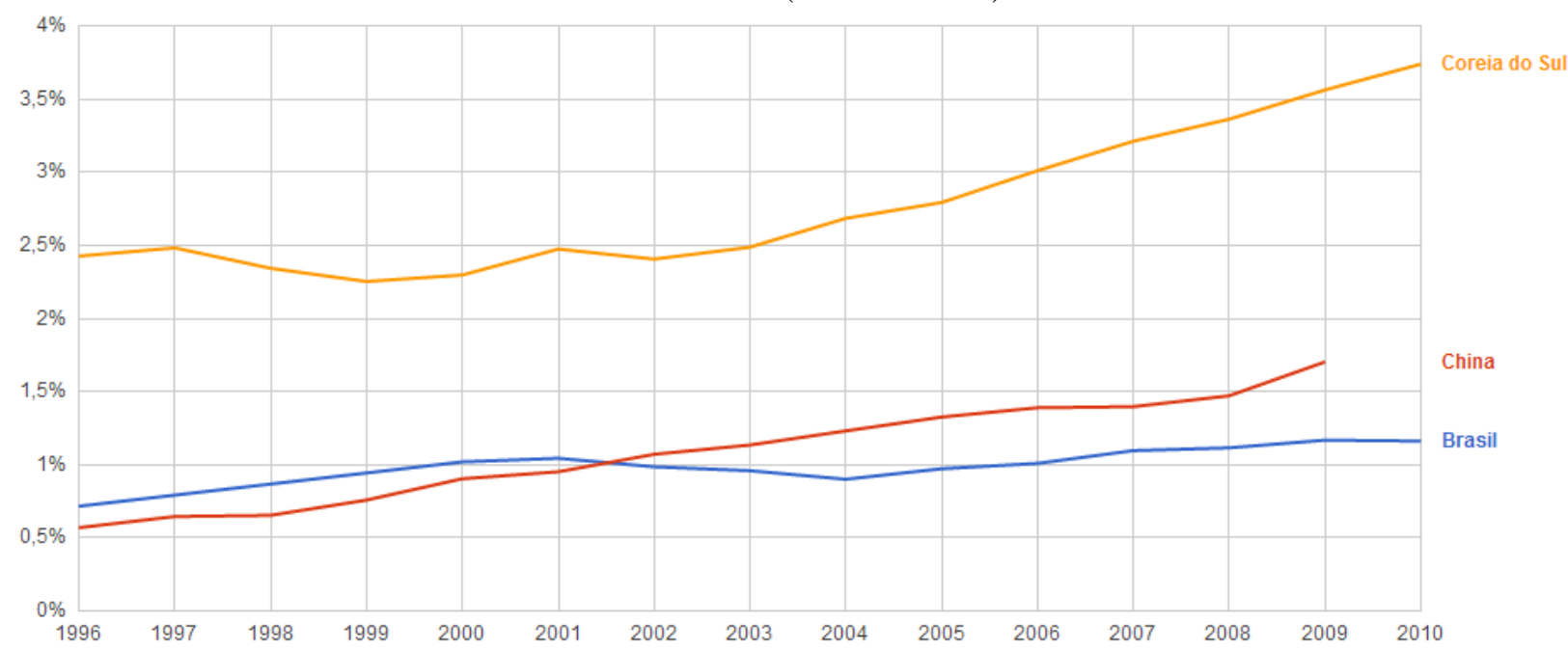

Fonte: Banco Mundial, extraído via Google Public Data, 2014. 
Já o envolvimento de pesquisadores em atividades de P\&D está consolidado no Gráfico 25, que aponta o número de pesquisadores por milhão de habitantes. É verdade que esse indicador tende a favorecer países com população reduzida e a prejudicar os países com contingentes populacionais gigantescos, como é o caso da China e, em bem menor medida, do Brasil. Mas, não bastasse a superioridade da Coreia nesse indicador ser avassaladora, mesmo a China apresenta números superiores aos brasileiros, demonstrando o baixo comprometimento das empresas e das instituições brasileiras com atividades de inovação tecnológica.

\section{GRÁFICO 25}

Pesquisadores em P\&D, por milhão de habitantes

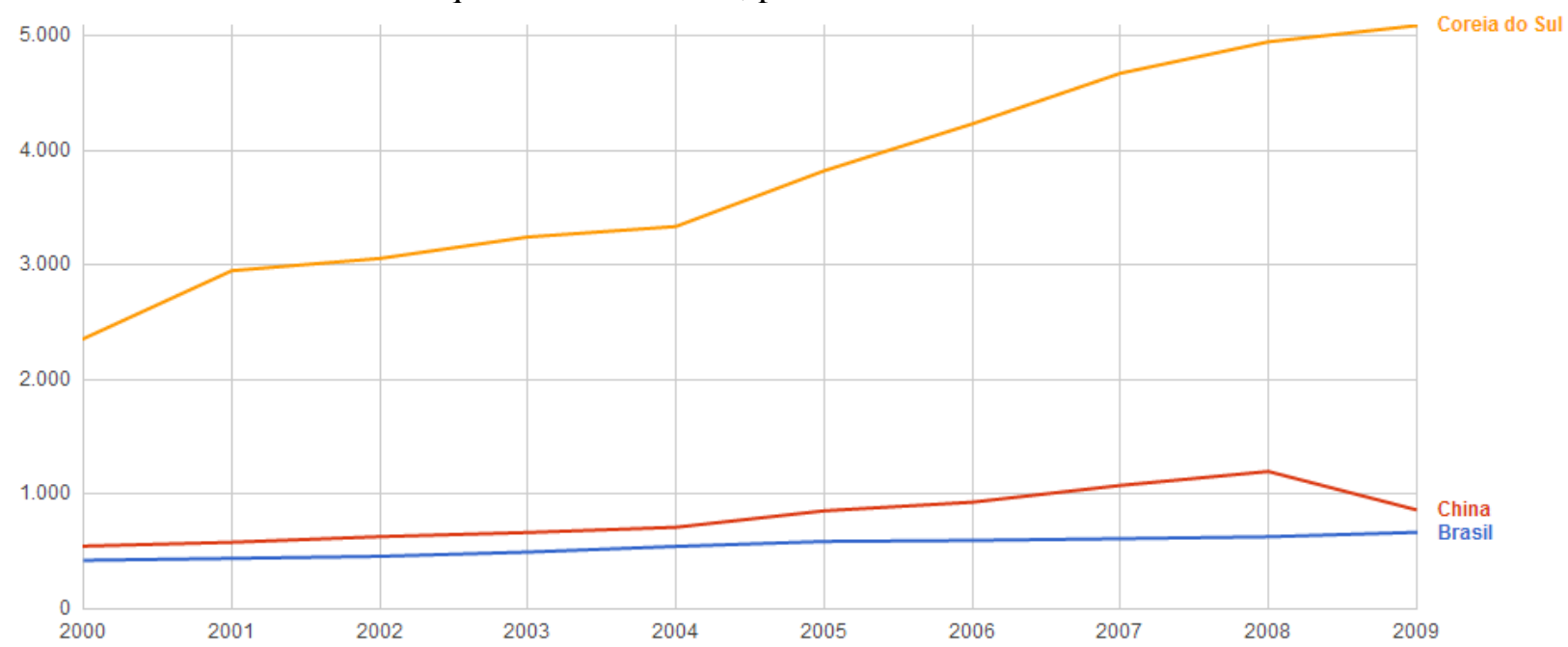

Fonte: Banco Mundial, extraído via Google Public Data, 2014.

Em síntese, pode-se apontar que o Brasil tem atividades de pesquisa relevantes, mas bastante inferiores aos dos países asiáticos.

\subsubsection{Resultados do esforço nacional de aprendizado tecnológico}

No que tange aos resultados do esforço nacional de aprendizado tecnológico, é válido cotejar a evolução verifica nesses países em relação tanto à atividade de pesquisa científica, como à atividade de patenteamento.

Apesar das limitações desses indicadores, a utilização de dados agregados de publicações científicas parece ser o melhor termômetro da intensidade e qualidade das pesquisas científicas realizadas em cada país. Para tanto, o melhor indicador é formulado pela 
Thompson Reuters, que reúne bases de dados de publicações científicas em periódicos internacionais.

Sobre patenteamento, o indicador mais amplamente utilizado é o total de patentes obtido por nacionais de cada país no escritório de patentes dos Estados Unidos. Por se tratar da maior economia do planeta, as inovações de maior relevância tendem a ser patenteadas no escritório estadunidense, e não apenas no escritório local do país em que foi criado o produto.

No que tange às publicações científicas, a Tabela 13 sumariza os resultados dos países. O total de publicações científicas brasileiras não é desprezível: o país é o mais bem situado país latino-americano e vem subindo de posição no ranking. Em duas décadas, passou de $24^{\circ}$ colocado para o $13^{\circ}$ na listagem de 2013.

Contudo, comparado aos países asiáticos, a situação brasileira já não é tão confortável, embora também não seja inteiramente negativa. O país fica bem atrás da China e em situação similar à da Coreia e de Taiwan. Vale notar que a tabela considera o total de artigos publicados, e não o total de publicações per capita. Desse modo, a situação de relativa proximidade com Coreia e com Taiwan deixa de ser favorável, dado que a população brasileira é quatro vezes superior à coreana e cerca de oito vezes a taiwanesa.

TABELA 13

Ranking de publicações em períodos científicos indexados, 1993-2013

\begin{tabular}{|c|c|c|c|c|c|}
\hline \multicolumn{2}{|c|}{1993} & \multicolumn{2}{|c|}{2003} & \multicolumn{2}{|c|}{2013} \\
\hline Posição/País & Artigos & Posição/País & Artigos & Posição/País & Artigos \\
\hline $1^{\circ} \mathrm{EUA}$ & 383.745 & $1^{\circ}$ EUA & 463.017 & $1^{\circ}$ EUA & 429.556 \\
\hline $2^{\circ}$ Inglaterra & 74.773 & $2^{\circ}$ Japão & 102.830 & $2^{\circ}$ CHINA & 288.424 \\
\hline $3^{\circ}$ Japão & 64.977 & $3^{\circ}$ Inglaterra & 98.376 & $3^{\circ}$ Alemanha & 114.316 \\
\hline $4^{\circ}$ Alemanha & 61.333 & $4^{\circ}$ Alemanha & 95.558 & $4^{\circ}$ Inglaterra & 108.311 \\
\hline $5^{\circ}$ França & 48.061 & $5^{\circ}$ CHINA & 65.905 & $5^{\circ} \mathrm{Japão}$ & 90.678 \\
\hline$(\ldots)$ & & $(\ldots)$ & & $(\ldots)$ & \\
\hline $15^{\circ}$ CHINA & 12.586 & $13^{\circ}$ COREIA & 26.552 & $12^{\circ}$ COREIA & 56.262 \\
\hline $22^{\circ}$ TAIWAN & 5.858 & $17^{\circ}$ BRASIL & 19.108 & $13^{\circ}$ BRASIL & 42.931 \\
\hline $24^{\circ}$ BRASIL & 5.457 & $18^{\circ}$ TAIWAN & 16.609 & $15^{\circ}$ TAIWAN & 32.956 \\
\hline
\end{tabular}

Mesmo com tais ressalvas, o total de publicações científicas brasileiras é significativo. Para um país que largou atrás no processo de industrialização e de absorção de conhecimento, é bastante razoável a $13^{a}$ posição na listagem. O avanço nas últimas duas décadas também é digno de nota.

O que torna a situação realmente preocupante é quando se examina a situação de patenteamento no Brasil. Nesse quesito, fica explícita a dificuldade nacional em converter 
o volume significativo de pesquisa realizada no país em produtos e processos inovadores, com aplicações industriais. Veja-se o ranking de patentes resumido no Gráfico 26.

\section{GRÁFICO 26}

Patentes registradas por nacionais de países selecionados (2000-2013)

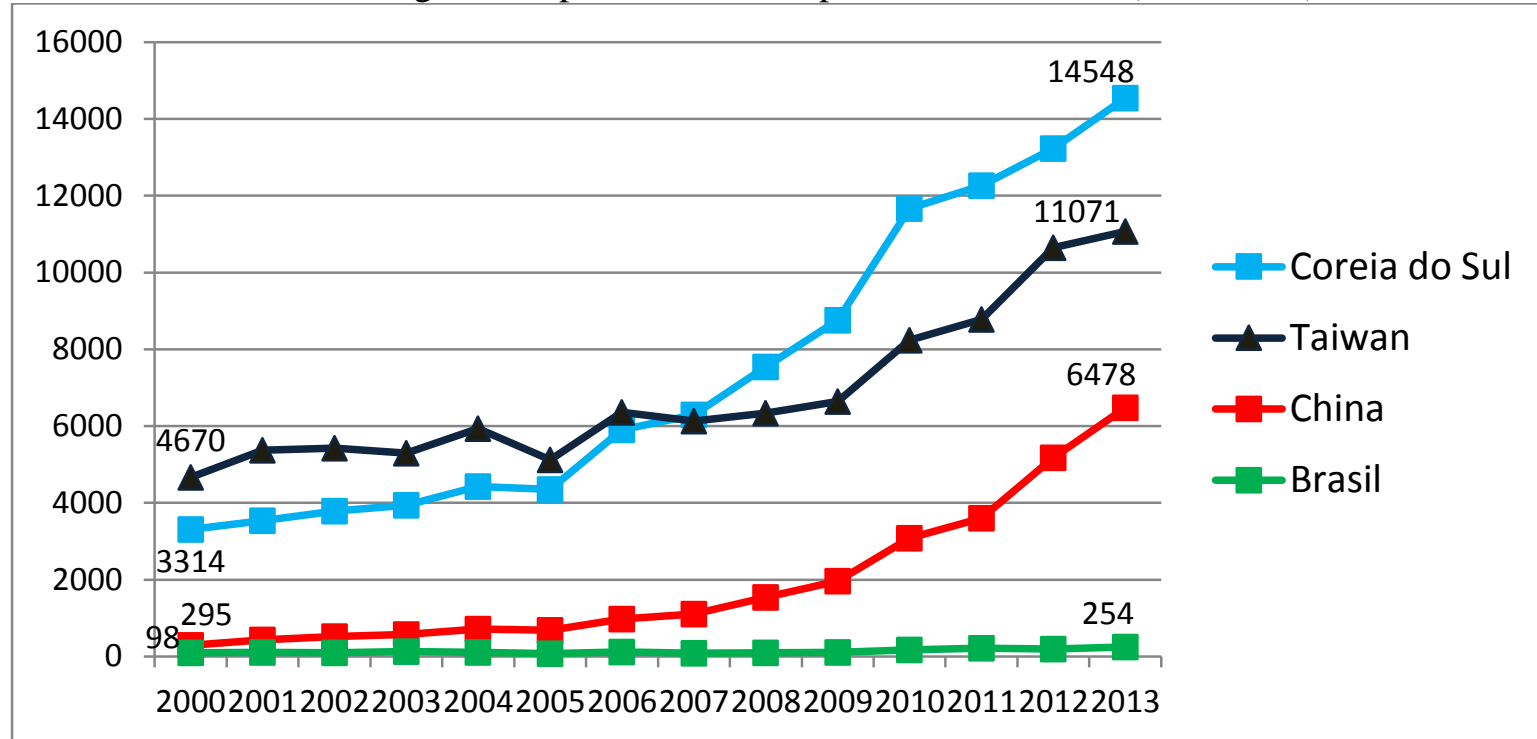

\begin{tabular}{|l|c|c|c|c|c|c|c|c|c|c|c|c|c|c|c|}
\hline Posição & País & $\mathbf{2 0 0 0}$ & $\mathbf{2 0 0 1}$ & $\mathbf{2 0 0 2}$ & $\mathbf{2 0 0 3}$ & $\mathbf{2 0 0 4}$ & $\mathbf{2 0 0 5}$ & $\mathbf{2 0 0 6}$ & $\mathbf{2 0 0 7}$ & $\mathbf{2 0 0 8}$ & $\mathbf{2 0 0 9}$ & $\mathbf{2 0 1 0}$ & $\mathbf{2 0 1 1}$ & $\mathbf{2 0 1 2}$ & $\mathbf{2 0 1 3}$ \\
\hline $4^{\text {o }}$ & Coreia & 3314 & 3538 & 3786 & 3944 & 4428 & 4352 & 5908 & 6295 & 7548 & 8762 & 11671 & 12262 & 13233 & 14548 \\
\hline $5^{\circ}$ & Taiwan & 4670 & 5371 & 5431 & 5298 & 5938 & 5118 & 6361 & 6128 & 6339 & 6642 & 8239 & 8781 & 10646 & 11071 \\
\hline $7^{\circ}$ & China & 295 & 432 & 523 & 574 & 715 & 686 & 971 & 1110 & 1537 & 1962 & 3087 & 3599 & 5172 & 6478 \\
\hline $26^{\circ}$ & Brasil & 98 & 110 & 96 & 130 & 106 & 77 & 121 & 90 & 101 & 103 & 175 & 215 & 196 & 254 \\
\hline
\end{tabular}

Fonte: USPTO, 2014.

OBS.: A origem da patente é definida pela residência do primeiro inventor. As patentes totais da China foram calculadas a partir da soma dos valores atribuídos à "República Popular da China", à "China/Hong Kong" e à "China/Macau".

A despeito da evolução do número de patentes no Brasil, passando de $98 \mathrm{em}$ 2000 para 254 em 2013, a situação fica em flagrante contraste com a evolução dos demais países examinados. A dificuldade em converter produção científica robusta em inovações tecnológicas fica muito evidente quando o gráfico de patentes é comparado com os números sobre produção científica. Enquanto que, em termos de publicações acadêmicas, a Coreia do Sul e o Brasil estão em situação muito próxima ( $12^{\circ}$ e $13^{\circ}$ do ranking global), em patentes o divórcio entre as trajetórias é evidente: a Coreia fica em $4^{\circ}$ lugar no mundo, enquanto que o Brasil fica em $26^{\circ}$.

O Brasil fica, apesar do resultado acanhado, em primeiro lugar entre os países da América Latina em termos de patentes. O México, por exemplo, registrou apenas 155 patentes em 2013; e a Argentina, somente 75. Esse quadro realça o contraste entre o modelo 
de aprendizado tecnológico passivo verificado na industrialização tardia latino-americana visà-vis o modelo vivenciado por alguns dos países do Leste Asiático.

Em outras palavras, pode-se afirmar que os resultados do esforço brasileiro de aprendizado tecnológico resultaram primordialmente em capacitação científica, mas não tanto em capacitação para inovação tecnológica. As descobertas e qualificações alcançadas no campo acadêmico não transbordam na mesma intensidade para o campo industrial inovador.

4.2.5. Outros fatores: orientação para a exportação, integração de instituto de pesquisa com empresas e condições macroeconômicas

Aos fatores examinados nos subtópicos anteriores se some ainda o modelo de industrialização com foco em substituição de importações, que contrasta com a industrialização orientada para a exportação dos países asiáticos.

É fato que a proteção à indústria nascente não necessariamente conduz à ausência de competição, já que haveria em tese disputa entre as empresas localizadas no mercado doméstico. Entretanto, a disputa não se dá nos mesmos moldes da disputa realizada no mercado externo, ou melhor, as empresas que concorrem no mercado internacional estão batalhando no estado da arte da tecnologia e buscando mercados consumidores mais prósperos e mais exigentes. $\mathrm{O}$ contato com o mercado externo faculta às empresas exportadoras essa relação imediata com inovações tecnológicas, com novos processos e novos modelos de negócios. É o chamado learning by exporting.

Ao direcionar sua industrialização para a substituição de importações, o Brasil logrou a criação de um parque industrial bastante amplo e diversificado, mas a maior parte das indústrias não estava disputando, no Brasil, os produtos de ponta tecnológica.

A reforçar esse elemento merece ainda ser mencionada a historicamente baixa integração do setor industrial com as atividades científicas, usualmente desenvolvidas nas universidades. Havia resistência mútua à aproximação, eis que de um lado pesquisadores de centros públicos julgavam que a pesquisa seria maculada pela busca do lucro e, de outro, empresários não viam muito sentido em aplicar recursos em atividades de retorno incerto e demorado. Apenas nos anos 1990 se iniciaram esforços mais robustos para integrar universidades e centros de pesquisa públicos com o setor privado, movimento que ganhou força com a aprovação da Lei de Inovação, em 2004.

É certo que, em alguns casos, a integração ocorreu no Brasil - são as exceções que comprovam a regra. Os três principais exemplos são: a) o Instituto Tecnológico da 
Aeronáutica - ITA e a empresa originalmente estatal e depois privatizada Embraer; b) a COPPE do Departamento de Engenharia da Universidade Federal do Rio de Janeiro - COPPE/UFRJ e a sociedade de economia mista Petrobrás; c) a Empresa de Pesquisa Agropecuária EMBRAPA e os produtores rurais brasileiros. Esses casos exitosos ilustram, por um lado, o quão relevante é a integração da academia com o setor produtivo para o florescimento de produtos e de processos inovadores em empresas no Brasil, mas também revelam que o Brasil lançou mão dessas ações em casos muito isolados, especialmente quando comprada a situação com a dos asiáticos.

Por fim, não se pode deixar de mencionar a diferença no histórico do gerenciamento macroeconômico do país, notadamente os abruptos movimentos cambiais, monetários e fiscais dos anos 1980 e 1990, com inflação descontrolada e elevada imprevisibilidade econômica para investimentos empresariais de longo curso. Esse cenário contrasta, como se verá adiante, com a relativa estabilidade macroeconômica dos países asiáticos, apenas abalada nos casos de Coreia e de Taiwan pela crise asiática de 1997, quando o nível de renda da população já havia atingido níveis maiores e a indústria já havia amadurecido para outro estágio.

É inegável que investimentos em inovação tecnológica demandam maturidade e previsibilidade econômica, e o cenário brasileiro das últimas décadas do século XX não pode ser caracterizado como propício a esse tipo de empreitada. Era justamente nesse período que a indústria estava se consolidando e poderia tomar lugar a transição de uma estratégia de imitação para uma baseada em inovação. Além disso, ao longo dos anos 2000 houve uma perda relevante da participação da indústria de transformação no PIB brasileiro, situação que se acentuou na década de 2010, conforme se examinará no Capítulo 7.

Em resumo, o sistema de aprendizado tecnológico do Brasil pode ser caracterizado, no conjunto, como passivo, o que se verifica pela baixa qualificação da mão-deobra, incorporação de tecnologia primordialmente por meio de investimento estrangeiro direto, reduzido esforço empresarial em pesquisa, atividade de patenteamento limitada, industrialização com foco em substituição de importações, parcerias muito restritas da indústria com a academia e instabilidade macroeconômica. Passemos à análise da situação dos países asiáticos selecionados, que será útil para realçar as características de cada modelo. 


\subsection{Coreia, Taiwan e China e o aprendizado ativo}

"Desenvolvimento é a única verdade objetiva." Deng Xiaoping, discurso, 1992

O modelo adotado por alguns dos países do leste asiático para promover sua industrialização tardia difere em alguns aspectos do verificado nos países latino-americanos. Houve, sem dúvida, vários aspectos comuns na busca pelo emparelhamento econômico (substituição de importações, fechamento do mercado, cópia de tecnologias estrangeiras, etc.), mas o que pretendemos destacar neste trabalho são as diferenças existentes que provocaram as diferentes trajetórias verificadas por esses países, em particular depois dos anos 1980.

A comparação entre os modelos é relevante. Como apontava Machiavel na clássica obra "O Príncipe”, "aqueles que traçam os contornos dos países põem-se na planície a fim de avaliar a natureza das montanhas, e para examinar a da planície vão ao topo delas”. Por isso, para expor com clareza o aprendizado passivo, vale a pena verificar onde o aprendizado se deu de modo diverso.

Vale esclarecer que o grupo de países que promoveu de maneira relativamente bem sucedida a industrialização no leste asiático é composto principalmente pelos chamados "Tigres Asiáticos", que abrangem Coreia do Sul, Taiwan, Hong Kong e Cingapura. Esses países conseguiram galgar níveis de renda equivalentes aos dos países desenvolvidos, muito embora tenham partido de patamares baixíssimos de renda per capita no início do processo de industrialização, nos anos 1950 e 1960.

Desse grupo, entretanto, excluiremos em nossa análise Hong Kong e Cingapura, que, pelo tamanho diminuto de suas populações (7 milhões e 5 milhões, respectivamente), tornam a comparação com o Brasil bastante inadequada, uma vez que ambos constituem em verdade "cidades-estado".

Além de Coreia e de Taiwan, incluiremos na análise a China, cujo processo de industrialização somente adquiriu vigor a partir das reformas implantadas no fim dos anos 1970, com a ascensão de Deng Xiaoping. Muito embora ainda não se possa afirmar que a China alcançou nível de renda equiparado ao dos demais tigres asiáticos (em verdade, o nível de renda per capita na China é ainda inferior ao do Brasil), seu gigantismo demográfico e seu papel de destaque em manufaturas de geração de energia justificam sua inclusão na comparação que se faz com o Brasil. Além disso, algumas das características do crescimento chinês se assemelham 
às verificadas no caso da Coreia do Sul e de Taiwan, o que permite, em alguns temas, tratá-los de maneira simplificada em um único bloco.

Nessa linha, em que pese as peculiaridades de cada país, pode-se apontar como características gerais de China, Coreia do Sul e Taiwan, que os distinguem das experiências de industrialização latino-americanas, os seguintes pontos:

- mão-de-obra crescentemente qualificada em rápida velocidade;

- importação de tecnologia via importação de máquinas e engenharia reversa;

- papel preponderante do capital nacional na formação de empresas, ainda que consorciado com o estrangeiro no caso chinês;

- comprometimento crescente de recursos para o aprendizado tecnológico;

- $\quad$ substituição de importação conjugada com orientação para exportar;

- alta integração do setor produtivo com a academia;

- condições macroeconômicas mais favoráveis do que a latino-americana.

Passamos à análise de cada uma dessas categorias, já abordadas no subtópico anterior em relação ao Brasil.

\subsubsection{Padrões nacionais de educação e treinamento dos trabalhadores}

Em relação aos padrões nacionais de educação e de treinamento dos trabalhadores, o avanço verificado nesses países nas últimas décadas é notável, embora a China mereça observações especiais adiante.

Da mesma maneira que na análise do caso brasileiro fizemos uso das notas dos estudantes no teste do PISA, da OCDE, utilizaremos o mesmo indicador para os países asiáticos. As notas obtidas pelos estudantes sulcoreanos e taiwaneses têm sido frequentemente classificadas entre as mais altas do mundo, acima da média dos países da OCDE. A China não participou das edições iniciais do exame. Nos últimos dois testes (2009 e 2012), entretanto, inscreveu algumas de suas redes de ensino (Xangai, Hong Kong e Macau), mas não há uma nota nacional para o país. O resultado está sintetizado na Tabela 14.

Em síntese, Coreia do Sul e Taiwan, assim como as entidades subnacionais chinesas que tomaram parte no exame ficaram entre as dez primeiras colocadas no ranking 
internacional. Obtiveram notas superiores às da média dos países que compõem a OCDE (497) e bem acima da nota média dos estudantes brasileiros (402).

TABELA 14

Nota média dos estudantes na edição do PISA de 2012, por ordem de classificação

\begin{tabular}{|c|c|c|c|c|c|}
\hline Posição & País / Região & Média & Posição & País / Região & Média \\
\hline 1 & CHINA (XANGAI) & 588 & 8 & Estônia & 526 \\
\hline 2 & Cingapura & 555 & 9 & Liechtenstein & 525 \\
\hline 3 & CHINA (HONG KONG) & 554 & 10 & CHINA (MACAU) & 523 \\
\hline 4 & COREIA & 543 & 11 & Canadá & 522 \\
\hline 5 & Japão & 540 & 12 & Holanda & 519 \\
\hline 6 & CHINA (TAIWAN) & 535 & - & Média OCDE & 497 \\
\hline 7 & Finlândia & 529 & 55 & BRASIL & 402 \\
\hline
\end{tabular}

Fonte: Elaboração própria a partir de dados da OCDE, PISA, 2013.

OBS.: Pontuação calculada a partir da média das notas em matemática, ciências e leitura.

Quando se observa a parcela de estudantes com desempenho muito elevado em matemática (notas superiores a 607, na escola do PISA), a Coreia do Sul alcançou a taxa 30,9\% dos estudantes e em Taiwan os alunos com esse desempenho elevado atingiram 37,2\%. Nos entes subnacionais chineses, o percentual de estudantes com alto desempenho também se destaca: em Macau foram 24,3\%; em Hong Kong o número ficou em 33,7\%; e em Xangai alcançou o nível impressionante de 55,4\%. Como já apontado anteriormente, na OCDE esse percentual de estudantes com alto desempenho foi de 12,6\% e no Brasil ficou em minguados $0,8 \%$ (OECD, 2013).

O mais expressivo é que esses países partiram de níveis educacionais muito baixos algumas poucas décadas atrás. Os indicadores de qualidade de ensino à época não eram tão precisos, mas alguns dados sobre analfabetismo ilustram esse atraso inicial e o salto impressionante que lograram alcançar. A Coreia do Sul, no período imediatamente seguinte à Segunda Guerra Mundial, apresentava taxas de analfabetismo em torno de $70 \%$ da população adulta. Situação similar se verificava em Taiwan, onde cerca de $40 \%$ da população adulta era analfabeta no início dos anos 1950. No começo dos anos 1980, a China ainda enfrentava taxas de analfabetismo próximas a $35 \%$ da população adulta, de acordo com o Banco Mundial - no Brasil o índice estava em torno de $25 \%$ na mesma época.

No caso da China, os indicadores educacionais do conjunto do país ainda são bastante deficientes, embora a taxa de alfabetização seja hoje pouco melhor que a brasileira. Por se tratar de um país com dimensões populacionais gigantescas, sua análise merece ser desagregada. 
A China não tomou parte no exame do PISA com o conjunto de seu sistema educacional, como se pode verificar da divulgação dos resultados por meio de entidades subnacionais. O país permitiu que apenas algumas localidades - justamente aquelas em que foram despendidos esforços especiais de qualificação - tomassem parte no exame. Assim, apenas os sistemas educacionais das regiões especiais de Hong Kong e de Macau e da metrópole de Xangai participaram do PISA. Tendo feito uma seleção de quais subgrupos populacionais fariam o exame, os resultados alcançados ficaram acima da média da OCDE - e Xangai figurou em primeiro lugar no ranking internacional.

Ainda que se minimizem os resultados por só cobrir parcela relativamente pequena da população do país, não se pode deixar de considerar que esses subgrupos já formam um contingente populacional bastante relevante. Somente Xangai conta com uma população superior a 23 milhões de habitantes, praticamente a mesma população de Taiwan. Hong Kong por sua vez tem uma população pouco superior a sete milhões, também expressiva. Macau é a única região selecionada para o teste com população muito pequena, inferior a um milhão. No conjunto, embora represente meramente $2,3 \%$ do total da população chinesa, o contingente dessas três localidades supera 30 milhões de pessoas, grupo robusto o suficiente para formar massa crítica e liderar atividades de inovação tecnológica.

Além disso, numa comparação não inteiramente adequada, mas ainda assim válida, se fosse escolhida apenas a cidade economicamente mais vibrante e mais populosa do Brasil, São Paulo, seus resultados educacionais estariam bem abaixo da média da OCDE (414 foi a nota do conjunto do Estado de São Paulo na edição do PISA de 2012). Isso pode ser visto como sinal do avanço obtido pela China em Xangai, mas também pode ser lido pela ótica da extrema desigualdade no ensino ofertado no território chinês, enquanto que o Brasil oferece um ensino de qualidade razoavelmente homogênea, ainda que muito baixa.

Coreia do Sul e Taiwan obtiveram elevadas notas no PISA desde a primeira edição do teste, em 2000, mantendo notas mais ou menos estáveis ao longo do período. Hong Kong, Macau e Xangai participaram do exame pela primeira vez em 2009, o que não permite aferir qual o ritmo da evolução na última década.

No ensino superior, a taxa de jovens que ingressam na universidade é bem superior à brasileira nos casos de Coreia e de Taiwan - e equivalente no caso da China (OECD, 2012). Enquanto que as taxas brasileira e chinesa ficam pouco abaixo dos $20 \%$, Coreia e Taiwan ostentam índices superiores a 50\%.

Também merecem ser citados os dados sobre a qualidade das universidades, já que inovação depende não apenas da média de qualificação dos trabalhadores, mas também da 
existência de grupos especialmente qualificados. Para tanto, faremos uso novamente do ranking acadêmico de instituições de ensino superior elaborado pela Universidade de Shanghai Jiao Tong, que confere particular importância às pesquisas. Nessa listagem das melhores 500 universidades do mundo, como já apontamos na Tabela 10, no tópico anterior, figuram apenas seis universidades brasileiras, contra 28 da China, 11 da Coreia e nove de Taiwan.

Nos casos de Coreia e de Taiwan, o número de instituições de destaque impressiona pela grande quantidade de universidades em relação à relativamente pequena população desses países. No caso da China, o número até guarda certa proporção com o Brasil, se considerado o gigantismo da população chinesa, mas o que chama a atenção é que, além de serem 28 instituições contra apenas seis brasileiras, esse sistema universitário foi praticamente construído do zero nas últimas três décadas, tendo em vista o prévio desmantelamento do sistema de ensino superior pela chamada Revolução Cultural (1966-1969), levada a cabo no período em que o país foi comandado por Mao Tsé-Tung.

Tendo em vista que o ranking confere peso maior para as atividades de pesquisa, o indicador é mais um a demonstrar a relevância da qualificação da mão-de-obra e de sua conexão com atividades de inovação nos países asiáticos. Embora o número de instituições brasileiras não seja desprezível - pelo contrário, o país é o que tem maior número de universidades listadas entre as nações da América Latina -, ainda assim ele mostra que, proporcionalmente, é baixo o número de instituições universitárias de elite no Brasil e bastante significativo nos três países asiáticos em questão.

\subsubsection{Padrões nacionais de aquisição tecnológica}

A apropriação de tecnologias estrangeiras, nos casos de Coreia e de Taiwan, baseou-se principalmente na importação de máquinas e de equipamentos e no uso intensivo da engenharia reversa, havendo relevantes restrições ao investimento estrangeiro direto nos estágios iniciais de industrialização. A cópia das tecnologias estrangeiras foi viabilizada pela fragilidade do regime de propriedade industrial desses países nos anos iniciais de industrialização. Somente no fim dos anos 1980 iniciaram-se as medidas para a adoção de regras mais rigorosas de patentes (CHANG, 2004; KIM, 2005; LIU e LIU, 2004).

Por meio dessas práticas, os países asiáticos puderam promover uma transição de suas empresas de retardatárias em tecnologia para corporações que disputavam o estado da arte, especialmente em tecnologia de informação. Para usar a expressão de KIM (2005), eles passaram da imitação à inovação. O padrão de importação de tecnologias estrangeiras contrasta 
com o brasileiro, uma vez que, no Brasil, predominaram os investimentos estrangeiros diretos em subsidiárias integrais, ao passo que, nos países asiáticos em questão, o investimento estrangeiro direto exerceu papel bastante secundário.

Dos três países examinados, a Coreia foi o que manteve a política mais hostil em relação ao investimento estrangeiro direto. Em Taiwan, até houve alguns esforços localizados - e muito bem regulados - para a atração de capital estrangeiro em polos de exportação. Mesmo com a crescente abertura ao capital estrangeiro nas últimas décadas, Taiwan ainda apresenta números comparativamente modestos em relação a outros países em desenvolvimento. De 2000 a 2010, o ingresso anual ficou em um único dígito em bilhão de dólares, com um pico de US\$ 7 bi em 2007. Segundo dados de 2010, o estoque total de IED em Taiwan era de apenas US\$ 64 bilhões - praticamente o mesmo valor que o Brasil vem recebendo por ano. Ainda em 2010, a Coreia tinha um estoque total de US\$ 127 bilhões; e a China, US\$ 579 bilhões (CHEN, KAO \& KUO, 2012). No mesmo ano, o estoque brasileiro de IED era de US\$ 473 bilhões (DAVIES, 2012).

No caso da China, diferentemente de Coreia e de Taiwan, os investimentos estrangeiros diretos fizeram parte central do modelo de crescimento, mas eles tiveram natureza diferente da que foi verificada no Brasil. Enquanto que no Brasil predominaram os investimentos do tipo turnkey, na China os investimentos vieram em larga medida consorciado com o capital local, principalmente estatal, por meio de modelos como as joint-ventures.

A abertura para os investimentos estrangeiros diretos foram parte da estratégia adotada a partir da assunção ao poder de Deng Xiaoping. Em sua avaliação, seria possível importar os "meios de produção" estrangeiros sem importar as "relações de produção", como escreveu o líder chinês em um ensaio que utilizava carregada linguagem marxista (citado pela THE ECONOMIST, 2005).

Assim, além do papel exercido pela engenharia reversa e pela importação de máquinas e equipamentos, também houve na China volumosos investimentos estrangeiros diretos, à semelhança do Brasil. Mas ao menos duas circunstâncias diferenciam o padrão chinês de IED do padrão brasileiro.

A primeira é que, no início da abertura da China ao mercado externo, ainda nos anos 1980, cerca de dois terços do volume de IED era originado, em rigor, de regiões fortemente associadas à China continental, nomeadamente de Hong Kong, Macau e Taiwan. Duas dessas regiões já foram formalmente incorporadas à China - Hong Kong foi devolvida pela Inglaterra em 1997; e Macau, por Portugal em 1999. Conquanto Taiwan mantenha o status peculiar de Estado independente - mas com governo soberano reconhecido por pouquíssimos 
países -, os laços entre a ilha e o continente só têm aumentado nas últimas décadas. A China, aliás, mantém o objetivo declarado de retomar o controle do território insular (consta até mesmo do preâmbulo da Constituição chinesa que Taiwan é parte de seu território), embora haja forte rejeição dos taiwaneses a essa pretensão. Assim, nessa etapa inicial, boa parte dos investimentos "estrangeiros" era em rigor investimentos oriundos da diáspora chinesa pelo mundo, incluindo o caso peculiar dos taiwaneses (THE ECONOMIST, 2005).

Vale notar que, mesmo utilizando dados mais recentes, de 2010, a participação dessas regiões vinculadas à China continua significativa: o estoque de investimentos estrangeiro direto em 2010 oriundo de Hong Kong corresponde a 41\% do total, e o capital taiwanês representa outros 5\% (DAVIES, 2012).

Some-se ainda que os dados sobre investimento estrangeiro na China, especialmente nos anos 1980 e 1990, são considerados de qualidade muito duvidosa. Já se apontou, por exemplo, que alguns dados ampliavam em até seis vezes o número real, uma vez que empresas locais, aproveitando-se dos incentivos fiscais e regulatórios conferidos às estrangeiras, montavam parceiras estrangeiras fictícias para gozar dos benefícios (KRUGMAN, 1994).

A segunda característica distintiva do IED chinês é que, nas duas primeiras décadas (anos 1980 e 1990), ele ocorreu primordialmente na forma de joint-ventures, e não na forma de IED turnkey. Desse modo, embora o IED tenha exercido um papel equiparável ao ocorrido no Brasil em termos de absorção de tecnologia, empresas locais, com centros decisórios localizados em território chinês, é que estavam direta e formalmente associadas com as multinacionais que dispunham das principais tecnologias. No Brasil, em contraste, a maior parcela do investimento estrangeiro direto ocorreu em empreendimentos inteiramente comandados pelas matrizes de empresas de países centrais, que criaram subsidiárias integrais apenas para operacionalizar algumas atividades fabris, fazendo uso de mão-de-obra mais barata e aproveitando-se da proteção do mercado brasileiro para as manufaturas locais.

De fato, na China, os investimentos estrangeiros diretos podem ser feitos de três maneiras principais: a) joint ventures, caracterizadas por terem capital estrangeiro e local consorciados num empreendimento; b) empresas cooperativas, caracterizadas por parcerias de negócios entre empresas ou instituições estrangeiras e empresas e instituições locais; e c) subsidiárias integrais da empresa estrangeira. Utilizando o total de IED ocorrido até 2002, isto é, nas duas primeiras décadas de abertura e de industrialização acelerada, as joint ventures representaram $53 \%$ do total de projetos e as cooperativas outros $12 \%$, ao passo que as subsidiárias integrais se limitaram a 34\% do total (LONG, 2005). 
O governo chinês estabelece setores econômicos que não estão sujeitos aos investimentos diretos, fixa os locais onde os investimentos podem ocorrer, determina que parcela da produção deve necessariamente ser exportada, ordena o uso de fornecedores locais, entre outros controles sobre o papel do IED na economia local. Além disso, o IED consorciado com empresas locais - muitas vezes empresas estatais - era o modelo preferencial para o IED. O regime somente começou a ser flexibilizado no início dos anos 2000, a partir da adesão da China à $\mathrm{OMC}$, quando as subsidiárias integrais de empresas estrangeiras passaram a ser admitidas em mais segmentos da economia e com menos restrições, seja montando um negócio do zero, seja por meio da aquisição integral de uma empresa pré-existente (TSENG e ZEBREGS, 2002; LONG, 2005).

Tanto as empresas locais se aproveitaram das tecnologias estrangeiras, que houve uma redução no fim dos anos 1990 do modelo de investimentos via joint venture pelo receio crescente dos investidores estrangeiros. Consultores passaram a orientar empresas ocidentais nos anos 2000 a não dar preferência por esse arranjo societário, em razão dos enormes riscos relacionados às joint-ventures.

No entanto, quando eles voltaram a ser praticadas no fim da década de 2000, um texto da consultoria McKinsey, de 2010, sugere que, embora justificáveis em alguns casos, deveriam ser adotadas inúmeras cautelas para as novas joint ventures na China, com o objetivo de evitar prejuízos às empresas ocidentais (McKINSEY, 2010). Entre as recomendações da McKinsey, constam medidas para garantir a proteção da propriedade intelectual, entre as quais a) trazer apenas tecnologias antigas para a China; b) deixar os desenhos técnicos na matriz; c) manter propriedade intelectual mais sensível inteiramente de fora da joint venture, executando apenas tarefas mais simples nas empresas locais; d) cobrar pelo uso da propriedade intelectual em valores pagos em espécie no momento inicial. As orientações da consultoria são resultado das experiências vivenciadas por multinacionais nos anos 1980 e 1990, quando boa parte das tecnologias levadas à China foram absorvidas e copiadas por outras empresas, na maior parte das vezes sem pagamento dos valores de licenciamento.

O resultado desses diferentes modelos de IED pode ser visto, a título exemplificativo, na indústria automotiva. Conquanto China e Brasil sejam grandes produtores de automóveis, não há no Brasil uma empresa automobilística sequer de capital brasileiro, ao passo que na China, além da produção das multinacionais, floresceram várias empresas locais de porte relevante, tais como Geely, JAC e Chery.

A essa trajetória de IED consorciado com o capital local se somou a notoriamente baixa proteção à propriedade intelectual no país, favorecendo a imitação de 
tecnologias estrangeiras. A frágil aplicação de propriedade industrial na China gera protestos frequentes até o presente de empresas estrangeiras, muitas vezes externados também pelos governos desses países, muito embora a China tenha feito inegáveis esforços na última década para ampliar a efetividade da legislação.

Com efeito, depois de 1999, a China passou a estimular fortemente as empresas estrangeiras a estabelecer centros de P\&D na China. Para tanto, estabeleceu várias políticas fiscais que desoneram ou reduzem o encargo tributário das atividades de P\&D desenvolvidas e das rendas obtidas a partir de tecnologias concebidas no país, além de mudanças em sua legislação de propriedade industrial. Em 2002, mais de 400 empresas haviam instituído algum tipo de centro de P\&D na China, incluindo empresas do porte de Microsoft, GE, Siemens, Intel, Honda. Ainda que inicialmente esses centros se limitassem a adaptar produtos desenhados nas matrizes para o mercado chinês, gradativamente essas unidades passaram a desenvolver tecnologias exportáveis, incluindo o licenciamento para outras empresas, aproveitando-se da mão-de-obra barata e crescentemente qualificada das principais universidades e centros de pesquisa chineses (LONG, 2005).

Na etapa inicial do processo de catching up (anos 1980 e 1990), o IED era fortemente dirigido pelo estado chinês. Depois da adesão da China à $\mathrm{OMC}$, houve uma progressiva liberalização das regras, mas permanecem vigentes várias restrições e limitações de setor.

O uso da engenharia reversa foi praticado em todos os países de industrialização tardia. Entretanto, nos países asiáticos ora examinados a engenharia reversa e a importação de maquinário constituíram os principais instrumentos para incorporar às empresas locais tecnologias desenvolvidas no exterior (no caso da China, em conjunto com o IED consorciado, como já indicado). No caso dos países latino-americanos, como boa parte da importação de tecnologia se deveu ao IED turnkey, o papel da engenharia reversa foi comparativamente menor, ainda que também tenha se feito presente.

\subsubsection{Comprometimento de recursos para o aprendizado tecnológico}

O terceiro elemento de contraste é esforço nacional realizado em atividades de pesquisa. Os dados indicados no Gráfico 24, no tópico anterior, revelam o papel crescente dos investimentos em P\&D na Coreia e na China. Taiwan não figura no gráfico por não integrar a base de dados do Banco Mundial, mas as estatísticas de lá são bastante similares às coreanas, ainda que um pouco mais modestas. Em 2001, o país superou a marca de $2 \%$ do PIB destinado 
a P\&D e, em 2012, superou a marca de 3\%. Tal como na Coreia e em outros países desenvolvidos, cerca de três quartos dos recursos têm origem privada e apenas um quarto tem origem estatal.

Coreia e Taiwan têm investido até mesmo acima da média de países da OCDE. No caso da China, embora o dado não seja tão elevado, ainda assim ele revela uma curva de ascensão mais acentuada que a brasileira. Saindo de um patamar um pouco inferior ao brasileiro no fim dos anos 1990, a China superou a marca de $1 \%$ por volta de 2001 e já se aproxima dos $2 \%$ do PIB, enquanto que o Brasil tem patinado em patamar em torno de $1 \%$ do PIB.

Situação parecida se verifica no número de pesquisadores em relação à população, constate do Gráfico 25. De novo, a Coreia consegue mobilizar contingentes maiores de sua população para as atividades de $\mathrm{P} \& \mathrm{D}$, ao passo que o Brasil empenha número bem mais reduzido. A China, mesmo com sua imensa população, conseguiu alcançar uma participação relevante de pessoas em desenvolvimento tecnológico, superior à brasileira. Embora esse dado não esteja disponível para Taiwan, há outros indicadores que sugerem que sua situação está bem próxima à coreana. Segundo o ranking da Bloomberg sobre países inovadores, na lista de países com maior concentração de pesquisadores (researcher concentration) Taiwan aparece em $5^{\circ}$ lugar, enquanto que a Coreia está em $6^{\circ}$, a China em $45^{\circ}$, e o Brasil em $51^{\circ}$ (BLOOMBERG, 2014). Embora a lista não forneça os dados desagregados, a metodologia esclarece que o critério para o cálculo de concentração de pesquisadores é feito por meio da divisão do número de pesquisadores envolvidos em P\&D dividido por milhão de habitantes cálculo similar ao do Banco Mundial.

\subsubsection{Resultados dos esforços nacionais de aprendizado tecnológico}

Os resultados do esforço nacional de aprendizado tecnológico serão mensurados a partir dos indicadores de publicação científica em periódicos internacional e no número de patentes registradas no escritório estadunidense de propriedade industrial.

Em relação às publicações acadêmicas, os dados estão sumarizados na Tabela 13, no subtópico anterior. Os países asiáticos revelaram avanço notável nas últimas duas décadas. No caso da China, passou de $15^{\circ}$ lugar no ranking de publicações indexadas em 1993 para o $5^{\circ}$ lugar em 2013. A Coreia do Sul nem mesmo figurava no ranking dos 25 países com maior número de publicações em 1993 e figura na $12^{a}$ colocação vinte anos depois. Taiwan passou, no mesmo período, do $22^{\circ}$ lugar para o $15^{\circ}$. 
Esses números revelam que o esforço de aprendizado nesses países rendeu frutos no campo acadêmico. Como já se apontou no tópico anterior, o Brasil também tem um desempenho considerável nesse indicador, figurando em $2013 \mathrm{em} 13^{\circ}$ lugar, tendo partido do $24^{\circ}$ em 1993. Entretanto, ao se examinar o indicador de patentes, fica clara a diferença entre os países quanto à incorporação do aprendizado tecnológico ao setor produtivo local.

Ao se examinarem o total de patentes registradas no escritório estadunidense de propriedade industrial por pedidos em que o primeiro solicitante é residente no país de origem, é notável como avançaram rapidamente os três países asiáticos nas últimas décadas, enquanto que o Brasil apresentou evolução apenas modesta. China, Coreia e Taiwan veem demonstrando êxito crescente em converter a capacidade científica que desenvolveram em habilidade tecnológica de seus setores produtivos, em evidente contraste com o Brasil.

O Gráfico 26, no tópico anterior, sintetiza a evolução no número de patentes na última década. Brasil e China partem de números relativamente próximos em 2000 (98 no Brasil, contra 295 na China), mas as trajetórias se divorciam com o passar dos anos: o Brasil sobe para 254 em 2013, enquanto que a China galga o patamar de 6478 patentes no mesmo ano. Taiwan e Coreia atingem números ainda mais impressivos: 11.071 e 14.548 patentes, respectivamente.

Mesmo ressalvando que o índice de patentes obtidas nos EUA tende a privilegiar os países asiáticos por disporem de indústrias orientadas para a exportação (o que tende a estimular que o patenteamento seja realizado também no escritório estadunidense de propriedade industrial), a vantagem do indicador dos países do extremo oriente é tão expressiva em relação aos dados brasileiros, que mesmo eventual atenuação desse viés não altera o baixo esforço inovador do conjunto das empresas e instituições brasileiras.

4.3.5. Outros fatores: orientação para a exportação, integração de instituto de pesquisa com empresas e condições macroeconômicas

Some-se ainda que, diferentemente do Brasil, a industrialização nos três países asiáticos examinados somou a substituição de importações à orientação exportadora. Territórios devastados no período seguinte à Segunda Guerra Mundial e profundamente carentes de recursos naturais, Coreia e Taiwan tinham na formação de uma indústria exportadora praticamente a única via para viabilizar a exportação de produtos primários de que necessitavam. 
É inegável que eles também se utilizaram de inúmeros mecanismos de proteção do mercado interno, entre os quais tarifas alfandegárias, vedação de importações, subsídios e benefícios fiscais. Mas, para além da proteção, as empresas locais também foram obrigadas a destinar uma parcela ou a totalidade de seus produtos para o mercado externo, principalmente para os Estados Unidos. Havia metas de exportações, conforme o setor e o período, conjugadas com subsídios, benefícios fiscais e créditos privilegiados (CANUTO, 1994). O contexto geopolítico da Guerra Fria, nos casos de Coreia e Taiwan (embora não na China), também facilitou o acesso ao mercado estadunidense para as manufaturas asiáticas, privilégio de que o Brasil não gozou.

Atualmente, as exportações desses países - concentradas, aliás, em produtos manufaturados - representam parcela substancial dos respectivos PIBs. No caso da China, a relação exportações/PIB fica em torno de 30\%, na Coreia atinge 49\% e em Taiwan alcança $63 \%$ do PIB. A situação contrasta com a brasileira, em que as exportações representam apenas $11 \%$ do PIB e estão em boa parte concentradas em produtos primários e agrícolas.

Além de evitar desequilíbrios no balanço de pagamentos - fator que muito interferiu na economia do Brasil ao longo das últimas décadas -, o grande papel da orientação exportadora foi manter as indústrias desses países na busca da fronteira tecnológica. Tivessem se limitado aos mercados domésticos, as empresas tenderiam a perder o contato com o que havia pelo mundo de mais novo em termos de produtos, processos e modelos de negócios. A obrigação de exportar impunha às empresas o dever de produzir em conformidade com as melhores técnicas e com preços competitivos, pois do contrário perderiam os benefícios ofertados pelos governos sulcoreano, taiwanês e chinês, seguindo o já referenciado learning by exporting.

Adicionalmente, a integração de institutos públicos de pesquisa e empresas privadas era prática comum e estimulada pelo governo. Em realidade, diferentemente das universidades brasileiras, criadas com foco no ensino, vários institutos públicos de pesquisa foram criados nesses países com o objetivo principal de auxiliar a indústria na incorporação e no desenvolvimento de tecnologias.

É o caso, por exemplo, do Instituto de Pesquisa Tecnológica Industrial de Taiwan, fundado em 1973 e ao qual está relacionada a criação de algumas das maiores empresas mundiais de semicondutores, como a TSMC e UMC. No caso da Coreia, merece destaque o KAIST (Instituto Avançado de Ciência e Tecnologia da Coreia), fundado em 1971 e vinculado à criação de várias tecnologias, além de formação de pessoal na fronteira científica. $\mathrm{Na}$ China, são inúmeras as agências públicas de pesquisa que exercem atividades também 
integradas com o setor privado. Daí a proximidade das linhas de evolução em matéria de publicações acadêmicas e registro de patentes - diferentemente da situação brasileira, em que se verifica avanço acadêmico descasado do progresso tecnológico industrial.

Por fim, em termos macroeconômicos, os países asiáticos não sofreram grandes abalos ao longo das últimas três décadas. O único impacto relevante - nos casos de Coreia e de Taiwan, mas não da China - ocorreu em 1997, por ocasião da crise asiática. Mas, apesar de fortemente afetados pela crise de 1997, nesse momento Coreia e Taiwan já estavam em grau de industrialização mais avançado, com renda per capita equivalente à metade do poder de compra de um americano e $60 \%$ de um europeu ocidental, e indústrias maduras em diversas áreas. A Coreia, por exemplo, já exportava semicondutores, eletrônicos, automóveis e navios. Taiwan já havia se tornado um dos líderes em eletrônicos e computadores, e a China, menos afetada pela crise, seguia seu passo de expansão industrial em numerosos setores.

A estabilidade macroeconômica é indiscutivelmente um fator central para viabilizar investimentos de longo prazo, como o são os investimentos em P\&D. A expectativa de crescimento relativamente balanceado confere horizontes mais claros para que os empresários e mesmo o governo invistam em atividades que tendem a render frutos apenas anos depois de iniciadas. Essa diferença de cenário econômico entre o Brasil e os países asiáticos examinados sem dúvida corroborou na constituição de empresas envolvidas em atividades de P\&D.

Em síntese, o sistema de aprendizado tecnológico que caracterizou os países asiáticos em questão contrasta com o modelo brasileiro e pode ser definido como "ativo", eis que, além da absorção tecnológica por empresas locais, possibilitou que elas dessem novos passos e criassem tecnologias próprias.

As principais características desse modelo se resumem em mão-de-obra muito qualificada, papel relevante do capital local nas empresas industriais, mobilização de atividades de $P \& D$, patenteamento crescente e pujante, substituição de importação conjugada com orientação exportadora, integração com institutos públicos de pesquisa e relativa estabilidade macroeconômica. 


\subsection{A industrialização e a incorporação de tecnologia como um projeto nacional}

Nenhum desses processos de industrialização examinados ocorreu à margem da ação estatal. Nem o aprendizado passivo, nem o ativo. Ambos fizeram parte de uma estratégia defendida pelos governos locais a partir dos anos 1950, com nuances locais. O desenho regulatório, o tipo de intervenção estatal, a intensidade, o momento e a duração das medidas é que produziu efeitos distintos nas trajetórias de cada nação.

Além do caso desses quatro países, as trajetórias de desenvolvimento de outras nações na história contemporânea estão sempre associadas a um papel importante do estado na formação de instituições e de estruturas econômicas que permitam o processo de emparelhamento. Esse processo ocorreu com pequenas variações de um país para o outro, mas as medidas gerais guardam forte semelhança, quer tenham ocorrido em países democráticos (a exemplo da Inglaterra, dos EUA e da França), quer sob regimes autoritários (Alemanha, Japão, Coreia e Taiwan).

A despeito da força das teses livre cambistas advogadas, entre outros, por Adam Smith (1723-1790), as políticas de desenvolvimento econômico seguiram uma linha muito mais próxima à proposta pelo americano Alexander Hamilton (1755-1804), ou pelo alemão Friedrich List (1789-1846). A proteção à indústria nascente e a forte regulação estatal dominaram as políticas de desenvolvimento econômico nos últimos dois séculos.

Mesmo a Inglaterra, berço e principal propagadora do livre mercado, adotou no início de seu processo de industrialização tarifas protecionistas, subsídios estatais, compras públicas voltadas para o mercado interno e restrições ao comércio em suas múltiplas colônias. Os Estados Unidos são célebres defensores de tarifas protecionistas até o desfecho das duas grandes conflagrações bélicas do século XX e, desse modo, construíram seu vultoso parque industrial.

Na segunda metade do século XX, os mais notórios casos de países que obtiveram êxito em suas estratégias de emparelhamento são as nações do leste asiático (Japão, China e os "tigres asiáticos") e algumas latino-americanas (especialmente Brasil e México). No caso destes, o avanço na industrialização foi pronunciado, mas a renda per capita estagnou ou parou de avançar tão rapidamente a partir da denominada crise da dívida externa, nos anos 1980. No caso daqueles, há diferenças no momento de crescimento de cada um, mas, à exceção da China, os demais já alcançaram níveis de renda per capita próximos à média da OCDE. 
Tanto no caso dos latino-americanos, quanto no dos países asiáticos esteve presente um estado atuante, que fomentou a indústria local, protegeu-a de importados e procurou criar condições para que as manufaturas locais se expandissem. Nenhum dos países que seguiu a trilha de emparelhamento da renda conseguiu fazê-lo sem a implantação de uma estratégia razoavelmente delineada e coordenada por um poder público central.

Há aqueles que mencionam os supostos exemplos de baixa intervenção estatal bem sucedidos, apontando para os casos de Singapura, Hong Kong ou mesmo Irlanda. É preciso ter em conta, porém, que esses países são verdadeiras cidades-estados ímpares, com populações diminutas. Suas políticas de desenvolvimento peculiares não podem ser estendidas a nações de maior porte.

Boa parte do sucesso econômico desses países se deve à localização privilegiada junto a grandes mercados (Japão e China, no caso dos asiáticos; e União Europeia, no caso da Irlanda) e à adoção de políticas tributárias que os tornaram praticamente paraísos fiscais. Ademais, mesmo nessas nações, o papel do Estado foi determinante na alocação de investimentos e na construção de instituições que respaldaram seu crescimento (CHANG, 2004).

O que esses casos revelam, inclusive os exemplos de opção por intervenção mais branda, é que o desenvolvimento econômico foi parte de um plano de longo prazo. Mesmo no caso de nações como Singapura, houve um planejamento decisivo para reduzir custos locais, atrair capital estrangeiro em grande volume em setores específicos, investir em infraestrutura e formar mão-de-obra qualificada. O estonteante progresso singapuriano não foi obra do acaso: mesmo para que o mercado funcione, há que haver um poder público que assegure o estado de direito e estabeleça as regras dentro das quais os agentes privados atuarão.

Os países do leste asiático que se industrializaram na segunda metade do século $\mathrm{XX}$, com destaque para a Coreia do Sul, adotaram como esforço de emparelhamento não apenas a busca por produzir produtos manufaturados, mas principalmente por produzir tecnologia local. Política tecnológica e política industrial estavam acopladas. Essa parece ser uma das diferenças centrais entre a política industrial asiática e o modelo latino-americano, já que este se voltou primordialmente ao exercício da atividade manufatureira, sem que o desenvolvimento tecnológico fosse objeto central do esforço industrializante. Em outras palavras, a política científica e tecnológica era parte distinta da política industrial na América Latina.

No caso brasileiro, assim como no de outros latino-americanos, o projeto inicial de desenvolvimento baseou-se em larga medida nas teses da Comissão Econômica para a América Latina e Caribe - CEPAL e da chamada "teoria da dependência". Segundo essa visão 
estruturalista, encampada por nomes como o argentino Raúl Prebisch e o brasileiro Celso Furtado, o subdesenvolvimento não seria uma etapa anterior ao desenvolvimento, e sim uma condição. No contexto da divisão internacional do trabalho, os países periféricos exerceriam o papel de exportadores de produtos primários, ao passo que os países centrais centralizavam o processo de manufatura. Muito resumidamente e ressalvando as diferentes nuances de vários pensadores da corrente, a ruptura dessa condição dependeria de uma intervenção estatal que permitisse aos países periféricos ingressar na etapa de industrialização.

Ao longo dos anos 1960 e 1970, vários dos adeptos da teoria, incluindo o próprio Celso Furtado, deram-se conta de que um processo de industrialização estava em curso na periferia, mas não estava rompendo o padrão centro-periferia. Persistia a dependência tecnológica. O "fluxo da tecnologia" continuava rumando dos países centrais para os periféricos, que apenas executavam certas etapas dos processos industriais, aproveitando-se da mão-de-obra mais barata, mas sem produzir novas tecnologias, nem, via de regra, exportar produtos industriais para os países em que se sediavam as matrizes das empresas que os fabricavam.

Essa situação retrata o processo de industrialização no Brasil vivenciado principalmente nos anos 1960 e 1970. O país foi bem sucedido em diversificar seu parque industrial, alcançando parcela relevante do PIB originada na produção industrial. Entretanto, as tecnologias empregadas nas principais indústrias eram desenvolvidas no exterior e executadas no Brasil por meio de investimentos estrangeiros diretos sob controle integral de empresas estrangeiras. Assim, foi no contexto da internacionalização das empresas do centro que o desenvolvimento industrial da América Latina se concretizou, e não propriamente de um esforço local de industrialização e aprendizado tecnológico.

Ainda nos anos 1970, Celso Furtado escrevia que, nessa etapa de industrialização do Brasil, posterior à histórica situação colonial, o país passou a "fabricar para uso interno produtos com tecnologias desenvolvidas no exterior. Nem os exportamos, nem desenvolvemos novas tecnologias".

Nessa leitura, a industrialização nos países periféricos refletia muito mais a expansão das empresas das economias centrais do que um esforço nacional de industrialização bem sucedido. Os países latino-americanos que se industrializaram - notadamente Brasil e México - eram considerados um apêndice da indústria dos países centrais, e não novas civilizações industriais. O principal fator para diferenciar essas categorias residia na capacidade tecnológica de cada um. No caso dos latino-americanos, isso se evidenciava na completa dependência tecnológica entre as indústrias locais e as matrizes nas economias centrais. 
Como aponta BORJA (2008), o sentido em que se dá a geração, difusão e assimilação do progresso técnico é fundamental para analisar a condição de subdesenvolvimento e para determinar a condição de dependência. O sentido da tecnologia, do centro à periferia, implica uma contrapartida no fluxo de renda.

Ao examinar o papel desempenhado pelo tripé constituído por Estado, capital nacional e capital transnacional, FURTADO registra que as atividades dirigidas por esses três grupos tendem a ser mais complementares que competitivas. Ele aponta que as empresas controladas diretamente pelo Estado têm a exclusividade de certas áreas e predominam em atividades infraestruturais ou criadoras de economias externas, as quais requerem grandes imobilizações de capital e não são afetadas pelo progresso tecnológico ligado à constante inovação de modelos.

Já o grupo privado nacional controla as atividades de construção, certas manufaturas tradicionais e opera amplamente como subcontratista das grandes empresas estatais e das ligadas aos grupos internacionais. Estas últimas, por sua vez, têm o controle quase total das indústrias de bens duráveis de consumo, químico-farmacêutica e equipamentos em geral, que em conjunto formam o bloco em mais rápida expansão e onde mais significativa é a penetração do progresso tecnológico (FURTADO, 1972).

$\mathrm{Na}$ leitura furtadiana, baseada nos casos europeus de industrialização tardia do século XIX, a consolidação de um sistema econômico nacional autônomo e calcado em centros nacionais de decisão constituiu um fator indispensável ao rompimento do atraso. Percebe-se em tais conceitos a preeminência da "questão nacional", da formação do Estado nacional (BORJA, 2008).

Em 1983, FURTADO apontava que a implantação de centros criadores e irradiadores de novas técnicas na periferia, subordinados aos interesses específicos delas próprias, constituiria condição necessária à eliminação da situação de dependência estrutural em que essas nações se encontravam. Somente assim, avaliava ele, poderiam surgir condições para que as relações internacionais deixem de operar como mecanismo de transferência de recursos em benefício de uns poucos povos privilegiados e em detrimento da maioria da humanidade (FURTADO, 1983).

Mas as mudanças por que passou a economia brasileira e a mundial desde os anos 1980 impuseram uma adaptação substancial desse pensamento cepalino. A abertura econômica que se seguiu nos anos 1990, a internacionalização crescente de empresas estrangeiras e mesmo de brasileiras, a autonomia progressiva de um sistema financeiro pouco regulado e internacionalizado (enfraquecendo a regulação estatal nacional), a criação da 
Organização Mundial do Comércio e a adoção do Acordo TRIPS (vedando estratégias de industrialização tardia outrora utilizadas em larga escala), tudo isso impôs uma readaptação das ferramentas utilizadas então para o processo de emparelhamento.

A abertura econômica e a internacionalização crescente das empresas tornaram mais difíceis o controle sobre os fluxos de capital e provocaram uma verdadeira disputa entre as nações a respeito da formação de empregos industriais, em geral mais bem remunerados. $\mathrm{O}$ sistema financeiro crescentemente desregulado, ao menos até a crise financeira de 2008, praticamente inviabilizou a adoção de medidas restritivas aos "movimentos de manada" e à fixação de limites à participação do capital estrangeiro na produção nacional, especialmente para os países periféricos e dependentes do ingresso de capital externo.

No campo dos regimes internacionais, a OMC e o Acordo TRIPS restringiram fortemente várias das políticas adotadas anteriormente por países em processos de emparelhamento, incluindo certas medidas de cunho protecionista e a cópia de tecnologias estrangeiras por empresas locais mediante engenharia reversa.

Além desses fatores, a redução dramática do nível de endividamento e de vulnerabilidade externa do Brasil na primeira década do século XXI situou o país em outro patamar em foros internacionais e nos fluxos de capital. A acumulação de reservas cambiais vultosas, a ampliação substancial das exportações e, mais recentemente, a descoberta dos campos de petróleo no pré-sal tornaram bem menos pronunciada a histórica dependência de capital estrangeiro para equilibrar o balanço de pagamentos e o déficit crônico da conta corrente. Mesmo com esse cenário, a partir de 2008, o país voltou a depender do ingresso de capital estrangeiro para o equilíbrio do balanço de pagamentos, situação que se tornou mais pronunciada a partir de 2012 .

Nesse contexto, outras estratégias de desenvolvimento assumiram papel de maior destaque, em lugar da tradicional proteção ao mercado doméstico para as manufaturas locais. Ampliaram-se as possibilidades da utilização de estímulos à $\mathrm{P} \& \mathrm{D}$ com fundos públicos, o que se materializou no Brasil principalmente por meio da criação e da expansão dos chamados fundos setoriais (administrados principalmente pela FINEP), do estímulo às pesquisas cooperativas entre academia e indústria (Lei de Inovação), da utilização do poder de compra do estado para aquisição de produtos fabricados ou desenvolvidos no Brasil (tais como as políticas de conteúdo nacional para embarcações e plataformas de petróleo para a Petrobrás, ou as compras públicas em licitações) e ainda do financiamento por meio de bancos oficiais a setores considerados estratégicos (notadamente via BNDES). 
Nesse rol de novas políticas de desenvolvimento tardio discutidas em foros econômicos, constam também medidas tributárias que favorecem a exportação de manufaturados e desestimulam a venda de produtos primários, tais como alíquotas decrescentes de exportação conforme o grau de processamento. O Brasil, no entanto, vem trabalhando com alíquotas zero para praticamente todos os bens vendidos no exterior.

Outra medida adotada pelos países é a mudança na estrutura da educação pública e de treinamento de mão-de-obra, de modo a estimular o aprendizado tecnológico e permitir a criação de empresas inovadoras. A estrutura federativa e descentralizada da educação brasileira, no entanto, tem dificultado a adoção de mudanças mais substantivas e generalizadas, embora iniciativas locais tenham prosperado aqui e acolá. Estão relacionadas com essas diretrizes a expansão do ensino superior, com ênfase em cursos de Engenharia (pela primeira na história, houve mais ingressantes em cursos de Engenharia do que em cursos de Direito em 2011), conjugada com a intensa ampliação do ensino técnico (a rede de ensino técnico federal mais do que dobrou na última década).

Não se encontram, entretanto, iniciativas mais arrojadas, como a criação de novos centros similares ao ITA, Embrapa ou CENPES, por exemplo. A criação da Embrapii em 2012 segue a linha de promover a integração de universidade-empresa e estimular a pesquisa custeada pelo poder público, mas os resultados ainda são incipientes.

O câmbio é indiscutivelmente um dos fatores estratégicos na formatação desse novo modelo de desenvolvimento industrial. Entretanto, muito embora as empresas manufatureiras de modo geral apoiem a desvalorização da moeda local, o fato de muitas das empresas do setor no Brasil trabalharem com parcela significativa dos insumos importados, a coalizão pró-desvalorização não é tão pronunciada, mas o tema será abordado com mais profundidade no Capítulo 7 desta pesquisa.

É preciso levar em conta também que, mesmo nos países desenvolvidos, o papel do estado não só foi, mas ainda é crucial no desenvolvimento de novas tecnologias. Como aponta MAZZUCATO (2013), praticamente todas as grandes inovações das últimas décadas foram produzidas a partir de forte participação estatal, quer comandando diretamente as pesquisas, quer financiando essas atividades. A autora aponta, por exemplo, para o caso do iPhone da Apple: a grande inovação do produto foi, na verdade, reunir de modo fácil tecnologias desenvolvidas ou financiadas diretamente pelo governo americano, tais como a internet, o celular, o GPS e a tela sensível. Mesmo o revolucionário algoritmo de pesquisa do Google foi desenvolvido em uma pesquisa financiada pelo governo estadunidense. Situação 
similar se verifica nos casos da indústria farmacêutica e de energia, para citar os setores mais intensivos em inovações nos últimos anos (MAZZUCATO, 2013).

A partir desses e de outros exemplos, a autora aponta que o papel de empreendedor e de tomador de risco vem sendo exercido, historicamente, pelo poder público, e não por empresas privadas. O setor privado - mesmo no caso de "venture capital" - executa atividades de inovação já nas etapas finais, de colocação de produtos no mercado. As inovações mais radicais, a criação e o desenho de novos mercados, tudo isso tem ficado a cargo do poder público, tanto nos Estados Unidos, quanto na Europa.

É nesse contexto que o esforço de emparelhamento tecnológico deve ser visualizado. O desenvolvimento econômico está conjugado com a política tecnológica. Seria temerário privar os países em desenvolvimento desse papel central exercido pelo poder público, relegando toda a atividade de inovação às forças de mercado, que nem nas pujantes economias centrais exercem essa tarefa de maneira ampla. No caso das indústrias de baixo carbono, muito provavelmente os países cujos estados estão engajados nesse esforço vão liderar as novas tecnologias. Cabe às nações que buscam o emparelhamento definir se preferem seguir como importadoras de tecnologias estrangeiras, ou se preferem arcar com o custo para disputar a liderança tecnológica nesse novo setor.

No caso da Coreia, por exemplo, o esforço de industrialização tardia significava não apenas produzir itens industrializados, mas principalmente absorver a tecnologia necessária para produzi-los. Esse elemento não esteve presente na mesma intensidade na industrialização brasileira.

A construção de um projeto nacional de industrialização tem se relevado decisiva não apenas sob o aspecto de crescimento econômico de longo prazo, mas também do ponto de vista geopolítico. Dispor de tecnologias próprias ou ter capacidade de alcançá-las em um breve espaço de tempo repercute no nível de autonomia de que goza um país no cenário internacional.

Além de econômica e politicamente relevante, o desenvolvimento de tecnologias próprias é também uma questão de peso do ponto de vista ambiental. Embora no caso do aquecimento global, os gases emitidos em um país afetem os demais, em vários outros casos o país afetado é aquele em que acontece a atividade industrial. Não custa lembrar que, quando ocupou o cargo de economista-chefe do Banco Mundial nos anos 1980, aquele que viria a ser Secretário de Tesouro dos EUA e Chefe do Conselho de Assessores Econômicos da Casa Branca chegou a propor num memorando interno (que vazou para a imprensa) que as indústrias poluentes fossem transferidas para os países menos desenvolvidos, porque os custos 
ambientais e financeiros seriam arcados primariamente por eles. Em suas palavras, Larry Summers escreveu: “'Dirty’ Industries: Just between you and me, shouldn't the World Bank be encouraging MORE migration of the dirty industries to the LDCs [Least Developed Countries]?"

Historicamente, o desenvolvimento tecnológico e industrial não se realizou com base apenas numa ideia pueril e simplista de livre mercado. O estado pré-existe ao mercado, e o desenho da regulação e atuação estatal é que definem o êxito ou o fracasso das iniciativas. Isso se deve não apenas aos empecilhos provocados por falhas de mercado, mas também às implicações políticas e estratégicas que o desenvolvimento econômico acarreta em todo o mundo.

Os países que lograram emparelhar-se e alcançar níveis de renda e de tecnologia próximos à fronteira tecnológica foram os que conseguiram manejar com eficácia os instrumentos estatais disponíveis para utilizar o mercado de modo eficaz e dar passos rumo ao aprendizado tecnológico e à inovação. O desafio é quais os instrumentos adequados e qual a intensidade em que eles devem ser implantados, já que, mal aplicados, seus resultados também podem ser profundamente danosos à economia local.

\subsection{Energia de baixo carbono e o nascimento da uma nova indústria}

Os tópicos anteriores deste capítulo buscaram demonstrar que, no processo de emparelhamento econômico (catching up), os países retardatários adotaram políticas públicas para construir sistemas nacionais de aprendizado, e não de inovação. Além disso, procurou-se diferenciar os sistemas de aprendizado de países selecionados do leste asiático, com um caráter mais ativo, do sistema verificado no Brasil, de natureza predominantemente passiva.

É relevante examinar se essa caracterização mais abrangente do setor manufatureiro desses países é válida também para o setor de energia. Mais especialmente, para o segmento de energia com baixa emissão de carbono. É essa a análise que se pretende fazer nos capítulos seguintes.

As razões para fazer uma análise destacada desse segmento são relativamente simples: 
1) o setor de energia tem indiscutível caráter estratégico, já que dele dependem praticamente todas as outras atividades econômicas;

2) o setor representa o principal componente da economia global e é o principal item de comércio internacional (nos EUA, por exemplo, o setor de energia isoladamente representa $8 \%$ do PIB);

3) as tecnologias para geração de energia de baixo carbono são relativamente recentes, de modo que não há ainda grande disparidade tecnológica entre os líderes e os late movers, diferentemente do que ocorre, por exemplo, na indústria de semicondutores para produtos eletrônicos;

4) a transição de fontes de energia representou historicamente um momento decisivo no papel desempenhado por países no cenário internacional, tal como evidenciado na adoção do carvão na Inglaterra e do petróleo nos Estados Unidos; e

5) em razão das mudanças climáticas, o regime internacional ruma no sentido de restringir a emissão de carbono e estabelecer rígidas regras de propriedade intelectual, acarretando a criação de um mercado potencial de grande porte para a geração de energia com baixa emissão de carbono.

Nesse contexto, pode-se dizer que há uma janela de oportunidade para que os países em processo de emparelhamento entrem na disputa pelas novas tecnologias. Ao mesmo tempo - e como contrapartida -, existem riscos elevados nesse processo: desde a completa dependência tecnológica para a geração de energia, passando pelos riscos empresariais de falência em um mercado saturado de novos concorrentes.

Para evitar um aumento da temperatura da terra cima de $2^{\circ} \mathrm{C}$, a redução das emissões teria que ser substancial e teria que se iniciar o quanto antes. Como o carbono se acumula por décadas, as atuais emissões seguem promovendo aquecimento pelos próximos anos. Quanto mais se adia a redução na curva de emissões, mais intensa teria que ser a redução nos anos seguintes.

O Gráfico 27 projeta trajetórias de emissões para os países desenvolvidos ("norte") e para os países em desenvolvimento ("sul”), buscando conferir maior espaço para que os países de menor renda façam uma transição suave. Mesmo segundo essa curva, o início das reduções já teria que se iniciar no início da década de 2010-2020, o que ainda não está ocorrendo. De todo modo, o gráfico deixa evidente a intensidade da mudança que seria necessária, e o gigantismo do mercado de baixo carbono para energia. 
É preciso ter em conta, no entanto, a ressalva apontada por ZYSMAN e HUBERTY (2013), para quem o crescimento econômico não advém exclusivamente da substituição de uma fonte energética por outra. Como aponta o autor, o simples fato de a geração de energia solar, para ficar em um exemplo, demandar mais trabalhadores do que a geração térmica para a mesma quantidade de energia é sinal de ineficiência do segmento, e não de expansão do emprego. O aumento de renda da população se dá pelo aumento da renda per capita. Se para gerar um mesmo produto ( $\mathrm{kW}$ de energia) estão sendo utilizados mais trabalhadores, há em rigor uma perda de eficiência, já que esses trabalhadores adicionais poderiam estar exercendo outras atividades produtivas.

\section{GRÁFICO 27}

Limites das emissões para evitar aumento superior a $2^{\circ} \mathrm{C}$

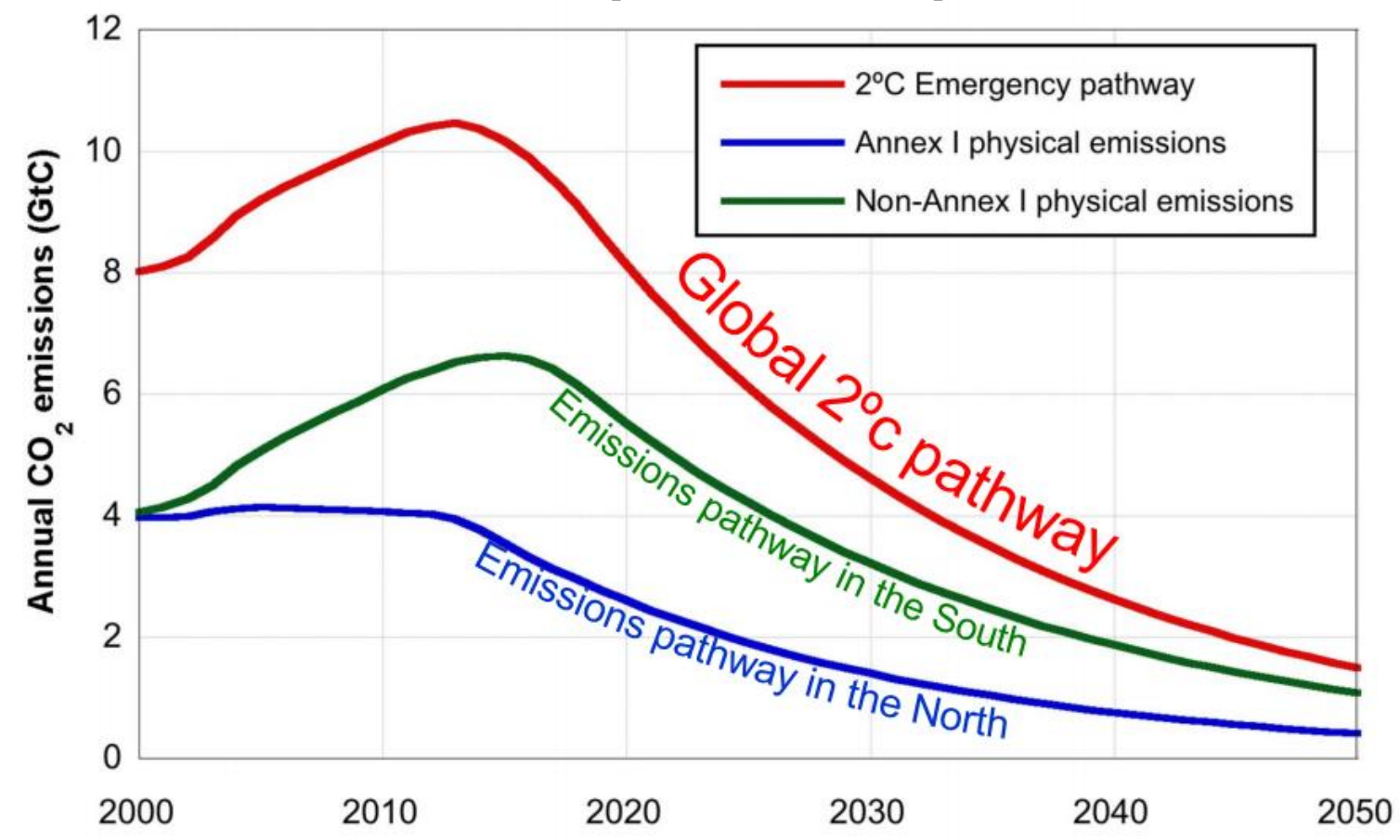

Fonte: KAMMEN, 2013.

Apesar da pertinência da ressalva à ingênua ideia de "crescimento verde" por meio da simples substituição de uma fonte pela outra, ainda assim é possível falar-se em crescimento econômico a partir da exploração do novo mercado de geração de energia com baixa emissão, especialmente em países retardatários.

Primeiramente, porque a alternativa de se resignar às fontes tradicionais de energia resultaria em completa dependência tecnológica quando advierem restrições mais sérias à emissão de gases estufa. Desse modo, mesmo a preservação do modelo atual de crescimento seria limitada pelo regime internacional em formação. 
Em segundo lugar, porque a manutenção do atual modelo de expansão da oferta de energia já é em larga medida dependente de tecnologia estrangeira. Para ficar apenas no caso das hidrelétricas, hoje nossa principal fonte de eletricidade, os geradores de todas as grandes usinas (Itaipu, Belo Monte, Jirau, Santo Antônio) foram desenvolvidos no exterior por empresas estrangeiras, ainda que alguns deles sejam parcialmente montados no Brasil. O desenvolvimento de novas fontes pode, portanto, reduzir a dependência já existente, ainda que não houvesse restrição à emissão de carbono.

Em terceiro lugar, porque existe um mercado de exportação potencialmente gigantesco, a seguir as previsões de crescimento do IPCC e da EIA/EUA, conforme indicado anteriormente. Demitir-se de disputar esse mercado seria extremamente desarrazoado.

Em quarto lugar, deve ser considerado o fato de o Brasil dispor, em seu território, de abundantes fontes de energia cuja geração provoca baixa emissão, notadamente biomassa, ventos, radiação solar e mesmo quartzo (matéria-prima dos paineis solares) e urânio (matéria-prima da energia nuclear). Somando-se a isso a existência de forte regulação estatal no setor, há espaço para algum nível de proteção do mercado nacional para fomentar tecnologias aqui desenvolvidas.

Em quinto lugar, existe o efeito spillover que o desenvolvimento de novas tecnologias num setor tão transversal como o de energia pode provocar. Além dos ganhos ambientais oriundos da baixa emissão de carbono, pode-se falar na autonomia tecnológica do setor energético, na utilização de tecnologias para geração de energia em outras atividades econômicas (a purificação do silício para paineis solares poderia, por exemplo, resultar em outras aplicações industriais, assim como a biomassa tem ensejado o desenvolvimento de bioplástico), na consolidação de um paradigma de inovação na economia.

Vale ainda notar que a continuidade do modelo de expansão da oferta energética com grande peso dos combustíveis fósseis tende a se revelar ilusória - ou catastrófica. Isso porque, como revelou relatório conjunto do CARBON TRACKER e do GRANTHAM RESEARCH INSTITUTE (2013), com a participação de economistas como NICHOLAS STERN, a queima das reservas de petróleo, gás e carvão já abrangidos nos balanços das empresas do setor provocaria uma elevação da temperatura bem superior à que se espera venha a ocorrer. A serem sérios os esforços governamentais para restringir a emissão de carbono, haverá limites à queima de combustíveis fósseis, o que significa que existe uma volumosa bolha nos ativos das companhias - "carbon bubble", na expressão do autor. Não havendo restrição à queima de todo o carbono contabilizado em seus ativos, estaremos em um cenário climático pior do que o previsto nos relatórios do IPCC. 
De fato, de acordo com o relatório, pelo menos dois terços do petróleo, gás e carvão que hoje estão computados nas reservas das empresas do setor teriam que permanecer intocados apenas para que o planeta cumpra as metas de redução de carbono já existentes, de modo a evitar mudanças climáticas perigosas. Assumindo que a meta seria evitar elevação da temperatura acima de $2^{\circ} \mathrm{C}$, a Figura 3 mostra a distância entre o máximo de queima de combustível fóssil aceitável e o montante bem superior de reservas das companhias, além das pesquisas que seguem em curso para ampliar as reservas.

FIGURA 3

Reservas listadas em comparação com o limite de emissões

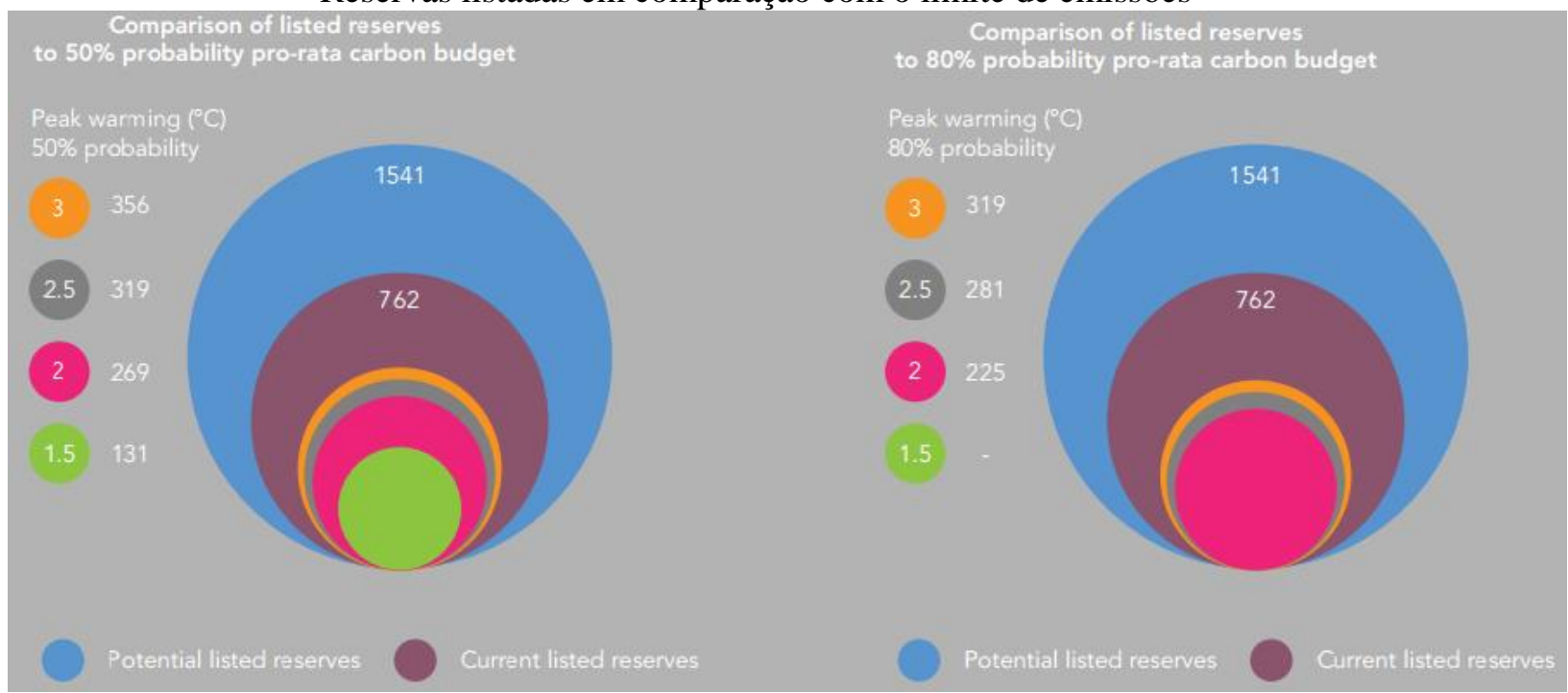

Fonte: CARBON TRACKER e GRANTHAM RESEARCH INSTITUTE, 2013.

Some-se ainda que o atual padrão brasileiro de dependência acentuada da fonte hídrica para geração de eletricidade enfrenta riscos adicionais trazidos pela mudança climática. O cenário de grave seca presente nos últimos anos acarretou a redução do volume de água armazenada nos reservatórios e pôs em alerta as autoridades do setor elétrico para assegurar o fornecimento de energia. Esse cenário explicitou alguns dos problemas que a preponderância da fonte hídrica pode provocar, especialmente em face dos riscos de recrudescimento de cenários de seca em razão da mudança climática.

Em síntese, um mercado de grande porte para a geração de energia a partir de fontes que provocam baixas emissões de gases estufa está em formação. Por ser o setor estratégico para a economia de todos os países, pelo fato de o Brasil dispor de grande potencial e de recursos abundantes, não conviria apostar na expansão da oferta pelas vias tradicionais de geração. Ao revés, trata-se de uma oportunidade para fazer uso das vantagens de que dispõe 
para reverter o modelo de aprendizado passivo e investir num sistema de inovação mais robusto.

Nos capítulos seguintes, o que examinaremos é justamente se o Brasil e os países asiáticos selecionados estão trilhando esse caminho. O estudo do caso desses países revelará que, também no setor de energia de baixo carbono, o Brasil vem reproduzindo o modelo de aprendizado passivo, baseando parcela significativa dessa nova indústria de baixo carbono em tecnologias importadas para manufatura em território nacional. Em contraste, os países asiáticos em questão têm mantido a busca pelo aprendizado ativo ou mesmo pela inovação radical executada por empresas locais, sediadas nos próprios países. 


\title{
CAPÍTULO 5
}

\section{COMO FOMENTAR NOVAS TECNOLOGIAS? POLÍTICAS PÚBLICAS NO SETOR DE ENERGIA EM PAÍSES DE INDUSTRIALIZAÇÃO TARDIA}

\begin{abstract}
"Nada é mais difícil de executar, mais duvidoso de ter êxito ou mais perigoso de manejar do que dar início a uma nova ordem de coisas. O reformador tem inimigos em todos os que lucram com a velha ordem e apenas defensores tépidos nos que lucrariam com a nova ordem." Nicolau Maquiavel, em "O Príncipe”
\end{abstract}

\subsection{Por que a mudança climática não se resolve pelo mercado?}

Os pressupostos para o funcionamento perfeito do mercado são muito raramente encontrados na realidade. Em regra, busca-se avaliar quão grave são as falhas de mercado encontradas e compará-las com as falhas de governo que eventual intervenção provocaria.

No caso das mudanças climáticas, pode-se dizer que há ao menos duas graves falhas de mercado: a externalidade negativa provocada pela emissão de gases de efeito estufa e também o uso excessivo de um recurso comum. Na definição de STERN (2006), a mudança climática é decorrência da "maior falha de mercado que o mundo já viu".

A externalidade negativa, em economia, é caracterizada pelo prejuízo que determinada atividade ou operação provoca para pessoas não envolvidas na ação. No caso das mudanças climáticas, aqueles que provocam danos ao meio ambiente por meio da emissão de gases de efeito estufa prejudicam o conjunto do planeta e não arcam com o custo que suas ações acarretam para terceiros. De fato, há uma flagrante externalidade negativa em atividades como o desmatamento e a queima de combustíveis fósseis, uma vez que o benefício obtido pela atividade não resulta numa compensação equivalente para o conjunto das pessoas que são prejudicadas pela emissão adicional de carbono.

Além disso, a emissão de gases estufa também caracteriza o uso excessivo de um recurso comum - no caso, a atmosfera. Os bens comuns são comumente conceituados como os recursos rivais e não-exclusivos. Por "não-exclusivos" estão compreendidos os bens cujo consumo não é restringido pela capacidade de pagar da pessoa (limitação via pelo preço), ao passo que por "rivais" se entendem os bens cujo consumo impede o consumo por outra pessoa (limitação pelo exaurimento ao consumir). 
No caso das mudanças climáticas, a emissão de gases estufa por um ator não impede que outro também o faça. Isso porque, como não existem limites estabelecidos para as emissões, não há exclusividade em fazer da atmosfera um local de despejo. Ao mesmo tempo, porém, ao emitir gases estufa, provoca-se um "exaurimento" gradativo da atmosfera (rivalidade), resultando numa modificação da temperatura média do planeta. Ou seja, embora rivais, as emissões não encontram limitações.

Vale notar que, nesse caso, embora caracterizada em parte a chamada "tragédia dos comuns" - teoria segunda a qual o livre acesso e a demanda irrestrita a um recurso finito terminam por provocar sua superexploração, caso não haja regulação adequada -, a situação difere levemente dos exemplos clássicos dessas situações, como os que envolvem o exaurimento de terras comuns não administradas ou a extinção de espécies (HARDIN, 1968). A diferença reside fundamentalmente no fator tempo. Enquanto que o exaurimento nesses outros casos é verificável via de regra em poucos anos, no caso das mudanças climáticas o impacto leva décadas para se tornar sensível e, dada a complexidade do fenômeno, ainda assim é objeto de controvérsia fora da comunidade científica.

Para tornar a situação ainda mais intrincada, o fenômeno das mudanças climáticas é internacional. Diferentemente de outros problemas típicos de poluição - que em geral provocam impactos locais, como a chuva ácida e a poluição de rios -, a emissão de gases estufa em qualquer lugar do planeta contribui para o conjunto da mudança climática. Não importa se os gases partiram de uma indústria estadunidense, ou da pecuária na Nova Zelândia, a atmosfera afetada é a do planeta.

Não bastassem todas essas complexidades, é preciso somar ainda que não só as empresas beneficiárias das atividades que provocam emissão não arcarão com o custo correspondente, mas nem mesmo os países que mais emitem tendem a ser os mais prejudicados pela mudança climática. Pelo contrário, a seguir os modelos indicados pelo IPCC, os países tropicais - em geral os mais pobres - tendem a sofrer os maiores impactos pela mudança climática, muito embora os países localizados nas zonas temperadas sejam historicamente os maiores emissores - e os mais ricos. Mesmo dentro de cada país, os grupos econômicos de menor renda tendem a ser mais afetados do que os grupos de maior renda.

Esse conjunto de fatores é crucial para compreender as soluções possíveis e as dificuldades para implantá-las. Tradicionalmente, as opções para lidar com os problemas das tragédias dos comuns podem ser agrupadas em três conjuntos de intervenções da coletividade, isto é, do poder público: a) a regulação de comando e controle; b) a privatização dos bens comuns; e c) os incentivos econômicos (DOREMUS ET AL., 2008). 
No caso da regulação de comando e controle, o poder público estabelece padrões obrigatórios para o uso ou o acesso a bens comuns. No caso de poluição, por exemplo, o governo pode fixar quantidades ou valores máximos permitidos por cada empreendimento. Para que sejam efetivos, os mecanismos exigem uma estrutura de acompanhamento rigorosa e a punição dos que descumprem as determinações oficiais. Essa é tradicionalmente a base da atual legislação ambiental em quase todo o mundo e é usualmente a preferida das pessoas ligadas ao movimento ambientalista. Os economistas ortodoxos, entretanto, são de modo geral críticos a essas medidas em razão do alto custo e da baixa eficiência. Em geral, esse grupo tende a preferir outro tipo de intervenção estatal no caso dos bens comuns, que é sua privatização.

A privatização dos bens comuns consiste em dividir os bens comuns em pequenos "pedaços" a serem alocados para determinadas pessoas ou empresas. Em havendo a divisão dos bens comuns, os custos de sua sobreutilização passam a ser arcados pelo proprietário, que tenderá a evitar sua sobreutilização e seu consequente exaurimento. $\mathrm{O}$ problema é que nem todos os bens são facilmente divisíveis e privatizáveis. Embora seja relativamente simples fixar cercas em torno de pastagens comuns, é bem mais difícil dividir a atmosfera em "lotes".

Difícil, mas não impossível, como já se fez no caso da emissão de dióxido de enxofre $\left(\mathrm{SO}_{2}\right)$, gás provocador da chuva ácida. Linhas gerais, o poder público fixaria um teto global de emissões para evitar mudanças climáticas descontroladas e seriam expedidas licenças a cada empresa para emitir até esse limite. Essas licenças tanto poderiam ser outorgadas livremente entre as empresas que exerçam atividades que provocam emissões, quanto poderiam ser leiloadas. Numa etapa seguinte, as empresas que conseguirem reduzir suas emissões com mais facilidade poderiam vender as licenças para emissão sobressalentes para as companhias que enfrentaram maior dificuldade para conter suas emissões, barateando o custo agregado da redução das emissões. Essa é a chamada "solução de mercado" e vem sendo cada vez mais advogada para problemas ambientais no âmbito internacional.

Ainda segundo DOREMUS ET AL. (2008), a terceira estratégia de intervenção para evitar a tragédia dos comuns é a utilização de incentivos econômicos. Em vez de estabelecer padrões obrigatórios para utilização de um bem comum, ou de expedir licenças para emitir, o poder público pode forçar os usuários de bens comuns a arcarem com o custo de suas ações mediante a imposição de impostos ou taxas.

Esses incentivos econômicos tanto podem ser negativos (imposto sobre atividade poluidora), como podem ter natureza positiva (subsídio para a atividade alternativa 
que não provoca danos ao bem comum). Embora garantam maior previsibilidade para os agentes econômicos, os incentivos trazem o lado negativo de não assegurar o alcance de uma meta específica de redução no uso do bem comum. Se, por exemplo, a atividade poluidora for tributada em excesso, a redução poderá ser maior do que a necessária, impondo-se um custo desnecessário à sociedade. Por outro lado, se a taxação for demasiado branda, a redução pretendida não será alcançada.

Existe um razoável consenso entre os economistas que se debruçam sobre a mudança climática em torno da necessidade de impor um preço adicional pela emissão de gases estufa, mas há uma forte divisão a respeito da maneira pela qual o preço deve ser estabelecido. Linhas gerais, um grupo prefere o modelo chamado de cap-and-trade, instituindo um comércio de emissões de carbono (privatização do bem comum da atmosfera), ao passo que outros defendem a imposição de um imposto sobre o carbono (desincentivo ao consumo).

A criação de um tributo sobre as atividades econômicas que provocam emissão desse tipo de gás exigiria a fixação de um valor para esse encargo. Seria o caso típico de um imposto Pigouviano, denominação que homenageia o economista inglês Arthur Pigou (18771959), o primeiro a abordar aprofundadamente as externalidades negativas. Com o custo adicional que as atividades tributadas passariam a arcar, seriam fomentadas atividades econômicas alternativas, que no momento inicial padecem ainda de um custo de produção mais elevado. No caso da energia, por exemplo, o custo da eletricidade oriunda da queima do carvão tenderia a elevar-se em razão da imposição do imposto, aumentando a competitividade de fontes renováveis de energia, como a eólica ou a solar.

Conquanto estabeleça uma previsibilidade para o investidor em relação ao custo adicional a ser arcado pela emissão, o tributo padece do problema de não assegurar a redução das emissões a um limite desejado. Embora o aumento do custo de certas atividades tenda a desestimulá-las e a fomentar alternativas mais sustentáveis, o valor ideal do imposto é desconhecido e pode resultar tanto em uma redução inferior à planejada (caso de um imposto relativamente baixo), quanto numa queda substancial das emissões e da produção econômica, prejudicando a economia global para além do necessário a evitar mudanças climáticas descontroladas (caso de um imposto relativamente alto).

A alternativa defendida por outro grupo de economistas é o chamado cap-andtrade, ou o comércio de emissões. A vantagem desse modelo é que ele garante que o teto não será ultrapassado e evita um impacto econômico para além do "necessário" a conter mudanças climáticas descontroladas, já que o número de licenças para emitir seria pré-determinado. No entanto, os defensores do imposto (em lugar do cap-and-trade) argumentam que por esse 
sistema haveria enorme imprevisibilidade para os investidores em relação ao custo da emissão de gases estufa, já que, a depender dos avanços de cada empresa e de quantas licenças forem postas à venda, o preço do carbono pode cair ou subir vertiginosa e imprevisivelmente.

A regulação via comando e controle (command-and-control regulation) é bem menos flexível que as demais e tende a resultar em custos mais elevados para os consumidores. A fixação de limites para a emissão por veículos, por exemplo, pode não ser a alternativa mais barata, mas o consumidor terá que arcar com uma tecnologia eventualmente mais cara em razão da imposição de um limite de emissões para os veículos. Caso o sistema fosse, hipoteticamente, de cap-and-trade, a mesma redução agregada das emissões poderia ser alcançada sem o custo de pagar por veículos com uma tecnologia de redução de emissão que não seria a melhor, comparativamente com outros segmentos econômicos.

Ocorre que a criação do Direito Ambiental foi inicialmente baseada no modelo de comando e controle. As primeiras normas ambientais eram baseadas em vedações ou obrigatoriedades estabelecidas por uma agência ambiental. Tais normas formaram o alicerce da atual estrutura legal na área ambiental e ainda baseia os raciocínios dos principais decisores na área.

Adicionalmente, há dois argumentos centrais em favor do modelo de regulação de comando e controle. O primeiro é que o controle decisório sobre quais as melhores tecnologias fica na mão do poder público, e não do mercado. Trata-se, em certa medida, de um debate ideológico, sobre quem exercerá o poder de decisão sobre as melhores tecnologias, que podem ser mais ou menos eficientes, mais ou menos compatíveis com a saúde pública, mais ou menos geradoras de empregos locais. Se de um lado se argumenta que o Estado teria mais legitimidade para realizar as escolhas, inclusive avaliando as externalidades de cada restrição ou estímulo, de outro se alega que o mercado faria tais opções com mais eficiência e evitaria alocação de recursos por um poder público muitas vezes capturado por interesses ilegítimos.

O segundo argumento em favor da regulação de comando e controle é a suposta "imoralidade" inerente ao modelo de privatização dos bens comuns. Conforme essa avaliação, é inaceitável que o poder público conceda "licenças" para poluir. Em razão desse argumento de cunho ético, houve enorme resistência política à primeira política de comércio de emissões adotada nos Estados Unidos no início dos anos 1990 - no caso já citado da chuva ácida. Não só grupos ambientalistas, mas também os países europeus viam com muita desconfiança a ação do governo estadunidense. O relativo êxito do programa em coibir as emissões de dióxido de enxofre e óxido de nitrogênio amainou as críticas ao programa ao longo dos anos 1990 e, ao 
fim da década, a política já vinha se tornando mainstream na área ambiental em foros internacionais (YERGIN, 2012).

Some-se ainda que, como aponta CARLSON (2012), se a política de comércio de emissões for realmente bem desenhada, seria até mesmo mais eficiente abandonar todas as outras políticas de incentivo existentes, como eficiência energética para eletrodomésticos, padrão mínimo de consumo de combustível para veículos, mistura obrigatória de biocombustível, etc. Isso porque, em sua argumentação, o teto fixado pela política de comércio de emissões imporia o custo adequado a cada segmento da atividade econômica e qualquer restrição adicional na prática imporia a adoção de uma solução que não necessariamente seria a mais adequada do ponto de vista da eficiência do mercado.

Nesse caso, em não se revogando as políticas existentes de comando e controle, estariam sendo descartadas opções mais econômicas porque obrigatoriamente seriam adotadas, ainda que parcialmente, algumas das medidas impostas, mesmo que menos eficientes. Por exemplo, eventualmente o custo para substituir uma térmica de carvão por uma de gás seria mais barato do que investir no aprimoramento da tecnologia para tornar uma geladeira mais eficiente, mas a opção pelo primeiro caminho não poderia ser tomada em razão da obrigatoriedade de buscar um padrão energético pré-definido para os eletrodomésticos.

Ocorre que a tese de CARLSON parte do pressuposto de que o comércio de emissões vai conseguir abranger com rigor todos os setores econômicos, abarcando a totalidade das emissões. Além disso, seu argumento pressupõe que essas outras medidas teriam sido adotadas exclusivamente para buscar a redução das emissões de gases estufa, ignorando outros benefícios almejados por essas políticas, como a redução de outros poluentes (caso do consumo de combustível de automóveis) e a busca por segurança energética (caso dos biocombustíveis). Dificilmente, portanto, uma opção exclusivamente cap-and-trade viria a ser adotada, tendo que ser compatibilizada com outras medidas já existentes.

Ainda no campo da terceira linha de medidas (incentivos e desincentivos), os subsídios para as fontes renováveis não são usualmente avaliados como a melhor escolha, porque, conquanto ampliem a competitividade das fontes de baixo carbono vis-à-vis os combustíveis fósseis, os subsídios estimulam o consumo de energia ao baratear seu preço. Como o consumo de energia gera externalidade negativa, o ideal seria encarecê-lo, e não barateá-lo.

Nesse sentido, o subsídio às renováveis poderia ser considerado como uma alternativa não-ótima para viabilizar politicamente as fontes renováveis. Afinal, seria mais fácil do ponto de vista legislativo aprovar medidas "em favor" das fontes renováveis (apenas 
indiretamente prejudicam as fontes fósseis, por melhorar a competitividade das primeiras) do que propriamente aprovar proposições "contra" os combustíveis fósseis, como um imposto sobre o carbono ou o comércio de emissões (nesse caso, o prejuízo às fósseis é direto e claro).

Dada a importância do tema da energia, as políticas públicas desenhadas nos países não buscam apenas a contenção das mudanças climáticas. Tendo em vista o caráter estratégico da questão, as políticas até o momento verificadas estão frequentemente conjugadas com um forte esforço por liderar novas tecnologias, novas fontes de energia e novos segmentos industriais.

A dificuldade para implantar uma política pública de mudança climática efetiva

A maioria dos economistas concorda que as duas medidas mais eficientes para enfrentar a questão seriam atribuir um preço à emissão de gases estufa, o que poderia ser feito por meio de um imposto sobre o carbono ou pelo mecanismo de cap-and-trade. Ocorre, contudo, que essas soluções econômicas não são necessariamente as melhores soluções políticas.

De fato, o impacto imediato da medida seria o encarecimento do preço da energia, além de vários outros produtos que dela se utilizam. Não é simples equacionar eventual imposição de um imposto sobre o carbono com desoneração equivalente em outros setores. Entram em questão os segmentos beneficiados e prejudicados, o pacto federativo, etc. Adicionalmente, se um país adota uma medida dessa natureza isoladamente, ele tende a perder competitividade internacional, já que as demais nações não estariam encarecendo seus preços de maneira equivalente - além de correr o risco de ineficácia da medida, uma vez que o impacto das emissões de gases estufa é global, e não local.

Além disso, o setor de energia representa parcela enorme da economia e, consequentemente, detém influência política particularmente forte. Embora não se possa atribuir uma correlação direta, pode-se utilizar as doações de campanha de empresas associadas ao setor de energia nas eleições para dimensionar, ainda que de maneira um tanto simplista, o peso de sua influência econômica:

Nos Estados Unidos, o setor de energia figura entre os dez maiores doadores tanto das campanhas presidenciais, quanto das campanhas para o Congresso Nacional estadunidense. Tanto na campanha para presidente de 2012, como nas eleições congressuais de 2014, o setor de energia/recursos naturais foi o $5^{\circ}$ que mais efetuou contribuições, totalizando US\$ 15 milhões no primeiro caso e cerca de US\$ 100 milhões no segundo. Em 
ambas as campanhas, lideram o setor de "energia/recursos naturais" a indústria de combustíveis fósseis ${ }^{21}$ (CENTER FOR RESPONSIVE POLITICS, 2014).

Além disso, o setor está associado à geração de empregos em vários locais relevantes. Ainda que a indústria de renováveis possa prover o conjunto da economia com novos empregos verdes, a substituição não é automática e não beneficia necessariamente os que estavam inseridos na cadeia produtiva da indústria fóssil.

Até mesmo em termos territoriais a nova indústria não ocupará o lugar em que se sediavam as empresas do setor fóssil. Isso provoca insatisfação nos segmentos desfavorecidos e impactos eleitorais para os que advogam medidas que prejudicam o setor de combustíveis fósseis. Na política estadunidense, por exemplo, alguns dos chamados "swing states" (estados que têm peso decisivo em campanhas presidenciais) são grandes produtores de carvão e têm exibido ressalvas quanto às políticas favoráveis às renováveis.

No caso brasileiro, vale notar que a legislação eleitoral veda a doação de concessionárias de serviços públicos (art. 24, inciso III, da Lei no. 9.504, de 30 de setembro de 1997), o que abrange parte do setor de energia, que é um segmento regulado. No entanto, em razão da tradicional verticalização do setor, é fácil para os empresários encontrarem uma parcela da empresa que atua em área não regulada e, portanto, autorizada a realizar contribuições eleitorais. Há ainda os fornecedores de equipamentos para o setor, que ficam desimpedidos de tomar parte no financiamento de campanhas. Evidentemente, não estamos nem mesmo considerando nesses valores já vultosos o papel das doações não-contabilizadas, usualmente denominadas de "caixa dois", que exercem inegável papel no jogo eleitoral de algumas nações.

Nesse contexto, mudanças de regra que imponham ônus adicional ao setor de energia - especialmente para as energias de origem fóssil - não são politicamente simples de implantar. Por isso, em lugar de uma confrontação direta com esse segmento econômico, temse visto que políticas "não-confrontacionistas" têm prevalecido. Desse modo, para ficar num exemplo, em lugar de encarecer os derivados do petróleo, opta-se por baratear as renováveis por meio de subsídios. À primeira vista, pode-se até acreditar que as duas medidas são equivalentes, mas, em rigor, elas diferem política e economicamente.

\footnotetext{
${ }^{21}$ Para a classificação dos maiores doadores, estão sendo desconsideradas as categorias "ideologia”, "outros", "negócios variados", "lobistas", já que nenhuma dessas constitui um setor econômico propriamente dito. No caso de "negócios variados", essa categoria abrange variadas manufaturas, como têxteis, aço e químicos, e também restaurantes, varejo, turismo, bebidas, etc. Não parece adequado tratar esse conjunto heterogêneo como um único setor econômico. Vale registrar que o setor de energia/recursos naturais perde em doações eleitorais apenas para os setores financeiro $\left(1^{\circ}\right)$, saúde $\left(2^{\circ}\right)$, comunicação/eletrônico $\left(3^{\circ}\right)$ e construção civil $\left(4^{\circ}\right)$.
} 
Politicamente, há uma grande diferença entre onerar um tipo de energia (os combustíveis fósseis) e dar tratamento privilegiado a outro tipo (beneficiar as renováveis). Não há um confronto entre os segmentos ao se estabelecer um subsídio. É mais fácil se opor à criação ou ao aumento de um tributo do que obstar a concessão de um privilégio para energias renováveis.

Economicamente, ao conceder um subsídio às renováveis, o efeito é o barateamento do preço da energia e o estímulo ao seu uso, e não o desestímulo que deveria ser provocado pela externalidade negativa que a produção de energia acarreta.

Por essas razões, as políticas públicas implantadas em vários lugares do mundo estão frequentemente optando por abordagens que não seriam as opções preferenciais da teoria econômica majoritária, mas sim por opções que são politicamente palatáveis. A subvenção para as renováveis, a opção por quotas e outras medidas assemelhadas são consideradas alternativas subótimas em relação ao comércio de emissões ou à instituição de um tributo sobre o carbono.

\subsection{Panorama das políticas públicas para energia de baixo carbono}

O panorama das políticas públicas no mundo para o fomento das energias de baixo carbono vem ganhando força desde a adoção do Protocolo de Quioto, mas permanece bastante aquém das necessidades de limitar o aquecimento global a $2^{\circ} \mathrm{C}$, nível que oferece certa segurança para evitar mudanças catastróficas. A Europa vem liderando os esforços globais, tendo adotado as medidas mais substantivas na área. A pedra angular do sistema é o Comércio Europeu de Licenças de Emissões - CELE, modelo baseado na ideia do cap-andtrade.

Afora essa medida central, vários países europeus têm implantado medidas de âmbito nacional para promover tecnologias de baixo carbono, especialmente o uso de fontes renováveis de energia. A Dinamarca tornou-se uma das grandes produtoras de energia eólica, a França aproveitou-se do já estruturado sistema elétrico baseado em energia nuclear, a Espanha e a Inglaterra também concederam vários incentivos às fontes de baixo carbono. Mas é a Alemanha que vem implantando a mais radical das medidas, cunhada de "energiewende" (transição energética). Por meio de várias medidas de fomento, os alemães ampliaram substancialmente a participação da energia solar e eólica em sua matriz energética. 
Os Estados Unidos adotaram tardiamente políticas nacionais sobre o tema. Com a recusa em ratificar o Protocolo de Quioto e a influência relevante de setores explicitamente céticos em relação à ciência climática, o país não conseguiu aprovar medidas abrangentes de combate à mudança climática. Em 2009, uma proposta legislativa que instituía um sistema de comércio de emissões chegou a ser aprovada na Câmara dos Representantes, mas foi rejeitada no Senado.

Isso não impediu, como indicado no Capítulo 1, que vários Estados e municípios estadunidenses implementassem medidas locais de fomento às energias de baixo carbono, com destaque para os países do nordeste do país e especialmente para a Califórnia. Voltando ao âmbito nacional, no segundo mandato, o governo de Barack Obama resolveu baixar por decreto e por resoluções da agência de proteção ambiental (sem passar pelo legislativo, já que o partido democrata não dispõe de maioria) normas que limitam as emissões das novas plantas geradoras de energia, notadamente das usinas térmicas movidas a carvão. Trata-se de normas ao estilo de comando e controle que fixam padrões de eficiência mínimos, já que um projeto ambicioso de comércio de emissões ou de tributação de carbono exigiriam aprovação congressual.

Em 2014, a agência de proteção ambiental apresentou pela primeira vez uma proposta de resolução (sem passar pelo Congresso) pela qual seriam fixadas metas de redução das taxas de emissão, com o propósito de alcançar uma redução agregada no país da ordem de 30\% em relação ao ano base de 2005 (e não de 1990, como no Protocolo de Quioto). A medida passaria a abarcar não apenas novas usinas de energia, mas também as existentes. A implementação das ações ficaria a cargo dos Estados, a partir das metas definidas nacionalmente. Cada Estado poderia alcançar a meta por meio de variadas medidas, como um mecanismo local de comércio de emissões, o estímulo às fontes renováveis, maior eficiência das plantas existentes ou iniciativas de eficiência energética. A medida é promissora em termos de redução, mas ainda pendente de implementação.

À parte dessas grandes iniciativas para geração de energia, tanto os europeus, quanto os estadunidenses vêm promovendo uma verdadeira corrida tecnológica para as tecnologias de baixo carbono. Várias subvenções e apoio às pesquisas foram assegurados para o desenvolvimento de produtos de baixo carbono, como paineis solares, motores eólicos, baterias e células de combustível. Nos Estados Unidos, foi até mesmo criada uma nova organização, chamada de ARPA-E (Advanced Research Projects Agency-Energy), inspirada na DARPA (Defense Advanced Research Projects Agency), a instituição que ganhou fama pela geração de inúmeras tecnologias militares, muitas das quais de uso dual (como as fases iniciais do GPS e da internet). 
Vale registrar que, para além da busca pelo combate ao aquecimento global, há uma disputa por liderança tecnológica entre os principais países. Dado o caráter estratégico da geração de energia e do controle das tecnologias, as políticas têm sido frequentemente desenhadas em conjunto para viabilizar redução das emissões e também para assegurar que país esteja na fronteira tecnológica nesse campo.

Retirando o olhar apenas dos principais países desenvolvidos, outros atores centrais nesse processo são alguns dos grandes emergentes, dos quais destacaremos a China. No caso dos emergentes, vale observar que o desenho das políticas muitas vezes busca conciliar não apenas a redução das emissões, mas também o processo de emparelhamento tecnológico frequentemente mais esta última meta do que a primeira. Entra em discussão não apenas o que seria melhor do ponto de vista ambiental, mas também do ponto de vista do catching up tecnológico, incluindo proteção de mercado e subsídios à indústria nascente.

A China, desde 2006 o país com a maior taxa de emissões de gases estufa, vem adotando políticas crescentemente incisivas para minorar sua elevação acentuada de emissões, conforme se verá com mais detalhes adiante. O país já instituiu programas regionais de comércio de emissões (ainda que sem grande abrangência e sem metas ousadas) e tem promovido energias de baixo carbono, notadamente hidráulica, nuclear, eólica e solar. Apesar dessas medidas favoráveis a uma transição para o baixo carbono, o país continua altamente dependente do uso de combustíveis fósseis, notadamente o carvão para a eletricidade e o petróleo para o setor de transporte.

Vê-se, também no caso da China, o claro esforço de conciliar uma política climática com uma política industrial e tecnológica. O país asiático tem buscado promover indústrias locais, adotando medidas de fechamento de mercado e de proteção à indústria nascente nos segmentos de baixo carbono, tais como nas medidas de conteúdo nacional, política alfandegária, subsídios e tarifas diferenciadas. O avanço das indústrias eólica e solar na China é um claro sinal do esforço feito pelo país para se posicionar como um dos principais atores nas discussões globais sobre energia, conforme se examinará adiante.

A discussão a respeito da conveniência e legitimidade de conferir subsídios às energias renováveis precisa também levar em conta os subsídios conferidos historicamente - e ainda no presente - aos combustíveis fósseis. De fato, comparar apenas os preços finais de fontes energéticas renováveis com as tradicionais fontes fósseis não é uma tarefa simples, porque a indústria fóssil gozou no passado e ainda goza de inúmeros subsídios.

Como aponta estudo feito pelo Fundo Monetário Internacional (IMF, 2013), cerca de US\$ 1,9 trilhão foi gasto em subsídios aos combustíveis fósseis, direta ou 
indiretamente, valor que corresponde a cerca de 2,5\% do PIB global. Cerca de $40 \%$ desse valor se origina dos países desenvolvidos.

Os subsídios diretos somam o valor US\$ 480 bilhões, perto de 1\% do PIB global. O mero corte desses subsídios já provocaria um reequilíbrio dos custos que essas atividades realmente implicam, aumentando a competitividade das indústrias de baixo carbono. Só a remoção dos subsídios aos combustíveis fósseis, na estimativa do FMI, poderia acarretar uma redução de $13 \%$ nas emissões de dióxido de carbono.

O FMI ainda aponta para o subsídio implícito, consistente na não-adoção de um imposto sobre o carbono, para compensar os custos coletivos provocados via poluição e mudança climática. Nesse sentido, para realmente ajustar os preços, além do corte dos subsídios diretos, seria necessário estipular um tributo sobre o carbono, onerando as indústrias pela externalidade negativa que a atividade provoca, como já apontado anteriormente. Vale notar que o fundo não levou em consideração subsídios conferidos no passado a essa tecnologia, tampouco considera toda a infraestrutura construída e mantida com recursos públicos para suportar a indústria, particularmente no setor de transporte.

Em outras palavras, há uma grande falha de mercado ocasionada pela ausência de precificação das externalidades decorrentes do lançamento na atmosfera (bem comum) de gases causadores do efeito estufa. Há várias maneiras distintas de lidar com as falhas de mercado, mas as medidas até o momento adotadas, além de tímidas, são ainda ofuscadas pelos enormes subsídios diretos e indiretos que ainda persistem em favor dos combustíveis fósseis.

Nos subtópicos seguintes, examinaremos algumas das principais medidas relacionadas às políticas de promoção da indústria de baixo carbono. Se de um lado as políticas climáticas se dividem claramente nas três categorais mencionadas acima (comando e controle; comércio de emissões; incentivos e desincentivos), de outro todas essas medidas vêm acompanhadas de um rol de ações associadas à política industrial e tecnológica de cada país.

\subsection{Políticas de comando e controle}

\section{Quotas de energia renovável}

A quota de energia renovável (renewable portfolio standard) é uma das medidas que vem ganhando maior disseminação entre as políticas de fomento às energias de baixo 
carbono, especialmente eólica e solar. A medida consiste em exigir que uma fatia prédeterminada da matriz energética seja necessariamente suprida por meio de determinadas fontes, usualmente eólica e solar - às quais se acrescentam em alguns casos hidráulica, biomassa, geotérmica e mesmo gás natural. Trata-se de uma das principais determinações da categoria de políticas públicas denominadas de comando e controle.

O objetivo é garantir uma fatia do mercado de energia para fontes que, em situação usual, não teriam condições de competir pelo preço com as fontes tradicionais de energia, principalmente o carvão. Como as concessionárias de energia elétrica são obrigadas a comprar a energia disponível mais barata, elas tendiam a preferir as fontes fósseis, que eram consideradas mais baratas. Além disso, a opção pelas energias fósseis também era reforçada pela segurança de suprimento que elas ensejam, já que garantem a energia de base e, dependendo da fonte, permitem elevar ou reduzir o fornecimento (ramp up / ramp down) em consonância com a demanda, tal qual ocorre com o gás natural.

O nível de rigidez da quota depende principalmente do volume exigido de energias renováveis e de quais fontes se qualificam nesse segmento. Na Califórnia, por exemplo, que adotou uma das regras mais rigorosas nos Estados Unidos, a legislação exigiu que, em 2010, as principais concessionárias de eletricidade fornecessem $20 \%$ do total a partir de fontes renováveis em 2010 e, para 2020, esse número se elevou a 33\%. No conceito californiano de renováveis estão abrangidas as energias solar, eólica, geotérmica, pequenas centrais hidrelétricas, entre outras, excluindo-se as grandes hidrelétricas, energia nuclear e todas as fontes fósseis.

Nem todos os Estados adotaram regras tão rigorosas. Vários almejam percentuais menores e alguns admitem o uso de algumas fontes fósseis dentro da quota, particularmente o gás natural. Conquanto a queima do metano esteja associada a emissões de carbono menores do que o carvão, ainda assim ele provoca emissões significativas. Sua inclusão entre as fontes elegíveis para a quota está particularmente associada ao drástico barateamento do gás natural, depois da difusão das técnicas de extração de gás nãoconvencional por meio do fraturamento hidráulico (fracking) e da perfuração horizontal (horizontal drilling).

Utilizando dados de março de 2013, nos Estados Unidos, um total de 29 Estados e também Washington/DC adotaram quotas de energia renovável, com graus de rigor variáveis, conforme Figura 4. Esses Estados são bastante representativos da economia estadunidense, eis que numericamente compõem mais da metade das unidades federativas do país, além de englobarem os maiores em população e em economia, como Califórnia, Texas e Nova Iorque. 
FIGURA 4

Quota de energia renovável nos EUA

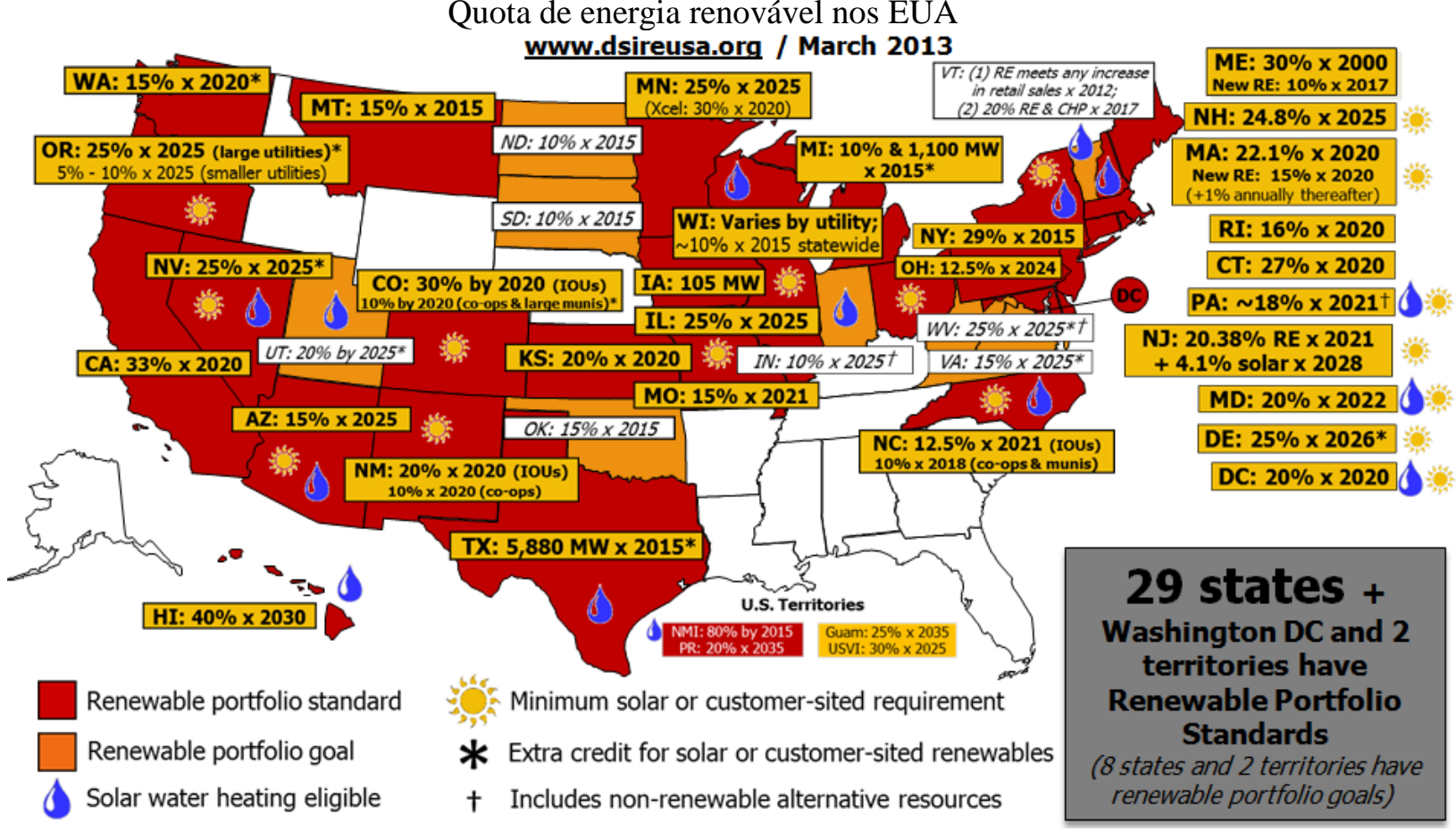

Fonte: DSIRE, 2013.

Para tornar o mercado mais eficiente, foi criado inicialmente na Europa, e depois expandido para outros países, o sistema de certificados de energia renovável (Renewable Energy Certificate System - RECS). Ele surgiu para aperfeiçoar a utilização de renováveis diante da realidade de que a oferta desse tipo de energia não está distribuída igualmente em termos territoriais, de modo que há locais com melhor aproveitamento eólico, ou solar, ou de outra fonte. Nesses casos, seria facultado às concessionárias de locais mais distantes adquirirem o certificado de renovável da empresa que realiza um projeto em um local privilegiado, ainda que a eletricidade em si desse projeto não seja diretamente oferecida ao usuário daquela concessionária.

Uma vez integrada ao sistema elétrico, a eletricidade é a mesma, quer se origine de fonte fóssil ou renovável. Os RECs permitem que o custo seja o menor para os que pretendem utilizar energia renovável, já que os projetos serão realizados nos locais mais adequados para o aproveitamento da radiação solar ou da intensidade dos ventos, e a energia abastecerá o sistema, sem que seja possível perquirir se aquela fonte necessariamente proveu o usuário da concessionária que pagou pelo certificado.

Ainda voltando ao caso da Califórnia, há exigência de que $75 \%$ da energia seja considerada da "categoria 1", isto é, fontes diretamente ligadas ao sistema elétrico da 
Califórnia. $\mathrm{O}$ argumento para tal exigência é que o fornecimento indireto acarretaria perdas de transmissão, ou não serviria para estimular novos projetos na área. O propósito também é o de garantir que os novos projetos sejam realizados no território do Estado, assegurando que arrecadação tributária e empregos sejam gerados localmente. Trata-se de uma maneira indireta de exigir conteúdo local.

No caso da Europa, vários países adotaram quotas de energia elétrica para energias renováveis, sintetizado na Figura 5.

\section{FIGURA 5}

Metas de energia renovável na União Europeia, em participação da matriz elétrica, 2010

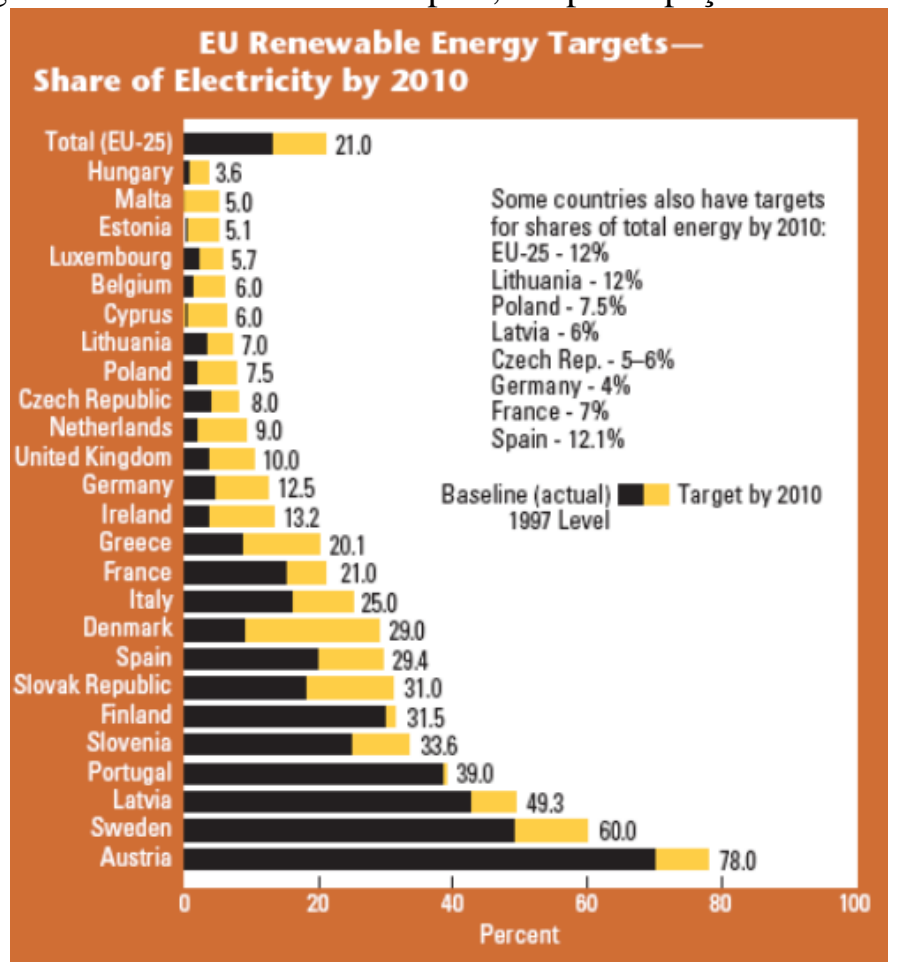

Fonte: KAMMEN, 2013. Lecture on Wind Power.

Vale registrar que existe bastante espaço para ampliar a utilização de fontes renováveis na matriz energética mundial. Apenas para dar a ordem de grandeza da quantidade de energia oriunda das principais fontes renováveis em discussão, a Figura 6 ilustra a disponibilidade de ampliar a utilização dessas fontes.

A quota de energia renovável pode ser adotada por meio da fixação de percentual da geração total, percentual da capacidade, ou pela definição de um número fixo de capacidade instalada. Cada Estado tem optado por formas distintas de definir a medida. Outra diferenciação diz respeito à adoção da medida no âmbito do sistema energético total, ou apenas no sistema elétrico ou ainda exclusivamente no setor de transporte. 
FIGURA 6

Disponibilidade das novas renováveis no planeta

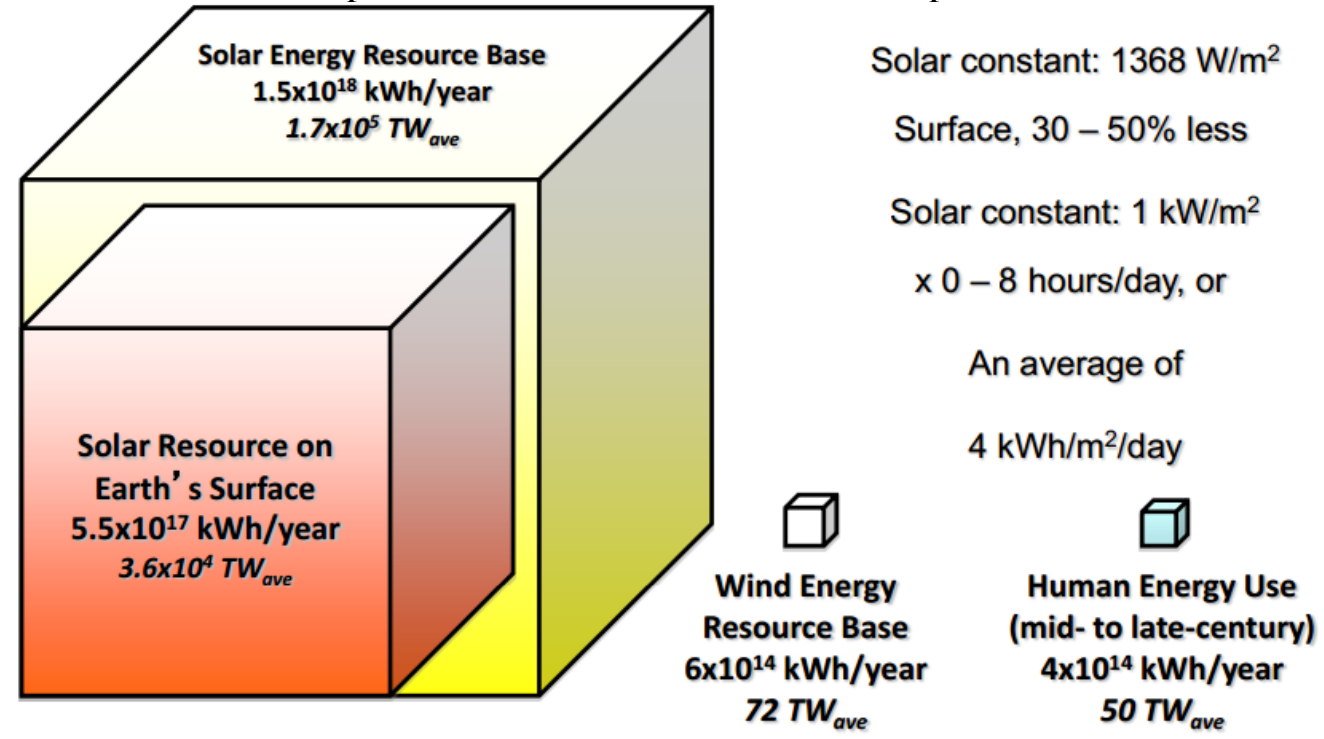

Fonte: KAMMEN, 2013. Lecture on solar power.

De fato, o conceito de quota de energia renovável se aplica de modo similar aos combustíveis, e não apenas às fontes de eletricidade. Assim, vários países ou regiões adotam também medidas que impõem a utilização de combustíveis de baixo carbono em conjunto ou em substituição às fontes fósseis. Os casos mais comuns são o biodiesel e o etanol, que podem ser utilizados isolada ou conjuntamente com os derivados do petróleo.

Passando à análise dos quatro países centrais para esta pesquisa, examinaremos que quotas de energia renovável foram adotadas e como se deu a implantação.

No caso brasileiro, a quota de energia renovável veio a partir de um ajuste no desenho inicial do Programa de Incentivo às Fontes Alternativas de Energia Elétrica, chamado de Proinfa, tema sobre o qual se falará em detalhes mais adiante. Em breve síntese, o programa foi lançado no contexto da crise energética de 2001 e visava a diversificar a matriz energética brasileira com o uso de fontes alternativas. A segunda etapa desse programa, remodelado em 2002, previa como meta que, em até 20 anos, $10 \%$ do consumo anual de energia elétrica fosse provido pelas fontes eólica, pequenas centrais hidrelétricas e biomassa (art. 3ㅜ, inciso II, alínea 'a', da Lei n⿳o 10.438, de 26 abril de 2002).

Ocorre que, em razão da primeira fase do Proinfa (examinada mais à frente) e do barateamento dos custos dessas fontes, o Brasil já dispunha em 2012 de cerca de 13\% da capacidade instalada dessas três fontes, tornando relativamente obsoleta a meta para 2022. Trata-se, portanto, de meta já atingida com bastante antecipação. Dada a abundância das fontes 
de baixo carbono no Brasil e a preços competitivos, essas fontes não enfrentaram grandes dificuldades para ampliar sua participação na matriz elétrica. Vale notar ainda que a fonte solar não está inserida na meta do Proinfa.

Além disso, a legislação brasileira prevê que sejam promovidos leilões de energia elétrica exclusivos para fontes "alternativas". Na prática, isso permite que se alcance determinado nível de capacidade instalada de fontes renováveis, já que o governo decide qual a quantidade de energia que será contratada nesses leilões, sem que as fontes renováveis precisem disputar preço com as fontes fósseis, ou mesmo entre si. De um lado, esse modelo confere flexibilidade para a gestão do sistema, pois o incremento de renováveis pode ser dosado aos poucos para conferir segurança energética, evitando a presença excessiva de fontes intermitentes. Por outro lado, ao não explicitar uma quota clara para renováveis, não se confere segurança ao investidor de longo prazo de que haverá contratações frequentes de determinada fonte, de modo a estimulá-lo a investir na produção e no desenvolvimento tecnológico.

Desde 2007, o governo promoveu alguns leilões exclusivos de energia "alternativa", incluindo principalmente projetos baseados em energia eólica, biomassa e pequenas centrais hidrelétricas. No primeiro dos leilões, por exemplo, realizado ainda em 2007 , foram contratados $640 \mathrm{MW}$ de energia, sendo $511 \mathrm{MW}$ em biomassa de cana-de-açúcar. No de 2010, por outro lado, a contratação total chegou a 2.900 MW, sendo 2.050 MW apenas de energia eólica, mostrando o avanço da competitividade dessa fonte (EPE, 2010).

Vale registrar que, no caso brasileiro, em razão da abundância de fontes renováveis a preços competitivos, projetos eólicos e hidrelétricos têm apresentado os menores preços, mesmo nos leilões abertos a todas as fontes. De certo modo, os projetos de termelétrica (gás, óleo e carvão) é que vêm sendo contratados separadamente para conferir segurança energética ao sistema, dado que podem ser acionados a qualquer momento e, com isso, permitem equilibrar em tempo real oferta e demanda, sem os riscos da intermitência.

Contudo, nos leilões abertos a todas as fontes, algumas tecnologias de baixo carbono de desenvolvimento mais recente, como a solar, não conseguem preços para competir. A hidrelétrica vinha sendo a principal favorecida até que, mais recentemente, os projetos eólicos passaram a dispor dos menores preços em razão da queda substancial do preço de geração na última década.

Saindo do campo da eletricidade e se voltando ao setor de transporte, existe já há bastante tempo no Brasil um programa consolidado de mistura obrigatória de etanol na gasolina e, mais recentemente, de mistura obrigatória de biodiesel no óleo diesel. 
A utilização de álcool como combustível para os automóveis vem desde a virada do século XIX para o XX, alternando momentos de alta e de baixa. O impulso recente do setor se deu a partir dos choques do preço do petróleo na década de 1970, quando o risco de desabastecimento agudo e a crise provada pela mudança dos preços na balança comercial impôs a adoção de medidas mais emergenciais.

Fortaleceu-se, então, a indústria da cana-de-açúcar e se criou uma grande frota nacional de veículos movidos exclusivamente a álcool, em paralelo com outros veículos movidos apenas a gasolina. Entretanto, a queda do preço do petróleo nos anos 1980 voltou a tornar a gasolina competitiva. Esse cenário se reforçou por algumas crises de abastecimento do álcool, que geraram incerteza nos consumidores acerca da capacidade da indústria de garantir fornecimento seguro e a preços adequados. Já em fins dos anos 1990 a frota de veículos novos voltou a ser majoritariamente composta por automóveis movidos exclusivamente a gasolina.

O cenário voltou a mudar com o lançamento dos veículos flex no início dos anos 2000, que permitem utilizar qualquer mistura de gasolina ou de álcool, conforme se verá em detalhes mais adiante. A tecnologia ampliou as opções para o consumidor e afastou o receio de desabastecimento de etanol.

O relevante é que, além da utilização de álcool hidratado em substituição à gasolina, o Brasil também impõe uma mistura obrigatória do álcool anidro à gasolina, isto é, não se vende gasolina "pura" no país, mas uma mistura de gasolina com etanol. A taxa de mistura obrigatória variou ao longo do temos, mas na última década oscilou entre $18 \%$ e $25 \%$. No fim de 2014, foi permitida a elevação da mistura a até $27,5 \%$, o percentual mais elevado de mistura obrigatória do mundo.

Atualmente, segundo a Única, entidade brasileira dos produtores de cana-deaçúcar, cerca de 60 países já adotam percentuais de mistura obrigatória de etanol com gasolina, mas os índices costumam ser bem inferiores aos brasileiros, de no máximo 10\%. Afora os países asiáticos, que serão tratados em seguida, merecem referência os EUA, que adotam 10\% de etanol, e os países da União Europeia, que adotam em média 5\% de mistura obrigatória (ÚNICA, 2014).

Mais recentemente, o programa de biodiesel também expandiu a utilização de fontes renováveis entre os combustíveis utilizados no Brasil. O Programa Brasileiro de Biodiesel foi lançado em fins de 2004, estabelecendo percentuais progressivos de mistura obrigatória de biodiesel ao diesel comum. O biocombustível é produzido a partir de diferentes tipos de oleaginosas, incluindo mamona, girassol e especialmente a soja. 
Inicialmente, o programa adotou como obrigatória a utilização de $2 \%$ de biodiesel na mistura do diesel vendido ao consumidor. Esse percentual foi depois gradativamente elevado, alcançando 7\% de mistura a partir de novembro de 2014. Essas taxas foram definidas de modo a viabilizar a oferta gradual da produção do setor e também a não exigir alterações nos motores dos veículos que utilizam diesel.

Em síntese, no campo da eletricidade o Brasil já alcançou com antecipação a quota relativamente modesta definida na legislação para as fontes renováveis. Além disso, o país tem metas relativamente avançadas no caso dos combustíveis para o setor automotivo, tanto com o etanol, como com o biodiesel. Deve-se considerar, contudo, que os padrões de eficiência energética dos veículos brasileiros são comparativamente baixos. Além disso, não há política clara para incentivar o uso de carros de etanol puro, que poderiam ser mais eficientes que os carros flex.

No caso da China, o sistema elétrico está sujeito a regulações substancialmente diferente da brasileira, não havendo propriamente uma disputa aberta em leilões com vistas à modicidade tarifária. O setor é dominado por grandes estatais, que atuam sem segmentos de mercado e áreas distintas, conforme orientações centrais do governo.

As metas definidas pelo governo central, portanto, têm peso bastante importante no plano de expansão do setor elétrico chinês. Em 2006, quando se iniciou a incorporação mais clara de questões ambientais ao centro das preocupações do governo, foram estabelecidas metas para ampliação do uso de fontes renováveis, de modo a mitigar a dramática utilização do carvão. Foi aprovada, então, a Lei de Energia Renovável, definindo várias regras em favor dessas fontes, incluindo a nuclear entre elas (LEWIS, 2013).

Foi estabelecida, então, com uma atualização em 2009, uma meta arrojada de capacidade instalada de $500 \mathrm{GW}$ energia renovável para o setor elétrico, sendo $300 \mathrm{GW}$ de hidrelétrica, $150 \mathrm{GW}$ de eólica, $30 \mathrm{GW}$ de biomassa e $15 \mathrm{GW}$ de solar. Para dar uma dimensão comparativa aos números, todo o sistema elétrico brasileiro dispõe hoje de cerca de $130 \mathrm{GW}$ de capacidade instalada.

Além dessa meta, a China fixou em 15\% a meta de energia renovável em 2020 para o conjunto da matriz energética do país, englobando também o setor de transporte. Somese ainda que, no acordo bilateral entre EUA e China firmado em 2014 sobre mudança climática, o país asiático assumiu o compromisso de chegar a 20\% de energia não-fóssil até 2030 em sua matriz energética.

Especificamente no setor de transporte, a China adotou em nove províncias uma meta de $10 \%$ de utilização de biocombustíveis. Essa meta, como se vê, não é tão abrangente 
(não cobre todo o país e compreende algumas exceções), dado o receio do país asiático em expandir a utilização de terras para geração de energia em face da necessidade de alimentar uma população superior a um bilhão de habitantes. As metas para biocombustíveis na China têm sido, por isso, mais cautelosas do que em outras tecnologias de baixo carbono.

Sinteticamente, a China tem metas bastante abrangentes de geração de eletricidade de baixo carbono, embora ainda exiba uma matriz energética preponderantemente poluente. No campo de transporte, no entanto, o esforço chinês é menos acentuado do que na geração de eletricidade.

Já em Taiwan, a meta de energia renovável foi estabelecida em 1998, mas apenas em termos voluntários, indicativos. Não se trata, pois, propriamente, de um mecanismo de comando e controle, mas de uma sinalização do esforço em ampliar as fontes renováveis.

Além disso, a meta inicialmente estabelecida era de $10 \%$ a $14 \%$ de energia renovável baseada na capacidade do sistema elétrico em 2020. Em 2005, a meta foi reduzida para 10\%. Em 2008, foi novamente revista para 8\% apenas em 2025 (JANG e XU, 2011). Não há propriamente, em termos de expansão da produção doméstica de baixo carbono, um esforço tão consistente do governo taiwanês, a despeito do esforço tecnológico e exportador nessa área, como se verá mais adiante.

No caso do setor de transportes, Taiwan adota metas modestas de 3\% para o etanol e de $1 \%$ para o biodiesel (ÚNICA, 2014). As metas também não são mandatórias, mas apenas exigem que alguns postos ofereçam essa opção de abastecimento ao consumidor, e não uma mistura obrigatória em todo combustível vendido. A produção de etanol e de biodiesel é baseada em importações, além de uma produção relativamente pequena baseada em rejeitos agrícolas, especialmente palha de arroz e óleo de cozinha (PERNG, 2009).

Em síntese, o esforço taiwanês de geração de energia com fontes renováveis é frágil. Diferentemente do empenho local em desenvolvimento de tecnologias e de exportação na área, o país não se comprometeu eficazmente com geração de baixo carbono no próprio território, fugindo ao custo adicional que as fontes renováveis ainda impõem ao sistema.

Por fim, na Coreia do Sul, foi adotada uma quota de energia renovável que entrou em vigor em 2012 para que os grandes geradores de energia adquirissem $2 \%$ da eletricidade com fontes não-fósseis. Esse percentual seria elevado em 0,5\% ao ano até 2016 e, a partir daí, em $1 \%$ ao ano, até alcançar $10 \%$ em 2022, aplicando-se apenas aos grandes produtores de energia (KIM, 2012).

O uso de fontes renováveis continua baixo na Coreia do Sul, conforme se verificou no Capítulo 3, e as metas também não são tão desafiadoras. A maior parte das fontes 
renováveis consiste em pequenas hidrelétricas, além de projetos de geração a partir da energia da maré (diferença do nível do mar entre maré alta e baixa, com pequenas barragens) e eólicos (EIA/EUA, 2014).

No caso do setor de transporte, a Coreia também não dispõe de mistura obrigatória na gasolina e, no caso do diesel, adotou a partir de 2012 a mistura obrigatória de $2 \%$ de biodiesel, boa parte dos quais importados (ÚNICA, 2014).

Resumidamente, pode-se dizer que a Coreia do Sul - de modo similar a Taiwan - também não tem apresentado esforço significativo de geração de eletricidade com baixo carbono, assim como não se verifica esse empenho no caso do setor de transporte. A situação contrasta com o esforço nacional em desenvolvimento tecnológico na área e com sua política externa retoricamente engajada no enfrentamento do aquecimento global, conforme se verá adiante.

\subsection{Privatização do bem comum: definição de teto e comércio de licenças para emitir}

A política de privatização do bem comum no caso sob análise implicaria a fixação de um teto de emissões e, a partir dessa referência, seriam outorgadas licenças para emitir até esse limite. O Protocolo de Quioto, já examinado no Capítulo 2, consistiu justamente na adoção de uma política inspirada no cap-and-trade, ainda que sem a abrangência de todos os países nas metas, já que se limitaram aos países do Anexo 1.

Como já se indicou, a Europa adotou o modelo mais arrojado de cap-and-trade entre os grandes atores globais no campo da mudança climática. Por meio do chamado Esquema da União Europeia de Comércio de Emissões, foram fixadas metas de redução global, facultando-se o comércio entre os países que superarem as metas e os que não a atingiram. $\mathrm{O}$ programa abrange 15 países integrantes da União Europeia.

Há projetos de comércio de emissões em níveis regionais e estaduais nos Estados Unidos, com destaque para o da Califórnia (por meio da lei AB-32, California Global Warming Solutions Act) e o do Nordeste estadunidense (Regional Greenhouse Gas Initiative). No restante do planeta, há também iniciativas nacionais e subnacionais, mas nenhuma com alcance equivalente ao sistema europeu. 
No caso dos quatro países examinados, a situação é mais modesta em todos eles, como veremos adiante.

Brasil e Taiwan não adotaram nenhuma medida similar em nível nacional ou subnacional. A despeito de várias medidas em áreas correlatas, nenhum dos dois estabeleceu ainda um teto de emissões abaixo do qual seriam negociadas permissões para emitir.

No Brasil, nem mesmo existe um debate público relevante sobre a fixação de metas rígidas e a venda de licenças. A meta fixada na Lei da Política Nacional sobre Mudança do Clima (Lei n⿳⺈ 12.187, de 29 de dezembro de 2009) é apenas um “compromisso nacional voluntário" (art. 12), que toma como referência o cenário business as usual, sem que se definiam a partir daí licenças de emissões.

Entretanto, o Brasil faz uso do Mecanismo de Desenvolvimento Limpo - MDL, instrumento previsto no Protocolo de Quioto. Pelo mecanismo, é possível vender crédito de carbono aos países integrantes do Anexo I do Protocolo em razão da realização de projetos que acarretem redução certificada de emissão de gases estufa em países não-integrantes do Anexo 1, como o Brasil. Tanto o próprio país do Anexo 1, como as empresas desses países para as quais foram fixadas metas internas podem adquirir esses créditos de projetos realizados nos países que não integram o grupo de modo a compensar as metas não-alcançadas.

Desse modo, o programa estimula iniciativas de redução de emissão em território brasileiro, já que permite a obtenção de créditos junto aos países integrantes do Anexo 1. Entretanto, ele é menos eficaz em desestimular atividades intensivas em emissão, já que não impõe um sobrepreço para essas atividades. Pode-se dizer, contudo, que, relativamente às inciativas de baixo carbono, os projetos intensivos em carbono perdem um pouco de competitividade por não poderem usufruir desse crédito extra.

No entanto, o estímulo adicional aos projetos de baixo carbono não é tão acentuado, porque o Protocolo exige "adicionalidade" na redução das emissões, isto é, apenas aqueles projetos que não teriam ocorrido sem o crédito do protocolo podem ser beneficiados. Exemplificativamente, um projeto eólico eficiente - que já é no Brasil em geral mais competitivo do que uma térmica a carvão - não poderia receber o benefício, já que ele seria realizado mesmo sem o MDL. Não haveria redução "adicional” de emissão. Mas um projeto de geração de energia a partir de resíduos sólidos - que sem o crédito não teria em princípio preço para competir com outras fontes - poderia candidatar-se ao crédito do MDL.

O Brasil foi o primeiro país a inscrever um projeto no MDL, o aterro sanitário de Nova Gerar, em Nova Iguaçu/RJ. Os projetos brasileiros são predominantemente focados no setor energético (55\% do total), seguidos dos projetos de tratamento e eliminação de 
resíduos $(23 \%)$ e agricultura (16\%). O total de projetos chegou a 330 até 30 de setembro de 2014 (MCTI, 2014).

Embora o Brasil seja o $4^{\circ}$ país a obter mais créditos no âmbito do MDL, o total de créditos em projetos brasileiro é relativamente pequeno quando comparados aos alcançados pela China (quase 60\%), Índia (14\%) e Coreia do Sul (8\%), conforme exibe o Gráfico 28.

\section{GRÁFICO 28}

Créditos certificados para projetos do MDL em cada país sede

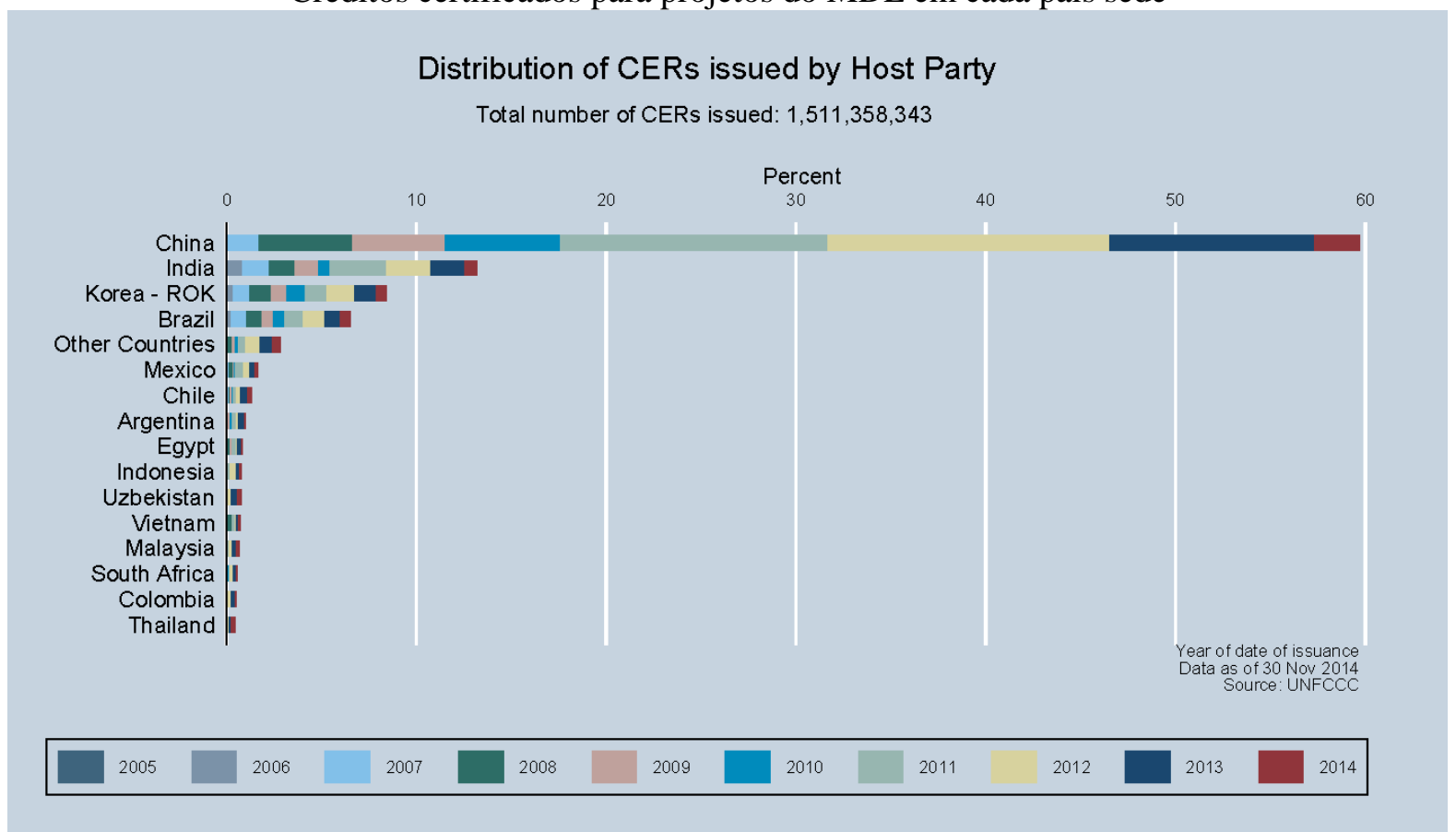

Fonte: UNFCCC, 2014.

Em Taiwan, o governo chegou a enviar em 2008 uma proposta ao Congresso Nacional para o estabelecimento de um teto de emissões, mas o projeto não chegou a ser aprovado. Desde então, nenhuma iniciativa relevante foi adotada na área. Vale notar ainda que, dado seu status internacional peculiar, Taiwan não integra do Protocolo de Quioto e, desse modo, não faz uso dos créditos do MDL.

Já na China, embora não exista ainda um mecanismo nacionalmente abrangente de comércio de emissões, a política já vem sendo implementada em caráter regional como projeto piloto a partir de 2011.

De fato, sete cidades e províncias chinesas aderiram a um mecanismo que cobre parcela das emissões oriundas dessas localidades. Desse projeto fazem parte Beijing, Chongqing, Guangdong, Hunan, Shanghai, Shenzhen and Tianjin (HAN; OLSSON; HALLDING; LUNSFORD, 2012). 
A China vem anunciando, além disso, que um mecanismo nacional de comércio de emissões pode vir a ser implantado a partir de 2016, mas os detalhes da proposta ainda não foram claramente anunciados, conforme noticiado em veículos de imprensa internacional, como matéria da Reuters de 31 de agosto de 2014 (China's national carbon market to start in 2016 -official).

Embora o projeto piloto nas sete cidades e províncias ainda esteja enfrentando dificuldades - houve poucos contratos efetivamente firmados e há pouca transparência nos números -, a China vem liderando os créditos internacionais no âmbito do MDL, como indica o Gráfico 28, com quase $60 \%$ do total global. O MDL tem sido o principal motor do mercado de baixo carbono na China - ao menos enquanto o programa nacional não entra em execução (HAN; OLSSON; HALLDING; LUNSFORD, 2012).

Por fim, na Coreia do Sul foi aprovada uma legislação que estabelece o mecanismo nacional de comércio de emissões, mas sua implantação foi sucessivamente postergada, e as metas não são muito audaciosas. Abarcando setores econômicos que respondem por cerca de $66 \%$ das emissões nacionais, o plano está sendo implantado a partir de 2015, e a meta seria uma redução até 2020 de 30\% das emissões em relação ao cenário business as usual. Como a Coreia vem apresentando uma das mais elevadas taxas de aumento nas emissões entre os países da OCDE, a redução com base no cenário BAU é bastante modesta.

Na tramitação da proposta no legislativo coreano, assegurou-se que as empresas receberão quotas gratuitas de emissão, cabendo-lhes comprar apenas o que exceder essa parcela, de modo a reduzir o ônus sobre o setor produtivo. Além disso, eventuais descumprimentos tiveram suas sanções abrandadas na tramitação da medida (PWC, 2012).

Vale notar também que, a despeito da atual renda per capita elevada, a Coreia é também beneficiária dos projetos do MDL, já que, ao tempo do Protocolo Quioto, o país não figurou no Anexo 1 (a ausência da Coreia no rol dos países com obrigações em Quioto é um dos indicadores extremos dos desequilíbrios do protocolo, o que também fica evidenciado pela exclusão de países como Arábia Saudita, Catar e Barein). Tal qual indicado no Gráfico 28, a Coreia foi a terceira nação que mais logrou créditos no âmbito do MDL, figurando inclusive à frente do Brasil.

Compendiando o subtópico, pode-se dizer que nenhum dos quatro países examinados adotou no campo doméstico um mecanismo rigoroso de comércio de emissões, embora Coreia e China estejam lançando sistemas incipientes com esse propósito. Entretanto, os três países que integram o Protocolo de Quioto vêm fazendo uso do MDL, com destaque para a China. 


\subsection{Incentivos e desincentivos econômicos}

\section{Tributo sobre o carbono}

O tributo sobre o carbono - na verdade, sobre a emissão de qualquer dos gases que provocam o efeito estufa, incluindo o carbono - é uma das principais apostas de uma ala importante dos economistas que acompanha o tema do aquecimento global, como mencionado no início deste Capítulo.

Como alternativa menos volátil - e portanto mais previsível - ao mecanismo de cap-and-trade, o imposto sobre o carbono permitiria fixar um valor que corresponderia à externalidade negativa que o carbono provoca para o conjunto da sociedade, de modo a precificar esse custo nas atividades que acarretam sua emissão na atmosfera. Ao tornar mais caras as atividades que impõem maior emissão de carbono, desencorajam-se esses empreendimentos e eleva-se a competitividade das alternativas econômicas. Num exemplo concreto, uma usina térmica a carvão seria mais pesadamente tributada do que uma usina eólica, conferindo maior competitividade a esta em detrimento daquela.

Como já indicado, a vantagem em relação ao comércio de emissões é que o preço é definido a priori, não se sujeitando à volatilidade que o mercado de carbono tem apresentado nos poucos lugares que já o implantaram. A desvantagem mais notória em relação ao cap-and-trade é que, a depender da alíquota do imposto sobre o carbono, pode-se obter uma redação inferior à necessária para conter o aquecimento global (se a alíquota for baixa), ou superior à prevista, prejudicando excessivamente a economia local (caso a alíquota seja demasiado elevada).

No caso dos quatro países examinados, embora essa medida seja discutida em alguns deles, nenhum dos quatro chegou a implantá-la - ao menos com essa abrangência. Há até tributos que guardam similaridade com esse imposto, como a Contribuição de Intervenção no Domínio Econômico, chamada também de CIDE-Combustíveis no Brasil. Mas elas não abarcam todas as emissões de carbono e incidem até mesmo sobre biocombustíveis, e não apenas sobre petróleo. Por essa razão, deixaremos de tratar do tema a fundo, fazendo essa referência apenas por se tratar de uma das opções mais importantes na discussão do tema. 
Vale notar, entretanto, que, embora não haja sido adotado um imposto sobre o carbono, praticamente todos os países examinados conferiram isenções ou reduções tributárias para equipamentos e serviços relacionados às energias de baixo carbono, fomentando a competitividade dessas fontes vis-à-vis as fontes fósseis, como será examinado à frente.

\section{Feed-in tariffs}

As políticas de feed-in tariffs - FIT (ou tarifas especiais para alimentação do sistema elétrico, numa tradução livre) exerceram papel importante na difusão de tecnologias de baixo carbono, especialmente em países europeus como Espanha e Alemanha.

Elas consistem fundamentalmente no estabelecimento de uma tarifa especial para a geração de energia, diferente para cada fonte e escala de projeto, por meio de contratos de longo prazo de compra de energia, usualmente baseados no custo da produção de energia daquela natureza. Muitas vezes estão associadas a tarifas declinantes ao longo do tempo, para estimular ganhos tecnológicos nesses setores.

As tarifas mais elevadas viabilizam a entrada no sistema de fontes que ainda não dispõem de condições de competir com as fontes tradicionais de energia, como a solar e, até alguns anos atrás, a eólica. A duração de longo prazo do contrato assegura que investimentos de porte feitos com a tecnologia atual podem ser rentáveis.

O país que liderou os esforços por essa tarifa especial de alimentação do sistema foi a Alemanha, que instituiu valores relativamente elevados e contratos de longo prazo, fomentando com vigor a entrada rápida de novas fontes na matriz energética do país.

O Brasil adotou uma variedade de FIT quando instituiu o Programa de Incentivo às Fontes Alternativas de Energia Elétrica, conhecido pela sigla Proinfa. Instituído em dezembro de 2001, o programa foi lançado no contexto da crise do setor elétrico daquele ano e buscou, inicialmente, diversificar as fontes utilizadas no sistema brasileiro - até então quase inteiramente dependente das grandes hidrelétricas.

Na última década, o Proinfa incentivou mais de 100 empreendimentos do setor, sendo 41 projetos eólicos, 59 pequenas centrais hidrelétricas e 19 térmicas a biomassa, atingindo uma contratação total de $2.649 \mathrm{MW}$. Vale notar que o programa brasileiro não abrange energia solar entre as fontes possivelmente beneficiadas. $\mathrm{O}$ desenho do programa previa a contratação de até $3.300 \mathrm{MW}$ de capacidade, tarifas diferenciadas, contratos de até 20 anos, além de descontos nas tarifas de uso do sistema de transmissão e de distribuição (art. 3o da Lei $\mathrm{n}^{\mathrm{O}}$ 10.438, de 26 de abril de 2002). 
Previa-se ainda uma segunda etapa para o programa, depois de contratados os primeiros 3.300 MW, com o propósito de expandir para 10\% da matriz em 20 anos as fontes eólica, biomassa e pequena central hidrelétrica (de novo, a solar fica de fora). Essa segunda etapa deveria observar regras que impõem tarifas mais competitivas do que as da primeira etapa do programa. Mas a exigência não constituiu propriamente um problema em razão do barateamento dos custos dessas fontes no Brasil, conforme examinado no tópico sobre quota de energia renovável.

É relevante observar que o FIT do Proinfa veio casado com a exigência de conteúdo nacional, item a ser examinado mais adiante, consistente no índice de nacionalização dos equipamentos e serviços utilizados em cada empreendimento. A legislação exige um grau de nacionalização de, no mínimo, 60\% na primeira etapa do Proinfa e de $90 \%$ na segunda.

Muito resumidamente, o Brasil fez uso do FIT na etapa inicial de desenvolvimento das fontes eólica, biomassa e PCHs, resultando em relevante avanço dessas fontes na matriz elétrica brasileira. Mas o programa, nos moldes generosos iniciais, já se encerrou, permanecendo apenas a quota (já atingida) de energia renovável para 2022.

$\mathrm{Na}$ China, o programa de feed-in tariff exerceu papel importante na fase inicial de desenvolvimento da fonte eólica e, mais recentemente, da solar. A política foi conjugada com exigência de conteúdo nacional, com investimentos crescentes em $\mathrm{P} \& \mathrm{D}$ e com integração de institutos de pesquisa com as empresas.

Como aponta LEWIS (2013), praticamente nunca houve um momento em que a China considerou utilizar energia eólica sem que, simultaneamente, desenvolvesse uma indústria própria de tecnologia eólica. A criação de um mercado doméstico local por meio de FIT visou a conferir escala à indústria nascente e a promover aprimoramentos tecnológicos antes de ocupar o mercado internacional com os produtos chineses. As políticas foram sendo ajustadas ao longo do tempo visando a expandir a geração eólica e especialmente desenvolver uma indústria tecnológica de energia eólica na China.

A primeira medida relevante veio em 1994, quando se determinou a facilitação da conexão das fazendas eólicas ao sistema elétrico e se instituiu pela primeira vez o FIT. A tarifa de alimentação foi definida pelo princípio de que representaria o custo de geração, mais o pagamento do financiamento e mais um lucro razoável. Essa fórmula de custo-mais-lucro persistia durante vários anos e permitiu a expansão das fazendas eólicas, ainda que a um custo alto de subsídio quando a margem de lucro foi fixada em níveis generosos.

Em 1997, quando a capacidade eólica instalada era de apenas 80 MW, foram estabelecidas regras mais rigorosas de conteúdo local nas turbinas, ao mesmo tempo em que se 
fixava a meta de dobrar a capacidade instalada. Isso gerou um conflito com os financiadores dos projetos, a maior parte dos quais governos ou empresas estrangeiras (principalmente Alemanha, Dinamarca e EUA), que forneciam os equipamentos e não pretendiam elevar o índice de nacionalização dos produtos.

Um novo impulso ocorreu entre 2003 e 2007, quando houve concessões de áreas propícias a usinas eólicas por meio de disputa pública, com vários benefícios (financiamento, contratação garantida, conexão favorecida, etc.). Em cinco rodadas de concessões, foram contratados 18 projetos eólicos totalizando $3.350 \mathrm{MW}$, e foi fixada pela primeira vez, em nível nacional, uma tarifa de alimentação com preços claros (entre RMB 0,42 e 0,551 por kWh) (LEWIS, 2013).

Em 2006, com a já mencionada Lei de Energia Renovável, foram assegurados em nível legal a obrigação de conexão de fontes renováveis (não apenas eólica) e definidas as regras pelas quais se poderia utilizar a FIT. Algumas províncias passaram a definir suas próprias tarifas de FIT, como Guangdong, que fixou em RMB 0,528 por kWh e depois elevou para RMB 0,689 por kWh (valor próximo a US\$ 0,11).

Em 2009, foram padronizadas nacionalmente as tarifas de FIT para eólica, fixando-se quatro faixas segundo a classe de ventos em cada região. Ventos da categoria 1, com os melhores recursos de vento, recebiam a menor das tarifas (RMB 0,51 por kWh); a categoria 2 subia para RMB 0,5; a categoria 3 alcançava em RMB 0,58; e a categoria 4 chegava a RMB 0,61 .

A China também passou a fazer uso em larga escala, a partir de 2006, do MDL, do Protocolo de Quioto, que fornecia um subsídio adicional de cerca de RMB 0,10 por kWh. Alguns anos depois boa parte dos projetos chineses passaram a enfrentar dificuldades em obtenção de créditos no MDL por não haver clareza se eles constituiriam redução "adicional" de emissões, como já examinado anteriormente, ou se caracterizariam business as usual.

Já em fins da década de 2000, como será examinado em detalhes mais à frente, a China dispunha de capacidade instalada vultosa no setor eólico, com várias indústrias locais de grande porte competindo diretamente com as grandes empresas europeias e estadunidenses do setor. As políticas de FIT exerceram papel central na criação de condições para o desenvolvimento tardia dessa indústria, casada com outras políticas locais.

Tanto Coreia, quanto Taiwan adotaram tarifas especiais para as renováveis, mas, diferentemente da China e mesmo do Brasil, os valores não foram tão expressivos e não resultaram propriamente em desenvolvimento significativo de geração por outras fontes. 
O governo sulcoreano fixou FIT com um valor pré-definido: 107,29 won por kWh (algo como US\$ 0,10), reduzindo-se $2 \%$ a cada ano após 2009 em com contratos de quinze anos (LEWIS, 2013). Mas em 2012 o sistema foi substituído pela quota de energia renovável já mencionada em tópico anterior, dado que o sistema FIT foi avaliado como ineficaz nos moldes como implementado na Coreia (IEA, Tracking Clean Energy Progress, 2013).

No caso de Taiwan, a política de FIT foi adotada em 2009 por meio da Lei do Desenvolvimento de Energia Renovável, que compeliu as distribuidoras de energia a adquirir energia renovável nos preços decrescentes definidos pelo poder público (FOX, 2011).

A legislação fixou uma fórmula de cálculo para cada tipo de fonte utilizada, com diferentes e decrescentes tarifas para solar fotovoltaica, eólica em terra, eólica offshore, biomassa e resíduos, com vários preços consoante o tipo de tecnologia e o porte do empreendimento.

A tarifa se baseia nos custos de produção, mais uma taxa de lucros decrescente por ano, iniciando em 5,25\% de retorno sobre o capital (CHOU; LIN, 2012). Com contratos de até vinte anos, as tarifas variam do equivalente a US\$ 0,08 para eólica em terra a até US\$ 0,24 para solar em telhados de residências (TSAI, 2014). A política de FIT em Taiwan foi revisada em 2012, para acelerar a taxa de desconto da tarifa máxima, passando a cair a cada seis meses, e não mais anualmente. No conjunto, a política taiwanesa de incentivo provocou alguma elevação da capacidade instalada das fontes abrangidas pelo programa, mas o país continua com participação muito reduzida de fontes renováveis em sua matriz.

Sinteticamente, Brasil e China adotaram medidas de FIT relevantes para a expansão da geração de baixo carbono no próprio sistema elétrico, ao passo que Coreia e Taiwan, a despeito da adoção formal de tarifas FIT, não fizeram esforço significativo para evitar a oneração do custo de energia local.

\section{Incentivos fiscais e tarifários}

Quase todos os países adotaram algum tipo de incentivo fiscal para as fontes renováveis. A crítica apontada por economistas ao modelo de desoneração tributária do setor reside no estímulo que a desoneração acarreta para o uso adicional de energia, ainda que de fonte menos poluente. Por um lado, a redução de tributos provoca o efeito inverso do que um imposto sobre o carbono provocaria, isto é, ela barateia a energia, em lugar de encarecê-la.

A despeito da crítica, o fato é que a desoneração tributária das fontes menos poluentes ajuda a reequilibrar a disputa de mercado. Ainda que idealmente as fontes poluentes 
devessem arcar com exação fiscal adicional, o que encareceria seus preços e tornaria as de baixo carbono mais competitivas, o efeito competitividade também se verifica no caso da desoneração das renováveis. Ao tornar, por exemplo, a eólica ou a solar mais baratas, elas passam a ter condições mais equilibradas para disputar o preço com as fontes fósseis - ainda que numa curva mais baixa de preços, e não numa disputa em torno de uma curva mais elevada.

As dificuldades políticas é que têm tornado os incentivos fiscais mais fáceis de implantar do que o imposto sobre o carbono ou o cap-and-trade. O tributo sobre carbono ou o cap-and-trade imporiam custos sociais imediatos, materializados principalmente em preços de energia mais caros - e, portanto, maior desgaste político. Simbolicamente, eles representam um movimento "contra" um setor econômico, particularmente o de combustíveis fósseis.

Inversamente, as desonerações tributárias não têm o efeito simbólico de ser "contra" um setor, mas sim de ser "a favor" de um outro, o das fontes de baixo carbono. Elas não trazem custos imediatos para a população, já que não provocam aumento imediato de preços. Pode-se argumentar que à medida que a participação de renováveis cresce, outras fontes tributárias terão que ser buscadas para suprir a receita que anteriormente se originava do setor energético, mas os efeitos são difundidos no longo prazo. De imediato, o impacto fiscal é relativamente pequeno, já que a adoção dos incentivos toma lugar em locais com baixa penetração de renováveis na matriz energética.

No caso do Brasil, os incentivos para o setor se iniciaram com as desonerações das tarifas de transmissão e de distribuição. Chamadas no setor de TUST e TUSD (Tarifa de Uso do Sistema de Transmissão e de Distribuição, respectivamente), essas tarifas são pagas pelos empreendimentos de energia que conectam suas usinas ao sistema interligado nacional. Por meio da Lei n⿳⺈ 9.648, de 27 de maio de 1998, alterou-se a Lei no 9.427 , de 26 de dezembro de 1996 (Lei da ANEEL), para instituir um desconto de pelo menos 50\% nessas tarifas quando a fonte de energia proviesse de pequenas centrais hidrelétricas ( $\$ 1$ o do art. 26).

A partir de 2002, depois da crise energética do ano anterior, esse desconto foi estendido para a biomassa, eólica, solar e cogeração qualificada, no esforço de ampliar e diversificar a matriz energética brasileira (Lei no 10.438 , de 2002; Lei no 10.762 , de 2003; e Lei $\mathrm{n}^{\mathrm{o}}$ 11.488, de 2007). Esse desconto, vale notar, tem peso principalmente para a operação das usinas, e não propriamente para a fabricação dos equipamentos e de tecnologias empregados em sua construção.

Outro movimento de desoneração se faz presente por meio da redução das alíquotas de tributos que incidem sobre os equipamentos do setor, notadamente IPI, PIS e Cofins. O Brasil concede isenções ou descontos substanciais nas alíquotas dos equipamentos 
das principais fontes renováveis, incluindo solar, eólica e biomassa. Há ainda iniciativas estaduais e municipais de desoneração, tais como a redução de ICMS em vários estados, e os descontos no IPTU para a utilização de paineis solares.

A desoneração de equipamentos e a desoneração da energia gerada a partir de fontes renováveis têm efeitos distintos. Embora esta última promova maior participação das fontes renováveis na matriz elétrica do país, ela não necessariamente fomenta a produção nacional e o desenvolvimento tecnológico. Afinal, se a energia for suprida com equipamentos importados, ela recebe o benefício tributário ou tarifária igualmente.

Já a desoneração dos equipamentos, embora também se reflita num preço menor de energia para o consumidor final, pode, a depender do desenho das alíquotas e dos reflexos sobre importações, impactar mais diretamente nas cadeias produtivas e fomentar a produção local. Tudo depende do arranjo dos tributos, no reflexo sobre produtos importados equivalentes e também nas alíquotas das tarifas aduaneiras.

Nos três países asiáticos em questão, também foram concedidos descontos similares sobre tarifas do sistema elétrico e sobre impostos sobre os equipamentos do setor. Conforme a tecnologia em questão, os países tentavam dosar proteção à indústria local, abertura à importação no caso de peças e componentes sem similares nacionais e desoneração completa para as exportações. As políticas e seus resultados serão mais detalhadamente examinados no Capítulo 6. Trata-se, em todo caso, de medida amplamente adotada em todos os países examinados, com resultados distintos em termos de geração de energia renovável e formação de um parque industrial inovador no setor.

\subsection{Medidas preponderantemente de política industrial e tecnológica}

Como já mencionado anteriormente, a discussão sobre enfrentamento da mudança climática está associada a políticas industriais e tecnológicas. Afinal, os países não apenas querem ter condições de crescer com menor emissão de carbono, mas também querem disputar a liderança das novas tecnologias de baixo carbono.

Nesse contexto, se é certo que as políticas discutidas nos subtópicos anteriores têm natureza híbrida - a um só tempo ambiental e industrial-tecnológica -, há também políticas importantes adotadas com o propósito predominante de fomento à indústria e à tecnologia 
locais. Nessa categoria se inserem especialmente a política alfandegária, a política de conteúdo local e os variados estímulos a atividades de P\&D adotados pelos países examinados.

\section{Política alfandegária}

As políticas alfandegárias para o setor de energias de baixo carbono seguem a tradição dos países de industrialização de proteção a indústria nascente. Tendo partido tardiamente no esforço de desenvolver tecnologias e produtos de baixo carbono, os países buscaram desestimular a importação de equipamentos completos com alíquotas de importação superiores, deixando mais baixas as alíquotas para a importação de partes dos equipamentos, isto é, de insumos que permitissem a fabricação nacional competitiva.

Além disso, à medida que se consolidava o setor industrial em dado segmento, as alíquotas poderiam ser progressivamente reduzidas, de modo a estimular a competição doméstica. Brasil e China adotaram em larga escala essas políticas, dado que suas indústrias saíram de patamares mais atrasados em relação ao estado da arte nesses segmentos.

Taiwan e Coreia do Sul fizeram uso dessas medidas em menor intensidade, porquanto seu ingresso nos setores de baixo carbono se deu a partir de indústrias já maduras em seus respectivos campos, como a conversão parcial da indústria de semicondutores para produtos eletrônicos em indústria de semicondutores para paineis solares.

\section{Conteúdo local}

A exigência de conteúdo nacional é uma das medidas tradicionais de política industrial. Trata-se de fazer uso do poder de compra - ou do poder de financiamento - do ente público para fomentar o desenvolvimento industrial de um país, ainda que ao custo de pagar mais caro temporariamente pelos equipamentos.

Há quatro razões principais para a adoção de medidas de conteúdo nacional em projetos de energia renovável: a) aumenta o apoio popular para os projetos; b) protege a indústria nascente, especialmente em países em desenvolvimento; c) cria "empregos verdes"; d) aumento da concorrência entre os fornecedores dessas tecnologias no médio prazo (STEPHENSON, 2013).

De outro lado, os críticos à medida apontam que elas trazem custos adicionais para a fabricação dos produtos, resultam em alocação ineficiente dos recursos, provocam 
preços de energia mais caros do que os necessários, os ganhos de empregos seriam minúsculos e há um impacto negativo sobre o comércio e sobre a inovação.

Para que as regras de conteúdo nacional no campo de energia de baixo carbono tenham impacto benéfico para a economia nacional, KUNTZE e MOERENHOUT apontam cinco pré-condições: a) estabilidade e dimensão do mercado; b) pequeno grau de exigência, proporcional à capacidade industrial local; c) cooperação entre governos e empresas; d) subsídios suficentes para manter a atratividade do mercado; e) ênfase na transferência de conhecimentos e de tecnologia para o corpo técnico local (learning by doing and training by doing), e não propriamente no processo de manufatura (2013).

No caso do setor de baixo carbono brasileiro, o Proinfa passou a exigir depois de 2003 índices de nacionalização de 60\% dos equipamentos e serviços de cada empreendimento, chegando a $90 \%$ no caso da segunda etapa do programa (art. $3^{\circ}, \S 4^{\circ}$, da Lei do Proinfa). Pela legislação, caberia à Aneel fiscalizar o cumprimento do índice de nacionalização dos equipamentos e dos serviços (art. 19 do Decreto do Proinfa).

Além dessa exigência do programa, as linhas de financiamento do BNDES passaram a exigir das usinas beneficiárias de seus empréstimos índices de nacionalização que variavam conforme o tipo de empreendimento. Como boa parte dos empreendimentos do setor são financiados pelo BNDES, a exigência passou a valer mesmo para os empreendimentos que não se enquadravam no Proinfa.

A política de conteúdo nacional brasileira resultou na formação de uma ampla indústria de fornecimento de equipamentos em território nacional, como se verá no Capítulo 6, ainda que majoritariamente dominada por empresas estrangeiras que montam as estruturas nas fábricas brasileiras, com escasso desenvolvimento tecnológico.

Merece notar que um dos desafios para as políticas de conteúdo nacional é a fiscalização dos percentuais fixados. Não é trivial a definição dos contornos para caracterizar um produto como nacional: a mera montagem de peças fabricadas no exterior é suficiente para tornar essa peça "nacional".

Em 2013, por exemplo, a partir de denúncias de descumprimento pelas empresas, o BNDES desclassificou de suas linhas de financiamento empresas do porte da Vestas, GE e outras grandes do setor. Mais recentemente, o banco público de fomento estabeleceu diretivas mais claras para o que vai considerar conteúdo nacional, com um critério crescentemente mais rigoroso. Em entrevistas realizadas para a tese, vários especialistas reconheceram que o critério anterior era pouco claro e dava margem a encobrir a relevância das etapas de fabricação nacional. 
Um dos principais riscos para as políticas de conteúdo nacional, afora o encarecimento dos produtos, é tornar o conteúdo nacional "acéfalo", como alertou o ex-diretor da Petrobras Guilherme Estrella em entrevista à Folha de S. Paulo. Em outras palavras, a nacionalização da produção não deveria limitar-se à montagem simples de equipamentos, mas abranger não apenas a operação de máquinas, mas a competência em engenharia para a fabricação das próprias máquinas, podendo agregar inovações aos produtos, sem que fiquem na dependência dos centros de tecnologia no exterior das empresas (ESTRELLA, 2013).

A China também fez larga utilização da política de conteúdo nacional em sua indústria eólica. No caso da solar, o histórico é diferente, já que os produtos eram majoritariamente fabricados na China, mas destinados à exportação. Nesse caso, o poder de compra estava no exterior, e não nas concessionárias de energia estatais chinesas.

Coreia do Sul e Taiwan, ainda que tenham adotado medidas dessa natureza, elas não alcançam inteiramente o objetivo em razão do relativamente pequeno mercado interno. As empresas sulcoreanas e taiwanesas estavam mais preocupadas em exportar seus produtos para os mercados europeu e estadunidense do que em alcançar espaço no exíguo - e pouco estimulado - mercado de baixo carbono local.

\section{Estímulo às atividades de $\mathbf{P \& D}$}

"Where were you guys [venture capitalists] in the 1950's and 1960 's when all the funding had to be done in the basic science?

Most of the discoveries that have fuelled [the industry] were created back then."

Paul Berg, Prêmio Nobel em Química

Talvez o estímulo às atividades de $\mathrm{P} \& \mathrm{D}$ corresponda à principal medida para que um país não apenas promova a produção industrial, mas também consiga absorver tecnologia estrangeira e desenvolver suas próprias inovações.

Há inúmeras maneiras de fomentar as atividades de P\&D, seja por execução direta pelo poder público, seja custeando ou financiando atividades realizadas por empresas privadas. Como indicado no Capítulo 1, a promoção dessas atividades constitui uma das mais modernas fórmulas de políticas industriais para países retardatários, dadas as restrições estabelecidas pela ordem internacional para as opções tradicionais de emparelhamento industrial e tecnológico. 
O mais óbvio estímulo à P\&D com financiamento direto do Estado se dá por meio de centros de pesquisa públicos. Os quatro países em questão trabalham com essa opção e constituíram centros de pesquisa voltados a energias de baixo carbono, ou direcionaram parte das atividades de centros pré-existentes para essas ações. Os resultados serão esmiuçados no Capítulo 6.

No caso do Brasil, além do apoio às universidades públicas, merecem referência a atuação dos denominados fundos setoriais, criados a partir de 1999, e também a política de P\&D obrigatória para o setor de elétrico.

São vários os fundos setoriais existentes, cada qual com uma fonte de recursos específica e voltado para a promoção de pesquisas em determinada área de conhecimento. Para fins desta pesquisa, o mais importante é o fundo setorial de energia (CT-ENERG). Esse fundo, administrado pela FINEP e pelo CNPq, tem por objetivo "estimular a pesquisa e inovação voltadas à busca de novas alternativas de geração de energia com menores custos e melhor qualidade; ao desenvolvimento e aumento da competitividade da tecnologia industrial nacional, com aumento do intercâmbio internacional no setor de P\&D; à formação de recursos humanos na área e ao fomento à capacitação tecnológica nacional”.

Os recursos se originam de uma contribuição obrigatória de parcela do "faturamento líquido" de empesas concessionárias do setor elétrico (Lei no 9.991, de 24 de julho de 2000) e resultaram na aplicação total de projetos em 2013 da ordem de R 63 milhões. Esses recursos financiam exclusivamente instituições de pesquisa e desenvolvimento e instituições de ensino superior.

Além dos investimentos via fundo setorial de energia, o setor também conta com recursos da chamada P\&D obrigatória. Trata-se de parcela - relativamente reduzida - do "faturamento líquido" das concessionárias do setor elétrico que obrigatoriamente deve ser aplicado em P\&D, nos termos de regulamentação da Aneel. Como se verá no Capítulo 6, os resultados desses investimentos não têm sido muito exitosos, dados os volumes acanhados de recursos e a amplitude dos critérios empregados para qualificar atividades como P\&D.

Afora isso, o Brasil também confere inúmeros incentivos fiscais para o desenvolvimento de atividades de $\mathrm{P} \& \mathrm{D}$, como depreciação acelerada e descontos adicionais no cálculo do lucro das empresas, conforme prevê a denominada Lei do Bem (Lei 11.196, de 21 de novembro de 2005).

Ocorre que, diferentemente dos países asiáticos, as empresas brasileiras não têm tradição de aportar volumes significativos de recursos em ações de P\&D. Enquanto que na 
Coreia o setor privado tem clara preponderância nos investimentos em pesquisa e desenvolvimento, no Brasil apenas metade dos valores tem origem privada.

Na China, a Lei de Energia Renovável, de 2005, estabelece como prioridade, no campo da ciência e da tecnologia, os projetos de pesquisa - e de desenvolvimento industrial para o desenvolvimento de energias renováveis, com vistas ao barateamento, melhoria da qualidade e difusão de seu uso (art. 12). Institutos de pesquisa públicos têm forjado parcerias com empresas chinesas para aperfeiçoar os produtos e desenvolver novas tecnologias, como se verá em detalhes mais à frente.

$\mathrm{O}$ fato de dispor de um setor industrial pujante e inovador permite que Coreia e Taiwan não exerçam o mesmo nível de esforço público para fomentar P\&D na área de energia de baixo carbono. Ainda assim, as duas leis fundamentais sobre o tema nesses países previram ampliação substancial dos recursos públicos conferidos a essas atividades.

Em Taiwan, a Lei de Desenvolvimento de Energia Renovável, de 2009, compôs o quadro para reforçar os investimentos públicos em centro de pesquisa na área de P\&D. Mas as próprias empresas taiwanesas é que estão puxando os esforços nacionais em investimentos em $\mathrm{P} \& \mathrm{D}$ para o baixo carbono, especialmente o setor de eletrônicos, que busca se reposicionar para ocupar o mercado dos painéis solares.

Na Coreia, a Lei Quadro sobre Crescimento Verde de Baixo Carbono, de 2010, também estipula regras para fomentar e facilitar os investimentos em P\&D na área de energia de baixo carbono. Tal qual Taiwan, os grandes investimentos vêm sendo promovidos pelas próprias empresas coreanas, como Samsung, Hyundai e várias outras, adentrando desde a fabricação de turbinas eólicas, passando pelos paineis solares e pelo armazenamento de energia.

\subsection{Custos e benefícios das medidas: quem se favorece e quem arca com o ônus}

"É uma interessante classe de contribuintes, módica em número, mas bastante forte. Pertencem a ela negociantes, proprietários, industriais, agiotas que esfolam o próximo com juros de judeu. Bem comido, bem bebido, o pobre povo sofredor quer escolas, quer luz, quer estradas, quer higiene. É exigente e resmungão.

Como ninguém ignora que se não obtém de graça as coisas exigidas, cada um dos membros desta respeitável classe acha que os impostos devem ser pagos pelos outros." 
As políticas para promover energias de baixo carbono trazem um custo inicial inquestionável, embora, segundo a maioria das estimativas, seja compensado mais à frente pela mitigação dos problemas ambientais. Mas como os ganhos futuros são incertos - assim como os riscos de mudanças climáticas são ainda percebidos como hipóteses -, nem todas as sociedades têm se mostrado dispostas a arcar com esse custo imediato.

De outro lado, há uma aposta crescente em alguns grupos empresariais de que se trata de uma janela de oportunidade de ocupar um mercado de grande potencial, em razão do alto nível de evidência científica do fenômeno e dos movimentos crescentes de restrição ao uso de carbono. Ser um early mover no mercado de baixo carbono pode trazer algumas vantagens acentuadas na disputa de longo prazo pela primazia das tecnologias a serem empregadas na geração, na estocagem e no manejo dos sistemas energéticos nacionais.

Os investimentos em inovação tecnológica são de retorno quase sempre incerto. Pode-se apostar em uma tecnologia e, depois de anos de pesquisa, perceber-se que não existe viabilidade econômica. Ao passo que outras, inicialmente sem caráter promissor, podem revelar-se extremamente eficazes a partir de um ajuste incremental inicialmente impensado. A diversificação dos investimentos tende a balancear os riscos, mas eles estão sempre presentes. O modelo claramente não é linear, no sentido de que o aumento do volume de pesquisas não necessariamente resulta em maior número de invenções comercialmente aproveitáveis.

Em que pese essas incertezas, pode-se afirmar que, sem assumir esses riscos, quase certamente não surgirão inovações. A capacidade de inovar, especialmente em um setor como o de energia, depende fundamentalmente do volume de investimentos aplicados em novas tecnologias.

No Vale do Silício, na Califórnia, houve uma grande frustração dos investidores de capital de risco em relação às start-ups da área de energia. Muitos apostaram que surgiriam do dia para a noite empresas que revolucionariam o mercado de energia, do mesmo modo surpreendente como surgiram, em negócios ligados à internet, empresas como o Google, o Facebook e o Twitter. Mas a frustração se deu pelo fato de que, em energia, os resultados dependem de um volume de capital investido em pesquisas bem superior ao necessário para empresas de software e, sobretudo, de tempo de maturação dos projetos bem mais longos do que o calculado inicialmente. 
Há um custo e um risco por apostar em futuras tecnologias, sempre incertas. Mas não pagar o preço por essas atividades representa uma condenação quase certa ao atraso tecnológico e à dependência da tecnologia alheia.

Esse custo, dada a imensa incerteza e os altos riscos, têm sido tradicionalmente bancados - ou ao menos fortemente apoiados - pelo poder público, como aponta MAZZUCATTO (2013). Poucas empresas dispõem de porte suficiente para encarar os riscos de fracasso de projetos caros e de longa duração. Além disso, os benefícios auferidos com o desenvolvimento de novas tecnologias trazem externalidades positivas para o conjunto da economia, como tarifas mais baratas e fornecimento mais seguro, o que também legitima a aplicação de recursos públicos. No caso de energias de baixo carbono, há ainda uma corrida tecnológico-industrial entre os países para liderar as tecnologias na área e dispor de capacidade de produção e de exportação nessas indústrias de ponta e com crescimento promissor.

Como se sabe, a mera pesquisa em laboratório não é suficiente para a incorporação ampla de uma tecnologia. O próprio processo de utilização de uma fonte energética em larga escala num sistema energético já permite o aprendizado com o manejo do sistema elétrico abastecido em parte por fontes intermitentes, com os diversos percalços inerentes à utilização de novas tecnologias.

Daí o motivo pelo qual o mero esforço em P\&D não é suficiente para que o país alcance o domínio amplo em sistema tão complexo como o setor elétrico. A capacidade industrial de produzir equipamentos e serviços e o próprio manejo de um sistema alimentado parcialmente por essas fontes constituem também elementos importantes do aprendizado tecnológico. Qual o custo a que cada sociedade está disposta a pagar e como elas percebem a urgência de dominar essas tecnologias tem definido o rumo das políticas, isto é, se focadas na geração de energia, na manufatura ou no desenvolvimento tecnológico.

É válido, aliás, para dimensionar o impacto concreto de certas medidas, estimar quanto custaria ampliar a participação, por exemplo, da geração solar no Brasil. Se, por hipótese, o Brasil adotasse um mandato de $1 \%$ para geração a partir de fonte solar e, ainda hipoteticamente, a energia solar custasse o dobro das demais fontes, o impacto na conta de luz do consumidor ficaria em torno de ínfimos $0,4 \%$. Isso se deve ao fato de que a parcela da tarifa correspondente à geração representa apenas trinta por cento da tarifa paga pelo consumidor, dividindo-se o restante em transmissão, distribuição, tributos e encargos (valores aproximados, já que há variações regionais).

Nesse exemplo hipotético, a oneração da tarifa se limitaria à parte da geração (com repercussão sobre impostos e encargos), mas não impactaria a transmissão e a 
distribuição. Ainda assim se criaria um enorme mercado de geração para o setor, em torno de $1,2 \mathrm{GW}$, se calculado o $1 \%$ em termos de capacidade instalada. Transformando a conjectura em valores monetários, numa conta residencial de energia de $\mathrm{R} \$ 50,00$, o impacto de cada ponto percentual de eventual mandato de energia solar seria de aproximadamente $\mathrm{R} \$ 0,22$, um valor bastante reduzido - e utilizando parâmetro de custo excessivamente elevado para a geração solar ${ }^{22}$.

Sintetizando este capítulo, há uma grande falha de mercado para promover tecnologias de baixo carbono e vários países têm enfrentado a questão por meio de diferentes modalidades de atuação estatal. A experiência internacional comparada oferece vasto arsenal de políticas públicas com o propósito de fomentar tecnologias nascentes. Essas políticas têm um custo inicial relevante e foram adotadas pelos países que hoje lideram o setor. É interessante identificar quais delas se revelaram eficazes e para que propósitos (gerar energia, promover atividades manufatureiras ou produzir inovações tecnológicos). Os resultados dessas políticas serão examinados no Capítulo 6.

\footnotetext{
22 Para chegar a esse valor, adotamos estimativas aproximadas do custo da tarifa de energia de $30 \%$ para geração ( $\mathrm{R}$ \$ 15,00 no exemplo), $10 \%$ para transmissão ( $\mathrm{R} \$ 5,00), 30 \%$ para distribuição $(15,00)$ e outros $30 \%$ para impostos e encargos $(\mathrm{R} \$ 15,00)$, totalizando $\mathrm{R}$ \$ 50,00. Assumindo que a energia solar custaria o dobro da geração tradicional, cada ponto percentual de energia solar inserido na geração acarretaria um custo adicional de $\mathrm{R} \$ 0,15$, o que significaria a incidência de impostos e encargos sobre um custo total de R\$35,15, totalizando R\$ 50,22.
} 


\title{
CAPÍTULO 6 \\ AS NOVAS TECNOLOGIAS DE ENERGIA LIMPA \\ NOS PAÍSES EXAMINADOS
}

\begin{abstract}
"We are like tenant farmers chopping down the fence around our house for fuel when we should be using Nature's inexhaustible sources of energy — sun, wind and tide... I'd put my money on the sun and solar energy. What a source of power! I hope we don't have to wait until oil and coal run out before we tackle that." Thomas Edison
\end{abstract}

\subsection{Brasil}

Examinaremos neste Capítulo o estágio atual da tecnologia empregada nas fontes de energia de baixo carbono nos quatro países examinados. Como a situação de cada fonte é bem distinta em cada um deles, as ênfases tentarão ser correspondentes à importância que os países atribuem a essas diferentes tecnologias, tanto em termos de geração, quanto de manufatura. Mas o foco da análise será o Brasil e as diferenças dos demais em relação às opções nacionais.

As políticas públicas brasileiras na área de energia têm conferido prioridade a garantir segurança energética e modicidade tarifária. $\mathrm{O}$ esforço por incrementar as atividades manufatureiras e de inovação tecnológica tem sido executado principalmente por órgãos e entidades governamentais que não integram o setor de energia, especialmente o MDIC, o MCTI, o BNDES e a FINEP, percebendo-se certa dissociação entre a geração e a inovação.

Como se viu anteriormente, o Brasil dispõe hoje de uma matriz energética cujo nível de emissão de carbono é comparativamente baixo, dispõe de amplo potencial para expandir a geração com fontes menos poluentes e já consolidadas (notadamente hidráulica e biomassa) e ainda desfruta de vastas reservas de combustíveis fósseis (notadamente o pré-sal). Some-se que o total de emissões do país vem sendo intensamente reduzido por meio de diminuição do desmatamento, sem necessidade de alterar significativamente sua matriz energética.

Nesse contexto, a preocupação das instituições que formulam a política de energia não está centrada na inovação tecnológica para explorar novas fontes de energia. A 
inovação nessa área é examinada apenas no contexto geral da política industrial e tecnológica, e não como uma medida estratégica de segurança nacional. Desse modo, os esforços envidados pelo país para inovar em energia estão fundamentalmente concentrados nas atividades desenvolvidas pelos ministérios e entidades responsáveis pela política de inovação, e não pela política energética.

É válido fazer um breve histórico do setor de energia elétrica brasileiro. O destaque do setor no país tem sido a participação privilegiada da hidroeletricidade, que, desde os primórdios, foi a principal fonte primária de energia elétrica no Brasil.

O país iniciou a geração hidráulica ainda na década de 1880. São controversos os dados da primeira usina hidrelétrica, mas a Usina de Marmelos, em Juiz de Fora (MG), é considerada a primeira de certo porte a entrar em funcionamento, em $1889^{23}$. Esse primeiro empreendimento foi realizado pelo empresário Bernardo Mascarenhas, um industrial da região que pretendia utilizar a eletricidade para suas fábricas de tecido e na iluminação da cidade.

Por se tratar de uma tecnologia recente no mundo, esse primeiro projeto de hidrelétrica no Brasil precisou, já então, importar tecnologia: a usina foi projetada pela empresa estadunidense Max Nothman \& Co., e os equipamentos de geração de energia foram importados da também estadunidense Westinghouse.

Vários empreendimentos foram em seguida se espalhando pelo país, a maior parte liderada por industriais e fazendeiros em busca de autossuficiência energética. Da virada do século até a década de 1940, grupos privados estrangeiros especializados em energia passaram a exercer papel de maior influência no setor, como o Grupo Light (de origem canadense), no eixo Rio de Janeiro - São Paulo, e a AMFORP (American \& Foreign Power Company, inicialmente um braço da estadunidense General Electric), em várias capitais do país. Essas empresas exploravam principalmente a hidroeletricidade e, em menor medida, a termoeletricidade.

O setor começou a mudar com a edição por Getúlio Vargas do Código de Águas (Decreto no 24.643, de 1934). Superou-se a fase em que os negócios eram regidos principalmente por contratos entre municípios e empresas de energia: a União passou a centralizar a outorga de todas as fases do setor de energia, incluindo geração, transmissão e distribuição. O tema da energia deixou de ser matéria de interesse municipal e passou a ser

\footnotetext{
${ }^{23}$ A usina Ribeirão do Inferno, em Diamantina/MG, foi provavelmente a primeira usina a gerar eletricidade a partir de fontes hídricas no Brasil, em 1883. De pequeno porte, a usina gerava energia capaz de movimentar bombas d'água para desmonte das formações nas minas de diamante (Eletrobras, 2014).
} 
acompanhado pela União - e também por Estados -, atuando tanto na regulação, quanto nos empreendimentos (TOLMASQUIM, 2011).

De fato, a partir principalmente dos anos 1950, no segundo governo Vargas e no de Juscelino Kubitschek, empresas estatais passaram a ocupar, gradativamente, parcela crescente das atividades em face do receio de falta de eletricidade para a economia em crescimento. A criação de várias estatais de geração elétrica - Chesf (1945), Furnas (1957) e distribuidoras regionais - culminou na formação de uma empresa holding, a Eletrobras, constituída em 1962 no governo João Goulart. A Eletrobras centralizou as atividades de planejamento, financiamento e expansão da oferta. As estatais conferiram novo impulso ao setor, o que resultou na construção de usinas de maior porte, como Paulo Afonso, Xingó e Sobradinho (Rio São Francisco), Itaipu (Rio Paraná) e Tucuruí (Rio Tocantins). Adotou-se um acordo tácito pelo qual a União cuidaria de geração e transmissão, cabendo aos Estados as atividades de distribuição - embora tenha havido várias exceções a essa diretriz geral (TOLMASQUIM, 2011).

As principais concessionárias privadas foram absorvidas pelas estatais, incluindo a Light e a AMFORP. O desenho geral do setor conferia papel central para o poder público, que era o ator central nos investimentos e na operação para geração, transmissão e distribuição de energia elétrica.

Nos anos 1980, o setor elétrico enfrentou uma forte crise, decorrente de três fatores principais: a) a extinção de fontes seguras de financiamento para a expansão de oferta, como o imposto único de energia elétrica; b) o uso das tarifas elétricas como forma de contenção da inflação; e c) ineficiência decorrente da remuneração garantida aos concessionários com base apenas nos custos, sem estímulos concorrenciais. Os dois primeiros fatores escassearam os recursos que vinham financiando a expansão contínua do setor nas décadas anteriores, e o terceiro implicou encarecimento excessivo dos custos do setor pela baixa competição.

Nos anos 1990, no impulso global de abertura da economia e de incremento da participação do setor privado, o setor energético foi um dos que passaram por intensa reformulação e as empresas estatais foram incluídas no Plano Nacional de Desestatização. Os marcos da mudança foram a Lei n- 8.987, de 1995 (Lei de Concessão de Serviços Públicos), que adotou o regime de prestação de serviços pelo preço, e não pelos custos, e a Lei no 9.427, de 1996 (Lei da ANEEL), que criou a Agência Nacional de Energia Elétrica e estabeleceu novas diretrizes para o setor. Estimulou-se a entrada de grupos privados, para elevar a eficiência do sistema, garantir capacidade de investimentos e mitigar o déficit fiscal pela venda de ativos. 
As atividades do setor foram desverticalizadas. Boa parte da distribuição foi privatizada, e as atividades de transmissão e de geração passaram a ter participação privada crescente, embora as estatais ainda tenham preservado parcela relevante desses segmentos.

A crise de abastecimento energético de 2001, provocada por deficiências no novo modelo regulatório agravadas pelo cenário hidrológico desfavorável, implicou novas mudanças no setor e a retomada de papel mais central para o poder público. Essa nova reforma, implantada por meio da Lei no 10.848 , de 2004, tinha como objetivos principais conferir maior segurança energética, ampliar a participação do estado no planejamento energético e conferir modicidade tarifária. Institucionalizou-se um modelo híbrido, que conjuga investimentos públicos e privados no setor elétrico, organizados em leilões centralizados para o mercado regulado, dentro de um sistema coordenado e planejado por instituições públicas. A Eletrobrás foi excluída do Plano Nacional de Desestatização, e as estatais voltaram a investir em ampliação da oferta (TOLMASQUIM, 2011).

Atualmente, as empresas do grupo Eletrobrás controlam cerca de $36 \%$ da geração e 56\% das linhas de transmissão de todo o sistema brasileiro. No caso da distribuição, a Eletrobrás controla o segmento apenas nos Estados de Piauí, Alagoas, Amazonas, Roraima, Acre e Rondônia.

Uma das diferenças relevantes entre o modelo adotado em 2004 em relação ao anterior diz respeito à estrutura dos leilões. Como um dos objetivos centrais passou a ser a modicidade tarifária, os leilões passaram a basear-se na oferta da menor tarifa, e não mais no maior valor pago pelo uso do bem público (caso das hidrelétricas). Todo o modelo foi concebido para baratear os custos, quase sempre com competição de preços das diversas fontes entre si, e não em leilões separados por fonte. O resultado é que a hidroeletricidade dominou a maior parte dos leilões e, mais recentemente, as eólicas têm tomado a maioria dos novos contratos.

O mercado de energia pode ser dividido no segmento de produção de energia e no segmento de fabricação de equipamentos para o setor, tema central desta tese. Até os anos 1970, na área de equipamentos, praticamente todos os produtos eram importados. O pouco que se montava aqui era fruto inteiramente de tecnologias desenvolvidas no exterior.

Até 1974, quando criado o Centro de Pesquisa em Energia Elétrica (CEPEL/Eletrobras), a pesquisa em eletricidade se restringia a trabalhos realizados por institutos eletrotécnicos ligados a universidades, além de pequenos laboratórios de algumas concessionárias de energia, com foco em solução de problemas de manutenção de equipamentos e instrumentos de medição. 
Nos anos 1970 e 1980, além da criação do centro, foram destinados recursos fixos aos investimentos em pesquisa no setor, cujo foco seguiu sendo a adaptação das tecnologias existentes para as necessidades locais, como transmissões em longa distância, sem inovações realmente radicais (CEPEL, 2014). Mesmo nos últimos anos os recursos do CEPEL foram destinados primordialmente ao aprimoramento do sistema de transmissão e de distribuição, e não tanto às novas fontes de energia (OLIVEIRA, 2011).

Para que se examine a utilização e o estágio tecnológico de cada uma das principais fontes de energia usadas no Brasil, dividiremos a avaliação nos tópicos seguintes:

\subsubsection{Hidráulica}

O aproveitamento da energia hidráulica, que tive papel decisivo no sistema elétrico brasileiro desde seu nascimento em fins do século XIX, hoje responde por cerca de três quartos da geração de eletricidade brasileira.

Centrando-se nos equipamentos mais intensivos em tecnologia, pode-se falar que as turbinas e geradores eram quase que inteiramente importados no início da criação do parque elétrico brasileiro. À medida que a industrialização foi ganhando espaço no Brasil, em meados do século XX, várias empresas estrangeiras vieram instalar-se no território brasileiro, e várias empresas locais de menor porte foram surgindo. Existem hoje no Brasil inúmeras fábricas de turbinas hidrelétricas. Trata-se, afinal, de tecnologia já bastante consolidada e de grande peso na matriz elétrica brasileira.

Além disso, é preciso registrar que a construção de uma hidrelétrica não depende apenas de geradores. Há várias outras tecnologias envolvidas, tais como comportas, válvulas e cilindros, boa parte dos quais fabricada no Brasil sem licenciamento de tecnologia estrangeira. Há ainda o próprio desafio da construção civil: várias das grandes empreiteiras brasileiras adquiriram grande especialização na construção de hidrelétricas, inclusive realizando esse tipo de serviço no exterior, notadamente na América Latina e na África.

A despeito disso, para a fabricação de unidades geradoras para usinas de grande porte, em que o desenho de turbinas e geradores são mais sensíveis e intensivos em conhecimento, o Brasil segue dependendo de tecnologias concebidas no exterior. Todas as grandes usinas hidráulicas em operação ou em construção no Brasil utilizam unidades de empresas estrangeiras, ainda que parcialmente montadas no Brasil, conforme Tabela 15: 
TABELA 15

Fabricantes de unidades geradoras das principais hidrelétricas no Brasil

\begin{tabular}{|c|c|c|c|}
\hline $\begin{array}{c}\text { Usina / } \\
\text { Capacidade }\end{array}$ & $\begin{array}{l}\text { Número de unidades } \\
\text { geradoras / Fabricante }\end{array}$ & Origem do fabricante & $\begin{array}{c}\text { Principal local de } \\
\text { fabricação }\end{array}$ \\
\hline $\begin{array}{l}\text { Itaipu (PR, com o } \\
\text { Paraguai) } \\
14 \mathrm{GW}\end{array}$ & $\begin{array}{l}20 \text { unidades geradoras } \\
\text { Voith }\end{array}$ & Alemanha & São Paulo \\
\hline $\begin{array}{l}\text { Belo Monte (PA) } \\
11,2 \mathrm{GW}\end{array}$ & $\begin{array}{l}24 \text { unidades geradoras } \\
20 \text { UG: "Consórcio } \\
\text { europeu" entre Alstom, } \\
\text { Voith e Andritz; } \\
4 \text { UG: Impsa }\end{array}$ & $\begin{array}{c}\text { França, Alemanha e } \\
\text { Áustria; } \\
\text { Argentina }\end{array}$ & $\begin{array}{l}\text { São Paulo } \\
\text { Pernambuco }\end{array}$ \\
\hline $\begin{array}{l}\text { Tucuruí (PA) } \\
8,4 \text { GW }\end{array}$ & $\begin{array}{l}25 \text { unidades geradoras } \\
6 \text { UG: Alstom } \\
8 \text { UG: Alstom/ABB } \\
6 \text { UG: GE } \\
3 \text { UG: ABB } \\
2 \text { UG: Voith } \\
\end{array}$ & $\begin{array}{l}\text { França } \\
\text { Suíça } \\
\text { EUA } \\
\text { Alemanha }\end{array}$ & $\begin{array}{c}\text { São Paulo } \\
\text { França }\end{array}$ \\
\hline $\begin{array}{l}\text { Jirau (RO) } \\
3,8 \mathrm{GW}\end{array}$ & $\begin{array}{l}50 \text { unidades geradoras } \\
28 \text { UG: Alstom/Voith/ } \\
\text { Andritz } \\
18 \text { turbinas: Dongfang }\end{array}$ & $\begin{array}{c}\text { França, Alemanha e } \\
\text { Áustria } \\
\text { China } \\
\end{array}$ & $\begin{array}{c}\text { São Paulo } \\
\text { China }\end{array}$ \\
\hline $\begin{array}{l}\text { Santo Antônio } \\
\text { (RO) } \\
3,6 \mathrm{GW}\end{array}$ & $\begin{array}{l}50 \text { unidades geradoras } \\
19 \text { UG: Alstom } \\
12 \text { UG: Andritz } \\
13 \text { UG: Voith } \\
6 \text { UG: indefindo } \\
\end{array}$ & $\begin{array}{c}\text { França } \\
\text { Áustria } \\
\text { Alemanha }\end{array}$ & São Paulo \\
\hline $\begin{array}{l}\text { Ilha Solteira (SP) } \\
3,4 \mathrm{GW}\end{array}$ & $\begin{array}{l}20 \text { unidades geradoras } \\
4 \text { UG: Consórcio entre } \\
\text { Hitachi, Asea, Brown- } \\
\text { Boveri } \\
12 \text { UG: "Consórcio } \\
\text { Europeu", entre Riva, } \\
\text { Neyrpic/Alstom e Voith } \\
4 \text { UG: "Consórcio francês" }\end{array}$ & $\begin{array}{c}\text { Japão, Suécia e Suíça } \\
\text { Itália, França e Alemanha } \\
\text { França }\end{array}$ & $\begin{array}{c}\text { Países europeus } \\
\text { França }\end{array}$ \\
\hline $\begin{array}{l}\text { Xingó } \\
3,2 \mathrm{GW} \\
\end{array}$ & $\begin{array}{l}6 \text { unidades geradoras } \\
\text { Voith }\end{array}$ & Alemanha & São Paulo \\
\hline $\begin{array}{l}\text { Paulo Afonso IV } \\
2,5 \mathrm{GW}\end{array}$ & $\begin{array}{l}6 \text { unidades geradoras } \\
\text { Voith }\end{array}$ & Alemanha & São Paulo \\
\hline
\end{tabular}

Fonte: Elaboração própria, a partir de informações das empresas geradoras e do Ministério de Minas e Energia.

Na prática, estabeleceu-se uma segmentação do mercado, que poderia ser sintetizada da seguinte maneira: empresas nacionais cuidam da construção civil, da fabricação de equipamentos elétricos acessórios e da fabricação das turbinas de menor porte. Destaca-se nessa área a WEG, empresa brasileira de porte significativo sediada em Santa Catarina, ao lado de outras empresas de menor porte, focadas em PCHs, tais como a Betta (SP) e a Alterima 
(MG). Por sua vez, turbinas de grande porte são todas fabricadas por grandes empresas estrangeiras, com tecnologia concebida no exterior, tais como Voith/Siemens, GE e Alstom.

Por se tratar de um mercado já maduro, o grau de inovação tecnológica nas usinas de menor porte é bem mais reduzido. A curva de aprendizado nessa área já praticamente se exauriu, e os avanços recentemente verificados são no geral marginais. O número de patentes na área, que será examinado no Capítulo 8, revelará como é reduzida a atividade inovativa nesse campo.

As usinas de grande porte, no entanto, ainda lançam desafios tecnológicos relevantes. É justamente nesse setor que a atuação das empresas brasileiras não se faz presente de modo significativo, e o papel das estrangeiras está baseado no desenvolvimento de tecnologias principalmente a partir de suas matrizes, utilizando as filiais no Brasil primordialmente para a montagem dos equipamentos.

A Tabela 16 sintetiza as patentes concedidas pelo Instituto Nacional de Propriedade Industrial, desagregado pela fonte energética. O quadro demonstra como as atividades de inovação tecnológica, mesmo as protegidas no Brasil, não estão tão centradas na área de hidreletricidade, que obtiveram apenas 44 do total de 838 (5\% do total).

TABELA 16

Patentes concedidas pelo INPI, 1990-2010

\begin{tabular}{|l|c|}
\hline \multicolumn{1}{|c|}{ Tecnologia } & Número de patentes \\
\hline Gás natural & 215 \\
\hline Energia do carvão & 5 \\
\hline Energia nuclear & 5 \\
\hline Bioenergia & 1 \\
\hline Energia das marés & 8 \\
\hline Energia eólica & 208 \\
\hline Energia solar & 307 \\
\hline Energia fotovoltaica & 45 \\
\hline Energia hidrelétrica & 44 \\
\hline
\end{tabular}

Fonte: OLIVEIRA, 2011.

Em outras palavras, mesmo na área em que o Brasil dispõe de maior destaque no campo da geração e um papel significativo em termos de manufatura, as empresas brasileiras e os institutos de pesquisa locais não demonstram papel relevante em termos de inovação. Os desafios tecnológicos de explorar os potenciais hidrelétricos de grande porte - especialmente com a utilização de turbinas de tipo bulbo, para evitar alagamentos na região amazônica - têm sido liderados por empresas estrangeiras, que desenvolvem boa parte dos produtos em suas matrizes. 


\subsubsection{Biomassa}

A tradição de uso da biomassa no Brasil para geração de energia é bastante antiga. O álcool exerceu papel importante desde a introdução dos veículos automotores, na virada do século XIX para o XX. Sua participação no mercado oscilou intensamente nesse período, assumindo grande importância durante o governo de Vargas e a Segunda Guerra Mundial, retraindo-se no período seguinte. Voltou a ter importância depois dos choques do petróleo da década de 1970, mas voltou a perder espaço nos anos 1990, depois que o preço do petróleo caiu acentuadamente e houve perda de credibilidade no fornecimento continuado do álcool.

O combustível voltou a dispor de grande espaço depois da criação do veículo flex fuel, em 2003, lançado inicialmente pela Volkswagen no modelo Gol. Atualmente cerca de $90 \%$ dos novos veículos de passeio licenciados no país utilizam a tecnologia para o bicombustível, como indica o Gráfico 29.

Por razões de estratégia comercial internacional, o combustível passou a ser denominado de etanol, e não mais álcool, como era chamado nos anos 1980 e 1990. A retomada do combustível nos anos 2000 veio acompanhada de novo esforço de pesquisa e inovação no setor. A intensificação dos debates sobre mudança climática tornou mais claras as vantagens do etanol brasileiro, particularmente quando comparado ao etanol estadunidense.

Com efeito, o etanol originado do milho, produzido em larga escala nos Estados Unidos, exige área plantada maior, utilização mais intensiva de fertilizantes e rendimento energético relativamente baixo. Considerando todo o ciclo produtivo, para cada unidade de energia gasta no processo de produção, o milho rende apenas 1,3 unidade de energia. Em comparação, o etanol da cana-de-açúcar permite que, para cada unidade despendida na fabricação, cerca de 8 unidades de energia sejam geradas, podendo chegar a mais de 11 com a utilização mais eficiente do bagaço e da palha.

Depois da ascensão do etanol ao longo dos anos 2000, depois que o motor bicombustível conferiu segurança de abastecimento aos consumidores por meio da possibilidade de adquirir gasolina como substituto, o Brasil voltou a investir mais intensamente em pesquisa na área. Além das atividades difusas em várias universidades, merecem destaque os trabalhos realizados no campo privado pelo Centro de Tecnologia Canavieira - CTC e 
também os liderados pelo CENPES, o Centro de Pesquisas da Petrobras, empresa de economia mista.

O CTC foi fundado em 1969 (sob o nome Centro de Tecnologia Copersucar) por um conjunto de usinas da região de Piracicaba, no interior de São Paulo, com o propósito de realizar pesquisas para a evolução genética da cana, visando a encontrar variedades que permitissem o aumento da produtividade (maior produção numa mesma área) e barateamento dos custos de produção. O centro permanece sediado em Piracicaba, mas tem mais de doze polos espalhados pelo país.

O centro passou por reformulações ao longo desse período, especialmente a reestruturação de 2004, com a retomada do etanol no Brasil, quando adotou o nome atual. Em 2011, o CTC foi convertido em uma sociedade anônima, para viabilizar seu novo modelo de negócios, baseado na cobrança de royalties das variedades que desenvolve. Seus acionistas são principalmente as usinas de cana-de-açúcar do centro-sul do Brasil, que respondem por cerca de $60 \%$ de toda a produção da região. O modelo foi adotado para evitar a disputa de tecnologias entre as usinas, o que implicaria custo muito elevado para cada empresa, mas sim por meio de uma estrutura de pesquisa consorciada entre os produtores. Em 2013, a instituição empregava cerca de 350 pessoas (CTC, 2014).

As pesquisas realizadas pelo CTC não se limitam ao melhoramento genético da cana, mas cuidam também de outros aspectos da produção, como os sistemas de plantio e colheita mecanizados, o manejo da lavoura e os processos industriais. Mas o foco das pesquisas não é realmente a produção de equipamentos, e sim os insumos e atividades agrícolas ligados à produção de cana-de-açúcar.

O CENPES da Petrobras também realiza investimentos de porte para inovação em etanol. Conforme aponta ZILBERMAN (2013), a própria empresa petrolífera tem interesse em desenvolver o etanol, para que o mercado brasileiro seja inteiramente suprido com essa fonte. Isso permitiria que a empresa exporte o petróleo produzido no Brasil para o exterior, onde ficaria menos vulnerável à política de preços administrados para o mercado doméstico de combustíveis no Brasil.

A Petrobras, portanto, tem de fato lançado mão de valores significativos para desenvolver novas gerações do etanol, com vistas especialmente à utilização do bagaço e da palha da cana, aumentando a geração de energia por hectare e reduzindo os rejeitos.

Ainda assim, os investimentos da Petrobras em P\&D na área de biocombustíveis constituem parcela reduzida do total investido pela empresa. Entre 2011 e 2013, apenas cerca de $4,3 \%$ do total foi destinado aos biocombustíveis, comparados com $60 \%$ para a área de 
exploração e produção e $20 \%$ para área de abastecimento. Como o valor total de investimento alcançou US\$ 3,7 bilhões, ainda que reduzida a participação de biocombustíveis, ela alcança a quantia significativa de aproximadamente US\$ 180 milhões (PETROBRAS, 2014).

Além do CTC e da Petrobras, há também pesquisas em curso custeadas pelos recursos do Plano de Apoio à Inovação dos Setores Sucroenergético e Sucroquímico - PAISS. Esse programa, levado a cabo conjuntamente pela FINEP e pelo BNDES, consiste em subvenção (recurso não-reembolsável) ou financiamentos com juros subsidiados para o setor sucroenergético e sucroquímico. Ele está estruturado em três linhas: a) bioetanol de $2^{a}$ geração, especialmente a utilização da palha da cana; b) novos produtos de cana-de-açúcar; c) gaseificação - tecnologias, equipamentos, processos e catalisadores. O montante total estimado para o quadriênio 2011-2014 foi de R\$ 1 bilhão.

Na linha do esforço tecnológico de produção, já há duas plantas de produção de etanol "de $2^{a}$ geração", como vem sendo chamada a produção de etanol a partir do bagaço e da palha da cana-de-açúcar (e não do caldo). Uma se localiza em São Miguel dos Campos (AL), pertencente à empresa Granbio, e a outra em Piracicaba (SP), do grupo Raízen.

Em vez de se tornarem resíduos da produção, essas partes da planta são processadas com enzimas, que "quebram" as fibras de celulosa em açúcares mais simples e permitem em seguida a fermentação para a produção do etanol. $\mathrm{O}$ grande desafio dessa $2^{\mathrm{a}}$ geração é tornar mais eficiente a primeira etapa, isto é, dispor de enzimas eficientes e baratos, já que, a despeito da queda recente no preço, o processo é ainda relativamente custoso. Os produtores estimam que, ao utilizar o bagaço e a palha, seria possível aumentar a produtividade de uma mesma área plantada em cerca de 30\%. Segundo informações das próprias empresas, há centros de pesquisa no Brasil, mas elas fizeram parcerias com várias empresas europeias que desenvolvem e produzem as enzimas utilizadas no processo.

Por fim, há ainda recursos de P\&D obrigatória da ANEEL, já mencionado no Capítulo 5. Ocorre que a parcela do faturamento líquido das empresas obrigatoriamente destinados às atividades de $P \& D$ tem se revelado de pouca importância para a criação de inovações mais relevantes.

Uma publicação do IPEA aponta que, do modo como regulado o programa, foi adotado conceito muito amplo do que seriam atividades de $\mathrm{P} \& \mathrm{D}$, o que permite incluir nesse percentual de despesas obrigatórias atividades muito próximas à gestão e à manutenção das empresas. Além disso, parcela significativa dos dispêndios foi "terceirizada" para universidades, sem que os estudos daí resultantes estivessem diretamente relacionados às necessidades e desafios empresariais do setor. O estudo revela que o balanço do programa de 
P\&D obrigatória produziu pequeno impacto nos setores que fizeram uso de projetos daí oriundos, em comparação com áreas em que não houve aplicação da $\mathrm{P} \& \mathrm{D}$ obrigatória da ANEEL (IPEA, 2011).

Em termos de geração e utilização de energia de biomassa, houve uma significativa expansão do uso do etanol ao longo dos anos 2000, embora a venda do combustível tenha enfrentado um desaquecimento no final da década. Os novos veículos leves vendidos no Brasil são majoritariamente bicombustíveis, como aponta o Gráfico 29.

O mercado de etanol é fundamentalmente dividido em dois grupos: o etanol hidratado e o etanol anidro. Este é utilizado numa mistura obrigatória com a gasolina, atualmente em 25\%, o mais elevado índice do mundo. Aquele é utilizado em modo praticamente puro, por decisão do consumidor que tiver um veículo bicombustível (ou única alternativa dos poucos que ainda têm carros exclusivamente movidos a álcool). A oferta é hoje largamente difundida no Brasil, estando disponível virtualmente em todos os postos de gasolina, quer na versão pura, quer na misturada.

\section{GRÁFICO 29}

Licenciamento de veículos flex-fuel no Brasil

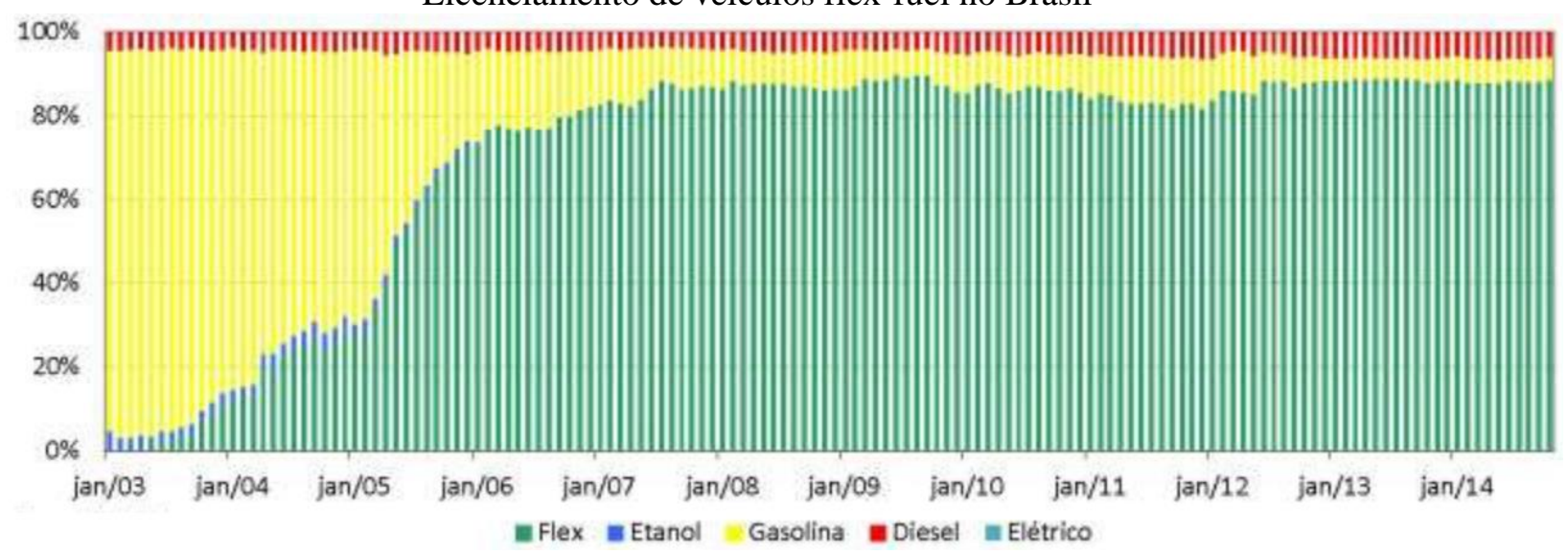

Fonte: ANFAVEA/MME

ANFAVEA: De 2003 a 2012: total de 18,5 milhões de veículos flex licenciados

A despeito do uso disseminado dos carros bicombustíveis, a maior parte dos usuários não utiliza o álcool de maneira automática e opta por escolher o combustível conforme o preço. Dada a diferença de eficiência entre o álcool e o petróleo, disseminou-se a regra de que só convém utilizar o álcool se o preço do produto corresponder a até $70 \%$ do valor da gasolina, uma vez que a mesma quantidade de álcool enseja uma quilometragem equivalente.

De 2003 até 2009, houve um aumento considerável do uso de etanol no Brasil, auxiliado pela expansão da frota bicombustível e de preços competitivos para o álcool. Depois 
disso, entretanto, a subida do preço do açúcar provocou a conversão de parte da produção de cana-de-açúcar no produto alimentar, reduzindo a oferta de etanol e encarecendo seus preços. O Brasil, que por anos vinha buscando conquistar o mercado estadunidense de etanol como destino de suas exportações, viu-se na embaraçosa situação de importar etanol de milho dos Estados Unidos, dada a insuficiência da produção doméstica.

De fato, enquanto que de 2003 a 2011 a produção de etanol no Brasil aumentou em mais de 100\% (ÚNICA, 2013) e 112 novas usinas foram construídas no país (ÚNICA, 2012), houve uma reversão clara do quadro a partir de 2009, a partir de quando praticamente nenhuma nova usina foi instalada e o consumo do combustível caiu em mais de um terço (SINDICOM, 2013). Essa queda está associada à perda de competitividade das usinas, com queda na produção de álcool hidratado e elevados custos de produção.

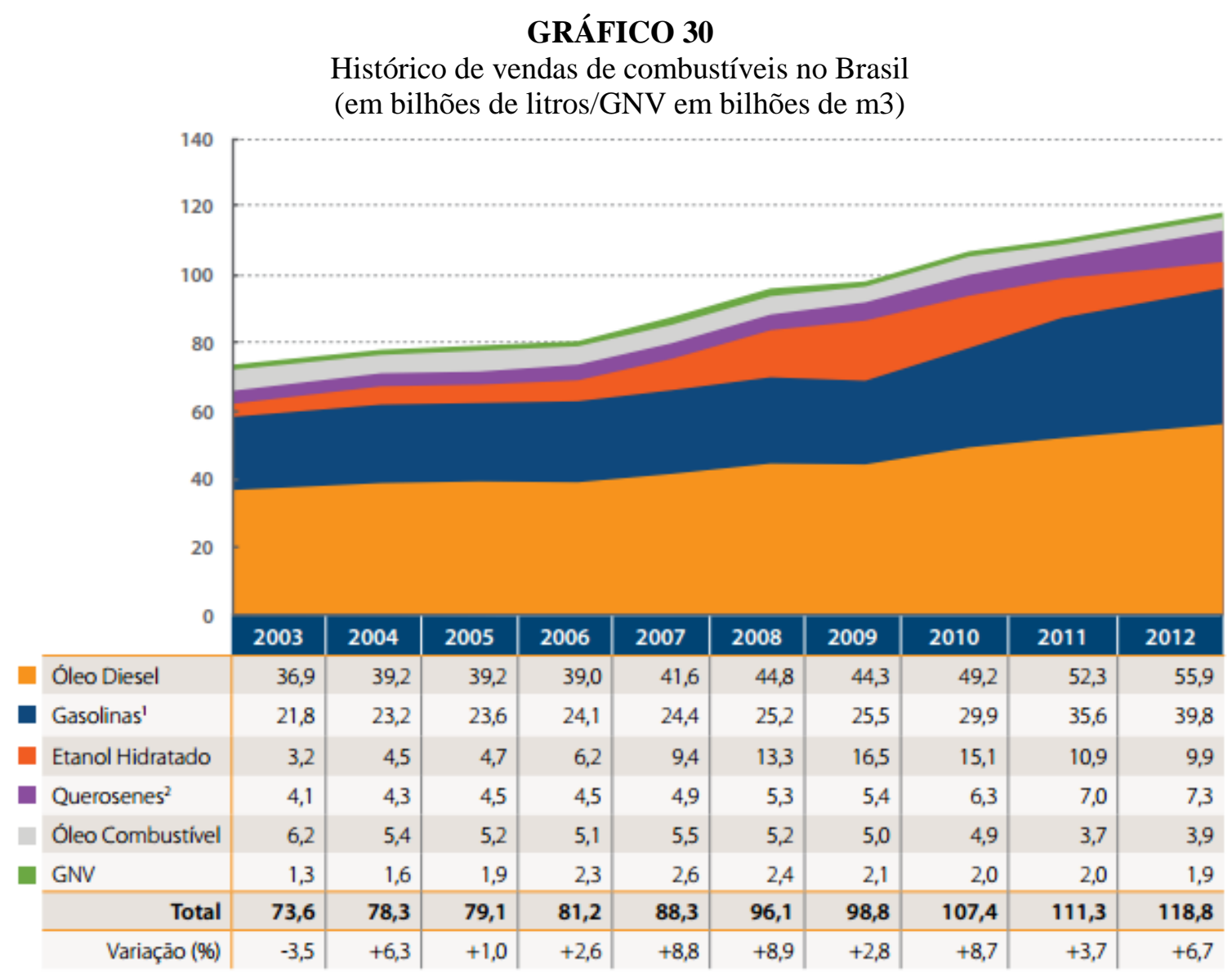

Fonte: SINDICOM, 2013.

É preciso notar que a política de etanol brasileira vem de longa data, se originando no início do século XX, como já se apontou. Desde os anos 1990, há um percentual relevante de mistura obrigatória do etanol à gasolina, que oscila entre $18 \%$ e $25 \%$ (elevado a até $27,5 \%$ em 2014). Trata-se de percentual bastante elevado em comparações internacionais, 
particularmente porque para veículos de passeio não se oferece à venda gasolina sem álcool. A escolha do consumidor, em rigor, está entre um combustível com aproximadamente um quarto de álcool, ou alguma variação a mais, até o uso do combustível totalmente de álcool.

O crescimento acentuado do setor no início da década, entretanto, foi revertido por uma crise a partir de 2009. A política de preços administrados para o petróleo, descolando em parte o preço doméstico do preço internacional, é um dos fatores apontados como central para o setor. Na avaliação do governo federal, entretanto, um conjunto de fatores se somaram para a crise do etanol brasileiro, merecendo ser listados os seguintes (DORNELLES, 2013):

a) a elevação dos custos de produção, em razão de novas exigências ambientais (descarte de água, imposição mais rigorosa de reserva legal e áreas de proteção permanente, etc.) e trabalhistas (normas de segurança, transporte, etc.);

b) o aumento substancial do custo da terra no Brasil, tradicionalmente arrendada pelos produtores de cana;

c) quebra da safra de cana-de-açúcar;

d) aumento dos preços das commodities, que deslocaram terras anteriormente destinadas à cana, incluindo deslocamento de parte da produção para o açúcar;

e) queda da produtividade em razão da ausência de renovação do canavial em algumas usinas; e

f) o controle do preço da gasolina, que fez os consumidores do álcool hidratado migrarem para a gasolina.

A crise levou o Brasil a realizar volumes relevantes de importação de etanol entre 2010 e 2011, o que provocou certo embaraço para a política comercial brasileira de exportação do etanol. O país, no entanto, seguiu exportando para os Estados Unidos, em particular para a Califórnia, onde pode obter um preço premium, mais vantajoso, por ser considerado um combustível avançado (de maior redução dos gases estufa, especialmente quando comparado ao etanol do milho).

Com isso, o Brasil passou a exportar para os EUA por ganhar esse prêmio pela baixa emissão, em lugar de exportar tanto para a Europa e Ásia, que passaram a ser supridos pelo etanol de milho dos EUA. Em 2012 e em 2013, as exportações brasileiras de etanol ficaram em torno de 3 bilhões de litros, ao passo que as importações ficaram em apenas 0,5 e em 0,13 bilhão, respectivamente, o que ainda demonstra a relevância do produto para a pauta de exportação nacional, mesmo em cenário de relativa crise.

Boa parte do maquinário utilizado no setor é fabricada na região de Piracicaba, centro produtor de cana no interior de São Paulo, em que pese um avanço recente nas 
importações de produtos de origem chinesa e, especialmente, indiana (DORNELLES, 2013). Predomina no setor a avaliação de que essa etapa do processo é formada por tecnologias já maduras, cabendo o avanço tecnológico principalmente à fase agrícola.

GRÁFICO 31

Importações e exportações de etanol no Brasil

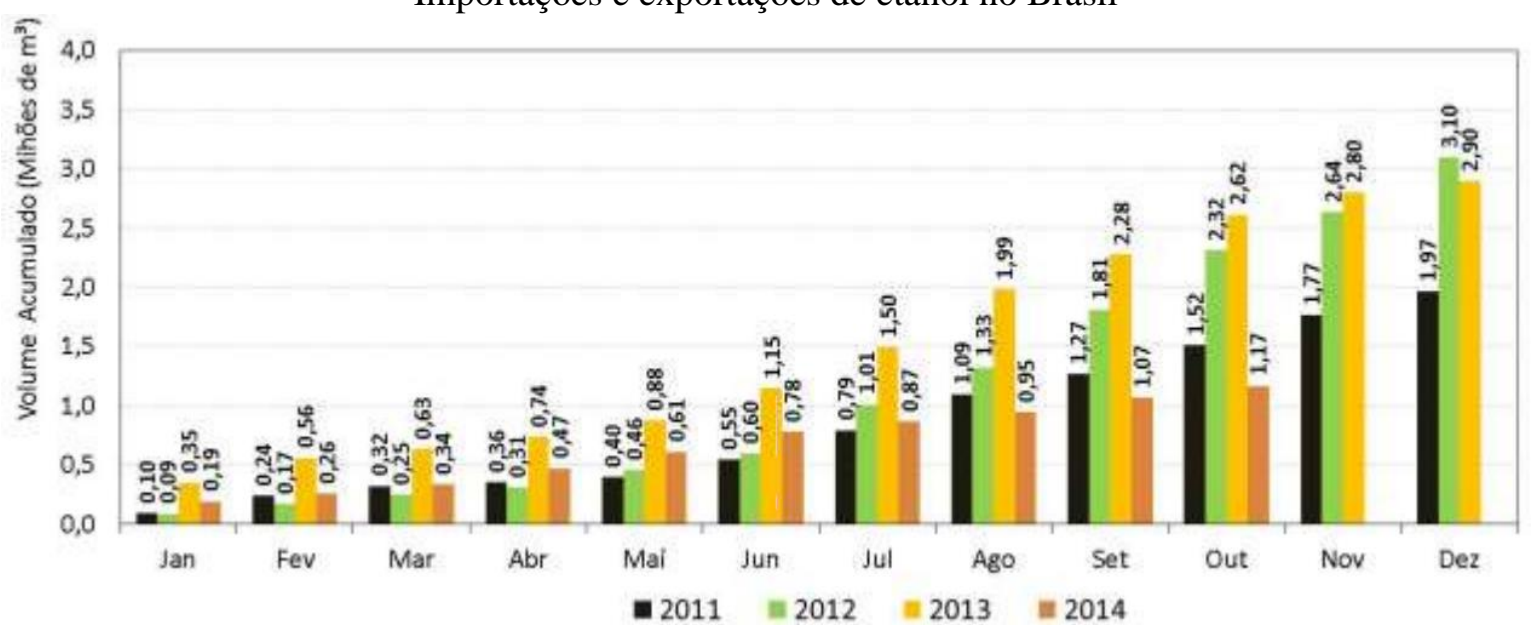

Fonte: Boletim Mensal dos Combustíveis Renováveis, MME, 2014.

Há expectativa de novas variedades de cana, mais produtivas e rentáveis, com maior resistência a pragas. Também se espera que as colheitadeiras possam implicar grande aumento de eficiência, dado que as atuais se originam de colheitadeiras de grãos, adaptadas sem grande eficiência para a colheita de cana. A produção de cana-de-açúcar representa menos de $5 \%$ da produção de grãos, o que explica o baixo esforço até o momento das fabricantes de colheitadeiras para investirem em maquinário superior para a cana.

O esforço brasileiro em pesquisa em biocombustível está focado no aprimoramento da cana-de-açúcar, notadamente para viabilizar o uso comercial do bagaço e também da palha, incluindo a co-geração para o setor elétrico. Nessa área, o Brasil tem provavelmente o mais avançado nível de pesquisa, parte das quais realizadas em cooperações internacionais com institutos dos Estados Unidos.

Há, entretanto, poucas pesquisas para inovações mais radicais para a biomassa, como a utilização de algas como fonte primária. Pesquisas dessa natureza estão em curso nos Estados Unidos, mas os resultados até o momento têm revelado custos proibitivos, como é natural em novas tecnologias.

Afora a utilização da cana-de-açúcar como combustível para o setor de transporte, parte da produção vem sendo utilizada para a geração de eletricidade. Na verdade, o caldo da cana é utilizado para a produção do combustível, enquanto que o bagaço é queimado 
para a geração de eletricidade, seja para utilização na própria usina, seja para fornecer ao sistema elétrico nacional.

Essa co-geração (combustível de transporte e fonte para eletricidade de origem térmica) tem permitido um uso mais amplo dos insumos, reduzido os rejeitos da produção e ampliado a competitividade do produto, já que as receitas provêm de dois segmentos distintos de mercado. Com a mesma área plantada e gerando a mesma quantidade de combustível, o produtor utiliza o que outrora se tratava como resíduo (o bagaço) para queimar e produzir eletricidade a partir de uma usina termelétrica a biomassa.

Houve em 2008 um leilão exclusivo para energia de reserva a partir da biomassa, que resultou na contratação de mais de 2,3 GW para o Sistema Interligado Nacional e permitiu que várias usinas se utilizassem da cogeração como alternativa para incrementar a eficiência e a rentabilidade (EPE, 2008).

Como já vimos no Capítulo 3, a biomassa (principalmente a partir da cana-deaçúcar) responde por cerca de $8 \%$ da capacidade instalada do sistema elétrico brasileiro. Em síntese, o etanol tem papel central da geração de eletricidade e na utilização de combustível no Brasil, existe uma indústria local relevante em certas partes da produção e uma capacidade inovativa considerável nesse segmento. Trata-se, provavelmente, da fonte de energia de cuja fronteira tecnológica o Brasil está mais próximo, liderando em alguns casos as pesquisas na área.

Vale esclarecer que, muito embora a queima do etanol também resulte na emissão de gases estufa, seja como combustível de transporte, seja como combustível para termelétrica, o fato é que o impacto é mais reduzido do que a gasolina se considerada a análise do ciclo de vida completo da produção. Simplificadamente, as emissões de carbono provenientes de sua queima são em parte reabsorvidas ao longo do crescimento da planta da cana-de-açúcar, compensando, assim, ao menos parcialmente, os gases lançados na atmosfera.

Afora o etanol, é também necessário mencionar o Programa Nacional de Produção e Uso de Biodiesel, área em que o Brasil também desenvolveu um mercado relevante. O Programa foi lançado em 2004, com o propósito não só de gerar combustível a partir de fonte renovável, como também de criar um mercado para a produção agrícola.

As regras do Programa estão estabelecidas na Lei no 11.097 , de 13 de janeiro de 2005. Foi estabelecida uma mistura obrigatória ao diesel vendido nos postos, inicialmente de $2 \%$ e desde 2010 em 5\% do diesel (o prazo original para os 5\% foi antecipado de 2013 para 2010 em razão da produção crescente). Em 2014, foi novamente elevado o percentual de mistura obrigatória, que passou para 7\% do diesel. 
A produção brasileira de biodiesel se origina fundamentalmente da soja (75\% do total em 2013), com presença menor de gordura bovina (19\%), óleo de algodão (2\%) e o restante distribuídos em outras fontes, como girassol, palma e canola (BRASIL, 2013). A produção brasileira é suficiente para fornecer os $7 \%$ e há pressão crescente dos produtores da matéria-prima para elevar esse percentual.

No campo tecnológico, considera-se que o setor utiliza uma tecnologia fabril relativamente consolidada. Os avanços residem em avanços na produtividade da matéria-prima - no caso, principalmente, a soja -, que responde por cerca de $80 \%$ dos custos de produção. As demais fontes resultam em poucos litros por hectare.

Uma das vantagens do biodiesel é que, diferentemente do etanol, o debate sobre a disputa por área agricultável entre alimentos e combustíveis não se aplica. Afinal, a maior parte da produção não disputa espaço com os alimentos por se originar do óleo, e não da proteína. No caso da soja, por exemplo, o uso do óleo para a produção de biodiesel não impede que as sementes sejam vendidas para alimentação. Em verdade, a produção do biocombustível melhora a rentabilidade do negócio, já que a proteína continua sendo vendida e o óleo também ocupa seu mercado. O obstáculo central para a difusão ainda maior do biodiesel é o preço, que, embora muito próximo do diesel, ainda é levemente superior.

No caso da biomassa, em síntese, o Brasil tem uma produção das mais elevadas do mundo, com larga utilização para energia como combustível e como eletricidade, e envolvimento substancial em inovação tecnológica. Dentre as fontes energéticas estudadas, é sem dúvida a área em que o Brasil apresenta os melhores resultados em termos de esforço nacional de inovação.

\subsubsection{Eólica}

Os investimentos em geração eólica no Brasil cresceram acentuadamente nos últimos anos. A capacidade instalada da indústria eólica se multiplicou em poucos anos, de modo que essa fonte se tornou relevante fornecedora de eletricidade, e não mais um experimento tecnológico, como ocorreu nos primeiros anos do Proinfa.

Em verdade, nos leilões de energia elétrica dos últimos anos, o preço da geração eólica tem superado o das demais fontes (em torno de R \$ 130,00 por MWh), incluindo o das pequenas centrais hidrelétricas. Enquanto que, uma década atrás, o setor pretendia dispor de favorecimento para disputar com as outras fontes, alcançado via Proinfa, nos últimos anos os 
geradores das demais fontes energéticas têm se queixado da impossibilidade de competir em preço com a eólica. Os gestores do sistema elétrico começaram a se preocupar com a segurança do sistema elétrico, dado que a penetração crescente da eólica vem associada aos riscos da intermitência.

Em razão da exigência de conteúdo nacional nos financiamentos pelo BNDES, as manufaturas locais estão crescendo em todo o país, fornecendo a maioria dos equipamentos utilizados nas novas fazendas eólicas. Entretanto, praticamente toda a tecnologia empregada na fabricação é licenciada do exterior. À exceção da empresa brasileira WEG, que entrou mais recentemente no mercado, todas as fabricantes de turbinas eólicas são estrangeiras, mantendo a tradição de aprendizado tecnológico passivo por meio de investimentos estrangeiros diretos.

No caso de eólica, ainda que haja variações para cada empreendimento específico, os custos aproximados de cada equipamento utilizado são os seguintes: a torre custa cerca de $20 \%$, o rotor (o cubo e principalmente as hélices) respondem por outros $20 \%$, e a nacele (motor e sistemas de controle) representa a maior fatia, com cerca de 60\% (CGEE, 2012).

Nesse contexto, é preciso examinar o cenário de fabricação e desenvolvimento tecnológico do setor. Na maior parte dos empreendimentos, as torres são produzidas no Brasil, mas a tecnologia de que dependem é bastante rudimentar. A maior parte é construída com concreto e/ou aço e, embora o tamanho das torres tenha se tornado cada vez maior, a tecnologia necessária para desenvolvê-las é decerto a parte menos intensiva em conhecimento do conjunto de uma usina eólica. Nesse segmento, predominam as indústrias brasileiras.

As pás (ou hélices) contêm um conteúdo tecnológico bem mais intenso. Nesse setor, há dois grandes atores no Brasil: a dinamarquesa LM Windpower e a empresa brasileira Tecsis, sediada em Sorocaba/SP.

A empresa dinamarquesa é a líder mundial e instalou em 2013 uma planta industrial em Pernambuco, visando a suprir o mercado nacional, que antes era atendido por meio de importações. É mais um exemplo da importação de tecnologia via investimento estrangeiro direto.

Já a Tecsis é um ator importante no mercado eólico, nacional e internacional. Segundo informações da própria empresa, é a segunda maior fabricante mundial independente de pás eólicas (não integrada à fabricante da nacele), atrás apenas da LM Windpower. Considerando-se apenas a fabricação de pás customizadas (em oposição às padronizadas), é a maior fabricante mundial, com faturamento acima de R \$ 1 bilhão em 2014 e mais de 10 plantas 
industriais em operação em Sorocaba e em Itu (SP). Ainda segundo dados da empresa, a Tecsis detém cerca de $70 \%$ do mercado nacional de pás e $15 \%$ do mundial (excluindo a China).

A Tecsis foi formada em 1995 por engenheiros oriundos do ITA, com experiência em aviação. Inicialmente a empresa destinava toda a sua produção para a exportação, mas, à medida que o mercado brasileiro cresceu nos últimos cinco anos, a Tecsis também passou a vender para o mercado nacional, para o qual destinou em 2014 cerca de um terço de sua produção. Também colaborou para esse novo perfil, também voltado ao mercado nacional, a crise internacional de 2008, que reduziu substancialmente as encomendas externas da empresa e acarretou inclusive a mudança do controle societário.

É única produtora relevante do Brasil e vem desenvolvendo tecnologia própria, aproveitando-se da experiência que o país adquiriu no setor aeronáutico. A Tecsis é o exemplo positivo de integração de instituto público de pesquisa com empresas privadas, a exemplo da Embraer. Os engenheiros incumbidos dos projetos, especialmente na fase inicial da empresa, eram praticamente todos oriundos do ITA, com treinamento em fluxos de vento por conta da conexão com o foco aeronáutico da Embraer. Em entrevista, o ex-presidente e hoje consultor para inovação da Tecsis, Bento Koike, afirmou o seguinte: "Só existe a Tecsis no Brasil porque existe um ITA” (KOIKE, 2013).

Além disso, o dirigente da empresa relatou o ingresso da empresa em atividades centradas em inovação: "No caso da Tecsis, inovação era não era uma questão de estratégia, mas sim uma questão de sobrevivência. Não havia alternativa para a empresa, senão inovar." Como a empresa era fornecedora do mercado de países desenvolvidos, especialmente da Alemanha, ela precisa estar na fronteira tecnológica da área para poder obter contratos (KOIKE, 2013).

Apenas recentemente a empresa passou a fazer uso dos instrumentos de inovação ofertados pelo poder público, como as linhas da Finep, da Fapesp e do BNDES. O ex-presidente afirma que a dinâmica era outra: a velocidade das encomendas era incompatível com a elaboração de projetos para essas organizações. Foi a entrada num mercado extremamente competitivo, especialmente o europeu, que a levou a adentrar fortemente a área de inovação. Ainda segundo dados da própria empresa, a Tecsis detém 42 patentes registradas no Brasil e há cerca de 40 pedidos em tramitação no INPI. A empresa registra suas patentes não só no Brasil, mas em todos os principais mercados, incluindo Europa, China, EUA.

No caso das naceles e de seu elemento mais sensível, os aerogeradores, praticamente toda a produção é realizada por empresas estrangeiras (Vestas, GE, Siemens, Goldwind, Gamesa, etc.), à exceção, como já se apontou, da WEG. 
A WEG é uma empresa catarinense inovadora e com foco em produtos empregados no setor elétrico. A empresa, com faturamento anual de R \$ 6,8 bilhões em 2013, entrou apenas recentemente no segmento de energia eólica. No momento inicial, a empresa vinha fabricando geradores de pequeno porte (para micro e mini geração, de cerca de $100 \mathrm{~kW}$ ) a partir de tecnologia estrangeira licenciada da espanhola-egípcia MTOI.

Foi anunciado em 2013 um acordo para licenciamento de tecnologia de uma empresa estadunidense para fabricação de aerogeradores de maior porte, de 2,1 e 2,3 MW. Pelo êxito da WEG em outros segmentos do mercado elétrico, pelo porte da empresa e pelo investimento global de aproximadamente $2,5 \%$ do faturamento em $\mathrm{P} \& \mathrm{D}$, é possível que ela venha a ocupar um espaço mais relevante no mercado de aerogeradores, mas atualmente ainda é bastante reduzida a participação da empresa no mercado nacional e mundial (Entrevista com representante da empresa em 9 de maio de 2013).

A maior parte dos parques eólicos brasileiros fizeram uso de aerogeradores importados. Entretanto, a exigência de conteúdo nacional para obter financiamento junto ao BNDES, utilizado pela esmagadora maioria das usinas eólicas, levou várias das empresas estrangeiras a montarem fábricas no Brasil. Atualmente, parcela significativa dos novos parques se utilizam dos aerogeradores montados no Brasil com tecnologia oriunda dessas empresas. A Tabela 17 indica os principais fabricantes de aerogeradores no Brasil. Nota-se o predomínio das empresas estrangeiras e o ingresso, ainda em pequena quantidade, da WEG em conjunto com a empresa ibero-egípcia MTOI.

TABELA 17

Principais fabricantes de aerogeradores no Brasil, em 2012

\begin{tabular}{|l|c|c|c|}
\hline \multicolumn{1}{|c|}{ Fabricante } & $\begin{array}{c}\text { Capacidade anual de } \\
\text { produção (em MW) }\end{array}$ & $\begin{array}{c}\text { Localização da } \\
\text { fábrica }\end{array}$ & Origem da empresa \\
\hline IMPSA & 1.000 & PE & Argentina \\
\hline Vestas & 800 & CE & Dinamarca \\
\hline Wobben/Enercon & 500 & SP, CE, RN & Alemanha \\
\hline GE & 500 & SP & EUA \\
\hline Gamesa & 400 & BA & Espanha \\
\hline Alstom & 300 & BA & França \\
\hline WEG/MTOI & 100 & SC & Brasil / Espanha e Egito \\
\hline
\end{tabular}

Fonte: CGEE, 2012.

Via de regra, as subsidiárias brasileiras dessas companhias produzem exclusivamente para o mercado brasileiro, sem ter exportações relevantes, especialmente para o mercado da empresa matriz. Em alguns casos, a instalação da fábrica no país é parte da 
estratégia da empresa de utilizar o Brasil como sede para exportação a outros países latinoamericanos. Mas o mercado desses países ainda é bastante limitado.

Não há centros de $\mathrm{P} \& \mathrm{D}$ casados com essas empresas. Entretanto, algumas empresas estrangeiras sediadas no país eventualmente executam atividades de pesquisa consorciadas com instituições de ensino. O objeto das investigações, entretanto, não se volta a inovações substanciais no desenho das turbinas, ou do processo produtivo, mas fundamentalmente para a "tropicalização" dos produtos.

Repete-se, no caso, o mesmo que ocorreu nos demais segmentos industriais, em que a atividade inovativa realizada pelo setor se limita a adaptar os produtos concebidos no exterior às peculiaridades brasileiras, como o nível de salinidade na região costeira do Nordeste, o tipo de vento encontrado na região, etc.

No caso da IMPSA, a empresa argentina com fábrica localizada em Suape/PE, as pesquisas têm sido realizadas em conjunto com universidades locais para enfrentar o desafio de tropicalização. Alguns fabricantes acreditaram incialmente que trariam equipamentos importados e tudo funcionaria em território brasileiro sem maiores dificuldades. Mas o nível de salinidade da região não tinha paralelo no mundo temperado. Havia também diferença nos padrões de vento, de modo que as fórmulas e teoremas não se aplicavam automaticamente, o que exigiu que o próprio desenho do parque fosse reexaminado. Isso abriu espaço para várias pesquisas em território brasileiro, em conjunto com universidades locais, para viabilizar a adaptação dos equipamentos estrangeiros às peculiaridades locais (LEÃO, 2013).

Embora seu principal centro de pesquisa seja localizado em Mendoza (Argentina), a IMPSA tem parcerias com várias universidades brasileiras, entre as quais a UFRJ, UFSC, UFRGS e UFPE. Ela faz uso de vários dos instrumentos de inovação ofertados pelo poder público, como o Inova Energia, P\&D obrigatório da Aneel, benefícios tributários da Lei do Bem e financiamento da Finep e do BNDES.

O Brasil montou um parque fabril no setor de eólicas relativamente importante: empresas nacionais dominam o segmento das torres e das pás, enquanto que empresas estrangeiras com fábricas no Brasil ocupam a maior parte do mercado de aerogeradores.

O mercado brasileiro tem se revelado robusto, como já indicado no Capítulo 3. Em sucessivos leilões de energia, as eólicas venceram quantidades significativas dos projetos, havendo já contratações de monta relevante para os próximos anos. De janeiro a dezembro de 2013, segundo dados da Global Wind Energy Council, o Brasil foi o sétimo país que mais adicionou capacidade eólica ao sistema elétrico (quase $1 \mathrm{GW}$ em um ano), atrás apenas de China, Alemanha, Reino Unido, Índia, Canadá e EUA (GWEC, 2014). 
A participação crescente de eólica no sistema brasileiro começa a realçar os desafios da integração dessa fonte para o manejo da rede, como os impactos ambientais locais e especialmente a intermitência. Por ter um sistema ainda fortemente lastreado em hidrelétricas com reservatórios grandes, é possível utilizar o estoque de água como back up para a intermitência das eólicas. Mas o licenciamento das novas hidrelétricas tem limitado crescentemente a utilização de grandes reservatórios, apontando desafios mais à frente.

Há ainda problemas localizados com o custo de transmissão e a rapidez com que os novos projetos se acoplam ao sistema - ainda que os principais projetos, depois de certo atraso, tenham sido interligados.

Em síntese, as atividades de P\&D no Brasil em energia eólica são relativamente muito baixas, concentrando-se na fabricação de pás e na tropicalização das naceles e dos sistemas de controle e de gerenciamento.

Há alguns núcleos de pesquisa em universidades, mas as empresas do setor praticamente não realizam P\&D no Brasil, já que o concentram em suas matrizes. Mesmo o pouco que é realizado no Brasil está fundamentalmente associado à tropicalização dos produtos, como a adaptação dos modelos tradicionais de torre e de eixo horizontal ao nível de salinidade da região, à topografia e ao clima.

O Programa de P\&D obrigatório da ANEEL, como já examinamos, tem canalizado a maior parte dos recursos para atividades mais próximas ao gerenciamento das empresas, e não tanto a pesquisas inovadores. Vale a pena transcrever trecho de análise do Centro de Gestão e Estudos Estratégicos sobre esse programa na área eólica:

"As empresas participantes do Programa de P\&D, regulado pela Aneel, investiram em 11 anos aproximadamente $\mathrm{R} \$ 19$ milhões no tema energia eólica, o que representa apenas $0,6 \%$ do montante total do programa e 3,6\% do total investido em energias renováveis. A segunda fase do programa ainda apresenta resultados poucos significativos, sendo que os investimentos em energia eólica continuam baixos e representando apenas $1 \%$ do total investido pelo programa ou $6 \%$ do total investido em energias renováveis.” (CGEE, 2012).

O mesmo relatório do CGEE avalia que, no que tange às agências de fomento, o CNPq investiu na última década menos da metade dos recursos investidos pelo Programa de P\&D da Aneel. Já a FINEP aplicou, na última década, um montante maior em pesquisas na área de energia eólica, totalizando $\mathrm{R} \$ 40$ milhões. A maior parte desse valor foi destinada à 
subvenção nas empresas, e uma fatia menor foi realizada por meio de editais no âmbito dos fundos setoriais. Esse valor, quando comparado com os investimentos totais da Finep, é pouco significativo (CGEE, 2012).

O relatório sugere que a reduzida quantidade de pesquisadores em eólica pode decorrer do descompasso entre a velocidade de crescimento do mercado eólico e dos investimentos para formação de profissionais para essa área. Por ter tido uma expansão muito acelerada, acabou atraindo os poucos especialistas do setor e deixou desestruturados os centros existentes de pesquisa. $\mathrm{O}$ estudo revela um número pequeno de instituições de pesquisa atuando na área, com poucos e pequenos grupos, tornando difícil a formação de massa crítica para dar suporte a ações mais estruturadas no segmento (CGEE, 2012).

De fato, praticamente não há pesquisas sobre tecnologias realmente inovadoras, muito menos de inovações radicais. Não foram encontrados casos no Brasil de pesquisas irruptivas, como, para ficar em três exemplos, os eixos horizontais, a utilização de estruturas magnéticas para reduzir o atrito da rotação, ou mesmo "pipas" que captam a energia eólica, como se verifica em alguns locais dos Estados Unidos, ou mesmo da China.

O mercado brasileiro de aerogeradores é, portanto, suprido na maior parte por meio de empresas estrangeiras que montam equipamentos no Brasil com tecnologias importadas, ou mesmo via importações diretas. A participação da única empresa nacional de aerogeradores - a WEG - ainda é incipiente e dependente da tecnologia licenciada da empresa espanhola. A Tecsis tem um peso relevante na fabricação de pás, mas esse item responde por apenas $20 \%$ do custo total. Em síntese, o esforço em P\&D realizado no Brasil é muito baixo e limitado a áreas tecnologicamente menos irruptivas.

\subsubsection{Solar}

As tecnologias para a utilização de energia solar podem ser divididas em duas categorias principais: a) solar térmica; e b) solar fotovoltaica. A térmica tanto pode servir simplesmente para o aquecimento (usualmente de água para uso doméstico ou industrial), quanto para a geração de eletricidade, por meio de concentradores solares que levam a água (ou outro líquido) ao ponto de ebulição e, a partir daí, fazem girar turbinas. No caso da solar fotovoltaica, seu uso está centrado principalmente na geração de eletricidade.

No caso da solar térmica, há várias empresas que fabricam paineis acumuladores de calor, com serpentina e boiler, para aquecer água, especialmente para uso residencial. São, 
em geral, empresas de pequeno ou médio porte, sem uso intensivo de tecnologia, que realizam um trabalho quase artesanal de fabricação e de instalação.

A utilização de aquecedores solares para água ganhou força a partir da adoção obrigatória da tecnologia na segunda fase do programa habitacional do governo federal "Minha Casa, Minha Vida", que visava a construir dois milhões de residências. Nessa segunda etapa do programa, estabeleceu-se que todas as casas (embora não os edifícios) deveriam necessariamente dispor de sistema de aquecimento solar de água, visando a reduzir a demanda por eletricidade e baratear a conta de luz dos usuários de baixa renda alvo do projeto $^{24}$.

Os aquecedores de água podem vir a cumprir papel relevante em termos de redução da demanda de eletricidade, já que, utilizando dados de 2013 , quase $90 \%$ das residências brasileiras que aquecem água para banho o fazem por meio de chuveiros elétricos. O chuveiro elétrico demanda quantidades significativas de energia, sendo ineficiente na conversão de energia elétrica em térmica. Algo em torno de 10\% dos domicílios promovem o aquecimento por meio de gás natural, processo mais eficiente, e apenas $2 \%$ fazem uso de aquecedores solares (BRASIL, 2013).

No que tange à utilização de energia solar térmica para geração de eletricidade, existem apenas projetos experimentais, sem escala comercial. Ela se baseia na concentração da radiação solar por meio de lentes ou espelhos retorcidos para aquecer um líquido (água, em geral) e, a partir de sua evaporação, fazer girar uma turbina, a exemplo das demais formas de geração de eletricidade pelo eletromagnetismo.

Vale notar que a solar térmica tem uma vantagem notável em relação a outras renováveis: é possível armazenar o calor e, desse modo, evitar o problema da intermitência. Não há no Brasil iniciativa em curso para construção de usinas solares térmicas de eletricidade, a exemplo das que existem atualmente no Deserto de Mojave, na Califórnia. A experiência brasileira na área, portanto, se limita à utilização distribuída de aquecimento solar apenas para água, e não para eletricidade.

Em relação à tecnologia solar fotovoltaica, o potencial do segmento e suas peculiaridades merecem maior atenção.

No que tange ao potencial, pode-se dizer que as principais apostas mundiais para a geração de energia com baixa emissão de carbono estão depositadas nessa tecnologia. Boa parte dos investimentos em P\&D em energia renovável mundial está focada no

\footnotetext{
${ }^{24}$ Indagado sobre o número de aquecedores solares instalados por meio do Programa, o Ministério das Cidades informou que não dispõe de um controle exato sobre o número de equipamentos instalados nas residências.
} 
desenvolvimento de formais mais eficientes e baratas de geração solar fotovoltaica. As patentes em energias renováveis também se concentram nesse segmento (ZHENG e KAMMEN, 2014). E o aumento de capacidade instalada nos últimos anos tem sido fortemente influenciado pela conexão de paineis fotovoltaicos, tanto distribuídos, quanto concentrados, ainda que mantenham modesta participação na matriz global.

Evidentemente, como todas as tecnologias de geração de energia, a solar fotovoltaica também enfrenta dificuldades, algumas similares à eólica. A principal delas é a intermitência, isto é, a impossibilidade de assegurar suprimento fixo em horários planejados. Se houver radiação solar suficiente, gera-se eletricidade, mas fatores climáticos podem interferir na quantidade de energia elétrica obtida.

Conjugado com a intermitência, há o problema da impossibilidade de armazenamento, já que, uma vez se pondo o sol, não há como fazer uso diretamente da energia solar. Além disso, o processo de fabricação dos paineis solares exige atividades de mineração agressivas ao meio ambiente. Por fim, a duração de cerca de 25 anos dos paineis cria um problema no descarte do material, repleto de substanciais também poluentes.

O cenário brasileiro atualmente é de geração praticamente irrelevante conectada ao sistema interligado nacional. A conexão pode se dar por meio de usinas solares (geração concentrada), ou por meio de aparelhos instalados localmente em residências ou empreendimentos comerciais (geração distribuída).

No primeiro caso, mantém-se o modelo tradicional do setor elétrico, pelo qual haveria um gerador, que transmitiria a energia em alta tensão e a empresa distribuidora receberia essa energia e a repassaria para os consumidores ${ }^{25}$. No segundo modelo, quebra-se em parte o papel da transmissão e da distribuição, já que a energia é produzida no próprio local de consumo (residência ou estabelecimento comercial), dispensando, em princípio, o papel do distribuidor e do transmissor. Ocorre que, por força da intermitência da fonte solar, a geração distribuída na prática vem sendo utilizada para fornecer a energia adicional produzida pelo consumidor para o sistema elétrico e fazer uso da eletricidade fornecida pela distribuidora nos momentos em que não há geração local (dias nublados ou períodos noturnos, por exemplo), compensando-se os valores injetados no sistema e dele utilizados.

\footnotetext{
${ }^{25}$ Não necessariamente a energia gerado por usinas solares precisa passar pela rede de transmissão, já que alguns projetos se localizam em regiões que permitem a conexão diretamente ao sistema de distribuição (EPE, 2014). Mas foi mantida a referência ao desenho geral do sistema para simplificar a análise, já que essa particularidade não interfere no argumento central da pesquisa.
} 
No caso de geração concentrada, há pequenos projetos isolados operando no Brasil, que representam menos de $0,1 \%$ da matriz energética. Nos leilões para contratação de energia para o mercado regulado, não há participação de empreendimentos com base em energia solar em razão dos preços substancialmente mais altos que a tecnologia ainda exige.

Mesmo com a queda verificada nos últimos anos no preço dos paineis, a geração concentrada de energia solar ainda é substancialmente mais cara do que a de outras fontes. Como os leilões, em regra, estão desenhados para que as diversas fontes de energia compitam entre si, a participação da solar praticamente se inviabiliza. A realização de leilões em que participariam exclusivamente empreendimento solares, que competiriam apenas entre si, sempre enfrentou resistências para evitar impactos na tarifa.

Em outubro de 2014, entretanto, houve pela primeira vez um leilão exclusivo de projetos solares para energia de reserva no mercado regulado, que resultou na contratação de 1.048 MW em 31 projetos. Com preço médio de R\$ 215,12 por MWh, o leilão resultou num deságio de $18 \%$ em relação ao preço-teto do certame - contra um preço médio na faixa de $\mathrm{R} \$$ 140,00 por MWh no leilão com as demais fontes (EPE, 2014).

Esse leilão criou pela primeira vez, em 2014, um mercado relevante no Brasil para a energia solar, mas os impactos sobre a cadeia produtiva ainda não estão claros. O Plano Decenal de Energia prevê que o país chegue a 3.500 MW de capacidade instalada em solar em 2023, sugerindo espaço para expansão nos próximos anos (BRASIL, 2014).

No que tange à geração distribuída, foi aprovada em 2012 a Resolução Normativa n⿳0 482, da Agência Nacional de Energia Elétrica - ANEEL, que instituiu o sistema de compensação para a tarifa do usuário, usualmente chamado de net metering. Por esse modelo, em vez de o consumidor apenas adquirir eletricidade da distribuidora de energia elétrica, também poderá ele injetar energia no sistema elétrico com a chamada microgeração ou minigeração, compensando os valores.

O modelo foi pensado especialmente para a instalação de paineis fotovoltaicos, ou pequenas turbinas eólicas. Desse modo, o medidor de consumo de eletricidade na unidade consumidora poderá se mover para ambos os lados, isto é, debitará do consumidor quando houver consumo do sistema e creditará o consumidor quando energia for fornecida ao sistema elétrico. Se ao final houver crédito, entretanto, o consumidor não poderá receber os valores em pecúnia, mas poderá repassar o adicional para compensação em outros meses ou outras unidades consumidoras, desde que atendidas certas condições (Perguntas e Respostas sobre a aplicação da Resolução 482/2012, da ANEEL). 
A despeito da regulação do net metering, não houve ampliação substancial da geração distribuída no Brasil. Conquanto não haja dados centralizados sobre o volume de paineis solares instalados, entre as autoridades do setor há amplo consenso de que a quantidade é bastante reduzida ${ }^{26}$.

Esse cenário de reduzida participação da solar na geração concentrada e de baixa difusão da geração distribuída sugere que o ambiente brasileiro, ainda que promissor, tem sido de baixa atividade na última década. Afinal, além do ainda pequeno mercado interno para energia solar, as empresas brasileiras não têm historicamente se empenhado na exportação de produtos, ainda mais de itens na fronteira tecnológica. De fato, as atividades de manufatura de painel solar e de seus principais insumos são bastante reduzidas, conforme se exporá a seguir.

Para compreender a situação da indústria de equipamentos solares, é preciso dissecar as etapas de fabricação dos paineis fotovoltaicos. Embora haja diferentes processos de fabricação, a manufatura mais comum compreende as seguintes fases:

a) mineração de silício $^{27}$;

b) purificação do silício para fabricação de lingotes de silício;

c) corte dos lingotes em finas camadas para fabricação de wafers (pastilhas);

d) fabricação das células solares pela injeção de fósforo e de metais na pastilha;

e) montagem dos paineis por meio da reunião de células solares cobertas com vidro e outros materiais de proteção ao equipamento e de condução da eletricidade; e

f) instalação dos paineis (YINGLI SOLAR, 2014).

No Brasil, são realizadas as etapas iniciais e finais do processo, isto é, a mineração do silício e parte da purificação, além da montagem e da instalação dos paineis. As empresas brasileiras têm "pulado" as etapas intermediárias, justamente as fases de maior intensidade tecnológica e maior potencial para saltos inovadores.

No que tange à mineração, vale registrar que o Brasil tem as maiores reservas mundiais de quartzo, matéria prima do silício e um dos minerais mais abundantes na crosta terrestre. A mineração desse produto em território brasileiro é significativa, mas a maior parte realizada de modo rudimentar.

\footnotetext{
${ }^{26}$ Apesar da solicitação de informações ao MME e à ANEEL, não há dados consolidados sobre as instalações de geração distribuída no Brasil. Mas os entrevistados no Ministério e na Agência reconhecem que o número é bastante reduzido.

${ }^{27}$ É possível produzir paineis solares a partir de elementos distintos do silício (Si), tais como Telureto de cádmio (CdTe) e Cobre-Índio-Gálio-Selênio (CIGS). Mas mais de $90 \%$ da produção global é feita a partir do silício em razão do custo e principalmente da ampla disponibilidade do minério em quase todo o mundo.
} 
Embora grande produtor e exportador de quartzo em nível mundial, o Brasil é dependente de importações dos produtos manufaturados a partir do quartzo, principalmente na indústria eletrônica, de telecomunicações e automobilística. Como não há tributação para a exportação e o país não tem amplo domínio da tecnologia de manufatura, quase toda a produção é destinada à exportação para depois retornar via importações com maior nível de pureza, já em grau eletrônico e solar (LOBATO, 2009).

Em síntese, na etapa da mineração de silício o Brasil tem participação relevante, mas esse é justamente o segmento com menor valor agregado. Mesmo nessa etapa, a maior parte das empresas adotam tecnologia rudimentar, em regime de garimpo, sem grandes investimentos em mecanização e em tecnologia para agregação de valor.

No que tange à etapa de purificação do silício, existem várias empresas no Brasil nessa etapa da cadeia de produção, mas elas fazem uso do chamado método siderúrgico, que resulta em nível de pureza comparativamente baixo (em oposição ao chamado método químico, utilizado na indústria eletrônica e com elevadíssima pureza).

Dependendo do uso a que se destina o produto, o nível de pureza necessário do silício é diferente. Entre os que exigem alto nível de pureza se encontram os paineis solares e os semicondutores utilizados em equipamentos eletrônicos. Por isso, é possível adotar a classificação do nível de pureza do silício em "grau siderúrgico", "grau solar", ou "grau eletrônico".

No primeiro caso, o nível de pureza fica em 99,5\%, empregado, por exemplo, em ligas de alumínio. No grau solar, chega a 99,999\% (três noves depois da vírgula), podendo ser utilizado para paineis solares. E no eletrônico, o produto alcança pureza de 99,9999999\% (sete noves após a vírgula ${ }^{28}$ ), podendo ser utilizado em circuitos eletrônicos.

As rotas metalúrgicas e química são bem diferentes. A indústria solar vem fazendo uso preponderantemente do silício com pureza eletrônica, obtido pela rota química. Até os anos 1990, ela se baseava na sucata do produto purificado para uso da indústria eletrônica, embora na última década os paineis solares passaram a dispor de fornecimento próprio, com a chamada rota química modificada, que demanda menos energia do que a tradicional.

A rota química foi desenvolvida nos anos 1950 pela empresa alemã Siemens (por isso é também chamado de método Siemens). Por esse modelo, a partir do silício

\footnotetext{
${ }^{28}$ Há pequenas variações nesses percentuais, mas, para fins desta pesquisa, esses valores servem como parâmetro aproximado do nível de pureza empregado para diferentes finalidades na utilização do silício.
} 
metalúrgico, adota-se a deposição química em fase de vapor, um processo que exige grande quantidade de energia (a temperatura precisa superar o $1.000^{\circ} \mathrm{C}$ ) e produtos químicos.

Já a rota siderúrgica envolve tecnologia menos complexa e se baseia em processos como a fusão e a solidificação controlada dos elementos.

Empresas e institutos públicos brasileiros vêm tentando desenvolver nos últimos anos a chamada "rota siderúrgica modificada", por meio da qual seria possível obter um grau de pureza maior do que a rota siderúrgica tradicional, ainda que não tão elevado quanto o da rota química. Entre outras vantagens potenciais está o fato de que se utilizam menos produtos químicos, gasta-se menos energia no processo e o custo é substancialmente mais barato. Ainda que o nível de pureza não seja tão elevado quanto a rota química, a diferença na eficiência do painel é pouco significativa, havendo prejuízo operacional significativo apenas se o produto fosse empregado na indústria eletrônica.

No Brasil, o Instituto de Pesquisas Tecnológicas (IPT), instituto vinculado à Secretaria de Desenvolvimento Econômico, Ciência, Tecnologia e Inovação do Estado de São Paulo, e a Universidade de Campinas (Unicamp) têm sido pioneiros em pesquisas nessa área e já alcançaram silício em grau solar por meio da rota metalúrgica modificada. As pesquisas foram realizadas em parceria com empresas nacionais, em particular com a Minas Ligas, a Ferroligas Paulistas, a RIMA e a Tecnometal, todas elas produtoras de silício em grau metalúrgico.

No caso do Grupo RIMA, por exemplo, líder nacional de produção de silício metalúrgico, sua produção é grande parte vendida para a empresa norueguesa REC (Renewable Energy Corporation), uma das maiores purificadoras de silício e fabricantes de células solares no mundo. A RIMA exporta mais de $90 \%$ de sua produção.

O grau de purificação do silício a partir da rota metalúrgica já permitiu ao Grupo RIMA alcançar eficiência de $15 \%$ na conversão de energia solar em eletricidade. A empresa considera entrar nas próximas etapas de fabricação de paineis solares, mas ainda não tem clareza se a rota metalúrgica é realmente a melhor. Afinal, não há, na avaliação da empresa, escala suficiente para avaliar a vantajosidade dessa rota em termos de preço, embora os ganhos ambientais sejam mais evidentes. Embora domine a tecnologia da rota metalúrgica modificada desde 2007, a empresa suspendeu seus investimentos na área em razão da saturação do mercado com a entrada de paineis chineses e a desaceleração do mercado europeu (VILELA, 2013).

A despeito do êxito das pesquisas para essa nova rota, nenhuma das empresas brasileiras passou a produzir o silício em grau solar em escala comercial. Questionadas em entrevistas, as empresas informaram que a queda substancial do processo dos paineis nos 
últimos anos com produtos chineses tornou pouco rentável a conversão dessa tecnologia em escala comercial.

Apesar disso, as empresas argumentam que o silício pela rota metalúrgica modificada acarreta menos resíduos que a rota química (menor utilização de produtos tóxicos), é menos intensivo em energia e é mais barato. Além disso, numa análise do ciclo completo da produção, a purificação de silício no Brasil resultaria em emissões mais baixas de gases estufa em comparação com outros países em razão da utilização preponderante de hidrelétricas.

No mundo, já há duas empresas fabricando silício para paineis solares por meio da rota siderúrgica modificada. Uma é a canadense CaliSolar e a outra, a norueguesa Elkem Solar (cujo controle foi adquirido em 2011 pela empresa chinesa China National Bluestar Group), que operam desde 2008 e 2009, respectivamente. Ambas são fornecedores de empresas fabricantes de paineis solares, mas os planos de expansão da produção acabaram se reduzindo depois do excesso de oferta decorrente da entrada massiva de empresas chinesas no mercado, que acarretou profunda queda nos preços globais dos paineis, como se verá à frente.

Afora não haver, ainda, purificação do silício em escala industrial no Brasil, também não executam no Brasil as etapas seguintes da produção, incluindo o corte dos lingotes em wafers e a fabricação de células.

Já a fase de montagem dos paineis é realizada no Brasil por uma única empresa, a Dya Energia Solar, do grupo Tecnometal. A fábrica de paineis solares da empresa, localizada em Campinas, tem capacidade relativamente pequena: capacidade de fabricar paineis anualmente equivalentes a $25 \mathrm{MW}$. Ela utiliza tecnologia adquirida da empresa estadunidense Spire Corporation e importa as células solares, fazendo apenas o módulo no Brasil.

A instalação é outra fase com baixa intensidade tecnológica e realizada difusamente por várias empresas. Apesar disso, é uma etapa que custa quase um terço do preço do painel (MEI, 2013), já que é - ao menos por enquanto - realizada de modo quase artesanal em residências e edifícios comerciais. A instalação em grandes usinas ainda está se iniciando no Brasil, já que o primeiro leilão a contratar quantidades significativas de energia solar ocorreu em fins de 2014.

Fora esse processo, ainda há a fabricação dos inversores, que representam cerca de $8 \%$ do custo dos equipamentos solares. O papel do inversor é converter a corrente direta, produzida pelo painel solar, em corrente alternada - que é a mais amplamente empregada nas 
redes elétricas ${ }^{29}$. No Brasil, há vários fabricantes de inversores, com destaque para a já citada empresa catarinense WEG. A própria WEG, entretanto, entrou no mercado apenas em 2012 e produz inversores com tecnologia licenciada de empresas europeias (Entrevista com representante da empresa em 15 de maio de 2013).

No caso da solar térmica, também não há projetos relevantes para geração de eletricidade. O uso para aquecimento de água existe, mas é quase artesanal. O uso para aquecimento residencial não é tão relevante em um país tropical.

Mesmo os investimentos feitos em purificação do silício pela rota metalúrgica não conferem mínima segurança de que essa tecnologia estará na disputa entre as mais eficientes. Algumas das empresas líderes do mundo, como a First Solar, sediada no Arizona (EUA), faz uso dos paineis solares feitos de telureto de cádmio, em lugar do silício. Esses têm sido utilizados especialmente na fabricação de células solares de filme fino (thin film), que, a despeito da eficiência menor que os módulos tradicionais, apresentam custo bem mais barato. Ou seja, várias frentes de pesquisa com tecnologias diferentes seriam necessárias para disputar a liderança em um setor de tamanha inovação.

Sintetizando o quadro da energia solar no Brasil, é lícito argumentar que o país participa atualmente das etapas menos intensivas em tecnologia da fabricação de equipamentos solares e apresenta baixo engajamento em pesquisas de ponta nesse segmento. A despeito disso, o país produz em grande quantidade a principal matéria-prima utilizada no setor e dispõe de tecnologia que permitiria a purificação adicional do produto. Em termos de geração, o Brasil ainda não permitiu uma penetração ampla dessa fonte da rede elétrica, mas permitiu o net metering e iniciou recentemente as primeiras contratações por leilões para o mercado regulado de eletricidade, sinalizando uma expansão consistente dessa fonte na próxima década.

\footnotetext{
${ }^{29}$ Como a maior parte dos equipamentos eletrônicos modernos utilizam corrente direta, iniciou-se um debate por enquanto em nível acadêmico - a respeito da conveniência de converter todo o sistema elétrico em corrente direta, em lugar da alternada. Esse tema retoma um debate travado em fins do século XIX chamada de "Guerra das Correntes": de um lado estava Nikola Tesla, apoiado pela empresa de George Westinghouse, e de outro Thomas Edison, criador da Thomas Edison General Electric (depois GE). Nesse período, prevaleceu a tese de Tesla em favor da corrente alternada por viabilizar transmissões em distâncias maiores (YERGIN, 2012). Ocorre que, a partir da difusão da geração distribuída solar e da utilização crescente de corrente direta em aparelhos eletrônicos, eventual mudança no modelo para a corrente direta evitaria as perdas decorrentes da conversão sucessiva entre corrente direta (oriunda da geração solar), corrente alternada (para inserção na rede elétrica) e nova conversão em corrente direta (para operar os aparelhos eletrônicos). Além disso, também se evitariam as perdas decorrentes da transmissão de eletricidade em longas distâncias, entre as unidades geradoras e consumidoras.
} 


\subsubsection{Nuclear}

A energia a partir da fissão nuclear não é propriamente a tecnologia favorita dos ambientalistas mais tradicionais. A tecnologia enfrenta objeções com base em três questões principais: a ausência de destinação seguro para os resíduos radioativos, a segurança ambiental (risco de vazamento da radiação) e o uso da tecnologia para fins bélicos.

O fato é que, sob a ótica exclusiva do aquecimento global, tema examinado nesta tese, a energia nuclear é considerada de baixa emissão de gases estufa e, portanto, uma das soluções possíveis para a mitigação da mudança climática. Diferentemente das fontes eólica e solar, a energia nuclear provê eletricidade de modo seguro, sem intermitência, sendo uma ótima fonte de base para o sistema.

Uma das dificuldades em comparar as tecnologias desenvolvidas por cada país na área nuclear reside nos segredos industriais - e estratégicos - que permeiam o setor. Os indicadores de patentes pouco refletem os investimentos em pesquisa realizados, como se verifica, por exemplo, até mesmo em países onde a energia nuclear é explorada por empresas privadas, como nos Estados Unidos. De fato, os indicadores de patentes na área nuclear nos EUA e no restante do mundo são baixíssimos e claramente descolados dos investimentos em P\&D.

Nesse contexto, avaliar as tecnologias em energia nuclear se torna difícil e se limita à análise da capacidade de geração de cada país, ao custo da energia nuclear e aos poucos dados sobre os fabricantes de equipamentos.

A energia nuclear no Brasil, apesar da ampliação de esforços no período imediatamente seguinte à Segunda Guerra Mundial, ganhou impulso verdadeiro a partir dos acordos nucleares firmados com os Estados Unidos e com a Alemanha nos anos 1970. Antes desses acordos, vários cientistas brasileiros se dedicaram ao domínio da tecnologia e surgiram algumas controvérsias públicas sobre a exportação para os Estados Unidos de areia monazítica $^{30}$, sem contrapartida tecnológica para o país (Acordo Atômico de 1945 entre Brasil e Estados Unidos) (MONGELLI, 2006).

Foi com a criação do Conselho Nacional de Desenvolvimento Científico e Tecnológico - CNPq, em 1951, sob a presidência do Almirante Álvaro Alberto, que as

\footnotetext{
${ }^{30}$ A areia monazítica é um tipo de areia repleta de minerais pesados, como o tório (Th, com número atômico 90), que é radioativo. É um dos três elementos radioativos encontrados naturalmente em quantidade significativa na Terra, ao lado do urânio (Ur, com número atômico 92) e do bismuto (Bi, com número atômico 83). Está disponível em algumas partes do litoral brasileiro, como algumas praias do Espírito Santo.
} 
pesquisas no Brasil ganharam mais impulso. Criaram-se grupos de pesquisa na área nuclear em algumas instituições de ensino brasileiras, civis e militares, e vários equipamentos foram importados.

Mas foi em 1970 que se abriu a primeira concorrência internacional para a compra de equipamentos destinados à construção da primeira usina nuclear brasileira. $\mathrm{O}$ certame foi vencido pela estadunidense Westinghouse. A compra, porém, era realizada sob a modalidade de contrato chamada de turnkey, isto é, pacote fechado sem transferência de tecnologia pelo fornecedor. Entre 1970 e 1972 foram assinados os termos entre o Brasil, a Westinghouse e a Comissão de Energia Atômica dos EUA para o fornecimento do reator de água pressurizada (PWR, na sigla em inglês) e de urânio enriquecido. Desse acordo resultou a Usina de Angra 1, com 626 MW de capacidade. A usina, porém, só começou a operar comercialmente em $1^{\circ}$ de janeiro de 1985 (ELETRONUCLEAR, 2014).

O acordo com os EUA, entretanto, limitava substancialmente a transferência da tecnologia nuclear, objetivo do governo brasileiro. A crise de petróleo de 1973 realçou a vulnerabilidade brasileira na área energética e a importância de dispor de tecnologia própria nesse segmento. Isso provocou a busca de um novo parceiro tecnológico para um programa de cooperação nuclear. Esse esforço acabou resultando no acordo nuclear assinado com a Alemanha Ocidental, em 1975.

O acordo com a Alemanha Ocidental abrangia praticamente todo o ciclo nuclear, incluindo a construção de 8 usinas nucleares de 1.300 MW de capacidade cada. A Alemanha passaria a atuar como exportadora de produtos e de equipamentos numa área até então dominada pelos Estados Unidos. Para viabilizar a execução do acordo foram criadas instituições no Brasil que pudessem realizar as atividades de cooperação e de aprendizagem na área. Destaca-se, nesse contexto, a Nuclep, empresa estatal incumbida da fabricação de equipamentos pesados.

As dificuldades econômicas brasileiras a partir da segunda crise do petróleo, em 1979, impuseram a reorganização do programa e mudanças sucessivas para retardar o cronograma original. Nos anos seguintes, restringiu-se a construção a apenas duas das usinas contratadas incialmente com a Alemanha (Angra 2 e 3).

Angra 2 somente começou a operar comercialmente em $1^{\circ}$ de fevereiro de 2001, com capacidade instalada de 1.350 MW. Angra 3 ainda está em construção, com início de funcionamento previsto para junho de 2018 (ELETRONUCLEAR, 2014). Caso se confirme a entrada em operação de Angra 3, a capacidade do sistema elétrico brasileiro de origem nuclear se elevará em 71\%, dos atuais 1.990 MW para um total de 3.395 MW (BRASIL, 2014). 
Ao longo desse período, as pesquisas na área nuclear se expandiram no Brasil e algumas empresas passaram a fornecer equipamentos para etapas do ciclo nuclear. A descoberta de um programa nuclear paralelo e secreto, nos anos 1980, provocou dúvidas sobre o caráter pacífico das pesquisas em curso no Brasil, mas a preocupação perdeu força depois que se conferiu maior transparência ao programa e o Brasil aderiu aos acordos internacionais para vedar o uso bélico da energia nuclear.

O Brasil detém a tecnologia para fazer todo o ciclo, além de dispor de grandes reservas de urânio. Atualmente, os dois reatores nucleares em operação no Brasil estão localizados na cidade de Angra dos Reis (RJ), mas há atividades de outras etapas do ciclo realizadas em outros locais.

A despeito de dispor da tecnologia para todo o ciclo nuclear, parte das etapas da geração não é feita em escala comercial no Brasil em razão do reduzido número de usinas nucleares e do custo que a baixa escala implicaria.

No caso brasileiro, em que a geração nuclear é praticada sob regime de monopólio estatal, a Eletronuclear investe em P\&D uma parcela de 2\% de seu faturamento. A empresa não paga diretamente royalties pela utilização de tecnologia estrangeira, mas uma parcela relevante dos equipamentos mais sensíveis foi adquirida de empresas estrangeiras, especialmente dos Estados Unidos (Westinghouse), da Alemanha (KWU/Siemens) e da França $(\text { Areva })^{31}$.

Mas, segundo informações prestadas em entrevista pela própria Eletronuclear (MONTALVÃO, 2013), há também empresas brasileiras entre as fornecedoras de equipamentos importantes, com os geradores de vapor, os transformadores e até partes dos motores a diesel para a alimentação de emergência do sistema de segurança. Entre essas empresas se destacam:

a) a Nuclep (Nuclebras Equipamentos Pesados), empresa estatal criada em 1975 com o propósito inicial de construir equipamentos de reposição para as usinas de Angra 1 e 2;

b) a Jaraguá Equipamentos Industriais, sediada em Sorocaba; e - novamente

c) a WEG, empresa catarinense e líder nacional em equipamentos elétricos.

Nenhuma das duas empresas privadas brasileiras, entretanto, insere o setor nuclear como elemento central de seu portfólio de produtos. Fabricam apenas equipamentos que são utilizados nas usinas nucleares, mas não em sua parte mais sensível. Afinal, nem há

\footnotetext{
${ }^{31}$ Em 2001, a francesa Areva realizou uma operação de fusão com o braço da Siemens ligado à área nuclear, por meio da empresa chamada de Frematome. No fim da década, a Siemens vendeu o restante da participação que ela detinha nessa companhia, deixando-a sob controle total da Areva.
} 
escala suficiente no Brasil para criar linhas específicas para o segmento, tampouco nenhuma delas se aventurou na exportação de produtos voltados à indústria nucelar.

No caso de Angra 1, além de o reator ter sido fornecido pela Westinghouse, outros equipamentos sensíveis foram fabricados pelas seguintes empresas:

a) Gerador de vapor: Areva (França) / Nuclep (Brasil)

b) Gerador elétrico: Westinghouse (EUA) / Siemens (Alemanha)

c) Gerador de diesel de emergência: Fairbanks Morse/Colt Industries (EUA)

d) Gerador de diesel de emergência 2: KHD Siemens (Alemanha)

No caso de Angra 2, não apenas o reator se originou da Siemens, mas também os demais equipamentos elétricos centrais, como o gerador de vapor, o gerador elétrico e os de emergência (ELETRONUCLEAR, 2014).

Vale esclarecer que o ciclo do combustível nuclear é o conjunto das etapas do processo industrial para transformar o urânio, mineral encontrado na natureza, em combustível a ser utilizado para abastecer o reator nuclear e, a partir daí, gerar eletricidade. O ciclo é formado pelas sete etapas seguintes:

1. Mineração: operações para extrair o minério do solo e etapa inicial do beneficiamento, consistente na separação do urânio, sua purificação e a formação de um sal de cor amarelo conhecido como "yellowcake" (no Brasil, esse processo é realizado pela INB em Caetité/BA);

2. Conversão: processo pelo qual o urânio, sob a forma de "yellowcake" $\left(\mathrm{U}_{3} \mathrm{O}_{8}\right)$, é dissolvido e purificado e, em seguida, convertido para o estado gasoso, sob a forma de hexafluoreto de urânio $\left(\mathrm{UF}_{6}\right)$ (para as usinas nucleares brasileiras, essa etapa vem sendo realizada no exterior);

3. Enriquecimento: é o processo realizado majoritariamente em ultracentrífugas (existem outras tecnologias) para aumentar a parcela do isótopo de urânio 235 de $0,7 \%$ (no estágio natural, o urânio 238 representa os outros 99,3\%) para um percentual em torno de 3\%, já que esse isótopo é que é o responsável pela reação em cadeia que permite sua utilização como combustível (para as usinas brasileiras, essa etapa vinha sendo realizada no exterior);

4. Reconversão: é a etapa em que o urânio, na forma de hexafluoreto de urânio $\left(\mathrm{UF}_{6}\right)$ já enriquecido, retorna ao estado sólido sob a forma de pó de dióxido de urânio $\left(\mathrm{UO}_{2}\right)$ (realizada pela INB em Resende/RJ); 
5. Pastilhas: processo em que o pó de dióxido de urânio é convertido em pastilhas, depois de processo de aquecimento, retificação para ajustar as dimensões e verificação de conformidade, concluindo-se com seu acondicionamento apropriado (realizada pela INB em Resende/RJ);

6. Fabricação de elementos de combustível: montagem das pastilhas de urânio em tubos de uma liga metálica especial (zircaloy) que formam 235 ou 236 varetas combustíveis, rigidamente espaçadas (realizada pela INB em Resende/RJ);

7. Geração: produção de energia elétrica por meio da fissão do núcleo do átomo, que provoca uma reação em cadeia e, com isso, libera calor para o aquecimento da água e a rotação de uma turbina (realizada pela Eletronuclear em Angra dos Reis/RJ) (ELETRONUCLEAR, 2014).

Ainda consoante informações da Eletronuclear, todo o ciclo do combustível nuclear é dominado pelo Brasil e operado pela estatal Indústrias Nucleares do Brasil (INB). No entanto, as etapas de conversão e de enriquecimento ainda são realizadas no exterior em razão da insuficiência de escala no Brasil. Como o investimento na conversão é muito elevado, a existência de apenas duas usinas não é suficiente para viabilizar comercialmente o empreendimento, ainda que o país detenha capacidade tecnológica para tanto.

A INB é a estatal federal incumbida de realização de todo o ciclo do urânio, desde a pesquisa e a mineração até a fabricação do combustível utilizado nas usinas nucleares brasileiras. Criada em 1988 como sucessora da Nuclebras, a empresa atua na cadeia produtiva do urânio, desde a mineração até a fabricação de elementos de combustível utilizados nas usinas nucleares. Sua sede é no Rio de Janeiro, mas realiza atividades na Bahia, Ceará, Minas Gerais e São Paulo.

Em 2015, o Brasil pela primeira vez utilizará combustível nuclear enriquecido no país. As atividades das INB resultaram no enriquecimento de urânio $\left(\mathrm{UF}_{6}\right)$ em escala comercial para a Usina Angra 1. Na primeira recarga da usina em 2015, 80\% do combustível se originará desse processo realizado no Brasil. Estima-se que, em recargas seguintes ainda em 2015, todo o urânio será fornecido pela INB. Até então, todo o urânio era importado (BRASIL, 2014).

No mundo, o setor tem vivenciado uma relevante evolução tecnológica nos últimos anos, com a fabricação de novos reatores mais seguros, com sistema de resfriamento passivo (ou sistema de segurança do tipo "walk-away", que permitem proteção sem intervenção direta), e também com o barateamento por meio da modularidade (utilização de padrão de 
construção que permite ampliar a escala dos equipamentos usados em usinas). Mas as objeções à energia nuclear prosseguirão, como dão prova as mobilizações por conta do desastre de Fukushima, no Japão, e o início do processo de desligamento das usinas nucleares na Alemanha.

De outro lado, o agravamento das mudanças climáticas e as dificuldades de integração ao sistema elétrico de fontes renováveis intermitentes podem voltar a conferir peso à indústria nuclear.

No caso do Brasil, apesar da disponibilidade de recursos hídricos e também da abundância de áreas com alta irradiação solar e intensidade de ventos, não é desprezível o fato de que o país goza de independência tecnológica no ciclo do urânio e dispõe de reservas significativas desse minério. Além disso, tem espaços geográficos adequados para construções nucleares, com disponibilidade segura de água e sem riscos significativos de terremotos e outros fenômenos extremos da natureza.

No campo nuclear, portanto, o que se verifica é que o Brasil é dos poucos países no mundo que detém a tecnologia para todo o ciclo nuclear, mas não há informações claras sobre a intensidade das inovações em curso no setor no Brasil. A geração corresponde a apenas aproximadamente $2 \%$ da matriz elétrica brasileira - percentual que deve se manter mesmo com a entrada em operação de Angra 3, dado que a demanda se elevará nesse período -, e o Brasil tem uma indústria relevante de fornecedores do setor, embora ainda importe parcela representativa dos equipamentos mais sensíveis.

\subsection{O contraste com os casos de China, Coreia e Taiwan}

"We will be second to none." Outdoor em sítio de construção em Beijing, abril 2011

Examinaremos neste tópico os resultados das ações de China, da Coreia e de Taiwan no fomento de inovações no campo das energias de baixo carbono, contrastando, quando pertinente, com a situação brasileira.

Há que se apontar, inicialmente, que os resultados desses três países asiáticos não são similares. Em verdade, pode-se apontar que a rota de Coreia e de Taiwan apresenta bastantes similitudes, mas a trajetória chinesa é um caso à parte. Enquanto que este último apresentou significativo avanço na manufatura de equipamentos e na geração de fontes de 
baixo carbono na última década, os dois primeiros avançaram apenas no campo da manufatura, mas não tanto na geração.

Por outro lado, embora o avanço em termos de geração na China tenha sido muito expressivo, Coreia e Taiwan é que vêm liderando as atividades de patenteamento em praticamente todas as principais tecnologias de baixo carbono.

Examinaremos a seguir as principais tecnologias de baixo carbono e a situação de cada um desses países.

\subsubsection{Hidráulica}

A energia de fonte hídrica não cumpre papel relevante na Coreia e em Taiwan. Ainda assim, eles têm pesquisas em curso na área, já que têm fabricantes de equipamentos do setor para exportação.

No caso da Coreia do Sul, só há uma hidrelétrica com potência igual ou superior a 1.000 MW. Trata-se da Usina de Yangyang, inaugurada em 2006, que também realiza estocagem de água por bombeamento fora dos horários de pico. As quatro unidades geradoras dessa usina, cada uma com $250 \mathrm{MW}$, foram construídas pelo consórcio Alstom/Doosan (GEO, 2014). A Alstom é a já citada multinacional francesa, ao passo que a Doosan Heavy Industries integra um dos grandes conglomerados industriais coreanos, com faturamento anual superior a US\$ 21 bilhões, segundo a própria companhia.

Esse caso também reforça a ideia da importação de tecnologia com aprendizado ativo, envolvendo uma empresa local em uma parceria com a empresa francesa. Um consórcio entre as mesmas duas empresas foi responsável pelo fornecimento das unidades geradoras da segunda maior usina hidráulica sul-coreana, de 800 MW, denominada Usina Yecheon, também dotada de bombeamento de água para estocagem (GEO, 2014).

Embora não represente uma parcela relevante do mercado de energia sulcoreano, ainda assim é possível verificar o engajamento de empresas de capital local na absorção de tecnologia e fabricação de equipamentos no próprio país.

No caso de Taiwan, há apenas duas hidrelétricas com potência superior a 1 GB. A maior delas é a Usina de Mingtan, inaugurada em 1995 e com capacidade instalada de 1.602 MW. Suas seis turbinas de 267 MW cada foram fabricadas pela alemã Voith.

A segunda maior, localizada em área bem próxima à primeira, é a Usina Takuan (também chamada de Usina Minghu), inaugurada em 1985 e com 1.008 MW de capacidade. 
Esta última utiliza unidades geradoras fornecidas pela japonesa Hitachi (GEO, 2014). Ambas as usinas também bombeiam água para armazenagem fora dos horários de pico. Nenhuma utiliza tecnologia de uma empresa local, mas, como se apontou, essa não é uma área de destaque no país.

Já na China, o papel da energia hidráulica é relevante e crescente, tanto doméstica, quanto internacionalmente. Como já se indicou, o país utilizava a meta de expandir a geração hidráulica para 300 GW até 2020, meta já elevada para 420 GW - em 2014 já estavam instalados mais de $280 \mathrm{GW}$. Cerca de $6 \%$ da matriz energética do país se baseia em hidrelétricas, ou $15 \%$ da matriz apenas do setor elétrico. Esse percentual, embora não tão expressivo, é suficiente para tornar a China o maior produtor mundial de energia hidráulica (EIA, 2014).

Também merece observação o fato de que praticamente todas as grandes usinas hidráulicas chinesas foram construídas na última década, revelando que o esforço de desenvolvimento tecnológico no setor é extremamente recente. Ainda assim, é notável o número de empresas chinesas já envolvidas com a fabricação de equipamentos intensivos em tecnologia, incluindo as turbinas e geradores. A Tabela 18 sintetiza as informações das cinco maiores usinas hidrelétricas em operação na China, todas com capacidade instalada acima de $5 \mathrm{GW}$.

Como se observa na tabela, todas as grandes usinas hidráulicas foram construídas e entraram em operação na última década. Há outras usinas de grande porte em construção, como a de Baihetan (13 GW previstos) e a de Wudongde (8,7 GW estimados). A usina de Três Gargantas tornou-se a maior do mundo, superando a usina brasileiro-paraguaia de Itaipu.

O que merece particular observação é como uma indústria tão recente na China, praticamente toda formada depois dos anos 2000, já logrou forjar empresas de grande porte, que fornecem não apenas para as usinas locais, como também se tornaram centros de exportação. Na hidrelétrica de Três Gargantas, por exemplo, empresas chinesas foram integradas aos dois consórcios formados pelas maiores fabricantes de unidades geradoras do mundo, com a obrigação de transferência de tecnologia.

Em todas as cinco principais usinas hidrelétricas, há empresas chinesas entre as fornecedoras das unidades de geração elétrica. Dentre essas, merecem destaque a Harbin e a Dongfang.

A Dongfang Electric Corporation é uma companhia chinesa fundada na década de 1980 e especializada na fabricação de geradores elétricos e equipamentos correlatos. O 
controle acionário da empresa é exercido pelo governo central chinês, mas a empresa é de capital aberto, com ações na bolsa de Hong Kong e de Xangai. Com faturamento anual em torno de US\$ 7 bilhões em 2013 (dados da Bloomberg), a empresa dispõe de centro de P\&D considerado como um dos polos de pesquisa nacional na área pelo governo chinês.

TABELA 18

Cinco maiores usinas hidrelétricas da China e fabricantes das unidades geradoras

\begin{tabular}{|c|c|c|}
\hline $\begin{array}{c}\text { USINA / CAPACIDADE / } \\
\text { ENTRADA EM } \\
\text { OPERACÃO }\end{array}$ & $\begin{array}{c}\text { FABRICANTES DAS } \\
\text { UNIDADES GERADORAS }\end{array}$ & $\begin{array}{c}\text { ORIGEM DOS } \\
\text { FABRICANTES }\end{array}$ \\
\hline $\begin{array}{l}\text { Três Gargantas } \\
22.500 \mathrm{MW} \\
2003-2012\end{array}$ & $\begin{array}{l}\text { Dois consórcios: } \\
\text { a) Alstom*, ABB, Kvaerner e } \\
\text { Harbin Electric e Dongfang; } \\
\text { b) Voith*, GE, Siemens e } \\
\text { Oriental Motor }\end{array}$ & $\begin{array}{l}\text { a) França, Suíça, Noruega, } \\
\text { China e China } \\
\text { b) Alemanha, EUA, Alemanha } \\
\text { e China }\end{array}$ \\
\hline $\begin{array}{l}\text { Xiluodu } \\
\text { 13.860 MW } \\
\text { 2013-2014 }\end{array}$ & $\begin{array}{l}\text { Voith } \\
\text { Dongfang } \\
\text { Harbin }\end{array}$ & $\begin{array}{l}\text { Alemanha } \\
\text { China } \\
\text { China }\end{array}$ \\
\hline $\begin{array}{l}\text { Xiangiiaba } \\
6.448 \mathrm{MW} \\
2012-2014\end{array}$ & $\begin{array}{l}\text { Alstom } \\
\text { Tianjin } \\
\text { Harbin }\end{array}$ & $\begin{array}{l}\text { França } \\
\text { China } \\
\text { China }\end{array}$ \\
\hline $\begin{array}{l}\text { Longtan } \\
6.426 \mathrm{MW} \\
2007-2009\end{array}$ & $\begin{array}{l}\text { Voith } \\
\text { Dongfang } \\
\text { Harbin } \\
\text { Alstom/Tianjin }\end{array}$ & $\begin{array}{l}\text { Alemanha } \\
\text { China } \\
\text { China } \\
\text { França/China }\end{array}$ \\
\hline $\begin{array}{l}\text { Nuozhadu } \\
5.850 \mathrm{MW} \\
2012-2014\end{array}$ & $\begin{array}{l}\text { Voith } \\
\text { Alstom/Tianjin } \\
\text { Dongfang }\end{array}$ & $\begin{array}{l}\text { Alemanha } \\
\text { França/China } \\
\text { China }\end{array}$ \\
\hline
\end{tabular}

* Parte das unidades geradoras da Alstom e da Voith em Três Gargantas foram manufaturadas no Brasil.

Fonte: Elaboração própria, a partir de várias fontes (www.threegorgesprobe.org; www.powertechnology.com; www.alstom.com; www.industcards.com; www.globalenergyobservatory.org).

A produção anual da Dongfang em equipamentos de geração alcança $30 \mathrm{GW}$, englobando não apenas hidráulica, mas também térmica, nuclear, eólica e solar. A empresa fornece não apenas equipamentos, mas também usinas completas (em modelo de contrato turnkey) em mais de 30 países. Especificamente na área de hidrelétrica, a produção anual chega a $10 \mathrm{GW}$, com unidades geradoras que podem variar de $1 \mathrm{MW}$ a $1.000 \mathrm{MW}$, com turbinas em operação em mais de 20 países (DONGFANG, 2014).

A Dongfang, por exemplo, já está exportando para o Brasil parte das unidades geradoras da hidrelétrica de Jirau. Ela também disputou, juntamente com a Harbin, o fornecimento de turbinas para a hidrelétrica de Belo Monte, mas as companhias chinesas perderam a disputa pelo contrato de fornecimento nesse caso, conforme noticiado pela 
imprensa (Folha de S. Paulo. Mercado: Europeus devem equipar Belo Monte. 8 de junho de 2010.)

Já a Companhia de Maquinário Elétrico Harbin, a outra gigante chinesa em equipamentos do setor, é responsável por praticamente metade das unidades geradoras de toda a capacidade hidrelétrica instalada de grande porte na China, segundo informações da própria companhia. Ela exporta produtos para mais de 34 países, incluindo Estados Unidos, Canadá, Japão, Rússia e até Brasil (HARBIN, 2014).

Fundada em 1983, a companhia também é controlada pelo governo central chinês e tem parte do capital aberto, com ações nas bolsas de valores de Hong Kong e de Shenzhen. A Harbin atua no desenvolvimento e fabricação de equipamentos elétricos de geração nas áreas hidráulica e térmica, além de construção de estruturas de transmissão de energia. A companhia já construiu usinas elétricas - também em contratos do tipo turnkey em mais de 20 países, incluindo Índia, Turquia, Indonésia e Equador.

Essa rápida e intensa expansão da indústria chinesa na construção de usinas hidrelétricas, juntamente com seus equipamentos, vem sendo incentivada pelo governo chinês, que provê inclusive financiamento aos países beneficiários por meio do Banco Chinês de Importação e Exportação e outras instituições financeiras oficiais. Ainda que o governo tente apresentar esses projetos como ganha-ganha (para a China e para o país beneficiado), cresceram as objeções por danos sociais e ambientais às comunidades afetadas em razão da não-adoção de padrões internacionais para projetos de infraestrutura dessa envergadura (McDONALD; BOSHARD; E BREWER, 2009).

Sinteticamente, percebe-se que a energia hidráulica não exerce papel relevante na Coreia e em Taiwan, embora, no caso da Coreia, ainda assim o país logrou o desenvolvimento de uma indústria local de unidades geradoras. No caso da China, o ritmo de expansão da fonte hidráulica se acelerou radicalmente na última década, tornando o país o maior produtor mundial de eletricidade a partir dessa fonte. Nesse período, uma indústria chinesa de larga escala e intensidade tecnológica conseguiu ocupar o mercado doméstico e iniciar um processo de expansão, mesmo nos projetos de maior vulto, com unidades geradoras de grande porte. 


\subsubsection{Biomassa}

A utilização de biomassa como fonte primária de energia - seja para eletricidade, seja para uso como combustível - não tem sido destaque entre os três países asiáticos examinados. Nenhum deles tem um programa agressivo nacional de utilização de biomassa como mistura obrigatória em combustíveis fósseis - como o etanol e o biodiesel brasileiro -, tampouco utilizam em larga escala a biomassa como fonte para usinas térmicas de eletricidade.

A razão principal para a baixa utilização é a escassez relativa de terra. Taiwan e Coreia dispõem de territórios pequenos e população proporcionalmente elevada, enquadrandose entre os dez países mais densamente povoados do planeta (645 habitantes por $\mathrm{km}^{2}$ e 505 habitantes por $\mathrm{km}^{2}$, respectivamente). Além da alta densidade, parte do território é montanhoso, não propício à agricultura. Desse modo, a maior parte das escassas terras agricultáveis é destinada a gêneros alimentícios, visando a proteger a segurança alimentar da população.

A China, apesar de ter um dos maiores territórios do planeta, tem também a maior população. Com densidade demográfica na casa de 140 habitantes por $\mathrm{km}^{2}$ (a título de comparação, o Brasil tem densidade de apenas 24 habitantes por $\mathrm{km}^{2}$ ), não se pode dizer que está entre as mais elevadas do mundo, ainda que seja alta, mas o fato é que nem todo o território é agricultável, já que parte dele é coberta por desertos e por grande cadeia de montanhas. Depois de ter enfrentado episódios históricos vexaminosos de fome, o país não tem conferido impulso tão significativo para a biomassa como fonte de energia para evitar riscos.

Ainda assim, a China é o único entre os três asiáticos examinados que tem uma produção merecedora de nota no uso de biomassa como fonte de energia. Os dados a seguir mencionados foram extraídos do relatório elaborado pela Renewable Energy Policy Network for the 21st Century (REN21, 2014).

Em termos de utilização de biomassa para eletricidade, a China figura entre os cinco maiores usuários dessa fonte em termos de capacidade instalada, com cerca de 6,2 GW ao final de 2013. Entretanto, apesar de estar entre os maiores produtores, essa capacidade é mínima frente ao sistema elétrico chinês, sendo bem inferior à capacidade instalada das fontes eólica e solar, mesmo que tomadas isoladamente.

No caso da utilização como combustível, a China também figura entre os produtores com alguma relevância de etanol e de biodiesel. No caso do etanol, porém, a preponderância da produção dos EUA (50 bilhões de litros) e do Brasil (25,5 bilhões de litros) 
é arrebatadora, restando pouco espaço aos demais. De fato, EUA e Brasil produziram em 2013 cerca de $87 \%$ do total global. A China produziu cerca de 2 bilhões de litros no mesmo ano, incluindo-a entre os grandes produtores mundiais, mas num patamar bem inferior ao dos dois países líderes.

No que tange ao biodiesel, EUA (5,1 bilhões de litros), Alemanha (3,1 bilhões de litros) e Brasil (2,9 bilhões de litros) lideram a produção mundial dessa fonte. A produção da China, nesse caso, é de apenas 0,2 bilhão de litros, levando o país a importar cerca de 1,9 bilhões de litros desse combustível.

Embora haja atividades de pesquisa em curso na área nos três países asiáticos o que se examinará mais detidamente no Capítulo 7 -, eles não se destacam como atores centrais nem na utilização de biomassa, nem no fornecimento de equipamentos para essa indústria.

\subsubsection{Eólica}

A China apresentou um crescimento notável de sua indústria eólica nos últimos anos. Desde o início dos anos 2000, o país foi acelerando seu programa eólico domesticamente a um ritmo acelerado, tornando-se o maior gerador mundial de eletricidade a partir dos ventos, ultrapassando Estados Unidos e Alemanha.

O Gráfico 32 sintetiza a situação do setor eólico no mundo. Em termos acumulados, a China lidera com 91 GW de capacidade instalada até o fim de 2013 e acrescentou quase metade de toda a capacidade global adicionada nesse mesmo ano. Coreia, Taiwan e mesmo Brasil não figuram entre os dez maiores em capacidade instalada, mas o Brasil tem crescido acentuadamente e já se tornou o $7^{\circ}$ maior em capacidade adicionada no ano de 2013.

Esse progresso rápido da China na última década é resultado de anos de esforço para construir uma indústria nacional de energia eólica. O sistema de inovação na área eólica se baseou tanto em apoio direto para o desenvolvimento industrial, como em apoio indireto por meio da criação de um grande mercado doméstico para energia oriunda dos ventos.

A primeira política relevante foi lançada em 1994, quando se determinou a facilitação da interconexão de fazenda eólicas com a rede elétrica. Essa política também fixou um preço para essa tarifa eólica, baseada no princípio de que deveria abranger o custo de 
geração, acompanhado do pagamento do financiamento e de lucro razoável (“cost-plusprofit").

\section{GRÁFICO 32}

Geração eólica no mundo, acumulado e capacidade adicionada em 2013

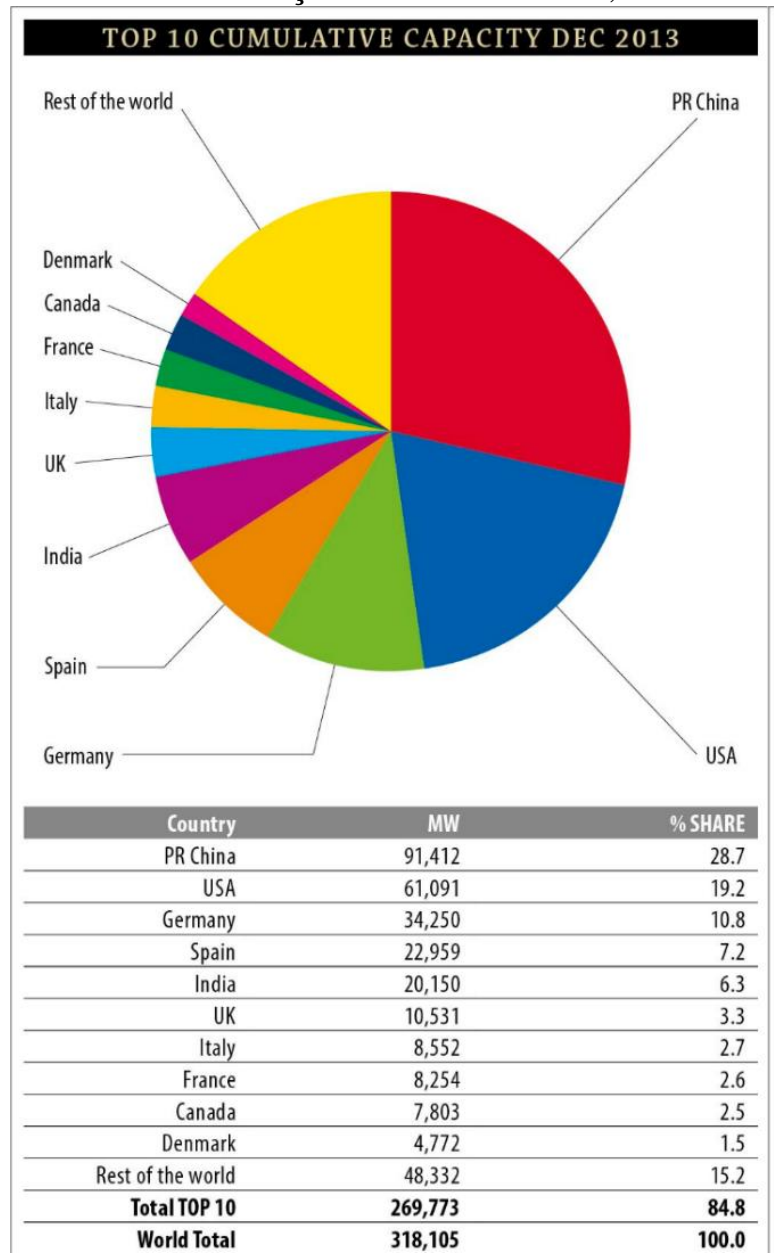

TOP 10 NEW INSTALLED CAPACITY JAN-DEC 2013

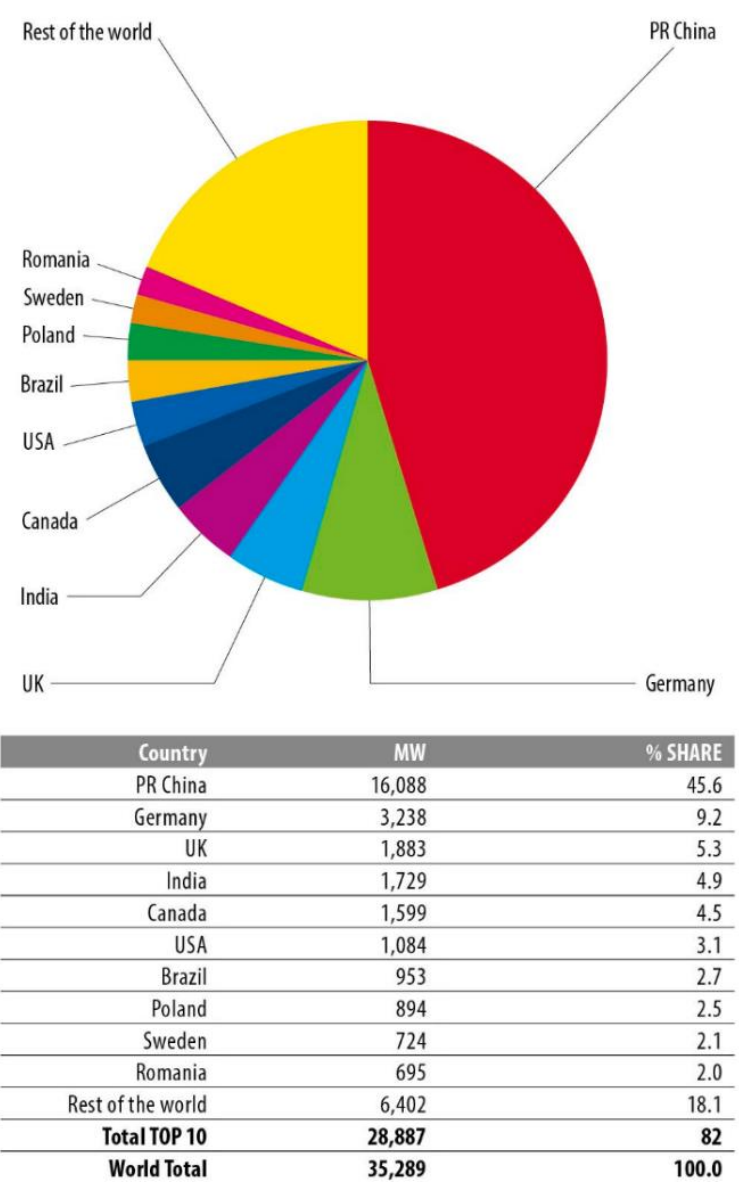

Fonte: GWEC, 2014.

Em 1997, o governo chinês lançou um programa para dobrar a capacidade eólica instalada - nesse momento, na casa de 80 MW. Nesse contexto, o governo lançou uma regra de estímulo ao conteúdo nacional, buscando quebrar o modelo que havia imperado até então, fundado principalmente no financiamento por meio de "ajuda internacional" casada com a obrigação de compra de produtos do país estrangeiros financiador (especialmente Dinamarca, Alemanha e Estados Unidos).

O desenho geral era "demanda criada pelo governo, produção por meio de joint ventures e competição ordenada no mercado". O governo lançou a meta de alcançar $1.000 \mathrm{MW}$ no ano 2000 de eólica, mas o objetivo não foi alcançado por longa margem. A indústria culpou 
o procedimento pouco claro de aprovação de projeto e regras irrealistas de conteúdo local (LEWIS, 2013).

De 2003 a 2007, houve uma mudança importante na política com a concessão de áreas selecionadas para projetos eólicos por meio de disputa competitiva. Aos projetos vencedores foram garantidas a localização, um contrato de compra de energia para as primeiras 30 mil horas do projeto, direito à conexão com o sistema elétrico, além de apoio financeiro, logístico e tributação diferenciados. Cinco rodadas de concessão resultaram na contratação de 3.350 MW de novas instalações. A partir dos preços obtidos na disputa foi estabelecido um valor nacional de feed-in tariff para eólica.

Nesse programa de concessões, foi tornada obrigatória a política de conteúdo local (antes ela era apenas encorajada) para as turbinas eólicas. No início a meta era de 50\% e depois foi elevada a 70\% de conteúdo nacional. Também foram aplicadas tarifas aduaneiras na importação de equipamentos eólicos para a China, estimulando não apenas a indústria local, mas também a instalação de empresas estrangeiras em território chinês.

Em 2006 foi aprovada a Lei de Energia Renovável da China, que institucionalizou e ampliou as políticas existentes na área, incluindo a eólica. Tornou-se obrigatória para as concessionárias de energia a conexão com as fazendas eólicas e a política de compra por meio de tarifas especiais de alimentação. O governo criou um fundo para subsidiar o valor adicional (LEWIS, 2013).

O governo passou a lançar metas cada vez mais ousadas para a incorporação de energia eólica ao sistema elétrico chinês. O objetivo era 5 GW em 2010 e 30 GW em 2020 esse último acabou elevado posteriormente para $200 \mathrm{GW}$ em 2020 e $1.000 \mathrm{GW}$ em 2050. Também se fixou o objetivo para eólica offshore de 1 GW em 2020.

A partir de 2005, o Mecanismo de Desenvolvimento Limpo do Protocolo de Quioto passou a impulsionar o financiamento dos projetos eólicos, aumentando sua competitividade em relação às demais fontes. $\mathrm{O}$ valor estimado desse subsídio do MDL era substantivo, na casa de RMB 0,10 por kWh - ele equivalia, por exemplo, à diferença das tarifas de feed-in entre as melhores regiões com ventos de categoria 1, que recebiam RMB 0,51 por $\mathrm{kWh}$, e as piores regiões com ventos de categoria 4 , às quais se custeava RMB 0,61 por kWh.

À parte desse esforço de criação de mercado, o governo chinês proveu amplo financiamento à P\&D na área eólica. Inicialmente, nos anos 1990, os projetos financiavam o desenvolvimento de turbinas de $600 \mathrm{~kW}$. Paulatinamente, o governo passou a financiar turbinas maiores de $2 \mathrm{MW}$ e $3 \mathrm{MW}$. A política tributária também buscava ampliar a produção local: 
eram isentas as importações de partes de turbinas, ao mesmo tempo que se tributava a importação de turbinas completas (LEWIS, 2013).

A pressão internacional para abolir as regras de conteúdo local era gerenciada pelo governo chinês. Finalmente, no final de 2009, o governo optou por deixar de exigir conteúdo local, decisão atribuída à maturidade das empresas locais na área eólica e ao fato de que as principais fabricantes estrangeiras já haviam instalado fábricas na China, o que tornava a regra obsoleta.

Os indicativos de aprendizado pelas empresas chinesas podem ser vislumbrados a partir de diferentes óticas. O tamanho das turbinas fabricadas se elevou substancialmente na década de 2000, passando de uma média de 600 kW em 2000 para cerca de 1.400 em 2010. Há indicativos de que o esforço em P\&D empresarial também se elevou: embora não haja dados consolidados e transparentes do investimento feito por empresa, a tentativa de várias delas de desenvolver turbinas de capacidade cada vez maior sugere o empenho crescente de recursos nessas atividades. Some-se ainda a compra de participações ou do controle de empresas estrangeiras por companhias eólicas chinesas. Isso permitiu a criação de redes de pesquisadores e a transferência direta de tecnologia entre as companhias resultantes dessas parcerias ou fusões.

Em 2013, a geração de energia oriunda de fonte eólica correspondeu a 2,6\% do total da matriz elétrica, uma elevação de $0,5 \%$ em relação ao ano anterior. A China dispõe de um grande número de fabricantes de turbinas eólicas. Há um número relevante de atores: as dez maiores empresas chinesas ocuparam $78 \%$ do mercado doméstico, com a Goldwind ${ }^{32} \mathrm{em}$ primeiro lugar, com participação de 23,3\% e $3.750 \mathrm{MW}$ em novas instalações. Em seguida, ainda no mercado doméstico, vêm outras empresas também chinesas, como a Guodian United Power (1.488 MW instalados em 2013) e a MingYang (1.286 MW adicionados).

Além disso, depois dessa evolução ampla no mercado doméstico, as empresas chinesas passaram a ingressar no mercado internacional. Em 2013, o país exportou 341 turbinas para 17 países (incluindo EUA, Itália e Austrália), totalizando 692 MW (GWEC, 2014).

Utilizando dados de 2013, verifica-se que as empresas chinesas, surgidas apenas em fins dos anos 1990, ultrapassaram várias das maiores fabricantes mundiais europeias e

\footnotetext{
${ }^{32}$ A Goldwind é liderada por Wu Gang, um CEO conhecido pelo compromisso com uma cultura corporativa que encoraja a criatividade, o que conferiu à empresa uma reputação de inovação tecnológica autônoma. Ainda parcialmente controlada pelo estado chinês, a empresa criou um ambiente de trabalho peculiar: os trabalhadores são estimulados a ter aulas de música e a participar de eventos esportivos, além de a empresa trazer músicos profissionais e atletas para motivar as equipes. Wu Gang descreve a corporação ideal como tendo iguais partes de militar, de universidade e de negócio: ela deve ser um lugar com regras rígidas, mas também um ambiente de aprendizado criativo e orientado para a maximização do lucro (LEWIS, 2013).
} 
estadunidenses e passaram a figurar entre as 10 maiores do mundo, conforme Tabela 19. As dez maiores fabricantes representam cerca de $70 \%$ do mercado global.

TABELA 19

Dez maiores fabricantes mundiais de turbinas eólicas

\begin{tabular}{|l|c|c|}
\hline \multicolumn{1}{|c|}{ FABRICANTE / FUNDAÇÃO* } & $\begin{array}{c}\text { PARTICIPAÇÃO NO } \\
\text { MERCADO }\end{array}$ & $\begin{array}{c}\text { ORIGEM DO } \\
\text { FABRICANTE }\end{array}$ \\
\hline Vestas (1979) & $13,1 \%$ & Dinamarca \\
\hline GOLDWIND (1998) & $\mathbf{1 1 \%}$ & CHINA \\
\hline Enercon (1984) & $9,8 \%$ & Alemanha \\
\hline Siemens (1980) & $7,4 \%$ & Alemanha \\
\hline GE Wind (1980) & $6,6 \%$ & EUA \\
\hline Gamesa (1994) & $5,5 \%$ & Espanha \\
\hline Suzlon Group (1995) & $5,3 \%$ & Índia \\
\hline GUODIAN UNITED POWER (2007) & $\mathbf{4 , 0 \%}$ & CHINA \\
\hline MINGYANG WIND (2006) & $\mathbf{3 , 5 \%}$ & CHINA \\
\hline Nordex (1985) & $3,3 \%$ & Alemanha \\
\hline
\end{tabular}

* $\mathrm{O}$ ano de fundação indicado na tabela se refere ao ano de ingresso da empresa no mercado eólico, e não à constituição da empresa.

Fonte: NAVIGANT RESEARCH, 2014.

Além de saltar aos olhos que três dos dez maiores fabricantes são chineses, como revela a Tabela 19, é ainda mais impressionante verificar que, dos 15 maiores fabricantes, 8 são chineses. Isto é, do $11^{\circ}$ ao $15^{\circ}$ no ranking, todos são chineses (NAVIGANT RESEARCH, 2014).

Sinteticamente, a China tem ampliado de modo substantivo sua geração elétrica a partir de fontes eólicas e, para tanto, conseguiu forjar uma vasta indústria nacional com capacidade inovativa relevante. Além de ter a maior capacidade instalada mundial de energia eólica, dispõe de metade das 15 maiores fabricantes mundiais de turbinas eólicas. A produção turbinas com capacidade de geração maior é sinal do esforço de inovação em curso no país, tanto por meio de P\&D empresarial, como por meio de apoio estatal ao segmento.

Em Coreia e em Taiwan, há avanço significativo da indústria eólica, mas o foco da produção local é principalmente a exportação. Localmente, a geração eólica ainda representa muito pouco da matriz elétrica sulcoreana e taiwanesa, além de não haver perspectiva de crescimento acelerado no futuro próximo.

No caso da Coreia, como já examinado, o governo estabeleceu uma quota de energia renovável (RPS) $11 \%$ em 2030. Trata-se de patamar não muito elevado, fixado sob o argumento de que simplesmente as fontes renováveis não existem em abundância na Coreia, como solar e eólica. Mas o fato é que o presidente sulcoreano Lee Myung-bak (2008-2013) 
incluiu no cerne de sua agenda de governo o "crescimento verde" e, para alcançar esse objetivo, lançou mão de algumas políticas com esse propósito.

A política de crescimento verde foi lançada em 2008 e tinha, entre outros objetivos, o propósito de reduzir as emissões coreanas em relação ao cenário business as usual e criar novos "motores" para o crescimento econômico. Em 2009, depois do agravamento da crise financeira internacional, o governo lançou um plano econômico anticíclico baseado na ideia de "New Deal verde", acompanhado de retórica internacional bastante favorável à limitação das emissões globais de carbono, o que levou analistas a apontar o pioneirismo da Coreia nesse campo. O Plano contempla investimentos de 50 trilhões de wons (valor equivalente a US\$ 45 bilhões) de 2009 a 2012 em nove projetos cruciais, que incluem transporte verde, carros verdes e energia limpa.

Entretanto, ao se esmiuçar o pacote de medidas incluídas nesse plano, o que se verificou é que cerca de metade dos recursos $(45 \%)$ foram destinados não tanto à geração de energia com fontes de baixo carbono, ou mesmo às inovações tecnológicas da área, mas sim a um projeto vultoso de construção civil. Denominado de Projeto de Restauração dos Quatro Grandes Rios, as ações consistiam na revitalização de trechos dos principais rios coreanos (Han, Nakdong, Geum e Yeongsan), além da construção de barragens, com vistas a controlar cheias, assegurar abastecimento de água e proteger ecossistemas. No caso da promoção de energia renovável, apenas $6 \%$ do valor total do pacote anticíclico foi destinado a essa finalidade (CHOI, 2013).

O Projeto de Restauração dos Quatro Rios, entretanto, virou um dos temas centrais da política coreana, com críticas ao Presidente Lee, inclusive de entidades ligadas à área ambiental, por lançar um projeto de grande vulto que resultaria em relevante impacto ambiental e beneficiaria a empresa de construção civil da qual havia sido CEO, a Hyundai Engineering and Construction (CHOI, 2013).

De todo modo, com as políticas de feed-in tariff, substituídas posteriormente pela quota de energia renovável, a Coreia do Sul passou de uma capacidade de geração eólica de apenas 6 MW em 2000 para 561 MW em 2013, sendo 79 MW instalados nesse último ano (GWEC, 2014). Ainda assim, essa quantia representa fatia minguada da matriz elétrica do país.

A despeito dessa elevação, os principais fornecedores de equipamentos eólicos ainda são grupos estrangeiros, notadamente Vestas (Dinamarca), com cerca de $70 \%$ das operações atuais, e Mitsubishi (Japão). Alguns grandes grupos econômicos sulcoreanos - em particular os maiores fabricantes de navios do mundo, como os chaebols Hyundai, Daewoo e 
mesmo Samsung - estão se preparando para adentrar o mercado eólico offshore, aproveitandose das experiências de construção naval e de plataformas de petróleo (BANA, 2013).

Em 2013, novos projetos foram lançados por empresas coreanas. A Hyundai Heavy Industries, por exemplo, iniciou a instalação de uma turbina eólica offshore de 5.5 MW, na costa da ilha Jeju. A Samsung também está construindo na mesma região uma fazenda eólica com novas turbinas de 7 MW (GWEC, 2014).

A Coreia tem priorizado o desenvolvimento de fazendas eólicas offshore em razão das limitações de terra e processos de aprovação custosos (trata-se de país densamente povoado, com várias regiões de terreno inadequado para usinas eólicas). Mas os fabricantes locais ainda têm enfrentado dificuldade não apenas na instalação local (metas modestas de RPS), mas também para ocupar mercados no exterior em razão do baixo histórico de testes de seus produtos (GWEC, 2014).

Gradativamente, entretanto, as empresas coreanas têm ocupado espaços no ainda acanhado mercado nacional. Ao que passo que os parques eólicos iniciais do país eram quase que inteiramente construídos com turbinas da dinamarquesa Vestas, da espanhola Gamesa ou da japonesa Mitsubishi, os parques mais novos têm cada vez mais utilizados turbinas coreanas.

Utilizando dados da Associação da Indústria de Energia Eólica da Coreia, os vinte primeiros parques eólicos sulcoreanos, instalados de 1998 até 2009, resultaram na instalação de cerca de 200 turbinas, várias de pequeno porte, sendo apenas 4 delas de fornecedores locais (2 da Hyosung, 1 da Hanjin, 1 da Unison).

Em contraste, os vinte parques eólicos mais recentes, instalados majoritariamente de 2010 até 2013, resultaram em mais quase 100 turbinas instaladas no país, sendo 70 delas fabricadas por empresas coreanas. Destacam-se aí a Unison (com 20 turbinas), Hyundai (com 14 turbinas), Hanjin (com 13 turbinas), Hyosung (com 8 turbinas), Doosan (com 7 turbinas) e Samsung (4 turbinas). Nesse segundo grupo de parques eólicos, o tamanho das turbinas já é superior ao do primeiro grupo, com algumas delas de 2,5 MW (Samsung) e até de 3 MW (Doosan) (KWEIA, 2014).

Esse rápido ingresso das empresas coreanas no mercado eólico doméstico, ainda que seja reduzido, demonstra o esforço de aprendizado tecnológico feito por essas empresas para adentrar esse novo setor.

Sinteticamente, a Coreia do Sul ainda utiliza energia eólica em pequena quantidade, mas dispõe de um grupo de empresas locais com grande qualificação para ingressar no segmento. A ideia do crescimento verde é uma aposta do governo sulcoreano para uma nova 
geração de produtos que podem permitir o crescimento de empresas coreanas por meio de exportação, aproveitando-se da expertise que já possuem em áreas tecnológicas correlatas. Afinal, o país sedia algumas das grandes corporações globais em vários campos de alta tecnologia, como eletrônica, semicondutores, TI, construção naval e automobilística.

Por fim, Taiwan dispõe hoje de uma capacidade instalada de usinas eólicas superior à da Coreia do Sul, mas ainda assim relativamente modesta, em torno de $614 \mathrm{MW}$, em fins de 2013, sendo 43 MW acrescidos nesse último ano. Praticamente toda a capacidade eólica também foi erigida a partir de 2005 (GWEC, 2014).

Ao se observar os fornecedores das turbinas eólicas taiwanesas, também se percebe a baixa participação de empresas locais e a forte presença das empresas europeias notadamente da alemã Enercon, que forneceu a esmagadora maioria das turbinas dos parques taiwaneses (THE WIND POWER, 2014).

O governo taiwanês tem iniciado apostas no desenvolvimento de usinas eólicas offshore, uma vez que enfrenta problemas similares aos da Coreia de escassez de terras. Embora não haja ainda usinas dessa natureza em operação comercial no país, duas empresas locais foram contratadas para construir parques eólicos offshore a partir de 2015, abrangendo de quatro a seis turbinas. A previsão é que ao menos duas turbinas de cada projeto estejam implantadas em 2015, mas os fornecedores dos equipamentos não estavam ainda definidos (GWEC, 2014).

As principais empresas taiwanesas, entretanto, não estão à frente do mercado eólico global, como na China e na Coreia. Há apenas duas empresas com alguma produção no setor. Uma delas, a Hi-Vawt Technology, fabrica aerogeradores de pequeno porte (até $3 \mathrm{~kW}$ ) para colocação em estruturas similares a postes de iluminação pública, com eixo vertical (e não horizontal, como é mais comum). Esse produto é especialmente voltado à geração distribuída, com exportações para China, Coreia e Estados Unidos. A empresa surgiu em 2005 a partir de apoio do governo taiwanês para projetos de pesquisa em energia renovável integrados com instituições públicas taiwanesas.

A outra empresa, a Teco Electric \& Machinery, é o principal produtor taiwanês de turbinas eólicas, com fábricas nos EUA (em parceria com a Westinghouse) e também na China. Ela ingressou apenas em 2010 no mercado eólico, com uma turbina de 2 MW. Trata-se de conglomerado industrial estabelecido nos anos 1950, com ações negociadas na bolsa de Taiwan, e especializado na fabricação de motores, embora atue em outras áreas. Segundo informações da própria empresa, seu principal mercado nesse segmento é a China continental, embora também venda turbinas em outros países, como o Vietnã. 
Em síntese, apesar do mercado doméstico limitado - e ocupado por empresas estrangeiras - Taiwan tem duas empresas com produtos e atividades inovativas na área eólica. Como se verá no Capítulo 8, Taiwan tem realizados esforços significativos para criar inovações na área, do que resulta uma atividade significativa de patentes no setor.

\subsubsection{Solar}

No âmbito das energias de baixo carbono, é na indústria solar fotovoltaica que as vantagens de Coreia, de Taiwan e da China ficam mais evidentes. Foi nesse segmento que as empresas locais desses países puderam fazer uso da experiência na fabricação de semicondutores para converter parte do negócio para o setor energético, incluindo pessoal qualificado e tecnologias já absorvidas.

Nos três países a indústria solar fotovoltaica tem papel relevante, mas principalmente para exportação. Embora a geração local de energia solar represente parcela minúscula da matriz elétrica desses países, os três conseguiram criar um setor industrial pujante na cadeia produtiva de energia solar, com foco especial nas etapas mais intensivas de tecnologia e capital.

De fato, em lugar de despender recursos na geração de eletricidade por uma fonte ainda mais cara do que as usuais, os três países asiáticos optaram por aproveitar o período de exuberantes subsídios europeus para energia solar. Daí por que, diferentemente da eólica na China (com preços mais competitivos), a produção solar asiática foi forjada prioritariamente para exportação.

No caso da China, há uma elevação recente na utilização doméstica de paineis solares, mas ainda é residual tanto em relação à matriz elétrica do país, quanto em relação à fabricação total de equipamentos solares. Coreia e Taiwan praticamente não utilizam para fins domésticos de geração energética, utilizando quase toda a produção para exportação.

A China dispunha, em fins de 2013, de pouco mais de 18,6 GW de capacidade instalada de geração solar para eletricidade ${ }^{33}$, sendo $11,8 \mathrm{GW}$ adicionados apenas em 2012, o que revela um ritmo de aumento muito acentuado (EPIA, 2014). Embora constitua uma quantia significativa em termos absolutos, essa geração solar não representa uma parcela relevante em relação à capacidade total do sistema elétrico chinês, sendo inferior a $1 \%$ do consumo total de

\footnotetext{
${ }^{33}$ A capacidade instalada global de geração solar fotovoltaica era de $138,8 \mathrm{GW}$ ao fim de 2013, e a Alemanha liderava o ranking com $26 \%$ do total, seguida por China (13\%), Itália (13\%), Japão (10\%) e EUA (9\%) (EPIA, 2014).
} 
eletricidade, dado que o fator de capacidade das usinas solares tende a ser inferior ao de outras fontes.

A Coreia do Sul, por sua vez, atingiu em 2013 uma capacidade instalada de 1,467 MW, com 442 MW adicionados em 2013. Esse montante, entretanto, corresponde também a menos de $1 \%$ do consumo de eletricidade local. Já Taiwan tinha no mesmo período apenas a meta de alcançar 170 MW de capacidade adicionada de geração solar fotovoltaica, totalizando $376 \mathrm{MW}$, o que contabiliza também menos de 1\% da matriz elétrica do país (IEA, 2014).

Nos casos dos três países, a capacidade instalada doméstica da fonte solar é pequena em relação à matriz elétrica, a despeito do robusto parque industrial existente em todos os três. Mas vale notar que praticamente toda a instalação nos três países foi realizada de 2009 para cá, com capacidade muito reduzida nos anos anteriores. Em 2008, a China tinha apenas 0,1 GW; a Coreia tinha 0,3 GW; e Taiwan sequer chegava a 0,1 GW instalada de solar fotovoltaica.

Em termos de fabricação de paineis solares, há muita imbricação entre as empresas dos países, com várias delas, mesmo europeias e estadunidenses, tendo fábricas na China. É o caso também de muitas das empresas de Taiwan, com linhas de montagem na China.

Como o nível de transparência nas informações das empresas do setor não é muito elevado, é difícil diferenciar nos dados agregados a produção de China e Taiwan. Por essa razão, muitos estudos e levantamentos estatísticos consideram a produção de China e Taiwan como um único bloco, como o retratado no Gráfico 33.

GRÁFICO 33

Produção global da indústria fotovoltaica (2000-2013)

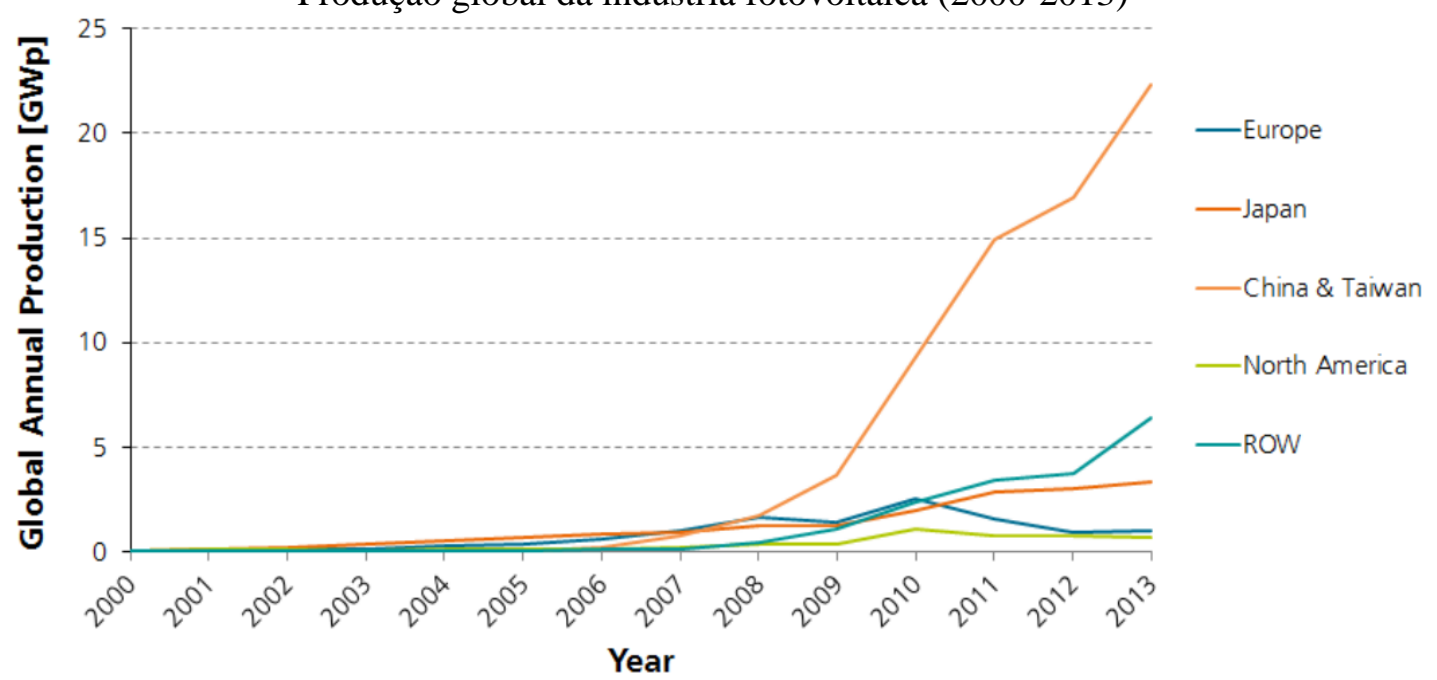

Fonte: Navigant Consulting, citado por Franhofer, 2014.

OBS.: "ROW" representa o restante do mundo, na sigla em inglês. 
O gráfico revela o aumento acentuado da produção de energia solar fotovoltaica a partir de 2008. Além disso, ele evidencia como a participação das empresas chinesas e taiwanesas passou a ocupar um lugar de destaque no contexto global de energia solar. Em 2013, já representava mais de $60 \%$ da produção mundial.

Por outro lado, o Gráfico 34 ilustra como a capacidade instalada mundial ainda está concentrada entre os países desenvolvidos, especialmente na Europa. O conjunto dos países europeus, com destaque para Alemanha e Itália, representam mais da metade da capacidade instalada global de energia solar fotovoltaica.

A despeito do avanço na instalação de paineis nos últimos três anos, a China ainda representa uma parcela pequena da demanda de paineis, conquanto seja responsável pela fabricação da maior parte deles. Isso explica a diferença entre a formação da indústria solar e da indústria eólica na China: ao passo que esta última se constituiu com foco no mercado doméstico, a primeira foi forjada como uma indústria de exportação, aproveitando-se dos subsídios europeus e evitando o ônus de arcar, no momento inicial, com um custo maior de geração de energia.

\section{GRÁFICO 34}

Distribuição global de capacidade instalada de energia solar fotovoltaica (2013)

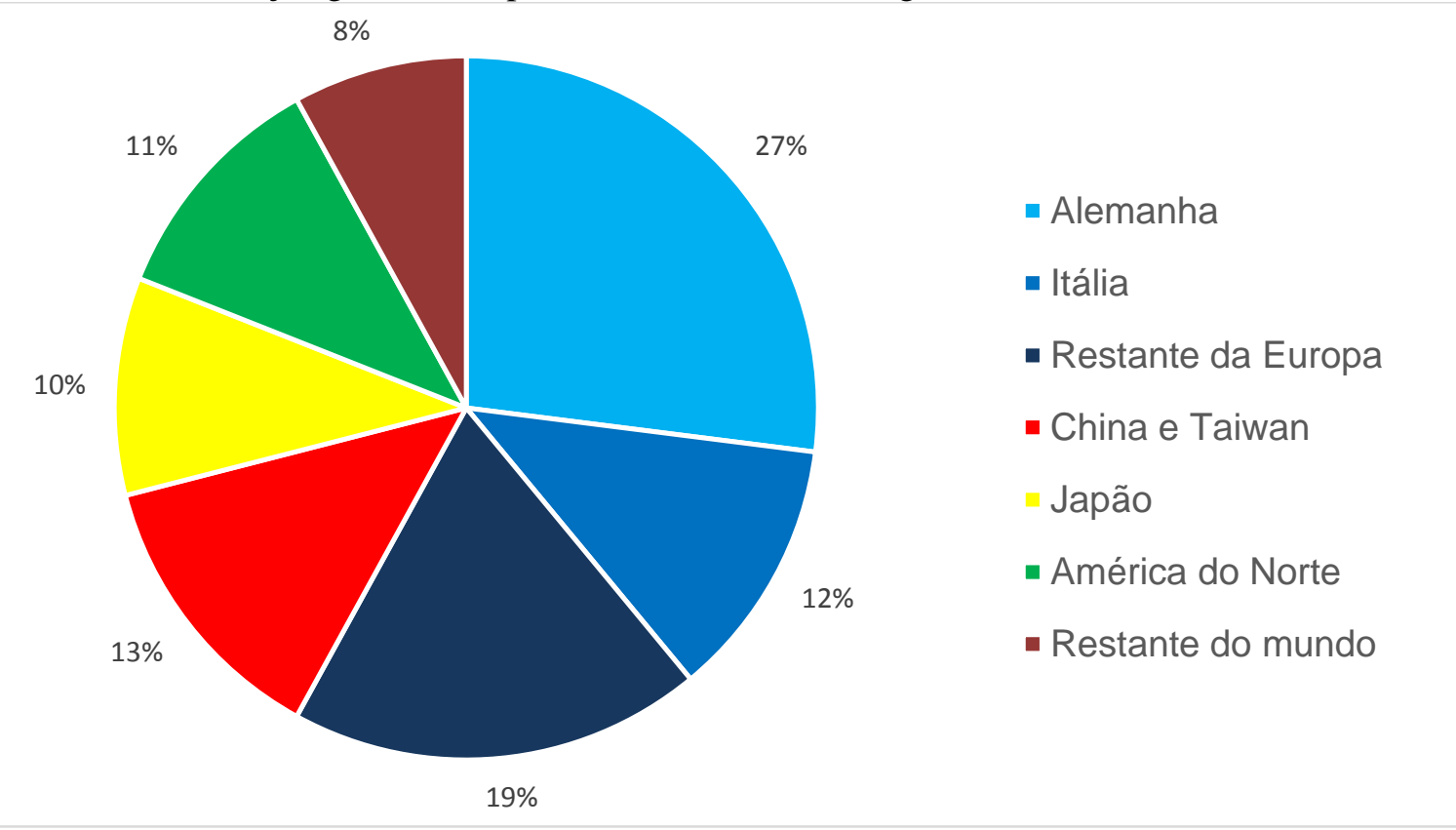

Fonte: EPIA, citado por Franhofer, 2014.

Entrando em mais detalhes sobre a fabricação mundial de equipamentos fotovoltaicos, é útil examinar a lista dos dez maiores fabricantes mundiais de células solares e de módulos. Esses dados estão sintetizados na Tabela 20, desnudando a forte participação das 
empresas chinesas em ambas as etapas, além de ilustrar a presença coreana e taiwanesa na etapa de fabricação das células solares.

TABELA 20

Dez maiores fabricantes mundiais, tecnologias selecionadas

\begin{tabular}{|c|c|c|c|}
\hline \multicolumn{2}{|c|}{ CÉLULAS SOLARES (2014) } & \multicolumn{2}{|c|}{ MÓDULOS SOLARES (2013) } \\
\hline $\begin{array}{c}\text { FABRICANTE } \\
\text { (PRODUCÃO, em MWp) }\end{array}$ & ORIGEM & $\begin{array}{c}\text { FABRICANTE } \\
\text { (PRODUCÃO em unidades) }\end{array}$ & ORIGEM \\
\hline Trina $(2.900)$ & CHINA & Yingli (13 milhões) & CHINA \\
\hline Hanwha Solar (2.763) & COREIA & Trina Solar (10 milhões) & CHINA \\
\hline Yingli (2.450) & CHINA & Canadian Solar (8 milhões) & Canadá* \\
\hline Neo Solar (2.066) & TAIWAN & Sharp (8 milhões) & Japão \\
\hline Jinko Solar (1.872) & CHINA & Jinko (7 milhões) & CHINA \\
\hline First Solar (1.785) & EUA & First Solar (7 milhões) & EUA \\
\hline Motech Solar (1.560) & TAIWAN & ReneSola (7 milhões) & CHINA \\
\hline Hareon (1.525) & CHINA & Kyocera (5 milhões) & Japão \\
\hline Canadian Solar (1.400) & Canadá* & JA Solar (5 milhões) & CHINA \\
\hline Gintech (1.350) & TAIWAN & Hanwha Solar (5 milhões) & COREIA \\
\hline
\end{tabular}

Fontes: Células Solares: SPV Market Research (2015); Módulos Solares: IHS Research (2014).

OBS.: Canadian Solar é uma companhia de capital aberto, sediada em Ontário (Canadá), mas praticamente toda sua linha de produção é na China. A maior parte dos levantamentos a classificam como chinesa, mas optamos por incluí-la como canadense.

Tanto no caso de células solares, como no caso de módulos solares, os dez maiores produtores mundiais respondem por pouco mais da metade da produção global.

No caso da energia solar, já se apontou que as etapas iniciais (mineração e primeira etapa da purificação) e as etapas finais (montagem e instalação dos paineis) são as menos intensivas em tecnologia. Nas etapas intermediárias, que exigem a purificação do silício a níveis elevados de pureza (grau solar ou grau eletrônico), seguida da montagem dos wafers e das células solares, o setor é hoje em larga medida dominado pelas empresas dos países asiáticos em questão, com participação também de algumas empresas europeias e estadunidenses.

Muitas das empresas são verticalizadas e produzem in-house parcela significativa de todas as etapas da produção. Além dos maiores produtores de células solares, já indicados na tabela, merece ser observada também a participação das empresas na purificação do silício. Para o silício policristalino ${ }^{34}$ e fabricação de wafers, China, Coreia e

\footnotetext{
${ }^{34}$ Como o silício policristalino representa mais da metade dos paineis solares fabricados no planeta, estamos adotando essa tecnologia como a predominante para fins dessas comparações. Além do silício policristalino, há outras duas tecnologias fortemente concorrentes. Uma é o silício monocristalino, com cerca de $30 \%$ do mercado. Ele tem a vantagem de ser mais eficiente do que o policristalino, mas é mais caro: o ganho de eficiência não tem conseguido superar o custo adicional desse tipo de material. A outra tecnologia concorrente é o filme fino (thin film), que pode ser produzido com diferentes tipos de semicondutores, como telureto de cádmio $(\mathrm{CdTe})$ e cobreíndio-gálio-selênio (CIGS). Embora o filme fino seja o mais barato dos materiais para células solares, apresenta
} 
Taiwan têm empresas entre as dez maiores do mundo. Nessa etapa, entre os grandes fabricantes mundiais se encontram as companhias chinesas GCL-Poly e LDK, as coreanas Kumgang Korea Chemical, OCI Company, SK Chemical e Woongjin Energy, além da taiwanesa LCY Chemical (JÄGER-WALDAU, 2012; ENERGY TREND, 2014).

Não há informações consolidadas para cada segmento da cadeia solar, mas informações das próprias empresas líderes nesses setores dão conta de significativos investimentos em P\&D realizados por cada uma delas. Todas as empresas mencionadas da China, Coreia e Taiwan relatam dispor de centros de P\&D, com foco especialmente em ampliar a eficiência da conversão da energia solar, além da busca de novos materiais.

Embora os dados fornecidos pelas próprias empresas não sejam inteiramente seguros, observa-se em paralelo um aumento na quantidade de patentes registradas por empresas desses países, conforme se examinará no Capítulo 7.

Veja-se, por exemplo, a Yingli Solar, que tem uma produção bastante verticalizada. Dispõe de capacidade de produção total de $2.450 \mathrm{MW}$, tanto na fabricação de wafers, como de células solares e de paineis. Para visualizar o ritmo de crescimento, é válido notar que, em 2004, empresa dispunha de capacidade de apenas 6 MW para wafers e células solares, além de $50 \mathrm{MW}$ para paineis. Além disso, a empresa possui três centros de P\&D nos EUA, na Espanha e na própria China.

Ainda a título exemplificativo, o grupo sulcoreano Hanwha adquiriu em 2012 o controle da empresa alemã Q-Cells, uma das empresas mais avançadas em tecnologia solar. Com isso, o grupo sulcoreano passou a dispor de tecnologia no estado da arte, além de erigir centros de $\mathrm{P} \& \mathrm{D}$ próprios na Coreia, integrados com atividades na Alemanha. Também o grupo Woongjin Chemical construiu desde 1979 um centro de $\mathrm{P} \& \mathrm{D}$ próprio, que, entre outros temas, pesquisa novos materiais no campo de energias renováveis.

No caso de Taiwan, para ficar no exemplo da Neo Solar, e empresa também possui estrutura verticalizada, mas não realiza no mesmo volume todas as etapas da produção. A empresa tem capacidade de produzir o equivalente a $2.100 \mathrm{MW}$ de células solares anualmente, mas apenas cerca de $480 \mathrm{MW}$ de paineis, vendendo o excedente de células para outras companhias. A empresa também tem patentes registradas, oriundas tanto de investimentos em centros de $\mathrm{P} \& \mathrm{D}$ próprios, como de parcerias com institutos públicos de pesquisa.

um nível de eficiência menor do que o silício policristalino e ocupa parcela ainda menor do mercado, em torno de $10 \%$. 
Por fim, embora a indústria solar fotovoltaica seja a que demonstrou maior crescimento nos últimos anos e tenha liderado os esforços de pesquisa e de patenteamento em nível mundial, trataremos brevemente também da solar térmica.

No caso de geração de eletricidade por meio de concentração de calor (os chamados “CSP”, de Concentrating Solar Thermal Power), nenhum dos países asiáticos em questão figuram na lista dos que dispõem de maior capacidade instalada, liderada por Espanha e EUA. A China foi a quinta nação que mais adicionou capacidade de CSP em 2013. Mas a capacidade instalada global era de apenas 3,4 GW (sendo 0,9 adicionados em 2013), o que revela o ainda limitado espaço ocupado por essa tecnologia.

Todas as dez maiores fornecedoras de equipamentos com tecnologia CSP são espanholas (Abengoa, Acciona, ACS Cobra e Torresol Energy), além de uma participação relevante de empresas estadunidenses e alemãs (REN21, 2014).

Já em termos de aquecimento de água com energia solar, a China lidera a lista dos países com maior capacidade instalada, seguida por EUA (5,8\%), Alemanha (4,2\%), Turquia (3,9\%) e Brasil (2,1\%). O peso do mercado chinês impressiona, já que era responsável por $64 \%$ da capacidade global dessa tecnologia em 2012.

Tanto na China, como em outros países (Brasil inclusive), seu uso tem crescido principalmente para instalação residencial, embora também haja aplicações para aquecimento em sistemas distritais ou mesmo instalações industriais. A China lidera a fabricação desses equipamentos em nível mundial, mas eles atendem primordialmente a demanda local, sem exportações significativas (REN21, 2014).

Resumidamente, China, Coreia e Taiwan têm empresas com papel de destaque nas etapas mais intensivas em tecnologia da energia solar, nomeadamente as parcelas intermediárias da fabricação de equipamentos solares fotovoltaicos. Aproveitando-se do cenário favorável para exportação à Europa e da experiência anterior na fabricação de semicondutores, várias empresas desses países conseguiram migrar parte da produção para o mercado solar, colocando-se entre as líderes mundiais na fabricação desses equipamentos e envolvimento crescente em P\&D.

\subsubsection{Nuclear}

Tal como mencionado anteriormente, é difícil ter informações acuradas sobre o setor em razão da conexão militar que está envolvida nessa tecnologia. Ainda assim, há dados 
suficientes sobre os três países que permitem indicar a importância que a tecnologia nuclear exerce sobre seus respectivos sistemas elétricos. Sinteticamente, cabe afirmar que China e Coreia fazem uso crescente da tecnologia e com capacidade local em rápida evolução, ao passo que Taiwan a utiliza em menor escala e com menor domínio tecnológico.

TABELA 21

Reatores nucleares em operação na China, 2014

\begin{tabular}{|c|c|c|c|c|}
\hline UNIDADES & $\begin{array}{l}\text { CAPACIDADE } \\
\text { LÍQUIDA } \\
\text { (CADA } \\
\text { REATOR) } \\
\end{array}$ & $\begin{array}{l}\text { TIPO DE REATOR / } \\
\text { FABRICANTE DE } \\
\text { REATOR, TURBINA } \\
\text { E GERADOR }\end{array}$ & $\begin{array}{l}\text { ORIGEM DO } \\
\text { FABRICANTE }\end{array}$ & $\begin{array}{l}\text { ENTRADA EM } \\
\text { OPERAÇÃO } \\
\text { COMERCIAL }\end{array}$ \\
\hline $\begin{array}{l}\text { Daya Bay } \\
1 \& 2\end{array}$ & $944 \mathrm{MWe}$ & $\begin{array}{c}\text { M310 } \\
\text { (Frematome, Alstom, } \\
\text { Alstom) }\end{array}$ & França & 1994 \\
\hline $\begin{array}{l}\text { Qinshan } \\
\text { Fase I }\end{array}$ & $298 \mathrm{MWe}$ & $\begin{array}{c}\text { CNP-300 } \\
\text { (MHI, Shanghai } \\
\text { Turbine, Shanghai } \\
\text { Electric) }\end{array}$ & $\begin{array}{l}\text { Japão, China, } \\
\text { China }\end{array}$ & 1994 \\
\hline $\begin{array}{l}\text { Qinshan } \\
\text { Fase II, 1\&2 }\end{array}$ & $610 \mathrm{MWe}$ & $\begin{array}{c}\text { CNP-600 } \\
(\mathrm{CNNC}, \mathrm{CNNC})\end{array}$ & China & 2002,2004 \\
\hline $\begin{array}{l}\text { Qinshan } \\
\text { Fase II, 3\&4 }\end{array}$ & $620 \mathrm{MWe}$ & $\begin{array}{c}\text { CNP-600 } \\
(\mathrm{CNNC}, \mathrm{CNNC})\end{array}$ & China & 2010,2012 \\
\hline $\begin{array}{l}\text { Qinshan } \\
\text { Fase III, } \\
\text { 1\&2 }\end{array}$ & $678 \mathrm{MWe}$ & $\begin{array}{l}\text { Candu } 6 \\
\text { (AECL, Hitashi, } \\
\text { Hitashi) }\end{array}$ & $\begin{array}{l}\text { Canadá, Japão, } \\
\text { Japão }\end{array}$ & 2002,2003 \\
\hline $\begin{array}{l}\text { Fangjiashan } \\
1 \& 2\end{array}$ & $1020 \mathrm{MWe}$ & CPR-1000 & França & 2014,2014 \\
\hline $\begin{array}{l}\text { Ling Ao } \\
\text { Fase I, 1\&2 }\end{array}$ & $938 \mathrm{MWe}$ & $\begin{array}{c}\text { M310 } \\
\text { (Frematome, Alstom, } \\
\text { Alstom) }\end{array}$ & França & 2002,2003 \\
\hline $\begin{array}{l}\text { Ling Ao } \\
\text { Fase II, 1\&2 }\end{array}$ & $1026 \mathrm{MWe}$ & $\begin{array}{l}\text { M310; CPR-1000 } \\
\text { (DFEC, Alstom, } \\
\text { Dongfang) }\end{array}$ & $\begin{array}{l}\text { China, França, } \\
\text { China }\end{array}$ & 2010,2011 \\
\hline $\begin{array}{l}\text { Tianwan } \\
1 \& 2\end{array}$ & $990 \mathrm{MWe}$ & $\begin{array}{c}\text { VVER-1000 } \\
\text { (AO } \\
\text { Atomenergoeksport) }\end{array}$ & Rússia & 2007,2007 \\
\hline Ningde 1\&2 & $1020 \mathrm{MWe}$ & $\begin{array}{l}\text { CPR-1000 } \\
\text { (CNPE, Alstom, } \\
\text { Dongfang) } \\
\end{array}$ & $\begin{array}{l}\text { China, França, } \\
\text { China }\end{array}$ & 2013,2014 \\
\hline $\begin{array}{l}\text { Hongyanhe } \\
1 \& 2\end{array}$ & $1024 \mathrm{MWe}$ & $\begin{array}{l}\text { CPR-1000 } \\
\text { (CNPE, Alstom, } \\
\text { Dongfang) }\end{array}$ & $\begin{array}{l}\text { China, França, } \\
\text { China }\end{array}$ & 2013,2014 \\
\hline Yangjiang 1 & $1021 \mathrm{MWe}$ & CPR-1000 & França & 2014 \\
\hline Fuqing 1 & $1020 \mathrm{MWe}$ & CPR-1000 & França & 2014 \\
\hline TOTAL: 23 & $20,115 \mathrm{MWe}$ & & & \\
\hline
\end{tabular}

Fontes: Elaboração própria a partir de WNA, 2015; IAEA, 2015; GEO, 2014.

OBS.: Não foram localizadas informações sobre os fornecedores das usinas de Fangjiashan, Yangjiang e Fuqing. 
No caso da China, a energia nuclear exerce um papel importante para substituir a utilização excessiva do carvão, permitindo mitigar não apenas a emissão de gases estufa, mas também a poluição doméstica que ele provoca. Além disso, a energia nuclear pode ser construída próximo aos grandes centros consumidores, compensando a desvantagem de transportar o carvão das áreas mais remotas onde é extraído. Essa vantagem também se aplica em relação às fontes eólica e hidráulica, já que os melhores locais para geração dessas fontes frequentemente estão distantes dos centros urbanos.

No final de 2014, a China dispunha de 23 reatores nucleares em operação e 26 em construção, além de outros planejados. Esse montante equivale a cerca de $2 \%$ do sistema elétrico chinês. O país planeja alcançar $58 \mathrm{GW}$ de capacidade instalada em energia nuclear até 2020, depois $150 \mathrm{GW}$ para 2030 (WNA, 2014).

Como se verifica na Tabela 21, a maior parte da tecnologia nuclear para geração elétrica na China provém da França, Canadá, Japão e Rússia, com desenvolvimentos locais partindo principalmente dos equipamentos franceses. Entretanto, as aquisições de tecnologia mais recentes provieram não apenas da França (Areva), mas também dos Estados Unidos (Westinghouse), como se verá à frente.

Desde meados dos anos 2000, com o propósito de enfrentar o grave problema de poluição local e também de reduzir suas emissões, a China vem buscando ampliar a utilização de energia nuclear em sua matriz elétrica. Embora esse esforço tenha sido parcialmente revisto depois do acidente de Fukushima, no Japão, em 2011, ainda assim o país estabeleceu metas de avanço arrojadas na construção de novas usinas. Nessa linha, a China estabeleceu quatro objetivos centrais de sua política de energia nuclear:

a) O reator de água pressurizada será o padrão, mas não o único tipo;

b) O combustível nuclear será suprido e fabricado domesticamente;

c) A fabricação da planta e dos equipamentos no mercado doméstico deve ser maximizada, com busca de autonomia no desenho e no gerenciamento dos projetos;

d) A cooperação internacional deve ser encorajada, respeitados os objetivos anteriores (WNA, 2014).

Atualmente estão em construção reatores nucleares de $3^{a}$ geração e também alguns de uma versão aprimorada da $2^{\mathrm{a}}$ Geração ( $2^{\mathrm{a}}$ Geração+). Há algumas variações entre os modelos, mas os dois principais tipos de reatores em construção na China são evoluções chinesas de tecnologias estrangeiras, notadamente duas categorias de reatores: 
a) Quinze usinas em construção com o reator CPR 1000, uma evolução chinesa de reator da Areva de 900 MW e melhorado para obter 1000 MW de capacidade ( $2^{\text {a }}$ Geração+), construídos pela empresa estatal China General Nuclear Power Group - CGN; e

b) Quatro usinas em construção com o reator AP 1000, desenvolvido pela Westinghouse ( $3^{\text {a }}$ Geração), de pouco mais de $1250 \mathrm{MW}$ de capacidade, com um contrato de transferência de tecnologia para empresas chinesas com o propósito de desenvolver o CAP 1400 e o CAP 1700, com capacidade de 1400 MW e 1700 MW respectivamente.

O reator AP 1000 e suas possíveis derivações são a grande aposta da China na $3^{\mathrm{a}}$ Geração de usinas nucleares, tendo recebido prioridade do governo chinês para as novas construções. Além dos que estão em construção, há cerca de 30 projetos em planejamento com esse modelo, com a vantagem da vida útil mais longo, da utilização de mecanismos de segurança passiva e de poder produzir em grande escala e com custo menor. O desenvolvimento do CAP 1400 e do CAP 1700 é uma aposta do governo chinês para viabilizar a exportação em grande escala de tecnologias de energia nuclear, em cooperação com a Westinghouse (WNA, 2014).

O país já vem assinando contratos de exportação de tecnologias nucleares, baseados principalmente no desenvolvimento do reator CAP 1400. O país já assinou contratos de construção com o Paquistão e tem parcerias firmadas para projetos com a Romênia, a Turquia e a Argentina.

Na Coreia do Sul, a energia nuclear contabiliza uma parcela significativa da matriz elétrica local, alcançando $29 \%$ do total. O país dispõe de seis conjuntos de usinas nucleares, cada um com mais de um reator nuclear. No total, são 23 reatores em operação. Além disso, há outros 5 reatores em construção, com previsão de entrada em operação de 2015 a 2018. Por fim, há outras 8 unidades planejadas para depois de 2020 (WNA, 2014).

Como se verifica, o país passou por um intenso processo de aprendizado no setor, iniciando com tecnologia inteiramente estrangeira e passando gradualmente a dispor de tecnologia nacional para os componentes mais críticos, como reator, turbina e gerador.

As primeiras unidades nucleares (Kori 1 e 2 e Wolsong 1) foram contratadas como projetos turnkey, sem que o país lograsse aprendizado significativo nas tecnologias mais sensíveis. Os seis projetos seguintes (Kori 3 e 4; Yonggwang 1 e 2; e Ulchin 1 e 2) integraram a segunda geração de plantas nucleares da Coreia, cujos contratos já envolviam a participação de indústrias locais. 
TABELA 22

Reatores nucleares em operação na Coreia do Sul, 2014

\begin{tabular}{|c|c|c|c|c|}
\hline UNIDADES & $\begin{array}{l}\text { CAPACIDADE } \\
\text { INSTALADA } \\
\text { (TOTAL) }\end{array}$ & $\begin{array}{c}\text { FABRICANTE } \\
\text { DE REATOR, } \\
\text { TURBINA E } \\
\text { GERADOR } \\
\end{array}$ & $\begin{array}{l}\text { ORIGEM DO } \\
\text { FABRICANTE }\end{array}$ & $\begin{array}{l}\text { ENTRADA EM } \\
\text { OPERAÇÃO } \\
\text { COMERCIAL }\end{array}$ \\
\hline Kori 1, 2, 3 e 4 & $3140 \mathrm{MW}$ & $\begin{array}{l}\text { Westinghouse, } \\
\text { GEC, GEC }\end{array}$ & $\begin{array}{l}\text { EUA, Inglaterra, } \\
\text { Inglaterra }\end{array}$ & $\begin{array}{c}1978,1983,1985, \\
1985\end{array}$ \\
\hline Shin-Kori 1 e 2 & $2000 \mathrm{MW}$ & $\begin{array}{l}\text { KHNP/Doosan, } \\
\text { Doosan, Doosan }\end{array}$ & Coreia & 2011,2012 \\
\hline Wolsong 1, 2, 3 e 4 & $2629 \mathrm{MW}$ & AECL & Canadá & $\begin{array}{c}1982,1997,1998, \\
1999\end{array}$ \\
\hline Shin-Wolsong 1 e 2 & $2000 \mathrm{MW}$ & $\begin{array}{c}\text { Doosan, Doosan, } \\
\text { Doosan }\end{array}$ & Coreia & 2012,2013 \\
\hline Ulchin 1 e 2 & $1840 \mathrm{MW}$ & $\begin{array}{c}\text { Framatome, } \\
\text { Alstom, Alstom }\end{array}$ & França & 1988,1989 \\
\hline Ulchin 3 e 4 & $1920 \mathrm{MW}$ & $\begin{array}{c}\text { Combustion } \\
\text { Engineering, GE, } \\
\text { GE }\end{array}$ & EUA & 1998,1999 \\
\hline Ulchin 5 e 6 & $1920 \mathrm{MW}$ & $\begin{array}{l}\text { KHNP/Doosan, } \\
\text { Doosan, Doosan }\end{array}$ & Coreia & 2004,2005 \\
\hline Yonggwang 1 e 2 & $1800 \mathrm{MW}$ & Westinghouse & EUA & 1986,1987 \\
\hline Yonggwang 3 e 4 & $1920 \mathrm{MW}$ & $\begin{array}{c}\text { Combustion } \\
\text { Engineering, } \\
\text { Doosan/GE, } \\
\text { Doosan/GE } \\
\end{array}$ & $\begin{array}{c}\text { EUA, } \\
\text { Coreia/EUA, } \\
\text { Coreia/EUA }\end{array}$ & 1995,1996 \\
\hline Yonggwang 5 e 6 & $1920 \mathrm{MW}$ & $\begin{array}{l}\text { KHNP/Doosan, } \\
\text { Doosan, Doosan }\end{array}$ & Coreia & 2002,2002 \\
\hline
\end{tabular}

Fontes: GEO, 2014; e WNA, 2014.

Em meados dos anos 1980, então, o país dispunha de usinas concebidas pela Combustion Engineering (EUA), Frematome (França) e AECL (Canadá), cada uma delas com concepções substancialmente diferentes. O programa nuclear coreano, então, optou por um plano para criar um padrão para a estrutura das plantas nucleares, de modo a alcançar autossuficiência, tecnologia própria e um padrão que permitisse ganhos de escala.

Foi lançado, então, o projeto da Usina Nuclear Padronizada da Coreia do Sul, buscando o desenvolvimento de reatores próprios. Usando o aprendizado dos reatores estadunidense e francês, a Coreia desenvolveu o reator OPR-1000 (Optimized Power Reactor), de $2^{\text {a }}$ Geração, e posteriormente o APR-1400 (Advanced Power Reactor), de $3^{\text {a }}$ Geração, ambos concebidos pela empresa de capital predominantemente estatal KEPCO (Korea Electric Power Corporation) (WNA, 2014).

A partir da capacidade tecnológica desenvolvida na área nuclear, a Coreia do Sul tem promovido intensamente um esforço de exportação de sua tecnologia para a construção 
de usinas nucleares em outros países. Em 2009, o país assinou contrato com os Emirados Árabes Unidos para construir quatro reatores nucleares até 2020 por cerca de US\$ 20 bilhões, além de outras quatro usinas planejadas.

O governo coreano chegou a anunciar em 2010 o objetivo de exportar 80 reatores nucleares até 2030, numa soma total de US\$ 400 bilhões. O objetivo seria tornar-se o terceiro maior fornecedor de tecnologia nuclear no mundo, $20 \%$ do mercado, atrás apenas dos EUA, França e Rússia. Há negociações em curso com a Turquia, Jordânia, Romênia e Ucrânia, assim como com países do sudeste asiático, como o Vietnã (WNA, 2014).

Apesar desse progresso nas etapas finais da geração nuclear, os depósitos naturais de urânio na Coreia do Sul são de baixa qualidade e antieconômicos, de modo que nunca foram propriamente explorados para mineração. Mas a Coreia busca diversificar a origem do produto e importa os concentrados de urânio da Austrália, Canadá, Reino Unido, França, Rússia, EUA e África do Sul (IAEA, 2014).

Parte do progresso sulcoreano provém do relacionamento próximo e intrincado com a indústria nuclear estadunidense. Essa cooperação entre os países exerceu papel crucial no aprendizado tecnológico da Coreia e resulta em integração forte entre as cadeias produtivas dos dois países nesse setor. Ao mesmo tempo em que a Coreia adentrou o mercado internacional para exportar produtos nucleares no caso dos Emirados Árabes Unidos, companhias estadunidenses fornecem parte dos equipamentos. Do mesmo modo, empresas sulcoreanas são fornecedores significativas dos reatores da estadunidense Westinghouse em construção na China (BROOKINGS INSTITUTION, 2015).

A Coreia do Sul figura na peculiar posição de dispor de tecnologia para fabricação de algumas das partes mais sensíveis da geração de energia nuclear, mas o país enfrenta limitações para o controle completo do ciclo do urânio em razão de acordo internacional de 1956. De fato, por meio desse Acordo sobre Energia Atômica firmado pelos EUA e pela Coreia, em troca da cooperação estadunidense, a Coreia fica impedida de exercer todo o ciclo do urânio, banindo atividades como o enriquecimento e o reprocessamento combustível utilizado, além de regular a importação de minerais radioativos.

Esse acordo entre Coreia e EUA, assinado ainda no contexto da Guerra Fria e com foco em evitar a proliferação de armas nucleares, foi emendado em 1974 e sua vigência expiraria em março de 2014. As duas nações concordaram em postergar o acordo até março de 2016, já que não conseguiram chegar a um acordo sobre o regime que deveria viger no atual contexto, depois de toda a expansão e modernização da indústria nuclear sulcoreana. A Coreia pretende ampliar suas atividades para dominar todo o ciclo, especialmente o reprocessamento 
de urânio, de modo a lidar com o problema ainda não resolvido dos rejeitos nucleares (KIM, 2013; XINHUA, 2013; THE KOREA HERALD, 2015).

É fato ainda que o esforço da Coreia para a energia nuclear enfrenta problemas de descrédito doméstico e internacional, envolvendo especialmente corrupção e insegurança do sistema. Dois reatores chegaram a ser paralisados em 2013, porque usavam equipamentos cujos certificados de segurança eram falsos, o que gerou risco de blackout no sistema elétrico. O mesmo problema de certificados forjados já havia afetado o país em 2012, também resultando no desligamento de dois reatores nucleares. Em 2013, ainda que temporariamente, 10 dos 23 reatores nucleares do país ficaram desligados, seja por manutenção, seja por riscos de falta de segurança, conforme matérias do Japan Times (South Korea halts two reactors delays two more, de 28 de maio de 2013) e do New York Times (South Korea Shuts 2 Reactors Over Faked Certificates, de 28 de maio de 2013).

O que há de realmente relevante no programa nuclear da Coreia é o compromisso de ampliar significativamente a participação da energia nuclear (59\% em 2030, a partir de cerca de $30 \%$ hoje). Há expectativa de se tornar exportador da tecnologia de energia nuclear, como o fez num leilão que venceu nos Emirados Árabes Unidos em 2010. A Coreia continuaria dependendo de importação de combustível (urânio, no caso), mas as fontes não seriam mais o instável Oriente Médio, e sim Canadá, Rússia, Cazaquistão ou Austrália.

$\mathrm{O}$ fato é que a Coreia conseguiu transcorrer o processo de aprendizado no setor nuclear e construiu uma indústria local pujante e inovativa. As empresas locais fornecem parcela significativa da energia utilizada no sistema elétrico coreano e dispõem de capacidade, tecnologia e preço competitivos para disputar o mercado externo. Com essa política, a Coreia consegue ao mesmo tempo reduzir a dependência da importação de combustíveis fósseis, diminuir as emissões de gases estufa e disputar a liderança tecnológica em um setor bastante sensível da economia.

Por fim, é preciso examinar o caso de Taiwan no campo nuclear. De modo similar ao Brasil, Taiwan também utiliza geração nuclear em sua matriz elétrica, mas o país não logrou uma absorção de tecnologia significativa com fornecedores domésticos.

Em 2014, Taiwan dispunha de três usinas nucleares em operação, cada uma delas com dois reatores: Chinshan (1208 MW), Kuosheng (1896 MW) e Maanshan (1780 MW). A primeira delas foi inaugurada em fins dos anos 1970 e as duas seguintes ainda nos anos 1980. Todas elas foram construídas com tecnologia estadunidense, com reatores e turbinas fornecidos pela GE ou pela Westinghouse, em contratos de estilo turnkey. 
Além dessa três, Taiwan iniciou em 1999 a construção da usina Lungmen, também com dois reatores (2700 MW no total). O reator seria fornecido pela GE, ao passo que as turbinas e geradores, pela japonesa Mitsubishi, mas em todas as etapas haveria participação de empresas locais. A conclusão do projeto, entretanto, prevista inicialmente para 2004, já foi adiada sucessivas vezes (GEO, 2014).

As usinas nucleares representam cerca de $16 \%$ da energia elétrica utilizada em Taiwan, o que representa uma quantia significativa na geração. No entanto, sob a ótico do avanço tecnológico não há esforços significativos em Taiwan. Todos os materiais e serviços empregados nesse segmento são importados, incluindo o urânio enriquecido. Mesmo em nível de $\mathrm{P} \& \mathrm{D}$, havia apenas pequenos reatores para pesquisas, mas nem mesmo esses reatores estão ativados (WNA, 2014).

Em síntese, no campo de energia nuclear, o papel de Taiwan não é significativo em termos de manufatura, nem em termos de inovação, mas o país dispõe de uma geração relevante dessa fonte em sua matriz energética.

Neste Capítulo, examinamos a situação atual da produção manufatureira dos quatro países em questão em relação às principais fontes de baixo carbono. O Brasil tem geração significativa de hidráulica, biomassa e eólica, mas, à exceção da biomassa, não está na disputa tecnológica dos demais campos.

Os países asiáticos examinados, embora tenham baixa geração de energia com fontes de baixo carbono, têm relevante produção industrial na área e estão próximos à fronteira tecnológica ao menos no caso da solar, eólica (principalmente China), hidráulica (caso da China) e nuclear (casos de Coreia e China). No Capítulo seguinte examinaremos especialmente esse esforço tecnológico. 


\title{
CAPÍTULO 7 \\ DOENÇA HOLANDESA E SEUS EFEITOS NAS MANUFATURAS DE ENERGIA NO BRASIL E NA BUSCA DE LIDERANÇA TECNOLÓGICA
}

\author{
"Deitado eternamente em berço esplêndido, \\ Ao som do mar e à luz do céu profundo, \\ Fulguras, ó Brasil, florão da América, \\ Iluminado ao sol do Novo Mundo!" \\ Trecho do Hino Nacional
}

\subsection{Paradoxo da plenitude: como funciona a maldição dos recursos naturais}

A atividade manufatureira no Brasil no fornecimento de equipamentos para a área de energia precisa ser compreendida no contexto das demais atividades industriais no país. Para se debruçar sobre a evolução recente da indústria brasileira, este capítulo discutirá os efeitos que a abundância de recursos naturais tem provocado sobre esse setor econômico, particularmente depois dos anos 1990.

A extração de recursos naturais é uma atividade econômica tradicional e conduz à compreensão intuitiva de que a abundância de recursos naturais favorece os países que dele dispõem. A realidade das últimas décadas, todavia, tem revelado que a relação não é tão direta e, em vários casos, existe até mesmo uma relação inversa entre disponibilidade de recursos naturais e desenvolvimento econômico.

A literatura tem utilizado nomenclaturas diferentes para fenômenos similares. Por vezes chamado de maldição dos recursos naturais, noutras qualificado como paradoxo da plenitude e, em uma de suas facetas, tachado de doença holandesa, a questão central que se busca abordar é esta: por que alguns países, mesmo com abundantes recursos naturais, não conseguem promover desenvolvimento econômico consistente, ao passo que outros, mesmo sem serem premiados pela natureza, atingem esse objetivo?

Vale aqui ressaltar que a análise em questão não aponta que a existência de recursos naturais é necessariamente um empecilho ao desenvolvimento, tampouco que sua ausência conduzirá ao progresso econômico. O que essa teoria apregoa é que, em certas circunstâncias adiante explicadas, a abundância pode resultar na deterioração das condições necessárias ao crescimento de longo prazo. 
O argumento foi concebido inicialmente ao examinar os casos de países exportadores de petróleo. Mesmo depois dos significativos aumentos do preço internacional do petróleo na década de 1970, vários dos grandes exportadores de óleo não conseguiram aumentar de maneira significativa seu desempenho socioeconômico. É o caso, entre vários outros, de Nigéria, Indonésia, Líbia e Venezuela. Há estudos, como o de Sachs e Warner (SACHS e WARNER, 1995), em que se mensura o índice de crescimento do PIB e de outros resultados socioeconômicos desses países, e se compara o resultado com o desempenho de outras nações equivalentes, controlando fatores como as diferentes rendas per capita de origem, políticas de comércio, etc.

\section{GRÁFICO 35}

Crescimento e abundância de recursos naturais (1970-1989)

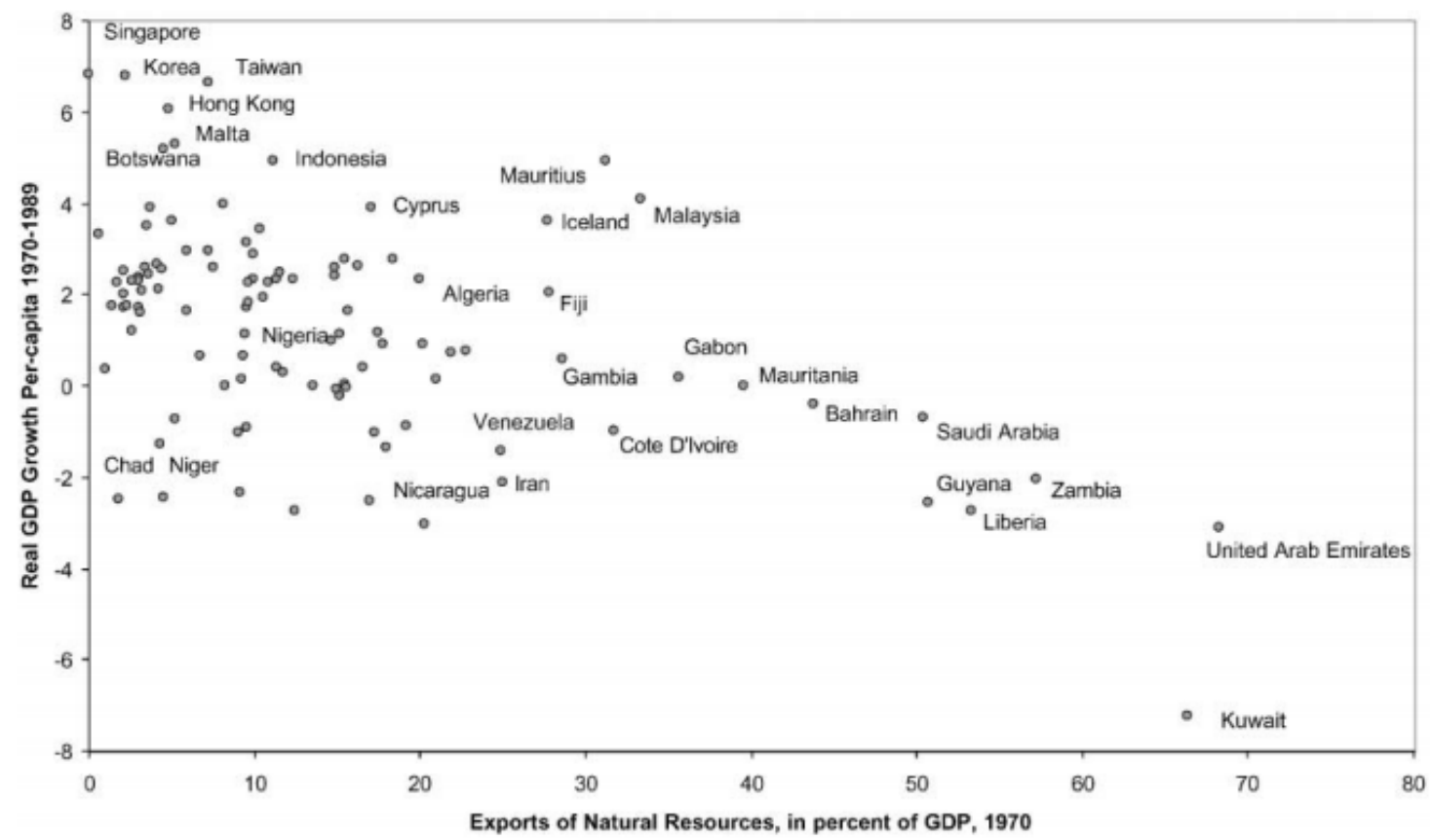

Fonte: SACHS e WARNER (2001).

SACHS e WARNER reuniram dados de inúmeros países sobre exportação de recursos naturais e crescimento econômico per capita. Os resultados, lançados no Gráfico 35, revelam a existência de uma correlação inversa entre disponibilidade de recursos e crescimento sustentado, utilizando dados de crescimento do PIB até o fim dos anos 1980. No topo do crescimento sustentado estão países com baixíssimas exportações de recursos naturais, como Cingapura, Coreia e Taiwan. Do lado inverso, com baixo crescimento médio da renda per capita, encontram-se países exportadores de produtos primários, particularmente no Oriente Médio (Kuwait e Emirados Árabes Unidos) e na África Subsaariana (Libéria e Zâmbia). 
Há distintas explicações para esse fenômeno, mas elas se concentram em quatro hipóteses principais:

a) Fragilidade das instituições estatais: a abundância de recursos naturais (usualmente petróleo, mas também diamantes, ouro, etc.) conduz a que uma dependência desproporcional da exploração desses recursos para a composição das receitas públicas, podendo enfraquecer o esforço de construção institucional do poder público;

b) Instabilidade política: a volatilidade das receitas oriundas dos recursos naturais, sujeitas às intensas flutuações dos preços internacionais, cria ilusões de prosperidade e de desenvolvimento nos períodos de alta, mas desestabiliza os regimes políticos quando das baixas dos influxos monetários, gerando mudanças de regime e instabilidade política e econômica;

c) Absorção da mão-de-obra qualificada: A capacidade de gerar receitas volumosas atrai para esse setor os quadros mais qualificados do país, reduzindo a mão-de-obra qualificada em outros setores econômicos e dificultando a consolidação de outras áreas da economia desvinculadas do recurso abundante; e

d) Apreciação cambial: a exportação dos recursos primários tende a sobreapreciar o câmbio e reduzir a competitividade de outros setores econômicos, como as atividades manufatureiras.

No primeiro caso, a hipótese é que os países passam a depender em grande medida, ou na totalidade, das rendas oriundas do setor primário, reduzindo o esforço para construção institucional. A baixa accountability desses governos é uma das características evidentes, em parte devida à inexistência ou aos baixos valores dos tributos pagos pela população, que reduziriam o incentivo à cobrança por contraprestação de serviços. O poder público não é visto como o gestor do bem comum, coletado com o esforço e participação de todos, mas sim uma entidade que gerencia uma receita "própria" oriunda da exploração dos recursos naturais ${ }^{35}$.

No segundo caso podem ser mencionados vários casos de países africanos, em que a renda do setor primário está associada à instabilidade política, divisões entre estados,

\footnotetext{
${ }^{35}$ Veja-se a situação da Arábia Saudita, em que praticamente não existe arrecadação tributária. Em rigor, existem impostos sobre o setor de petróleo e algumas tarifas de cunho "religioso", mas não existe imposto de renda de pessoa física, tampouco imposto sobre propriedade ou transações comerciais (ASIA TRADE HUB, 2014).
} 
formação de milícias. Quando há períodos de alta no preço do produto, o que ocorre é uma degradação paulatina do regime por meio do reforço dos interesses ligados ao setor petrolífero e crescente enfraquecimento da capacidade estatal (KARL, 1997).

A terceira hipótese consiste na atração que o setor primário exerce sobre a mãode-obra qualificada do país. Embora pouco relevante se se está diante de país com população abundante e bem educada, o problema se torna crucial quando se está à frente de um país com população reduzida ou com baixo nível educacional médio. Os salários no setor primário nos períodos de alta tendem a ser bem mais atrativos do que os do restante da economia, particularmente em países em desenvolvimento. Isso resulta na atração dos melhores estudantes para que se formem na área favorecida, atraindo também os melhores profissionais já graduados a se especializar no setor.

A quarta hipótese, com a qual trabalharemos mais a fundo nesta tese, é a da sobreapreciação cambial. Esse modelo passou a ser tachado de "doença holandesa". A origem da expressão está associada à descoberta de grandes depósitos de gás natural na Holanda em 1959, na bacia do Mar do Norte. Ao contrário da esperada aceleração do crescimento econômico em razão dos novos recursos naturais, a taxa de crescimento holandês caiu no longo prazo.

De fato, o rápido incremento das exportações de gás natural nos anos seguintes, especialmente na década de 1970, a partir do choque do petróleo, provocou uma apreciação acentuada do florim, a então moeda local. Isso provocou a perda da competitividade do setor manufatureiro holandês, a redução de sua participação na economia holandesa, além de desemprego e baixas taxas de crescimento econômico nos anos 1970 e 1980 (BATISTA, 2009; e VERÍSSIMO, 2010).

Essa perspectiva da doença holandesa contradiz a visão econômica tradicional, segundo a qual os recursos naturais são uma dádiva do país, constituem ativos naturais, e sua exploração tenderia a facilitar o desenvolvimento econômico, seja em países desenvolvidos, seja em países retardatários (DAVIS e TILTON, 2005). A abordagem tradicional se baseia no exemplo histórico dos Estados Unidos, que foi - e ainda é - um grande produtor de recursos primários, e mais recentemente nas experiências de Canadá e Austrália.

Para a perspectiva tradicional, a atividade de mineração é a chave para converter riquezas minerais estocadas na natureza em escolas, habitações, portos e outras formas de capital que contribuem diretamente para o crescimento econômico. A questão central, apontam DAVIS e TILTON (2005), é se as oportunidades advindas das riquezas naturais estão sendo 
utilizadas adequadamente para a promoção do desenvolvimento, ou se os recursos são mal gerenciados.

O que os defensores da existência da maldição dos recursos naturais argumentam é que, especialmente em países de renda mais baixa, em que estruturas estatais ainda não estão adequadamente estruturadas, as instituições se deterioram no curso do processo e podem surgir instabilidades políticas. Além disso, no que tange aos efeitos econômicos, aponta-se essa falha de mercado - que é negada pelos autores tradicionais - consistente na especialização da economia em atividades primário-exportadora, decorrente da apreciação cambial, da perda de competitividade industrial e da especialização das forças produtivas (“doença holandesa”) (BATISTA, 2009).

O modelo clássico para explicar a doença holandesa foi exposto no artigo de CORDEN e NEARY (1982), posteriormente aprimorado por CORDEN (1984). Segundo esse desenho, existem três setores na economia: o que está em expansão (recursos naturais), o que cresce lentamente (manufaturados) e o setor de não-comercializáveis (serviços). O pressuposto é que os preços dos dois primeiros setores são definidos pelo mercado internacionais, enquanto que os preços do terceiro setor são estabelecidos primordialmente pela economia doméstica. A taxa de câmbio é definida como a razão entre os preços de bens comercializáveis e nãocomercializáveis.

A expansão do primeiro setor pode decorrer de melhoramento técnico, descoberta de novos recursos, ou aumento exógeno dos preços do produto no mercado internacional em relação ao preço das importações. Como aponta VERÍSSIMO (2010), há dois efeitos principais decorrentes da expansão desse primeiro setor: a) o efeito de gastos; e b) o efeito de deslocamento.

Por efeito de gastos se considera que uma parcela da renda extra do setor em expansão tenderá a ser gasta no setor de não-comercializáveis. Nesse caso, haveria aumento da demanda por bens não-comercializáveis, resultando no aumento do preço desses bens em relação ao dos comercializáveis, causando apreciação da taxa de câmbio real.

No que tange ao efeito de deslocamento, os autores apontam que o setor em expansão passa a exigir mais trabalho, o que implica aumento da remuneração do trabalho nesse setor. Isso desloca recursos produtivos (capital e trabalho) dos outros setores da economia para o setor em expansão, tendendo a reduzir a produção tanto dos outros setores comercializáveis (os que não estão em expansão), quanto dos não-comercializáveis. $\mathrm{O}$ resultado pode ser a desindustrialização e o aumento adicional dos preços dos nãocomercializáveis, o que pressiona por uma apreciação adicional do câmbio. Conjugados, os 
efeitos de gastos e de deslocamento acarretam diminuição na participação da produção de comercializáveis em relação aos não-comercializáveis, além de apreciação da taxa de câmbio real, caracterizada pelo aumento dos preços do setor não-comercializável em relação ao comercializável.

O problema central decorrente do ingresso excessivo de moeda estrangeira proveniente da exportação de produtos primários é a formação de uma taxa de equilíbrio no câmbio inferior à taxa necessária para o "equilíbrio industrial". Em outras palavras, o câmbio se equilibra em um patamar que não é compatível com a competitividade do setor manufatureiro de maior intensidade tecnológica (BRESSER-PEREIRA; MARCONI, 2008).

A grande vantagem de assegurar a competitividade do setor industrial é que esse segmento da economia, diferentemente do setor primário, possui retornos crescentes de escala na produção, envolve externalidade positivas, efeitos de aprendizado, encadeamentos para frente e para trás na cadeia produtiva e maior elasticidade-renda das importações (OREIRO e FEIJÓ, 2010).

A ausência de competitividade da indústria de transformação pode acarretar sérias consequências em termos de dinâmica tecnológica e ganhos de produtividade, resultando em perdas de know-how, capacidades locais e plantas produtivas (GALA, 2006). No longo prazo, portanto, assegurar taxa de câmbio competitiva para o setor industrial pode se revelar decisivo para o crescimento de longo prazo.

Exportações em tecnologia sofisticada favorecem a dinâmica de criação e difusão de inovações e ganhos de produtividade originados no setor industrial. A doença holandesa, nesse contexto, pode acarretar a especialização da estrutura produtiva em setores baseados em recursos naturais, que têm menor efeito de transbordamento e de difusão de conhecimento para outras atividades econômicas.

O câmbio para o equilíbrio industrial, vale notar, implica não apenas o fomento de exportações, mas também a competitividade do mercado interno do país em face da concorrência do importados. A apreciação do câmbio decorrente da doença holandesa torna mais difícil até mesmo que o setor manufatureiro local consiga disputar com seus produtos o próprio mercado doméstico em razão do barateamento dos produtos importados.

O que pretendemos demonstrar, nos tópicos seguintes, é que, diferentemente dos países asiáticos, o Brasil vem amargando os efeitos de uma doença holandesa de natureza crônica, que afetou, especialmente a partir dos anos 1990, o desenvolvimento de seu parque manufatureiro, inclusive na área de energia. 


\subsection{Desalinhamento cambial no Brasil}

"Inflação aleija, mas câmbio mata." Mario Henrique Simonsen

O primeiro passo para avaliar a caracterização da doença holandesa no Brasil é verificar a persistência do desalinhamento cambial. Esse desalinhamento pode ser definido, como apontam OREIRO, PUNZO, ARAÚJO e SQUEFF (2011), como uma situação em que há desvios duradouros na taxa de câmbio real com relação à taxa de equilíbrio de longo prazo. Se a taxa é menor do que a do equilíbrio, há sobreapreciação; se maior, há subapreciação.

Ainda que à primeira vista seja de fácil compreensão, não é trivial a definição do que seria a taxa de equilíbrio em uma economia aberta, já que a taxa não é diretamente observável. A literatura econômica se baseia principalmente em três abordagens distintas para definir o que seria a taxa de câmbio de equilíbrio de longo prazo, a seguir descritas.

A primeira se baseia na paridade do poder de compra, assumindo que os preços dos bens de uma economia, cotados em moeda estrangeira, não deveriam diferir dos preços dos mesmos bens praticados no exterior, ignorando-se as restrições ao comércio e os custos de transporte. A segunda foca no equilíbrio da conta corrente do balanço de pagamentos, lastreada na ideia de que o saldo deve equivaler ao fluxo líquido de capitais a médio e longo prazos, considerando-se as políticas macroeconômicas, efeitos defasados de mudanças na taxa de câmbio e expectativas sobre outras variáveis. A terceira está centrada nos fundamentos econômicos do país, levando em conta variáveis como a corrente de comércio exterior em relação ao PIB, o preço externo, relação do saldo da balança comercial e PIB, consumo do governo em relação ao PIB, termos de troca e diferencial da taxa de juros (OREIRO, PUNZO, ARAÚJO e SQUEFF, 2011).

$\mathrm{O}$ argumento central da doença holandesa é que, sob esses critérios de taxa de câmbio de equilíbrio, ocorre um desalinhamento cambial dos países que se tornam grandes exportadores de produtos primários. Examinaremos a seguir a situação cambial dos países selecionados, com foco particular para a taxa de câmbio brasileira.

Utilizando dados de OREIRO ET AL. (2011), baseados na abordagem da taxa de equilíbrio cambial a partir dos fundamentos econômicos, o Gráfico 36 coteja a taxa de câmbio real observada com a taxa de câmbio esperada. Pelas informações, pode-se verificar que, à exceção dos picos de desvalorização em 1999, 2001 e 2003, a taxa de câmbio real 
observada esteve consistentemente valorizada em relação ao que seria a taxa de equilíbrio e, a partir de 2005, essa valorização se consolidou em patamares consistentemente elevados.

\section{GRÁFICO 36}

Taxa de câmbio efetiva real e esperada real (índice - média de $2000=100$ )

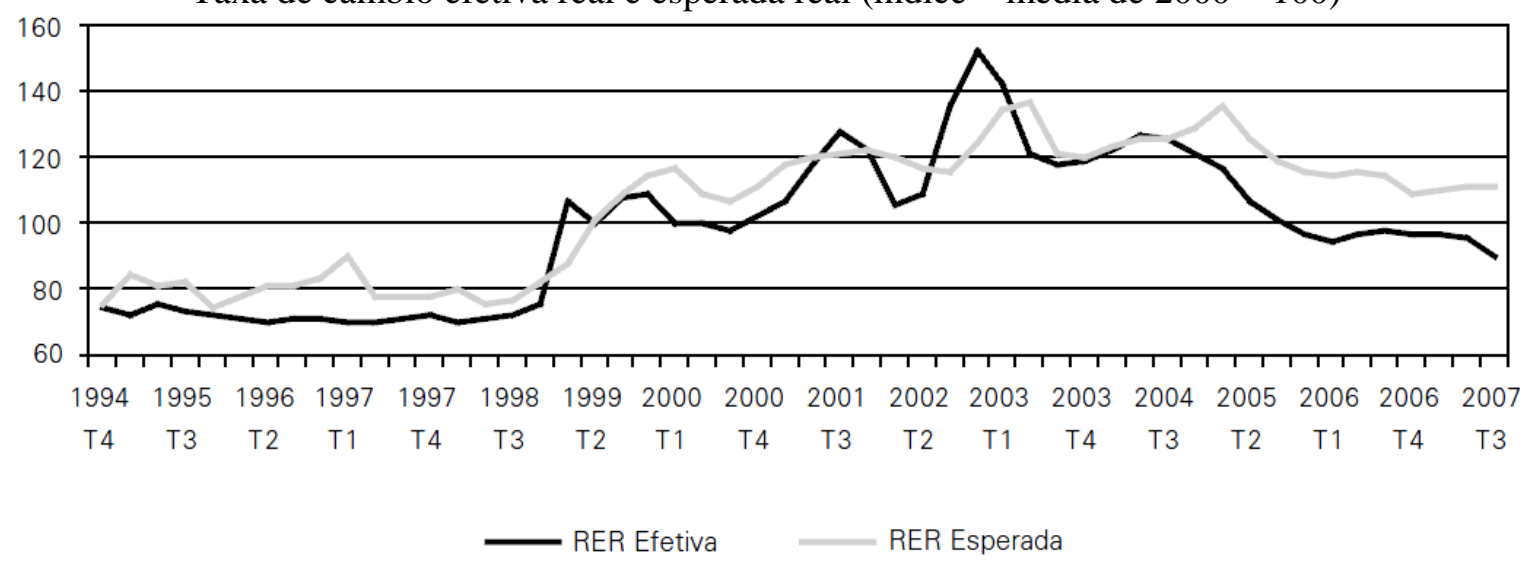

Fonte: OREIRO ET AL. (2011)

Outra abordagem possível, como já indicado, é a avaliação da taxa de câmbio a partir da paridade do poder de compra da moeda. Há várias metodologias para calcular o poder de compra a partir de uma cesta de produtos, comparando-as com o preço da mesma cesta em outros países.

Nesse critério, é possível fazer uso do indicador cambial simplificado criado pelo periódico inglês THE ECONOMIST, chamado de Big Mac Index. A ideia, baseada na abordagem da taxa de câmbio pela paridade do poder de compra, é que o preço do principal produto da rede McDonald's, convertido pela taxa de câmbio, tenderia a refletir a diferença no poder de compra da moeda de cada país, uma vez que os preços nos diferentes países deveriam incluir os custos dos ingredientes, os salários dos trabalhadores, etc. Eventual diferença nos preços, quando convertidos para uma mesma moeda à cotação de mercado, indicaria apreciação ou depreciação do câmbio.

O curioso é que, criado inicialmente em tom algo jocoso, o índice do Bic Mac passou a ser amplamente utilizado, porque, além de ser de fácil compreensão, ele reflete razoavelmente indicadores mais sofisticados, criados com base em cestas de produtos. O "zero" na escala corresponde ao preço do sanduíche convertido em dólar comparado ao preço do mesmo produto nos Estados Unidos. O Gráfico 37 sintetiza os preços desse item nos quatro países examinados.

Os indicadores cambiais que fazem uso da abordagem da paridade do poder de compra revelam, via de regra, moeda apreciada nos países de renda alta, especialmente em razão dos elevados custos de salários, e moeda depreciada em países de renda mais baixa. Por 
essa razão, é frequente que os países escandinavos figurem entre os que têm moeda mais apreciada. A despeito desse padrão geral, alguns países exportadores de petróleo também figuram por vezes no grupo dos países de moeda valorizada. Nesse grupo também se encontra o Brasil, fugindo à regra de que países com renda menor tenderiam a ter câmbio depreciado (embora, no caso brasileiro, não seja o petróleo o item a influenciar o desalinhamento).

\section{GRÁFICO 37}

Índice Big Mac para Brasil, Coreia, China e Taiwan (1999-2012)
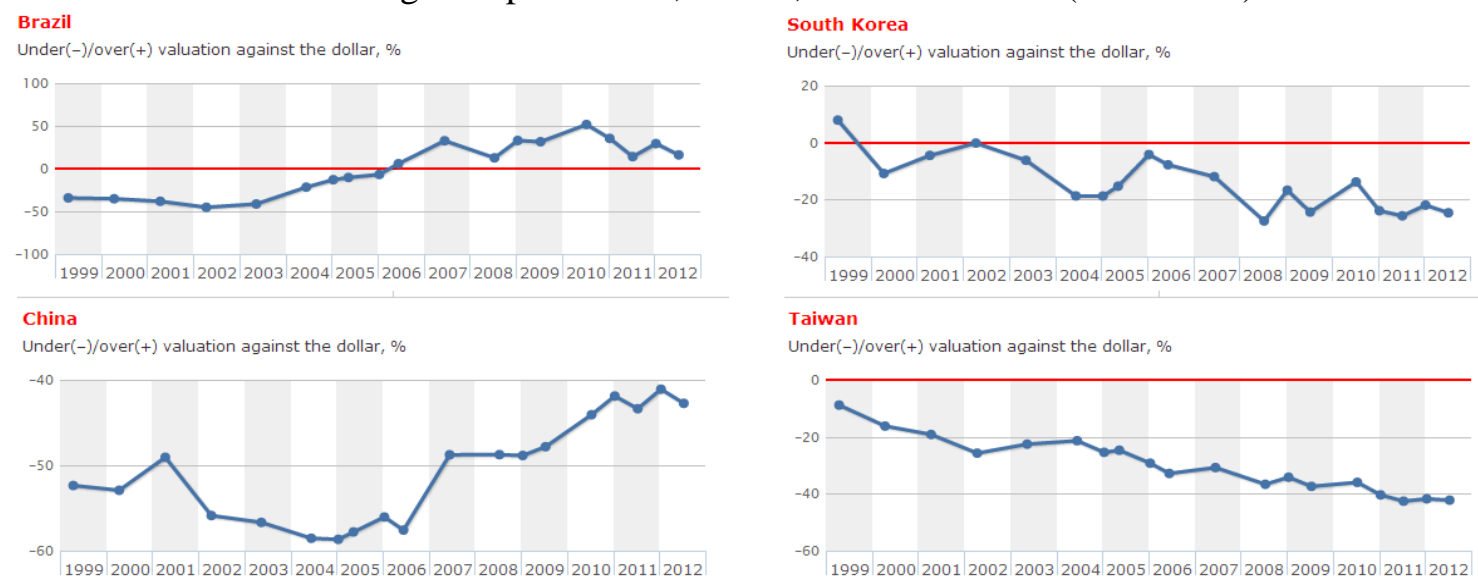

Fonte: The Economist - The Bic Mac Index, 2013.

Como se observa no Gráfico 37, o Brasil desde 2006 passou a ter câmbio mais valorizado do que a moeda dos Estados Unidos. Entretanto, já em 2004 e 2005 a moeda brasileira estava oscilando numa faixa muito próxima à da economia estadunidense, que possui renda per capita várias vezes superior à brasileira. Seria esperado que, por dispor de renda inferior, os preços no Brasil fossem menores, especialmente porque os custos de mão-de-obra seriam substancialmente inferiores.

Vale ainda observar que o gráfico traz dados a partir de 1999, quando houve uma grande desvalorização cambial no Brasil. Houvesse dados anteriores a esse período, seria possível assumir que provavelmente os dados entre 1994 e 1999 indicariam também um período de apreciação cambial. No conjunto, o país teve, em verdade, uma pequena janela de depreciação na virada do século, antecedida e sucedida por períodos de forte apreciação.

Em contraste com a situação brasileira, os países asiáticos consistentemente mantêm seu câmbio depreciado (à exceção de 1999, no caso da Coreia do Sul). No caso da China, a taxa de depreciação foi bastante acentuada, com a cotação da moeda abaixo de 50\% do valor que corresponderia ao poder de compra do índice, reduzindo-se a diferença nos últimos anos. Em Taiwan e Coreia, a desvalorização não chegou a tanto, mas ficou em uma 
faixa em torno de $20 \%$ do que seria o poder de compra esperado. Vale observar, contudo, que nos anos 2000 a renda per capita da Coreia e de Taiwan já estava muito próxima à dos países da OCDE (a Coreia passou até mesmo a integrar formalmente a OCDE), mas, mesmo assim, foi mantido o patamar de desvalorização cambial.

Vale ainda apontar outro indicador da apreciação cambial brasileira, ainda com a abordagem da paridade do poder de compra. Desta vez trabalhando com um indicador mais amplo, é possível comparar o PIB per capita nominal e o PIB per capita em paridade do poder de compra (PPP, na sigla em inglês) dos quatro países em questão. Como uma mesma remuneração em dólares tende a permitir um maior poder de compra em países de renda média inferior em razão da diferença dos salários, é de se esperar que, quanto menor a renda per capita nominal do país, maior a diferença relativa entre a renda per capita nominal e a renda per capita calculada em PPP.

Ao se examinar a situação dos quatro países, entretanto, não é exatamente o que se observa. O Brasil tem a segunda menor renda per capita nominal entre os quatro examinados, quase a metade da taiwanesa e menos do que a metade da renda per capita nominal sulcoreana. A despeito disso, a renda per capita em PPP é quase igual à renda per capita nominal, revelando que a diferença salarial a menor no Brasil não se reflete em maior poder de compra.

A Tabela 23 sintetiza esses números, utilizando informações de 2013. Os dados sugerem que, em 2013, a moeda com maior depreciação seria a taiwanesa, seguida pela chinesa e pela sulcoreana. A renda per capita brasileira convertida diretamente para o dólar é a única que espelha praticamente o mesmo valor da renda em PPP, o que não seria esperado em razão da diferença do salário médio em cada economia.

TABELA 23

Relação entre renda per capita nominal e em PPP, 2013

\begin{tabular}{|l|c|c|c|}
\hline & $\begin{array}{c}\text { PIB per capital } \\
\text { nominal, em US\$ (1) }\end{array}$ & $\begin{array}{c}\text { PIB per capita PPP, } \\
\text { em US\$ (2) }\end{array}$ & Razão entre 2 e 1 \\
\hline Brasil & 11.100 & 12.100 & 1.09 \\
\hline China & 6.900 & 9.800 & 1.42 \\
\hline Taiwan & 20.900 & 39.600 & 1.89 \\
\hline Coreia & 24.400 & 33.200 & 1.36 \\
\hline
\end{tabular}

Fonte: CIA Factbook 2013. Tabela e cálculos elaborados pelo autor.

Essas informações sugerem que há uma tendência à apreciação da taxa de câmbio brasileira. Esse desalinhamento teria efeitos negativos sobre o crescimento do produto real e atuaria no sentido de reduzir o saldo em conta corrente. 


\subsection{Desalinhamento cambial e limitação da poupança doméstica}

Vale esclarecer a maneira pela qual o câmbio afeta o setor manufatureiro e, talvez ainda mais importante, o modo pelo qual o câmbio interfere na poupança e no investimento em uma economia. No debate acadêmico brasileiro, duas correntes econômicas apresentam visões opostas a respeito desse fenômeno.

A corrente tradicional aponta que, em virtude da reduzida taxa de poupança brasileira (poupança em relação ao PIB), um crescimento econômico sustentado deve ser baseado em um acréscimo da poupança externa, via déficit em transações correntes. Segundo essa perspectiva, a poupança externa complementa a poupança interna e eleva a poupança total do país, o investimento e, daí, o crescimento econômico (FRANCO, 1998).

O Gráfico 38 permite que se interprete uma correlação negativa entre poupança doméstica brasileira e uso de poupança externa, via déficit em transações correntes. Isso fica claro, por exemplo, na segunda metade dos anos 1980, quando a poupança doméstica se eleva e a poupança externa se reduz, assim como na segunda metade dos anos 1990, quando o inverso ocorre: a poupança doméstica cai à medida que a poupança externa se eleva.

\section{GRÁFICO 38}

Taxa de poupança doméstica e uso de poupança externa, em \% do PIB (1947-2007)

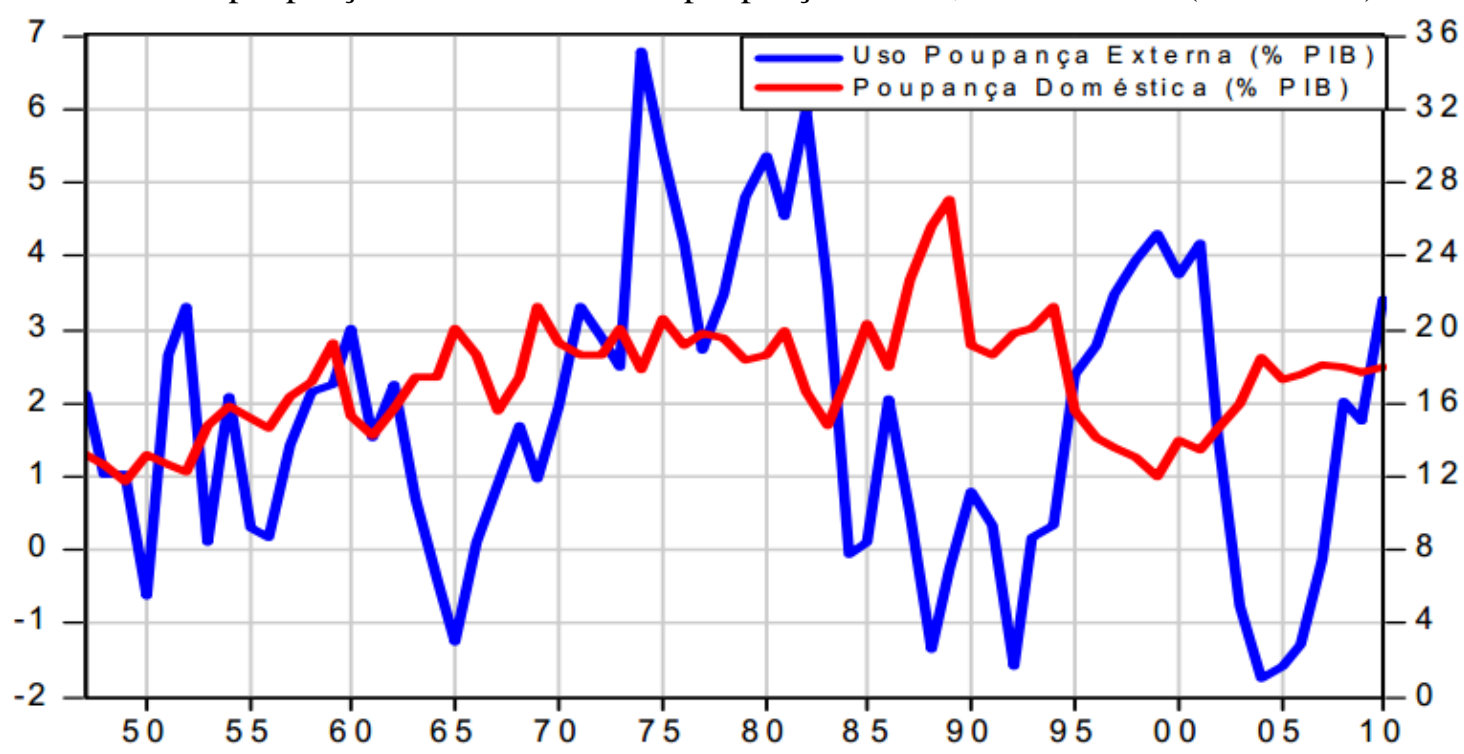

Fonte: HOLLAND, Márcio, 2014.

A segunda corrente, da qual BRESSER-PEREIRA, GALA e ARAÚJO (2010) se destacam, alega que a estratégia de crescimento com base em poupança externa provoca apreciação da taxa de câmbio. O ingresso adicional de poupança externa provoca a apreciação 
do câmbio. Do lado da oferta, isso implica o aumento artificial dos salários, seguido de aumento do consumo e redução da poupança interna. Sob a ótica da demanda, o resultado da apreciação cambial é a diminuição das oportunidades de investimento lucrativos voltados à exportação, o que reduz o investimento e a poupança interna. Nesse sentido, a poupança externa substitui e não complementa - a poupança interna.

Esse fenômeno ocorre da seguinte maneira: quanto mais apreciada for a taxa de câmbio, mais altos serão os salários reais, à medida que o preço dos bens de consumo que são comercializáveis internacionalmente baixa com a apreciação da moeda local. O consumo, por sua vez, depende dos salários e ordenados reais. Logo, o consumo se modifica na mesma direção da variação dos salários e dos ordenados. Em contrapartida, os lucros das firmas cairão, porque, pela renda, os salários aumentaram e, pela demanda, porque há menos oportunidades para exportar e investir lucrativamente (BRESSER-PEREIRA ET AL., 2010).

Conforme o modelo, uma vez que os trabalhadores recebem salário nominal e adquirem bens comercializáveis e não-comercializáveis, o custo de vida dos trabalhadores dependerá do câmbio nominal e da parcela de bens comercializáveis em sua cesta de consumo. Eventual valorização do câmbio acarretará redução do preço dos produtos comercializáveis, isto é, aumento real de salário real porquanto a cesta de produtos do trabalhador custará menos.

A taxa de lucros, por sua vez, é o inverso da taxa de salário. Aumentando-se esta, diminui-se aquele. Adicionalmente, os lucros dependem dos investimentos, que, por sua vez, além de dependerem da taxa de lucro esperada, dada a taxa de juros, dependem das exportações. A taxa de lucro esperada, os investimentos e os lucros, portanto, diminuem quando a taxa de câmbio de aprecia e as exportações caem. A diminuição dos lucros das firmas é complementar ao aumento dos salários e ordenados dos trabalhadores e da classe média profissional.

Desse modo, ainda segundo BRESSER-PEREIRA ET AL. (2010), havendo apreciação do câmbio, salários e ordenados subirão em termos reais, ao passo que lucros cairão. Adotando-se a premissa de que a propensão a consumir dos trabalhadores e da classe média é elevada, o consumo aumentará e a poupança interna diminuirá constantemente. A poupança interna é função da taxa de câmbio, e o efeito da variação da taxa de câmbio real sobre a poupança doméstica será tanto maior quanto maior for a propensão marginal a consumir.

Ainda que haja argumento favorável ao aumento real dos salários, o fato é que o aumento real por meio da apreciação cambial tende a ser artificial e não-sustentável. Os ganhos salariais de curto prazo tendem a ser perdidos no longo prazo em razão da redução do 
crescimento econômico. Inversamente, a desvalorização cambial provoca perdas reais de salário no curto prazo, mas tendência de ganhos adicionais e sustentados no longo prazo.

Pelo lado da demanda, a apreciação da moeda provocará a diminuição da poupança por meio da diminuição das oportunidades de investimentos lucrativos voltados para a exportação. A queda das expectativas de lucro provocará a diminuição dos investimentos, em consequência, da poupança interna.

Lucros, salários e ordenados, portanto, além de dependerem substancialmente do nível de produtividade da economia e de seu padrão de distribuição de renda, dependem também da taxa de câmbio. A tentativa de crescer com poupança externa tende a tornar a poupança doméstica permanentemente deprimida. Em síntese, em lugar de a poupança externa complementar a poupança doméstica, aquela tende a substituir esta (savings displacement).

\section{GRÁFICO 39}

Taxa de investimento, poupança interna e poupança externa, em \% do PIB (1990-2011)

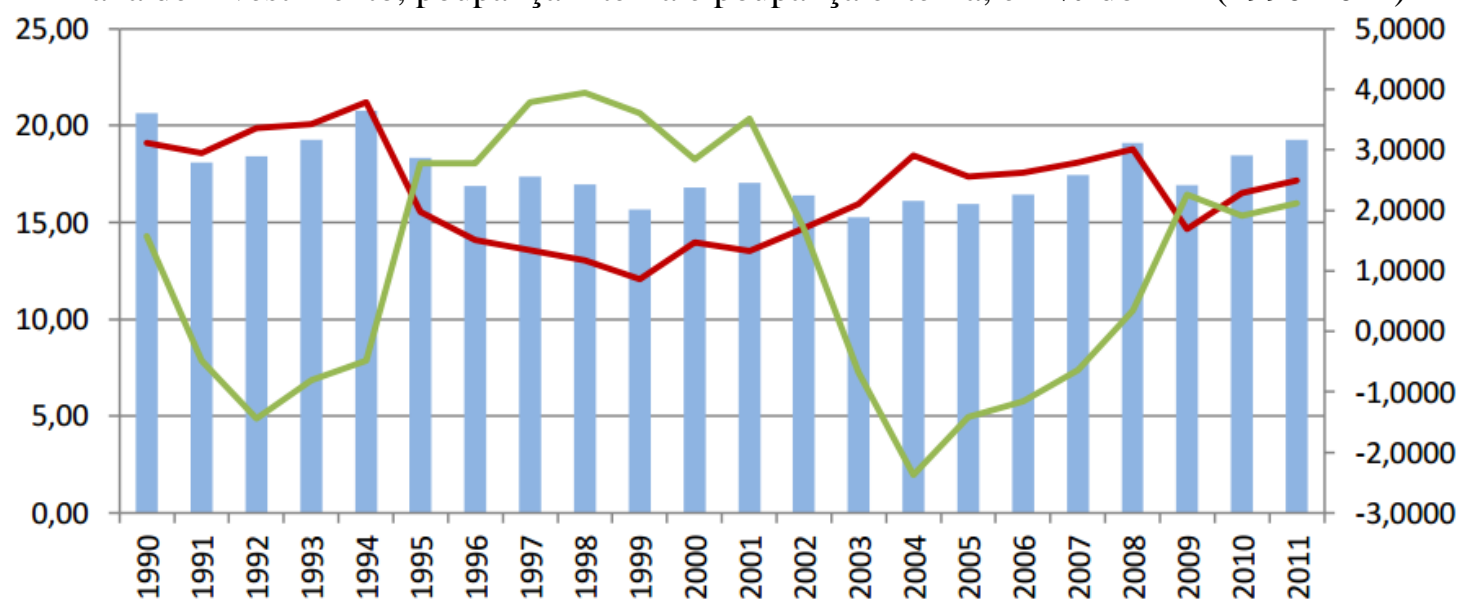

TX inv.\% do PIB $\longrightarrow$ Sint \% PIB $\longrightarrow$ S ext \% PIB

OBS.: Poupança interna e investimento no eixo vertical esquerdo e poupança externa no eixo vertical direito.

Fonte: Dados do IPEADATA e BCB, organizados por BARRETO; VELOSO; e ILHA, 2013.

Esse debate está diretamente ligado à comparação dos modelos de crescimento asiático e latinoamericano. Os que argumentam em favor do uso da poupança externa alegam que a estratégia de crescimento do leste asiático não é replicável na América Latina em razão da baixa poupança doméstica daqui, contrastada com a elevada propensão a poupar dos países asiáticos. É a poupança doméstica elevada que permitiria aos países asiáticos manter superávits pujantes nas contas externas.

Em oposição a essa avaliação, os que criticam a dependência da poupança externa invertem essa relação. Segundo BRESSER-PEREIRA ET AL. (2010), não é a propensão a poupar que explica a poupança elevada e a conta corrente superavitária dos 
asiáticos, e sim a taxa de câmbio competitiva. Ao manter taxas de câmbio depreciadas e evitar movimentos de apreciação, os asiáticos conseguem, por uma banda, reduzir o consumo agregado e aumentar a poupança interna e, pela outra banda, criar oportunidades de investimento lucrativo.

A seguir esse modelo, o nível de poupança elevado dos asiáticos residiria principalmente no câmbio depreciado, e não na propensão a poupar. De imediato, isso provoca redução dos salários reais para certo nível de produtividade, mas, no longo prazo, a medida traz crescimento mais sustentado e, com o aumento da produtividade, elevar os salários de modo sustentado. Inversamente, o que explicaria as minguadas taxas de poupança latinoamericanas, incluindo a brasileira, é a tendência à apreciação cambial decorrente principalmente da exportação de produtos primários.

É evidente que a taxa de poupança não pode ser reduzida única e exclusivamente à taxa de câmbio. Fatores como a existência de um estado de bem-estar social, a instituição de um sistema de aposentadoria e de saúde pública, a estruturação do sistema financeiro, a existência de liberdade de organização sindical própria de um regime democrático, expectativas quanto ao desempenho econômico, enfim, vários outros fatores vão colaborar na definição da taxa. Mas é consistente a correlação entre câmbio apreciado/depreciado e taxa de poupança baixa/alta.

\subsection{Desindustrialização precoce no Brasil}

“Tudo acaba, leitor; é um velho truísmo, a que se pode acrescentar que nem tudo o que dura, dura muito tempo. Esta segunda parte não acha crentes fáceis; ao contrário, a ideia de que um castelo de vento dura mais que o mesmo vento de que é feito, dificilmente se despegará da cabeça, e é bom que seja assim, para que se não perca o costume daquelas construções quase eternas." Machado de Assis

Os exemplos tradicionais de doença holandesa estão relacionados ao súbito incremento dos ingressos de exportações decorrentes da descoberta de recursos naturais, de novos campos, de novas tecnologias de extração, ou ainda de elevação repentina no preço internacional de uma commodity. No caso brasileiro, ao menos nas últimas duas décadas, é 
difícil apontar um único produto que justifique o enquadramento do país na moldura teórica clássica da doença holandesa.

BRESSER-PEREIRA, contudo, argumenta que a doença holandesa no Brasil goza da particularidade de ser caracterizada como crônica, e não aguda. Não é um único produto que provoca a elevação súbita dos ingressos de exportação, tampouco o aumento verificado é tão crítico a ponto de se tornar-se flagrantemente prejudicial ao conjunto do setor industrial. A despeito de não ser aguda, ela não deixa de ser preocupante, já que o resultado tem sido a erosão lenta, mas sistemática do setor manufatureiro do país.

Nas últimas décadas, o Brasil vivenciou a elevação substancial da quantidade exportada e dos preços de um conjunto de produtos primários (minerais e agrícolas) e, simultaneamente, o país abriu mão de parte relevante da proteção de que o país dispunha para contrabalançar a pujança de longa data de seus produtos primários. A elevação dos preços no mercado internacional se deveu principalmente à ascensão de países em desenvolvimento, em particular a economia chinesa, que elevou os preços de vários produtos primários a patamares muito acima da média histórica.

\section{GRÁFICO 40}

Preço do minério de ferro (1992-2007)

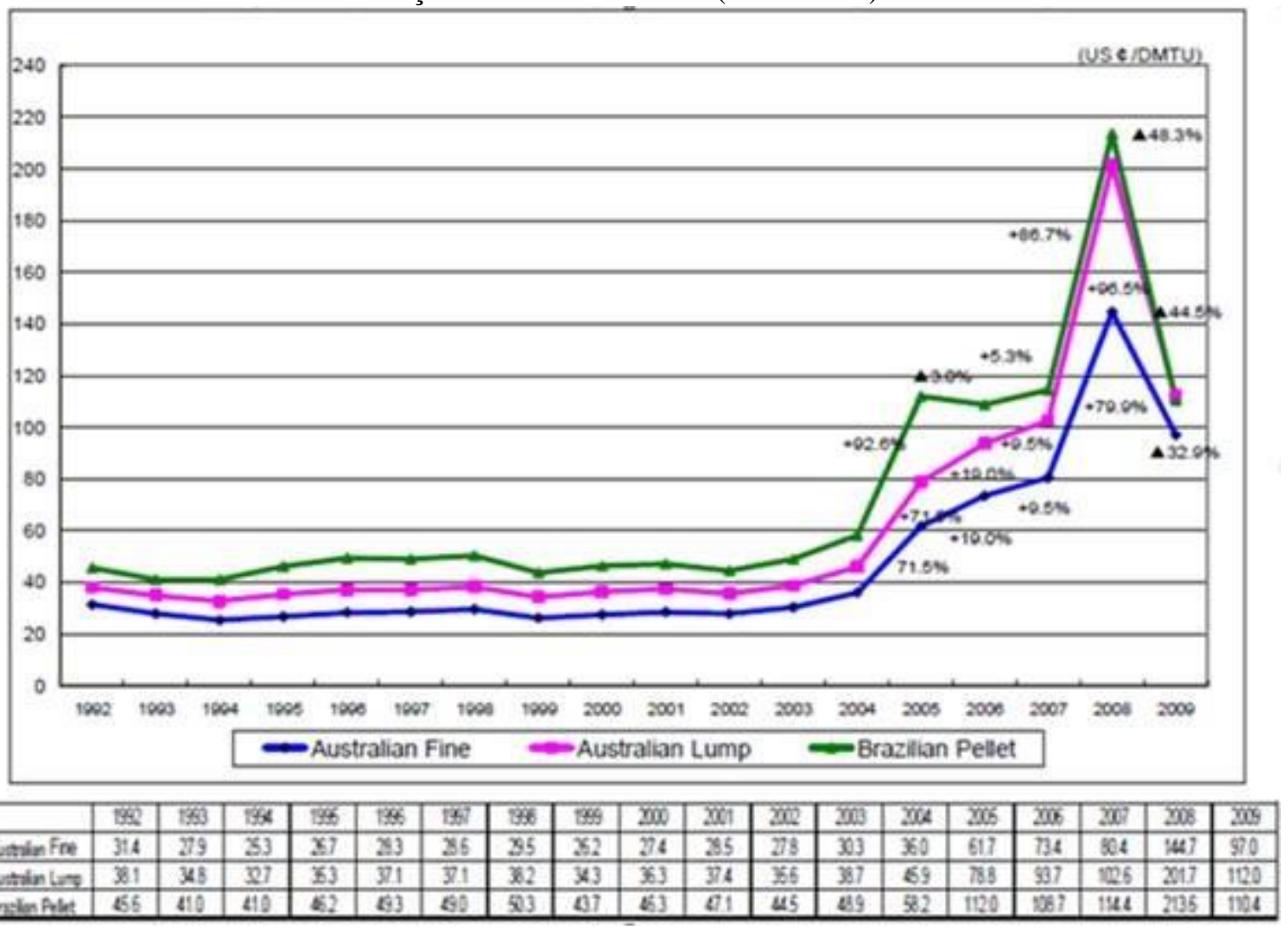

Fonte: MITSUI, citado por HEIDER, 2012 (Siderurgia e o Mercado de Minério de Ferro). 
Dentre os produtos que mais subiram, merece destaque o minério de ferro, cujos preços estão destacados no Gráfico 40. O preço de determinada quantidade de pelota do minério brasileiro passou de pouco mais de US\$ 40,00 nos anos 1990 para mais de US\$ 200,00 em 2008. As exportações brasileiras de minério de ferro saltaram, de 2002 a 2007, de aproximadamente US\$ 3 bilhões para US\$ 10 bilhões, quase três vezes o valor inicial, embora a quantidade de carga embarcada haja aumentado $72 \%$.

O aumento na cotação de commodities exportadas pelo Brasil na metade dos anos 2000 não se limitou ao minério de ferro, mas, por se tratar do principal item de exportação, optou-se por utilizá-lo como exemplo. A elevação acentuada de preços também se verificou em outros itens importantes da pauta de exportações brasileira, como o complexo de soja, carnes e açúcar, contribuindo para a valorização cambial.

Segundo dados do Ministério do Desenvolvimento, Indústria e Comércio Exterior, aumentou substancialmente a participação de algumas commodities na pauta de exportação brasileira entre 2004 e 2011: o minério de ferro passou de 5\% para 16\%, o complexo de soja de $10 \%$ para $11 \%$, o petróleo em bruto de $3 \%$ para $9 \%$, o açúcar de $3 \%$ para $6 \%$ e o complexo de carnes de $6 \%$ para $7 \%$ do total. Somados, esses cinco itens passaram de $28 \%$ para $48 \%$ das exportações brasileiras.

BRESSER-PEREIRA e MARCONI (2008) argumentam ainda que o Brasil, dos anos 1930 ao fim dos anos 1980, dispunha de uma proteção tarifária contra os efeitos da apreciação cambial. Com a abertura econômica do início dos anos 1990, essa barreira deixou de agir de maneira tão intensa.

De fato, a partir de fins dos anos 1980, impulsionado pela vaga liberalizante que ganhou força em todo o mundo, o Brasil reduziu substancialmente as alíquotas de exportações que aplicava. O movimento prosseguiu até meados dos anos 1990, quando se estabilizou em patamares bem mais baixos do que os anteriores, embora ainda acima da média dos países desenvolvidos. O Gráfico 41 resume o movimento de redução das alíquotas de importação no Brasil.

O resultado desses dois movimentos (aumento das exportações de commodities e abertura econômica) foi um influxo volumoso de dólares oriundo da exportação de produtos primários, casado com a perda da competitividade da indústria de transformação brasileira, tanto em sua capacidade de exportar, quanto em sua condição de competir com produtos importados no mercado brasileiro. À parte dos benefícios inegáveis que a abertura comercial trouxe em certas áreas, o fato é que, ao casar a abertura comercial com a valorização cambial, o impacto sobre o setor industrial foi significativo. 
GRÁFICO 41

Evolução das alíquotas nominais de importação (1983-2012)

\begin{tabular}{|l|l|r|r|r|r|r|}
\hline \multirow{2}{*}{ Ano } & \multirow{2}{*}{$\begin{array}{l}\text { No de } \\
\text { códligos }\end{array}$} & \multicolumn{5}{|c|}{ Aliquotas (\%) } \\
\cline { 3 - 7 } & Minima & Máxima & Meddia & Modal & Mediana \\
\hline 1983 & 11.004 & 0 & 105 & 47 & 30 & 46 \\
\hline 1984 & 11.106 & 0 & 105 & 47 & 30 & 45 \\
\hline 1985 & 11.289 & 0 & 105 & 51,3 & 30 & 45 \\
\hline 1986 & 11.333 & 0 & 105 & 51,3 & 30 & 45 \\
\hline 1987 & 11.516 & 0 & 105 & 51 & 30 & 45 \\
\hline 1988 & 11.516 & 0 & 85 & 41 & 40 & 40 \\
\hline 1989 & 12.444 & 0 & 85 & 35,5 & 40 & 35 \\
\hline 1990 & 12.750 & 0 & 105 & 32,2 & 40 & 30 \\
\hline 1991 & 12.763 & 0 & 85 & 25,3 & 20 & 25 \\
\hline 1992 & 12.578 & 0 & 65 & 21,15 & 20 & 20 \\
\hline 1993 & 13.117 & 0 & 55 & 16,5 & 20 & 20 \\
\hline 1994 & 12.745 & 0 & 40 & 14,38 & 20 & 20 \\
\hline 1995 & 8.803 & 0 & 70 & 11,2 & 14 & 14 \\
\hline 1996 & 9.046 & 0 & 70 & 11,13 & 14 & 14 \\
\hline 1997 & 9.212 & 0 & 63 & 13,81 & 17 & 17 \\
\hline 1998 & 9.212 & 0 & 49 & 13,81 & 17 & 17 \\
\hline 1999 & 9.234 & 0 & 35 & 13,79 & 17 & 15 \\
\hline 2000 & 9.372 & 0 & 55 & 13,8 & 17 & 17 \\
\hline 2001 & 9.414 & 0 & 55 & 12,82 & 4,5 & 14 \\
\hline 2002 & 9.626 & 0 & 55 & 11,79 & 3,5 & 13,5 \\
\hline 2003 & 9.690 & 0 & 55 & 11,52 & 3,5 & 13,5 \\
\hline 2004 & 9.750 & 0 & 55 & 11,83 & 14 & 13 \\
\hline 2005 & 9.784 & 0 & 55 & 10,73 & 14 & 12 \\
\hline 2006 & 9.811 & 0 & 35 & 10,59 & 14 & 12 \\
\hline 2007 & 9.721 & 0 & 35 & 11,46 & 14 & 12 \\
\hline 2008 & 9.767 & 0 & 35 & 11,49 & 14 & 12 \\
\hline 2009 & 9.809 & 0 & 35 & 11,49 & 14 & 12 \\
\hline 2010 & 9.866 & 0 & 35 & 11,64 & 14 & 12 \\
\hline 2011 & 9.891 & 0 & 35 & 11,65 & 14 & 12 \\
\hline 2012 & 10.028 & 0 & 35 & 11,61 & 14 & 12 \\
\hline & & & & & \\
\hline
\end{tabular}

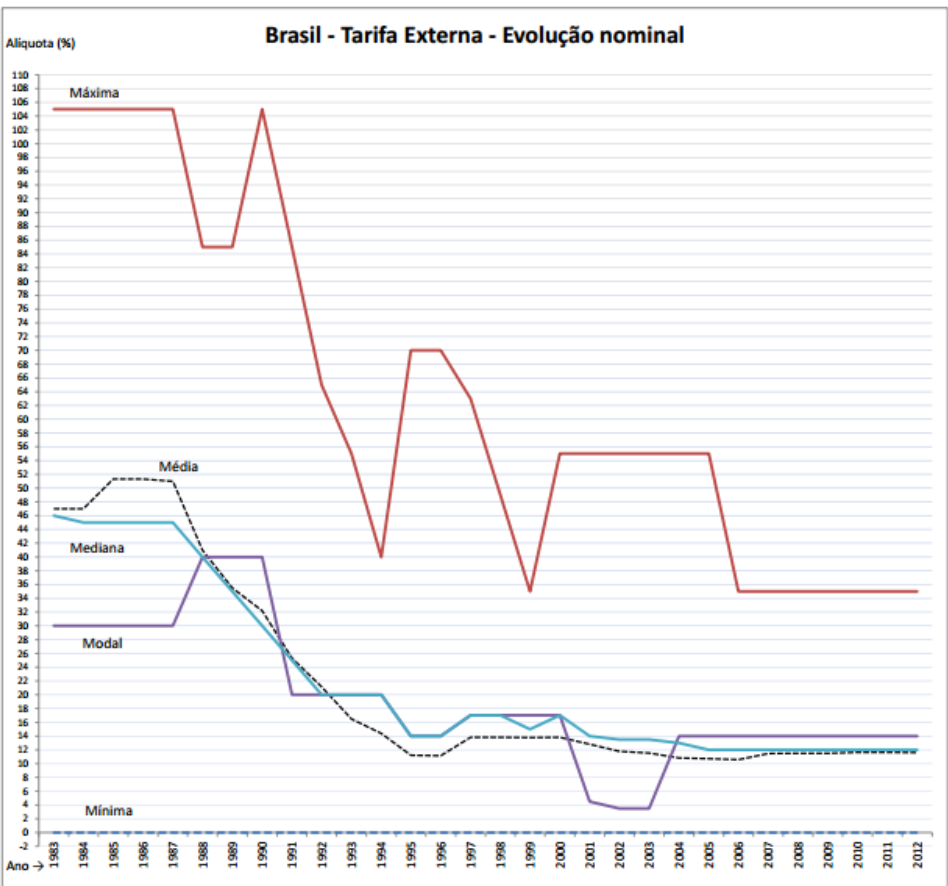

Fonte: MDIC, 2014.

Os resultados trazidos por essa valorização excessiva do câmbio estão refletidos na diminuição precoce da indústria de transformação, especialmente nos setores de alta tecnologia (com a importante exceção da Embraer e de algumas partes da cadeia produtiva do petróleo). A participação desse segmento econômico vem se reduzindo em relação ao PIB, em relação às exportações e em relação aos empregos da economia e é mais grave nos casos de maior intensidade tecnológica.

Antes de adentrar os dados sobre a redução da indústria de transformação, cabe apontar a precocidade desse fenômeno. Os países desenvolvidos, noutros tempos chamados de países industrializados, perderam a exclusividade da produção industrial para outras nações, e viram a participação do setor de serviços aumentar substancialmente em relação aos respectivos PIBs. Entretanto, essa transição pós-industrial ocorreu quando já desfrutavam de níveis de renda mais altos do que a brasileira. O Brasil é um país apenas de renda média, bem inferior à dos chamados "tigres asiáticos" e à dos países desenvolvidos, e já vivencia esse fenômeno, enquanto que os asiáticos ainda não.

No que tange à indústria de transformação brasileira, a Tabela 24 sintetiza sua evolução desde os anos 2000, discriminando a participação de cada um dos quatro setores que compõem a atividade industrial. Muito embora a participação do conjunto da indústria não tenha sofrido variação relevante, oscilando entre 25 e $30 \%$ do PIB, o segmento da indústria de 
transformação propriamente vem declinando de modo consistente a partir de 2004, quando atingiu a $19 \%$ do total. Em 2012, estava em apenas $13 \%$.

TABELA 24

Participação percentual da indústria no valor adicionado a preços básicos, 2000-2013

\begin{tabular}{|r|c|c|c|c|c|c|c|}
\hline & $\mathbf{2 0 0 0}$ & $\mathbf{2 0 0 2}$ & $\mathbf{2 0 0 4}$ & $\mathbf{2 0 0 6}$ & $\mathbf{2 0 0 8}$ & $\mathbf{2 0 1 0}$ & $\mathbf{2 0 1 2}$ \\
\hline INDÚSTRIA & 27,7 & 27,1 & 30,1 & 28,8 & 27,9 & 28,1 & 26,0 \\
\hline Extrativa Mineral & 1,6 & 1,6 & 1,9 & 2,9 & 3,2 & 3,0 & 4,3 \\
\hline Transformação & $\mathbf{1 7 , 2}$ & $\mathbf{1 6 , 9}$ & $\mathbf{1 9 , 2}$ & $\mathbf{1 7 , 4}$ & $\mathbf{1 6 , 6}$ & $\mathbf{1 6 , 2}$ & $\mathbf{1 3 , 0}$ \\
\hline Construção Civil & 5,5 & 5,3 & 5,1 & 4,7 & 4,9 & 5,7 & 5,7 \\
\hline $\begin{array}{c}\text { Eletricidade, gás, água, } \\
\text { esgoto e limp. urb. }\end{array}$ & 3,4 & 3,3 & 3,9 & 3,8 & 3,1 & 3,2 & 3,1 \\
\hline
\end{tabular}

Fonte: IBGE, 2014.

Veja-se que o breve período de elevação, justamente no início da década, coincide com o período de desvalorização cambial brasileira. Em seguida, consolidada a apreciação cambial, a participação vem se reduzindo sistematicamente.

Além disso, verifica-se crescente "hedge produtivo", termo ligado à estratégia empresarial de redução de custos de produção pelo exportador por meio da importação crescente de insumos. Desse modo, eventual valorização do câmbio implica redução dos custos operacionais (insumos importados), compensando em parte a perda da receita das exportações. O resultado é a crescente participação de insumos importados, desmontando cadeias produtivas existentes e evitando a formação de novas na maioria dos setores, ainda que não em todos (MARCONI e BARBI, 2011).

No setor de energia renovável, a participação de insumos importados é estratégia adotada por praticamente todas as empresas instaladas no país, conforme abordamos nos capítulos anteriores da tese. Boa parte dos equipamentos são importados e, nos que têm fabricação nacional, há dificuldades para atingir as metas para o cumprimento dos requisitos de conteúdo nacional, como ocorre na indústria eólica.

Pode-se dizer, assim, que há indícios relevantes de que o Brasil não se enquadra na definição tradicional da doença holandesa, por se enquadrar num modelo crônico, e não agudo. O impacto sobre a indústria nacional decorrente da abundância de recursos naturais não se baseia em uma única commodity, mas num conjunto delas (minério de ferro, soja, entre outros). A sobreapreciação cambial não foi súbita e intensa, mas sim gradativa e duradoura.

No caso brasileiro, não se verificou uma desorganização profunda do sistema político (tais como queda de regime, fragilização de instituições ou disputa violenta pelo poder), tampouco se inviabilizou a arrecadação tributária. No que tange a esta, entretanto, os royalties do petróleo do pré-sal, como se verá adiante, tornaram-se objeto de grande disputa 
política, reforçando a ideia de “no-man's money”, e não a ideia de recurso tributário arrecadado a partir de esforço comum.

O resultado desse cenário, no caso brasileiro, tem sido a redução substancial da participação do setor da indústria de transformação no PIB - e mais ainda das atividades de inovação, que depende largamente da atividade industrial.

\subsection{Mitigação do desalinhamento cambial}

É curioso notar que o período de apreciação excessiva da taxa de câmbio brasileira coincide com o aumento acentuado do preço do minério de ferro, um dos principais produtos de exportação brasileiros, revelado no Gráfico 40.

$\mathrm{Na}$ Coreia, Taiwan e China, não há recursos naturais abundantes para exportação. Na China há grande disponibilidade de carvão, mas ainda assim insuficiente para abastecer o robusto mercado interno - especialmente em função de obstáculos logísticas que tornam mais caro utilizar carvão de regiões remotas do oeste do país do que importar o produto da Austrália. Esses países, portanto, importam boa parte das fontes de energia, mas conseguem custeá-las com a exportação crescente de produtos manufaturados, e não de produtos primários.

Vale ainda notar que a exportação de manufatura pelos países asiáticos tenderia também a apreciar o câmbio (ainda que a apreciação cambial decorrente de manufaturas eficientes seja menos preocupante do que a apreciação proveniente da exportação de produtos primários, que não agregam muito valor, nem geram muitos empregos). Mas a moeda desses países, apesar do viés exportador, é intencionalmente desvalorizada pelo Estado, que consegue ou conseguiu no passado controlar ou limitar movimentos de valorização.

A explicação para esse descasamento está no fato de que eles são grandes compradores de reservas internacionais, evitando que o excesso de dólares ingressante na economia encareça sua moeda e prejudique as indústrias exportadoras no longo prazo. A Coreia do Sul e Taiwan, por exemplo, a despeito dos PIB's bem inferiores ao brasileiro, têm reservas internacionais de porte equivalente. Já a China, com o PIB bem superior ao brasileiro, tem reservas bem maiores, em valores absolutos ou relativos.

O Brasil iniciou esforços tímidos para mitigar os efeitos da doença holandesa a partir da aquisição crescente de reservas internacionais, especialmente depois de 2006. Mais 
recentemente, foi instituído um fundo soberano, com o propósito de gerenciar parte dos valores que seriam mantidos no exterior, de modo a evitar a apreciação da moeda local. Mas a aplicação de recursos nesse fundo foi bem inferior à cogitada inicialmente, não havendo impacto significativo no enxugamento de dólares no mercado brasileiro.

TABELA 25

Reservas internacionais, agosto de 2013

\begin{tabular}{|l|c|c|}
\hline & $\begin{array}{c}\text { Reservas internacionais } \\
\text { (em US\$ bilhões) }\end{array}$ & Reservas/PIB \\
\hline Brasil & 367 & $15 \%$ \\
\hline China & 3.557 & $43,2 \%$ \\
\hline Taiwan & 411 & $85 \%$ \\
\hline Coreia do Sul & 329 & $28,5 \%$ \\
\hline
\end{tabular}

Fonte: Elaboração própria.

Nas discussões sobre o que fazer com a renda oriunda da exploração do pré-sal, novamente o tema voltou à tona. Como se verá mais detalhadamente à frente, acabou sendo substancialmente desfigurada no Congresso Nacional a proposta inicialmente apresentada pelo governo de criar um Fundo Social para manter os recursos no exterior e investir no Brasil apenas os rendimentos do fundo. O texto final aprovado prevê a aplicação diretamente dos recursos oriundos da exploração petrolífera, e não os rendimentos desses valores.

A questão central, portanto, é que a abundância de recursos naturais (sejam minerais ou agrícolas) pode provocar especialização da estrutura produtiva, tornando as exportações do país concentradas em commodities em relação às quais possui vantagens comparativas. Essa especialização da produção traria consigo a determinação da taxa de câmbio em níveis inferiores àqueles necessários para a viabilização da atividade industrial (câmbio apreciado), já que a manufatura não conta com vantagens correspondentes de custos e demanda um câmbio mais competitivo para manter a rentabilidade. Esse desalinhamento pode provocar um obstáculo à industrialização, ou, em casos de países já industrializados, um processo de desindustrialização precoce, consistente na perda de participação da indústria de transformação na geração de produto e de emprego.

Por isso, aponta-se que a consequência não-pretendida da abundância de recursos naturais pode ser não o crescimento econômico de longo prazo, mas, pelo contrário, a redução das taxas de crescimento no longo prazo em razão da redução ou do desmantelamento da estrutura produtiva da indústria doméstica. 


\subsection{A descoberta de petróleo no pré-sal}

"Dentro de diez años, dentro de veinte años, lo verán:

el petróleo nos traerá la ruina...

El petróleo es el excremento del diablo." Juan Pablo Pérez Alfonzo, ex-Ministro de

Hidrocarbonetos da Venezuela e um dos fundadores da OPEP

"The Kingdom of Heaven runs on righteousness, but the Kingdom of Earth runs on oil!"

Ernest Bevin, ex-Secretário de Assuntos Exteriores do Reino Unido

O Brasil ampliou substancialmente sua produção de petróleo depois da mudança do marco legal brasileiro nos anos 1990, com o fim do monopólio estatal (Emenda Constitucional no -9, de 1995) e a instituição do regime de concessão (Lei no 9.478, de 1997). A produção diária passou da faixa de 700 mil barris por dia em 1995 para cerca de 1,7 milhão uma década depois. A maior parte dessa produção era realizada em mar, com menos de $20 \%$ do total produzido em terra.

Em 2007, o governo brasileiro anunciou a descoberta de uma nova fronteira de exploração petrolífera, localizada em áreas ultraprofundas denominadas de pré-sal. As estimativas para o montante total de petróleo recuperável nessa região variam bastante em razão da insuficiência de informações geológicas, mas provavelmente lançariam o Brasil entre os maiores produtores mundiais de petróleo.

Vale notar que o Brasil já dispõe de uma produção significativa de petróleo $\left(11^{\circ}\right.$ maior produtor mundial, com 2,7 milhões de barris/dia) e uma reserva relevante do produto ( $15^{\circ}$ maior reserva mundial, com 13,2 bilhões de barris). Contudo, como também consome domesticamente quantidades elevadas de petróleo ( $6^{\circ}$ maior consumidor, com 3,0 milhões de barris/dia), não há saldo líquido para exportação - em verdade, depois de oscilar em torno da autossuficiência líquida entre 2006 e 2010, o país voltou a importar mais petróleo do que exporta (informações da US Energy Information Administration sobre 2013). Essa retomada da importação líquida se deveu em boa parte ao grande aumento do consumo, relacionados aos subsídios à gasolina e aos automóveis entre 2009 e 2014, juntamente com a redução no ritmo de aumento da produção doméstica.

Os novos campos no pré-sal sugerem que as reservas brasileiras podem se elevar acentuadamente em relação às reconhecidas. O primeiro campo já leiloado pelo modelo de 
partilha de produção - o de Libra, em outubro de 2013 -, tem reservas recuperáveis estimadas entre 8 e 12 bilhões de barris, praticamente dobrando as atuais reservas brasileiras em um único campo. Em novembro de 2013 a Petrobras anunciou a descoberta do campo de Franco, que pode ter reservas recuperáveis ainda superiores às de Libra. Em maio de 2014, também se anunciou o campo de Entorno de Iara, com potencialmente 5 bilhões de barris recuperáveis. Em se confirmando esses e outros novos campos, o pré-sal colocaria as reservas brasileiras do hidrocarboneto entre as 10 maiores do mundo.

Em seguida ao anúncio da descoberta do pré-sal, em 2007, o governo federal apresentou propostas legislativas para modificar o regime jurídico que disciplina a exploração do petróleo no território brasileiro: em lugar do modelo de concessão (que continua em vigor para as áreas já licitadas do pré-sal e para outras regiões do território), estabeleceu-se o regime de partilha de produção e definiu a Petrobras como única operadora dos campos (Lei no 12.351, de 2010).

Sinteticamente, assumindo que o risco exploratório nessa área é menor, a mudança de modelo transfere a propriedade do óleo resultante da exploração para uma empresa pública federal (Pré-Sal Petróleo S/A - PPSA), altera as alíquotas dos royalties e permite que o poder público dite o ritmo da exploração dos campos. A ideia subjacente é que, por se tratar de produto estratégico, cabe ao poder público definir a velocidade da exploração, atenuando os efeitos de uma exploração acelerada, seguida de esgotamento rápido dos campos.

Para esta tese, porém, mais relevante do que o regime de exploração do petróleo é o regime de aplicação e divisão de suas rendas. A divisão dos royalties do petróleo foi objeto de intenso debate nacional. Qual parcela caberia aos chamados "Estados-produtores" e qual parcela seria destinada às áreas de educação, saúde, meio ambiente e outras?

A proposta inicial determinava que parte relevante da receita seria destinada a um Fundo Social. Suas receitas seriam majoritariamente aplicadas no exterior, para mitigar o impacto sobre a economia das flutuações do preço do petróleo, evitar a sobreapreciação do câmbio e garantir uma poupança pública de longo prazo para a economia nacional. Os rendimentos desse fundo seriam internalizados para aplicação exclusiva em algumas áreas que se relacionariam diretamente com o aumento da produtividade sistêmica da economia, tais como educação, ciência e tecnologia, além de meio ambiente e combate à pobreza. Ainda assim, a proposta resguardava parcela significativa dos fundos para aplicação direta por Estados e municípios, que ficariam autorizados a investir os recursos (e não seus rendimentos) com algumas poucas limitações. 
Durante a tramitação no Congresso, a disputa entre os setores contemplados pela proposta foi a extremos, resultando em veto e judicialização da matéria (Ação Direta de Inconstitucionalidade no 4917). O resultado legislativo final, ainda pendente de julgamento no Supremo Tribunal Federal, destina a maior parte dos recursos para Estados e municípios, embora determine que os valores serão aplicados exclusivamente em educação (75\%) e saúde (25\%). A parcela da União, de apenas $22 \%$, também ficou limitada a essas duas áreas, mas os recursos devem ser aplicados majoritariamente de imediato, em lugar de ficarem investidos em um fundo no exterior.

Esse regramento final pode agravar substancialmente a doença holandesa crônica vivenciada pelo Brasil. Caso a exploração de petróleo de fato venha a ocorrer no ritmo inicialmente previsto (deixando de lado as restrições que o regime internacional de mudança climática pode ocasionar), as receitas com a exploração de petróleo e as rendas oriundas de sua exportação podem voltar a provocar uma sobreapreciação ainda mais forte da moeda brasileira.

Dadas as dimensões do horizonte geológico do pré-sal e as perspectivas de figurar entre as dez maiores reservas globais, as rendas daí oriundas podem provocar impacto substancial na economia brasileira.

Além da sobreapreciação cambial, pode tornar-se mais nítido o fenômeno da atração de mão-de-obra qualificada para o segmento do petróleo. Pesquisas de salário médio realizadas por publicações como a EXAME já indicam que os salários no setor para engenheiros são superiores aos de profissionais com qualificação e experiência equivalente em outros setores econômicos (Tabela de Salários da Exame). Mas as diferenças não são ainda tão pronunciadas como podem vir a tornar-se.

Veja-se, a título exemplificativo, que o salário médio de um diretor de operações no setor de óleo e gás, com mais de dez anos de experiência e em empresa de grande porte, oscila entre R\$ 38 mil e R \$ 68 mil. Já um diretor de operações na área industrial, com experiência similar, tem salário médio entre $\mathrm{R} \$ 25$ mil e $\mathrm{R} \$ 45$ mil. Diferença equivalente também se verifica no caso de engenheiro de projetos nesses dois setores, ainda segundo a mesma Tabela de Salários da Exame.

Some-se que a renda adicional do petróleo, embora não deva afetar a carga tributária usual já incorporada pela sociedade brasileira, tende a provocar desequilíbrios nos entes federativos de menor porte, especialmente em municípios. As flutuações de ingressos públicos pode provocar mudanças bruscas na qualidade dos serviços públicos, além de já ser possível verificar em vários municípios deficiência de governança para gerenciar volumes tão expressivos de recursos. 
Mais preocupante ainda é a perspectiva de criação de uma imensa infraestrutura e uma forte especialização em um setor econômico que pode vir a perder força no caso de fortalecer-se o regime internacional de mudança climática.

Seja por meio de um acordo internacional que estipule metas de redução de carbono ou preço sobre sua emissão, seja ainda por meio do regime de natureza bottom-up que vem paulatinamente se formando, é razoável assumir que alguma limitação às emissões de gases estufa será adotada. Nesse cenário, não apenas o preço do petróleo pode ser afetado, prejudicando a rentabilidade desses projetos, como também boa parte das reservas já reconhecidas - no Brasil e no mundo - podem tornar-se "inqueimáveis", como já apontamos no Capítulo 4.

Nesse caso, o redirecionamento dos esforços brasileiros para o setor de petróleo a partir de 2007, reduzindo o destaque que o setor de etanol vinha recebendo, prenuncia uma especialização da economia em uma área que pode não viabilizar-se na amplitude esperada no longo prazo.

O etanol vinha obtendo espaço significativo não apenas nas vendas de combustível no Brasil, como também na agenda política nacional. O tema passou a ocupar a agenda da política externa brasileira, propagandeado como uma opção para ampliar a autonomia energética de outros países e reduzir a queima de combustíveis fósseis.

No entanto, depois da descoberta do pré-sal, o etanol perdeu a centralidade que vinha ocupando, embora nem toda a perda de espaço se deva à priorização do pré-sal. De fato, parte do problema do setor se deveu ao desalinhamento do preço internacional do petróleo com a gasolina vendida domesticamente, mas esse descasamento estava mais associado ao controle da inflação do que à priorização do petróleo. Mas é fato que se aplicou uma quantidade significativa de esforços políticos e mesmo de aporte de capital no setor de petróleo, com destaque especial para a volumosa capitalização da Petrobras ocorrida em 2010, com os contratos chamados de cessão onerosa.

Em outras palavras, se houver um endurecimento do regime internacional contra a mudança climática, a rentabilidade dos projetos no pré-sal pode cair substancialmente ou até mesmo tornar-se negativa, inviabilizando alguns deles. De outro lado, se o regime internacional sobre mudança climática continuar brando, o Brasil corre risco de ver agravado o problema da doença holandesa, em particular por conta da sobreapreciação cambial e da atração dos melhores quadros para esse setor econômico.

No segundo semestre de 2014, houve uma mudança relevante no cenário do petróleo em razão da queda acentuada dos preços internacionais do produto. Depois de se 
estabilizar por um período longo acima de US\$ 100,00, o preço do barril caiu praticamente à metade. Além de reduzir a rentabilidade de cada campo explorado, ainda não se sabe exatamente qual o ponto limite (break-even) para tornar viável a exploração dos campos do pré-sal.

Outro fator que provocou impacto relevante nas ações da Petrobras foi a operação da Polícia Federal denominada de Lava Jato, que resultou na prisão de vários exdirigentes da empresa, além de executivos de algumas das principais empresas fornecedoras da companhia. A troca da direção, a queda brutal das ações e o rebaixamento da dívida da empresa afetaram seus planos de investimentos, que foram revisados a menor, postergados ou até cancelados. Ainda não está claro quanto isso impactará no ritmo de expansão da produção no pré-sal.

Por fim, no que tange especificamente à moeda brasileira, houve uma vigorosa desvalorização no início de 2015 , que poderia corrigir em parte a apreciação excessiva dos anos anteriores. Apontam-se como fatores determinantes a queda no preço das principais commodities, as dúvidas sobre o cumprimento das metas fiscais, a desaceleração da economia nacional, a crise política vivenciada pelo governo e até mesmo os riscos de falta de energia e de água.

Ocorre que parcela significativa da desvalorização atual está relacionada, em verdade, à apreciação do dólar em razão dos sinais de retomada do crescimento econômico nos Estados Unidos. Quando se compara o real a uma cesta de moedas - e não apenas ao dólar -, a mudança de preços relativos não é tão acentuada, embora o real venha revelando uma volatilidade maior do que as demais moedas, de modo que se desvalorizou mais do que as outras em relação ao dólar.

Esse cenário conjuntural de depreciação do real, contudo, não afasta o quadro de doença holandesa crônica no Brasil. Afinal, parte da depreciação atual está justamente relacionada à queda significativa de algumas das principais commodities exportadas pelo país, dentre as quais o minério de ferro. Essa perda temporária de valor da moeda apenas reflete o ciclo de baixa que também é intrínseco à doença holandesa.

O que se pretende destacar é que, aliado aos efeitos de doença holandesa crônica decorrente da elevada participação de commodities na pauta exportadora brasileira, o pré-sal pode vir a agravar a situação. Caso a produção de petróleo nessa camada geológica atinja realmente os patamares previstos, o Brasil passará a ser exportador líquido em larga escala de petróleo, que, conjugado com as demais commodities, pode fragilizar fortemente a participação da indústria de transformação brasileira. 
Mais preocupante ainda é que a estrutura já criada para o setor de petróleo vem absorvendo capitais e mão-de-obra de outros setores, inclusive da biomassa. Uma vez que o hidrocarboneto tende a perder espaço no longo prazo em razão do regime de mudança climática, os investimentos nesse campo tendem a gerar se tornar obsoletos ou menos rentáveis.

Em síntese, há fortes sinais de que a indústria de transformação no Brasil vivenciou a partir dos anos 1990, e agravado nos anos 2000, um problema crônico de apreciação cambial relacionado à exportação de produtos primários não-beneficiados. As vendas externas desses produtos contribuíram para o processo de perda de competitividade da indústria nacional.

Nos países asiáticos examinados, diferentemente, não há exportações líquidas relevantes de produtos primários. A pauta exportadora é formada principalmente por itens manufaturados. Ainda assim, esses países adotam medidas que minimizam a valorização de suas moedas, como a compra de volumosas reservas internacionais e, no caso da Coreia, a restrição a investimentos estrangeiros diretos.

Além do efeito sobre o câmbio, a abundância de recursos naturais, inclusive energéticos, também possui efeito acomodatício. Com amplas reservas de petróleo, terras aráveis para biomassa e potencial hidráulico ainda inexplorado, as autoridades brasileiras também não se sentem compelidas a desenvolver novas fontes de energia, diferentemente dos países asiáticos. A abundância desses recursos energéticos oferece uma aparente segurança para o setor, ainda que a crise hidrológica tenha afetado o setor energético nos últimos anos e tenha levantado algumas incertezas sobre a segurança dessa fonte no longo prazo.

Como resultado desses processos, não bastasse o histórico industrial de aprendizado passivo no Brasil, as indústrias locais enfrentaram esse obstáculo adicional para disputar mercados mais intensivos em tecnologia, além de haver comparativamente pouco incentivo ao desenvolvimento de tecnologias para fontes de baixo carbono. Já os países asiáticos, fortalecidos pelo processo de aprendizado tecnológico ativo, puderam se aproveitar de uma moeda consistentemente depreciada para alavancar o setor de manufatura, inclusive nas áreas mais intensivas em tecnologia. Somaram ainda o esforço local para o desenvolvimento de tecnologias com novas fontes. 


\section{CAPÍTULO 8 \\ MODERNIZAÇÃO INDUSTRIAL DEPENDENTE E AUTONOMISTA NO SETOR DE ENERGIA}

\subsection{Síntese dos principais indicadores de energia renovável nos países selecionados}

Examinamos, nos Capítulos antecedentes, o processo em curso para formação de um regime de mudança climática e a consolidação do novo regime internacional de propriedade industrial. Também examinamos alguns processos de industrialização tardia e as políticas públicas associadas a esse movimento. Em seguida, discutimos a relação do setor energético com o tema das mudanças climáticas e a necessidade de adotar políticas públicas para enfrentar a falha de mercado existente. Passamos, depois, pelas políticas adotadas pelos quatro países examinados e os resultados alcançados.

Este tópico se dedicará à comparação da situação corrente desses países, com foco especial em inovação. Pretendemos fazer um balanço em termos de geração de energia, manufatura local, patentes e publicações científicas, de modo a relacionar os dados atuais à luz dos Capítulos anteriores.

Em relação às atividades de inovação, um indicador consistente é o número de patentes registradas no escritório de patentes dos Estados Unidos - USPTO (United States Patents and Trademark Office). A relevância do indicador estadunidense é que, como cada patente tem validade apenas no âmbito nacional, eventuais tecnologias de maior relevo tendem a ser patenteadas no escritório de propriedade industrial da maior economia do mundo. Assim, inovação importantes realizadas em qualquer dos países examinados provavelmente estarão refletidas em pedidos de patentes nos Estados Unidos.

Optamos, nessa análise, por discriminar algumas das principais tecnologias relacionadas às atividades de baixo carbono, não limitando a tabela apenas às fontes primárias de energia. Os dados estão consolidados nas Tabelas 26 e 27.

É flagrante a discrepância entre o total de patentes de origem brasileira e as obtidas por residentes nos demais países examinados. Mesmo a China, que tem o segundo número mais baixo, tem mais de cinco vezes o total brasileiro. As patentes brasileiras estão concentradas na área de biocombustíveis, com $75 \%$ do total, ilustrando como o êxito brasileiro 
está limitado a essa fonte, a despeito das dificuldades por que o setor passou nos últimos anos. $\mathrm{Na}$ área solar e em células de combustíveis os brasileiros não têm nenhuma patente registrada nos Estados Unidos.

TABELA 26

Patentes concedidas pelo UPSTO por residência do beneficiário, 2002-2013

\begin{tabular}{|l|c|c|c|c|c|c|c|c|c|c|}
\hline & Hidro & $\begin{array}{c}\text { Bio- } \\
\text { massa }\end{array}$ & Eólica & Solar & $\begin{array}{c}\text { Oceâ- } \\
\text { nica }\end{array}$ & $\begin{array}{c}\text { Geotér } \\
- \text {-mica }\end{array}$ & $\begin{array}{c}\text { Células } \\
\text { de } \\
\text { combus- } \\
\text { tível }\end{array}$ & $\begin{array}{c}\text { Veículo } \\
\text { elétrico } \\
\text { híbrido }\end{array}$ & $\begin{array}{c}\text { Ou- } \\
\text { tras }\end{array}$ & Total \\
\hline BRASIL & 1 & 12 & 2 & 0 & 0 & 0 & 0 & 1 & 0 & $\mathbf{1 6}$ \\
\hline CHINA & 0 & 3 & 20 & 35 & 4 & 1 & 15 & 16 & 3 & $\mathbf{9 1}$ \\
\hline COREIA & 1 & 4 & 22 & 139 & 2 & 0 & 574 & 108 & 0 & $\mathbf{8 4 0}$ \\
\hline TAIWAN & 3 & 2 & 47 & 185 & 11 & 0 & 127 & 14 & 8 & $\mathbf{3 8 9}$ \\
\hline
\end{tabular}

OBS.: A coluna com o total pode não corresponder exatamente à soma das colunas das tecnologias, porque algumas patentes são classificadas em mais de uma categoria, mas não se faz dupla contagem na definição do total.

Fonte: Dados do USPTO, organizados por Heslin Rothenberg Farley \& Mesiti P.C., consolidados a pedido do autor, 2013.

Conforme já examinado anteriormente, a hidroeletricidade não tem sido objeto de grandes investimentos em inovações, uma vez que se trata de tecnologia madura. Daí o reduzido número de patentes na área em todos os países (embora, mesmo aí, Taiwan detenha mais patentes do que o Brasil).

A energia solar, as células de combustíveis e - em menor medida - a eólica concentram o grosso dos investimentos tecnológicos, com números bastante elevados de patentes por parte da Coreia e de Taiwan. Esses países são favorecidos pelo fato de terem indústria de semicondutores bem estruturada, o que facilita a busca por novas aplicações do silício, mesmo material utilizado nos paineis solares.

Outro dado interessante é a evolução do número total de patentes ao longo dos anos, observado na Tabela 26 e no Gráfico 42. Nesse indicador estão consolidadas todas as tecnologias limpas enumeradas na Tabela 26. Há evolução anual do número total de patentes em todos os países examinados.

A evolução no Brasil é quase insignificante, quase se confundindo com o eixo ' $\mathrm{x}$ ' do gráfico. Ela contrasta com os passos acelerados verificados nos outros países. Percebese uma inequívoca aceleração da atividade de patenteamento nos países asiáticos no final da década de 2000, resultado da definição de uma política mais clara em favor do desenvolvimento de tecnologias limpas. 


\section{GRÁFICO 42}

Evolução das patentes de tecnologias limpas concedidas pelo UPSTO, por residência do beneficiário, 2002-2013

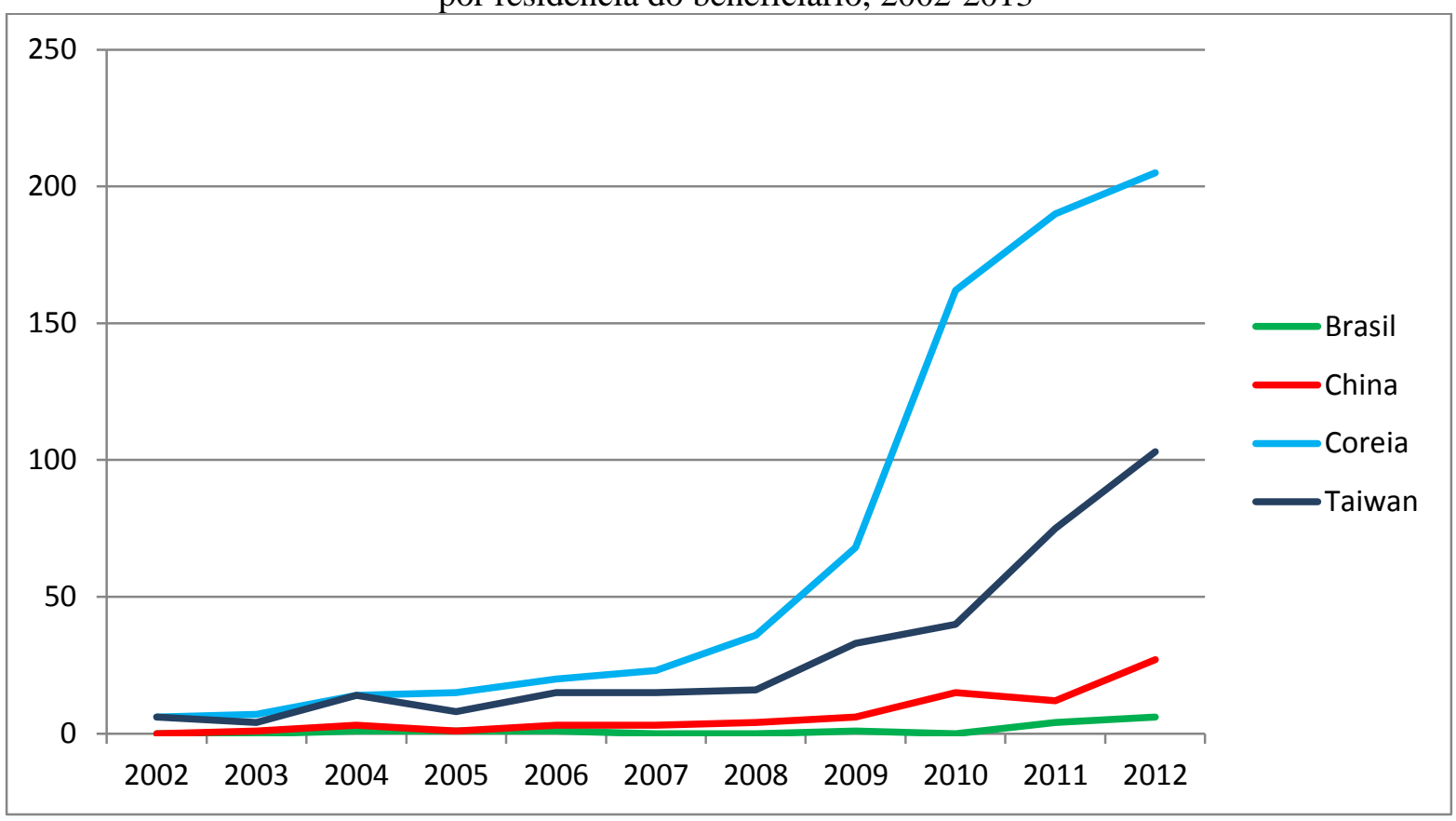

TABELA 27

Evolução das patentes de tecnologias limpas concedidas pelo USPTO, por residência do beneficiário, 2002-2013

\begin{tabular}{|l|c|c|c|c|c|c|c|c|c|c|c|c|c|}
\hline & 2002 & 2003 & 2004 & 2005 & 2006 & 2007 & 2008 & 2009 & 2010 & 2011 & 2012 & 2013 & Total \\
\hline BRA & 0 & 0 & 1 & 1 & 1 & 0 & 0 & 1 & 0 & 4 & 6 & 2 & $\mathbf{1 6}$ \\
\hline CHI & 0 & 1 & 3 & 1 & 3 & 3 & 4 & 6 & 15 & 12 & 27 & 16 & $\mathbf{9 1}$ \\
\hline COR & 6 & 7 & 14 & 15 & 20 & 23 & 36 & 68 & 162 & 190 & 205 & 94 & $\mathbf{8 4 0}$ \\
\hline TWN & 6 & 4 & 14 & 8 & 15 & 15 & 16 & 33 & 40 & 75 & 103 & 60 & $\mathbf{3 8 9}$ \\
\hline
\end{tabular}

Fonte: Dados do USPTO, organizados por Heslin Rothenberg Farley \& Mesiti P.C., consolidados a pedido do autor, 2013.

Vale ainda notar que, utilizando dados de 2013 também do USPTO, num ranking global de patentes de tecnologia limpa, a Coreia figura em $4^{\circ}$ lugar e Taiwan em $5^{\circ}$, atrás apenas de Estados Unidos, Japão e Alemanha. A China fica um pouco mais atrás, na $8^{\text {a }}$ colocação, depois de Dinamarca e França, mas já à frente de Canadá, Reino Unido e Espanha.

Esses dados pouco alvissareiros em relação à inovação de baixo carbono no Brasil estão em linha com outras maneiras de calcular patentes - mesmo considerando os registros nacionais. Muito embora o INPI não forneça os dados desagregados por fonte energética, é possível inferir a baixa intensidade de inovação brasileira na área por meio de dados brutos.

Para tanto, optamos por examinar o total de patentes de invenção concedidas pelo INPI em dois campos tecnológicos, denominados de "engenharia mecânica: motores, 
bombas, turbinas" e também de "engenharia elétrica: aparatos eletrônicos, engenharia eletrônica e energia elétrica".

No primeiro caso, o total de patentes registradas por residentes no Brasil entre 2008-2012 foi de 76, ao passo que os não-residentes registraram no país 1.016. No segundo caso, os residentes no Brasil chegaram a 68, mas os não-residentes alcançam 682. A diferença é clara e revela que mesmo as patentes registradas no Brasil são majoritariamente concebidas no exterior (mais de $90 \%$ do total) (INPI, 2013).

\section{GRÁFICO 43}

Investimentos em $\mathrm{P} \& \mathrm{D}$ por proporção do PIB Research and development expenditure (\% of GDP)

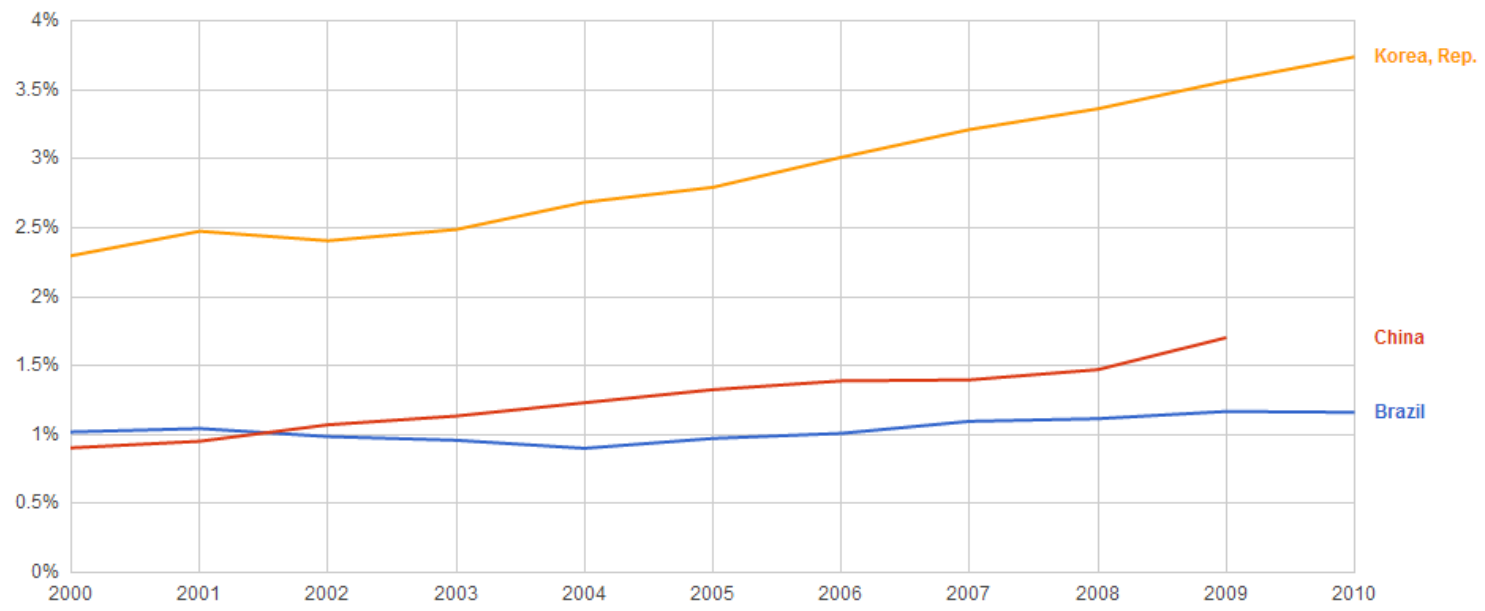

GRÁFICO 44

Pesquisadores em P\&D por milhão de pessoas Researchers in R And D (per million people)

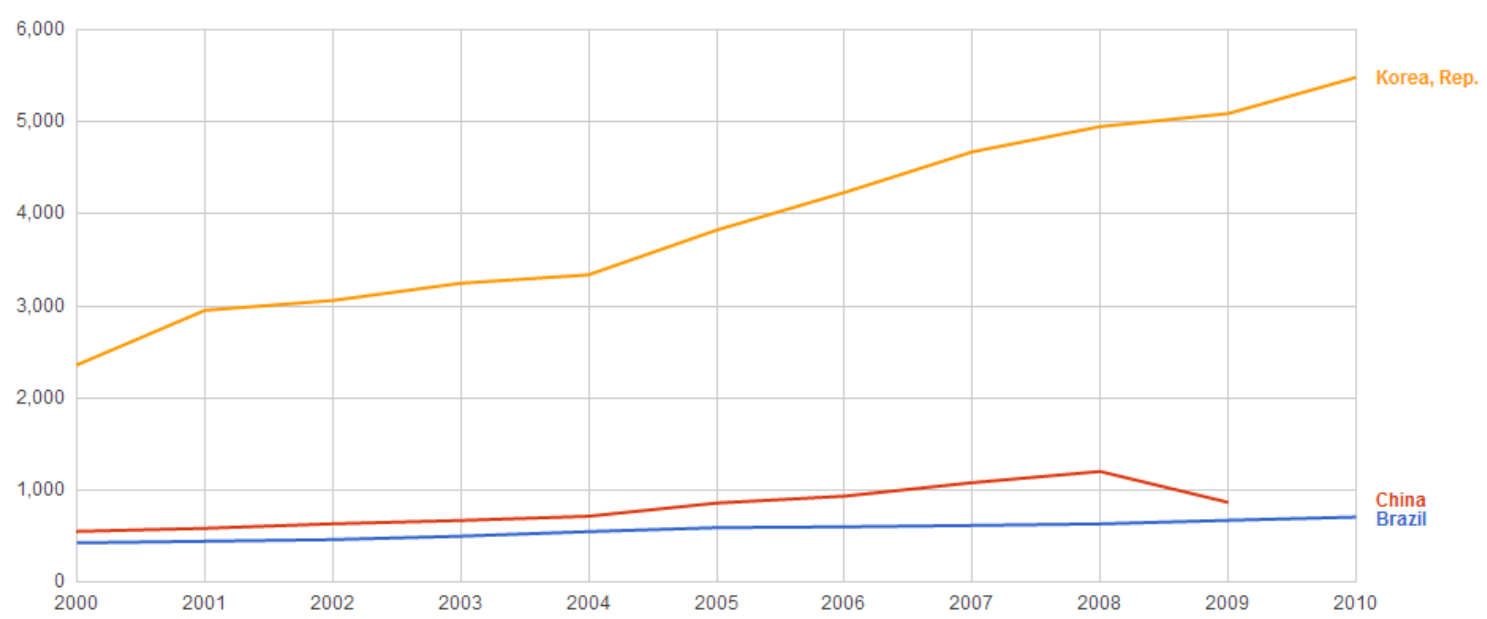

Fonte: Banco Mundial, 2013.

Os Gráfico 43 e 44 sintetizam o esforço nacional de inovação, isto é, o volume de recursos investidos em $\mathrm{P} \& \mathrm{D}$ em proporção do $\mathrm{PIB}$, e o número de pesquisadores em 
atividades de $\mathrm{P} \& \mathrm{D}$ por milhão de pessoas. A Coreia está bem à frente dos demais e a China, mesmo com sua imensa população, mantém uma proporção de pesquisadores em $\mathrm{P} \& \mathrm{D}$ maior do que a brasileira. Nesse levantamento, não há dados sobre Taiwan, mas outros indicadores apontados no Capítulo 4 sugerem que os dados taiwaneses são próximos aos sulcoreanos.

No que tange à participação de institutos públicos de pesquisa - área da qual as inovações são mais dependentes no Brasil em razão da baixa participação empresarial no esforço inovador -, também aí o investimento em P\&D em energias de baixo carbono não se destaca. Mesmo nessa área, China e Coreia têm uma participação maior de pesquisas de baixo carbono realizadas por institutos públicos, quando comparada com o Brasil, conforme sintetizado no Gráfico 45. Ou seja, entre as patentes oriundas de instituições públicas de pesquisa, há proporcionalmente mais inovações "verdes" na Coreia e na China do que no Brasil. Essa situação merece realce pelo fato de que o setor privado, como já apontado, tem papel de menor relevância no Brasil.

\section{GRÁFICO 45}

Patenteamento de institutos públicos de pesquisa, 2004-2009

Percentual de patentes requeridas no âmbito do PCT

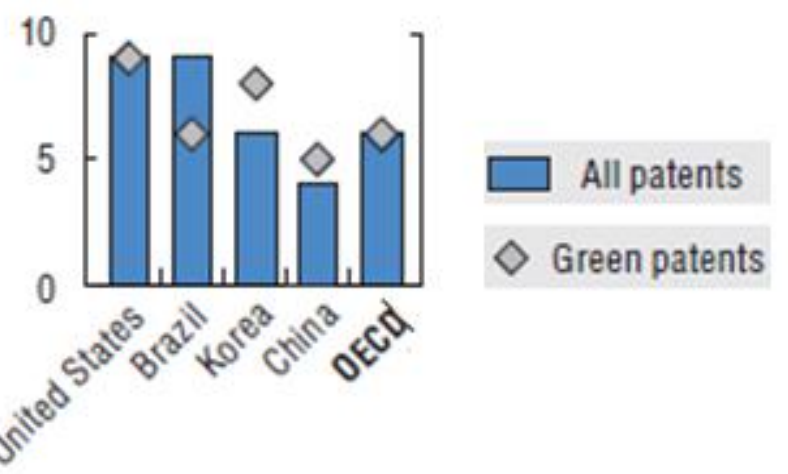

Fonte: OECD, 2012.

Conquanto não haja dados desagregados que permitam avaliar quanto exatamente está sendo investido em cada subárea por cada país, o MCTI informa que, da parcela de P\&D pública no Brasil, cerca de $2 \%$ vai para energia e meio ambiente. No caso da Coreia, a OCDE assinala que, também da parcela de P\&D de origem pública, 7,6\% vai para energia e meio ambiente (OCDE, 2012). Pode-se dizer, portanto, que o esforço de P\&D no Brasil em energia não tem sido substancial nem no setor privado, nem no setor público.

No que tange à geração de energia, as informações consolidadas no Gráfico 46 revelam a preponderância das fontes fósseis na matriz energética dos países asiáticos. Nos casos de Coreia e de Taiwan, as fontes renováveis têm papel quase irrelevante, mesmo depois 
da formação de setores industriais fortes nesses países na área de energia de baixo carbono, notadamente em energia solar.

No caso da China, a participação agigantada do carvão em uma economia de grande dimensão reflete o desafio que sua matriz energética traz ao mundo, pelo efeito nefasto que essa fonte provoca. Ao mesmo tempo, embora ainda pequena, as fontes renováveis já têm uma participação com algum peso e vêm crescendo a passos acelerados nos últimos cinco anos. O Brasil, por fim, apresenta a maior diversificação, com participação praticamente dividida ao meio entre fontes renováveis e fósseis, tendo a nuclear um papel secundário.

\section{GRÁFICO 46}

Fontes primárias de energia, 2012
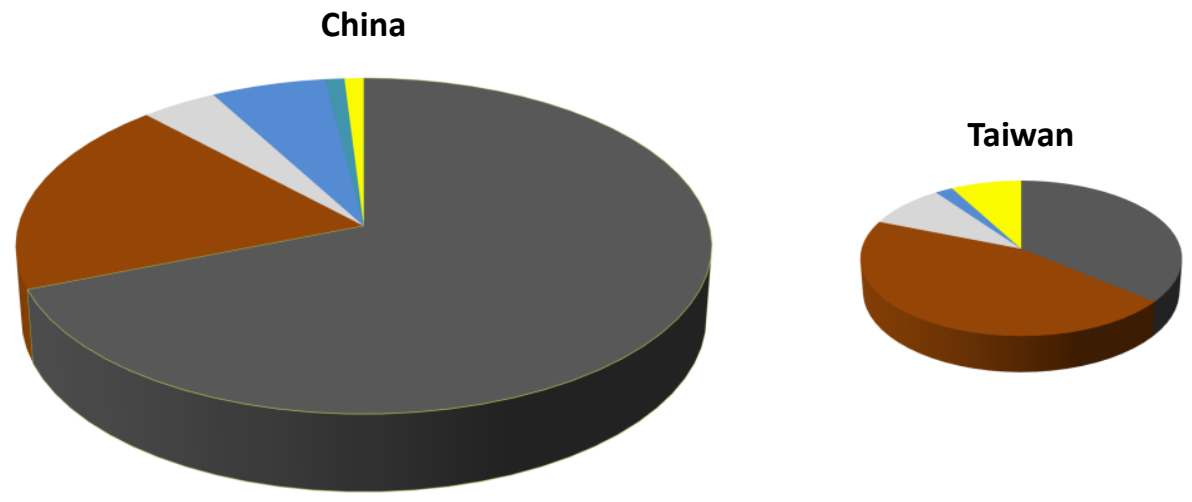

Brasil
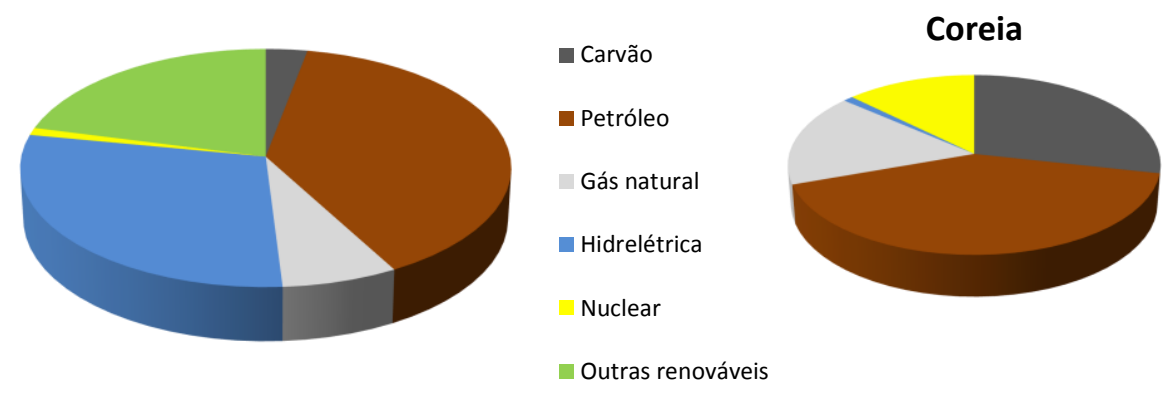

Fonte: Elaboração própria, a partir de dados da US/EIA.

OBS.: A proporção dos círculos espelha apenas grosseiramente as diferenças entre o total de energia produzido em cada um dos países.

Em relação às atividades de manufatura, não existe um índice global que sintetize as manufaturas em cada segmento, mas é possível extrair algumas informações relevantes a partir de alguns dados sobre produção industrial.

No caso da hidráulica, examinamos que essa fonte tem um peso especial na matriz elétrica brasileira e chinesa e ambas as nações exercem relevante atividade de manufatura no setor, ainda que com diferente intensidade tecnológica. Na China, há empresas 
fabricantes das turbinas de maior porte e intensidade tecnológica, viabilizando até mesmo a exportação desses produtos.

Em se tratando de biomassa, o foco da tecnologia migra dos equipamentos para a matéria-prima do combustível propriamente. No caso do etanol, o Brasil figura em segundo lugar entre os maiores produtores, atrás apenas dos Estados Unidos, com seu etanol de milho. A China ocupa uma distante terceira colocação, com uma produção total equivalente à décima parte da produção brasileira. Coreia e Taiwan têm produção apenas experimental de biocombustíveis, não se apresentando como atores relevantes no mercado global dominado por EUA e Brasil.

Essa é a única área em que realmente o Brasil se destaca em razão de seu amplo programa de estímulo aos biocombustíveis. A tecnologia do setor não se limita à produção agrícola, embora a produtividade agrícola seja um elemento central. Pesam bastante também as enzimas e os produtos químicos utilizados para acelerar e otimizar a reação química. Nesse campo, os dados de produção são ainda frágeis, já que boa parte desse trabalho ainda consiste em pesquisa para aprimorar as tecnologias existentes e viabilizar as novas gerações de etanol.

No caso da energia eólica, dos quinze maiores fabricantes mundiais, oito são chineses - e eles ocuparam essas posições recentemente, subindo progressivamente no ranking. Os produtores coreanos não estão no topo, mas empresas coreanas de grande porte, entre as quais Hyundai, Samsung e Doosan, estão entrando tardiamente na disputa e, pela estrutura empresarial ramificada de que dispõem, estão elevando rapidamente sua produção.

No caso das turbinas eólicas, a lista dos maiores aerogeradores e seus respectivos fabricantes mostra que o único fabricante brasileiro (a WEG) produz turbinas de porte apenas intermediário $(2,1 \mathrm{MW})$, enquanto que a disputa pelas turbinas de grande porte (acima de $5 \mathrm{MW}$ ), mais intensivas em tecnologia, tem a participação chinesa e coreana. É o caso, por exemplo, das companhias chinesas Sinovel e Guodian (ambas com modelos de turbina de $6 \mathrm{MW}$ ) e dos grupos coreanos Hyundai (com turbina de 5,5 MW) e Samsung (desenvolvendo turbina de 7 MW) (THE WIND POWER, 2014).

No caso da energia solar, já se apontou que as etapas iniciais (mineração e primeira etapa da purificação) e as etapas finais (montagem e instalação dos paineis) são as menos intensivas em tecnologia. Nas etapas intermediárias, que exigem a purificação do silício a níveis elevados de pureza (grau solar ou grau eletrônico), seguida da montagem dos wafers e das células solares, o setor é hoje em larga medida dominado pelas empresas dos países asiáticos em questão, com participação também de algumas empresas europeias e estadunidenses. O Brasil tem participação apenas nas etapas inicial (mineração e purificação 
do silício ao grau metalúrgico, mas não solar) e final (montagem dos paineis). Mas mesmo essa participação na etapa final é reduzida, uma vez que a principal empresa brasileira no segmento (Tecnometal) tem capacidade anual de produção de apenas $25 \mathrm{MW}$ de paineis (bem baixo da chinesa Yingli, por exemplo, com 2,5 GW de capacidade anual de produção e com estrutura verticalizada).

Por fim, em manufatura na área nuclear, como examinado no Capítulo anterior, destacam-se aí as indústrias sulcoreanas e chinesas. Além de um programa nuclear amplo domesticamente, as empresas da Coreia e da China têm se aventurado no mercado internacional na exportação de tecnologia nuclear, com fornecimento de alguns dos equipamentos mais sensíveis, incluindo reatores e turbinas.

É preciso relacionar essa situação de geração de energia, manufatura e inovação com o contexto internacional de mudança do clima e regime patentário.

O regime internacional em formação para enfrentamento da mudança climática não influenciou tanto Taiwan e Coreia no sentido de modificar sua matriz energética. Em rigor, o receio desse novo regime se prestou a que os governos desses países, juntamente com as empresas locais, fizessem apostas de longo prazo para seus setores industriais, e não propriamente para converter para o baixo carbono sua própria matriz energética. Aproveitaram especialmente a expertise adquirida anteriormente na purificação de silício e na construção de células fotovoltaicas para a indústria de eletrônicos a fim de convertê-la em um novo mercado para essas empresas.

A China, por sua vez, vem promovendo uma transição em sua matriz energética, movida em parte pelo contexto internacional e em parte pela necessidade de reduzir os níveis de poluição domésticos. Sua indústria recém formada já vem migrando com êxito para as fontes de energia de baixo carbono, dando passos importantes no aprendizado tecnológico e iniciando um movimento para a inovação.

Já o Brasil não vivencia hoje crise de segurança energética de longo prazo, em razão do potencial inexplorado hidrelétrico, do etanol e do pré-sal. Também não deve enfrentar restrições à emissão de carbono, dado o perfil relativamente limpo da matriz energética. Entre as principais fontes de baixo carbono, apenas na biomassa o Brasil exerce papel de destaque na geração, produção e inovação.

Vale notar que o etanol se desenvolveu no Brasil graças à necessidade de segurança energética, depois da crise de 1973, e não por uma aposta tecnológica estratégica. Embora disponha de radiação solar e de ventos privilegiados, o Brasil não dispõe de tecnologia 
desenvolvida localmente. Quanto à nuclear, o país dispõe de vastas reservas de urânio e de tecnologia básica para a geração, mas não inova, nem manufatura para exportar.

Em síntese, diferentemente dos asiáticos, o Brasil não se mobilizou em torno das novas fontes de baixo carbono, deixando de aproveitar a janela de oportunidade proporcionada pela necessidade de mudar a matriz global. Os demais países examinados estão mobilizados em inovar por razões de segurança energética e principalmente por cálculo estratégico das empresas locais, resultante das etapas anteriores de aprendizado tecnológico ativo.

\subsection{Crença dos agentes: percepção dos dirigentes nacionais sobre a relevância do tema e a oportunidade existente}

A definição das políticas públicas em cada país está relacionada em certa medida à visão que os líderes têm a respeito dos principais temas em questão. É evidente que outros fatores também pesam, tais como a estrutura econômica existente, as molduras institucionais do país e os valores culturais prevalecentes.

Conquanto não seja simples inferir os pensamentos e as ideias dos líderes dos países, é possível extrair algumas ideias a partir dos discursos proferidos e de documentos governamentais estratégicos. Esse tema será abordado no subtópico 8.2.1 a seguir.

O subtópico subsequente, 8.2.2, cuida de survey realizado com autoridades brasileiras a respeito da influência da mudança climática na matriz energética e da conexão de certos fatores com as atividades de manufatura e de inovação.

\subsubsection{Discursos e documentos oficiais}

Adotaremos nesse subtópico principalmente os discursos de posse dos atuais presidentes dos quatro países examinados: Dilma Rousseff, no Brasil (janeiro de 2011); Xi Jinping, na China (março de 2013); Park Geun-hye na Coreia (fevereiro de 2013); e Ma Yingjeou em Taiwan (maio de 2008). Frequentemente os discursos de posse presidencial resumem as diretrizes pretendidas pelos mandatários e expõem, ainda que de modo subjacente, as ideias que moldam os objetivos anunciados. 
Além dos discursos de posse presidencial, também há referências a documentos estratégicos do governo, notadamente os planos de expansão do setor de energia ou documentos que encerram o planejamento estratégico do país para os próximos anos, conforme detalhado à frente.

\section{Brasil, Dilma Rousseff}

Em seu discurso de posse como Presidenta da República, proferido em $1^{\circ} \mathrm{de}$ janeiro de 2011 perante o Congresso Nacional, Dilma Rousseff tratou do tema de geração de energia a partir de fontes limpas, enfatizando a importância de salvaguarda do meio ambiente. Também cabe observar que não foi feita referência ao desenvolvimento tecnológico em geração de energia. Eis o trecho central:

"Queridos brasileiros e queridas brasileiras,

Considero uma missão sagrada do Brasil a de mostrar ao mundo que é possível um país crescer aceleradamente, sem destruir o meio-ambiente.

Somos e seremos os campeões mundiais de energia limpa, um país que sempre saberá crescer de forma saudável e equilibrada.

$\mathrm{O}$ etanol e as fontes de energia hídricas terão grande incentivo, assim como as fontes alternativas: a biomassa, a eólica e a solar. O Brasil continuará também priorizando a preservação das reservas naturais e das florestas.

Nossa política ambiental favorecerá nossa ação nos fóruns multilaterais. Mas o Brasil não condicionará sua ação ambiental ao sucesso e ao cumprimento, por terceiros, de acordos internacionais.

Defender o equilíbrio ambiental do planeta é um dos nossos compromissos nacionais mais universais." (BRASIL, 2014)

De fato, o discurso da Presidenta corresponde à perspectiva de preservar a matriz energética nacional relativamente limpa. Há uma clara busca por associação da política energética com a política ambiental, mas não com uma estratégia de desenvolvimento industrial e tecnológico.

A Presidenta também associa a busca por energia renovável às discussões internacionais de proteção ao meio ambiente, mas não faz referência explícita ao tema da "mudança climática". Ela deixa claro que o esforço brasileiro não está condicionado à existência de um acordo internacional, de modo que o país agiria por interesse ou desejo autônomo de garantir um meio ambiente equilibrado.

É verdade que, em outros trechos do discurso, há referências claras à importância da inovação tecnológica e às atividades de $\mathrm{P} \& \mathrm{D}$. Entretanto, essas referências 
integram parte de uma política separada de ciência e tecnologia, e não de um sistema conjugado com a política energética e ambiental. Veja-se esse trecho:

"O mundo vive num ritmo cada vez mais acelerado de revolução tecnológica. Ela se processa tanto na decifração de códigos desvendadores da vida quanto na explosão da comunicação e da informática.

Temos avançado na pesquisa e na tecnologia, mas precisamos avançar muito mais. Meu governo apoiará fortemente o desenvolvimento científico e tecnológico para o domínio do conhecimento e a inovação como instrumento da produtividade.” (Idem, 2011.)

Vale ainda fazer referência ao trecho em que a Presidenta aborda a descoberta de petróleo no pré-sal. Nesse excerto, a mandatária menciona a importância da exploração do combustível fóssil e como a tecnologia nacional desempenhou papel central para sua viabilização.

"Queridas brasileiras e queridos brasileiros,

O pré-sal é nosso passaporte para o futuro, mas só o será plenamente se produzir uma síntese equilibrada de avanço tecnológico, avanço social e cuidado ambiental. A sua própria descoberta é resultado do avanço tecnológico brasileiro e de uma moderna política de investimentos em pesquisa e inovação. Seu desenvolvimento será fator de valorização da empresa nacional e seus investimentos serão geradores de milhares de novos empregos.

O grande agente desta política é a Petrobrás, símbolo histórico da soberania brasileira na produção energética.

O meu governo terá a responsabilidade de transformar a enorme riqueza obtida no Pré Sal em poupança de longo prazo, capaz de fornecer às atuais e às futuras gerações a melhor parcela dessa riqueza, transformada, ao longo do tempo, em investimentos efetivos na qualidade dos serviços públicos, na redução da pobreza e na valorização do meio ambiente. Recusaremos o gasto apressado, que reserva às futuras gerações apenas as dívidas e a desesperança." (Idem, 2014.)

No discurso de posse do segundo mandato, em janeiro de 2015, não houve referências claras à política energética, tampouco ao papel das fontes de baixo carbono. O setor foi mencionado apenas no momento em que se falava da importância dos investimentos em infraestrutura, incluindo-o ao lado das obras de logística e de saneamento. O pré-sal, por outro lado, foi abordado como uma das fontes importantes de recursos para o desenvolvimento brasileiro por meio do aporte de recursos no fundo social.

Em relação à política externa, há no discurso de 2015 uma referência ao engajamento nas negociações climáticas internacionais "para que nossos interesses sejam contemplados no processo de estabelecimento dos parâmetros globais de redução de emissões" (BRASIL, 2015). 
Embora não seja inequívoco o sentido da sentença, ela sugere a ideia de uma postura mais defensiva do Brasil nessa esfera, com vistas a evitar limitações ao crescimento do país. A negociação climática internacional é abordada mais como um entrave potencial ao desenvolvimento brasileiro do que como uma oportunidade para setores empresariais brasileiros ocuparem mercados com tecnologia local.

Em síntese, no caso brasileiro, é possível extrair dos discursos presidenciais a importância conferida às fontes limpas no contexto de proteção do meio ambiente, mas não no contexto de uma política industrial e tecnológica. Conquanto se assevere a importância da ciência e da inovação, esse tema é tratado de maneira apartada da política energética.

Por fim, mesmo havendo referência a negociações internacionais ambientais, o tema das "mudanças climáticas" foi abordado apenas no discurso de 2015, mas não como eixo para uma reorganização do padrão de geração e consumo de energia. Pelo contrário, a exploração do pré-sal é tratada nos dois discursos como uma das ações centrais da nova administração.

\section{China, Xi Jinping}

No caso do mandatário chinês, não existe propriamente um discurso de posse. Em verdade, existe uma transição suave, mediante sucessivas cerimônias em que o novo mandatário vai gradualmente assumindo as diferentes posições de cúpula do governo chinês, notadamente Secretário-Geral do Comitê Central do Partido Comunista Chinês, Presidente da Comissão Central das Forças Armadas e Presidente da República.

Consideraremos como discurso principal, definidor das novas diretrizes sugeridas pelo novo líder, a fala realizada durante o 12- Congresso do Povo Chinês, realizado em Pequim em 11 de março de 2013, uma vez que esse foi o principal discurso tornado público nessas cerimônias. Essa manifestação foi examinada pelos principais estudiosos da China como elemento definidor do novo mandato, sobretudo por sua referência ao "sonho chinês", mimetizando a expressão consagrada nos Estados Unidos do sonho americano.

Nessa ocasião, Xi fez referências a três temas estudados nesta tese: a economia liderada pela inovação, ao crescimento sustentável e, por fim, redução da poluição. Embora o tema da poluição esteja mais relacionado à poluição local nas grandes cidades, o assunto está indiretamente ligado à mudança climática, eis que passa por causas comuns, notadamente o uso intensivo de combustíveis fósseis. 
Apesar de não fazer menção direta aos temas energia, tampouco mudança climática, o mandatário chinês declarou que, para realizar o sonho chinês, será necessário garantir um crescimento econômico de qualidade e sustentável. Afirmou ainda que a economia deve passar por transformações para implantar uma estratégia orientada pela inovação (XINGUA, 2014). Embora não fique explícito, a referência aos temas em sequência sugere que a inovação está casada com o conjunto da mudança a ser feita no crescimento econômico, incluindo a sustentabilidade.

Além do discurso do Presidente chinês, é válido mencionar o 12ํ Plano Quinquenal da China para o período de 2011-2015, aprovado pelo Congresso do Povo da China em 14 de março de 2011. Como indica a consultoria KPMG, entre as três prioridades definidas pelo plano estão o crescimento sustável - ao lado de progresso industrial e promoção do consumo doméstico. Isso ajuda a explicar o porquê de certos setores, em particular o de energia, recebeu uma atenção especial (KPMG, 2011).

Ainda conforme a KPMG, entre as sete indústrias apontadas como prioritárias pelo plano, ao menos três estão diretamente relacionadas à economia de baixo carbono: 1) Novas energias (nuclear, eólica e solar); 2) Conservação de energia e proteção ambiental; e 3) Veículos movidos a energia limpa.

O 12을 Plano Quinquenal Chinês já reflete a ênfase que foi conferida ao setor de energia e de eficiência energética no $11^{\circ}$ Plano Quinquenal (2006-2010). Já então, em meados dos anos 2000, estava clara a necessidade de expansão em larga escala das emissões de carbono chinesas se fosse mantido modelo de ampliação da matriz com base em carvão. Os problemas de poluição local já estavam cada vez mais claros e o cenário internacional de discussão em torno da mudança climática também vinha ganhando contornos mais nítidos.

As autoridades chinesas perceberam, nesse período, que o país precisava optar por um rumo que conferisse segurança energética e vantagem industrial e tecnológica. Ao comentar no New York Times os avanços verificados na China em relação à eficiência energética, o professor Amory Lovins argumentou o seguinte:

"How did China make energy efficiency its top strategic priority for national development in the Eleventh Five Year Plan in 200? It wasn't because a treaty made them do it. There wasn't one. It was because people like Wen Jiabao understood that otherwise China couldn't afford to develop because the supply side would eat the budget. It was enlightened economic self interest." Amory Lovins, no NYT (REVKIN, 2013) 
Sinteticamente, a China tem desde meados dos anos 2000 adotado metas arrojadas para fazer uma transição para uma economia de baixo carbono, embora ainda mantenha padrões de uso acentuado das fontes fósseis. Seus esforços nessa transição têm sido executados por meio de uma integração forte entre política energética, ambiental, industrial e tecnológica.

\section{Coreia do Sul, Park Geun-hye}

No caso da Coreia do Sul, é válido examinar não apenas o discurso da atual mandatária, Park Geun-hye, como também de seu antecessor, Lee Myung-bak.

Afinal, em 2008 Lee tomou posse como Presidente e com isso restaurou o controle do governo pelo Grande Partido Nacional (posteriormente denominado de Partido Saenuri), de centro-direita, que governa o país desde os anos 1960, com exceção do intervalo entre 1998 e 2008, quando o Partido Democrático, de centro-esquerda, assumiu o comando.

Em seu discurso de posse, em 25 de fevereiro de 2008, Lee tratava diretamente do tema da economia de baixo carbono e da necessidade de inovação tecnológica no setor. Ele destacava os riscos da mudança climática e as necessidades de mudanças de paradigma que a situação exigia, sugerindo que o país pudesse se ajustar ao novo cenário por meio da criação de novos motores de crescimento econômico. Em suas palavras:

"Preservation of the environment improves the quality of life while the environment industry creates new engines of growth.

Climate change is threatening our very future. Natural disasters and abnormal weather patterns are on the rise and the damage caused by them is becoming more serious. We must actively take part in reducing carbon emissions.

In the short term, our economy may undergo a period of difficulty while adjusting to these changes. But, we must endure. We must creatively adapt. The various issues that affect our state policy - such as food, environment, water, natural resources, energy must undergo an overall paradigm shift so that they become more eco-friendly.

(...)

In order to ensure that our economic engine runs smoothly, we will work to acquire a safe and stable supply of resources and energy. Moreover, we shall take the lead in environment-friendly international cooperation."

Discurso de posse de Lee Myung-bak (HANKYOREH, 2008)

Durante o governo de Lee, a Coreia assumiu um protagonismo internacional no tema das mudanças climáticas a partir de sua política de "crescimento verde" e de sua posição reformadora no campo das negociações da CQNUMC. Como já apontado anteriormente, foi em sua gestão que foi criado o Green Growth Institute e foi também durante seu mandato que 
a Coreia adotou algumas políticas mais favoráveis às energias renováveis - embora, como visto, os resultados ainda sejam bastante tímidos em termos de utilização doméstica das novas tecnologias, ainda tidas como caras.

Já em 2013, tomou posse a Presidenta Park Geun-hye, filha do presidente Park Chung-hee, ditador coreano que governou o país entre 1963 e1979 e tido como um dos principais responsáveis pela industrialização tardia do país. Embora do mesmo partido do presidente Lee, a nova mandatária era tida como sua rival interna.

Park tratou em seu discurso de posse, em 25 de fevereiro de 2013, do casamento da ciência com a indústria, mas não fez referência direta ao tema da energia ou da mudança climática. A integração da indústria com a academia tem sido central no desenvolvimento coreano. Parte central das novas ferramentas de política industrial da Coreia do Sul reside justamente em aproximar esses segmentos e conferir apoio estatal ao desenvolvimento das áreas em que as indústrias locais avaliam ter vantagens competitivas. Eis um trecho de seu discurso:

\footnotetext{
"To begin with, economic revitalization is going to be propelled by a creative economy and economic democratization. Across the world, we are witnessing an economic paradigm shift.

A creative economy is defined by the convergence of science and technology with industry, the fusion of culture with industry, and the blossoming of creativity in the very borders that were once permeated by barriers. It is about going beyond the rudimentary expansion of existing markets, and creating new markets and new jobs by building on the bedrock of convergence.

At the very heart of a creative economy lie science technology and the IT industry, areas that I have earmarked as key priorities. I will raise our science and technology to world-class levels. And a creative economy will be brought to fruition by applying the results of such endeavors across the board."

Discurso de posse de Park Geun-hye (YONHAP NEWS AGENCY, 2013)
}

Vale notar que o tema da inovação assumiu grande força na Coreia do Sul desde os anos 1990, quando o país passou a produzir grandes quantidades de patentes e a liderar alguns setores industriais intensivos em inovação, tais como eletrônicos e tecnologia de informação. Para dar uma dimensão de como o assunto se entranhou na política local e do simbolismo que se conferiu à inovação tecnológica, até mesmo o equivalente ao Ministério da Fazenda na Coreia passou a ser denominado de Ministério da Economia do Conhecimento.

\section{Taiwan, Ma Ying-jeou}


Taiwan, por sua vez, abraçou o tema da mudança climática especialmente a partir da gestão de Ma Ying-jeou, que assumiu o comando do país em 2008 e foi reeleito em 2012. O mandatário é também integrante do Kuomintang, o partido que exerceu papel central na história do país, governando-o desde sua fundação nos fins da década de 1940 - à exceção do breve período em que Chen Shui-bian, do Partido Democrático Progressista, assumiu o comando entre 2000 e 2008.

Embora algumas medidas já hajam sido adotadas em Taiwan durante a gestão de Chen Shui-bian (2000-2008), seu discurso de posse não aborda os temas de mudança climática, política energética, economia de baixo carbono.

Foi apenas durante as duas gestões de Ma Ying-jeou que o tema entrou na pauta central do país, figurando inclusive com destaque em seu discurso de posse para o segundo mandato. Em 20 de maio de 2012, Ma fez referências diretas em sua fala à necessidade de P\&D para energia limpa, apontada como um pilar das novas medidas de competitividade. Ele aponta os cincos pilares para tornar Taiwan mais competitiva, o terceiro dos quais é o desenvolvimento de tecnologias de baixo carbono. Eis o trecho de seu discurso:

"The third pillar for bolstering Taiwan's competitiveness is developing an environment characterized by low carbon emissions and high reliance on green energy. Global climate change and imbalances between resource supply and demand present Taiwan with both challenges and opportunities. In the future, all industries around the world will emphasize green production.

Green industry will be a new arena of industrial competition, and consumer behavior must fall in line with the need for energy conservation and reduced carbon emissions. Therefore, we encourage the private sector to step up $\mathrm{R} \& \mathrm{D}$ and investment in greenenergy industries, green architecture and green production, so that these become a new economic bright spot that brings employment and development, and gradually turns Taiwan into a 'low-carbon, green-energy island.'

(...)

In terms of policy, we must ensure that energy prices are reasonable and create the impetus for energy conservation, carbon reduction and increased investment in greenenergy industries."

Discurso de posse de Ma Ying-jeou (TAIWAN, 2012)

Comparando-se os quatro discursos, pode-se concluir que, nos casos de Coreia do Sul e Taiwan, fica claro o propósito de casar a energia de baixo carbono com o setor industrial e tecnológico local, embora a incorporação das tecnologias localmente não sejam fator central (energia + indústria + tecnologia). No caso da China, além desse casamento entre energia de baixo e desenvolvimento tecnológico e industrial local, há também uma preocupação crescente com a poluição local do país, o que impõe o lançamento dessas novas tecnologias no campo doméstico (energia + indústria + tecnologia + meio ambiente). 
No caso brasileiro, o discurso de energia renovável está mais associado à questão ambiental do que ao desenvolvimento tecnológico local, embora haja alguma associação com a indústria via importação de tecnologia (energia + meio ambiente + indústria).

\subsubsection{Entrevistas e survey com autoridades sobre relevância e urgência do tema}

Ferramenta também útil para avaliar a percepção de atores relevantes é a realização de questionário com perguntas sistematizadas aplicadas ao grupo em questão. Para avaliar a percepção de autoridades do poder público brasileiro envolvidas com o tema de inovação em energia limpa, aplicou-se um survey online restrito a um grupo relativamente pequeno de servidores ocupantes de cargos de chefia ou de assessoramento.

Para dispor de uma amostra representativa, foram selecionados servidores ocupantes de cargos de chefia ou assessoramento nos seguintes ministérios: a) Fazenda; b) Minas e Energia; c) Desenvolvimento, Indústria e Comércio Exterior; d) Ciência e Tecnologia; e e) Meio Ambiente. Foram escolhidos cerca de dez servidores em cada uma dessas pastas, preferencialmente ocupantes de cargos de "Direção e Assessoramento Superiores" nível 4 ou superior, e desde que as atribuições do cargo guardassem relação com política energética, industrial, ou de inovação. O total de respondentes foi de apenas 16 pessoas, mas as respostas apresentadas espelham razoavelmente os resultados obtidos com as entrevistas realizadas com parte desse grupo e também as diretrizes do governo no setor.

Numa escala de 0-10 sobre importância do tema de mudanças climáticas para a estratégia de desenvolvimento brasileira no longo prazo, a média dos respondentes ficou em 6,9, uma avaliação entre "alguma importância" e "muita importância" para o tema, tendo 25\% dos respondentes atribuído "altíssima importância". Quando a pergunta é feita sobre qual a importância que o governo federal brasileiro atribui às mudanças climáticas, a nota média cai para 5,6, mais próxima de "alguma importância".

No que tange aos impactos que as mudanças climáticas devem provocar no mercado de energia de baixo carbono no Brasil, cerca de dois terços dos respondentes acham que o mercado deve ser ampliado suave ou substancialmente, e pouco menos de 1/3 considera que não haverá impacto significativo ou mesmo que o mercado será reduzido.

Quanto ao mercado brasileiro de energia daqui a dez anos, foram avaliadas as perspectivas dos respondentes para cada uma das principais fontes de energia utilizadas, com as respostas sintetizadas no Gráfico 47. Como indica o gráfico, juntamente com o gás natural, as perspectivas de aumento suave ou incremento substancial do mercado estão concentradas 
nas chamadas "novas renováveis", incluindo solar fotovoltaica, solar térmica, eólica e biomassa. São essas as que apontam menores índices de "redução da participação" no mercado, ou situação "mais ou menos igual".

\section{GRÁFICO 47}

Expectativa para o mercado de equipamentos no Brasil em 2023

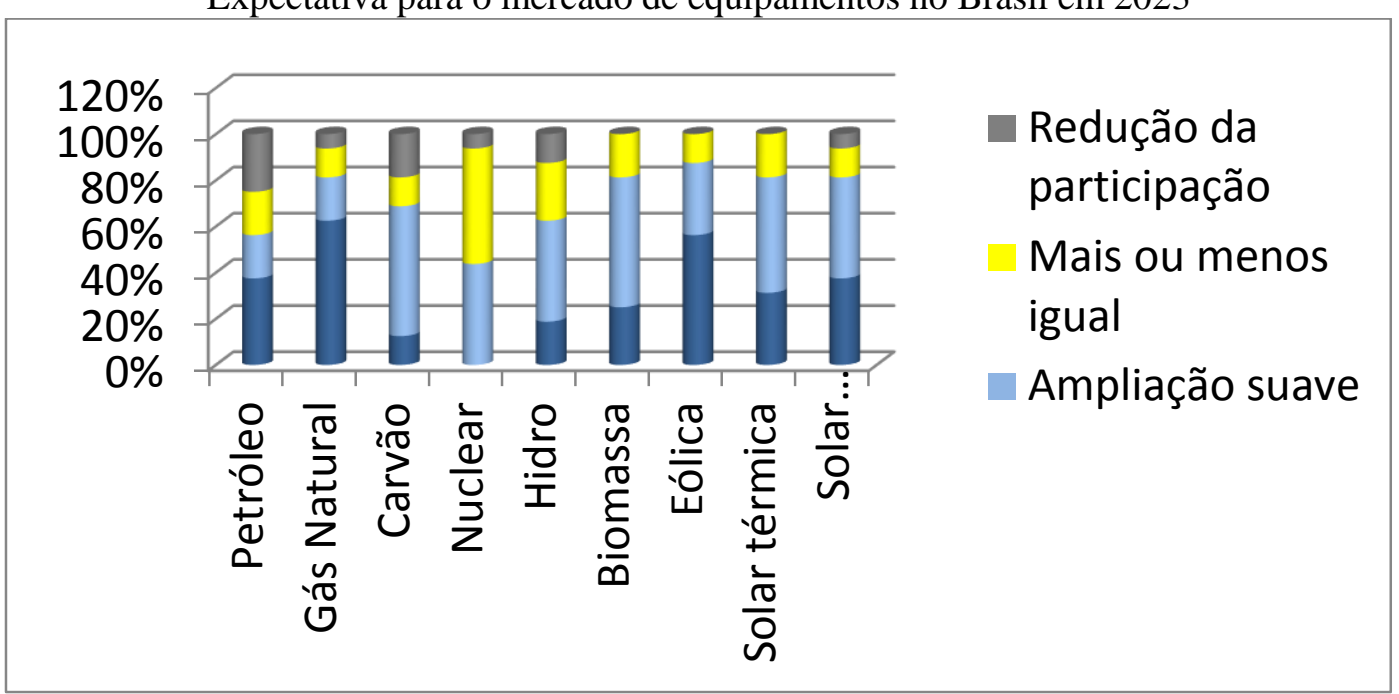

Fonte: Survey elaborado pelo autor, 2013.

O curioso desse indicador é que algumas das principais autoridades do país reconhecem que o mercado para as energias solar e eólica devem ser ampliados nos próximos anos, a despeito da relativamente pequena atenção conferida ao desenvolvimento de inovações brasileiras na área. Aliás, no que tange às novas tecnologias, cerca de dois terços dos entrevistados entendem que as tecnologias estrangeiras exercerão um papel secundário, seja por serem desnecessárias, seja por avaliarem que o Brasil pode facilmente incorporá-las. Apenas um terço deles entende que as tecnologias de energia limpa desenvolvidas no exterior terão um papel central para o mercado brasileiro.

Há ainda uma avaliação bastante negativa dos obstáculos "burocráticos" existentes à inovação no setor de energia, notadamente problemas de licenciamento ambiental, complexidade tributária, exigências para crédito em agências oficiais e aquisição e importação de insumos. Numa escala de zero a dez, sendo zero nenhuma dificuldade e dez muita dificuldade, a nota média atribuída pelas autoridades aos obstáculos ficou em 7,2, o que indica um reconhecimento da existência de muita dificuldade. Adicionalmente, a totalidade dos entrevistados entendeu que esses empecilhos ou permaneceram iguais ou aumentaram na última década, em vez de haverem se reduzido. 
No que tange à importância do câmbio para que empresas brasileiras definam estratégias de investimentos em inovação para gerar energia com baixo carbono, a nota média atribuída pelos entrevistados foi de 6,6, o que indica uma importância de intermediária para alta (sendo zero nenhuma importância e dez máxima importância).

No entanto, esses mesmos entrevistados se dividem quanto ao papel que o câmbio exerce no setor: menos de um terço deles considera que a desvalorização do real produziria efeitos majoritariamente positivos por aumentar a competitividade dos bens nacionais. Os demais se dividem entre os que avaliam que o real valorizado é positivo por baratear os insumos importados, os que consideram que os efeitos se compensam (insumos mais baratos e produtos menos competitivos, ou insumos caros com produtos mais competitivos), e ainda os que julgam que câmbio não é peça central nessa questão.

Nas entrevistas realizadas com parte das autoridades desses vários ministérios, predomina a percepção de que o papel central da política energética é assegurar a ampliação da oferta de energia e a modicidade tarifária. Nesse contexto, o desenvolvimento de inovações tecnológicas no Brasil está bem distante das prioridades da política setorial de energia.

A despeito disso, há iniciativas para estimular atividades manufatureiras no Brasil e ainda inovação tecnológica no setor. Entretanto, essas ações ocorrem à margem da política energética, sendo adotadas pelos órgãos setoriais incumbidos desses temas, notadamente o MDIC e o BNDES (manufaturas no Brasil) e o MCTI e a FINEP (inovação tecnológica). Sendo iniciativas setorizadas, seu alcance é mais restrito e não há criação de um mercado que assegure demanda para essas atividades.

A experiência de outros países tem revelado que parte substancial do aprendizado se dá por meio do processo de produção (“learning by doing”). Sem ocupar o mercado internacional, tampouco fazer florescer um mercado local, o aprendizado tecnológico encontra grandes empecilhos para criar produtos competitivos. Pode-se até reproduzir uma tecnologia de baixo carbono em laboratório, mas há uma longa distância desse ponto até criar uma indústria com qualidade e preços competitivos. A curva de aprendizado tecnológico em outras nações tem revelado que a geração crescente de energia, localmente ou via exportação, está associada à redução dos custos e ao aumento da confiabilidade dos equipamentos. 


\subsection{A modernização dependente: os riscos de reprodução do aprendizado passivo na nova indústria de energia de baixo carbono}

Ao aplicar a ideia do sistema de aprendizado tecnológico passivo especificamente ao setor de energia de baixo carbono no Brasil, vê-se que a hipótese é novamente confirmada. O Brasil segue a trajetória de modernização do setor industrial, com manufaturas de novos produtos, mas mantém a dependência tecnológica dos países estrangeiros - dessa vez não só com os países de alta renda, mas até mesmo com outros países de industrialização tardia, como a China.

Repete-se em certa medida o modelo de dependência centro-periferia que caracterizou nossa industrialização no século XX, modelo esse que não se aplica às experiências asiáticas examinadas no estudo e até contrasta com elas. O modelo, nesse momento, no caso da energia de baixo carbono, tem a peculiaridade de que o fluxo das novas tecnologias provém não somente do centro (Estados Unidos, Alemanha, etc.) para a periferia, mas ruma para o Brasil a partir também de outros países de renda média que adotaram um sistema de aprendizado ativo.

$\mathrm{Na}$ indústria eólica, a expansão das atividades de manufatura, notadamente de aerogeradores, tem se baseado em investimentos estrangeiros diretos por meio de subsidiárias integrais de grandes multinacionais, tais como GE, Siemens e Vestas. A absorção tecnológica nesses casos tem se restringido à montagem dos equipamentos, com capacidade de inovação local de baixa relevância, pouca pesquisa e pequena quantidade de exportação. Caracterizamse como exceções os casos da Tecsis, fabricante de hélices, e da WEG, fabricante de aerogeradores, conforme examinado no Capítulo 6.

Em hidroeletricidade, o quadro é similar. Nas áreas em que ainda há alguma atividade inovadora relevante, concentrada nas grandes turbinas, o setor é dominado por empresas estrangeiras que realizam montagem de peças no Brasil, como Alstom e GE. Há fabricantes brasileiras em turbinas de menor porte e com limitada capacidade de inovação.

No caso da energia solar, as etapas industriais realizadas no Brasil são apenas as de baixa intensidade tecnológica, notadamente a extração de silício e sua purificação em grau metalúrgico, assim como a montagem dos paineis. As etapas mais intensivas em tecnologia e inovação não são realizadas no Brasil - que, de resto, dispõe de demanda baixíssima para essa fonte energética. 
A energia oriunda da biomassa é a única em que o Brasil tem desempenhado um papel protagonista em termos de inovação, com destaque para o etanol e o biodiesel. Afora dispor de um grande mercado doméstico em biomassa - tanto para eletricidade, quanto como combustível -, há várias empresas brasileiras participantes do mercado, juntamente com empresas estrangeiras, e a atividade de inovação tem sido relevante. Apesar de ter avançado entre 2003 e 2007, houve em seguida certa acomodação no setor, com perda de espaço das exportações líquidas.

No caso da energia nuclear, o Brasil dispõe da tecnologia necessária para todo o ciclo nuclear, mas não emprega algumas dessas fases em escala comercial, tampouco tem se empenhado em inovações radicais no setor. Os reatores e turbinas em uso e em construção se baseiam em tecnologias de origem principalmente estadunidense e alemã, sem que o país tenha priorizado o desenvolvimento tecnológico do setor.

Em síntese, à exceção da biomassa, predominam os investimentos estrangeiros diretos por meio de subsidiárias integrais, mão-de-obra com formação relativamente baixa, reduzida ou inefetiva atividade de $\mathrm{P} \& \mathrm{D}$ e pouca exportação. A situação se enquadra justamente na caracterização do sistema de aprendizado tecnológico passivo, com reprodução local das tecnologias desenvolvidas no exterior.

Os vários fatores examinados ao longo desta tese podem ser sumarizados nos termos da Figura 7. Nos países estudados, destacaram-se cinco fatores explicativos: o regime climático internacional, o regime internacional de patentes, a segurança energética dos países, a situação do câmbio e o sistema de aprendizado tecnológico. Esses cinco fatores têm moldado de maneiras diferentes as escolhas políticas das autoridades públicas e, com elas, o desenho das políticas energética, industrial e ambiental. Esses vetores conduzem ao tipo de indústria de energia em cada um dos países examinados, com caráter mais autonomista ou mais dependente de tecnologia.

No caso brasileiro, o regime climático internacional não é visto como uma ameaça relevante ao modelo de desenvolvimento do país. Isso se deve ao uso intensivo de fontes renováveis na matriz energética - notadamente hidrelétricas e biomassa - e à recente redução do desmatamento, que vinha sendo a principal fonte das emissões brasileiras. Casa-se com isso a avaliação de que os países em desenvolvimento disporão de alguma folga para ampliar suas emissões. O cenário, portanto, é de baixa preocupação com a mudança do atual modelo de expansão da oferta de energia.

O regime internacional de patentes se consolidou no Brasil em meados dos anos 1990, quando as indústrias locais ainda não dispunham de desenvolvimento tecnológico 
substantivo. Em lugar de servir como estímulo às atividades inovadoras, a implantação no Brasil de rigoroso regime internacional resultou na ampliação das atividades de patenteamento de empresas estrangeiras, e não tanto de empresas locais, que seguem com baixos níveis de investimentos em P\&D.

FIGURA 7

Principais fatores a influenciar a indústria de energia de baixo carbono

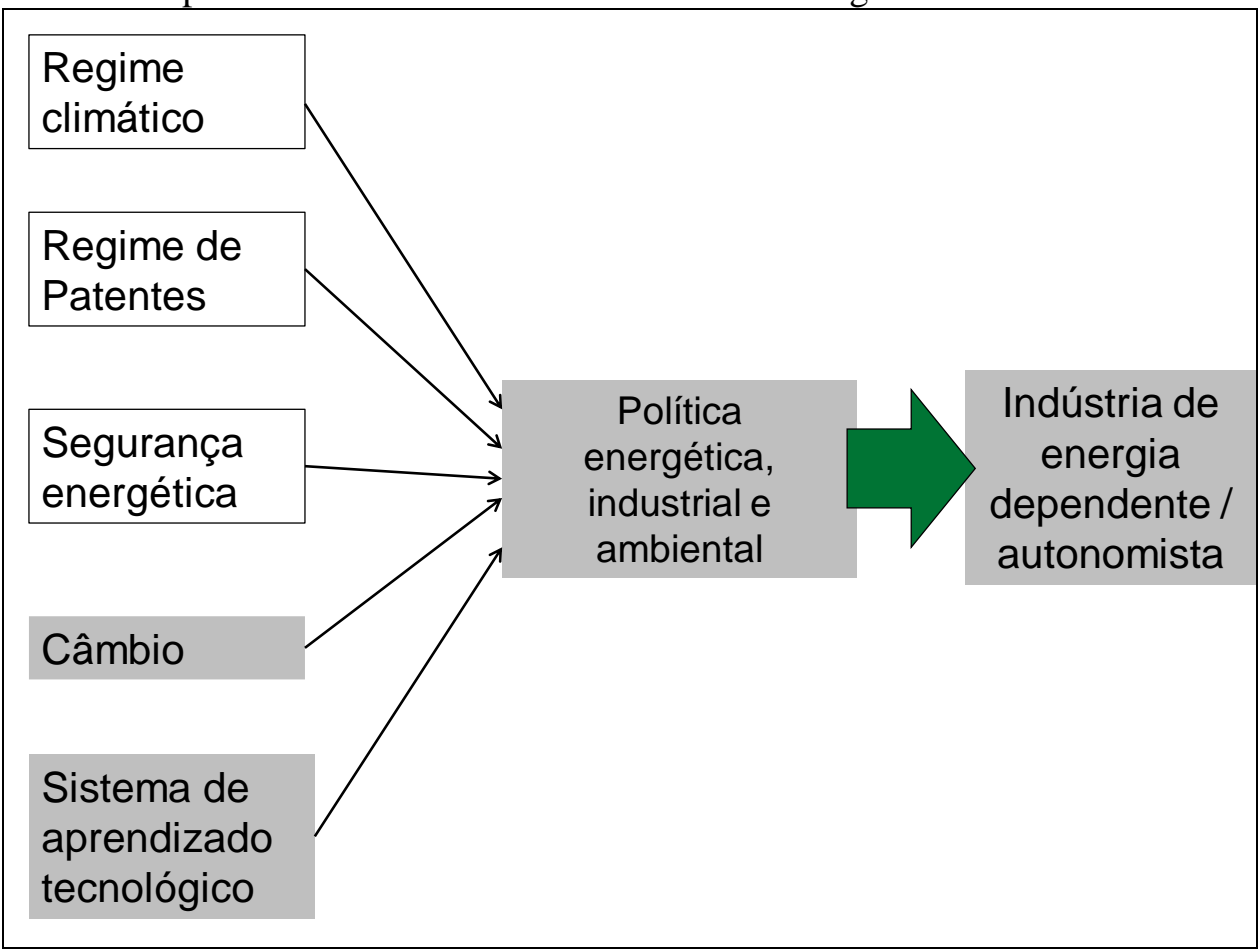

Fonte: Elaboração própria.

OBS.: Os quadros em branco sugerem fatores pouco suscetíveis de alteração por política doméstica de cada país, podendo ser considerados, para as estratégias examinadas nesta tese, um dado de realidade. Em cinza estão marcados os fatores que, em tese, poderiam ser modificados por políticas adequadas.

A segurança energética, do ponto de vista da dependência de importação de fontes primárias de energia, também não é vista com grande preocupação. As importações brasileiras atualmente se limitam à eletricidade de Itaipu - considerada razoavelmente segura - e importações de petróleo e gás, com tendência declinante em razão da exploração do présal.

O câmbio apreciado tem reduzido a competitividade das indústrias brasileiras. A situação de doença holandesa crônica tem provocado um volume muito reduzido de investimentos em tecnologias de baixo carbono, havendo absorção de recursos financeiros e humanos para a exploração de combustíveis fósseis, além das atividades extrativas e agrícolas tradicionais.

Por fim, o sistema de aprendizado tecnológico tem sido efetivamente a principal barreira à inovação no setor industrial. A baixa qualificação da mão-de-obra, a preponderância 
de empresas estrangeiras no setor desenvolvendo pesquisas inovadoras na matriz, os baixos níveis de investimento em P\&D e a frágil integração universidade-empresa, tudo isso tem atuado como obstáculo para a inovação tecnológica em energia de baixo carbono.

Em síntese, enquanto que os regimes internacionais de carbono e de patentes, assim como a relativa segurança energética não pressionam o Brasil a investir em novas fontes de energia, o câmbio e o sistema de aprendizado passivo são verdadeiros obstáculos a essa transição. O resultado é o desenho de uma política energética em larga medida descasada da política tecnológica, ainda que comparativamente avançada em termos ambientais.

Nesse contexto, a indústria brasileira de geração de energia de baixo carbono é razoavelmente robusta, o país gera energia em larga medida renovável - quando comparada internacionalmente -, mas a capacidade de desenvolver novas tecnologias é muito baixa quando cotejada com outras nações. Mantém-se o traço da dependência tecnológica, historicamente apontada no Brasil por autores que se debruçaram sobre o desenvolvimento econômico nacional.

Os três países asiáticos estudados contrastam com o desenho brasileiro. $\mathrm{Na}$ China, em Taiwan e na Coreia, os cinco fatores citados atuaram de maneira diferente na moldagem da política energética, industrial, tecnológica e ambiental, ainda que com variações perceptíveis entre essas nações.

No caso do receio de um regime climático que limite suas emissões, os três países se veem como potenciais afetados por serem grandes emissores. Nenhum dos três, vale notar, integra o Anexo I do Protocolo de Quioto, isto é, a lista dos países com compromissos de redução de emissão em vigor. A Coreia, a despeito da renda per capita mais elevada, caracterizou-se no Protocolo como nação de industrialização tardia, fugindo às obrigações do acordo. Taiwan também não integra, porque, em que pese a renda alta, também se industrializou tardiamente e, principalmente, porque vive na peculiar situação de não ser reconhecido como um Estado soberano nas Nações Unidas.

Um novo regime para suceder a Quioto, porém, tende a incluir ao menos Coreia e China, não havendo clareza do tratamento a ser dado a Taiwan - que, de todo modo, em sua busca por inserção e reconhecimento internacional, tende a seguir as diretrizes de eventual acordo adotado, ainda que não esteja juridicamente vinculado.

A despeito de os países se verem como potenciais afetados pelo novo regime, suas reações têm sido diferentes. Enquanto que a ameaça de limitação de emissões levou a China a empenhar-se fortemente na transição - ainda que muito gradual - para uma economia de baixo carbono, nos casos de Coreia e de Taiwan esse esforço ainda não ficou tão claro em 
ações no campo doméstico, embora em termos retóricos os países tenham assumido posição progressista nos foros internacionais. Em verdade, esses dois países parecem estar apostando no cenário de baixo carbono como instrumento de política industrial, isto é, como um meio para garantir mercados novos para seus setores industriais de baixo carbono, conquanto não incorporem domesticamente os produtos de baixo carbono que têm desenvolvido e fabricado - ao menos não em grande intensidade. Coreia e Taiwan têm aproveitado o mercado de baixo carbono que se formou na Europa, nos Estados Unidos e em outros países para exportar produtos que concebem e manufaturam.

No caso do regime de patentes, os países conseguiram realizar uma transição mais suave de uma economia baseada em imitação para uma economia em transição para a inovação. Na Coreia e em Taiwan, quando o novo regime de propriedade industrial foi consagrado no Acordo TRIPS, em meados dos anos 1990, o nível de sofisticação da economia já era superior à brasileira, se observada a renda per capita e a intensidade tecnológica da pauta de exportação.

Ainda assim, os países adiaram a implementação das novas regras, promovendo uma transição mais suave do que a brasileira. No caso da China, o ingresso do país na Organização Mundial do Comércio e a consequente adoção do Acordo TRIPS foi ainda mais retardada, só sendo implementadas as medidas - e ainda assim com restrições - em fins da década de 2000.

A preocupação com a segurança energética afeta diretamente os três países asiáticos, embora de modo diferente. Enquanto que Coreia e Taiwan não dispõem de fontes energéticas primárias em seu território, a China, embora disponha delas, depende majoritariamente de fontes intensivas em carbono, associadas à mudança climática e à grave crise de poluição atmosférica local. Os três países lançaram um grande esforço, nessa linha, por encontrar fontes energéticas que mitiguem sua dependência. Desenvolvimento de tecnologia de baixo carbono, notadamente solar, é marca comum aos três. No caso da Coreia, somou-se a ênfase à tecnologia nuclear. No caso da China, o esforço foi mais abrangente, incluindo também eólica, biomassa e nuclear, além de, diferentemente de Coreia e Taiwan, vir acompanhado da adoção doméstica das novas tecnologias em larga escala.

Quanto ao câmbio, ele exerceu papel importante em assegurar a competitividade do setor industrial nos três países examinados, que lograram, por diversas medidas, garantir um câmbio sistematicamente depreciado. Além de não enfrentarem o problema da exportação abundante de recursos naturais (Coreia e Taiwan por ausência deles, China por utilização majoritária para a própria economia), os asiáticos restringiram os investimentos estrangeiros 
diretos, estabeleceram regras cambiais que restringem o livre fluxo de capital e dispõem de volumosas reservas cambiais.

Por fim, os três países forjaram um sistema de aprendizado ativo, baseado em empresas de capital local, trabalhadores com alta qualificação, investimentos em P\&D e parcerias com institutos públicos de pesquisa. $\mathrm{O}$ sistema ativo foi um facilitador para que as tecnologias de baixo carbono, inicialmente concebidas em outros países, fossem incorporadas e aprimoradas pelas empresas locais, permitindo que suas indústrias assumissem papel de destaque em partes tecnologicamente intensivas da cadeia produtiva.

Somados, esses elementos permitiram que a política energética nas três nações asiáticas examinadas estivesse fortemente casada com a política industrial e tecnológica. A garantia de oferta segura de energia dentro de um contexto internacional de propriedade intelectual rígida e restrição à emissão de gases estufa teria que ser viabilizada por meio do desenvolvimento de novas tecnologias para acessar fontes de baixo carbono. Na China, além do casamento com a política industrial e tecnológica, a política energética esteve, em certa medida, associada à política ambiental local, dada a necessidade de melhorar a qualidade do ar nos grandes centros urbanos. Na Coreia e em Taiwan, entretanto, esse casamento não foi tão pronunciado, dado que a maior parte das novas tecnologias têm servido para exportação.

Em síntese, embora o Brasil disponha de uma matriz energética relativamente menos poluente, a indústria brasileira que fornece os equipamentos para o setor permanece tecnologicamente dependente de tecnologias concebidas no exterior. No caso dos três países asiáticos, a despeito de ostentarem uma matriz energética muito intensiva em carbono, eles estão atualmente em busca por liderança em setores industriais intensivos em tecnologia para as fontes energéticas de baixo carbono.

\subsection{Indicador sintético para mensurar situação do setor de energia de baixo carbono}

Para mensurar a situação dos países examinados na área de energia limpa, é útil e ilustrativo fazer uso também de dados quantitativos. Para tanto, trabalhamos com a construção de indicadores que condensem em um gráfico de fácil leitura três fatores: a) geração de energia; b) manufatura; e c) inovação tecnológica. 
Para fins desse indicador, adotaremos no conceito de energia limpa as fontes hidráulica, biomassa, eólica, solar e nuclear. Ficam, portanto, excluídas as fontes fósseis, dada a elevada emissão de carbono que sua combustão acarreta.

O gráfico consiste na construção de um triângulo com três indicadores, com escalas de zero a cem, cada uma para um dos segmentos avaliados. No caso da geração, o indicador consiste na participação das diferentes fontes de energia limpa na matriz energética do país, medida pela capacidade instalada em 2012. Zero seria a ausência de qualquer capacidade instalada dessas fontes e cem corresponderia ao suprimento de toda a energia por meio de fontes renováveis.

Já quanto à manufatura, o indicador consistirá no cálculo do total de manufatura produzida no país em energia limpa em 2012. Não existe um indicador simples a sintetizar esses dados em todas essas fontes, tampouco é trivial consolidar as informações referentes a todas as etapas de produção. A partir de dados agregados de produção e de rankings de grandes produtores, concebemos um índice que sintetiza, por aproximação, dados sobre as etapas da manufatura mais tecnologicamente intensivas das quatro fontes energéticas: no caso da hidráulica, as turbinas; no caso da eólica, os aerogeradores; na solar, as células solares; na biomassa, a produção agrícola de etanol e biodiesel; na nuclear, a fabricação de reatores. A opção pelo uso do que se adicionou à capacidade instalada em determinado ano se deve ao fato de que esse é o universo em que trabalham as manufaturas, e não o total da geração acumulada ao longo de décadas de investimentos, que pode refletir as manufaturas outrora existentes, mas não as atuais.

Por fim, quanto à inovação, serão condensados dois indicadores: patentes e investimentos em P\&D em relação ao PIB (assumindo que a proporção de investimentos em energia de baixo carbono segue o padrão do restante da economia).

Os triângulos constantes do Gráfico 48 sintetizam as informações dos quatro países examinados. Como se pode observar, todos os países têm atividade manufatureira robusta no campo de energias renováveis (traços à direita no triângulo, de modo que, quanto mais longo, maior a atividade no setor). Nesse item, a China tem uma produção ainda mais destacada do que a dos demais, o Brasil e a Coreia ficam em uma posição intermediária e Taiwan, por não atuar em todas as fontes, fica um pouco mais atrás, ainda que em patamar não muito distante.

De fato, a industrialização tardia dos quatro países passou pela criação de uma estrutura industrial ampla de substituição de importações e as fábricas locais passaram a suprir parcela significativa da demanda doméstica. Mas há variações relevantes omitidas pelo uso da 
média: o destaque para a hidráulica, biomassa e eólica no Brasil (juntamente com a quase inexistência em solar); a ênfase em solar e nuclear na Coreia; a preponderância da indústria solar de Taiwan, com pouca participação em biomassa e hidráulica; e o papel de grande centro industrial exercido pela China em praticamente todas as áreas, com menos destaque apenas em biomassa.

\section{GRÁFICO 48}

Inovação, manufatura e geração de energia de baixo carbono, 2012

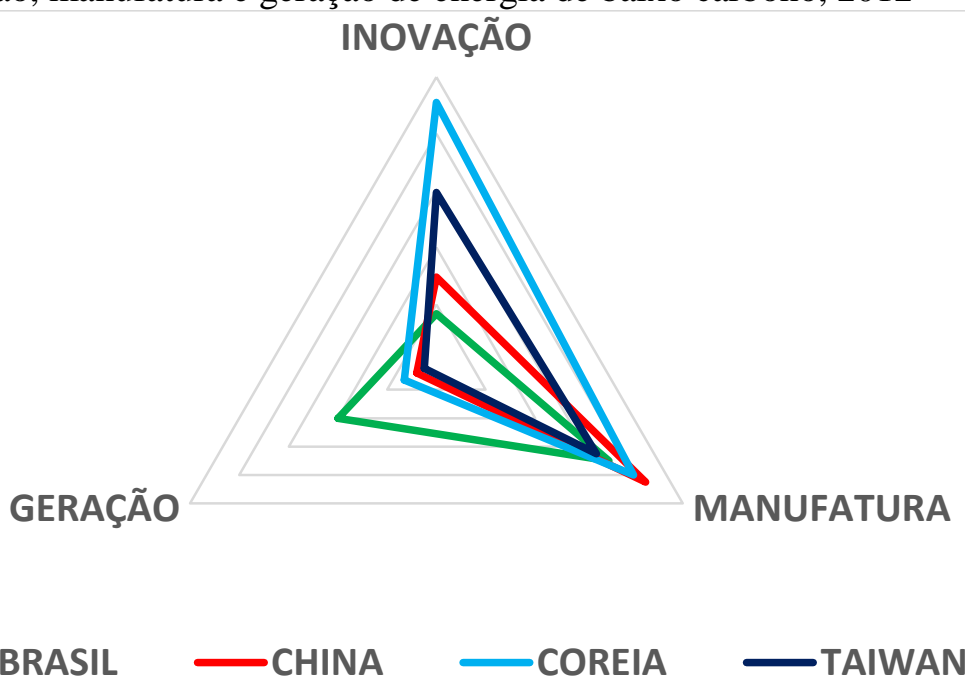

Fonte: Elaboração própria.

Em termos de geração de energia, contudo, a situação se altera substancialmente. O Brasil é o claro destaque entre os que geram energia com fontes renováveis, predominando a hidráulica e a biomassa (traços à esquerda no triângulo, de modo que, quanto mais longo, maior a geração com baixo carbono). Na China, embora a geração renovável venha crescendo em ritmo acelerado, ela ainda não é tão elevada em relação à demanda total do país. A geração de energia renovável na Coreia e em Taiwan é praticamente irrelevante (menos de $1 \%$ da matriz), mas a Coreia pontua um pouco melhor em razão da presença relevante da energia nuclear.

Por fim, o índice de inovação é o que torna a situação mais curiosa, uma vez que o maior gerador de energia renovável - caso do Brasil -, mesmo com uma atividade manufatureira robusta, apresenta atividade inovativa muito baixa (traços acima no triângulo, de modo que, quanto mais alta a linha, maior a atividade inovativa). Já Coreia e Taiwan, mesmo com geração quase irrelevante de energia renovável e um nível intermediário de manufatura, exibem uma capacidade de inovação claramente sobressaída. A China, por fim, com sua 
pujança industrial, apresenta uma atividade de inovação relevante, ainda que abaixo da verificada em Coreia e Taiwan.

O Gráfico 48, com os quatro triângulos sobrepostos, auxilia na visualização das estratégias de cada país. O Brasil aproveitou a abundância de fontes renováveis e vem priorizando a geração de energia por essas fontes por intermédio de manufaturas locais, ainda que fazendo uso em larga medida de tecnologias concebidas no exterior. A área de biomassa é a única em que o país, além de ter uma atividade de produção relevante, também se destaca em inovação. A ênfase em hidrelétricas também não auxilia na inovação, por se tratar de uma tecnologia já madura, na qual a curva de aprendizado apresenta resultados muito modestos.

Coreia e Taiwan, por sua vez, têm conferido pouca importância até o momento para a geração de energia a partir de fontes de baixo carbono - à exceção da nuclear na Coreia. Aproveitam, entretanto, o cenário internacional de gradativa restrição ao carbono para praticar uma política industrial e tecnológica agressiva, pela qual desenvolvem e executam produtos de baixo carbono com foco em exportação, especialmente na fonte solar. Desse modo, não arcam de imediato com o custo da transição para uma economia de baixo carbono, mas se posicionam como líderes das tecnologias em que a curva de aprendizado ainda dá margem a bastante inovação e aumento de produtividade.

A China, por sua vez, tem ao mesmo tempo se empenhado em elevar a geração de energia renovável e em desenvolver tecnologias para indústrias locais. Mesmo no caso chinês, o esforço inicial em energia solar passou pela mesma estratégia sulcoreana e taiwanesa de deixar a maior parte do custo da transição para os países desenvolvidos, criando inicialmente uma indústria local com foco em exportação e, só posteriormente, passando a promover o mercado interno com essa tecnologia. Nas outras fontes, a atividade industrial chinesa foi casada com a expansão de um mercado interno inicialmente protegido, de modo a garantir escala e menor risco aos investimentos.

Em síntese, o Brasil optou por priorizar a geração e a manufatura em energias de baixo carbono, embora com pouca intensidade tecnológica desenvolvida localmente. A política energética brasileira se relaciona com a ambiental e a industrial, mas não tanto com a tecnológica.

Coreia e Taiwan têm dado baixa ênfase à geração de fontes renováveis, mas têm se valido do contexto internacional para montar uma indústria inovadora no segmento de baixo carbono. Ainda que um tanto apartada da política ambiental doméstica, há um forte componente de política industrial e tecnológica nas políticas energéticas desses países. 
Por fim, a China tem se valido de um forte entrelaçamento da política energética com as políticas ambiental, industrial e tecnológica, ainda que o país permaneça como intensivo usuário de fontes fósseis em sua lenta transição para uma economia de baixo carbono. 


\section{CONCLUSÃO}

\section{Observações gerais}

Brasil, China, Taiwan e Coreia do Sul estão seguindo diferentes trajetórias para adaptar as respectivas matrizes energéticas ao cenário internacional de crescente restrição à emissão de carbono.

Esta tese de doutorado argumenta que o receio de restrições internacionais à emissão de carbono levou os países a adotarem ações concretas para adaptar seus parques industriais e suas matrizes energéticas a esse cenário. O mero risco de limitar as emissões de gases estufa provocou mudanças nas políticas industrial e energética dos países examinados, ainda que as medidas tenham natureza e objetivos distintos.

Adicionalmente, o regime internacional de propriedade industrial estabelecido pelo Acordo TRIPS levou os países de industrialização tardia a modificar suas práticas de incorporação de tecnologia estrangeira, passando a utilizar instrumentos mais sofisticados de absorção de inovações que não transgridam as rígidas regras internacionais de patentes.

No projeto de tese, trabalhava-se com a hipótese de que o Brasil, favorecido por condições naturais privilegiadas (potencial hidráulico disponível, terras aráveis para biomassa e reservas de petróleo recém descobertas), não estaria encorajando na mesma intensidade que outras nações o desenvolvimento de inovações em fontes limpas de energia, mantendo uma estratégia de expansão da matriz energética com as tecnologias e fontes tradicionais. Essa hipótese foi em parte confirmada pelos dados arrolados ao longo deste trabalho, que evidenciam a expansão da matriz energética brasileira desacompanhada de grandes inovações. Entretanto, o Brasil é um dos líderes em geração de energia de baixo carbono, tem um parque industrial relevante na área e, no caso da biomassa, tem atividade inovativa relevante.

Em contraste, ainda que usando domesticamente fontes de baixo carbono em menor quantidade do que o Brasil, os países asiáticos em questão têm investido fortemente em inovação tecnológica em energia. Mas o ritmo de expansão doméstica do uso das novas tecnologias é bastante lento na Coreia e em Taiwan e levemente mais acelerado na China.

Os dados examinados ao longo da tese apontam para a existência de cinco fatores moldando a nova política energética das nações em questão: a) potencial regime 
internacional de carbono; b) segurança energética; c) sistema nacional de aprendizado tecnológico; d) regime internacional de patentes; e) câmbio.

O potencial regime internacional de carbono levou Coreia, Taiwan e China, países cujas economias são intensivas em emissões, a direcionarem suas políticas energéticas no sentido de construir um parque industrial robusto em tecnologias de baixo carbono. No Brasil esse impulso não se fez tão presente em razão da situação de relativo conforto do país no que tange às emissões de carbono, se consideradas em termos per capita ou em relação ao PIB.

No que tange à segurança do suprimento das fontes primárias de energia, Coreia e Taiwan, por dependerem quase que integralmente de importação de carvão, óleo e gás, foram impulsionados a buscar as fontes renováveis disponíveis em seus territórios, além da expansão da nuclear. A China também se viu em situação de relativa vulnerabilidade em razão da abundância no território chinês apenas de carvão, altamente intensivo em carbono. Já o Brasil, além de usufruir de baixa dependência de importados, conta ainda com abundância de potencial hídrico, de terras aráveis para biomassa e, ainda que intensivo em carbono, do petróleo e do gás do pré-sal.

Esses dois fatores (potencial regime climático e disponibilidade de fontes energéticas) serviram para impulsionar os países asiáticos a enveredar pelo campo das energias de baixo carbono. Ao mesmo tempo, esses fatores exerceram pouca influência no Brasil, dada a situação de relativamente baixa intensidade de carbono e de abundância de fontes no próprio território. Outros três fatores foram incorporados à análise por exerceram influência diferente em cada um dos países.

O primeiro é o sistema de aprendizado tecnológico predominante em cada nação. Os três países asiáticos construíram um sistema de aprendizado tecnológico ativo, baseado em industrialização a partir de empresas locais, qualificação de mão-de-obra, investimentos em P\&D empresarial, parceria de empresas com universidades e institutos públicos de pesquisa, além de substituição de importações casada com a orientação exportadora. No Brasil, o sistema de aprendizado prevalecente se baseou na industrialização a partir de subsidiárias integrais de empresas estrangeiras, baixa qualificação média da mão-deobra, baixo nível de investimentos em P\&D empresarial, reduzida integração com universidades e institutos de pesquisa e foco na substituição de importações.

O segundo fator reside na implantação do regime internacional de propriedade industrial, consolidado no Acordo TRIPS. O novo modelo enfraqueceu as estratégias de emparelhamento tecnológico típicas dos anos 1970 e 1980, por colocar entraves à imitação de 
inovações concebidas no exterior. Coreia e Taiwan, que já estavam alguns estágios à frente do Brasil no emparelhamento tecnológico, ainda assim postergaram a mudança e transitaram com menos dificuldade para o novo estágio. A China logrou adiar ao máximo a adoção do novo regime e, quando o fez, ainda se beneficiou do poder de barganha que seu imenso e crescente mercado interno proporcionou para cumprir apenas parcialmente as normas internacionais. $\mathrm{O}$ Brasil adotou as novas regras de maneira relativamente prematura e enfrentou mais obstáculos na transição para o novo desenho institucional.

Por fim, o câmbio desempenhou papel importante para a industrialização. A recorrente depreciação das moedas asiáticas foi um dos fatores que as auxiliou no processo de emparelhamento tecnológico. No caso brasileiro, especialmente depois da redução da proteção tarifária no início dos anos 1990, a abundância de recursos naturais provocou o processo denominado de "doença holandesa", consistente na sobreapreciação cambial decorrente da exportação de produtos primários. Como consequência da apreciação excessiva da moeda, o setor manufatureiro perdeu competitividade e enfrentou limitações em sua capacidade de empreender esforços de inovação.

Desse modo, o potencial regime de mudança climática e a ausência de fontes primárias de baixo carbono em seus territórios impulsionaram os países asiáticos a buscar novas tecnologias de baixo carbono. Nessa empreitada, esses países puderam se utilizar do sistema de aprendizado ativo que já haviam estruturado e da moeda depreciada, conseguindo beneficiar-se do regime internacional de propriedade industrial. No caso brasileiro, o regime de mudança climática e a abundância de recursos naturais não serviram como impulso substantivo para inovações de baixo carbono. Além disso, o sistema de aprendizado passivo e o câmbio sobreapreciado serviram como obstáculos para as tentativas de desenvolver tecnologia na área.

É nesse contexto que foram moldadas as políticas energéticas dos quatro países. As medidas adotadas na Coreia do Sul e em Taiwan têm se voltado muito mais ao desenvolvimento do setor industrial, do que à mudança da matriz energética. Esses países tentam se beneficiar do cenário internacional principalmente pela exportação de tecnologias de baixo carbono, mas os esforços domésticos para mitigar as emissões de carbono são ainda muito limitados. Ressalvado o uso crescente de energia nuclear na Coreia, ambos mantêm uma matriz energética intensiva em carbono, mas estão criando setores industriais fortes e inovadores em tecnologias limpas, focadas em exportação.

A China, por sua vez, a despeito da utilização ainda intensa de carvão, adotou política energética em direção à descarbonização, tanto por meio de novos segmentos 
industriais, como por intermédio da mudança da matriz. Os esforços lançados pelo governo chinês não se limitam a construir um setor industrial pujante e crescentemente inovador em tecnologias de baixo carbono, mas o país tem também adotado medidas concretas para ampliar substancialmente a participação dessas tecnologias em sua própria matriz energética. Embora tenha atualmente a matriz energética mais intensiva em carbono, é também o que tem avançado mais rapidamente na instalação de capacidade de geração de energia de baixo carbono, por meio de um setor industrial local com poder e influência crescentes.

No caso do Brasil, consolidou-se ao longo dos anos a utilização de fontes energéticas de baixo carbono, notadamente a hidráulica e a biomassa. Ambientalmente, o país sul-americano tem hoje a matriz energética mais limpa dos quatro países comparados e dispõe de uma estrutura industrial robusta, que fornece parcela relevante dos equipamentos. O modelo industrial, contudo, preserva os traços históricos da dependência tecnológica, logrando, por um lado, que parcela relevante dos equipamentos seja manufaturada no Brasil, mas, por outro, que esses mesmos produtos sejam concebidos e desenhados no exterior.

\section{Sugestões de políticas públicas para o Brasil}

Esta tese aborda dois problemas de grande relevo: a mitigação da mudança climática e o desenvolvimento econômico e tecnológico do Brasil. A adoção de medidas que equilibrem esses dois objetivos não é trivial e exige um balanceamento sutil, além de exigir a avaliação da conjuntura e das possibilidades políticas e econômicas.

É certo, porém, que as medidas devem almejar esses dois objetivos: a) a redução da curva de aumento das emissões de carbono; e, principalmente, b) o desenvolvimento de tecnologias de baixo carbono no Brasil. Entre as medidas concretas que podem auxiliar esses dois propósitos, listam-se as seguintes:

- Criação de estrutura de P\&D pública na área de energia de baixo carbono, para exercer papel similar à da Embrapa no setor agrícola, ou à do ITA no setor aeroespacial, com estrutura de governança adequada para essa missão; 
- Remover barreiras ainda existentes e fomentar a aproximação universidade-empresa com vistas a pesquisas inovadoras, além de desestimular essa relação nos casos de mera tropicalização, que deveriam ficar a cargo inteiramente das empresas estrangeiras;

- Rever desenho do Programa de P\&D administrado pela Aneel, a fim de que as pesquisas custeadas pelas empresas sejam voltadas exclusivamente a atividades de inovação tecnológica, e não a atividades de mera operação e manutenção de atividades de rotina;

- Utilizar parâmetro de conteúdo nacional nas energias eólica e solar com foco em desenvolvimento tecnológico nacional, e não tanto em manufatura local, definindo-se prazos claramente delimitados e estrutura transparente;

- Instituir tributo sobre o carbono com vistas a reforçar a "paridade" das renováveis em relação às demais fontes, precificando a externalidade negativa dos combustíveis fósseis;

- Ampliar gradativamente a inserção da energia solar fotovoltaica no sistema interligado nacional, seja por meio de quota (Renewable Portfolio Standard), seja via feed-in tariff, seja ainda pela realização de leilão exclusivo para a fonte, em pequenas quantidades, com o propósito principal de erigir esse segmento industrial no Brasil enquanto o preço da tecnologia segue em queda;

- Restabelecer imposto sobre a exportação de produtos primários sem agregação de valor no país, em particular no caso do silício não-purificado e do minério de ferro bruto;

- Planejar novas hidrelétricas com reservatórios adequados e com bombeamento d'água para viabilizar o armazenamento de energia potencial oriunda das fontes intermitentes, particularmente solar e eólica;

- Retomar os planos de expansão de geração de energia nuclear para além das usinas localizadas em Angra dos Reis, de modo a conferir escala aos processos industriais e viabilizar até mesmo exportações brasileiras no segmento;

- Acelerar os passos para instalar uma rede inteligente (smart grid), de modo a permitir o gerenciamento do sistema elétrico com os desafios trazidos pela penetração progressiva das novas renováveis.

\section{Observações finais}


Os dados mais recentes sobre mudança climática indicam claramente que a queda necessária nas emissões globais terá que ser substancial para evitar impactos muito danosos ao meio ambiente. Essa impositiva redução drástica das emissões deverá ser liderada pelos países de renda alta, mas em alguma medida um esforço extra terá que ser feito pelos países de renda média. O flagrante atraso global em adotar medidas de mitigação restringiu enormemente o "orçamento" mundial disponível para emissão adicional de carbono, o que demandará uma solução que envolva todos os países, ainda que os custos sejam concentrados.

Sob a ótica brasileira, há que reconhecer que o desafio de promover tecnologias limpas não é trivial quando a tarifa energética (ou o custo fiscal de subsidiá-la) afeta tão fortemente a limitada renda de parte da população. Visto sob a ótica da justiça ambiental e do histórico de emissões, o ônus pela redução dos gases estufa deveria recair principalmente sobre os maiores emissores de gases estufa, particularmente os países de renda alta, além de alguns de renda média, como Rússia e China.

Entretanto, examinada a questão com uma perspectiva de longo prazo para um país que ainda busca consolidar o setor industrial e fomentar a inovação, o fato é que um mercado global de dimensão gigantesca está claramente em gestação. O país precisará - já precisa - de tecnologias de baixo carbono e atualmente tem se utilizado do licenciamento das tecnologias desenvolvidas no exterior. A mudança em curso da matriz energética pode ser vista como uma janela de oportunidade. Demitir-se de tentar a liderança tecnológica nesse setor pode revelar-se um equívoco no longo prazo.

Quando comparado a outros países em relação à sua contribuição para a mudança climática, o Brasil está relativamente bem situado: a matriz energética é comparativamente mais limpa do que a média global, a industrialização foi mais recente, o desmatamento vem caindo de maneira acentuada. Em termos de manufaturas, o Brasil tem uma produção robusta no fornecimento de equipamentos para o setor elétrico, ainda que bastante dependente de empresas estrangeiras que construíram linhas de montagem no país. No que tange à inovação é que o país tem deixado de investir suficientemente, particularmente no setor privado.

Mas a ausência de investimento em pesquisa energética pelo setor privado se deve em larga medida à estrutura industrial brasileira dependente e à ausência de um mercado local estruturado e previsível, particularmente para o etanol e para a energia solar fotovoltaica. Não recaindo sobre o país a responsabilidade principal pela mudança climática, o Brasil não tem o dever de agregar em larga escala e no curto prazo a geração de energias caras, como a 
solar. Mas gradualmente o país pode fazer uso de seu volumoso mercado interno para criar uma indústria nacional no setor, que tenha condições de disputar a fronteira tecnológica.

O Brasil pode, portanto, ao mesmo tempo em que colabora para a resolução de um desafio global de grandes proporções - a mudança climática -, também beneficiar-se na formação de uma indústria de energia de baixo carbono. Com o parque industrial já montado e com uma rede de universidades e centros de pesquisa organizados, as empresas brasileiras não estão fora da disputa internacional pela liderança tecnológica nas fontes de baixo carbono. Cabe ao Brasil, portanto, promover a integração do setor industrial com a academia, melhorar as condições de competitividade da indústria brasileira, fomentar o mercado de baixo carbono doméstico e expandir as exportações nesse segmento.

Caso a política tecnológica brasileira também passe a integrar a política energética, faz sentido que a política externa nacional também se adapte nas negociações de mudança climática. Em vez de tratar a questão apenas como uma ameaça ao desenvolvimento brasileiro, a posição brasileira poderia se voltar à promoção das indústrias em que o país disputa a fronteira tecnológica - como, atualmente, ocorre com a biomassa. Desse modo, ao mesmo tempo em que defenderia os interesses nacionais, a política externa também se alinharia com o interesse da humanidade em evitar mudanças climáticas desastrosas. 


\section{REFERÊNCIAS BIBLIOGRÁFICAS}

ABRAMOVAY, Ricardo. A apropriação da sustentabilidade pelas grandes marcas globais. Publicado no jornal Folha de S. Paulo, na edição de 18/07/2013. São Paulo: Folha de São Paulo, 2013.

ACEMOGLU, Daron; e ROBINSON, James A. Why nations fail: the origins of power, prosperity, and poverty. New York: Crown Business, 2012.

ALBUQUERQUE, Eduardo da Motta. Patentes segundo a abordagem neo-schumpeteriana: uma discussão introdutória. Revista Economia Política, 18, no. 4, 1998.

ALLEN, Benjamin S. Brazil: Disentangling Green Industry from Brown Consequences. In: Can Green Sustain Growth? From the Religion to the Reality of Sustainable Prosperity. Edited by Mark Huberty and John Zysman. Stanford University Press, 2013.

ALVES, José Augusto Lindgren. Relações Internacionais e temas sociais: a década das conferências. Brasília: IBRI, 2001.

ARRHENIUS, Svante. Worlds in the making: the evolution of the universe. New York: Harper \& Brothers, 1908.

ASIA TRADE HUB. Saudi Arabia: Tax Structure. Disponível em: http://www.asiatradehub.com/saudiarabia/tax.asp. 2014.

ASSAD, Eduardo Delgado. Agricultura de Baixa Emissão de Carbono: A evolução de um novo paradigma. Organização: Fundação Getúlio Vargas - Centro de Agronegócio da Escola de Economia de São Paulo. 2013.

BANA, Sarosh. Market report: South Korea and its renewable energy ambition. Disponível em: FONTE: http://www.renewableenergyfocus.com/view/31555/market-reportsouth-korea-and-its-renewable-energy-ambition/. Publicado em $1^{\circ}$ de abril de 2013.

BANCO MUNDIAL. Conhecimento e inovação para a competitividade. Tradução: Confederação Nacional da Indústria. Brasília: CNI, 2008.

BARBOSA, Denis Borges. Uma introdução à propriedade intelectual. $2^{\mathrm{a}}$ edição. Rio de Janeiro: Lumen Juris, 2003.

. Direito da Inovação - Comentários à Lei no 10.793/2004 - Lei Federal de Inovação. $1^{\text {a }}$ edição. Rio de Janeiro: Lumen Juris, 2006. 
BARRETO, Clayton Ribeiro; VELOSO, Gilberto de Oliveira; e ILHA, Adayr da Silva. Poupança externa, variações cambiais e crescimento econômico no Brasil: uma abordagem com mecanismo de correção de erros. Disponível em http://www.anpec.org.br/sul/2013/submissao/files_I/i6cb4d6931fe20d4ee3d7a83097aec80da.pdf. 2013.

BATISTA. Biano Gotelipe Gomes. O boom do minério de ferro na economia brasileira: houve dutch disease? Dissertação de mestrado. Universidade Federal de Ouro Preto. 2009.

BLOOMBERG. Most innovative in the world 2014: Countries. Disponível em: http://images.businessweek.com/bloomberg/pdfs/most_innovative_countries_2014_ 011714.pdf. 2015.

BORJA, Bruno. O sentido da tecnologia: a teoria do subdesenvolvimento de Celso Furtado. Dissertação de mestrado do Instituto de Economia da Universidade Federal do Rio de Janeiro. Rio de Janeiro, 2008.

BRASIL, Ministério de Minas e Energia, Empresa de Pesquisa Energética. Plano Decenal de Expansão de Energia 2022. Brasília: MME/EPE, 2014.

BRASIL, Portal Brasil. Ciência e Tecnologia: usina de enriquecimento fornecerá urânio para Angra 1. Disponível em: http://www.brasil.gov.br/ciencia-etecnologia/2014/11/usina-de-enriquecimento-fornecera-uranio-para-angra-1. 2014.

Governo: Leia íntegra do discurso de posse de Dilma Rousseff no Congresso. Disponível em: http://www.brasil.gov.br/noticias/arquivos/2011/01/01/leia-integra-do-discurso-deposse-de-dilma-rousseff-no-congresso. 2014.

Portal Planalto: Discurso da Presidenta da República, Dilma Rousseff, durante Compromisso Constitucional perante o Congresso Nacional. Disponível em: http://www2.planalto.gov.br/acompanhe-o-planalto/discursos/discursos-dapresidenta/discurso-da-presidenta-da-republica-dilma-rousseff-durantecompromisso-constitucional-perante-o-congresso-nacional-1. 2015.

BRESSER-PEREIRA, Luiz Carlos; MARCONI, Nelson. Existe doença holandesa no Brasil? Trabalho apresentado ao IV Fórum de Economia da Fundação Getúlio Vargas. Disponível em http://www.bresserpereira.org.br/papers/2008/ 08.14.Existe.doen\%C3\%A7a.holandesa.comNelson.Marconi.5.4.08.pdf. 2008.

BRESSER-PEREIRA, Luiz Carlos; GALA, Paulo; ARAÚJO, Eliane. Efeitos da taxa de câmbio na poupança interna: análise teórica e evidências empíricas para o caso 
brasileiro. Textos para discussão 252 - Escola de Economia de São Paulo, Fundação Getúlio Vargas. 2010.

BROOKINGS INSTITUTION. ROK-U.S. Civil Nuclear and Nonproliferation Collaboration in Third Countries. Por McGoldrick, Fred F.; Einhorn, Robert J.; Kim, Duyeon; Tyson James L. Washington/DC: Brookings, 2015.

BUTTI, Ken. Horace de Saussure and his hot boxes of the 1700s. Excerto da obra: A golden thread: 2500 years of solar architecture and technology. Disponível em http://solarcooking.org/saussure.htm. 2004.

CANUTO, Otaviano. Brasil e Coréia do Sul: os (des)caminhos da industrialização tardia. São Paulo: Nobel, 1994.

CARBON TRACKER e GRANTHAM RESEARCH INSTITUTE. Unburnable Carbon 2013:

Wasted capital and stranded assets. Disponível em http://carbontracker.live.kiln.it/Unburnable-Carbon-2-Web-Version.pdf. 2013.

CARLSON, Ann E. Designing Effective Climate Policy: Cap-and-Trade and Complementary Policies. Harvard Journal on Legislation. Disponível em http://www3.law.harvard.edu/journals/jol/files/2013/09/Carlson.pdf. 2012.

CENTER FOR RESPONSIVE POLITICS. OpenSecrets.org: Contributions by sector. Disponível em https://www.opensecrets.org/overview/sectors.php?Cycle=2014\&Bkdn=Source $\&$ Sor tby=Rank e https://www.opensecrets.org/pres12/sectorall.php?cycle=2012. 2014.

CEPEL - Centro de Pesquisas de Energia Elétrica. A história do Cepel: o setor de energia elétrica e o desenvolvimento científico tecnológico. Disponível em: http://fund.cepel.br/organizacao/historia.shtm. 2014.

CGEE - CENTRO DE GESTÃO E ESTUDOS ESTRATÉGICOS. Análises e percepções para o desenvolvimento de uma política de CT\&I no fomento da energia eólica no Brasil. Brasília: CGEE, 2012.

CHANG, Ha Joon. Intellectual Property Rights and Economic Development - historical lessons and emerging issues. Journal of Human Development, v. 2, n. 2, 2001.

. Chutando a escada: a estratégia do desenvolvimento em perspectiva histórica; tradução Luiz Antônio Oliveira de Araújo. São Paulo: Editora UNESP, 2004.

CHEN, Victor Zitian; KAO Ming-Sung; e KUO, Anthony. Inward FDI in Taiwan and its policy contexto. Vale Columbia Center on Sustainable International Investment. Disponível em: http://ccsi.columbia.edu/files/2014/03/Profiles-Taiwan_IFDI-_FINAL__22_Mar_2012.pdf. 2012. 
CHENGSI, Zheng. The TRIPS Agreement and Intellectual Property Protection in China. In: Duke Journal of Comparative \& International Law. Disponível em: http://scholarship.law.duke.edu/djcil/vo19/iss1/10. 1998.

CHOU, Li-Fang; LIN, Liang-Feng. Renewable Energy Feed-in-Tariff System Design and Experience in Taiwan. Disponível em http://cdn.intechopen.com/pdfs-wm/26810.pdf. 2012.

CIA - CENTRAL INTELLIGENCE AGENCY. The World Factbook. Disponível em https://www.cia.gov/library/publications/the-world-

factbook/rankorder/2254rank.html?

countryname $=$ Korea, $\% 20$ South $\&$ countrycode $=\mathrm{ks} \&$ regionCode $=$ eas \&rank=7\#ks . 2013.

CIMOLI, Mario; DOSI, Giovanni; NELSON, Richard R.; e STIGLITZ, Joseph. Institutions and Policies Shaping Industrial Development: an introductory note. Laboratory of Economics and Management (LEM). Sant'Anna School of Advanced Studies. Pisa, 2006.

COHEN, Stephen S; ZYSMAN, John. Manufacturing matters: the myth of the post-industrial economy. Basic Books Inc. Publishers: Nova York, 1987.

COLE, Daniel H. Climate Change, Adaptation, and Development. Faculty Publications. Paper 386. Disponível em $\quad$ http://www.repository.law.indiana.edu lcgi/viewcontent.cgi? article=1384\&context=facpub. 2007 .

CORDEN, W. Max; NEARY, J. Peter. Booming Sector and De-Industrialisation in a Small Open Economy Source. The Economic Journal, Vol. 92, No. 368, 1982.

CORDEN, W. Max. Booming sector and dutch disease economics: survey and consolidation. Oxford Economic Papers, 1984.

CORREA, Carlos M. Recent international developments in the area of intellectual property rights. ICTSD-UNCTAD Dialogue. 2nd Bellagio Series on Development and Intellectual Property, 18-21, Setembro de 2003.

CPUC - California Public Utilities Comission. Energy Storage Framework Staff Proposal. CPUC Energy Stoarage Proceeding R-10-12-007 - Elizaveta Malashenko, Rebecca Lee, Chris Villareal, Ted Howard and Aloke Gupta. 2012.

CTC - CENTRO DE TECNOLOGIA CANAVIEIRA. Energia Brasileira para o Mundo. Disponível em: http://www.ctcanavieira.com.br/energiabrasileira.html. 2014.

DAVIES, Ken. Inward FDI in China and its policy context. Vale Columbia Center on Sustainable International Investment. Disponível em: 
http://ccsi.columbia.edu/files/2014/03/Profiles_China_IFDI_24_Oct_2012__FINAL.pdf. 2012.

DAVIS, Graham A.; TILTON, John E. The resource curse. Natural Resources Forum 29. Disponível em http://lawweb.colorado.edu/profiles/syllabi/banks/Davis \%2520\%2520Tilton\%2520-\%2520The\%2520resource\%2520curse.pdf. 2005.

DODSON, Bill. China Fast Forward: The Technologies, Green Industries and Innovations Driving the Mainland’s Future. Singapore: John Wiley \& Sons Singapore, 2012.

DOREMUS, Holly; LIN, Albert C.; ROSENBERG, Ronald H.; SCHOENBAUM, Thomas J. Environmental Policy Law. Fifth edition. Thomson Foundation Press: Nova York, 2008.

DORNELLES, Ricardo de Gusmão. Entrevista realizada pelo autor por telefone em 5 de dezembro de 2013.

DUBEUX, Rafael. Inovação no Brasil e na Coreia do Sul: os efeitos do novo regime internacional de patentes sobre as estratégias de desenvolvimento econômico. Curitiba: Editora Juruá, 2010.

EPI - EARTH POLICY INSTITUTE. Annual Solar Photovoltaics Production by Country: 1995-2010. Disponível em www.earth-policy.org/datacenter/xls/book_wote ch9_solar_2.xls. 2011.

EASTERLY, William Russell. O espetáculo do crescimento; tradução Alice Xavier. Rio de Janeiro: Ediouro, 2004.

EIA - US Energy Information Administration. US Annual Energy Review. Disponível em http://www.eia.gov/totalenergy/data/annual/pdf/sec1_3.pdf. 2011a.

Brasil Overview/Data. Disponível em

http://www.eia.gov/countries/cab.cfm?fips=BR, 2011 b.

Brasil Overview/Data. Disponível em

http://www.eia.gov/countries/cab.cfm?fips=CH, 2011c.

Coreia Overview/Data. Disponível em http://www.eia.gov/countries/cab.cfm?fips=KS, 2011d.

Taiwan Overview/Data. Disponível em http://www.eia.gov/countries/countrydata.cfm?fips $=$ tw, $2011 \mathrm{e}$.

. Electric Power Monthly: Average Retail Price of Electricity to Ultimate Customers by End-Use Sector. Disponível em: http://www.eia.gov/electricity/monthly/epm_table_grapher.cfm?t=epmt_5_6_a.

2013. 
ELKIND, Ethan N. Reuse and repower: How to Save Money and Clean the Grid with SecondLife Electric Vehicle Batteries - September 2014. UCLA Law and Berkeley Law Report. Disponível em http://webshare.law.ucla.edu/Emmett/climate-andbusiness/reuse-and-repower.pdf. 2014.

EPE - Empresa de Pesquisa Energética. Informe à imprensa - Leilão de Energia de Reserva.

Disponível em: http://www.epe.gov.br/imprensa/PressReleases/20080814_1.pdf. 2008.

Informe à imprensa - Leilões de fontes alternativas 2010. Disponível em http://www.epe.gov.br/imprensa/PressReleases/20100826_1.pdf. 2010.

. Leilão de Energia de Reserva de 2014: Participação dos Empreendimentos Solares Fotovoltaicos: Visão Geral. EPE, Brasília, 2014.

EPIA - EUROPEAN PHOTOVOLTAIC INDUSTRY ASSOCIATION. GLOBAL MARKET OUTLOOK For Photovoltaics 2014-2018. Disponível em: http://www.epia.org/index.php?eID=tx_nawsecuredl\&u=0\&file=/uploads/tx_epiapu blications/44_epia_gmo_report_ver_17_mr.pdf\&t=1424059000\&hash=7d99c992c5 b9a81a3e20973462f1987c59f97d44. 2014.

ESTRELLA, Guilherme. Entrevista ao jornal Folha de S. Paulo, Caderno Mercado. Edição de 28 de outubro de 2013. Disponível em: http://www1.folha.uol.com.br/mercado/2013/10/1363062-gestao-de-reservas-delibra-deveria-ser-exclusiva-do-estado-diz-pai-do-pre-sal.shtml. 2013.

EVANS, Andrew. Taming the counterfeit dragon: the WTO, TRIPS and Chinese amendments to intellectual property laws. In: Georgia Journal of International and Comparative Law, 2003.

FAPESP. Políticas de desenvolvimento de atividades tecnológicas em filiais brasileiras de multinacionais - Relatório científico. Campinas: FAPESP, 2005.

FEARNSIDE, Philip M. Global warming: How much of a threat to tropical forests? In: Gokçekus, Huseyin; Turker, Umut; e LaMoreaux, James (eds.). Survival and Sustainability: Environmental concerns in the 21st Century. Berlim: Springer-Verlag, 2011.

FEDERMAN, Sonia Regina. Patentes: desvendando seus mistérios. Rio de Janeiro: Qualitymark, 2006.

FLEMING, James Rodger. Historical perspectives on climate change. New York: Oxford University Press, 1998.

FOX, Benjamin. Why Taiwan’s Sustainable Energy Policy Matters, 2011. 
FRANCO, Gustavo H. B. A inserção externa e o desenvolvimento. Revista de Economia Política, Vol. 18, no. 3, 1998.

FRIEDMAN, Thomas. Hot, Flat and Crowded: why we need a green revolution - and how it can renew America. Nova York: Farrar, Straus and Giroux, 2009.

FURTADO, Celso. Criatividade e dependência na civilização industrial. Círculo do Livro AS: São Paulo, 1978. Introdução ao Desenvolvimento: enfoque histórico-estrutural. Rio de Janeiro: Paz e Terra, 2000.

GALA, Paulo. Política cambial e macroeconomia do desenvolvimento. Tese de Doutorado na Fundação Getúlio Vargas de São Paulo. 2006.

GEO - Global Energy Observatory. Power Plants data. Disponível em http://globalenergyobservatory.org/select.php?tgl=Edit. 2014.

GILPIN, Robert. Global Political Economy: understanding the international economic order. Princeton: Princeton University Press, 2001.

GLOBAL COMPACT CITIES PROGRAMME. Disponível em http://citiesprogramme. com/archives/1426, 2012.

GRAU, Eros Roberto. A ordem econômica na Constituição de 1988. $8^{a}$ edição. São Paulo: Malheiros, 2003.

GWEC - Global Wind Energy Council. Global Wind Statistics 2011. Disponível em http://www.gwec.net/fileadmin/images/News/Press/GWEC_-_Global_Wind_ Statistics_2011.pdf. 2012.

HAMILTON, Alexander. Report on manufactures. Disponível em http://presspubs.uchicago.edu/founders/documents/v1ch4s31.html. 1791.

HAN, Guoyi; OLSSON, Marie; HALLDING, Karl; e LUNSFORD, David. China's Carbon Emission Trading: An Overview of Current Development. Stockholm Environment Institute. Disponível em http://www.seiinternational.org/mediamanager/documents/Publications/china-cluster/SEI-FORES2012-China-Carbon-Emissions.pdf, 2012.

HANKYOREH. Full text of Lee's inaugural speech. Disponível em: http://english.hani.co.kr/arti/english_edition/e_national/271850.html. Publicado em 25 de fevereiro de 2008.

HARDIN, Garret. The tragedy of the commons. Science, New Series, Vol. 162, No. 3859, 1968. 
HERMANN, Breno. O Brasil e a Lei de Propriedade Industrial (9.279/96): um estudo de caso da relação interno-externo. Dissertação (Mestrado em Relações Internacionais) Instituto de Relações Internacionais, Universidade de Brasília, Brasília, 2004.

IBGE - Instituto Brasileiro de Geografia e Estatística. Indicadores IBGE: Contas Nacionais Trimestrais: indicadores de volume e valores correntes. Disponível em: INftp://ftp.ibge.gov.br/Contas_Nacionais/Contas_Nacionais_Trimestrais/Fasciculo_I ndicadores_IBGE/pib-vol-val_201402caderno.pdf. 2014.

IEA - INTERNATIONAL ENERGY AGENCY. PVPS Report Snapshot of Global PV 19922013 Preliminary Trends Information from the IEA PVPS Programme. Disponível em: http://www.iea-pvps.org/fileadmin/dam/public/report/statistics/PVPS_report_A_Snapshot_of_Global_PV___1992-2013__final_3.pdf. 2014.

IMF - International Monetary Fund. World Economic Outlook Database. Disponível em http://www.imf.org/external/pubs/ft/weo/2012/01/weodata/index.aspx. 2012.

Energy Subsidy Reform: lessons and implications. Disponível em: http://www.imf.org/external/np/pp/eng/2013/012813.pdf. 2013.

INEP - INSTITUTO NACIONAL DE ESTUDOS EDUCACIONAIS ANÍSIO TEIXEIRA. Relatório Nacional Pisa 2012: resultados brasileiros. Disponível em http://download.inep.gov.br/acoes_internacionais/pisa/resultados/2014/relatorio_nac ional_pisa_2012_resultados_brasileiros.pdf. 2013.

INPE - INSTITUTO NACIONAL DE PESQUISAS ESPACIAIS. Dados do PRODES 19882013. Disponível em http://www.obt.inpe.br/prodes/prodes_1988_2013.htm. 2014.

INPI - INSTITUTO NACIONAL DE PROPRIEDADE INDUSTRIAL. Patentes concedidas a residentes segundo o campo tecnológico. Disponível em: http://www.inpi.gov.br/images/docs/dirpa_estat_portal_out_13_tabela_4_campo_tec _concess.pdf. 2013.

. Patentes concedidas a não-residentes segundo o campo tecnológico. Disponível

em: http://www.inpi.gov.br/images/docs/dirpa_estat_portal_out_13_tabela_5_campo_tec _concess_0.pdf. 2013.

IPCC - Intergovernmental Panel on Climate Change. IPCC Fourth Assessment Report: Climate Change 2007 (AR4). Disponível em http://www.ipcc.ch/publications_and_data/ar4/syr/en/contents.html. 2007.

IPEA - Instituto de Pesquisa Econômica Aplicada. Inovação tecnológica no setor elétrico brasileiro: uma avaliação do programa P\&D regulado pela Aneel. Organizadores: 
POMPERMAYER, Fabiano Mezadre; DE NEGRI, Fernanda; CAVALCANTE, Luiz Ricardo. Brasília: Ipea, 2011.

JÄGER-WALDAU, Arnulf. PV status report 2012. European Commission - Institute for Energy and Transport. European Union, 2012.

JANG, Show-ling; XU, Chungyi. Renewable Energy and the Electric Power Industry: the cases of the United States, Germany, South Korea and Taiwan. Disponível em http://proj3.sinica.edu.tw/ tea/images/stories/file/WP0173.pdf. 2011.

KAMMEN, Daniel. Environmental Justice lecture. Disponível em http://er100200.berkeley.edu/lectures/L18_environmental-justice.pdf. 2013.

KARL, Terry Lynn. The Paradox of Plenty: Oil Booms and Petro-States. 1997.

KIM, Chung-yum. From Despair to Hope Economic Policymaking in Korea 1945-1979. Disponível em http://people.duke.edu/ myhan/kaf1107.pdf. Seul: Korea Development Institute, 2011.

KIM, Do-Yo. Introduction of RPS and phase-out of FIT in renewable energy policy. International Financial Law Review - IFLR Disponível em: http://www.iflr.com/Article/3072471/Introduction-of-RPS-and-phase-out-of-FIT-inrenewable-energy-policy.html. 2012.

KIM, Jay. Korea-US Atomic Energy Agreement. Disponível em http://www.koreatimes.co.kr/www/news/opinon/2014/10/305_134801.html.

Publicado em 29 de abril de 2013.

KIM, Linsu. Da imitação à inovação: a dinâmica do aprendizado tecnológico da Coréia; tradutor: Maria Paula G. D. Rocha. Campinas: Editora da UNICAMP, 2005.

KLEIN, Ruben. A reanalysis of PISA results: comparability problems. http://www.scielo.br/scielo.php?pid=S010440362011000500002\&script=sci_arttext\&tlng=en. Ensaio: avaliação e políticas públicas em educação. Vol.19, no. 73, Rio de Janeiro. 2011.

KOIKE, Bento. Entrevista realizada pelo autor por telefone em 17 de junho de 2013.

KOOMEY, Jonathan. Cold cash, cool climate: Science-based advice for ecological entrepreneurs. Burlingame: Analytics Press, 2012.

KPMG. China's 12th five-year plan: overview. Disponível em: http://www.kpmg.com/CN/en/IssuesAndInsights/ArticlesPublications/Publicationser ies/5-years-plan/Documents/China-12th-Five-Year-Plan-Overview-201104.pdf. 2011. 
KRAEMER, Kenneth L.; LINDEN, Greg; \& DEDRICK, Jason. Capturing Value in Global Networks: Apple's iPad and iPhone. Disponível em http://pcic.merage.uci.edu/papers/2011/Value_iPad_iPhone.pdf. 2011.

KRASNER, Stephen D. Structural causes and regime consequences: regimes as intervening variables. International Organization. v. 36, n. 2, 1982.

KRUGMAN, Paul. The Mith of Asia’s Miracle. Foreign Affairs. Vol. 73. 1994.

Building a green economy. Disponível em http://www.nytimes.com/2010/04/11/magazine/11Economy-t.html?pagewanted=all. Publicado em NYTimes.com. 2010.

KURAMOTO, Renato Yoichi Ribeiro; APPOLONI, Carlos Roberto. Uma breve história da política nuclear brasileira. Caderno Brasileiro de Ensino de Física, volume 19. 2002.

KWEIA - KOREA WIND ENERGY INDUSTRY ASSOCIATION. Wind power statistics information: wind power facilities in operation. Disponível em: http://www.kweia.or.kr/. 2014.

LEÃO, José Antônio de Souza. Entrevista realizada pelo autor por telefone em 16 de julho de 2013.

LEWIS, Joanna I. Green innovation in China: China's Wind Power Industry and the Global Transition to a Low-Carbon Economy. New York: Columbia University Press, 2013.

LIJPHART, Arend. Comparative Politics and the Comparative Method. American Political Science Review, vol. 65, n. 3. 1971.

LIST, Friederich. The National System of Political Economy. Disponível em http://www.econlib.org/library/YPDBooks/List/lstNPE1.html. 1841.

LIU, Yao-Jen; e LIU, Shang-Jyh. The intellectual property policy of Taiwan: a strategic viewpoint. Engineering Management Conference, IEEE International. Disponível em http://ieeexplore.ieee.org/stamp/stamp.jsp?tp=\&arnumber=1407072), 2004.

LIVERMAN, Diana M. Conventions of climate change: constructions of danger and the dispossession of the atmosphere. Journal of Historical Geography, vol. 35. 2009.

LOBATO, Emílio. A mineração brasileira - Produto técnico 37: Perfil do Quartzo. J. Mendo Consultoria. MME: Brasília, 2009.

LONG, Guoqiang. China's Policies on FDI: Review and Evaluation. In Theodore H. Moran, Edward M. Graham, and Magnus Blomstrom, eds. Does Foreign Direct Investment Promote Development? Disponível em: http://www.piie.com/publications/chapters_preview/3810/12iie3810.pdf.

Washington, DC: Peterson Institute for International Economics, 2005. 
MACHADO, Luiz Alberto Figueiredo. O êxito da Conferência do Clima de Durban e o caminho para a Rio+20. In: Política Externa - Ambiente e ciência. Volume 20, número 4. São Paulo: Editora Paz e Terra, 2012.

MARCONI, Nelson; e BARBI, Fernando. Taxa de câmbio e composição sectorial da produção.

In: Taxa de câmbio no Brasil - estudos de uma perspectiva do desenvolvimento econômico (Org: NAKANO, Yoshiaki; e HOLLAND, Márcio). Rio de Janeiro: Elsevier, 2011.

MAZZOLENI, Roberto; NELSON, Richard. The roles of research at universities and public labs in economic catch-up. Pisa, Itália: LEM Papers Series, 2006.

MAZZUCATO, Mariana. The entrepreneurial state: debunking public vs. private sector myths. London: Anthem Press, 2013.

McDONALD, Kristen; BOSSHARD, Peter; e BREWER, Nicole. Exporting dams: China's hydropower industry goes global. Journal of Environmental Management, volume 90. 2009.

McKINSEY \& COMPANY. Past lessons for China's new joint ventures. Por Stephan Bosshart, Thomas Luedi, and Emma Wang. Insights \& publications. Disponível em: http://www.mckinsey.com/insights/corporate_finance/past_lessons_for_chinas_new joint_ventures. 2010.

MCTI - MINISTÉRIO DA CIÊNCIA, TECNOLOGIA E INOVAÇÃO. Status dos projetos do Mecanismo de Desenvolvimento Limpo (MDL) no Brasil. Disponível em http://www.mct.gov.br/upd_blob/0235/235795.pdf, 2014.

MEADOWS, Donella H.; MEADOWS, Dennis L.; RANDERS, Jorgen; BEHRENS III, William W. The limits to growth - a report for the Club of Rome's project on the predicament of mankind. Nova York: Universe Books, 1972.

MEI, Paulo Roberto. Parceria Universidade-Empresa: Purificação de Silício Grau Solar. Apresentação no Workshop Inovação para o Estabelecimento do Setor de Energia Solar Fotovoltaica no Brasil. Campinas, 2013.

MENSING, Blake M. Putting Aeolus to Work Without the Death Toll: Federal Wind Farm Siting Guidelines Can Mitigate Avian and Chiropteran Mortality. Journal of Environmental Law \& Litigation. Oregon University, 2012.

MIGUEZ, José Domingos Gonzalez; OLIVEIRA, Adriano Santhiago; MENDES, Thiago de Araujo. O desafio das novas tecnologias de mitigação da mudança do clima no contexto do desenvolvimento sustentável. Brasília: CGEE/MCT, 2010. 
MITTELBACH, Maria Margarida P. Algumas considerações sobre o sistema de patentes e a saúde humana. In: PICARELLI, Márcia Flávia Santini; ARANHA, Márcio Iorio (Org.). Política de patentes em saúde humana. São Paulo: Atlas, 2001.

MONGELLI, Sara Tânia. Geração núcleo-elétrica: retrospectiva, situação atual e perspectivas futuras. Dissertação de mestrado no Instituto de Pesquisas Energéticas e Nucleares da Universidade de São Paulo. 2006.

MONTALVÃO, Wilson. Entrevista por email com o assistente da Presidência da Eletronuclear em 18 de novembro de 2013.

NAVIGANT RESEARCH. A BTM Wind Report: World Market Update 2013 - Executive Summary. Disponível em http://www.navigantresearch.com/wpcontent/uploads/2014/03/WMU-14-Executive-Summary.pdf. Chicago: Navigant Research, 2014.

NELSON, Richard. As fontes do crescimento econômico; tradução de Adriana Gomes de Freitas. Campinas: Editora da UNICAMP, 2006.

NOBRE, Carlos A.; SAMPAIO, Gilvan; e SALAZAR, Luis. Mudanças Climáticas e Amazônia. In: Ciência e Cultura, volume 59, n. 3. Disponível em http://cienciaecultura.bvs.br/scielo.php?pid=s0009-67252007000300012\&script=sci _arttext. São Paulo, 2007.

OECD - ORGANIZATION FOR ECONOMIC COOPERATION AND DEVELOPMENT. Transitioning to green innovation and technology. In: OECD Science, Technology and Industry Outlook 2012. OECD Publishing, 2012.

PISA 2012 Results in Focus: What 15-year-olds know and what they can do with what they know. Disponível em http://www.oecd.org/pisa/keyfindings/pisa2012-results-overview.pdf. 2013.

. Education at a Glance 2012: Highlights, OECD Publishing. Disponível em http://dx.doi.org/10.1787/eag_highlights-2012-en. 2012.

OLIVEIRA, Luiz Guilherme. Tendências Tecnológicas do Setor Elétrico. Brasília: Ipea, 2011. OMC - ORGANIZAÇÃO MUNDIAL DO COMÉRCIO. Report of the Working Party on the $\begin{array}{lllll}\text { accession } & \text { of } & \text { China. } & \text { Disponível }\end{array}$ http://www.cecc.gov/pages/selectLaws/WTOimpact/wkptrptPRCWTO.php. 2001. . Member information: Separate Customs Territory of Taiwan, Penghu, Kinmen and Matsu (Chinese Taipei) and the WTO. Disponível em http://www.wto.org/english/thewto_e/countries_e/chinese_taipei_e.htm, 2014. 
OREIRO, José Luis; PUNZO, Lionello; ARAÚJO, Eliane; e SQUEFF, Gabriel. Taxa real de câmbio, desalinhamento cambial e crescimento econômico no Brasil (1994-2007). Revista de Política Econômica, volume 31, n. 4, 2011.

PARADA, Ana Maria Mülser. A declaração da OMC sobre o Acordo TRIPS e saúde pública (Doha, 2001) - um estudo de caso sobre a liderança do Brasil em foros multilaterais. 237p. Dissertação (Mestrado em Relações Internacionais) - Instituto de Relações Internacionais, Universidade de Brasília, Brasília, 2005.

PASTORE, Affonso Celso. Câmbio real e crescimento econômico. Economia \& Tecnologia, Ano 6, Vol. 21, 2010.

PERNG, Chiou Mey. Taiwan: Biofuels annual. Disponível em http://gain.fas.usda.gov/Recent\%20GAIN\%20Publications/General\%20Report_Taip ei_Taiwan_5-19-2009.pdf. USDA Foreign Agricultural Service, 2009.

PETROBRAS. Tecnologia Petrobras 2013. Coordenação Editorial: PAIS, Francisco; FURLANI, Clarisse; VELLOSO, Cristina; e GODINHO, Paulo. 2014.

PIMENTEL, Luiz Otávio. Direito Industrial - as funções do Direito de Patentes. Porto Alegre: Síntese, 1999.

POLANYI, Karl. The Great Transformation: the political and economic origins of our time. Beacon Press: Boston, 2001.

PRITCHETT, Lant. Where has all the education gone? World Bank Policy Research Working Paper 1581, 1997.

PWC - PRICEWATERHOUSECOOPERS. Emissions trading: South Korea steams ahead. Disponível em https://www.pwc.com/en_GX/gx/sustainability/publications/assets/pwc-emmisionstrading-south-korea.pdf, 2012.

REN 21 - RENEWABLE ENERGY POLICY NETWORK FOR THE 21 ${ }^{\text {ST }}$ CENTURY. Renewables 2014: Global Status Report. REN21 Secretariat: Paris, 2014.

REVELLE, Roger; e SUESS, Hans E. Carbon dioxide exchange between atmosphere and ocean and the question of an increase of atmospheric $\mathrm{CO} 2$ during the past decades. Disponível em http://uscentrist.org/about/issues/environment/docs/RevelleSuess1957.pdf. 1957.

REVKIN, ANDREW. Dot Earth: Exploring Solar, Efficiency, Gas and More with Amory Lovins and Joel Makower. Disponível em: http://dotearth.blogs.nytimes.com/2013/10/22/exploring-solar-efficiency-gas-andmore-with-amory-lovins-and-joel- 
makower/?src=rechp\&gwh=A3C7CC862362D4F8636F2

D94FE41C59C\&_r=0.

Publicado em 22 de outubro de 2013.

REZEK, José Francisco. Direito Internacional Público. $8^{a}$ edição. São Paulo: Saraiva, 2000.

RICUPERO, Rubens. A Amazônia e a Rio+20: uma proposta para a revitalização da cooperação amazônica. In: Política Externa - Ambiente e ciência. Volume 20, número 4. São Paulo: Editora Paz e Terra, 2012.

ROBINS, Nick; CLOVER, Robert; e SINGH, Charanjit. A Climate for Recovery: the colour of stimulus goes green. Disponível em http://www.euractiv.de/fileadmin/images/HSBC_Green_New_Deal.pdf. $\quad$ HSBC Global Research, 2009.

RODRIK, Dani. Getting interventions right: how South Korea and Taiwan grew rich. National Bureau of Economic Research, Edição 4964. Disponível em http://www.excellentfuture.ca/sites/default/files/How\%20Korea\%20and\%20Taiwan \%20grew\%20rich.pdf. 1994.

ROMM, Joseph. Global warming is fact, and denial won't change climate back. US News. Disponível em http://www.usnews.com/opinion/articles/2010/03/23/global-warmingis-fact-and-denial-wont-change-climate-back. 2010.

SACHS, Jeffrey; WARNER, Andrew. Natural Resource Abundance and Economic Growth. Cambridge/EUA: National Bureau of Economic Research, 1995.

The curse of natural resources. Center for International Development, Harvard University. Cambridge/EUA: European Economic Review 45, 2001.

SCHUMPETER, Joseph Alois. Capitalism, Socialism and Democracy. New York: Harper \& Row Publishers, 1975.

Teoria do desenvolvimento econômico: uma investigação sobre lucros, capital, crédito, juro e o ciclo econômico. Tradução de Maria Sílvia Possas. São Paulo: Nova Cultura, 1988.

STERN, Nicholas. The Stern Review on the Economics of Climate Change. Cambridge: Cambridge University Press, 2006.

China's growth, China's cities, and the new global low-carbon industrial revolution. Policy Paper Disponível em http://www.cccep.ac.uk/ Publications/Policy/docs/PPStern_China-green-revolution.pdf. 2010.

STERN, Nicholas; RIBERA, Teresa; e TUBIANA, Laurence. Towards a resilient Green economy. Disponível em http://www.europeanvoice.com/article/ 2012/march/towards-a-resilient-green-economy-/73758.aspx. 2012. 
STIGLITZ, Joseph. Some Lessons from the East Asian Miracle. World Bank Research Observer, August, 1996.

TACHINARDI, Maria Helena. A Guerra das Patentes: o conflito Brasil x EUA sobre propriedade intelectual. Rio de Janeiro: Paz e Terra, 1993.

TAIWAN. Office of the President: President Ma's Inaugural Address. Disponível em: http://english.president.gov.tw/Default.aspx?tabid=491\&rmid=2355\&itemid=27199. Publicado em 20 de maio de 2012.

THE ECONOMIST. The insidious charms of foreign investment. Special Report. Disponível em: http://www.economist.com/node/3689274. 2005.

Green Growth: shoots, greens and leaves. 16 de junho de 2012.

European Utilities: How to lose half a trillion euros. Disponível em: http://www.economist.com/news/briefing/21587782-europes-electricity-providersface-existential-threat-how-lose-half-trillion-euros. 2013. Pocket World in Figures - 2012 edition. 2012.

THE KOREA HERALD. Seoul, Washington 'virtually' wrap up nuclear accord: sources. Disponível em: http://www.koreaherald.com/view.php?ud=20150208000060. Reportagem de 8 de fevereiro de 2015.

THE NEW YORK TIMES. Scandal in South Korea over nuclear revelations. Reportagem de 3 de agosto de 2013.

THE WIND POWER. Wind turbines and wind farms database: Taiwan Wind Farms. Disponível em: http://www.thewindpower.net/country_windfarms_en_24_taiwan.php. 2014.

TOLMASQUIM, Maurício T. Novo Modelo do Setor Elétrico Brasileiro. Rio de Janeiro: Sinergia Editora, 2011.

TSAI, Wen-Tien, Innovative Promotion of Renewable Energy Development for Challenging Sustainable Low-Carbon Society: Case Study of Pingtung County, Taiwan. Journal: Challenges, 2014.

TSENG, Wanda; e ZEBREGS, Harm. Foreign Direct Investment in China: some lessons for other countries. IMF Policy Discussion Paper. Asia and Pacific Department. Disponível em: http://www.imf.org/external/pubs/ft/pdp/2002/pdp03.pdf. 2002.

TYNDALL, John. On the absorption and radiation of heat by gases and vapours, and on the physical connexion of radiation, absorption, and conduction. Disponível em http://nsdl.org/archives/onramp/classic_articles/issue1_global_warming/n3.Tyndall_ 1861corrected.pdf. 1961. 
UNFCCC. Kyoto Protocol Reference Manual on accounting of emissions and assigned amount. Bonn, 2008.

. Discurso do Ministro do Meio Ambiente da China na Conferência de Durban, COP 17. Disponível em http://unfccc.int/files/meetings/ durban_nov_2011/statements/application/pdf/111207_cop17_hls_china.pdf. 2011a.

Discurso da ministra do Meio Ambiente do Brasil na Conferência de Durban, COP 17. Disponível em http://unfccc.int/files/meetings/ durban_nov_2011/statements/application/pdf/111208_cop17_hls_brazil.pdf. 2011b.

Discurso do ministro do meio ambiente da Coreia do Sul na Conferência de Durban, COP 17. Disponível em http://unfccc.int/files/meetings/ durban_nov_2011/statements/application/pdf/111207_cop17_hls_replublic_korea.pd f. 2011c.

. Information provided by Annex I and non-Annex I Parties relating to Appendix I and II of the Copenhagen Accord. Disponível em http://unfccc.int/meetings/copenhagen_dec_2009/items/5262.php. 2012.

ÚNICA - União da Indústria de Cana-de-Açúcar. Etanol: 60 países já adotam mistura obrigatória de biocombustíveis aos combustíveis fósseis. Disponível em http://www.unica.com.br/noticia/27251092920325965467/60-paises-ja-adotammistura-obrigatoria-de-biocombustiveis-aos-combustiveis-fosseis/. 2014.

UNIVERSIDADE DE SÃO PAULO - INSTITUTO DE ESTUDOS AVANÇADOS. Observatório da Inovação e Competitividade. São Paulo, 2008.

USCAN CLIMATE WORK. Who's On Board With The Copenhagen Accord? Disponível em http://www.usclimatenetwork.org/policy/copenhagen-accord-commitments \#Note1, 2015.

USPTO - UNITED STATES PATENTS AND TRADEMARK OFFICE. Utility Patents By Country, State, and Year - Patent Technology Monitoring Team Report. Disponível em: http://www.uspto.gov/web/offices/ac/ido/oeip/taf/cst_utl.htm, 2014.

USTR - OFFICE OF THE UNITED STATES TRADE REPRESENTATIVE. 2012 Special 301 Report. Disponível em http://www.ustr.gov/sites/ default/files/2012\%20Special\%20301\%20Report_0.pdf, 2012.

VERÍSSIMO, Michele Polline. Doença holandesa no Brasil: ensaios sobre taxa de câmbio, perfil exportador, desindustrialização e crescimento econômico. Tese de doutoramento. Instituto de Economia da Universidade Federal de Uberlândia. 2010.

VILELA, Adriana. Entrevista realizada pelo autor por telefone em 7 de junho de 2013. 
VIOLA, Eduardo. Mitigação da Mudança Climática e Oportunidades para o Brasil. Interesse Nacional, volume 1. Disponível em http://interessenacional.uol.com. br/2008/07/mitigacao-da-mudanca-climatica-e-oportunidades-para-o-brasil/, 2008.

As potências climáticas na economia política internacional. Pontes - ICTSD (International Center for Trade and Sustainable Development), Volume 7, número 4, 2011a.

. Perspectivas internacionais para a transição para uma economia verde de baixo carbono. Conservação Internacional, Economia Verde, No.8. Disponível em: http://www.conservation.org.br/publicacoes/files/P\%E1ginas\%20de\%20PoliticaAm biental08viola.pdf. 2011 b.

. Entrevista ao jornal Folha de S. Paulo. Edição de 22 de maio de 2012.

VIOLA, Eduardo; FRANCHINI, Matías; e RIBEIRO, Thais Lemos. Sistema internacional de hegemonia conservadora: governança global e democracia na era da crise climática. São Paulo: Editora Annablume, 2012.

VIOTTI, Eduardo Baumgratz. Passive and active national learning systems: a Framework to Understand Technical Change in Late Industrializing Economies and Some Evidences from a Comparative Study of Brazil and South Korea. Tese de doutorado na New School for Social Research. Nova York, 1997.

National Learning Systems: A new approach on technical change in late industrializing economies and evidences from the cases of Brazil and South Korea. Science, Technology and Innovation Discussion Paper No. 12. Disponível em http://www.cid.harvard.edu/archive/biotech/papers/discussion12_viotti.pdf. Center for International Development, Harvard University. Cambridge, MA, USA. 2001.

WEART, Spencer R. The discovery of global warming. Cambridge: Harvard University Press, 2008.

WNA - WORLD NUCLEAR ASSOCIATION. Country Profiles: Nuclear Power in China. Disponível em: http://www.world-nuclear.org/info/Country-Profiles/Countries-AF/China--Nuclear-Power/. 2014.

WORLD COMISSION ON ENVIRONMENT AND DEVELOPMENT. Our Common Future. London: Oxford University Press, 1987.

XINHUA. S. Korea, U.S. to Extend Nuclear Pact for Another 2 Years. Xinhua English News. Disponível em http://news.xinhuanet.com/english/world/201304/24/c_132336968.htm. 24 de abril de 2013. 
. Profile: Xi Jinping - Pursuing Dream for 1.3 Billion Chinese. Disponível em: http://english.cri.cn/6909/2013/03/17/2941s754138.htm. 2014.

YALE CENTER FOR ENVIRONMENTAL LAW \& POLICY. Climate Policy \& Emissions

Data Sheet: China. Disponível em http://envirocenter.yale.edu/uploads/pdf/ China_Climate_Policy_Data_Sheet.pdf. 2012.

Climate Policy \& Emissions Data Sheet: South Korea. Disponível em $\underline{\text { http://envirocenter.yale.edu/ }}$ uploads/pdf/South_Korea_Climate_Policy_Data_Sheet.pdf. 2012.

. Climate Policy \& Emissions Data Sheet: Brazil. Disponível em http://envirocenter.yale.edu/uploads/pdf/ Brazil_Climate_Policy_Data_Sheet.pdf. 2012.

YERGIN, Daniel. The Quest: Energy, Security, and the Remaking of the Modern World. New York: Penguin Group, 2012.

YONHAP NEWS AGENCY. Full text of Park's inauguration speech. Disponível em: http://english.yonhapnews.co.kr/national/2013/02/25/95/0301000000AEN20130225 001500315F.HTML. Publicado em 25 de fevereiro de 2013.

ZEHNER, Ozzie. Green illusions: the dirty secrets of clean energy and the future of environmentalism. Lincoln: University of Nebraska Press, 2012.

ZHENG, Cheng; KAMMEN, Daniel. An innovation-focused roadmap for a sustainable global photovoltaic industry. Energy Policy, volume 67, pages 159-169. Elsevier, 2014.

ZYSMAN, John; HUBERTY, Mark. Can Green Sustain Growth? From the Religion to the Reality of Sustainable Prosperity. 2013. 